\title{
Hydrologian perusteet
}

Matti Leppäranta ${ }^{1}$, Juhani Virta ${ }^{1}$ ja Timo Huttula ${ }^{2}$

${ }^{1}$ Helsingin yliopisto, Fysiikan laitos, Helsinki

2Suomen ympäristökeskus (SYKE), Jyväskylä

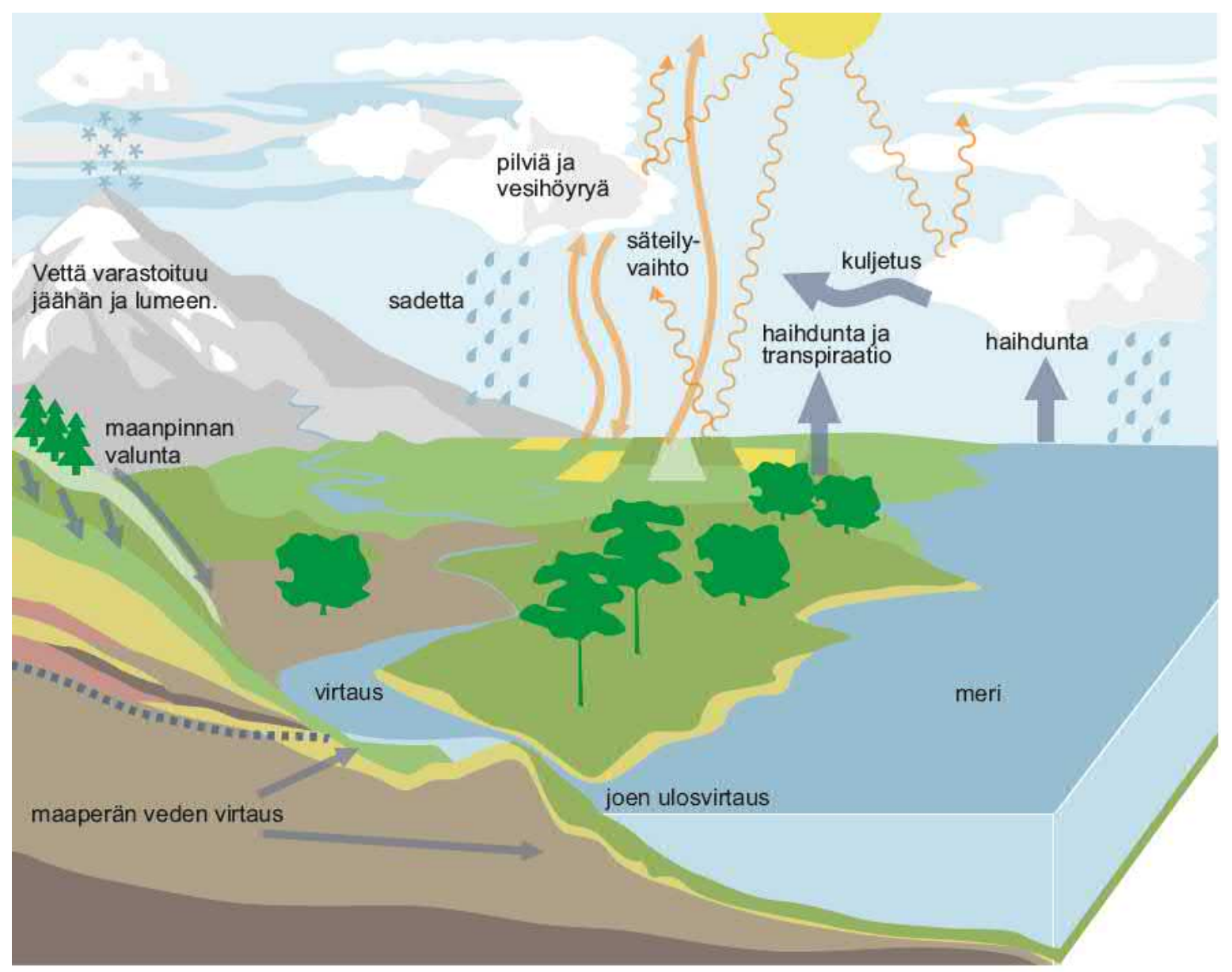

Helsingin yliopisto, Fysiikan laitos

Helsinki 2017 
Makea vesi (lämpötila $10{ }^{\circ} \mathrm{C}$, paine 1013,25 mbar)

Moolimassa

$m_{0} \quad 18,016 \mathrm{~g} \mathrm{~mol}^{-1}$

Tiheys

$\rho \quad 999,70 \mathrm{~kg} \mathrm{~m}^{-3}$

Dynaaminen viskositeetti

$\mu \quad 1,31 \cdot 10^{-3} \mathrm{~kg} \mathrm{~m}^{-1} \mathrm{~s}^{-1}$

Pintajännitys

$\sigma \quad 0,0742 \mathrm{~N} \mathrm{~m}^{-1}$

Kokoonpuristuvuus

K $\quad 4,82 \cdot 10^{-7} \mathrm{~Pa}^{-1}=4,82 \cdot 10^{-5} \mathrm{bar}^{-1}$

Äänen nopeus

$c_{\mathrm{s}} \quad 1450 \mathrm{~m} \mathrm{~s}^{-1}$

Lämpölaajenemiskerroin

a $\quad 0,88 \cdot 10^{-4}{ }^{\circ} \mathrm{C}^{-1}$

Ominaislämpökapasiteetti

c $\quad 4,19 \mathrm{~kJ}^{\circ} \mathrm{C}^{-1} \mathrm{~kg}^{-1}$

Lämmönjohtokyky

$k \quad 0,580 \mathrm{~W}^{\circ} \mathrm{C}^{-1} \mathrm{~m}^{-1}$

Höyrystymislämpö

Suhteellinen permittiivisyys

$L_{\mathrm{e}} \quad 2,47 \mathrm{MJ} \mathrm{kg}^{-1}$

$\varepsilon \quad 83,8$

Jäätyminen ja jää (lämpötila $0^{\circ} \mathrm{C}$, paine $1013,25 \mathrm{mbar}$ )

Maksimitiheyden lämpötila

$\begin{array}{ll}T_{\mathrm{m}} & 3,98{ }^{\circ} \mathrm{C} \\ T_{\mathrm{f}} & 0{ }^{\circ} \mathrm{C} \\ L_{\mathrm{f}} & 333,6 \mathrm{~kJ} \mathrm{~kg}^{-1} \\ \rho_{\mathrm{i}} & 917 \mathrm{~kg} \mathrm{~m}^{-3} \\ \alpha & 1,5 \cdot 10^{-4}{ }^{\circ} \mathrm{C}^{-1} \\ c_{\mathrm{i}} & 2,11 \mathrm{~kJ}^{\circ} \mathrm{C}^{-1} \mathrm{~kg}^{-1} \\ k_{\mathrm{i}} & 2,14 \mathrm{~W}^{\circ} \mathrm{C}^{-1} \mathrm{~m}^{-1} \\ \varepsilon_{\mathrm{i}} & 91,6\end{array}$

Jäätymispiste

$T_{\mathrm{f}} \quad 0^{\circ} \mathrm{C}$

Jäätymis/sulamislämpö

Tiheys

Lämpölaajenemiskerroin

Ominaislämpökapasiteetti

Lämmönjohtokyky

Suhteellinen permittiivisyys

$\varepsilon_{\mathrm{i}} \quad 91,6$

\section{Vesihöyry}

Vesihöyryn kaasuvakio

$R_{\mathrm{w}} \quad 461,5 \mathrm{~J}^{\circ} \mathrm{C}^{-1} \mathrm{~kg}^{-1}$

\section{Ilma (lämpötila $10^{\circ} \mathrm{C}$, paine 1013,25 mbar)}

Keskimääräinen molekyylipaino

$$
\begin{array}{ll}
m_{\mathrm{a}} & 28,97 \mathrm{~g} \mathrm{~mol}^{-1} \\
R_{\mathrm{a}} & 287,04 \mathrm{~J} \mathrm{~kg}^{-1}{ }^{\circ} \mathrm{C}^{-1} \\
\rho_{\mathrm{a}} & 1,250 \mathrm{~kg} \mathrm{~m}^{-3} \\
\mu_{\mathrm{a}} & 1,764 \cdot 10^{-5} \mathrm{~kg} \mathrm{~m}^{-1} \mathrm{~s}^{-1} \\
c_{\mathrm{a}} & 1,004 \mathrm{~kJ} \mathrm{~kg}^{-1} \mathrm{C}^{-1} \text { (vakiopaineessa) } \\
k_{\mathrm{a}} & 2,501 \cdot 10^{-2} \mathrm{~W} \mathrm{~m}^{-1}{ }^{\circ} \mathrm{C}^{-1}
\end{array}
$$$$
\text { Tiheys }
$$$$
\text { Dynaaminen viskositeetti }
$$$$
\text { Ominaislämpökapasiteetti }
$$$$
\text { Lämmönjohtokyky }
$$ 


\section{Alkusanat}

Hydrologia tutkii maapallon makean veden varoja ja veden kiertokulkua. Sen lähtökohta on käytännönläheinen: talous-, kastelu- ja teollisuusveden saatavuus ihmisen käyttöön. Tieteenala juontaa juurensa jokivesien käytöstä ja säännöstelystä muinaisen Egyptin, Kaksoisvirran maan, Intian ja Kiinan maataloudessa. Veden merkityksen esitti jo ensimmäinen luonnonfilosofi, kreikkalainen Thales Miloteslainen (636 - 546 eKr.), joka piti vettä kaiken alkuperänä. Tieteellinen, todenmukainen käsitys veden kiertokulusta vahvistui 1600-luvulla, ja vesivarojen seurantajärjestelmiä alettiin käynnistää seuraavalla vuosisadalla. Vesihuolto on toimivien yhdyskuntien infrastruktuurin peruskiviä. Nykyaikana veden saatavuuden lisäksi vesivoiman tarpeet, tulvasuojelu, vesiliikenne ja veden laatu ovat tulleet yhä tärkeämmiksi avainkysymyksiksi.

Hydrologian tutkimuskohteita ovat sadanta ja haihdunta (hydrometeorologia), valunta, järvet ja joet, maaperän vesi eli maa- ja pohjavesi (geohydrologia), jäätikköhydrologia sekä nämä yhdistävä veden kiertokulku. Pohjavesi muodostaa maapallon merkittävimmän nestemäisen makean veden varaston, ja joet ovat tärkeitä veden ja ainesten kuljetusteitä sekä maiseman ja maaperän muokkaajia. Järvet ovat vesien väliaikaisia varastoaltaita, ja erityisesti Suomen oloissa järvihydrologian merkitys on ollut suuri. Jäätikötkin toimivat vesivarastoina, ja eräiden vuoristojäätiköiden sulamisvesiä käytetään vesitaloudessa. Vesiekologian tutkimuksiin hydrologia tarjoaa fysikaaliset taustatiedot vesivaroista sekä tietoa fysiikan kytkennästä luonnonvesien tilaan ja ekologiaan.

Tämä teos sisältää johdatuksen hydrologiaan. Lähtötiedoiksi oletetaan lukion perustietoja tai vastaavan laajuista vesiluonnon tuntemusta. Taustatietoja voi syventää teoksen Geofysiikka - tunne maapallosi (Ahvenisto ym. 2004) avulla. Tuorein suomenkielinen alan käsikirja on jo 30 vuoden takaa (Mustonen 1986). Englanninkielistä alan kirjallisuutta on runsaasti saatavilla, esimerkiksi Hendricks (2010) sopii hyvin aloittelijalle. Hydrologian yliopistollista opetusta annetaan Helsingin yliopiston fysiikan laitoksessa, Jyväskylän yliopiston bio- ja ympäristötieteiden laitoksessa sekä Turun yliopiston maantieteen ja geologian laitoksessa. Insinöörihydrologiaa opetetaan Aalto-yliopistossa ja Oulun yliopistossa.

Tämän kirjan pohjana on ollut emeritusprofessori Juhani Virran luentomoniste Hydrologian peruskurssi, johon dosentti Timo Huttula ja professori Matti Leppäranta ovat tuoneet omia lisäyksiään kurssin kehittyessä. Teosta käytetään oppikirjana Helsingin yliopiston hydrologian peruskurssilla, joka kuuluu geofysiikan, limnologian ja kalataloustieteen opintoihin. Kirja itsessään soveltuu yleisemminkin yliopistolliseksi oppikirjaksi, itseopiskeluun asiasta kiinnostuneille sekä alan pieneksi käsikirjaksi. Kurssin sisältö on painottunut Suomen olojen hydrologiaan. Sen laajuus on 5 opintopistettä ja se käsittää 30 tuntia luentoja sekä 15 tuntia harjoituksia. Päivitettyä lisämateriaalia löytyy kurssin verkkosivuilta Helsingin yliopiston fysiikan laitokselta. Kirjan lopussa on FM Anna-Riikka Leppärannan laatima matemaattisia aputietoja kattava liite lyhyen matematiikan pohjalta kurssille tulevia opiskelijoita varten.

Kiitämme dosentti Esko Kuusistoa asiantuntevasta avusta kirjaa työstettäessä ja kuvamateriaalista. Hydrologian peruskurssin assistentit ja opiskelijat ovat niin ikään ansiokkaasti ottaneet esille hydrologian kysymyksiä, joihin tässä kirjassa on myös koetettu vastata. Tekstin ovat tarkastaneet LuK Jesse Heikkilä, LuK Arttu Jutila, FM Niina Kotamäki, FM Anna- 
Riikka Leppäranta, FT Pekka Rossi, ja LuK Cecilia Äijälä. Monet kirjan piirroksista ovat FT Salla Jokelan käsialaa. Kuvamateriaalia ovat antaneet käyttöömme Elonet kansallisfilmografia, Hämeenlinnan taidemuseo, Kansallisgalleria, Tomas Kohout, Petrina Köngäs, Mobilia museo, Päijät-Hämeen liitto, professori Jouko Sarvala, professori Kari Suomalaisen perikunta, Suomen ympäristökeskus, Tretjakovin taidegalleria, Moskova ja FM Jouni Tulonen.

Kirjan lopullinen kokoaminen tapahtui ensimmäisen kirjoittajan puolen vuoden sairasloman aikana vuonna 2016. Tämä oli mahdollista, kiitos Päijät-Hämeen Keskussairaalan osasto 33:n sekä Meilahden kolmiosairaalan osasto 5B:n henkilökuntien hyvän hoidon ja huolenpidon. Suomen tietokirjailijat ry. on myöntänyt apurahan kirjan laatimiseksi, mistä esitämme sille suuret kiitokset.

Emeritusprofessori Juhani Virta poistui luotamme äkillisen sairauden murtamana 6. marraskuuta 2016. Tämä oli meille allekirjoittaneille, hänen oppilailleen syvä suruviesti ja muistamme lämmöllä häntä luentojen ja maastotöiden ajoilta. Juhani Virran opetuksia ja ajatuksia on tämän kirjan sivuille monin paikoin taltioituna.

Helsingissä ja Jyväskylässä 31.1.2017

Matti Leppäranta ${ }^{1}$ ja Timo Huttula ${ }^{2}$

${ }^{1}$ Helsingin yliopisto, Fysiikan laitos, Helsinki

${ }^{2}$ Suomen ympäristökeskus, Vesikeskus, Jyväskylä 


\section{Sisällys}

$\begin{array}{ll}\text { 1. Johdanto } & 7\end{array}$

2. Hydrologian tutkimusmenetelmät 13

$\begin{array}{ll}2.1 \text { Maastomittaukset } & 13\end{array}$

2.2 Tilastollinen hydrologia 16

2.3 Dimensioanalyysi 26

2.4 Mallit $\quad 30$

3. Vesi ja veden kiertokulku 38

3.1 Luonnonvesien ominaisuuksia 38

$\begin{array}{ll}\text { 3.2 Luonnonvesien tilayhtälö } & 48\end{array}$

3.3 Veden kiertokulku ja vesitase $\quad 51$

4. Hydrometeorologia $\quad 65$

4.1 Maanpinnan energiatase $\quad 65$

$\begin{array}{ll}\text { 4.2 Sadanta } & 73\end{array}$

$\begin{array}{ll}4.3 \text { Haihdunta } & 79\end{array}$

$\begin{array}{ll}4.4 \text { Lumi } & 86\end{array}$

5. Järvien fysiikka 93

5.1 Morfologia ja vesitase $\quad 93$

5.2 Lämpötalous 100

5.3 Jääolot 105

5.4 Järvien dynamiikka 110

5.5 Valaistusolot 114

6. Uomien virtaus $\quad \mathbf{1 2 0}$

6.1 Uomien karakterisointi $\quad 120$

6.2 Uomien virtausoppi 123

6.3 Virtaaman ja vedenkorkeuden mittaaminen $\quad 130$

$\begin{array}{ll}6.4 \text { Talviolot } & 133\end{array}$

6.5 Vesi kuluttavana ja kuljettavana väliaineena 137

7. Geohydrologia 142

$\begin{array}{ll}7.1 \text { Maavesi } & 142\end{array}$

$\begin{array}{ll}7.2 \text { Pohjavedet } & 149\end{array}$

7.3 Maaperän lämpötila 158

7.4 Jäätiköt 166

8. Valunta 171

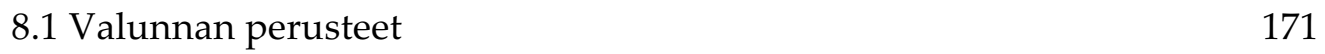

8.2 Valuntamallit $\quad 175$

8.3 Veden laatua kuvaavat mallit 183

9. Hydrologia ja tulevaisuus 189

10. Lähdeluettelo 196

$\begin{array}{lr}\text { Symboliluettelo } & 199\end{array}$

Harjoitustehtäviä 202

$\begin{array}{ll}\text { Matematiikkaliite } & 209\end{array}$ 


\section{Johdanto}

Maapallon vesivaippa eli hydrosfääri käsittää valtameret, jään ja lumen, maaperän vedet, järvet ja joet sekä ilmakehän vedet. Lähes koko vesivaippa ( $97 \%$ ) on suolaista merivettä, mutta ihmiskunta tarvitsee kotitalouskäyttöön, maatalouteen ja teollisuuteen makeaa vettä ${ }^{1}$. Näitä käyttökelpoisia vesiä kutsutaan vesivaroiksi. Vesivarojen esiintyminen ja kierto ovat ohjanneet elämän jakaantumista maapallolla, kansojen vaelluksia sekä asutuskeskusten muodostumista ja kehitystä historian saatossa (kuva 1-1). Voidaan sanoa, että ihmiskunnan tulevaisuus ja koko elämä maapallolla ovat riippuvaisia puhtaan veden saatavuudesta.

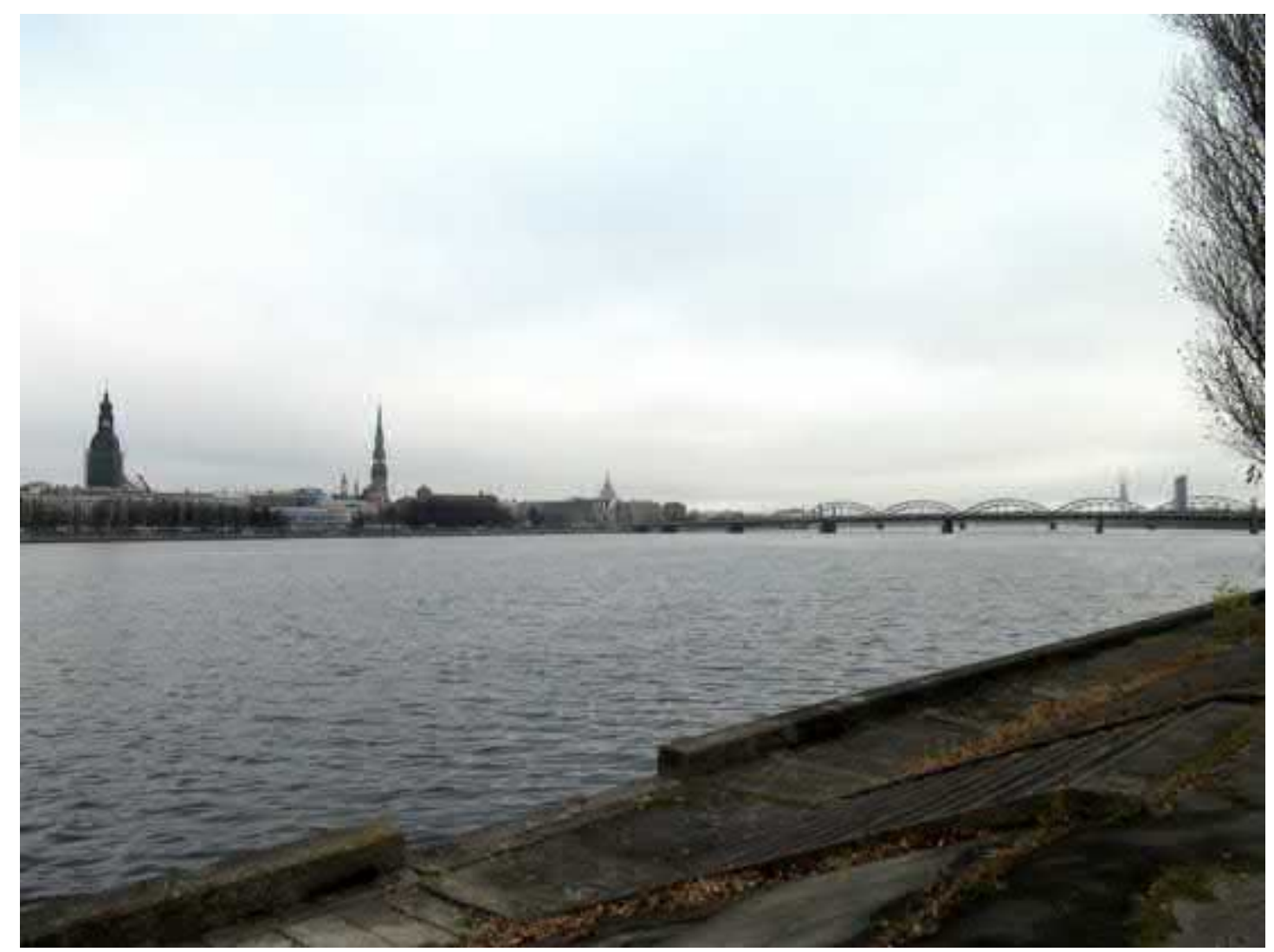

Kuva 1-1. Jokivarret ovat keränneet asutusta historiallisena aikana vesitalouden sekä viljavien maiden ansiosta, ja jokisuut ovat kasvaneet liikennekeskuksiksi. Kuvassa Väinäjoki [Daugava] halkomassa Riian kaupunkia. Väinäjoki on kolmanneksi suurin Itämereen laskevista joista; sen virtaama on 20,8 $\mathrm{km}^{3}$ vuodessa ja valuma-alue $87900 \mathrm{~km}^{2}$. Itämereen tuleva jokivirtaama on yhteensä $440 \mathrm{~km}^{3}$ vuodessa. Kuva: Matti Leppäranta.

Vesi käy maapallolla ikuista kiertokulkua. Sitä haihtuu maapallon pinnalta ilmakehään ja palautuu takaisin sateena. Vesi puhdistuu kiertäessään ilmakehän kautta, sillä haihdunta siirtää ilmakehään vain vesimolekyylejä. Maahan langettuaan sadevesi kulkeutuu valuntana pinta- ja pohjavesiin ja lopulta meriin haihtuen matkalla tai viimeistään merestä taas ilmakehään. Veden kiertokulussa maapallon vesien kokonaismäärä säilyy. Vähäistä vuotoa tapahtuu lähiavaruuteen, mutta toisaalta komeetat tuovat tilalle uutta vettä. Hydrologisissa

\footnotetext{
${ }^{1}$ Makea vesi viittaa veteen, jossa liuenneiden aineiden pitoisuus on alle $0,5 \%$.
} 
tarkasteluissa voidaan satojen ja tuhansien vuosien aikaperspektiivissä pitää maapallon vesimäärää vakiona.

Maapallon vesivaippa sisältää usean suuren varaston (Taulukko 1-1). Makeaa vettä on kaikkiaan noin 35 miljoonaa kuutiokilometriä, ja sitä löytyy eniten (2/3) jäätiköistä, joiden muodostamat varastot muuttuvat hyvin hitaasti. Etelämantereen ja Grönlannin mannerjäätiköt sisältävät lähes kaiken (yli 99 \%) jäätiköiden kokonaismassasta. Pohjavesistä on makeaa vettä noin puolet, ja tämä käsittää lähes $1 / 3$ makean veden varoista. Ne ovat ihmisen kannalta tärkeässä, nestemäisessä muodossa (kuva 1-2). Järvet ovat merkittävä vesivarasto useilla järvialueilla, vaikka niiden globaalinen osuus onkin pieni. Jokien kautta kulkeutuu suuri osa kiertokulkuun osallistuvasta vedestä meriin. Niiden vesivarasto on itsessään pieni, noin 2120 $\mathrm{km}^{3}$ eli 2,3 \% järvien vesivarastosta. Myös ilmakehän vesimäärä on pieni, mutta sen vedenkuljetuskyky on huomattava ja lisäksi ilmakehäväylä toimii myös tehokkaana vedenpuhdistajana, sillä haihdunta sisältää vain puhdasta vettä. Veden keskimääräinen viipymä ilmakehässä on noin 10 vuorokautta.

Taulukko 1-1. Maapallon vesivarat (UNESCO 1978). Pintavesi käsittää järvet ja joet.

\begin{tabular}{l|r|r|r} 
Varasto & Tilavuus $\mathbf{( k m}^{\mathbf{3}} \mathbf{)}$ & \multicolumn{1}{|c|}{ Tilavuus } \\
$\mathbf{( \% )}$ & $\begin{array}{c}\text { Makea vesi } \\
\mathbf{( \% )}\end{array}$ \\
\hline Valtameret & 1338000000 & 96,5 & - \\
Jäätiköt & 24023500 & 1,7 & 68,6 \\
Makea pohjavesi & 10530000 & 0,76 & 30,1 \\
Suolainen pohjavesi & 12870000 & 0,93 & - \\
Maavesi & 27970 & 0,002 & 0,08 \\
Lumi ja jää (kausittainen) & 340600 & 0,025 & 1 \\
IImakehän vesi & 12900 & 0,001 & 0,04 \\
Biosfäärin vesi & 1120 & 0,0001 & 0,003 \\
Makea pintavesi & 93120 & 0,007 & 0,27 \\
Suolainen pintavesi & 85400 & 0,006 & - \\
Vedet yhteensä & $\mathbf{1 3 8 5} \mathbf{9 8 4} \mathbf{6 1 0}$ & $\mathbf{1 0 0}$ & - \\
Makea vesi & $\mathbf{3 5 0 2 9} \mathbf{2 1 0}$ & $\mathbf{2 , 5}$ & $\mathbf{1 0 0}$
\end{tabular}

Vuonna 1995 Suomen teollisuudessa käytettiin vettä 7,2 miljardia kuutiometriä (Repo \& Hämäläinen 1996). Tästä pääosan (62 \%) käyttivät erilliset voimalaitokset lähinnä jäähdytykseen. Massa- ja paperiteollisuuden osuus oli 17 \% (jäähdytys- ja prosessivesi), ja öljy- ja petrokemianteollisuuden osuus oli 12 \% (lähinnä jäähdytysvettä). Muita pienempiä veden kuluttajia olivat kemianteollisuus (4\%) ja metallien valmistus (3\%).

Suomessa veden käyttö on yksityistalouksissa 270 miljoonaa kuutiometriä vuodessa eli noin 150 litraa vuorokaudessa henkeä kohti (kuva 1-3). Tämä voidaan jakaa kolmeen suunnilleen yhtä suureen osaan: henkilökohtainen hygienia, WC:n huuhtelu ja siivous sekä muu käyttö, joka sisältää lähinnä astioiden ja pyykin pesua. Ruoan valmistukseen ja veden juontiin menee $6 \%$ kokonaiskulutuksesta.

Hydrologia tutkii vesivaroja ja veden kiertokulkua. Siihen kuuluvat maaperän vesivarojen tutkimus eli geohydrologia ${ }^{2}$, järvien tutkimus eli limnologia, jokien tutkimus eli potamologia, ilmakehän vesitalous eli hydrometeorologia ja veden kiertokulku. Lisäksi jäätikköhydrologian eli glasiaalihydrologian erikoisala tutkii jäätiköiden sulamisvesiä ja niiden käyttöä.

\footnotetext{
${ }^{2}$ Geologian puolella käytetään termiä hydrogeologia.
} 
Suurin osa hydrologisesta tutkimuksesta tehdään yhä alueelliselta pohjalta, vaikkakin globaalinen lähestyminen on alalla kasvanut. Erityisen tärkeitä hydrologian tutkimuskohteita ovat valunnan muodostuminen veden kiertokulussa, tulvat sekä veden laatu. Suomen oloissa kaikki hydrologian pääalat ovat olleet tutkimusten kohteina, mutta järvien sekä talvikauden hydrologian - lumen ja jään - merkitys on ollut tavanomaista suurempi. Merten tutkimus eli oseanografia on käynnistynyt merenkulun tarpeista, ja sitä käsitellään omana vesivaroihin liittymättömänä alanaan (Myrberg \& Leppäranta 2014). Viime aikoina on tosin alettu puhdistaa merivettä kemiallisesti paikallisiin vesihuoltotarpeisiin.

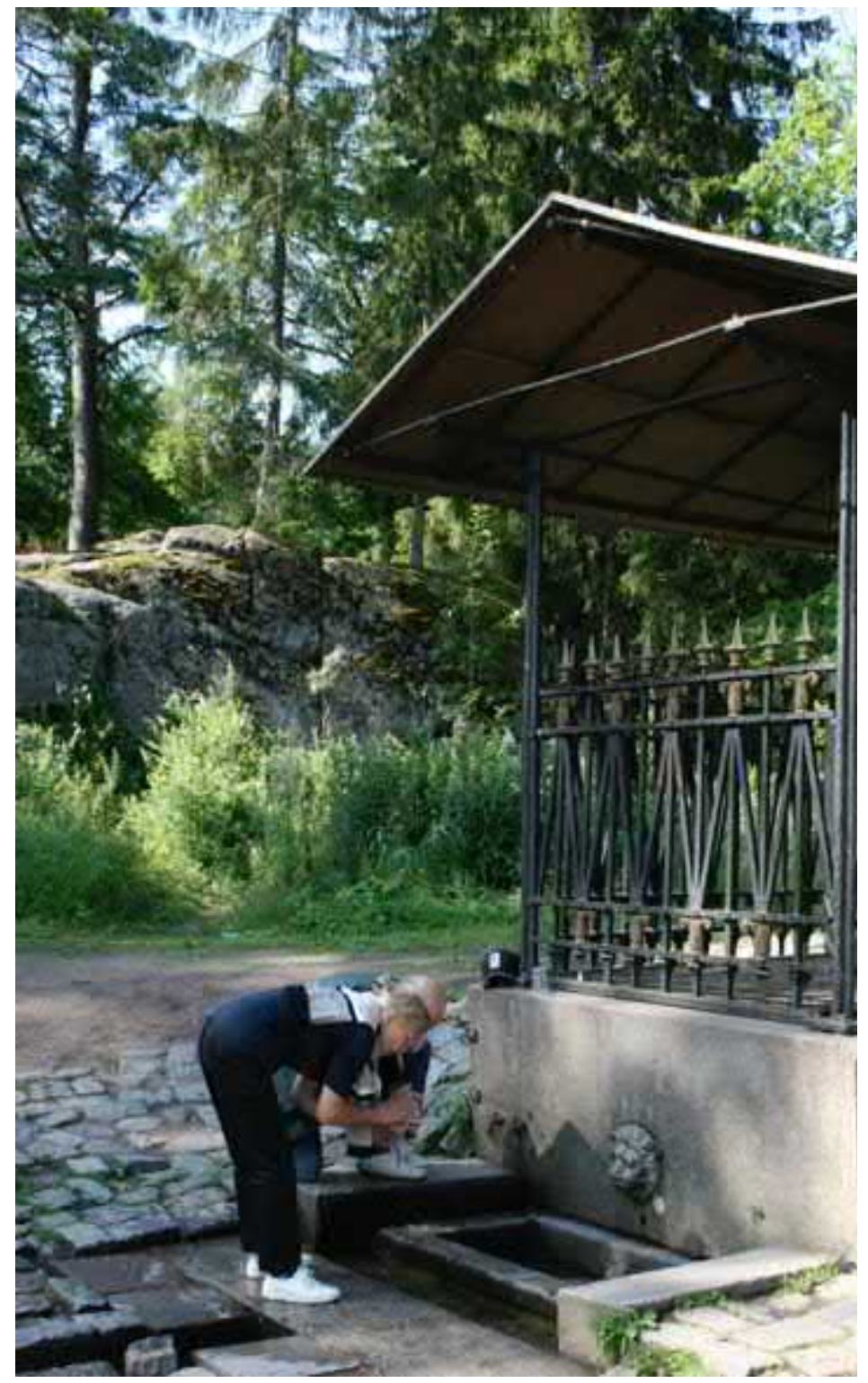

Kuva 1-2. Narkissoksen lähde Monrepos'n puistossa Viipurissa. Lähteen vedellä uskottiin olevan terveyttä parantavia vaikutuksia. Kansan suussa tämän lähteen nimi on ollut 'silmä'. Kuuluisin lähteemme lienee Runebergin lähde Ruovedellä, josta hän kirjoitti runonsa

Vid en källa

Jag sitter, källa, vid din rand

Och ser på molnens tåg,

Hur, ledda af en osedd hand,

De vexla i din våg.

Lähteitä ylläpitää pohjaveden virtaus. $\mathrm{Ne}$ ovat nykyisin suojeltuja vesistökohteita.

Kuva: Matti Leppäranta.

Hydrologian tutkimus on varhaisista ajoista lähtien liittynyt vesihuoltoon ja kastelujärjestelmiin. Antiikin aikana pohdittiin veden olemusta ja vettä pidettiin yhtenä maailman neljästä peruselementistä. Vesirakentaminen kehittyi sangen pitkälle Rooman valtakunnassa, josta erityisesti akveduktit ovat kuuluisia. Luonnonvesien tieteellinen tutkiminen alkoi renessanssin aikana. Leonardo da Vincillä oli jo oikea käsitys veden kiertokulusta, ja sitä askelittain terävöitettiin uuden ajan tieteen edistyessä. Da Vinci tutki myös jokien virtauksia ja suunnitteli kanavarakenteita. Hydrologian fysikaalinen perusta tuli valmiiksi 1800-luvulla, kun virtaus- 
ja lämpöoppi oli kehitetty ja veden kemiallinen rakenne saatu selvitetyksi. Edelleen 1800-luvulla aloitettiin systemaattinen hydrologisten aikasarjojen kerääminen ja laajempi kokeellinen työ luonnonoloissa.

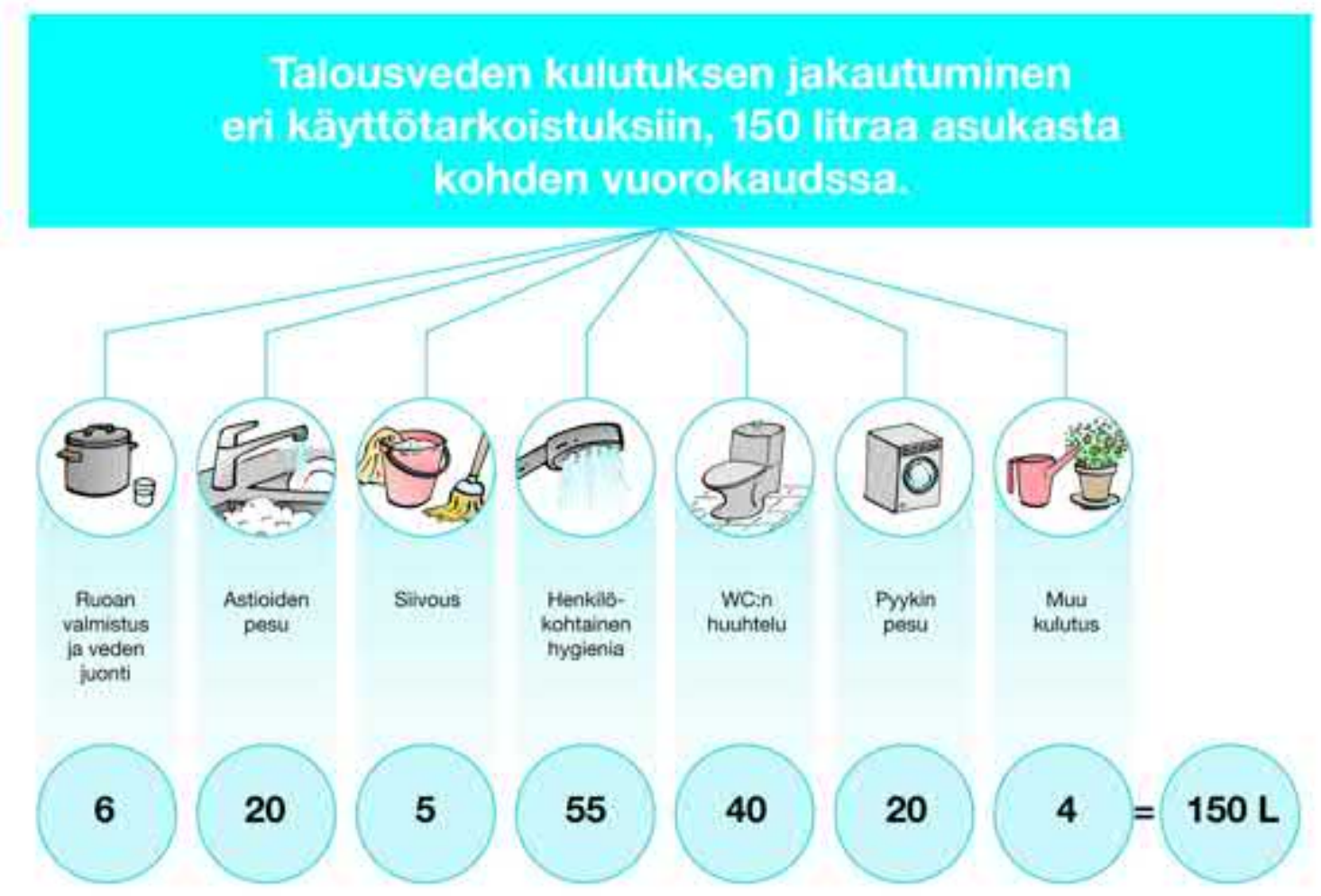

Kuva 1-3. Talousveden käyttö Lahden alueella henkeä kohti vuorokaudessa. Lähde: Lahti Aqua, http://www.lahtiaqua.fi.

Suomessa otettiin 1700-luvulla hydrologian ensiaskeleet, jotka liittyivät koskien perkauksiin viljelysalan lisäämiseksi järvien laskun avulla, tulviin sekä vähävetisten kausien esiintymiseen (Simojoki 1978). Halla oli suuria alan tutkimuskysymyksiä 1800-luvulla, kun ilmasto oli Euroopassa nykyistä kylmempi. Vuoden 1899 suurtulvasta aiheutui huomattavia vahinkoja, ja sen seurauksena Tie- ja vesirakennushallitukseen perustettiin vuonna 1908 Hydrografinen toimisto (Kuusisto 2008), jonka tehtäväksi tuli havaintojärjestelmien perustaminen. Maataloushallitus käynnisti vuonna 1928 maataloushydrologian tutkimuksen. Vesihallinnon uudistuksen myötä vuonna 1969 näiden tahojen toiminnot yhdistettiin ja siirrettiin Vesihallituksen Hydrologian toimistoon.

Moderni hydrologia alkoi muotoutua 1960-luvulla tietokoneiden tarjoaman laskenta-kapasiteetin, automaattisten mittaus- ja seurantajärjestelmien sekä kaukokartoitusmenetelmien astuttua kuvaan. Pisimmät hydrologiset aikasarjat saavuttivat silloin jo sadan vuoden virstanpylvään. Hydrologisten prosessien ja vesistöjärjestelmien numeerinen mallintaminen käynnistyi niin ikään 1960-luvulla. Vesien laatu- ja ympäristöongelmat tulivat silminnähtävästi esille ja asettivat suuria haasteita hydrologian tutkimukselle. Ympäristökysymykset muodostavat nykyisin suuren ongelmakokonaisuuden, ja niiden lisäksi merkittävänä tutkimuskysymyksenä on ilmastonvaihteluiden vaikutus vesivaroihin ja ilmaston sekä vesivarojen väliset kytkennät. Ennakoitavissa olevien ongelmien käytännön ratkaisut ovat suuria poliittisia ja taloudellisia kysymyksiä. Suomessa hydrologian tutkimus keskitettiin vuonna 1995 uuteen Suomen ympäristökeskukseen (SYKE) ja maakunnallisiin ympäristöpiireihin, 
jotka myöhemmin liitettiin maakunnallisiin Elinkeino, liikenne ja ympäristö (ELY) keskuksiin. Luonnontieteellistä hydrologiaa opetetaan ja tutkitaan Helsingin, Jyväskylän ja Turun yliopistoissa, ja hydrologian teknisiä sovelluksia eli insinöörihydrologiaa opetetaan ja tutkitaan Aalto-yliopistossa sekä Oulun ja Tampereen yliopistoissa.

Hydrologisen tutkimuksen tarve on kasvanut ja monipuolistunut teknologian kehityksen myötä. Jotta puhtaan veden lisääntyvä tarve voitaisiin tyydyttää, on entistä perusteellisemmin jouduttu selvittämään järvien ja jokien virtauksia ja sekoittumista, pohjavesien liikkeitä sekä veden laatua. Akvaattisen ekologian ja kalatalouden tutkimuksessa luonnonvesien fysiikan tuntemus on tullut yhä tärkeämmäksi tämän asettaessa elinolosuhteiden ja näiden kehityksen reunaehdot (kuva 1-4). Vesistöjen perustuntemus on vaatinut kerättäväksi pitkäaikaisia havaintosarjoja, joita edelleen ylläpidetään. Vesirakentamisesta sekä vesien hyötykäytöstä ja säännöstelystä aiheutuvat ongelmat, happamoituminen ja ympäristön pilaantuminen ovat edelleen lisänneet hydrologisen perustutkimuksen tarvetta.

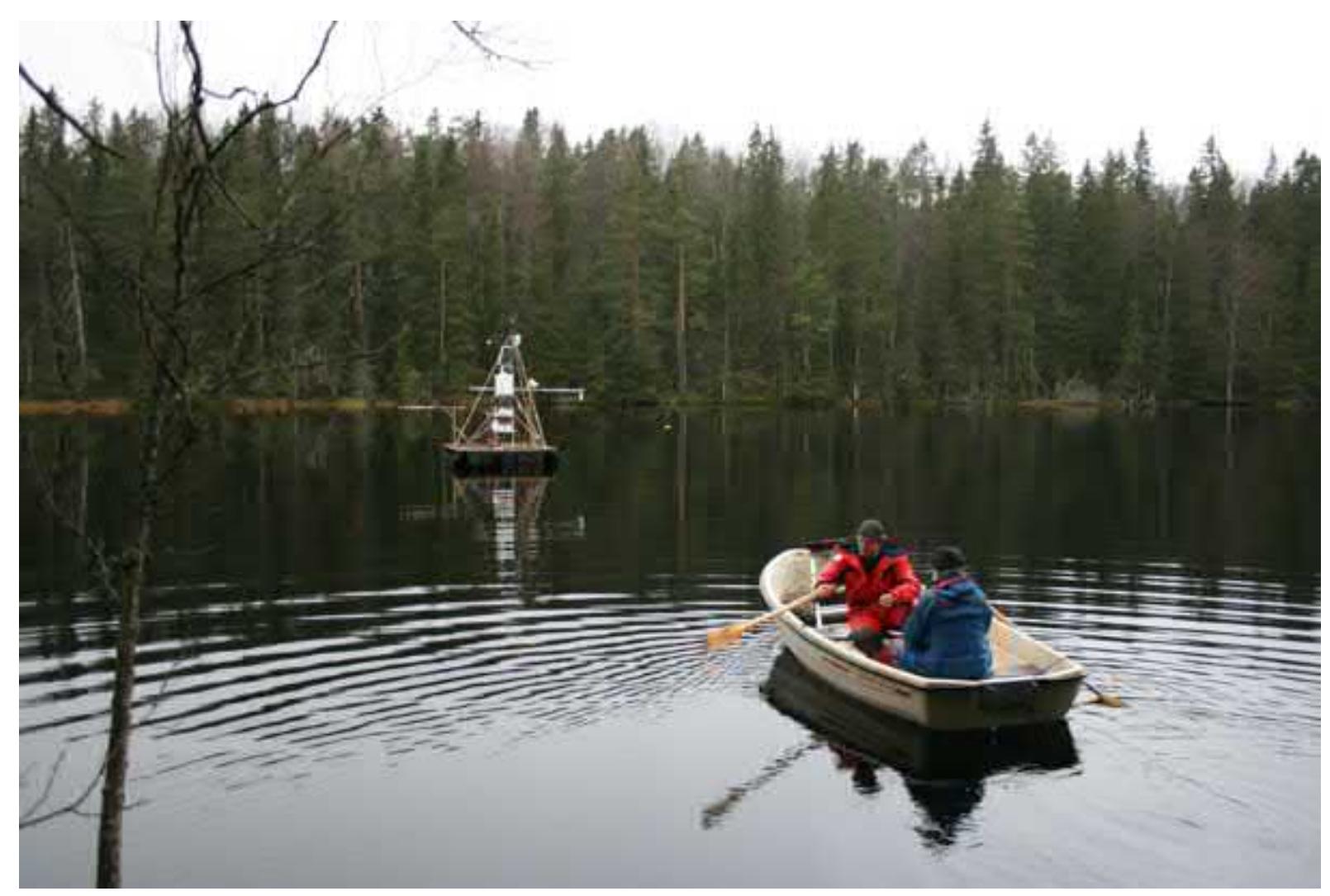

Kuva 1-4. Evon Valkea-Kotinen valuma-alueineen on ollut merkittävä hydrologinen tutkimuskohde 1980-luvulta lähtien. Se edustaa pieniä boreaalisia humusjärviä. Tässä ollaan menossa huoltokäynnille tutkimuslautalle. Kuva: Matti Leppäranta.

Tässä kirjassa esitetään hydrologian perusteet painottaen Suomen olojen keskeisiä kysymyksiä. Kohderyhmänä ovat hydrologian sekä muiden akvaattisten tieteiden opiskelijat. Kirjassa käytetään opetuksen tukena sovellettua hieman lukiotason ylittävää matematiikkaa, mutta itse asian ymmärtämisen kannalta matemaattinen osaaminen ei ole välttämätöntä. Kirjan liite sisältää tukitietoa lyhyen matematiikan pohjalta kurssia opiskeleville. Hankalissa kohdissa voi tukeutua sanalliseen esitykseen.

Luvussa 2 esitellään lyhyesti hydrologian tutkimusmenetelmiä ja esimerkkejä niiden soveltamisesta. Näitä perustietoja tarvitaan myöhemmissä luvuissa. Kolmas luku käsittelee 
vettä kemiallisena yhdisteenä ja veden fysikaalisia ja laadullisia ominaisuuksia. Veden kiertokulku peruskäsitteineen esitetään tässä luvussa. Yksityiskohtia lisätään siihen vähitellen, ja kokonaiskuva seuraa kirjan loppupuolella. Luku 4 sisältää hydrometeorologian eli sateen ja haihtumisen, ja sen yhteydessä käsitellään lisäksi lumihydrologia. Luvuissa 5 ja 6 tarkastellaan pintavesiä. Järvien hydrologia sisältää vesivarastokysymyksen lisäksi järvien sisäistä lämpöoppia ja dynamiikkaa sekä veden laatua, ja jokien hydrologia keskittyy virtaaman muodostukseen sekä virtauksen aiheuttamaan eroosioon ja aineskuljetukseen. Luvun 7 aiheena on geohydrologia, joka tarkastelee maanpinnan alaisten vesien liikkeitä ja esiintymistä sekä osallistumista hydrologiseen kiertokulkuun. Luku sisältää maa- ja pohjavedet sekä maaperän lämpötalouden ja roudan muodostuksen. Jäätikköhydrologia on myös otettu siihen mukaan. Kahdeksas luku on edellä opittua hydrologiaa kokoava ja käsittelee valuntaa hydrologisessa kierrossa sekä valuntamalleja. Luvussa 9 vielä tarkastellaan vesivarojen tulevaisuutta ympäristö- ja ilmastokysymysten valossa. Lopussa on vielä kokoelma harjoitustehtäviä ja liite kurssilla tarvittavan matematiikan perusteista. 



\section{Hydrologian tutkimusmenetelmät}

Tässä luvussa käydään läpi hydrologian tutkimuksessa käytettäviä menetelmiä. Näitä elävöitetään hydrologian kysymyksiin liittyvien esimerkkien avulla. Menetelmät on jaettu neljään kategoriaan: maastotyöt, tilastollinen hydrologia, dimensioanalyysi ja mallit. Maastomittausten ja tilastollisten analyysien avulla on perinteisesti koetettu ratkaista hydrologian tehtäviä. Dimensioanalyysille on omistettu oma kohtansa, sillä se on voimakas ja suhteellisen helppo lähestymistapa tutkittaessa empiirisiä laskentamenetelmiä ja niiden fysikaalisia perusteita. Matemaattisista ja fysikaalisista malleista keskustellaan pintapuolisesti tarkoituksena kertoa niiden perusajatuksista ja soveltamisesta. Matemaattista aputietoa lyhyen matematiikan pohjalta opiskeleville löytyy kirjan liitteestä. Matemaattisten ja tilastollisten menetelmien perusteet hallitseva opiskelija voi tämän luvun sivuuttaa.

\subsection{Maastomittaukset}

Hydrologiset kysymykset ja järjestelmät ovat yleensä monimutkaisia johtuen maaston topografian, maaperän laadun, maankäytön, kasvillisuuden ja sään vaihteluista. Tämän takia teoreettisten menetelmien ja matemaattisten mallien käyttö voi olla ongelmallista. Oikeaa tietoa saadaan vain luonnossa tehtyjen mittausten avulla, ja sitä voidaan myös käyttää laskennallisten menetelmien ja mallien kalibroinnissa ja kontrolloinnissa. Maastotyöt muodostavat hydrologisten tutkimusten ytimen (kuva 2-1). Niiden kustannukset ovat merkittäviä, minkä takia maastotuloksia on olemassa sangen rajoitetusti.

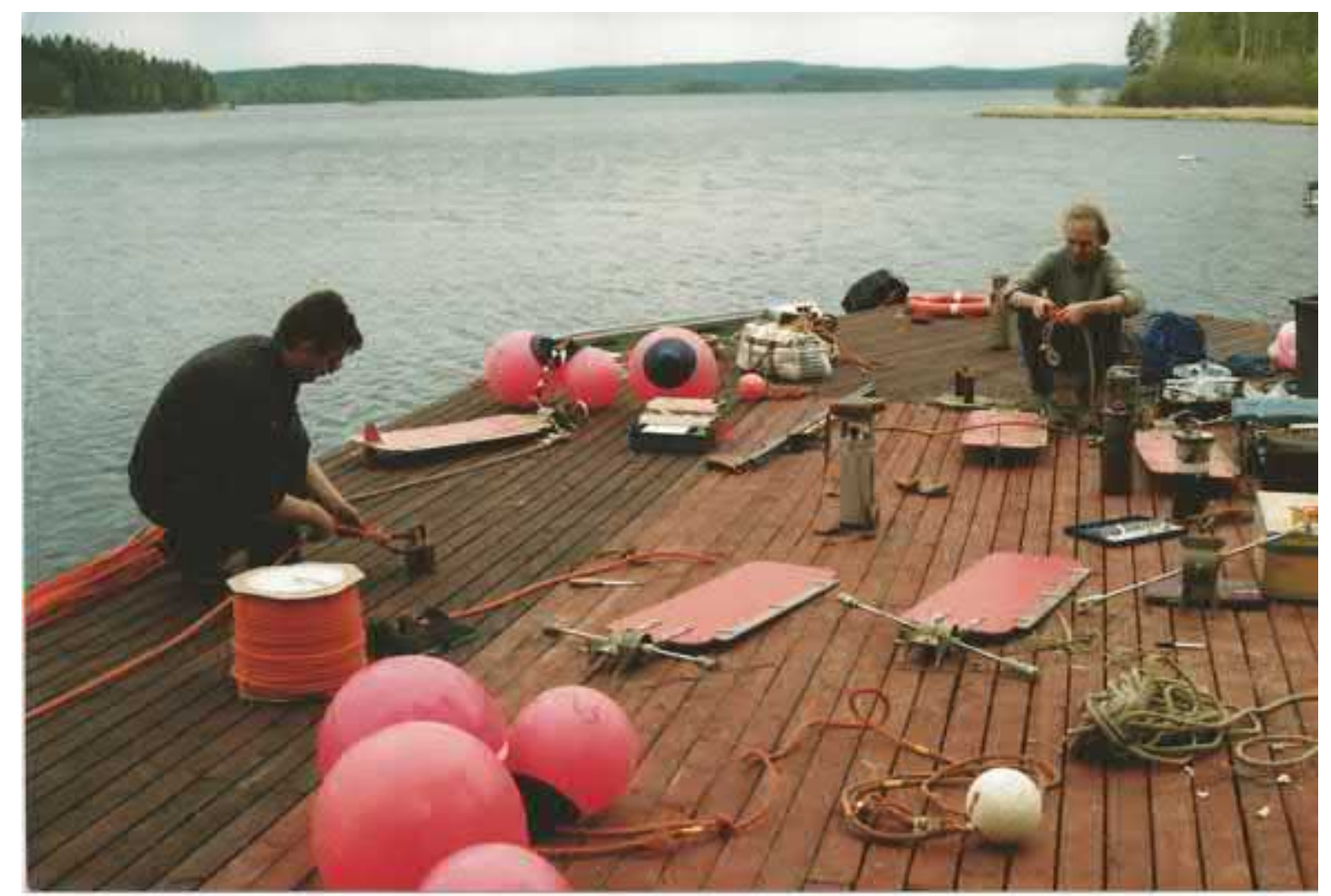

Kuva 2-1. Rekisteröivän virtausmittauskaluston valmistelua Keski-Päijänteellä kesällä 1987. Kuvassa Timo Huttula (etualalla) ja Jorma Koponen. Kuva: Juhani Virta. 
Viranomaiset ovat perustaneet hydrologisia seurantajärjestelmiä vesivarojen käyttöä ja suojelua varten. Mittaukset tehdään osin automaattisin ja osin manuaalisin menetelmin (kuva 22). Suomen ympäristökeskuksen (SYKE) laajaan seurantajärjestelmään kuuluvat seuraavat maastohavainnot:

Suure
lumen paksuus ja vesiarvo
vedenkorkeus
järvien tila
jokien tila
pohjaveden tila
routa

\author{
Mittausstrategia \\ lumiasemat ja lumilinjat \\ limnigrafit \\ lämpötila, veden laatu, jääasemat \\ lämpötila, veden laatu, jääasemat \\ pinnankorkeus, veden laatu \\ esiintyminen, paksuus
}

Ilmatieteen laitos huolehtii Suomessa sademäärän mittauksista. Tätä varten on käytössä noin 200 sadeasemaa.

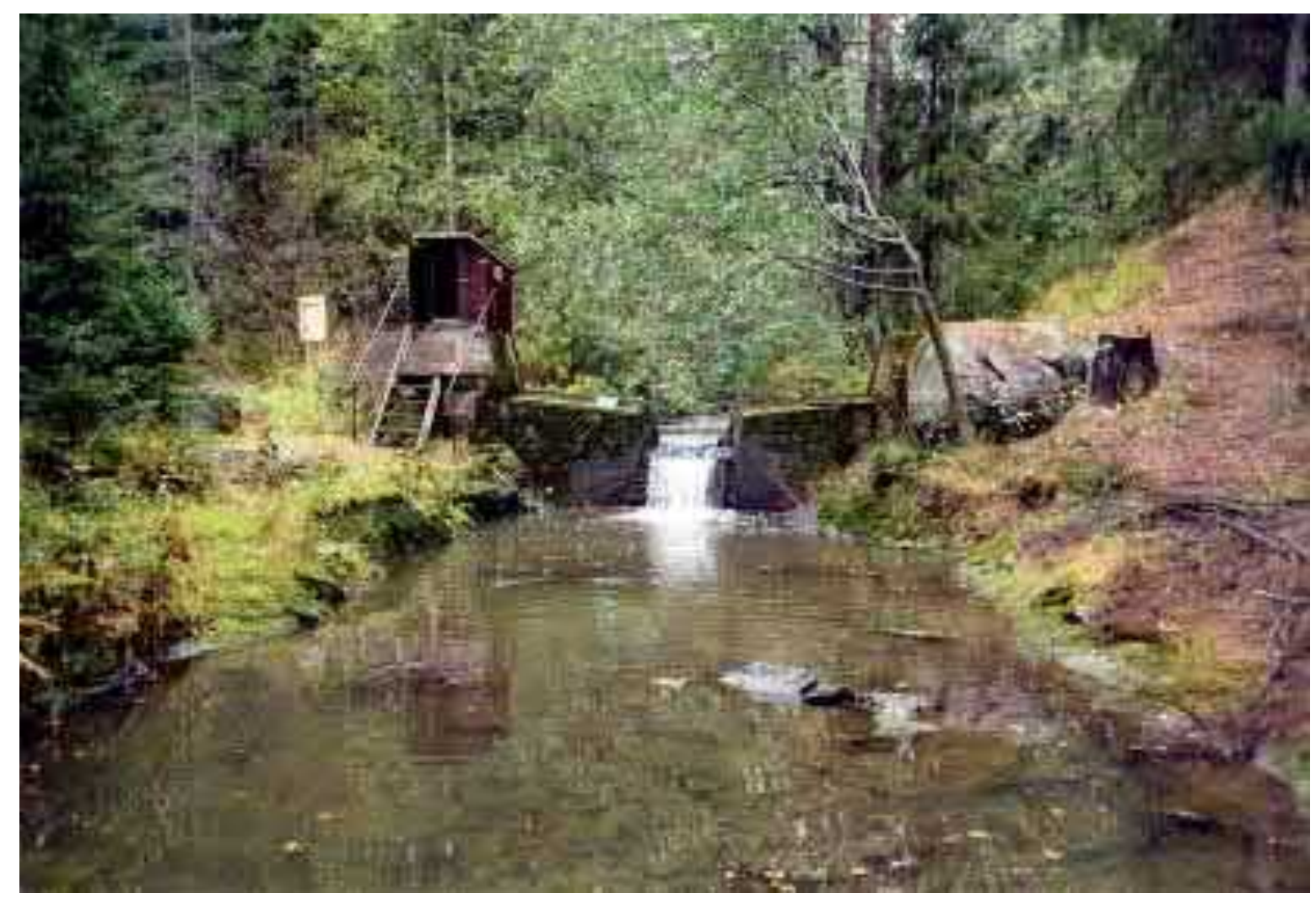

Kuva 2-2. Vuonna 1958 rakennettu Niittyjoen betoninen mittapato lähellä Kouvolaa. Mittapadon avulla voidaan määrittää virtaama vedenkorkeuseron perusteella. Valuma-alueen ala on $29,7 \mathrm{~km}^{2}$ ja keskivaluntaa $0,25 \mathrm{~m}^{3} \mathrm{~s}^{-1}$. Lähde: Suomen ympäristökeskus (Kuusisto 2008).

Vesivarojen tilan kehittyminen riippuu voimakkaasti sääoloista, minkä vuoksi operatiivisia säähavaintoverkostoja käytetään vesivarojen seurannan tukena. Hydrologisen tiedon lisäksi seurantajärjestelmä kertoo myös yhteiskunnallisista kysymyksistä kuten tulvien esiintymisestä sekä järvi- tai jokijään laadusta ja paksuudesta riippuvasta jäällä liikkumisen turvallisuudesta. Tarjolla on myös hydrologisiin malleihin perustuvia varoituksia ja ennusteita.

Erityisissä maastokokeissa kerätään tarkempia havaintosarjoja, joiden avulla selvitetään fysikaalisia suureita ja mekanismeja sekä haetaan menetelmiä ja parametreja ${ }^{1}$ hydrologisten

\footnotetext{
${ }^{1}$ Parametri tarkoittaa systeemin ominaisuutta, joka yksittäisessä tapauksessa voidaan kiinnittää vakioksi. Esimerkiksi jokivirran kitkakerroin voi toimia hydrologisen mallin yhtenä parametrina.
} 
havaintoverkostojen tarkempaan hyödyntämiseen. Tällaisia kokeita ovat esimerkiksi haihdunnan suorat mittaukset, järvien kiertoliike ja veden purkautuminen järvistä, jokien virtaama, pohjavesivaraston antoisuus ja lumen ominaisuuksien vaihtelut.

Kaukokartoitus tarkoittaa kohteen ominaisuuksien havaitsemista ilman kontaktia. Yleensä sillä ymmärretään ilmasta tai lähiavaruudesta sähkömagneettisiin signaaleihin perustuvia havaintomenetelmiä. Kartoitusta voidaan tehdä myös maanpinnalta. Esimerkiksi maanpinnalla liikuteltavan maatutkan avulla voidaan luodata maaperän kerrostuneisuutta ja veden esiintymistä. Vedenpinnan alla akustiset menetelmät toimivat hyvin ja niitä on käytetty järvien ja jokien pohjatopografian ja pohjasedimentin ominaisuuksien kartoitukseen.

Kaukokartoitusmenetelmien hydrologiset sovellukset ovat 1960-luvulta lähtien kasvaneet voimakkaasti (kuva 2-3). Ensin käytettiin ilma-aluksia, mutta viimeisen 30 vuoden aikana satelliitit ovat tulleet pääasialliseksi mittausalustaksi, kun satelliittihavaintojen paikallinen ja ajallinen erotuskyky ovat riittävästi parantuneet ja mittausten aallonpituusalue on laajentunut. Satelliitit havaitsevat maapallon pintaa sähkömagneettisten aaltojen avulla. Hydrologiassa hyödynnetään näkyvän valon $(0,4-0,7 \mu \mathrm{m})$, lähi-infrapunan $(0,7-1,0 \mu \mathrm{m})$, lämpökanavan $(5-15 \mu \mathrm{m})$ sekä mikroaaltojen $(1-100 \mathrm{~cm})$ ikkunoita. Niiden avulla nähdään maan ja veden pintaan mutta ei juurikaan pinnan alle.

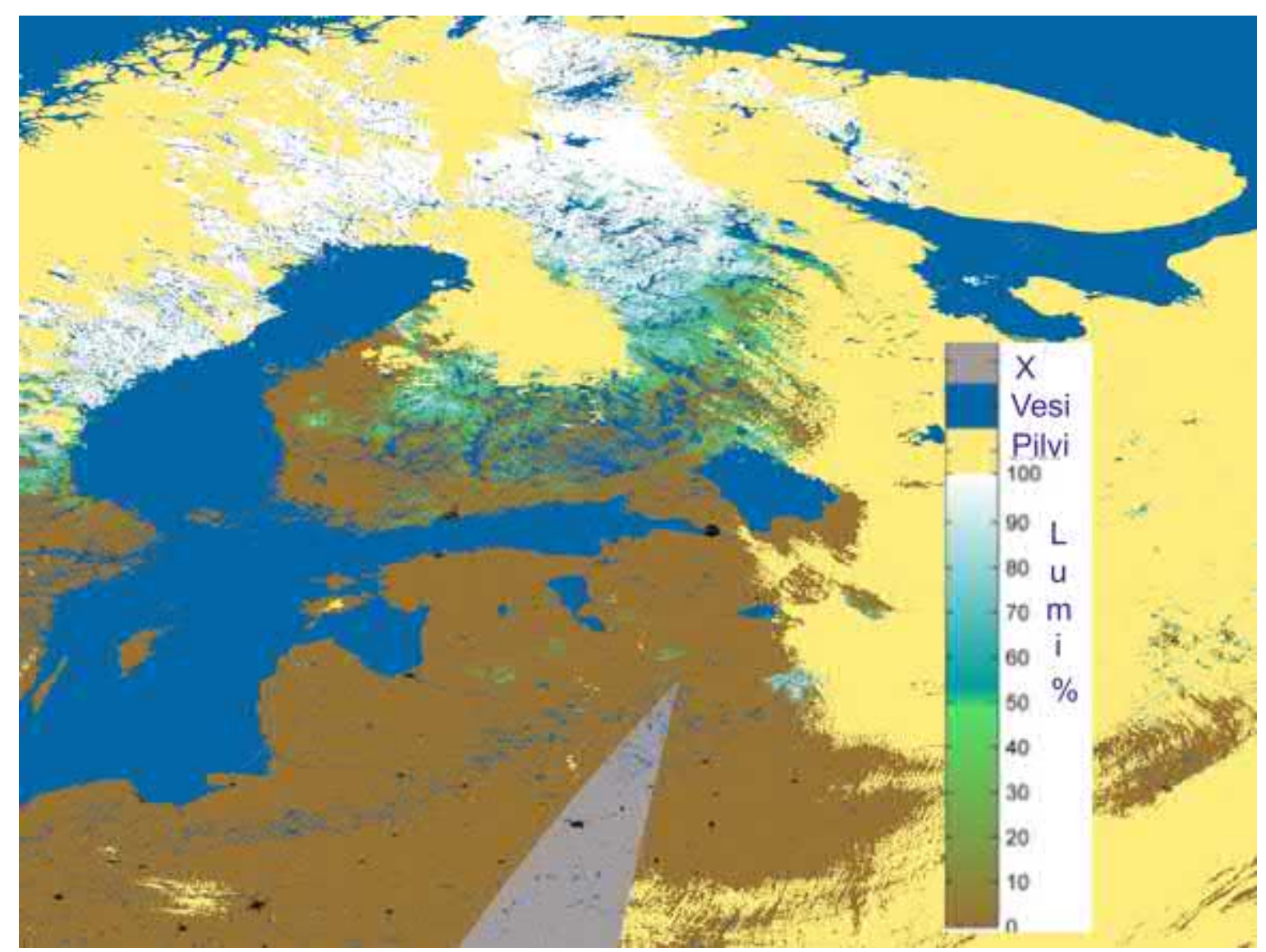

Kuva 2-3. Aqua/Terra satelliitin MODIS (Moderate Resolution Imaging Spectroradiometer) kuvan pohjalta tuotettu lumen peittävyys Pohjois-Euroopassa 21.4.2013. Sävyt ruskeasta valkoiseen kuvaavat lumen peittävyyttä $0-100 \%$ asteikolla, keltainen on pilveä ja sininen kuvaa vesialueita. Lähde: Suomen ympäristökeskus, alkuperäinen satelliittikuva @ NASA.

Kaukokartoitusmenetelmien hydrologisissa sovelluksissa lumipeitteen tutkimus ja seuranta ovat jo 1970-luvulta lähtien kuuluneet tärkeimpiin (Kuittinen 1988). Satelliitit näkevät lumi- 
peitteen laajuuden, mutta lumen paksuutta tai vesiarvoa voidaan vain epäsuorasti arvioida. Vuoden 2000 jälkeen myös korkean erotuskyvyn operatiivista satelliittidataa on tullut helposti saataville, mikä on laajentanut tosiaikaisten kartoitusten mahdollisuuksia. Järvien pintalämpötila, jääpeite ja leväkukinnot ovat näin tulleet mukaan sovellusalueisiin. Hydrologisten kaukohavaintoaineistojen tulkintaan liittyy kuitenkin epävarmuutta, eivätkä ne kovinkaan pian pysty syrjäyttämään perinteisiä havaintoverkostoja.

\subsection{Tilastollinen hydrologia}

\subsubsection{Klassinen tilastotiede}

Klassisella tilastotieteellä tarkoitetaan yhdestä tai useammasta satunnaismuuttujasta kerättyjen riippumattomien havaintojen tutkimista. Tämä sisältää muuttujien jakaumien selvittämistä, parametrien estimointia, hypoteesien testausta ja havaintojoukkojen vertailua. Usein riippumattomiin havaintoihin päästään tarkastelemalla muutoksia tai riittävän pitkiä aikakeskiarvoja. Monimuuttuja-analyysissä tutkitaan satunnaismuuttujien välisiä riippuvuuksia. Vastaus $X: n$ ja $Y: n$ riippuvuudesta voidaan saada kysymällä "jos tiedän $X: n$ arvon, antaako se mitään lisätietoa $Y: n$ arvosta". Riippuvuuksien löytäminen tarjoaa mahdollisuuksia arvioiden ja ennusteiden tekemiseen. Tilastollinen riippuvuus tarkoittaa yhteyksiä suureiden esiintymisessä mutta ei fysikaalisia syy-seuraus suhteita. Tilastollisten menetelmien soveltamiseksi on olemassa paljon kirjallisuutta (esimerkiksi Heino ym. 2012) ja hyviä tilasto-ohjelmia kuten Excel, R, SPSS, SAS ja Matlab.

Esimerkki 2-1. a) Järvien vedenkorkeus noudattaa vuotuista kulkua, jossa peräkkäisten kuukausien keskiarvot ovat riippuvaisia toisistaan, mutta poikkeamat keskimääräisistä kuukausiarvoista tai muutokset kuukaudesta toiseen ovat korkeintaan heikosti riippuvia. Samoin maaperän pintalämpötilat ainakin noin kuukauden sisään ovat riippuvia toisistaan mutta niiden vuosikeskiarvot eivät enää ole.

b) Peräkkäisten viikkojen lottoarvonnat ovat riippumattomia toisistaan, olettaen että lottokone on kunnossa eli poimii pallot satunnaisesti. Niinpä vanhat lottorivit eivät anna mitään informaatiota tulevista.

c) Keväällä jäätelön myynti ja peipposten lukumäärä ovat ilmeisesti tilastollisesti riippuvia, mutta syyseuraus suhdetta näiden suureiden välillä ei ole.

d) On ajateltavissa, että pintavirtauksen nopeus riippuu tuulen nopeudesta. Havaintojen avulla voidaan määrittää siihen täsmällisempi yhteys sovelluksia varten.

Tilastolliset suureet jaetaan niiden mitta-asteikon mukaan neljään kategoriaan, joissa kussakin vain tietyt aritmeettiset operaatiot ovat sallittuja:

\section{Asteikko}

nominaaliasteikko

järjestysasteikko

intervalliasteikko

absoluuttinen asteikko

\section{Sallitut operaatiot} kokonaismäärät luokittain

järjestäminen yhteen- ja vähennyslasku kaikki aritmeettiset operaatiot

\author{
Esimerkki \\ maastotyypit \\ jokien suuruusjärjestys \\ lämpötila (Celsius-asteikko) \\ nopeus
}

Nominaaliasteikon suureilla on nimet, ja ainoastaan näiden esiintymistiheyksiä voidaan tarkastella. Suureita ei voida asettaa järjestykseen. Ihmisjoukon nimet muodostavat tällaisen asteikon. Voidaan tarkastella nimien esiintymistiheyksiä ja määrittää moodi yleisimpänä nimenä. Perimätiedon mukaan kiinalainen nimi $L i$ on sukunimien globaali moodi. Järjestysasteikon suureet voidaan laittaa suuruusjärjestykseen, mutta niiden välisiä eroja ei voida mitata. 
Tästä on hyvänä esimerkkinä Seinäjoen tangomarkkinat, joilla laulajat asetetaan paremmuusjärjestykseen. Järvet voidaan luokitella usean indikaattorin avulla laatujärjestykseen.

Intervalliasteikon ja absoluuttisen asteikon suureilla on numeerisia arvoja, mutta niillä on yksi olennainen ero. Absoluuttiasteikko sallii kaikki aritmeettiset operaatiot, mutta intervalliasteikolla voidaan ainoastaan laskea yhteen ja vähentää. Lämpötila on hyvä esimerkki näistä. Anders Celsiuksen (1701-1744) esittämä Celsius-asteikko on intervalliasteikko, ja William Thompsonin eli lordi Kelvinin (1824-1907) Kelvin-asteikko on absoluuttinen. Absoluuttisia asteikoita ovat myös massan ja nopeuden tavanmukaiset asteikot.

Esimerkki 2-2. Hydrologiassa sangen tärkeä intervalliasteikko on lämpötilan Celsius-asteikko. Siinä lämpötilaeroja voidaan tarkastella, mutta niitä ei voida suhteuttaa. Niinpä jos lämpötila muuttuu arvosta $5{ }^{\circ} \mathrm{C}$ arvoon $6{ }^{\circ} \mathrm{C}$, voidaan sanoa, että lämpötilan on noussut $1{ }^{\circ} \mathrm{C}$, mutta toteamus "lämpötila kasvoi $20 \%$ " ei ole mielekäs. Kelvin-asteita käyttämällä voitaisiin sanoa, että lämpötila on noussut $0,36 \%$, mutta se ei arkikokemukseen sovellettuna ole kovin havainnollista.

Satunnaismuuttujat noudattavat erilaisia jakaumia, joiden tunteminen on tilastollisen analyysin perusta. Jakauma kuvaa muuttujan arvojen todennäköisyyksiä ja voidaan esittää histogrammina tai tiheysfunktiona, jossa muuttujan arvot ovat vaaka-akselilla ja vastaavat todennäköisyydet pystyakselilla. Järjestysasteikkoon histogrammi ei kuitenkaan ole mielekäs. Intervalli- ja absoluuttiasteikolle on olemassa useita teoreettisia jakaumia, joissa on avoimia parametreja.

Tilastotieteessä käytetään sangen laajasti normaalijakaumaa eli Gaussin jakaumaa. Tilasto-ohjelmien tarjoamat tilastomuuttujien luotettavuusrajat sekä testit perustuvat tavallisesti Gaussin jakauman oletukseen, joten on tärkeätä tietää, onko jakauman käyttö perusteltua. Sen todennäköisyystiheys $p$ kirjoitetaan

$$
p(x)=\frac{1}{\sqrt{2 \pi} \sigma} \exp \left[-\frac{1}{2 \sigma^{2}}(x-\mu)^{2}\right]
$$

missä $x$ on tarkasteltavan satunnaismuuttujan arvo, $\mu$ on keskiarvo eli odotusarvo ja $\sigma$ on hajonta ( $\sigma^{2}$ on varianssi). Tämä jakauma on symmetrinen keskiarvon suhteen ja kirkonkellon muotoinen (kuva 2-4a). Hajonta kuvaa, kuinka tiiviisti arvot ovat asettuneet keskiarvon ympärille. Hyödyllinen sääntö on, että väli $\mu \pm 2 \sigma$ sisältää $95 \%$ jakauman todennäköisyys-massasta.

Todennäköisyys $P[a, b]$, että muuttujan arvo on välillä $[a, b]$, saadaan integroimalla tiheys tämän välin ylitse: $P[a, b]=\int_{a}^{b} p(x) d x$. Gaussin jakaumaa ei voi suljetussa muodossa integroida, mutta sen arvoja on ohjelmistoista ja taulukoista helposti saatavissa. Todennäköisyyslaskennan keskeisen raja-arvolauseen mukaan riittävän säännöllisesti jakautuneiden suureiden otokset lähestyvät Gaussin jakaumaa, kun otoskoko kasvaa.

Intervalli- ja absoluuttiasteikon tapauksessa voidaan myös konstruoida fraktiileja $x_{p}$, jotka määritellään seuraavasti:

$$
x_{p}: P\left(X \leq x_{p}\right)=p
$$

missä $X$ on tarkasteltava suure. Siispä $p$-fraktiili $x_{p}$ on raja, jota pienempi $x$ on todennäköisyydellä $p$. Esimerkiksi fraktiilia $x_{0,1}$, joka voi edustaa suureen käytännöllistä alarajaa, pienempi $X$ on todennäköisyydellä 0,1 . Fraktiileja käytetään esimerkiksi maahiukkasten kokojakaumien kuvauksessa ja ääriarvojen analyysissä (kuva 2-4b). Jakauman mediaani on sen 
keskimmäinen arvo, niin että $P\left(X \leq x_{m d}\right)=P\left(X \geq x_{m d}\right)=\frac{1}{2}$. Fraktiili $x_{0,5}$ esittää mediaania suoraan määritelmän mukaan.

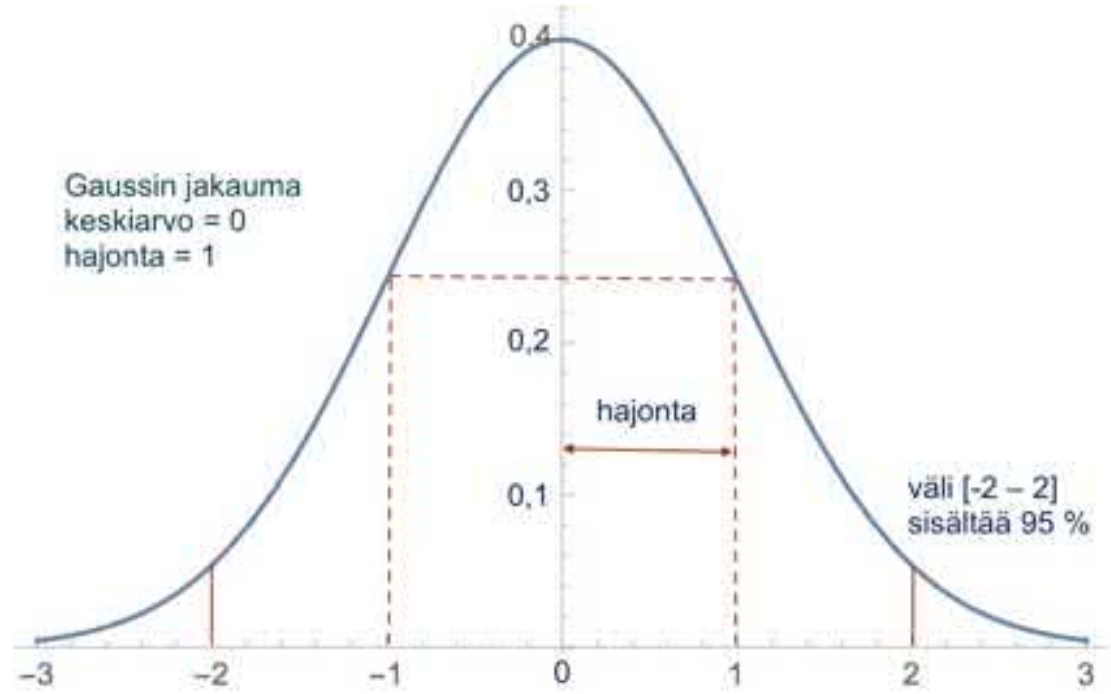

Kuva 2-4a) Gaussin jakauma, jonka keskiarvo on $\mu=0$ ja hajonta $\sigma=1$.

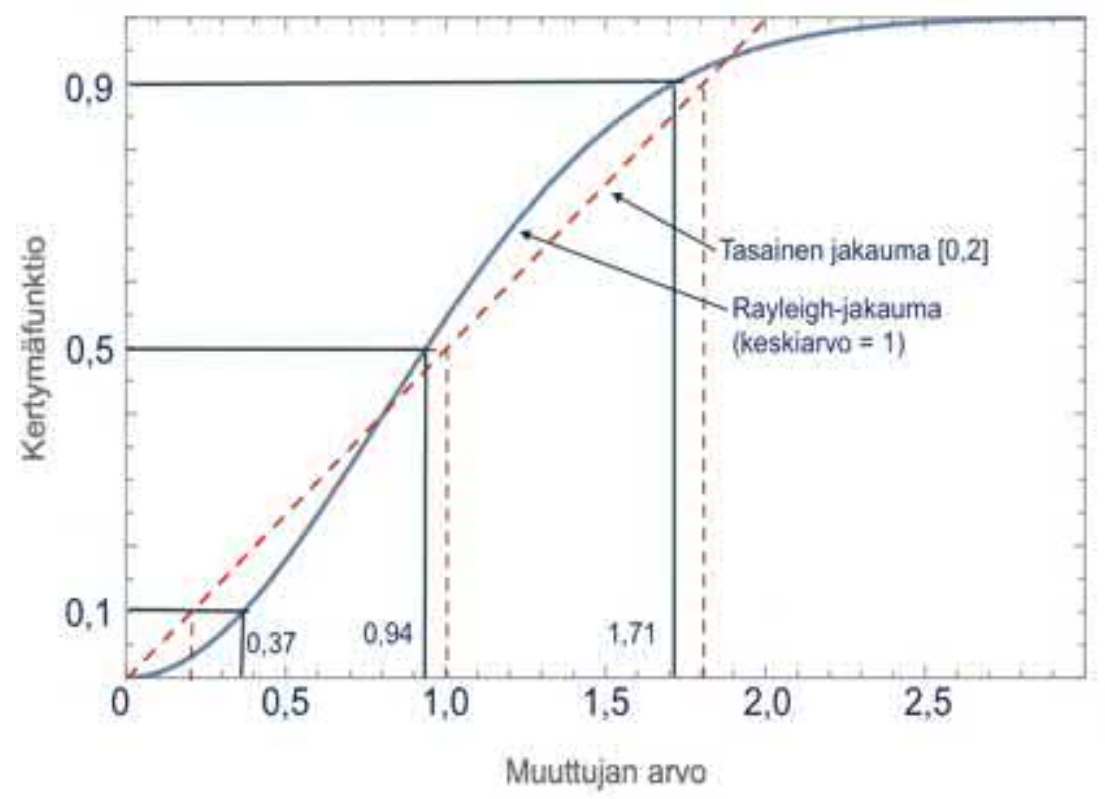

Kuva 2-4b) Fraktiilien määritys todennäköisyyden kertymäfunktiosta. Tässä esimerkissä on merkitty $0,1,0,5$ ja 0,9 fraktiilit Rayleigh-jakauman (yhtenäinen viiva) ja tasaisen jakauman (katkoviiva) tapauksissa. Jakaumat on normitettu niin, että niiden keskiarvo $=1$. Tämän Rayleigh-jakauman todennäköisyystiheys on $p(x)=\frac{\pi}{2} x \exp \left(-\frac{\pi}{4} x^{2}\right), x>0$, ja tasaisen jakauman $p(x)=0,5,0 \leq x \leq 2$.

Esimerkki 2-2. Laajasti käytössä on eksponentiaalinen jakauma, jonka tiheysfunktio on $p(x)=$ $\lambda e^{-\lambda x}$. Tällä on maksimi origossa, ja funktio laskee monotonisesti $x$ :n kasvaessa. Jakauma voi kuvata esimerkiksi harvinaisten tapausten esiintymistä, silloin $x$ on edellisestä tapahtumasta kulunut aika. Asiakkaan jonotusaikaa on myös tällä funktiolla kuvattu, parametri $\lambda$ kuvaa silloin liikkeen toimintastrategiaa. Tiheysfunktio voidaan suoraan integroida, ja todennäköisyys, että muuttujan arvo on pienempi kuin $x$, on $1-e^{-\lambda x} \cdot x_{\mathrm{p}}$-fraktiili saadaan yhtälöstä $p=1-e^{-\lambda x_{p}}$.

Tilastollisissa jakaumissa on tunnuslukuja, joiden arvot on estimoitava. Näitä ovat esimerkiksi keskiarvo eli odotusarvo, hajonta sekä minimi ja maksimi. Vaikka tiedettäisiin, että 
Gaussin jakauma sopii annettuun aineistoon, jakauman odotusarvo ja varianssi on määritettävä havainnoista. Estimaattorin tärkeimmät kriteerit ovat harhattomuus eli odotusarvo on sama kuin haettava tunnusluku ja tarkkuus eli mahdollisimman pieni hajonta. Odotusarvon ja varianssin optimiestimaattorit ovat

$$
\bar{x}=\frac{1}{n} \sum_{k=1}^{n} x_{k}, s^{2}=\frac{1}{n-1} \sum_{k=1}^{n}\left(x_{k}-\bar{x}\right)^{2},
$$

missä $x_{1}, \ldots, x_{n}$ muodostavat havaintojoukon. Varianssissa neliösumman jakajana on $n-1$ johtuen siitä, että keskiarvoa laskettaessa menetetään yksi vapausaste ${ }^{2}$ ja riippumattomia keskiarvopoikkeamia on $n-1$ kappaletta. Varianssia käytetään tilastollisissa analyyseissa sen matemaattisten ominaisuuksien takia. Tärkeä tilastotieteen raja-arvotulos on suurten lukujen laki. Sen mukaan otoskeskiarvo lähestyy odotusarvoa, kun havaintojen lukumäärä $n$ kasvaa, ja otoskeskiarvon hajonta ${ }^{3}$ on $s / \sqrt{n}$. Hajonnan laatu on sama kuin itse suureen laatu, ja sen vuoksi sitä käytetään kuvaamaan vaihtelua.

Hydrologisessa tutkimuksessa on usein arvioitava ääriarvoparametreja kuten 50 tai 1000 vuoden aikana esiintyvä maksimitulva (vedenkorkeus). Ääriarvojen analyysiä ja ekstrapolointia varten on olemassa oma tilastotieteen haaransa. Yleisesti, jos satunnaismuuttujasta $X$ on $n$ riippumatonta havaintoa $x_{1}, \ldots, x_{\mathrm{n}}$, maksimin jakauma saadaan itse muuttujan jakaumasta

$$
P\left(\max X_{k} \leq x\right)=P\left(X_{k} \leq x\right)^{n} .
$$

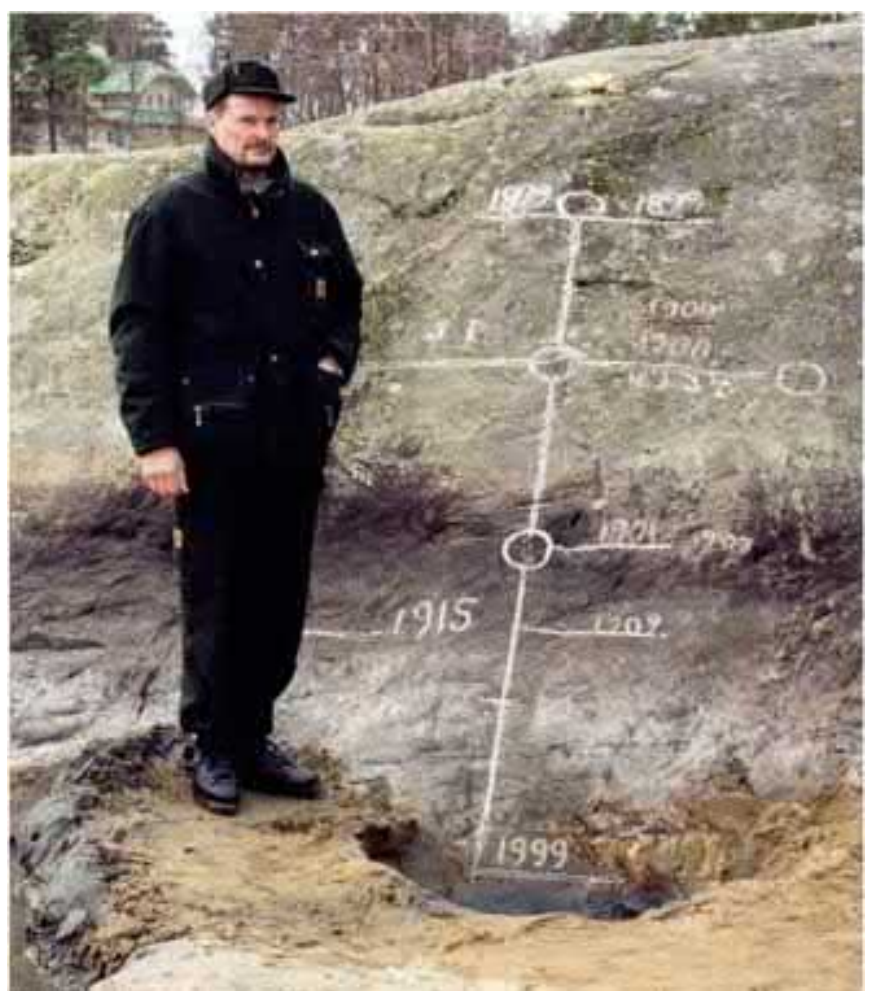

Kuva 2-5. Kallavedellä on taltioitu vedenkorkeuden historiaa rantakallioon. Vuoden 1899 suurtulva on selvästi ylin. Lähde: Suomen ympäristökeskus (Kuusisto 2008). Aaro Jalkasen kuuluisa Kallavesj runo kertoo järvien merkityksestä koko elämän kirjossa: Kallavesj, Kallavesj, järviij järvi, siinä pesj/äet mun paetanj monta kertoo,/isä särillep pitj mertoo,/veljmies salloo tuulastelj, tiirustelj, riijustelj.

\footnotetext{
${ }^{2}$ Klassisessa tilastotieteessä vapausaste tarkoittaa lineaarisesti riippumattomien havaintojen lukumäärää.

${ }^{3}$ Otoskeskiarvon hajontaa on kutsuttu myös nimellä 'otoskeskiarvon keskivirhe'.
} 
Esimerkki 2-3. Pienen joen sillalla maksimi vedenkorkeus $X$ kevättulvien aikana olkoon jakaantunut tasaisesti $0-5 \mathrm{~m}$ välille keskiveden yläpuolelle. Todennäköisyyden kertymäfunktio on silloin $P(X \leq x)=0,2 \cdot x$ ja edelleen

$$
P\left[\max \left(X_{k} ; 1 \leq k \leq n\right) \leq x\right]=(0,2 \cdot x)^{n} .
$$

Tästä nähdään, että maksimi on korkeintaan $4 \mathrm{~m}$ todennäköisyydellä 0,33 , kun $n=5$, tai 0,11 , kun $n=$ 10. Usein kysytään myös ääriarvoa $x_{\max }$, jolla $P\left(\max X_{k} \leq x_{\max }\right)=P^{*}$. Tämä saadaan eo. todennäköisyyden lausekkeesta: $x_{\max }=5 \sqrt[n]{P^{*}}$. Kun $P^{*}=0,9$ ja $n=5$ (10), on $x_{\max }=4,90 \mathrm{~m}(4,94 \mathrm{~m})$. Tasainen jakauma on epärealistinen tähän ääriarvotehtävään, mutta se kuvaa menetelmän käyttöä.

Ääriarvotarkasteluissa harvinaiset havaitut tapahtumat ohjaavat jakaumien arviointia. Niiden esiintymiset ovat poikkeavia tilanteita, ja jakaumien ominaisuuksiin ääriarvoalueella liittyy paljon epävarmuutta. Esimerkiksi vuosien 1898-1899 suurtulva Suomessa oli huomattava poikkeus normaalista, ja siitä on tehty kalliomerkintöjä eri puolilla Etelä-Suomea (kuva 2-5). Käytännössä usein ääriarvojen toistuvuutta on ekstrapoloitava havaintosarjaa pidemmälle aikajaksolle. Olemassa olevaan aineistoon sovitetaan jakauma, jonka avulla tällainen arviointi voidaan tehdä, mutta ekstrapolointi tuo tuloksiin merkittävästi lisää epävarmuutta. Gaussin jakauma jatkuu äärettömään positiivisella ja negatiivisella akselilla, mutta hydrologisissa järjestelmissä on fysikaalisista ehdoista seuraavia ylä- ja alarajoja, joita tarkasteltava suure lähestyy aina pienevin todennäköisyyksin. Näitä ylä- ja alarajoja ei tosin kovin hyvin tiedetä. On osoittautunut, että Gaussin jakauma ei yleensä sovellu hyvin ääriarvojen tarkasteluun, vaan tätä varten on erityisiä ääriarvojakaumia (kuva 2-6).

Satunnaismuuttujien välisiä riippuvuuksia tarkastellaan yleensä korrelaatioanalyysin avulla. Korrelaatiokerroin $\left(r_{X y}\right)$ on muuttujien $X$ ja $Y$ kovarianssi $s_{x y}$ jaettuna hajonnoilla:

$$
r_{x y}=\frac{s_{x y}}{s_{x} s_{y}}, s_{x y}=\frac{1}{n-1} \sum_{k=1}^{n}\left(x_{k}-\bar{x}\right)\left(y_{k}-\bar{y}\right)
$$

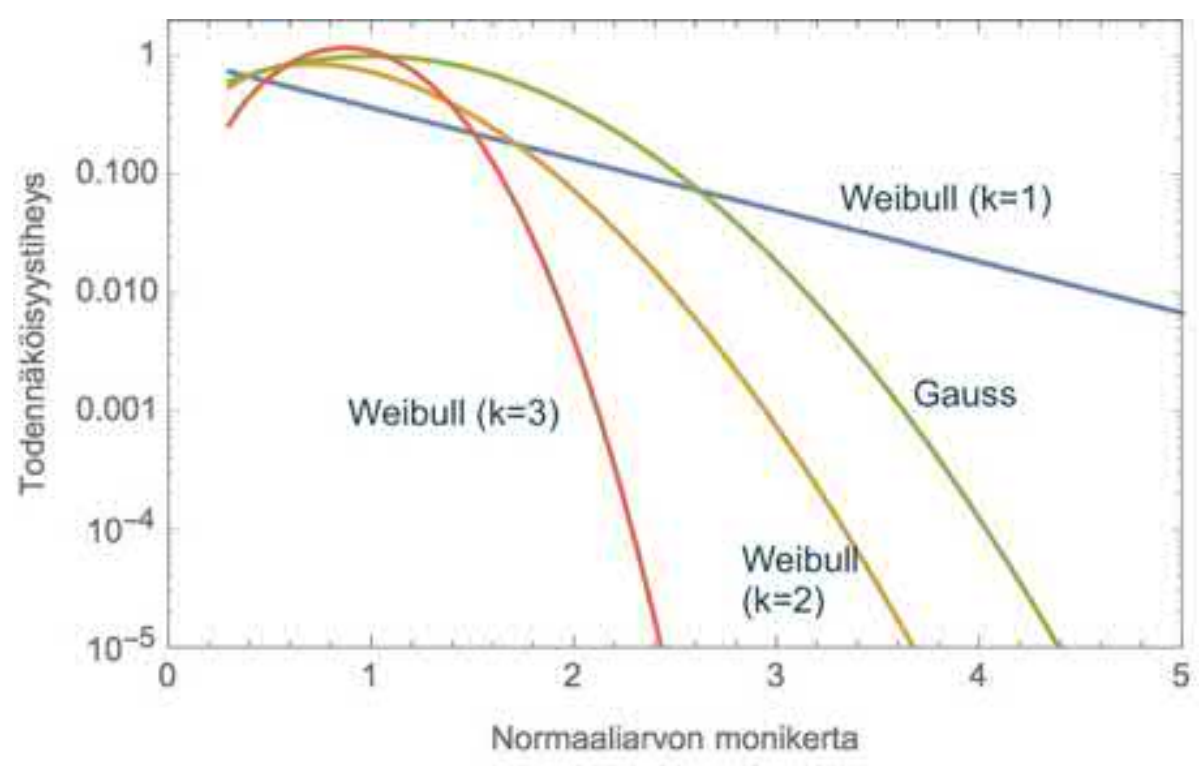

Kuva 2-6. Weibullin ääriarvojakauma ja sen vertaus Gaussin jakaumaan. Tässä normaaliarvo viittaa keskiarvon suuruusluokkaan, ja esimerkiksi monikerta $=3$ kertoo missä todennäköisyystiheys on, kun muuttujan arvo on normaaliarvosta kolminkertaistunut. Kun Weibullin k-parametri kasvaa, jakauma yhä nihkeämmin sallii suurten arvojen esiintymisen. Näiden jakaumien tiheysfunktiot ovat seuraavat: Weibull $=\frac{k}{a}\left(\frac{x}{a}\right)^{k-1} \exp \left[-\left(\frac{x}{a}\right)^{k}\right]$ ja Gauss $=\frac{1}{\sqrt{2 \pi} \sigma} \exp \left[-\frac{(x-\mu)^{2}}{2 \sigma^{2}}\right]$. 
On syytä muistaa, että korrelaatio mittaa vain lineaarista riippuvuutta. Jos esimerkiksi $X^{2}+Y^{2}$ $\approx 1, X$ ja $Y$ ovat voimakkaasti toisistaan riippuvia mutta niiden välinen korrelaatio on nolla. Riippuvuuksia voidaan kvantifioida regressioanalyysin avulla, jolloin tarkastellaan suhteita

$$
Y=F\left(X_{1}, X_{2}, \ldots, X_{m} ; a_{1}, a_{2}, \ldots, a_{p}\right)+\mathcal{E},
$$

missä $a_{1}, a_{2}, \ldots, a_{p}$ ovat suhteen parametrit ja $\varepsilon$ on havaintopisteeseen liittyvä poikkeama. Suuretta $Y$ kutsutaan selitettäväksi muuttujaksi ja suureita $X_{k}$ selittäviksi muuttujiksi. Hyvin paljon käytetään lineaarista regressiota, joka kahden muuttujan tapauksessa tarjoaa yhtälön

$$
Y=a+b X+\varepsilon
$$

Tämä menetelmä kulkee myös nimellä pienimmän neliösumman menetelmä johtuen siitä, että sovituksessa minimoidaan virhetermin varianssi eli havaintopisteiden poikkeamien neliöt regressiosuorasta. Suureet $X$ ja $Y$ voivat olla myös muunnettu alkuperäisestä kuten $X^{\mathrm{n}}$, kun vain yhtälö on lineaarinen estimoitavien parametrien $a$ ja $b$ suhteen. Erityisesti jos hypoteettinen riippuvuus on $Y=a e^{b X}$, tämä voidaan linearisoida muotoon $\log Y=\log a+b X$, ja vastaavasti $Y=a X^{b}$ voidaan linearisoida muotoon $\log Y=\log a+b \log X$.

Esimerkki 2-4. a) Usein tiedetään, että $X$ ja $Y$ ovat toisiinsa verrannollisia eli $a=0$. Tällöin voidaan kerroin $b$ arvioida tarkemmin käyttäen reunaehtoa $a=0$. Pienimmän neliösumman menetelmässä määritetään parametri $b$ siten, että virheiden neliöiden summa $\sum_{k}\left(y_{k}-b x_{k}\right)^{2}$ saavuttaa miniminsä. Ratkaisu on $b=s_{x y} / s_{x}^{2}$.

b) Regressioanalyysissa usein halutaan tietää estimoitujen regressiokertoimien tarkkuus. Kahden muuttujan mallin (yhtälö 2.7) tapauksessa kertoimien $a$ ja $b$ kovarianssimatriisi on

$$
\operatorname{Cov}(a, b)=\sigma_{\varepsilon}^{2}\left(\begin{array}{cc}
n & \sum x_{i} \\
\sum x_{i} & \sum x_{i}^{2}
\end{array}\right)^{-1}
$$

missä $\sigma_{\varepsilon}^{2}$ on virheen $\varepsilon$ varianssi.

Hypoteesien testauksessa asetetaan nollahypoteesi $H_{0}$, joka vastaa yleistä käsitystä tai vallitsevaa tilannetta, ja sen vaihtoehtohypoteesi $H_{1}$. Päätöstaulu on silloin seuraavanlainen:

\begin{tabular}{rlll} 
Tosi & & $\boldsymbol{H}_{0}$ & $\boldsymbol{H}_{1}$ \\
\hline Hyväksytään & $H_{0}$ & oikein & virhe II \\
Hyväksytään & $H_{1}$ & virhe I $(P)$ & oikein
\end{tabular}

Tilastollisen analyysin avulla selvitetään, hyväksytäänkö vai hylätäänkö $H_{0}$. Jos $H_{0}$ hylätään, vaikka se pitää paikkaansa, tapahtuu virhe I. Tämän todennäköisyys on testin merkitsevyysraja $P$, ja se säädetään pieneksi. $5 \%$ tasoa pidetään tilastollisesti merkitsevänä, mutta jos vaaditaan hyvin vahvaa näyttöä, niin merkitsevyysraja viedään pienemmäksi kuten tasolle $1 \%$ tai $0,1 \%$. Virhettä II ei pidetä niin kriittisenä kuin virhettä 1, mutta testin matemaattisessa johtamisessa se pidetään alhaisena. Testin soveltaja ei automaattisesti tiedä virheen II suuruutta.

Havaintoaineistosta lasketaan testisuureita, joille on johdettu todennäköisyysjakaumat. Niiden pohjalta tilastollinen päättely voidaan tehdä. Testattaessa poikkeaako aineiston $\left(x_{1}, \ldots\right.$ $x_{n}$ ) keskiarvo annetusta arvosta $\mu$ lasketaan testisuure

$$
t_{n-1}=\frac{\bar{x}}{s / \sqrt{n}}, \bar{x}=\frac{1}{n} \sum_{k=1}^{n}\left(x_{k}-\mu\right), s^{2}=\frac{1}{n-1} \sum_{k=1}^{n}\left(x_{k}-\bar{x}\right)^{2},
$$


missä $t_{n-1}$ noudattaa Studentin $t$-jakaumaa vapausastein $n-1$. Mitä suurempi testisuure on, sitä selkeämmin aineisto poikkeaa nollahypoteesista. Esimerkiksi voidaan tutkia vaikuttaako sillan rakentaminen uoman virtaamaan. Tällöin nollahypoteesi olisi 'ei vaikutusta'. Hypoteesien asettaminen ja testaaminen ovat tärkeä osa hydrologian tutkimusta.

\subsubsection{Aikasarjat}

Aikasarja-analyysiin on siirryttävä, kun satunnaismuuttujan havaintosarjassa on ajallista riippuvuutta. Tätä menetelmää voidaan soveltaa myös yksiulotteiseen spatiaaliseen analyysiin. Hydrologisissa aikasarja-analyyseissa tärkeitä kysymyksiä ovat ajalliset vasteet sekä ilmiöiden toistuvuus, pysyvyys ja ääriarvot. Kuten edellä todettiin, aikasarjoista päästään riippumattomiin muuttujiin valitsemalla vain havaintoväli riittävän pitkäksi, ts. pidemmäksi kuin korrelaatioajan mitta. Niinpä monien hydrologisten suureiden vuosiarvoja voidaan analysoida klassisen tilastotieteen keinoin.

Esimerkki 2-5. Tarkastellaan prosessia $Y_{n+1}=a Y_{n}+e_{n+1}$, missä $a<1$ on vakio ja $e_{\mathrm{n}}$ :t ovat riippumattomia satunnaismuuttujia, joiden keskiarvo on nolla ja varianssi $\sigma^{2}$. Prosessi voidaan kirjoittaa muotoon $Y_{n}=\sum_{k=0}^{\infty} a^{k} e_{n-k}$, ja sen keskiarvo ja varianssi ovat

$$
\bar{Y}_{n}=0, \sigma_{Y}^{2}=\sum_{k=0}^{\infty} a^{k} \sigma^{2}=\frac{\sigma^{2}}{1-a},
$$

ja edelleen autokovarianssi viiveellä $k$ on $\sigma_{k}=a^{k} \frac{\sigma^{2}}{1-a}$. Autokorrelaatio on sitten autokovarianssi jaettuna hajonnoilla eli $r_{k}=a^{k}$. Kun $k$ kasvaa, korrelaatio vähitellen häviää. Systeemin muisti voidaan määritellä asettamalla korrelaatiolle alaraja; jos valitaan siihen $r_{0}$, saadaan muisti yhtälöstä $a^{k}=r_{0}$. Objektiivisempi tapa on määrittää korrelaation integraaliaikamitta

$$
\sum r_{n}=1+a+a^{2}+\cdots=\frac{1}{1-a} .
$$

Jos $a=0,9$, muistin pituus on 10 aika-askelta. Käytännön sovelluksena voidaan ajatella $Y$ :n esittävän kesäajan pintalämpötilan vuorokausikeskiarvoa ja $e: n$ sään vaihteluiden aiheuttamia häiriöitä. Parametri $a$ kuvaa silloin kuinka kauas vallitsevalla lämpötilalla on vaikutusta tulevaisuuteen.

Hydrologian aikasarjat ovat yleensä verrattain lyhyitä, muutaman vuosikymmenen pituisia. Erikoistapauksen muodostaa Niili, jonka tulvista on tietoa yli 2000 vuoden ajalta. Suomesta on joitakin yli 100 vuoden pituisia vedenkorkeuden, virtaaman ja jääolojen havaintosarjoja. Vedenkorkeushavainnot on aloitettu kanavien rakentamisen yhteydessä. Vanhoja tietoja on saatu säännöllisten havaintojen lisäksi ihmisen tekemistä tulvamerkeistä poikkeuksellisten tulvien aikana.

Hydrologisissa aikasarjoissa kuten yleensä aikasarjoissa on ajasta riippuva säännöllinen rakenne ja satunnaisvaihtelu. Rakenne on osin sisäistä, suureen luontaista vaihtelua sekä osin ulkoisten tekijöiden aikaansaamaa. Sisäisen rakenteen vaikutukset ulottuvat systeemin muistin päähän, ja ulkoiset tekijät tulevat esimerkiksi maankäytön muutoksista sekä sään ja ilmaston vaihteluista ja ovat usein pidempijaksoisia. Aikasarjojen peruskomponentit ovat:

1. Trendi tarkoittaa monotonista muutosta ajan mukana. Hydrologiassa tämä koskee yleensä vuosikymmenien aikana tapahtuvia muutoksia. Usein trendit aiheutuvat ilmastollisista muutoksista. Esimerkiksi järvien syksyinen jäätyminen on viimeisen sadan vuoden aikana myöhentynyt noin viikon verran. Myös maankäytön muutoksilla (viljelyalan muutokset, metsän hakkuut, soiden kuivatus ym.) voi olla merkitystä. 
2. Jaksollisuus tarkoittaa säännöllistä toistumista. Tavalliset jaksot ovat vuosi ja vuorokausi. Vesivarastojen veden vaihtumisaika muodostaa sisäisen perusjakson. Virtausdynamiikassa tulee esiin lyhyitä säännöllisiä jaksoja kuten järvien ominaisheilahdukset, jotka suomalaissa järvissä ovat yleensä minuuttien ja tuntien suuruusluokkaa (esimerkiksi Jyväsjärvi 12 minuuttia ja Päijänne 5 tuntia). Vuotta pidemmät ilmastojaksot ovat kymmenien tuhansien vuosien mittaisia ja liittyvät maapallon akselin suunnan ja kiertoradan muutoksiin ja selittävät jääkausien esiintymistä. Niitä sanotaan Milankovichin jaksoiksi. Auringonpilkkujakso (11 vuotta) ei tunnu hydrologisissa aikasarjoissa.

3. Siirros ilmenee aikasarjan äkillisenä suuruustason muutoksena. Tämä voi aiheutua havaintopaikan muutoksesta, ympäristön muutoksesta tai ihmisen toiminnasta kuten vesistön säännöstelyn aloittamisesta tai suon ojituksesta.

4. Satunnainen komponentti on hydrologisissa havaintosarjoissa yleensä verrattain voimakas. Se on ennustamaton ja kertoo aikasarja-analyysin perusteella tehtävän ennusteen epävarmuudesta. Satunnaiskomponentin ominaisuuksia voidaan kuitenkin tutkia, esimerkiksi mikä on sen varianssi.

Aikasarjan trendi voidaan selvittää erilaisia sovitusmenetelmiä käyttäen. Yksinkertaisin, lineaarinen trendi saadaan lineaarisen regressioanalyysin avulla. Jaksolliset komponentit puolestaan saadaan selville käyttäen spektrianalyysia tai harmonista analyysia. Esimerkiksi kuukauden sadantasummien muodostamassa aikasarjassa vuosijakso ja satunnaisosa ovat usein tärkeimmät komponentit. Virtaaman kuukausikeskiarvojen aikasarjassa vuosijakso niin ikään on merkittävä, ja residuaalista voi löytyä jaksollisuuksia satunnaiskomponentin lisäksi.

Toistumisaika on hydrologiassa usein esille tuleva kysymys, jota tutkitaan sekä klassisen tilastotieteen että aikasarja-analyysin avulla. Se tarkoittaa sen ajan keskiarvoa, jonka kuluessa kyseinen ilmiö toistuu kerran. Ilmiö voi olla esimerkiksi "vedenkorkeus ylittää annetun arvon". Toistumisajan käänteisarvo on toistuvuus. Ne voidaan määrittää asettamalla havainnot suuruusjärjestykseen $y_{1}>y_{2}>\ldots>y_{\mathrm{N}}$. Tällöin $N / k$ on suureen $y_{k}$ toistumisaika ja $k / N$ sen toistuvuus. Kuva 2-7 esittää esimerkin toistumisajan määrittämisestä. Ilmiön pysyvyys tarkoittaa sen kestoaikaa. Esimerkiksi halutaan tietää, kuinka kauan vedenkorkeus on tietyn rajan alapuolella.

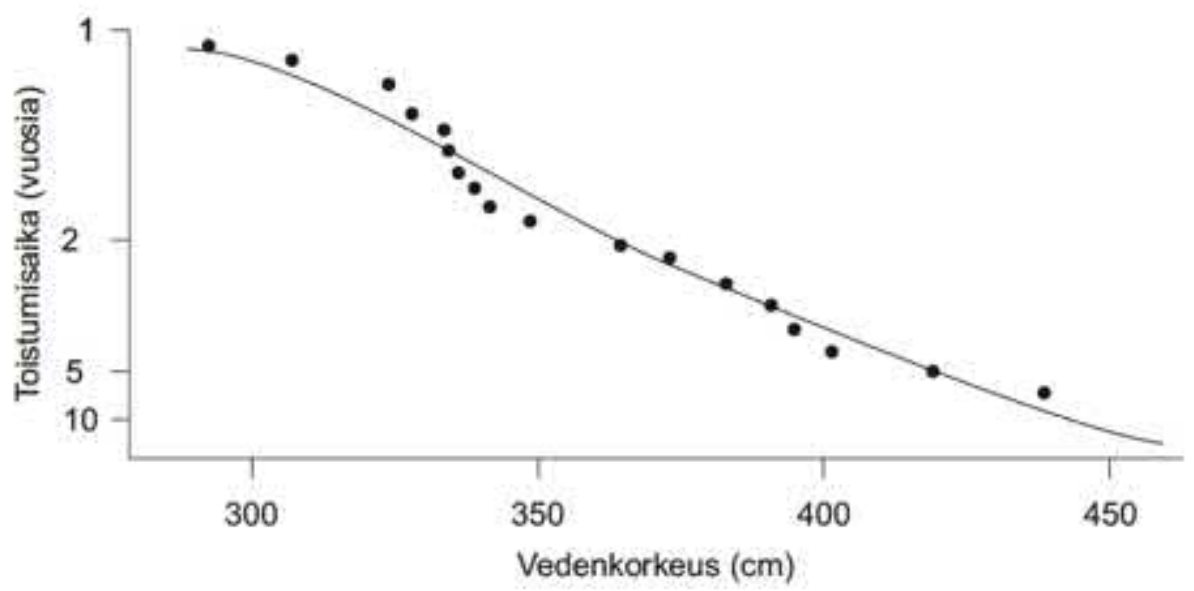

Kuva 2-7. Saimaan vedenkorkeuden vuotuisen suurimman arvon toistumisaika kauden 1958-1977 havaintojen perusteella. Lähde: Mustonen (1986), muokattu. 
Suunniteltaessa rakenteita lähtien laiturin rakentamisesta aina suuriin siltoihin ja voimalaitoksiin, tai onpa kyse raakaveden otosta, jätevesien laskusta tai muusta vesivarojen käytöstä, vaikutukset vesivaroihin on tällöin tunnettava. Nämä vaikutukset liittyvät pinta- ja pohjavesien vedenkorkeuden ajallisiin vaihteluihin, jokivirtaamien kehitykseen sekä vesivarojen riittävyyteen ja laatuun. Vesistön käyttötapa, säännöstelyrajat ja juoksutukset määräytyvät arvioidun veden tarpeen ja toisaalta käytettävissä olevan vesimäärän perusteella. Keskivirtaama ja keskivedenkorkeus kuvaavat keskimääräistä tilaa eivätkä yksinään kelpaa suunnittelun pohjaksi.

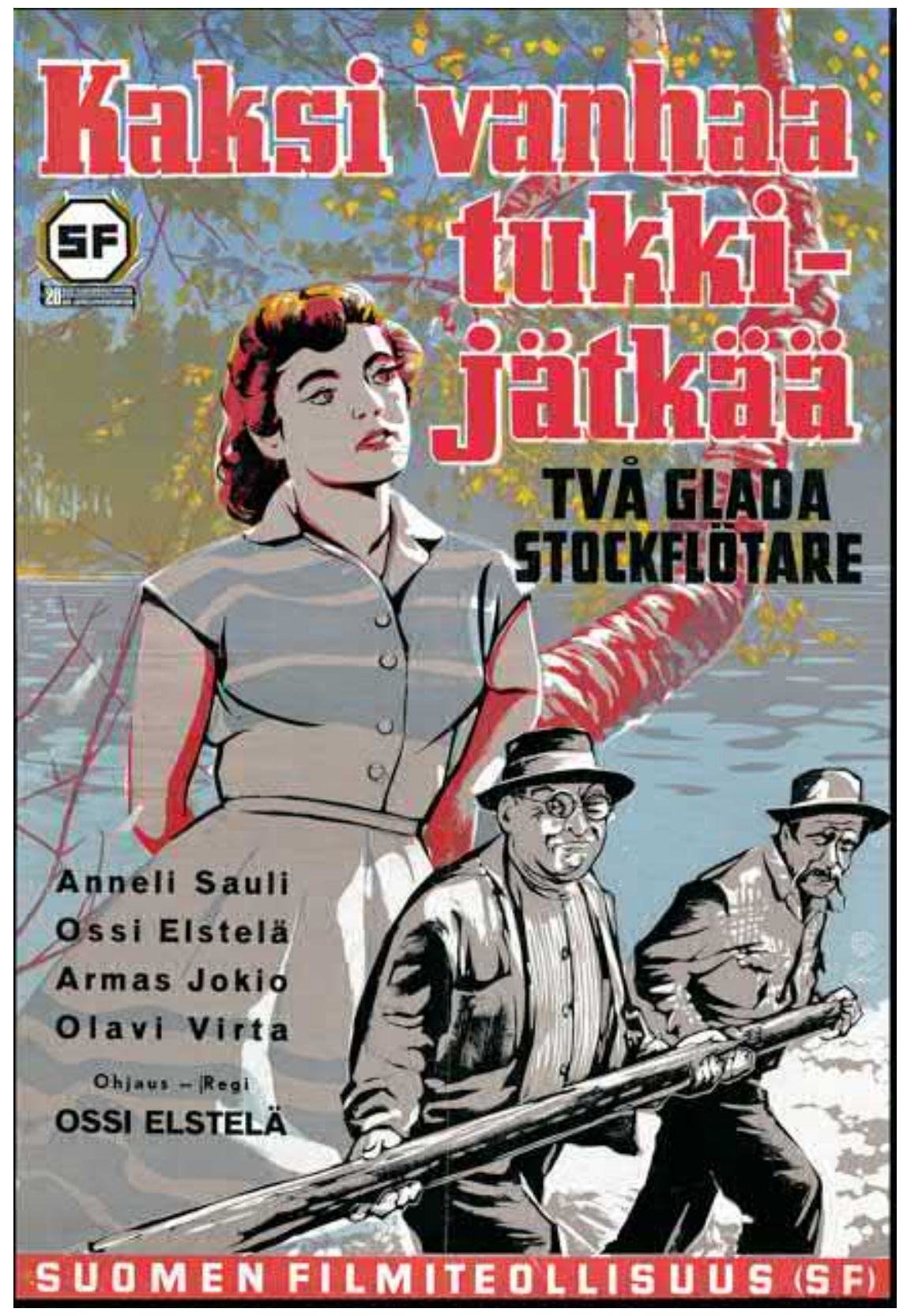

Kuva 2-8. Tukinuitto on kuulunut suomalaiseen vesistötyöhön ja oli voimakkaimmillaan 1900-luvun alkupuolella. Tukkilaiskulttuuri vaikutti merkittävästi suomalaiseen taidemaailmaankin. Kuvassa Ossi Elstelän (ohjaus), Reino Helismaan (käsikirjoitus) ja Toivo Kärjen (musiikki) Kaksi vanhaa tukkijätkää elokuvan (1954) juliste. @ Elonet kansallisfilmografia. 
Suunnittelun perustaksi valittava toistumisaika määräytyy siitä, kuinka pitkäaikaiseksi rakenne on tarkoitettu, ja siitä, miten suuri vahinko aiheutuu, jos vastaava arvo ylitetään. Vastaavasti voidaan tarkastella alimman virtaaman ja vedenkorkeuden toistumisaikaa. Pysyvyydessä on kysymys tietyn tulva-ajan pituudesta tai vastaavasti tiettyä alivesikauden pituutta vastaava virtaama tai vedenkorkeus. Alivesikausi liittyy läheisesti raakaveden ottoon ja jätevesien laskuun. Pysyvyyskäyrä ilmoittaa sen suhteellisen ajan, jonka virtaama tai vedenkorkeus on tietyn arvon ylä- tai alapuolella.

Muita tärkeitä tilastollisia tunnuslukuja ovat vesiliikennekauden alin vedenkorkeus liikenneväylillä ja satamissa sekä uittokauden alin vedenkorkeus uittovesistöissä (kuva 2-8). Kalatalouden kannalta voidaan pitää merkittävänä kutuajan vedenkorkeutta. Kaikki tunnusluvut määritetään monivuotisen havaintoaineiston perusteella. Jos riittävän pitkää havaintosarjaa ei ole, käytetään havaintosuureiden arvioimiseen vertailuvesistöjä, tilastollisia jakaumia tai hydrologisia malleja. Toistumisaika joudutaan usein määrittämään huomattavasti pidemmälle jaksolle kuin minkä havaintosarja kattaa.

\subsubsection{Spatiaalinen tilastotiede}

Kun suureen arvo riippuu paikasta, siirrytään spatiaaliseen analyysiin. Tätä menetelmää käytetään yleensä kaksiulotteisiin pintoihin, mutta periaatteessa voidaan tarkastella myös kolmiulotteista maaperää. Yksiulotteiseen tapaukseen voidaan käyttää aikasarja-analyysin menetelmiä. Spatiaalisten tilastomenetelmien sovellukset alkoivat malminetsinnän alalla, mutta sittemmin ne ovat levinneet laajalti geotieteisiin. Kun ulottuvuuksia ja siis argumentteja on kaksi tai jopa kolme, havaintomäärien pitää olla suuria, jotta jotain merkitsevää voidaan päätellä.

Kaksiulotteisessa spatiaalisessa analyysissä tarkastellaan suureita $f(x, y)$, missä $x$ ja $y$ ovat paikkakoordinaatteja. Menetelmää voidaan ajatella aikasarja-analyysin laajennuksena kahteen ulottuvuuteen. Niinpä voidaan tutkia suureen $f$ rakennetta ja vaihteluita paikan suhteen esimerkiksi pinnan erilaisten sovitusten avulla, trendipintoja, autokorrelaatiorakennetta ja laikkuisuutta (kuva 2-9). Useamman spatiaalisen suureen kanssa tarkastellaan niiden yhteyksiä. Esimerkiksi voidaan tutkia valunnan, vedenlaadun ja maankäytön välisiä alueellisia riippuvuuksia.

Esimerkki 2-6. Spatiaalianalyysin perussuureita on variogrammi. Tarkastellaan kaksiulotteista kenttäsuuretta $Z=Z(x, y)$. Variogrammi kertoo, miten suureen $Z$ vaihtelu muuttuu pisteiden välisen etäisyyden muuttuessa. Stationäärisessä tapauksessa variogrammi riippuu vain pisteiden välisestä etäisyydestä. Semivariogrammi on variogrammi jaettuna kahdella ja se määritellään

$$
\gamma(h)=\frac{1}{2} \operatorname{Var}\left[Z\left(x+h_{x}, y+h_{y}\right)-Z(x, y)\right], h=\sqrt{h_{x}^{2}+h_{y}^{2}} .
$$

(Semi)variogrammin kaksi tärkeätä ominaisuutta ovat siirrosefekti [nugget effect] ja korrelaatioetäisyys. Kun $h \rightarrow 0$, semivariogrammin raja-arvo on

$$
\gamma(h) \rightarrow \gamma_{0+} \geq 0
$$

ja toisaalta $\gamma(0)=0$. Suuretta $\gamma_{0+}$ sanotaan siirrosefektiksi, ja se kuvaa semivariogrammin nopeaa kasvua, kun astutaan pois pisteeltä $(x, y)$. Voitaisiin löyhästi sanoa, että jalan alla on erilaista kuin askeleen päässä. Kun $h \rightarrow \infty$, raja-arvo on $\gamma(h) \rightarrow \operatorname{Var}(Z)$ eli semivariogrammi lähestyy Z:n varianssia. Tämä tarkoittaa, että tarkastelupisteen antama informaatio ei kanna loputtoman kauas. Korrelaatioetäisyys voidaan määrittää semivariogrammista niin, että sen päässä semivariogrammi on vielä 
merkittävästi $Z$ :n varianssia pienempi. Tämä raja-arvo saavutetaan, kun $h$ on suurempi kuin spatiaalinen korrelaatiopituus.

Spatiaalista analyysiä varten on olemassa GIS (Geographic Information Systems) ohjelmistoja, joiden avulla voidaan tehdä tilastollisia tutkimuksia ja tarkastella monenlaisia karttaaineistoja samanaikaisesti. GIS-ohjelmistoilla on runsaasti sovelluksia kaikissa geotieteissä. Hydrologiassa voidaan esimerkiksi tarkastella vesistöjen veden laatua yhdessä vesistöalueen kasvillisuuden, maankäytön, ilmaston ym. kanssa ja sen pohjalta tehdä arvioita ympäristömuutosten ja ihmistoiminnan vaikutuksista.

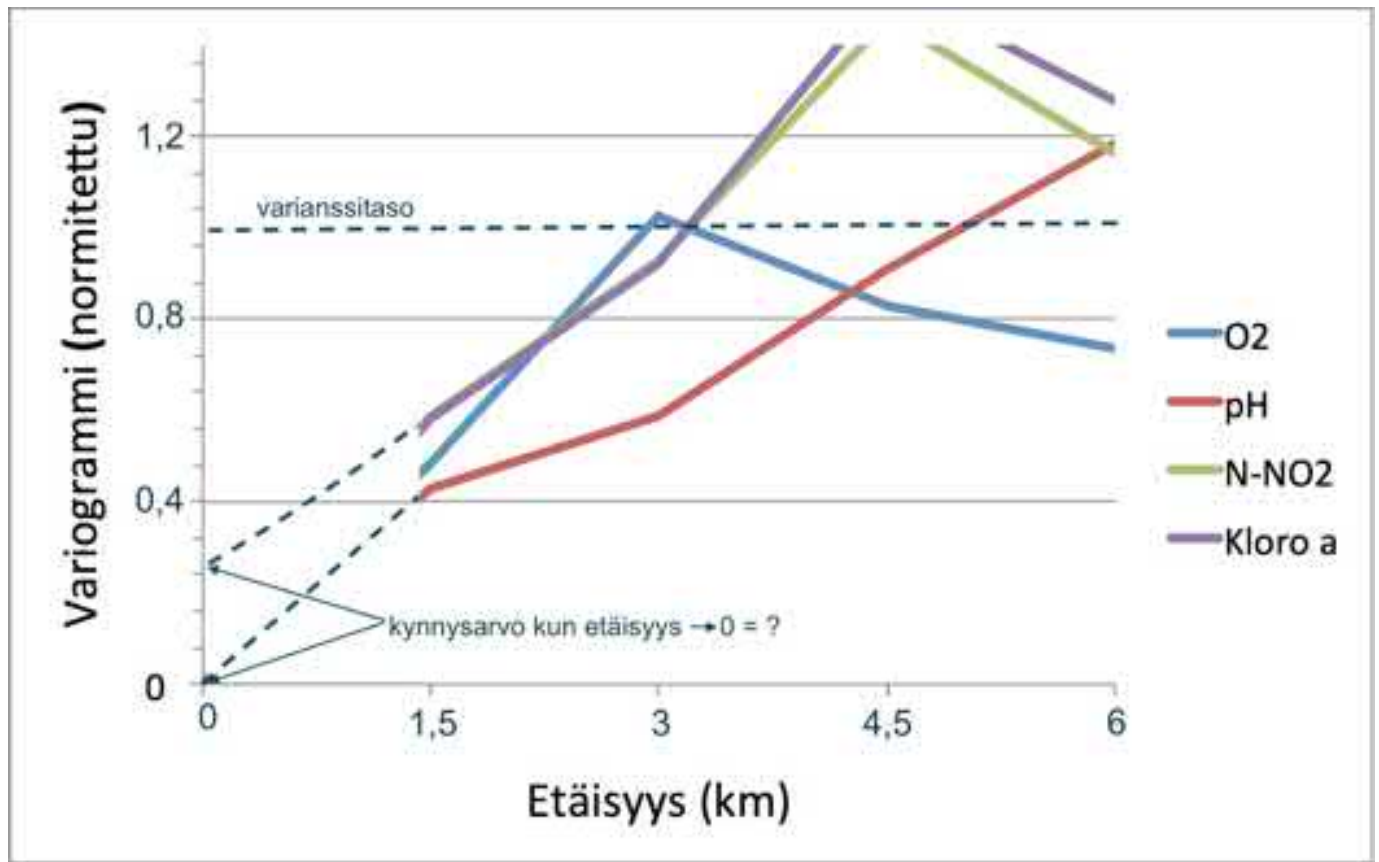

Kuva 2-9. Semivariogrammeja Vanajavedeltä kesätilanteista (happi, $p H$, nitraat-ti-typpi ja a klorofylli. Semivariogrammi kuvaa vaihtelun tasoa etäisyyden funktiona. Se saavuttaa kokonaisvarianssin korrelaatioetäisyyden jälkeen. Lähde: Leppäranta ym. (2017), muokattu.

\subsection{Dimensioanalyysi}

\subsubsection{Periaatteita}

Fysikaalisilla suureilla on laatu eli dimensio. Voidaan valita riittävä joukko perussuureita, joista muiden, johdettujen suureiden dimensiot saadaan. Puhtaissa klassisen mekaniikan ongelmissa perussuureita on kolme: massa, pituus ja aika. Niiden dimensioita merkitään vastaavasti symbolein $M, L$ ja $T$. Muiden mekaniikan suureiden $(Q)$ dimensiot ovat:

$$
\operatorname{dim} Q=M^{A} L^{B} T^{C}
$$

missä potenssit $A, B$ ja $C$ ovat kokonais- tai murtolukuja. Dimensiottoman suureen dimensio on $1(A=B=C=0)$. Jokaisen fysiikan yhtälön täytyy olla dimensiollisesti konsistentti eli johdonmukainen, mikä tarkoittaa, että kunkin termin dimension on oltava sama. Dimensioita merkitään myös hakasuluin eli $\operatorname{dim} Q=[Q]$. Dimensioilla on yksikkö, ja vastaavasti johdettujen suureiden yksiköt saadaan perussuureiden yksiköistä. 
Esimerkki 2-7. Muutamien tavallisten suureiden dimensioita:

$$
\begin{aligned}
& \operatorname{dim}(\text { nopeus })=\frac{L}{T}, \operatorname{dim}(\text { kiihtyvyys })=\frac{L}{T^{2}}, \operatorname{dim}(\text { ala })=L^{2}, \operatorname{dim}(\text { tilavuus })=L^{3}, \\
& \operatorname{dim}(\text { tiheys })=\frac{M}{L^{3}}, \operatorname{dim}(\text { voima })=\frac{M L}{T^{2}}, \operatorname{dim}(\text { paine })=\frac{M}{L T^{2}}, \operatorname{dim}(\text { kulma })=1 .
\end{aligned}
$$

Newtonin II lain mukaan $F=m a$, missä $F$ on voima, $m$ on massa ja $a$ on kiihtyvyys. Nähdään, että $[F]$ $=M L T^{-2},[m]=M,[a]=L T^{-2}$. Yhtälön molemmat puolet ovat dimensiollisesti samoja ja se on siis konsistentti. SI-järjestelmässä massan perusyksikkö on kilogramma $(\mathrm{kg})$, pituuden metri $(\mathrm{m})$ ja ajan sekunti (s), joten kiihtyvyyden perusyksiköksi tulee $\mathrm{m} \mathrm{s}^{-2}$ ja voiman $\mathrm{kg} \mathrm{m} \mathrm{s}^{-2}$.

Huomaa, että kulman dimensio on yksi. Kulma tarkoittaa kaaren pituuden suhdetta säteeseen, ja asteen $\left({ }^{\circ}\right)$ tai radiaanin $(\mathrm{rad})$ merkintä vain kertoo mistä asteikosta on kyse. Koko ympyrän kulmaa sanotaan kierrokseksi tai sykliksi. Siispä 1 kierros $=2 \pi \mathrm{rad}=360^{\circ}$.

Dimensioanalyysiä voidaan käyttää yhtälöiden tarkistuksessa ja niiden konsistenssin kontrolloimiseksi, mutta ennen kaikkea menetelmä tarjoaa yksinkertaisen ja vahvan työkalun suureiden välisten riippuvuuksien hahmottamiseksi. Dimensioanalyysin avulla voidaan pelkistää ongelmia vähentämällä tehtävässä vaikuttavien muuttujien lukumäärää dimensiottomia suureita käyttäen. Fysiikan lakeja tässä ei tarvitse tuntea, mutta tutkijalla on oltava intuitiota nähdäkseen millaiset suureet tehtävässä vaikuttavat. Seuraavat esimerkit valaisevat asiaa.

Esimerkki 2-8. a) Tarkistetaan valuma-alueen vesitaseen konsistenssi. Tämä tase kirjoitetaan $\frac{d V}{d t}=$ $(P-E) A-O$, missä vasemmalla on vesivaraston tilavuuden $V$ muutosnopeus ja oikealla sadan-ta $P$, haihdunta $E$, valuma-alueen ala $A$ ja ulosvirtaama $O$. Dimensiot ovat $\left[\frac{d V}{d t}\right]=\frac{L^{3}}{T}$, haihdunnan ja sadannan $L T^{-1}$, alan $L^{2}$ ja ulosvirtaaman $L^{3} T^{-1}$. Näin termien dimensiot ovat samat ja vesitase on konsistentti.

b) Jokivirtauskaavan suureiden dimensioita tarkastellaan seuraavaksi. Nopeuden $U$ klassinen Chezyn kaava kirjoitetaan $U=C \sqrt{R \beta}$, missä $R=A / P$ on joen hydraulinen säde, $A$ on poikkileikkauksen ala, $P$ on märkä piiri, $\beta$ on joen kaltevuus ja $C$ on säätökerroin. Selvästikin $[R]=L$ ja $[\beta]=1$, joten nopeuden dimension saamiseksi täytyy säätökertoimen dimension olla $[C]=L^{1 / 2} T^{-1}$. Tällaisia dimensioita esiintyy usein semiempiiristen yhtälöiden parametreissa. Niitä sovellettaessa on syytä olla tarkkana dimensioiden ja yksiköiden kanssa, sillä aiemmin käytettiin eurooppalaisessa tieteessä paljon cgs-järjestelmää, jossa perusyksiköt ovat senttimetri, gramma ja sekunti, ja anglosaksisessa tieteessä jalka-naula-sekunti-järjestelmää. SI-järjestelmä alkoi yleistyä 1970-luvulla.

c) Chezyn jokivirtauksen kaava voidaan itse asiassa johtaa dimensioanalyysin avulla. Homogeenisen joen keskivirtaukseen $U$ voidaan ajatella vaikuttavan painovoima $g$, joen kaltevuus $\beta$ ja joen poikkileikkauksen mittaa $R$. Painovoima joen uoman suunnassa on $g \beta$. Tästä saadaan dimensioyhtälö $U \propto$ $R^{A}(g \beta)^{B}$, jonka ratkaisu on $U=$ vakio $\sqrt{g} \cdot \sqrt{R \beta}$. Chezyn säätökerroin on siis muotoa $C=$ vakio $\sqrt{g},[C]=L^{1 / 2} T^{-1}$. Tämän vakion riippuvuutta jokiparametreista voidaan edelleen yrittää selvittää.

d) Tarkastellaan heilurin heilahdusaikaa $t$. Tähän voidaan ajatella vaikuttavan heilurin langan pituus $l$, langan päässä olevan riipuksen massa $m$ ja putoamiskiihtyvyys $g$. Dimensiot ovat $[t]=T,[l]=L,[m]=$ $M \mathrm{ja}[g]=L T^{-2}$. Siispä täytyy olla ${ }^{4} \propto \propto m^{A} l^{B} g^{C}$. Dimensioiden perusteella saadaan yksi ratkaisu: $A=$ $0, B=1 / 2$ ja $C=-1 / 2$ eli $t=$ vakio $\cdot \sqrt{l g^{-1}}, \operatorname{dim}[$ vakio $]=1$. Heilahdusaika ei riipu riipuksen massasta. Vakion löytämiseksi pitäisi järjestää heilurikoe (huom. mekaniikan opista tiedämme, että tämä vakio on $2 \pi)$.

\footnotetext{
${ }^{4}$ Symboli $\propto$ tarkoittaa verrannollisuutta, siis $y \propto x$, jos $y=$ vakio $\cdot x$.
} 
Esimerkeissä 2-8c-d näytettiin, miten dimensioanalyysin avulla voidaan johtaa yksinkertaisia fysikaalisten suureiden suhteita. Kun systeemin toimintaan vaikuttaa $n$ perussuuretta ja $m>$ $n$ johdettua suuretta, voidaan konstruoida $m-r$ ratkaisun määräävää dimensiotonta suuretta, missä $r$ on riippumattomien johdettujen suureiden lukumäärä. Heilurin tapauksessa oli $n$ $=3, m=4$ ja $r=3$, ja tehtävä pelkistyi yhteen dimensiottomaan suureeseen $\Pi=t \sqrt{g / l}$. Tällöin ratkaisu saadaan asettamalla $\Pi=$ vakio.

Jos dimensiottomia suureita tulee kaksi, $\Pi_{1}$ ja $\Pi_{2}$, saadaan yhtälö $\Pi_{1}=f\left(\Pi_{2}\right)$ jne. Matemaattisesti voidaan ratkaista se, kuinka monta dimensiotonta suuretta kulloinkin tarvitaan. Suureiden valinta riippuu tutkijasta itsestään. Menetelmä soveltuu vakaan tilan ongelmiin, joissa fysikaalinen systeemi on saavuttanut tasapainotilansa. Perussuurejoukko valitaan soveltuvasti tehtävän mukaan. Mekaniikan alalla voidaan voima ottaa perussuureeksi massan asemasta, jolloin massasta tulee johdettu suure $M=F L^{-1} T^{2}$.

Virtausopissa dimensioanalyysiä on käytetty paljon. Virtauskenttää kuvataan karakteristisella nopeudella $U$, pituusmitalla $L$ sekä nesteen ominaisuuksilla. Pituusmittana on jokin altaan tai siihen liittyvän topografisen piirteen mitta kuten kanavan syvyys, järven pituus, tai uomassa olevan kumpareen halkaisija.

\subsubsection{Suurejoukon tarkastelu}

Dimensioanalyysin yleisen teorian avulla voidaan määrätä tehtävässä välttämättä tarvittavien dimensiottomien suureiden lukumäärä. Olkoon perussuureita $P_{i}$ yhteensä $n$ kappaletta ja johdettuja suureita $Q_{k}$ yhteensä $m>n$ kappaletta. Johdettujen suureiden dimensiot voidaan esittää muodossa

$$
\left[Q_{k}\right]=\left[P_{1}\right]^{b_{1 k}}\left[P_{2}\right]^{b_{2 k}} \ldots\left[P_{n}\right]^{b_{n k}}, k=1,2, \ldots, m
$$

Näistä voidaan muodostaa dimensiottomia suureita $\prod_{j}$, joilla perussuureiden eksponenteiksi tulee nollat:

$$
\left[\Pi_{j}\right]=\left[Q_{1}\right]^{k_{1}}\left[Q_{2}\right]^{k_{2}} \ldots\left[Q_{m}\right]^{k_{m}}
$$

Ratkaisemalla tästä eksponentit $k_{j}$ saadaan tietää lineaarisesti riippumattomien johdettujen suureiden lukumäärä $r$, ja sen jälkeen voidaan valita sopivat $m-r$ dimensiotonta suuretta. Sitten valitaan primäärinen tutkimuskohde $\Pi_{1}$ ja muodostetaan yhtälö

$$
\Pi_{1}=f\left(\Pi_{2}, \ldots, \Pi_{m-r}\right)
$$

Jos $m-r=1$, on $\Pi_{1}=$ vakio. Itse dimensiottomien suureiden valinta jää tutkijan tehtäväksi, koska valinta voidaan tehdä monella eri tavalla. Alempana seuraa esimerkkejä. Dimensioanalyysiä sovelletaan yleensä tehtävissä, joissa dimensiottomia suureita tulee korkeintaan noin viisi. Tällöin tulosten tulkinta on vielä yksinkertaista ja yhtälöiden johtaminen sujuu helposti.

Esimerkki 2-9. Heiluritehtävässä (Esimerkki 2-8d) oli $n=3$ perussuuretta ja $m=4$ johdettua suuretta $(t, l, g, m)$. Tavoitteena oli tutkia, miten heilahdusaika määräytyy. Perusdimensiot ja johdetut suureet voidaan järjestää matriisiksi 


$\begin{array}{lcccc} & t & l & g & m \\ M & 0 & 0 & 0 & 1 \\ L & 0 & 1 & 1 & 0 \\ T & 1 & 0 & -2 & 0\end{array}$

Sarakkeesta saadaan johdettujen suureiden dimensiot: $[t]=T,[l]=L,[g]=L T^{-2}$ ja $[m]=M$. Näistä saadaan yhtälö dimensiottomille suureille

$$
\left[\Pi_{j}\right]=[t]^{k_{1}}[l]^{k_{2}}[g]^{k_{3}}[m]^{k_{4}} .
$$

Dimensiottomuusehto antaa seuraavat yhtälöt:

$$
\begin{array}{ll}
M & 0=k_{4} \\
L & 0=k_{2}+k_{3} \\
T & 0=k_{1}-2 k_{3}
\end{array}
$$

Tästä saadaan kolme lineaarisesti riippumatonta ratkaisua $k_{2}=-k_{3}, k_{3}=1 / 2 k_{1}$ ja $k_{4}=0$, ja $k_{1}$ jää vapaaksi. Siispä $r=3$, ja systeemiä kuvaa yksi dimensioton suure:

$$
\Pi=t^{k_{1}} l^{-\frac{1}{2} k_{1}} g^{\frac{1}{2} k_{1}} m^{0} .
$$

Jos otetaan $k_{1}=1$, saadaan $k_{2}=-1 / 2$ ja $k_{3}=1 / 2$. Tämä dimensioton suure on $\Pi=t \sqrt{g / l}$ ja koska niitä on vain yksi, niin täytyy olla $\Pi=$ vakio. Lopputulos on sama, vaikka $k_{1}$ valittaisiin toisinkin. Valinnassa kiinnitetään huomiota yksinkertaisuuteen ja eleganssiin.

Esimerkki 2-10. a) Tarkastellaan matkaan $s$ kuluvaa aikaa $t$ vakiokiihtyvyydellä $a$ olevassa liikkeessä. Muita tekijöitä ei tässä vaikuta. Tehtävässä on $n=2, m=3$, ja dimensiotaulukko on

$\begin{array}{cccc} & t & s & a \\ L & 0 & 1 & 1 \\ T & 1 & 0 & -2\end{array}$

Tästä löytyy kaksi lineaarisesti riippumatonta johdettua suuretta, joten dimensiottomia suureita riittää $m-r=1$. Vastaavasti kuten edellisessä esimerkissä saadaan $[\Pi]=[t]^{k_{1}}[s]^{k_{2}}[a]^{k_{3}}$, missä $k_{2}=-k_{3}$ ja $k_{3}=1 / 2 k_{1}$, ja siis $\Pi=t \sqrt{a / s}=$ vakio. Mekaniikan peruslaeista tiedetäänkin, että $t=\sqrt{s / a}$ ja siis vakio $=1$.

b) Pythagoraan teoreema voidaan johtaa dimensioanalyysin avulla. Teoreeman mukaan suorakulmaisen kolmion hypotenuusan pituus $c$ ja kateettien pituudet $a$ ja $b$ toteuttavat yhtälön $c^{2}=a^{2}+b^{2}$. Kun tarkastellaan suorakulmaisia kolmioita yleensä, nähdään, että niiden ala määräytyy hypotenuusan pituuden ja hypotenuusan ja kateetin välisen kulman avulla: $A=f(c, \theta)$.

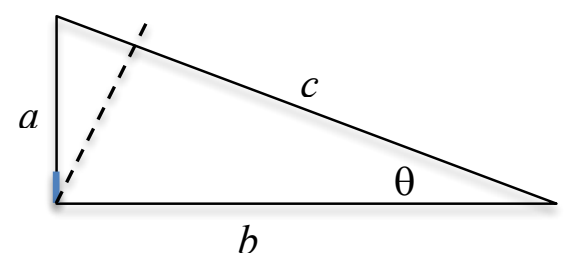

Katkoviivalla kolmio voidaan jakaa kahteen pienempään suorakulmaiseen kolmioon, ja niiden alat ovat vastaavasti $A_{1}=f(a, \theta)$ ja $A_{2}=f(b, \theta)$. Koska $[\theta]=1$, dimensiollinen konsistenssi edellyttää, että $f(c, \theta)=c^{2} g(\theta)$. Näin ollen

$$
c^{2} g(\theta)=a^{2} g(\theta)+b^{2} g(\theta) .
$$

Jakamalla $g$ :1lä Pythagoraan teoreema seuraa.

Esimerkki 2-11. Mielenkiintoinen vaikkakin vaativa esimerkki tulee vielä kilpasoudun alalta. Tarkoituksena on tässä vain havainnollistaa dimensioanalyysin ajattelutapaa ja voimakkuutta. Tarkastellaan $N:$ n soutajan veneitä, joista oletetaan 
- veneet ovat geometrisesti samankaltaisia eli similaarisia

- lastatun veneen tilavuus soutajaa kohti $=$ vakio $=G$

- $\quad$ soutajien teho $=$ vakio $=A$

Kiinnostuksen kohteena on veneen nopeus $v$. Soutuveneiden vastusvoima $F$ on pintakitka, jossa kitkakerroin on $\lambda$. Märän pinnan pituusmitta on $l$. Tasapainoehto syöttötehon ja kulutuksen välillä on

$$
A N=v F=\lambda \rho v^{3} l^{2} .
$$

Tehtävän perussuureiksi voidaan valita $U=$ nopeus, $N=$ soutajien lukumäärä, $l=$ pituus, ja $R=$ tiheys, ts. $n=4$. Massan asemasta tässä on kätevä ottaa perussuureeksi tiheys, ja soutajien lukumäärä otettiin omaksi perussuureeksi. Johdettuja suureita on $m=5$, ja niiden dimensiot ovat

$$
[v]=U,[N]=N,[G]=\frac{P}{N},[\rho]=R,[A]=\frac{1}{N} R U^{3} l^{2} .
$$

Voidaan helposti osoittaa, että $r=4$. Riippumattomia dimensiottomia suureita on yksi, jonka siis täytyy olla vakio. Voidaan valita

$$
\Pi=v \frac{\rho^{1 / 3} G^{2 / 9}}{A^{1 / 3} N^{1 / 9}}=\text { vakio. }
$$

Kun $A, \rho$ ja $G$ ovat kiinteät, on $v \propto N^{1 / 9}$. Alla olevassa kuvassa on kilpailutuloksia $1,2,4$ ja 8 hengen souduista. Rata on $2000 \mathrm{~m}$, ja suoritusajan pituus riippuu soutajien lukumäärästä potenssiin $-1 / 9$. Dimensioanalyysin tulos sopii kilpailutuloksiin erittäin hyvin ja kertoo menetelmän vahvuudesta (kuva 2-10). Huomataan myös, että soutajien lisääminen kasvattaa nopeutta hyvin hitaasti potenssilain ${ }^{1} / 9$ takia. Niinpä $10(100)$ soutajan tuottama nopeus on vain 1,29 $(1,67)$ kertaa yhden soutajan nopeus.

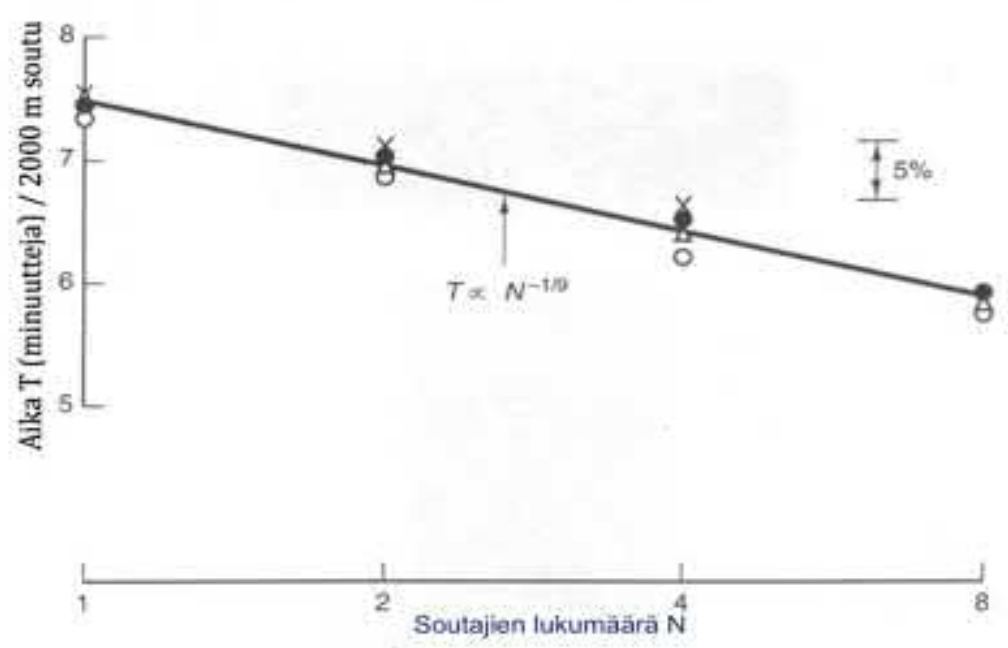

Kuva 2-10. Soutuaika 2000 m matkalla soutajien lukumäärän funktiona. Malli (-) ja kilpailutuloksia tyynessä tai lähes tyynessä säässä $(\Delta-$ Tokion olympialaiset $1964, \bullet-$ Mexico Cityn olympialaiset 1968, x - soudun MM-kilpailut Ontariossa 1970, o - Soutukilpailut Lucernessa 1970. Lähde: McMahon (1971), muokattu.

\subsection{Mallit}

\subsubsection{Fysikaaliset mallit}

Fysikaalisella mallilla tarkoitetaan tehtävän tutkimista pienoismallin avulla laboratoriossa. Esimerkiksi kappaleen virtaukselle aiheuttamaa vastusta voidaan mitata koetankissa. Mallit ovat pienempiä kuin itse taustalla oleva todellinen luonnonallas, eikä virtauksen fysiikka muunnu luonnosta malliin kovin helposti. Eteen tulee erilaisia mittasuhdeongelmia. Suurin osa fysikaalisista malleista on liittynyt virtauksiin, mutta lisäksi voitaisiin tutkia esimerkiksi 
lämmön siirtymistä maaperässä tai valon kulkua vedessä. Seuraavassa käsitellään virtausmalleihin liittyviä kysymyksiä.

Pituusmitta, aikamitta ja virtausnopeuden mitta ovat luonnossa ja mallissa $(L, T, U)$ ja $\left(L_{m}\right.$, $\left.T_{m}, U_{m}\right)$. Yksinkertaisessa tapauksessa vain altaan tai kohteen geometria vaikuttaa. Tällöin riittää, että altaat ovat samanmuotoiset, ja silloin

$$
\frac{U_{m} T_{m}}{L_{m}}=\frac{U T}{L}
$$

Kun mallin pituusmitta ja nopeus on valittu, aika kulkee suhteessa $\frac{T_{m}}{T}=\frac{L_{m}}{L}\left(\frac{U_{m}}{U}\right)^{-1}$. Yleisesti fysikaalisen mallin tehtävää asetettaessa on tarkasteltava sen keskeisiä dimensiottomia suureita pitäen huolta siitä, että ne ovat samat luonnossa ja mallissa. Geometrisella skaalauksella ei kuitenkaan päästä pitkälle virtausten tutkimuksissa. Jos jokin fysikaalinen ilmiö kuten kitka on tutkimuksessa tärkeä tekijä, malli on tämän ilmiön osalta rakennettava similaariseksi eli samankaltaiseksi luonnonolojen kanssa. Tällaisia kysymyksiä voidaan tutkia dimensio-analyysin avulla.

Luonnonvesien virtauksissa on kaksi erityisen tärkeätä ilmiötä: viskositeetti ja vesirungon aaltoliike. Näiden merkitystä kuvataan kahden dimensiottoman suureen avulla: Reynoldsin luku $R e=\frac{U L}{v}$ ja Frouden luku $F r=\frac{U}{\sqrt{g} L^{\prime}}$ missä $v$ on kinemaattinen viskositeetti ja $g$ on putoamiskiihtyvyys. Nämä luvut esitellään tarkemmin kohdassa 3.3.1. Jotta similaarisuus toteutuisi, täytyisi Reynoldsin ja Frouden lukujen olla samat mallissa ja luonnossa:

$$
\text { viskositeetti: } \frac{U_{m}}{U}=\left(\frac{L_{m}}{L}\right)^{-1} \text {, ja aallot: } \frac{U_{m}}{U}=\sqrt{\frac{L_{m}}{L}} \text {. }
$$

Niinpä viskositeetti edellyttää, että mallissa virtausnopeuden pitää olla suurempi kuin luonnossa, mutta aaltojen eteneminen edellyttää päinvastaista. Tilanne on ristiriitainen. Siitä voitaisiin selvitä valitsemalla malliin neste, jolla on eri viskositeetti kuin vedellä, tai sitten tehdä kokeet erilaisen putoamiskiihtyvyyden vallitessa. Mutta nämä tiet johtavat helposti käytännön hankaluuksiin. Mallikokeita voidaan tehdä hyvin, jos joko viskositeetti tai aaltoliike on tärkeä mutta ei molemmat (kuva 2-11).

Fysikaalisia malleja on virtausopissa käytetty yleensä yhden tekijän ongelmissa. Tällaisia kysymyksiä ovat olleet virtauksen kulku esteiden ohitse ja laivan kulkuvastus. Mutkikkaammissa kysymyksissä kuten järven virtauskentän muodostumisessa ei fysikaalisilla malleilla päästä pitkälle. Maapallon pyörimisen vaikutuksia laajojen vesialueiden virtauksiin on jossain määrin voitu tutkia pyörivien altaiden avulla; Tällöin similaarisuusehto on $\frac{U_{m}}{U}=\frac{\Omega_{m}}{\Omega} \cdot \frac{L_{m}}{L}$, missä $\Omega_{m}$ on mallialtaan pyörimisnopeus ja $\Omega$ on maapallon pyörimisnopeus.

\subsubsection{Matemaattiset mallit}

Matemaattiset mallit perustuvat tutkittavaa ilmiötä hallitsevien matemaattisten yhtälöiden ratkaisemiseen. Mallin kalibrointi tai säätäminen tarkoittaa mallin parametrien optimointia siten, että sen tuottamat tulokset vastaavat mahdollisimman hyvin havaintoja. Kalibroinnissa saatujen parametriarvojen pitää olla sopivia myös muissa tilanteissa, jotta malli toimisi yleispätevästi.

Olemassa olevat mallit voidaan jakaa neljään kategoriaan: analyyttiset, numeeriset, stokastiset ja tilastolliset mallit. Analyyttiset mallit antavat hyviä yleisiä suureiden välisiä riip- 
puvuussuhteita ja peukalosääntöjä, ja numeeristen mallien avulla voidaan hydrologisten systeemien fysiikkaa selvittää yksityiskohtaisesti. Kun satunnaismuuttuja lisätään analyyttiseen tai numeeriseen malliin, puhutaan stokastisesta mallista. Tilastolliset mallit nojautuvat ainoastaan havaintoihin ja kuvaavat parhaiten keskimääräisiä suhteita. Ne kertovat myös tulosten tarkkuudesta ja luotettavuudesta tilastollisten tunnuslukujen avulla.

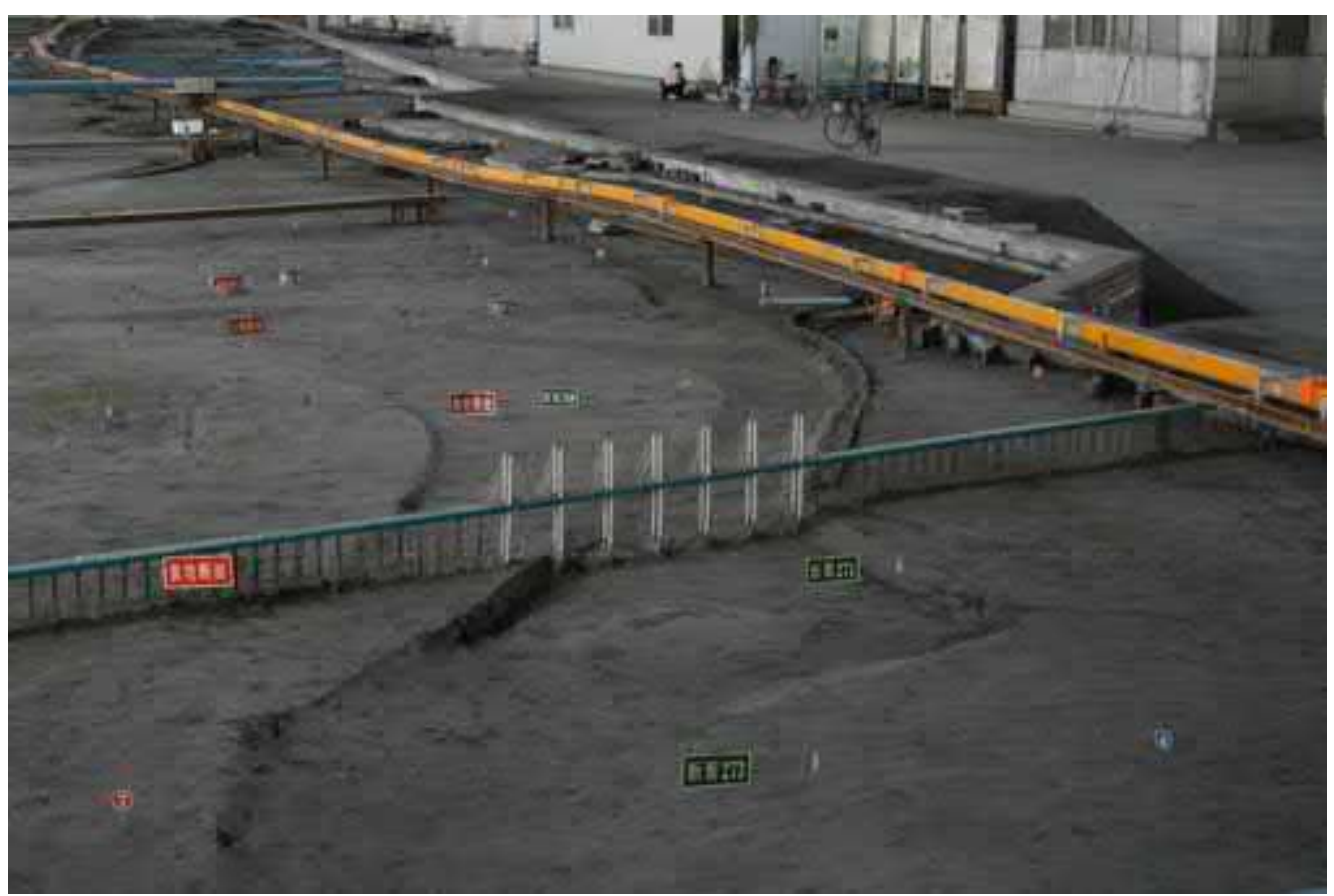

Kuva 2-11. Jokivirtauksissa aaltoliike joen vesirungossa on hallitseva tekijä, ja sen vaikutuksia voidaan tutkia fysikaalisten mallien avulla. Kuvassa osa noin $1 \mathrm{~km}$ pitkästä Keltaisen joen pienoismallista. Kuva: Matti Leppäranta.

Esimerkki 2-12. Tarkastellaan järven pintakerroksen lämpötilan $T=T(t)$ ennustamista. Perusyhtälö on

$$
\frac{d T}{d t}=k\left(T_{a}-T\right)
$$

missä $T_{a}$ on ilman lämpötila ja $k$ on lämmönvaihtokerroin. Fysiikasta tiedetään, että tämä kerroin on likimain kääntäen verrannollinen sekoittuneen pintakerroksen syvyyteen $H_{1}, k \sim \frac{1}{2} H_{1} \mathrm{~m}^{-1} \operatorname{vrk}^{-1}$.

(a) Jos $k=$ vakio, yhtälö voidaan ratkaista analyyttisesti:

$$
T(t)=\int_{-\infty}^{t} k e^{k(s-t)} T_{a} d s .
$$

Systeemiin aiheutetut häiriöt vaimenevat pois relaksaatioajan $k^{-1}$ puitteissa.

(b) Jos $k=k(\ldots)$ riippuu esimerkiksi pintakerroksen turbulenssista, malli on yleensä ratkaistavissa vain numeerisesti.

(c) Stokastisessa mallissa on ulkoiseen pakotteeseen lisätty satunnaishäiriö $\varepsilon$

$$
\frac{d T}{d t}=k\left[\left(T_{a}+\varepsilon\right)-T\right] .
$$

Vaikka lämpötilan muutoksia ajava stokastinen termi on keskimäärin nolla, integroitaessa se kumuloi lämpötilan kehitykseen vaihtelevan lisätermin.

(d) Tilastollinen malli seuraavan päivän (n) pintalämpötilan ennustamiseksi voidaan kirjoittaa

$$
T\left(t_{n}\right)=\sum_{j=0}^{m} a_{j} T_{a}\left(t_{n-j}\right)+e_{n}
$$


missä $T_{a}$ on ilman lämpötila, $m$ kuvaa systeemin muistin pituutta, $e_{n}$ on jäännöstermi ja $a_{j}$ :t ovat tilastollisesti estimoitavia kertoimia. Pintalämpötila tulee siis ilman lämpötilahistorian painotettuna summana; on ilmeistä, että $a_{0}>a_{1}>a_{2} \ldots, \sum_{j} a_{j} \approx 1$.

Matemaattiset mallit kuvaavat tutkittavia suureita ja niiden muutoksia paikan ja ajan suhteen. Piste aika-avaruudessa on $(x, y, z ; t)$, joista $x$ on itäkoordinaatti, $y$ on pohjoiskoordinaatti, $z$ on vertikaalikoordinaatti ja $t$ on aika. Kolmiulotteisissa malleissa vertikaalikoordinaatin nollataso kiinnitetään yleensä maan tai vesistön pintaan tai tarkastelutilavuuden pohjan alapuolelle ja otetaan korkeutena, positiivisena ylöspäin. Puhtaissa vertikaalimalleissa $(z, t)$ avaruudessa on sen sijaan usein kätevä ottaa $z$-koordinaatti syvyytenä, positiivisena alaspäin, ja pitää sen nollataso veden tai maan pinnassa.

Hydrologian malleissa on merkittäviä epätarkkuuksia. Näitä aiheuttavat erityisesti veden kulku maaperä-kasvillisuussysteemin läpi ja siihen kuuluvien prosessien parametrisointi sekä monimutkainen geometria altaiden ja uomien reunaehdoissa. Niinpä mallien tuottamat arviot hydrologian ongelmista eivät yksinään riitä päätösten pohjatiedoiksi. Lisätietoa on tuotettavissa havaintojen avulla. Alla olevassa jaotelmassa on kuvattu matemaattisten mallien osat. Näiden havainnollistamiseksi viereen on sijoitettu esimerkki järvien kiertoliikkeen mallista.

\begin{tabular}{|c|c|}
\hline Yleinen kuvaus & Esimerkki: järvien kiertoliikkeen malli \\
\hline mallin yhtälöt & liikeyhtälö, jatkuvuusyhtälö, lämmön säilymislaki \\
\hline mallin muuttujat & virtausnopeus, vedenkorkeus, lämpötila \\
\hline mallin fysiikan parametrit $^{1}$ & kitka- ja lämmönvaihtokertoimet (pinta, pohja, sisäinen) \\
\hline mallin numeeriset parametrit ${ }^{2}$ & hilakoko, aika-askel \\
\hline mallin syöttötiedot & sään kehitys \\
\hline mallin tulostustiedot & kiertoliike, vedenkorkeus, lämpötila \\
\hline
\end{tabular}

Analyyttisia malleja käytettiin erityisesti ennen tietokonelaskennan aikakautta, mutta nykyisinkin niiden avulla voidaan tarkastella 'metsää puilta' ja konstruoida yksinkertaisia peukalosääntöjä. Analyyttiset mallit ovat algebrallisia yhtälöitä tai differentiaaliyhtälöitä, jotka voidaan ratkaista analyyttisin menetelmin. Hydrologiassa yksi kuuluisista analyyttisista malleista on Chezyn jokivirtauksen kaava (ks. Esimerkki 2.8). Yhtälö kertoo, miten virtausnopeus määräytyy painovoiman ja kitkan tasapainosta.

Esimerkki 2-13. Beerin lain käyttö valon vaimenemiseen vedessä. Yksinkertainen valon kulkua kuvaava malli perustuu Beerin lakiin. Jos valon säteilytys eli irradianssi ${ }^{5}$ on $E=E(z, \lambda)$, missä $z$ on syvyys ja $\lambda$ on valon aallonpituus, niin $\frac{d E}{d z}=-\kappa E$, missä $\kappa=\kappa(\mathrm{z}, \lambda)$ on valon vaimenemiskerroin. Tämän ratkaisu on

$$
E(\lambda, z)=E(\lambda, 0) \exp \left[-\int_{0}^{z} \kappa\left(z^{\prime}\right) d z^{\prime}\right] .
$$

Kerroin $\kappa$ on vielä valittava. Siihen voidaan käyttää mitattua tietoa tai olettaa jokin realistinen jakauma. Erityisesti kun $\kappa=$ vakio, ratkaisu voidaan kirjoittaa $E(\lambda, z)=E(\lambda, 0) e^{-\kappa z}$.

Numeeriset mallit pyrkivät ratkaisemaan malliyhtälöt koneellisen laskennan avulla, ja niillä on mahdollista päästä kvantitatiivisiin tuloksiin. Hydrologian perusyhtälöt ovat pääsääntöisesti differentiaaliyhtälöitä. Ratkaisun konstruointi lähtee liikkeelle hilasta, laskentasolukosta,

\footnotetext{
${ }^{5}$ Irradianssi eli säteilytys summaa kaiken kohteeseen tulevan säteilyn annetusta puoliavaruudesta tai avaruudesta. Tässä tämä alue on yläpuolinen puoliavaruus.
} 
jossa kuhunkin hilaruutuun lasketaan tuntemattomien suureiden arvot (kuva 2-12). Hila kiinnitetään yleensä paikka-avaruuden $(x, y, z)$ kiinteisiin pisteisiin, ja ajassa $t$ se etenee tietyn aika-askeleen verran kerrallaan. Koordinaatistoon $(x, y, z ; t)$ asetetaan diskreetit hilapisteet $\left(x_{\mathrm{i}}\right.$, $\left.y_{\mathrm{j}}, z_{\mathrm{k}} ; t_{\mathrm{p}}\right)$. Mallin perusyhtälöt kuvaavat ratkaistavia funktioita $f_{\ell}(x, y, z ; t)$, ja numeerisessa tehtävässä tuntemattomia ovat näiden funktioiden arvot $f_{\ell}\left(x_{\mathrm{i}}, y_{\mathrm{j}}, z_{\mathrm{k}} ; t_{\mathrm{p}}\right)$ kaikissa hilapisteissä.

Äärellisten differenssien menetelmässä derivaatat korvataan erotusosamäärillä. Funktion $f=f(x, y, z ; t)$ aikaderivaattaa approksimoidaan usein etuerotuksella ja paikkaderivaattoja keskeiserotuksilla. Suoraan derivaatan määritelmästä saadaan

$$
\begin{aligned}
& \frac{\partial f}{\partial t} \approx \frac{f(x, y, z, t+\Delta t)-f(x, y, z, t)}{\Delta t}, \\
& \frac{\partial f}{\partial x} \approx \frac{f(x+\Delta x, y, z, t)-f(x-\Delta x, y, z, t)}{2 \Delta x} \mathrm{ja} \\
& \frac{\partial^{2} f}{\partial x^{2}} \approx \frac{f(x+\Delta x, y, z, t)-2 f(x, y, z, t)+f(x-\Delta x, y, z, t)}{(\Delta x)^{2}},
\end{aligned}
$$

missä $\Delta t$ on aika-askel ja $\Delta x$ on paikka-askel. Vastaavasti hoituvat muut tarvittavat derivaatat. Kun erotusosamäärät sijoitetaan mallin perusyhtälöihin derivaattojen paikoille, saadaan algebrallinen yhtälöryhmä tuntemattomien $f_{\ell}\left(x_{\mathrm{i}}, y_{\mathrm{j}}, z_{\mathrm{k}} ; t_{\mathrm{p}}\right)$ ratkaisemiseksi. Hilapisteiden lukumäärä on yleensä suuri, minkä takia tarvitaan suurta laskentakapasiteettia.

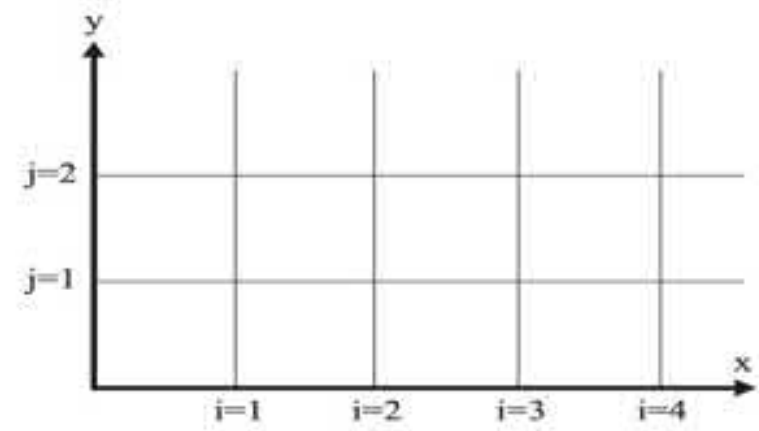

Kuva 2-12. Numeerisissa malleissa käytetään laskentasolukoita eli hiloja, joissa solmupisteisiin lasketaan ennustettavien suureiden arvot.

Hilakoon tavoite määrätään annetun ongelman perusteella, kuinka hyvää erotuskykyä haluttaisiin, mutta viime kädessä hilakokoa rajoittaa laskentakapasiteetti. Pienempi hilakoko tuo lisää ratkaistavia pisteitä ja tarkemman ratkaisun mutta vaatii yhä enemmän laskentaaikaa. Kun paikkahila on kiinnitetty, aika-askeleen valinta riippuu käytetystä numeerisesta menetelmästä. Aika-askeleen täytyy pystyä kuvaamaan ulkoisen pakotteen vaikutuksia, jolloin sen pituus saa olla korkeintaan kymmenesosan pakotteen ajallisten vaihteluiden jaksonpituuksista. Toisaalta numeerisen ratkaisun stabiliteettivaatimus voi asettaa myös ylärajan aika-askeleen pituudelle.

Esimerkki 2-14. Tarkastellaan järven vertikaalista lämpötilamallia. Perusyhtälö on

$$
\frac{\partial T}{\partial t}=K \frac{\partial^{2} T}{\partial z^{2}}+\kappa^{*} \frac{Q}{\rho c} e^{-\kappa^{*} z},
$$

missä $K$ on lämmön diffuusiokerroin, $Q=Q(t)$ on auringonsäteily pinnassa, $\kappa^{*}$ on auringonvalon vaimenemiskerroin vedessä ja $c$ on veden ominaislämpökapasiteetti. Eulerin menetelmän mukaan tätä 
yhtälöä approksimoidaan äärellisten differenssien avulla seuraavasti:

$$
\frac{T\left(t_{p+1}, z_{k}\right)-T\left(t_{p}, z_{k}\right)}{\Delta t}=K \frac{T\left(t_{p}, z_{k+1}\right)-2 T\left(t_{p}, z_{k}\right)+T\left(t_{p}, z_{k-1}\right)}{(\Delta z)^{2}}+\frac{Q\left(t_{p}\right)}{\rho c} e^{-\kappa z_{k}},
$$

missä aika-askel $\Delta t=t_{p+1}-t_{p}$ ja paikka-askel $\Delta z=z_{k+1}-z_{k}$ ovat vakioita. Piste $z_{0}$ on järven pinnassa ja piste $z_{\mathrm{N}}$ pohjassa. Kun lämpötila ajanhetkellä $t_{\mathrm{p}}$ tunnetaan, yhtälöstä voidaan suoraan laskea lämpötila ajanhetkillä $t_{\mathrm{p}+1}$ ja niin edelleen. Lämpötilan $T\left(t_{\mathrm{p}+1}, z_{\mathrm{k}}\right)$ laskeminen edellyttää, että lämpötila tunnetaan pisteissä $T\left(t_{\mathrm{p}}, z_{\mathrm{k}-1}\right), T\left(t_{\mathrm{p}}, z_{\mathrm{k}}\right)$ ja $T\left(t_{\mathrm{p}}, z_{\mathrm{k}+1}\right)$; reunapisteisiin $z_{\mathrm{o}}$ ja $z_{\mathrm{N}}$ lämpötila on tuotava reunaehtojen kautta.

Systeemiä ohjaavat auringonsäteilyn tuoma lämmitys sekä lämmönvaihto pinnassa ja pohjassa. Näissä reunaehdoiksi voidaan asettaa kiinteät lämpötilat, $T\left(t_{\mathrm{p}}, z_{0}\right)=T_{\mathrm{o}}$ ja $T\left(t_{\mathrm{p}}, z_{\mathrm{N}}\right)=T_{\mathrm{b}}$. Aika-askelten määrä riippuu siitä, miten pitkästä ajassa ulottuvasta laskennasta on kyse. Vertikaalikoordinaatin hilapisteiden määrä kiinnitetään etukäteen. Jos veden syvyys on $50 \mathrm{~m}$, hilaväliksi voitaisiin ottaa $0,5 \mathrm{~m}$, jolloin näiden hilapisteiden lukumääräksi tulisi 100. Eulerin menetelmän stabiliteettikriteerin mukaan $K<\frac{1}{2} \frac{(\Delta z)^{2}}{\Delta t}$. Jos otetaan $K=0,01 \mathrm{~m}^{2} \mathrm{~s}^{-1}$, on siis oltava $\Delta t<12,5 \mathrm{~s}$.

Numeeristen mallien avulla on mahdollista kuvata melko hyvin hydrologisia systeemejä, kuten valunta-alueen vesivaraston kehittymistä ja arvioida kuivuus- ja tulvariskejä. Veden kiertokulku järvissä ja maaperässä sekä jään ja lumen rakenne ja paksuus ovat muita laajasti numeeristen mallien avulla tutkittavia kohteita (kuva 2-13). Veden kiertoliikkeen malleihin voidaan edelleen lisätä ainesten kulkeutumisia veden mukana, kun tarkasteltavien ainesten syöttö systeemiin sekä kulutus parametrisoidaan.

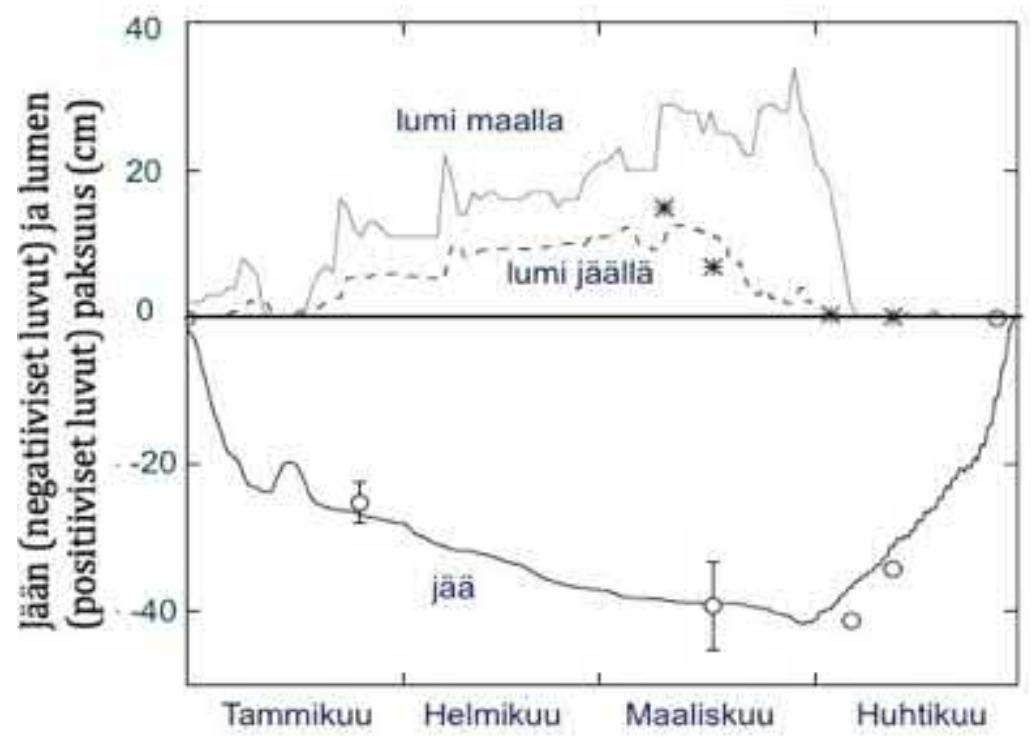

Kuva 2-13. Vanajaveden jää- ja lumipeitteen kehitystä kuvaavan numeerisen mallin tulos talven 2009 ajalle (viivat). Lumen paksuus maalla on vertailun vuoksi. Tähdet kuvaavat lumihavaintoja jäällä ja ympyrät jäähavaintoja. Lähde: Yang ym. (2012), muokattu.

Tilastollisten riippuvuuksien pohjalta voidaan konstruoida tilastollisia malleja. Näiden lähtökohtana on se, että aineisto itsessään sisältää tarpeellisen informaation eikä fysikaalisia lakeja käytetä hyväksi. Tilastollisia malleja käytettiin erityisesti ennen numeeristen mallien aikakautta, mutta nykyisinkin ne ovat käyttökelpoisia yksinkertaisuutensa ansiosta. Varsin suosittu menetelmä on monilla aloilla ollut lineaarinen regressio, jossa havaintoaineistoon sovitetaan suora tai pinta minimoimalla sovitusvirheen varianssi. Muita menetelmiä ovat esimer- 
kiksi empiiriset ortogonaaliset funktiot, autokovarianssimallit ja Markovin ketjut. Toisaalta tilastollisten mallien avulla voidaan myös kompressoida havaintoaineistoja fysikaalisten yhteyksien selvittämiseksi sekä käyttämiseksi muunlaisten mallien vertailuaineistona.

Esimerkki 2.15. Pinnalla kelluvan kappaleen tuulen aiheuttamaa ajelehtimisnopeutta $(u, v), u$ on itäkomponentti ja $v$ pohjoiskomponentti, mallitetaan usein lineaarisella mallilla

$$
\begin{aligned}
& u=a u_{a}-b v_{a}+e_{x}, \\
& v=b u_{a}+a v_{a}+e_{y},
\end{aligned}
$$

missä $u_{\mathrm{a}}$ ja $v_{\mathrm{a}}$ ovat vastaavasti tuulen itä- ja pohjoiskomponentit, $\left(e_{x}, e_{y}\right)$ on virhetermi ja $a$ ja $b$ ovat ratkaistavat parametrit, joka lyhentävät $(a)$ ja kiertävät $(b)$ tuulta ajelehtimishavaintoihin sopivaksi nopeudeksi. Parametrien arvot riippuvat kelluvan kappaleen muodosta ja uppoumasta. Ne voidaan lineaarisen regression avulla havainnoista määrittää minimoimalla virheen varianssi. Ratkaisuksi saadaan, kelluvan kappaleen geometriasta riippuen, että ajelehtimisnopeus on $2-5 \%$ tuulen nopeudesta ja kulkusuunta 0-30 astetta tuulen suunnasta oikealle (pohjoisella pallonpuoliskolla).

Tärkeä aikasarja-analyysin mallisovellutus on ollut vesistöjen säännöstelyn tarvitsemat virtaaman ennusteet käyttäen lineaarista monimuuttujamallia. Suurilla vesistöalueilla, jotka reagoivat hitaasti esimerkiksi sateen aiheuttamaan lisäykseen, on käytetty verrattain pitkää aika-askelta, esimerkiksi kuukautta. Ennustemalli on laadittu pienimmän neliösumman keinolla kuukauden tulovirtaaman ollessa selitettävänä muuttujana ja selittäjinä saman kuukauden ja muutaman edellisen kuukauden sademäärä. Nykyään ennusteet voidaan suorittaa tehokkaammilla tietokoneilla kehittyneempien mallien avulla.

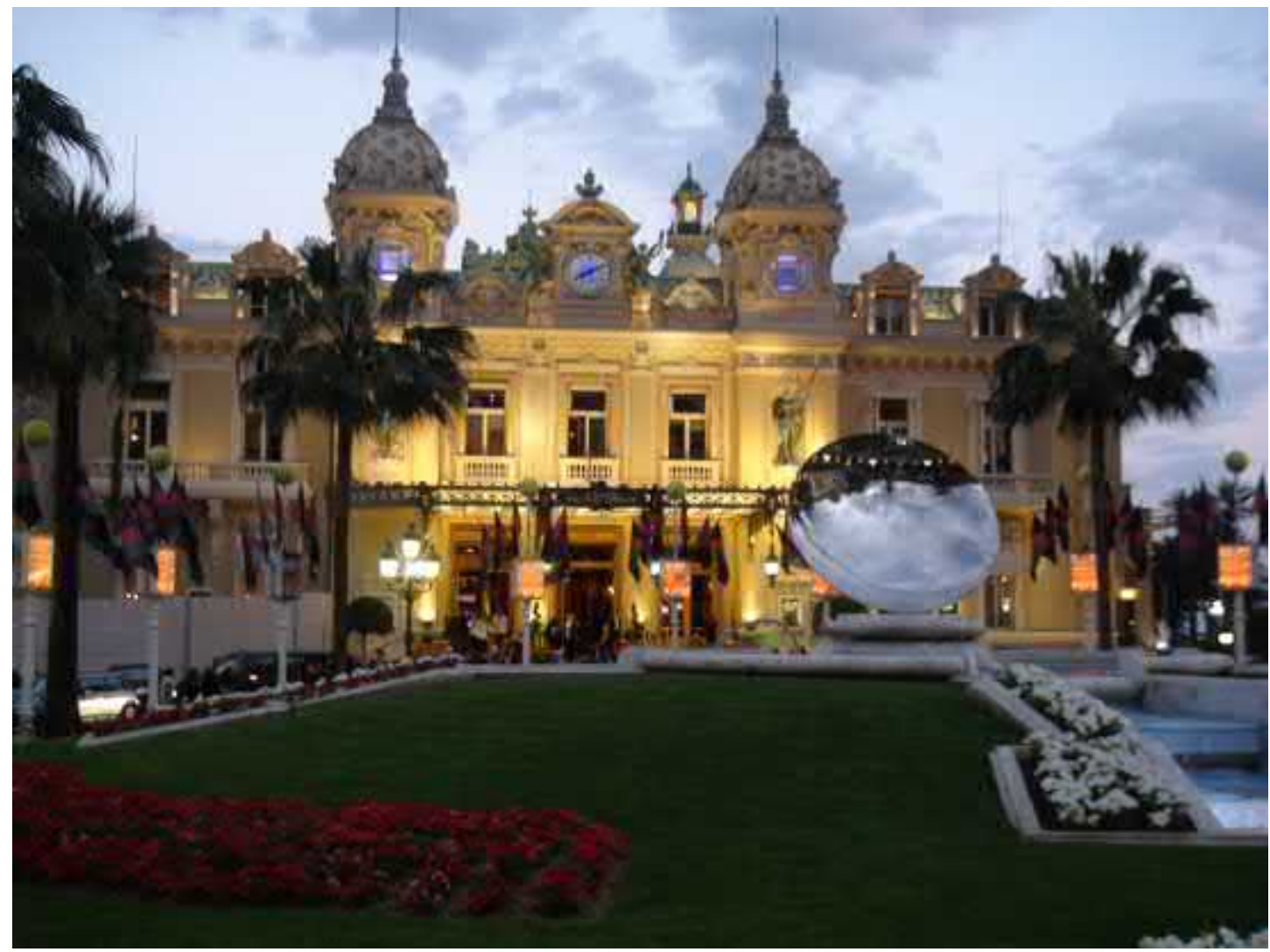

Kuva 2-14. Monte Carlon kasino Monacossa. Se on inspiroinut todennäköisyyslaskennan kehitystä. Satunnaislukuihin perustuvia laskentamenetelmiä alettiin laajemmin käyttää Los Alamosissa Toisen maailmansodan aikana, ja John von Neumann antoi tähän Monte Carlo menetelmä nimen. Sillä on nykyisin sovelluksia useilla tieteenaloilla. Kuva: Leena Leppäranta. 
Stokastinen malli viittaa analyyttiseen tai numeeriseen, fysiikkaan perustuvaan malliin, johon on lisätty satunnaistekijöitä mukaan. Lähtökohtana oleviin fysikaalisiin yhtälöihin otetaan satunnaismuuttujia kuvaamaan epätarkkuuksia tai luonnollista vaihtelua. Stokastiset mallit ovat yleensä fysiikkaa sisältäviä differentiaaliyhtälöitä, joissa muuttujille ja mahdollisesti myös parametreille annetaan deterministinen ja stokastinen eli satunnainen komponentti. Ideana on ratkaista suoraan fysiikan lakien kautta satunnaistekijöiden merkitys tarkasteltavassa fysikaalisessa systeemissä. Epälineaarisissa systeemeissä satunnaistekijät voivat merkittävästi muokata deterministiseltä pohjalta tuotettuja tuloksia.

Monte Carlo menetelmässä (kuva 2-14) simuloidaan satunnaistekijöiden vaikutusta käyttäen satunnaislukugeneraattoria. Manuaalisena esimerkkinä toimii seuraava. Epäsäännölliseen kartta-alueen pinta-ala voidaan määrittää heittämällä kartan päälle umpimähkään merkkejä, jolloin pinta-alaksi saadaan osumaprosentti x koko kartan ala. Menetelmä soveltuisi erinomaisesti moniin hydrologian ongelmiin.

Matemaattisia malleja on nyisin verrattain hyvin saatavilla sähköisen verkon välityksellä. Jokaisen tutkijan ei tarvitse itse konstruoida malleja, mutta sen sijaan on kyllä syytä tuntea mallimaailman ajatustapa ja mahdollisuudet. Vaikkei itse mallia konstruoisikaan, on hyvä tehdä mallilla monipuolisia testejä sen ominaisuuksien ymmärtämiseksi, aivan kuten tutkija tekee kokeita luonnossa sen ilmiöiden ymmärtämiseksi. Mallit eivät ole täydellisiä. Niissä on yksinkertaistavia oletuksia sekä säätöparametreja, jotka usein ovat vielä aluekohtaisia. Mallinrakentamisen motoksi sopii suomalainen sanonta 'Minkä teet, se tervaa!'.

Tämä kirja ei käsittele mallien konstruointia. Siksi malleihin ei mennä syvemmälti, mutta esityksessä kyllä käytetään mallien tuloksia hyväksi. Seuraavassa luvussa astutaan hydrologian kivijalkaan tarkastellen luonnonvesien yleisiä ominaisuuksia ja veden kiertokulun pääpiirteitä. 


\section{Vesi ja veden kiertokulku}

\subsection{Luonnonvesien ominaisuuksista}

\subsubsection{Puhdas vesi}

Vesimolekyyli koostuu happiatomista ja kahdesta vetyatomista (kuva 3-1a). Kumpikin vetyatomi muodostaa happiatomin kanssa kovalenttisen kemiallisen sidoksen, jossa happiatomi ja vetyatomi jakavat yhden elektroniparin. Sidosten pituus on 95,8 pm, ja ne ovat järjestyneet epäsymmetrisesti muodostaen $104,5^{\circ}$ koveran kulman. Tämän epäsymmetrian takia vesimolekyyli on sähköinen dipoli: happiatomin puolella on negatiivinen osittaisvaraus ja vetyatomien puolella positiivinen. Dipolarisuudesta seuraa monia veden poikkeuksellisia ominaisuuksia kuten erinomainen liuotuskyky.

Vesimolekyylit sidostuvat toisiinsa vetysidosten avulla. Näitä muodostuu sähköisen epäsymmetrian takia yhden molekyylin happiatomin ja viereisen molekyylin vetyatomin vetäessä toisiaan puoleensa. Vetysidokset ovat 117 pm:n mittaisia ja paljon heikompia kuin kovalenttiset sidokset. Niiden ansiosta veden jäätymis- ja kiehumispiste ovat korkeampia kuin vastaavanlaisilla kemiallisilla yhdisteillä. Nestemäisessä olomuodossa vesimolekyylit ovat lineaarisissa ketjuissa vetysidosten sitomina. Näitä syntyy ja purkautuu jatkuvasti ja näin veden rakenne elää. Veden kiinteä olomuoto eli jää muodostaa molekyyleistä kiderakenteita. Maapallon pinnalla ja siitä $10 \mathrm{~km}$ alaspäin tai ylöspäin vallitsevissa paineissa ja lämpötiloissa vesi jäätyy heksagonaaliseen eli kuusikulmioiseen kiderakenteeseen Jää $I^{1}$ (kuva 3-1b). Kukin vesimolekyyli on liittynyt neljään naapurimolekyyliin vetysidoksin muodostaen tetraedrirakenteita. Elektroniparit ovat tasavälein kehällään, ja $\mathrm{H}-\mathrm{O}-\mathrm{H}$ sidosten koverat kulmat ovat $109,5^{\circ}$ suuruisia säännöllisen tetraedrin geometrian mukaisesti. Tetraedrit asettuvat heksagonaaliseen symmetriaan, mistä kiderakenteen nimitys tulee.

a)

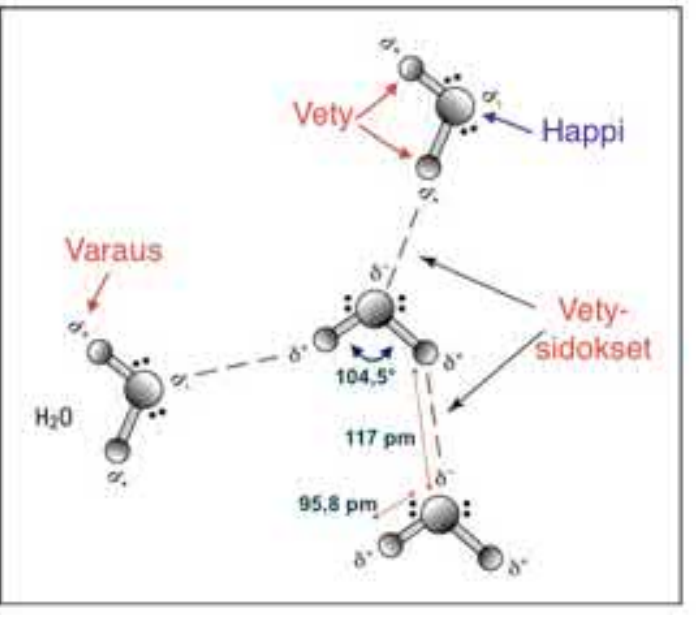

b)

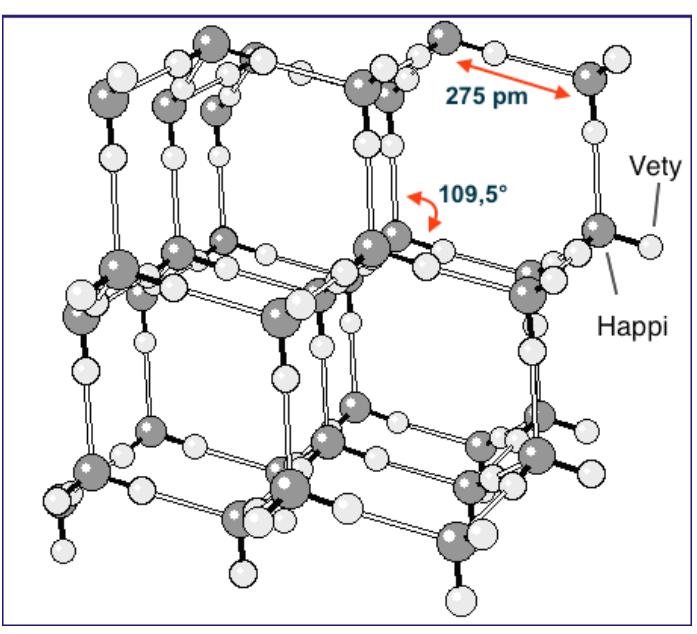

Kuva 3-1. Puhtaan veden molekyylirakenne. a) Nestemäinen olomuoto. Molekyylien kovalenttisten happi-vety sidosten pituus on 95,8 pm ja sidosten muodostama kovera kulma on $104,5^{\circ}$. b) Jää Ih. Molekyylit verkottuvat niin, että kuhunkin molekyyliin liittyy vetysidoksin neljä muuta, jolloin muodostuu toistuva kuusikulmio- eli heksagonaalirakenne. Molekyylien kovalenttisten happi-vety sidosten muodostama kovera kulma on $109,5^{\circ}$.

\footnotetext{
${ }^{1}$ Veden kiinteästä olomuodosta tunnetaan useita erilaisia kiderakenteita, mutta muita kuin Jää $I h$ muodostuu vain hyvin korkeissa paineissa tai hyvin matalissa lämpötiloissa, eikä niitä tule vastaan maapallon hydrologiassa. Yläilmakehässä esiintyy pieniä määriä kuutiohilaista jäätä 'Jää Ic'.
} 
Jää Ih:n rakenteessa molekyylit ovat pakkautuneina harvempaan kuin nestemäisessä vedessä, ja siksi sen tiheys on paljon pienempi $(8,3 \%)$ kuin nestemäisen veden. Makrotasolla heksagonaalisuus näkyy usein kiteiden muodossa ja lumihiutaleiden kuusisakaraisuutena. Aineen tiheyden aleneminen sen muuttuessa nestemäisestä kiinteään olomuotoon on poikkeuksellista $^{2}$, eikä millään muulla luonnonaineella tämä muutos ole niin suuri kuin vedellä. Myöhemmin tässä kirjassa 'jää' viittaa aina heksagonaaliseen kiderakenteeseen.

Veden kolmoispiste on lämpötilassa $273,16 \mathrm{~K}\left(0,01^{\circ} \mathrm{C}\right)$ ja paineessa $611,73 \mathrm{~Pa}$. Kolmoispisteessä faasit ovat tasapainossa eli järjestelmän kaikki aine on mahdollista muuttaa kiinteäksi, nesteeksi tai kaasuksi erittäin pienellä paineen tai lämpötilan muutoksella.

Vesi on ainoa aine, joka maapallon luonnonoloissa esiintyy kaikissa olomuodoissa: kaasumaisena (vesihöyry), nestemäisenä ja kiinteänä (jää). Vesimolekyylit myös muuttuvat olomuodosta toiseen (kuva 3-2). Lisäksi huomattava määrä vettä on sitoutunut kemiallisiin yhdisteisiin kidevetenä. Maapallon pintakerroksessa on vettä enemmän kuin mitään muuta ainetta, ja normaalioloissa veden nestemäisyys on tässä pintakerroksessa poikkeuksellista verrattuna muihin epäorgaanisiin aineisiin. Ei ole niinkään merkillistä, että vettä on pidetty yhtenä maapallon peruselementeistä ja että siihen on liitetty monia jumalia ja haltioita (kuva 3$3)$.

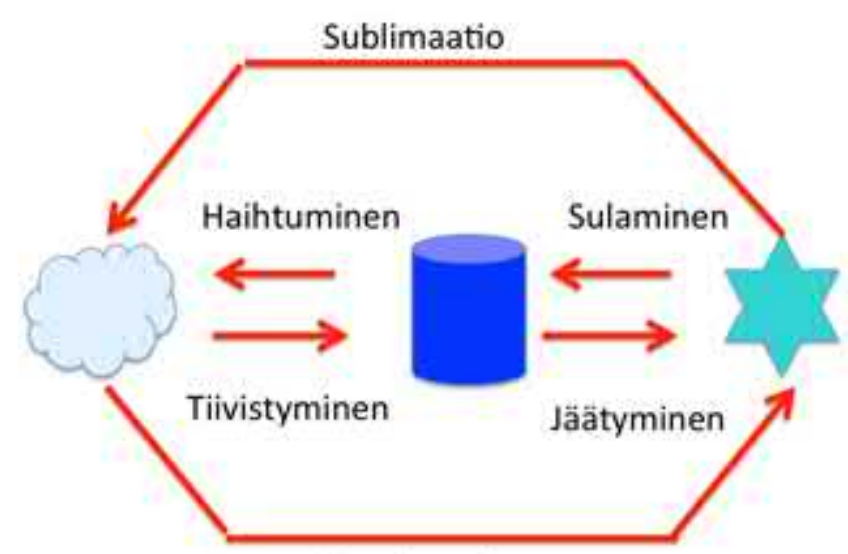

Härmistyminen

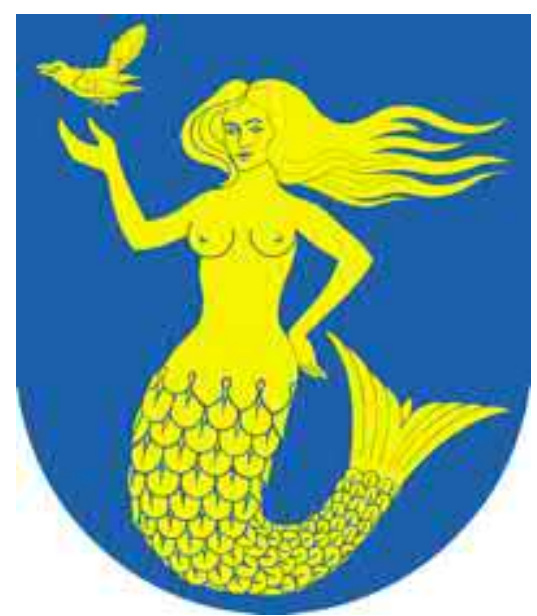

Kuva 3-2. Veden olomuodon muutokset.

Kuva 3-3. Vellamo on muinaissuomalaisten veden jumalatar, joka edelleen elää suomalaisessa kulttuurissa kuten puolisonsa Ahti. Päijät-Hämeen maakunta on ottanut Vellamon kuvan vaakunaansa. Vaakunan on suunnitellut professori Tapani Aartomaa vuonna 1997. (C) Päijät-Hämeen liitto.

Taulukossa 3-1 on esitettynä hydrologiassa tärkeitä puhtaan veden ominaisuuksia. Nämä riippuvat hieman lämpötilasta ${ }^{3}$ ja paineesta. Luonnonvesien ominaisuuksiin vaikuttavat lisäksi siihen liuenneet aineet, mutta taulukon arvot soveltuvat hyvin makean veden hydrologisiin tutkimuksiin. Kun veteen liukenee epäpuhtauksia, sähkömagneettiset ominaisuudet muuttuvat nopeasti. Sähkönjohtavuus kasvaa, ja sitä käytetäänkin epäsuorana liuenneitten aineitten konsentraation mittausmenetelmänä. Optisesti aktiivit epäpuhtaudet vai-kuttavat jo hyvin pieninä määrinä voimakkaasti valon absorptioon ja sirontaan.

\footnotetext{
${ }^{2}$ Veden lisäksi esimerkiksi vismutti, gallium ja germanium ovat tällaisia aineita.

${ }^{3}$ Veden lämpötila ilmaistaan hydrologiassa yleensä Celsius-asteina. Tämä on intervalliasteikko, jossa lämpötiloja voidaan laskea yhteen ja vähentää toisistaan; kerto- ja jakolaskut eivät ole hyvin määriteltyjä. Absoluuttista lämpötilaa kuvataan Kelvin-asteilla $\left(273,15 \mathrm{~K}=0^{\circ} \mathrm{C}\right)$.
} 
Taulukko 3-1. Nestemäisen puhtaan veden ja jään fysikaalisia ominaisuuksia eri lämpötiloissa ja ilmakehän normaalipaineessa 1013,25 mbar.

\begin{tabular}{|c|c|c|c|c|c|}
\hline & \multicolumn{3}{|c|}{ Nestemäinen vesi } & Jää & \\
\hline Lämpötila & $0^{\circ} \mathrm{C}$ & $10^{\circ} \mathrm{C}$ & $20^{\circ} \mathrm{C}$ & $0^{\circ} \mathrm{C}$ & Yksikkö \\
\hline Tiheys & 999,8 & 999,7 & 998,2 & 917 & $\mathrm{~kg} \mathrm{~m}^{-3}$ \\
\hline Dynaaminen viskositeetti* & $1,8 \cdot 10^{-3}$ & $1,31 \cdot 10^{-3}$ & $1,01 \cdot 10^{-3}$ & $\sim 10^{15}$ & $\mathrm{~kg} \mathrm{~m}^{-1} \mathrm{~s}^{-1}$ \\
\hline Lämpölaajenemiskerroin ${ }^{\dagger}$ & $-0,68 \cdot 10^{-4}$ & $0,88 \cdot 10^{-4}$ & $2,1 \cdot 10^{-4}$ & $1,5 \cdot 10^{-4}$ & ${ }^{\circ} \mathrm{C}^{-1}$ \\
\hline Pintajännitys & 0,076 & 0,074 & 0,072 & - & $\mathrm{N} \mathrm{m}^{-1}$ \\
\hline Ominaislämpökapasiteetti & 4,22 & 4,19 & 4,16 & 2,11 & $\mathrm{~kJ}^{\circ} \mathrm{C}^{-1} \mathrm{~kg}^{-1}$ \\
\hline Lämmönjohtokyky & 0,56 & 0,59 & 0,62 & 2,14 & $\mathrm{~W}^{\circ} \mathrm{C}^{-1} \mathrm{~m}^{-1}$ \\
\hline Jäätymis/sulamislämpö & 333,6 & - & - & 333,6 & $\mathrm{~kJ} \mathrm{~kg}^{-1}$ \\
\hline Höyrystymislämpö & 2,49 & 2,47 & 2,45 & 2,82 & $\mathrm{MJ} \mathrm{kg}^{-1}$ \\
\hline Suhteellinen permittiivisyys & 87,9 & 83,8 & 80,1 & 91,6 & 1 \\
\hline
\end{tabular}

*Jää käyttäytyy viskoosin nesteen tavoin pitkäaikaiskuormituksessa kuten jäätiköiden virtauksessa.

†Tilavuuden laajeneminen.

Luonnonvesien tiheys riippuu lämpötilasta, liuenneiden aineiden konsentraatiosta ja paineesta. Tiheys on keskeinen vesiä kuvaava suure, sillä se määrää vertikaalisen kerrostuneisuuden. Tiheyden muuttuessa vesi siirtyy aina omalle tiheystasolleen, ja kerrostuneisuuden kehityksessä pienetkin tiheyserot ovat merkitseviä. Jos pintaveden tiheys kasvaa esimerkiksi jäähtymisen takia, se vajoaa alaspäin syvyyteen, jossa tiheys on vastaavan suuruinen. Tätä tiheysmuutosten aiheuttamaa pystysuoraa kiertoa sanotaan konvektioksi.

Useat veden ominaisuudet ovat poikkeuksellisia verrattuna vastaavanlaisiin kemiallisiin yhdisteisiin (taulukko 3-2). Erityisesti liuotuskyky, höyrystymislämpö ja pintajännitys ovat suurempia kuin muilla aineilla, voimakas laajeneminen jäätyessä on ainutlaatuista, ja lämpökapasiteetti sekä jäätymislämpö ovat suurimpien joukossa. Suhteellinen permittiivisyys on vedellä myös hyvin korkea.

Taulukko 3-2. Veden poikkeuksellisia ominaisuuksia ja niiden merkityksestä hydrologiassa.

\begin{tabular}{|c|c|}
\hline Ominaisuus & Merkitys \\
\hline Suuri liuotuskyky & $\begin{array}{l}\text { Luonnonvesissä on liuenneina lähes kaikkia luon- } \\
\text { nossa esiintyviä alkuaineita. }\end{array}$ \\
\hline $\begin{array}{l}\text { Jäätymis- ja kiehumispiste suhteellisen } \\
\text { korkeita }\end{array}$ & $\begin{array}{l}\text { Maapallolla on vettä kaikissa olomuodoissa. Nes- } \\
\text { temäiseen veteen perustuva elämä on mahdollis- } \\
\text { ta. }\end{array}$ \\
\hline Suuri ominaislämpökapasiteetti & $\begin{array}{l}\text { Veden lämpötila muuttuu hitaasti, mikä tuo ter- } \\
\text { mistä hitautta säähän ja ilmastoon eli vaimentaa } \\
\text { ilman lämpötilan vaihteluita. }\end{array}$ \\
\hline Olomuodon muutoslämmöt korkeita & $\begin{array}{l}\text { Jäätyminen/sulaminen puskuroi veden lämpöti- } \\
\text { laa, ja haihduntaan kuluu paljon lämpöä. }\end{array}$ \\
\hline $\begin{array}{l}\text { Tiheysmaksimin lämpötila korkeampi } \\
\text { kuin jäätymispisteen lämpötila (makea } \\
\text { vesi ja murtovesi) }\end{array}$ & $\begin{array}{l}\text { Talvikerrostuneisuus muodostuu järviin niin, että } \\
\text { ylempi kerros on jäätymispisteen tuntumassa ja } \\
\text { alempi kerros lämpimämpi }\left(\leq 4^{\circ} \mathrm{C}\right) \text {. }\end{array}$ \\
\hline Huomattava laajeneminen jäätymisessä & $\begin{array}{l}\text { Jää kelluu veden pinnalla, ja jäätyminen aiheut- } \\
\text { taa paineita. Routa muokkaa maaperää. }\end{array}$ \\
\hline Suuri suhteellinen permittiivisyys & $\begin{array}{l}\text { Puhdas vesi on huono sähkönjohde (luonnon- } \\
\text { vesien sähköiset ominaisuudet riippuvat voimak- } \\
\text { kaasti liuenneen aineksen määrästä). }\end{array}$ \\
\hline Korkea pintajännitys & $\begin{array}{l}\text { Kapillaari-ilmiö ja siitä seuraava veden nousemi- } \\
\text { nen maaperän onkaloissa ja kasvien varsissa se- } \\
\text { kä sadepisaroiden muodostuminen }\end{array}$ \\
\hline
\end{tabular}


Vesiliuoksen happamuutta kuvataan $p H$-luvulla, joka kertoo aktiivisten vetyionien $\left(\mathrm{H}^{+}\right)$määrästä. Asteikko on kymmenkanta-logaritminen. Kun $p H$-luku laskee yhden yksikön verran happamuus kasvaa kymmenkertaiseksi. Neutraalin liuoksen $p H$ on 7,0, happamilla luku on pienempi ja emäksisillä suurempi. Luonnonvesien $p H$ on yleensä välillä 4-10. Esimerkiksi etikan $p H$ on 3 ja pyykinpesuaineen 12,5 .

\subsubsection{Jää ja lumi}

Kylmän ilmaston vyöhykkeillä osa vedestä on lumena ja jäänä (kuva 3-4). Nämä alueet voidaan jaotella seuraavasti:

Ympäristö
ilmakehän jää
talvimaasto
vesien jääpeite
jäätiköt
routa
maanpinta

Laatu
lumihiutaleet
lumipeite
jää ja lumi
lumi ja jää
jää-maa-aines
kuura
huurre
iljanne

Alkuperä
syntyvät pilvissä vesihöyrystä
lumisateen kertyminen
veden jäätyminen ja lumisade
lumisade ja lumen metamorfoosi
maaperän veden jäätyminen
vesihöyryn härmistyminen
alijäähtyneiden pisaroiden jäätyminen
pinnalla olevan veden jäätyminen

Jäätiköt ja ikirouta sisältävät vanhaa jäätä ja niiden uusiutumisaika on pitkä. Muissa ympäristöissä lumi ja jää esiintyvät kausittain, kylmänä vuodenaikana muutamia poikkeustapauksia lukuun ottamatta. Esimerkiksi Etelämantereen kuivissa laaksoissa on monivuotisen jään peittämiä järviä.

Jää ja lumi ovat kemiallisesti samanlaista. Niiden erottelu perustuu visuaaliseen havaintoon ja erilaisiin fysikaalisiin ominaisuuksiin. Lumessa on paljon, jopa $90 \%$ tilavuudesta kaasua (lähinnä ilmaa) sisältäviä onkaloita, kun taas jäässä on kaasukuplia yleensä $1 \%$ verran. Tämän takia lumen ja jään makro-ominaisuudet ${ }^{4}$ ovat hyvin erilaisia. Kaasukolot sirottavat valoa voimakkaasti ja kaikkia värejä yhtä paljon, koska ne ovat paljon valon aallonpituutta suurempia. Siksi lumi näyttää auringonvalossa valkoiselta. Kaasukolot lisäävät lämmöneristyskykyä ja alentavat lujuutta.

Puhtaan jään ominaisuuksia esitettiin edellä taulukossa 3-1. Lämpöopilliset ominaisuudet ovat samaa suuruusluokkaa kuin vedellä, mutta mekaanisissa ominaisuuksissa on suuria eroja. Vesi on viskoosi neste ja sen viskositeetti on pieni, minkä takia vesi liikkuu herkästi. Jää on sangen luja viskoelastinen kiinteä aine. Lyhytaikaisissa kuormituksissa jää käyttäytyy kimmoisan eli elastisen aineen tavoin murtolujuuteensa asti, ja suuruusluokaltaan kimmokerroin on $1 \mathrm{GPa}$ ja murtolujuus $1 \mathrm{MPa}$. Jään aiheuttama paine voi kasvaa murtolujuuteen asti. Pitkäaikaisessa kuormituksessa kuten painovoiman alaisena rinteellä makaavassa vuoristojäätikössä tapahtuu hidasta, viskoosia virumista samaan tapaan kuin taikinan leviämisessä painonsa alla.

Lumen tärkeä perusominaisuus on sen tiheys, joka Suomen luonnossa on tavallisesti 200 $300 \mathrm{~kg} \mathrm{~m}^{-3}$. Tiheys voidaan kirjoittaa $\left(1-v_{a}\right) \rho_{i}$, missä $v_{a}$ on lumen suhteellinen kaasutilavuus ja $\rho_{i}$ on puhtaan jään tiheys. Lumen lämpökapasiteetti on sen tiheys kerrottuna jään ominaislämmöllä ja lämmönjohtokyky on verrannollinen tiheyden neliöön. Mekaaniselta käyttäytymiseltään lumi eroaa jäästä jo kvalitatiivisesti. Lumen pinnan kantokyky kertoo esimerkiksi kuinka leveillä suksilla pinnalla voi liikkua, ja sen sisäinen lujuus kertoo lumivyö-

\footnotetext{
${ }^{4}$ Makro-ominaisuus viittaa riittävän suuriin elementteihin, joissa jääkiteet ja kaasukolot yhdessä vaikuttavat.
} 
ryriskeistä ja lumeen kaivautumisen vaikeudesta. Lumen ominaisuudet muuttuvat ajan kuluessa merkittävästi lumipeitteen metamorfoosin seurauksena.
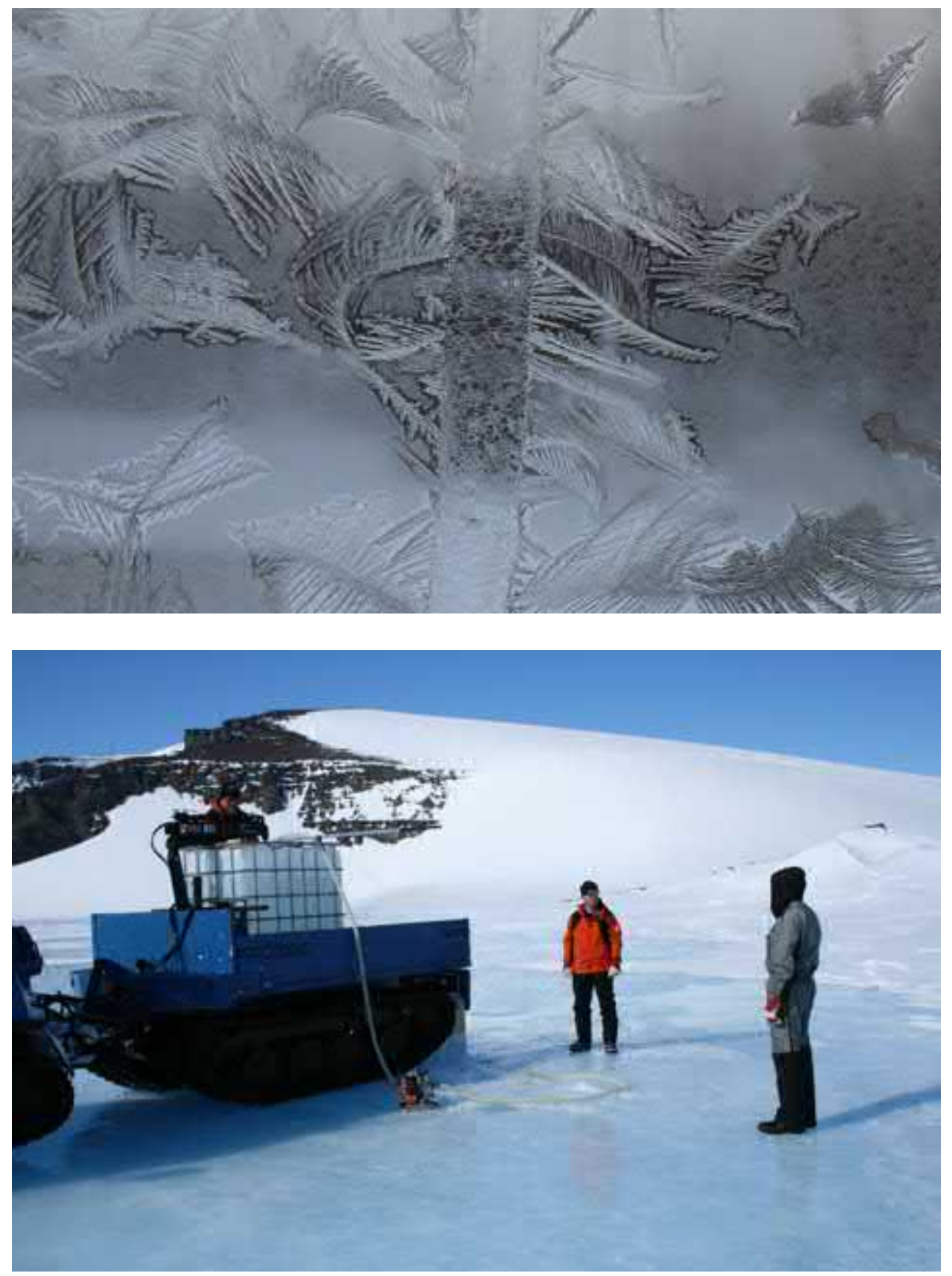

Kuva 3-4. Esimerkkejä veden kiinteästä olomuodosta luonnossa. Yläkuva: kuurankukkia akkunalla. Alakuva: Suomen Aboa-aseman vesihuolto supraglasiaalisella Suvivesi-järvellä Etelämantereella. Kuvat: Matti Leppäranta.

\subsubsection{Luonnonvesien epäpuhtaudet}

Luonnonvesien fysiikassa tarkastellaan myös veden geokemiallisia ominaisuuksia, koska nämä vaikuttavat luonnonvesien fysikaalisiin ominaisuuksiin ja käyttäytymiseen, ja koska geokemiallisia tietoja tarvitaan sovelluksissa (kuva 3-5). Epäpuhtauksia on luonnonvesissä liu- 
enneena ja liukenemattomassa muodossa eli kiintoaineena. Lisäksi löytyy kolloideja ${ }^{5}$, jotka suodatuksessa voivat jäädä kiintoaineeseen tai suotautua läpi liuenneitten ainesten kanssa, suodattimen tiheydestä riippuen. Epäpuhtauksista saadaan perustietoa automaattisin luotauksin, mutta tarkempi geokemiallinen analyysi tehdään laboratoriossa (kuva 3-6).

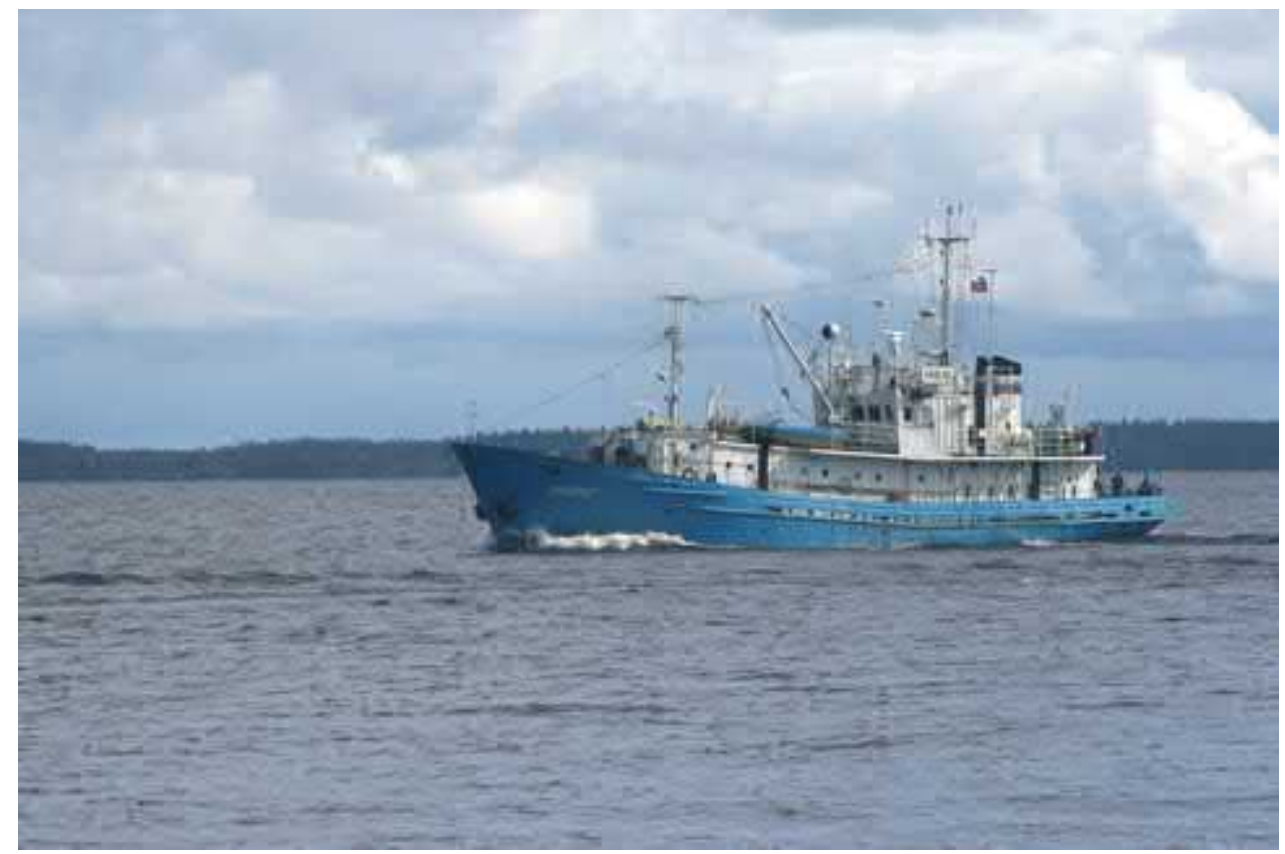

Kuva 3-5. Järvien tutkimuksissa tehdään luotauksia automaattisten mittalaitteiden avulla ja otetaan vesinäytteitä biogeokemiallisiin tutkimuksiin. Suurilla järvillä käytetään tutkimusaluksia. Kuvassa Venäjän tiedeakatemian Karjalan tutkimuskeskuksen tutkimusalus Ekolog Äänisellä. Kuva: Matti Leppäranta.

Liuenneiden aineiden konsentraatio vaikuttaa veden tiheyteen merkittävästi erityisesti murtovesissä ja suolajärvissä. Ravinteet (lähinnä fosfori ja typpi) puolestaan kertovat biologisen perustuotannon potentiaalista ja niiden taseita liitetään mukaan fysikaalisiin tarkasteluihin. Kiintoainesta on vesirungossa erikokoisina partikkeleina, ja sitä voidaan eristää vesinäytteistä suodattamalla. Suodattimien normaali huokoskoko on mikrometrin suuruusluokkaa (esimerkiksi $0,4-1,0 \mu \mathrm{m}$ klorofyllipitoisuuden tutkimuksissa ja ympäristöhallinnossa $0,45-2,0$ $\mu \mathrm{m})$. Kiintoaines taltioituu suodattimeen, ja liuennut aines voidaan puolestaan eristää haihduttamalla suodatetusta näytteestä vesi. Jos kiintoainesta on paljon, vesi-kiintoaines yhdistelmää voidaan tarkastella binäärisekoitteena. Veden käyttötarkoituksen mukaan epäpuhtauksien määriin on olemassa viranomaisten asettamia laatustandardeja.

Liuenneen aineen ja kiintoaineen konsentraation laatuna on yleensä massa per tilavuus, yksikkönä milligrammaa litraa kohti ${ }^{6}\left(\mathrm{mg} \mathrm{L}^{-1}\right)$. Luonnonvesissä on liuenneena myös kaasuja, joista tärkein on elämälle välttämätön happi. Liuenneen aineen konsentraatio $(c)$ määritetään yleensä sähkönjohtavuuden $(\sigma)$ perusteella. Tämän laatu on sähkövirran voimakkuus jaettuna jännitteellä ja matkalla, yksikkönä $S \mathrm{~m}^{-1}$ (Siemens per metri). Sähkövastus on sähkönjohtavuuden käänteisarvo, $S=\Omega^{-1}$. Sähkönjohtavuus riippuu myös lämpötilasta $(T), \sigma=\sigma(c, T)$. Tämä redusoidaan kiinteään referenssilämpötilaan, joka on yleensä $25^{\circ} \mathrm{C}$ :

\footnotetext{
${ }^{5}$ Kolloidi on homogeenisen ja heterogeenisen seoksen välimuoto, joka koostuu dispergoituneesta faasista ja jatkuvasta faasista. Edellinen faasi sisältää pieniä (1-1000 nm) hiukkasia, jotka ovat tasaisesti jakautuneet jatkuvaan faasiin. Esimerkiksi sumu (vesihiukkaset ja ilma) on kolloidi, samoin maito.

${ }^{6}$ Litrayksikön merkintänä käytetään tässä kirjassa isoa L-kirjainta.
} 


$$
\begin{aligned}
& \sigma\left(c, 25^{\circ} \mathrm{C}\right)=\sigma(c, T)+\Delta \sigma_{25^{\circ} \mathrm{C}} \\
& \Delta \sigma_{25^{\circ} \mathrm{C}}=\sigma(c, T) \cdot 0,0191{ }^{\circ} \mathrm{C}^{-1} \cdot\left(25^{\circ} \mathrm{C}-T\right),
\end{aligned}
$$

missä $\Delta \sigma_{25^{\circ} \mathrm{C}}$ on johtokyvyn lämpötilakorjaus. Liuenneen aineen konsentraatio voidaan yhtälön (3.1) pohjalta arvioida seuraavasti:

$$
c=6,7 \cdot \frac{\sigma\left(c, 25^{\circ} \mathrm{C}\right)}{\mathrm{mS} \mathrm{m} \mathrm{m}^{-1}} \cdot \frac{\mathrm{mg}}{\mathrm{L}} .
$$

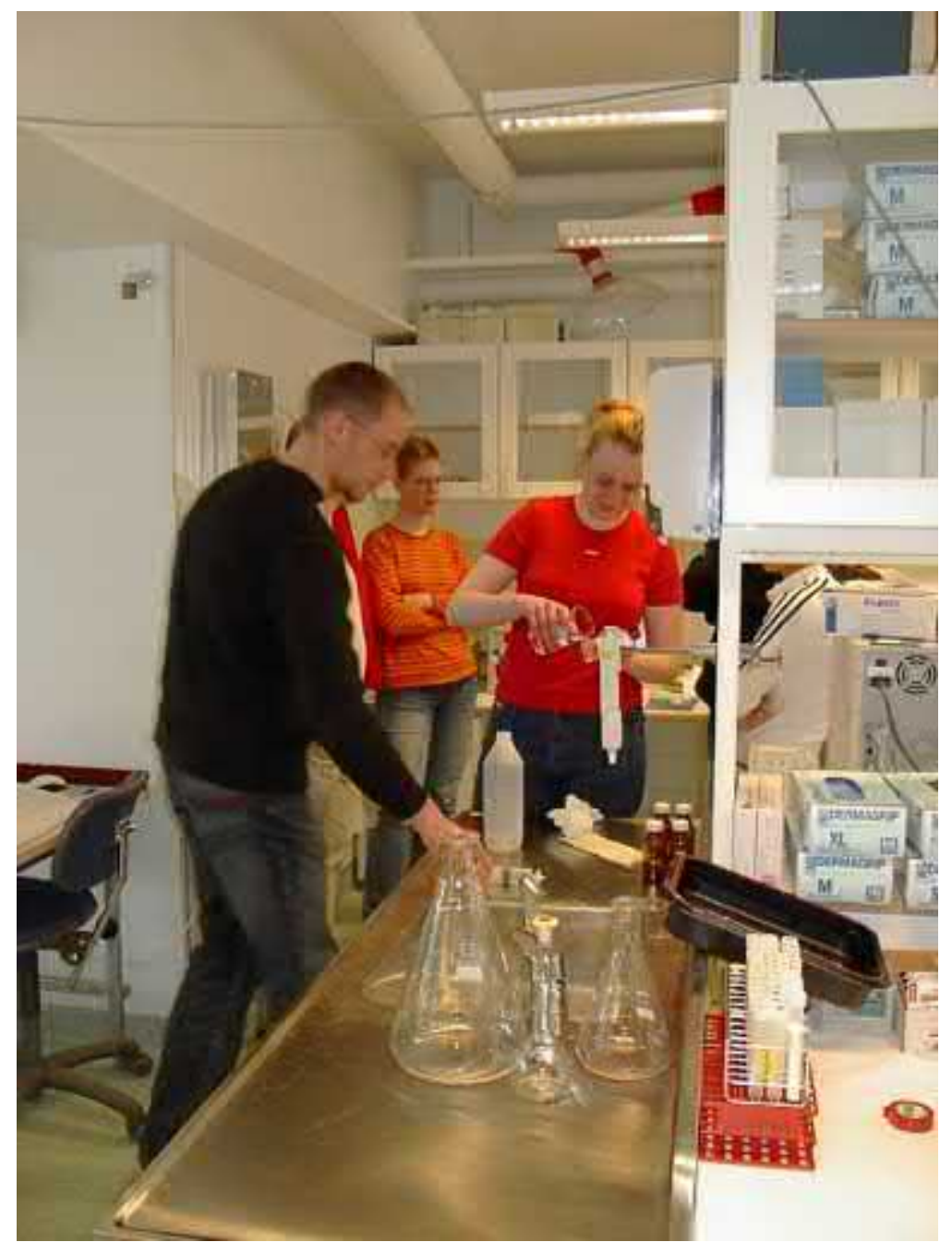

Kuva 3-6. Vesinäytteiden käsittelyä Lammin biologisen aseman vesilaboratoriossa Luonnonvesien optiikan kurssilla. Kuva: Matti Leppäranta.

Meritieteessä liuenneen aineksen pitoisuus ilmaistaan suolaisuutena $(S)$, joka määritellään liuenneen aineksen ja liuoksen massojen suhteeksi ja on siis laaduton. Suolaisuus on aina ilmaistu promilleina (\%o), mutta meritieteen nykyisten suositusten mukaan promillen symbolia ei enää tarvitse kirjoittaa. Siis $S=35$ luetaan $S=35 \%$. Tässä kirjassa promille symbo-lia

\begin{tabular}{|c|c|}
\hline $\begin{array}{c}S<0,5 \% \\
0,5 \% 0 \leq<25 \% \\
25 \% 0 \leq S<40 \% \\
S>40 \%\end{array}$ & $\begin{array}{l}\text { makea vesi } \\
\text { murtovesi } \\
\text { merivesi } \\
\text { hypersuolainen vesi }\end{array}$ \\
\hline
\end{tabular}
kuitenkin käytetään sekaannusten välttämiseksi. Luonnonvedet jaotellaan suolaisuuden $S$ mukaan seuraavasti: 
Koska makean veden litran massa on sangen tarkasti $1 \mathrm{~kg}$, liuenneen aineen pitoisuus yksikössä $\mathrm{mg} \mathrm{L}^{-1}$ on numeroarvoltaan sama kuin suolaisuus miljoonasosina. Suolaisuuden kasvaessa tiheys kasvaa, ja vesilitran massa tulee hieman yhtä kilogrammaa suuremmaksi, ja tällöin ero näiden suureiden numeroarvojen kohdalla tulee havaittavaksi.

Järvien, jokien ja maaperän vesivarojen liuenneiden aineiden konsentraatio on Suomen oloissa yleensä alle $100 \mathrm{mg} \mathrm{L}^{-1}$ eli suolaisuus on alle $0,1 \%$. Nämä ovat sangen pieniä arvoja. Käytännössä juomaveden suolaisuuden on oltava pienempi kuin 0,5 \%o. Ihmisveren suolaisuus on $9 \%$, joten tätä alempisuolaisempaa vettä voisi käyttää juomavetenä, mutta makuhaitat ovat merkittäviä, kun suolaisuus on yli $0,5 \%$. Valtamerten veden suolaisuus on noin 35 \% ja Itämeren suolaisuus on Suomea reunustavilla alueilla $4-8 \%$. Eräät suolajärvet ovat hypersuolaisia, Kuolleen meren suolaisuus on jopa $250 \%$.

Kiintoaines sisältää epäorgaanista ainesta ja orgaanisia yhdisteitä. Sitä tutkitaan suodattimeen kerätystä ainejäämästä. Orgaanisen aineksen osuus voidaan selvittää polttamalla. Orgaanista hiiltä on liuenneessa muodossa ja partikkeleina. Elävää orgaanista kasvustoa kuvataan lehtivihreän eli klorofyllin pitoisuudella, jonka yksikkönä käytetään mikrogrammaa litraa kohti $\left(\mu \mathrm{g} \mathrm{L}{ }^{-1}\right)$. Biologisen perustuotannon ${ }^{7}$ tarvitsemat pääravinteet ovat typpi ja fosfori, ja myös niiden pitoisuudet ilmaistaan yksikössä $\mu \mathrm{g} \mathrm{\textrm {L } ^ { - 1 }}$.

Kiintoainesta laskeutuu ilmakehästä tai irtoaa maaperästä. Pohjasta irtoamista, jota tapahtuu esimerkiksi aallokon tai voimakkaiden virtausten takia, kutsutaan resuspensioksi. Kiintoainespartikkelit kulkeutuvat virtauksen mukana ja siirtyvät vedessä pystysuunnassa Stokesin lain mukaan:

$$
w=\frac{\left(\rho_{s}-\rho\right) g d^{2}}{18 \mu}
$$

missä $w$ on vertikaalinopeus, $\rho_{s}$ on partikkelin tiheys, $\rho$ on veden tiheys, $g=9,81 \mathrm{~m} \mathrm{~s}^{-2}$ on putoamiskiihtyvyys, $d$ on partikkelin halkaisija ja $\mu$ on veden dynaaminen viskositeetti. Nopeus riippuu voimakkaasti partikkelien koosta. Lain johtamisessa on oletettu, että partikkelit ovat muodoltaan pyöreitä, mitä ne luonnossa eivät suinkaan aina ole. Turbulenttisessa jokivirtauksessa intensiiviset virtauspyörteet auttavat partikkeleja pysymään vedessä kauem$\min$.

Esimerkki 3-1. Oletetaan, että järvessä partikkelien koko on $d$ ja theys $\rho_{s}=2500 \mathrm{~kg} \mathrm{~m}^{-3}$ ja veden lämpötila $10^{\circ} \mathrm{C}$, jolloin viskositeetti on $\mu=1,3 \cdot 10^{-3} \mathrm{~kg} \mathrm{~m}^{-1} \mathrm{~s}^{-1}$. Savipartikkelit $(d=0,2 \mu \mathrm{m})$ vajoavat nopeudella $2,2 \mathrm{~mm} \mathrm{vrk}{ }^{-1}$, ja hiekanjyvästen $(d=1 \mathrm{~mm})$ vajoamisnopeus on $63 \mathrm{~cm} \mathrm{~s}^{-1}$. Savi pysyy vesirungossa pitkään, mutta hiekka saostuu nopeasti pohjalle. Savipartikkelit ovat muodoltaan levymäisiä, leijuvia, ja niiden laskeutuminen on vielä edellä arvioituakin hitaampaa.

Vesi läpäisee valoa, mikä mahdollistaa biologisen perustuotannon vedenpinnan alapuolella. Valoa absorboivat ja sirottavat puhdas vesi ja niin sanotut optisesti aktiivit aineet, joita ovat liuennut orgaaninen väriaine, kiintoaines sekä $a$-klorofylli. Puhdas vesi läpäisee auringonvaloa noin sataan metriin asti, mutta sameassa järvivedessä läpäisykyky jää alle yhden metrin. Valon kulkua luonnonvesissä tutkitaan absorptio- ja sirontaspektrin avulla. Näiden perusteella voidaan veden värikin ilmaista.

\footnotetext{
${ }^{7}$ Perustuotanto tarkoittaa vihreiden kasvien yhteyttämisen kautta sitomaa energiamäärää tai niiden valmistamaa orgaanista ainesta.
} 
Limnologiassa veden väriarvo määritetään suodatetusta vesinäytteestä platina-koboltti vertailuliuosta käyttäen. Se kertoo liuenneen orgaanisen väriaineksen määrästä. Aikaisemmin vertailussa käytettiin värilevyä, mutta nykyisin käytetään spektrofotometrin tuottamaa absorptiospektriä, josta väri määritetään $420 \mathrm{~nm}$ tai jonkin muun lyhyen aallonpituuden kohdalta. Suomen oloissa väri kuvaa veden ruskeutta ja kertoo humuspitoisuudesta. Tulos ilmoitetaan yksikössä mg Pt L ${ }^{-1}$. Värittömien vesien väriarvo on $5-15 \mathrm{mg} \mathrm{Pt} \mathrm{L}^{-1}$ ja humuspitoisten 50 - $100 \mathrm{mg} \mathrm{Pt} \mathrm{L}{ }^{-1}$. Väriarvo ei huomioi kiintoainesta, ja siksi se ei aina vastaa ihmissilmän visuaalista havaintoa järvestä. Jos kiintoainesta on vähän, humusta runsaasti sisältävät järvet näyttävät ruskeilta paljain silmin katsottuna.

Kiintoaines yleensä harmaannuttaa veden väriä, ja sitä voidaan epäsuorasti arvioida sameusmittausten avulla. Sameuden mittayksikkönä käytetään standardiliuokseen vertaavaa FTU (Formazin Turbidity Unit) sameuslukua. Formazin on polymeeri, jota on kiintoaineena vertailuliuoksessa. Kirkkaan veden sameus on alle 1,0 FTU, lievästi samean 1 - 5 FTU. Klorofylli $a$ :lla on absorptiokaistat sinisen $(430-440 \mathrm{~nm})$ ja punaisen $(660-690 \mathrm{~nm})$ valon alueella, ja näitä kaistoja on voitu hyödyntää klorofyllin identifioimiseksi ja sen konsentraation arvioimiseksi.

Juomaveden vaatimukset ovat hyvin tiukat ja koskevat ainespitoisuuksia, bakteereja ja aistimuksia. Taulukossa 3-3 on esitetty keskeisiä laatuparametreja ja Helsingin juomaveden arvoja. Haitallisille aineille on säännöksissä erikseen omat kriteerinsä. Suomen oloissa vesijohtovesi täyttää juomaveden laatukriteerit yleensä hyvin, itse asiassa vesijohtovetemme laatu on parempi kuin kaupan hyllyllä olevan pullotetun veden laatu (kuva 3-7). Helsingin vesi tulee tunnelia pitkin Päijänteeltä. Se on maailman pisin yhtenäinen kalliotunneli, $120 \mathrm{~km}$. Vesi virtaa siinä 30-100 metrin syvyydessä ja tulee yli miljoonan asukkaan tarpeisiin.

Taulukko 3-3. Juomaveden laatuvaatimukset Suomessa. Esimerkkinä Helsingin juomavesi, joka johdetaan Päijänteestä tunnelia pitkin. (Helsingin seudun ympäristöpalvelut, HSY)

\begin{tabular}{l|l|l} 
Suure & Vaikutus & Laatuvaatimus \\
\hline Sähkönjohtavuus & suolaisuus & alle $2,5 \mathrm{mS} \mathrm{cm}^{-1}$ \\
\hline$p H$ & happamuus & $6,5-9,5$ (HSY: noin 8,0) \\
\hline Sameus & kirkkaus & ei suositusarvoa (HSY: 0,06 FTU) \\
\hline $\begin{array}{l}\text { Kalsium ja } \\
\text { magnesium }\end{array}$ & $\begin{array}{l}\text { kovuus, aiheuttaa } \\
\text { kalkkisaostumia }\end{array}$ & ei suositusarvoa (HSY: pehmeä) \\
\hline Alkaliniteetti & $\begin{array}{l}\text { veden kyky vastustaa } \\
\text { happamuuden kasvua }\end{array}$ & ei suositusarvoa \\
\hline Fluoridi & $\begin{array}{l}\text { pieninä määrinä hyvä, } \\
\text { vahvistaa hammaskiillettä }\end{array}$ & alle $1,5 \mathrm{mg} \mathrm{L}^{-1}\left(\mathrm{HSY}: 0,2 \mathrm{mg} \mathrm{L}^{-1}\right)$ \\
\hline Rauta & ei terveyshaittaa & alle $0,20 \mathrm{mg} \mathrm{L}^{-1}\left(\mathrm{HSY}: 0,02-0,08 \mathrm{mg} \mathrm{L}^{-1}\right)$ \\
\hline $\begin{array}{l}\text { Koliformiset } \\
\text { bakteerit }\end{array}$ & saastuneisuus & $\begin{array}{l}0 \text { pmy }(\text { pesäkkeen muodostava yksikkö) / } \\
100 ~ \mathrm{~mL}^{-}\end{array}$ \\
\hline Haju ja maku & aistimus & riittävä laimennus
\end{tabular}

\subsubsection{Happipitoisuus}

Veden happipitoisuus on tärkeä veden laatua kuvaava suure. Se ilmaistaan absoluuttisena $\left(\mathrm{mg} \mathrm{L}^{-1}\right)$ tai suhteessa kyllästystilaan (\%). Happea saadaan lähinnä ilmakehästä ilman ja veden rajapinnan kautta sekä pieniä määriä yhteyttämisen tuotteena. Sitä kuluu biokemiallisissa prosesseissa maaperän vesissä sekä pintavesissä ja niiden pohjalla. Veden happipitoisuus vaikuttaa veden makuun; $3 \mathrm{mg} \mathrm{L}^{-1}$ tasoa pidetäänkin hyvän talousveden alarajana. Pintavesien ekologiassa happipitoisuus on keskeinen niiden terveyttä kuvaava suure 


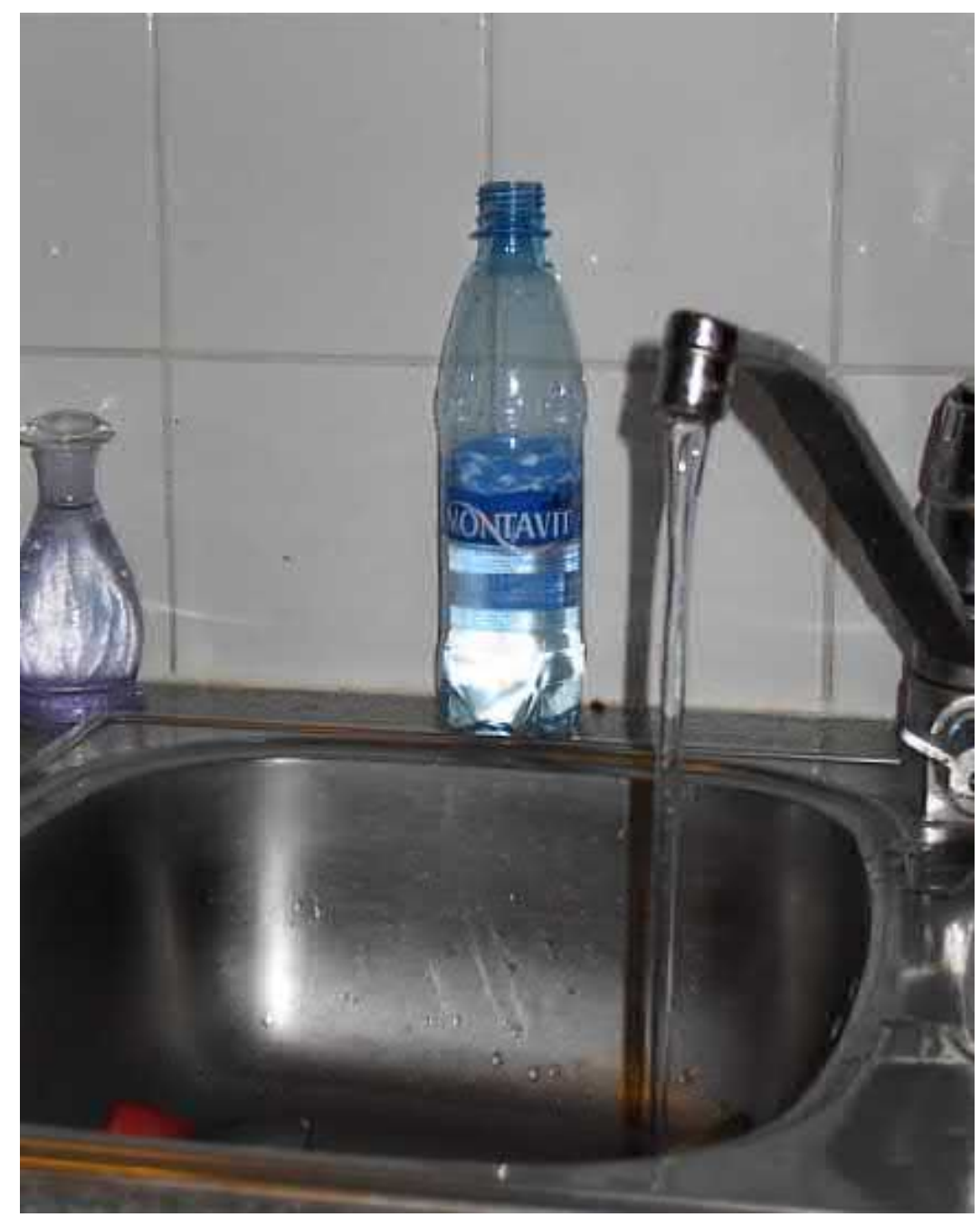

Kuva 3-7. Suomessa vesijohdosta saatava vesi on teollisesti pullotettua juomavettä korkealaatuisempaa. Tämä on maailmanlaajuisesti katsoen ylellistä. Kuva: Matti Leppäranta.

Hapen liukoisuus veteen riippuu lämpötilasta ja paranee lämpötilan laskiessa. Kyllästystila saadaan taulukosta 3-4. Kylmät vedet voivat siis sisältää happea paljon enemmän kuin lämpimät. Kun veden happipitoisuus on alle $2 \mathrm{mg} \mathrm{L}^{-1}$, happea tarvitsevat eliöt eivät voi enää elää siinä. Hapettomassa vedessä hajoamisprosesseissa muodostuu mädän kanamunan hajuista rikkivetyä.

Taulukko 3-4. Veden happipitoisuuden kyllästystilan riippuvuus lämpötilasta.

\begin{tabular}{c|c} 
Lämpötila $\left({ }^{\circ} \mathbf{C}\right)$ & $\mathbf{O}_{\mathbf{2}}$ kyllästystila $\left(\mathbf{m g ~ L}^{-1}\right)$ \\
\hline 0 & 14,6 \\
10 & 11,4 \\
20 & 9,2 \\
30 & 7,7
\end{tabular}

Järvien pintakerroksen happitilanne pysyy avovesikautena hyvänä. Happea puolestaan kuluu vesirungossa ja pohjalla, ja se voi loppua syvemmällä, jos uudistus on hidasta. Kun pintaveden tiheys kasvaa, sekoittuminen ulottuu vapaan konvektion ansiosta yhä syvemmälle. Kun konvektio pääsee pohjaan asti, tapahtuu täyskierto ja ilmakehän hapen avulla happivarat uudistuvat koko vesirungossa. Puhdas konvektiivinen täyskierto tapahtuu maksimiti- 
heyden lämpötilassa, mutta tuulen nopeudesta riippuen täyskierto tapahtuu syksyllä laajalla lämpötila-alueella, jopa $1-7^{\circ} \mathrm{C}$ välillä. Pitkinä talvina on Suomessa useista järvistä happi loppunut ja seuraukset ovat näkyneet kalakuolemina.

\subsection{Luonnonvesien tilayhtälö}

\subsubsection{Veden tiheys}

Puhtaan veden tilasuureet ovat lämpötila $T$, tiheys $\rho$ ja paine $p$, ja luonnonvesiä tarkasteltaessa suolaisuus $S$ on otettava lisäksi mukaan. Tilasuureita liittää toisiinsa tilayhtälö, joka esitetään yleensä muodossa

$$
\rho=\rho(T, S, p),
$$

Suolaisuuden vaikutus tulee merkittäväksi yli $1 \%$ tasolla, mutta heikosti virtaavissa tilanteissa kuten järvissä jään alla pienemmätkin suolaisuuserot vaikuttavat vesirungon kerrostuneisuuteen. Nestemäisen puhtaan veden tiheydessä on poikkeuksellista tiheysmaksimin lämpötila jäätymispisteen yläpuolella (kuva 3-8). Jäätymispiste on $0{ }^{\circ} \mathrm{C}$, ja tiheys on suurimmillaan lämpötilassa $3,98^{\circ} \mathrm{C}$. Taustalla on vesimolekyylien vetysidosten järjestyminen tetraedrirakenteita kohti lähestyttäessä jäätymispistettä. Tiheysmaksimin lämpötilan alapuolella tämä järjestyminen alentaa tiheyttä enemmän kuin lämpötilan laskusta johtuva molekyylien lämpövärähtelyn aleneminen kasvattaa sitä.

Puhtaan veden tiheys on normaalissa ilmakehän paineessa $p_{0}$ lämpötilan $T\left({ }^{\circ} \mathrm{C}\right)$ polynomifunktio (UNESCO 1981; ks. myös Myrberg ym. 2017)

$$
\begin{aligned}
\rho\left(T, 0, p_{0}\right) & =999,842594+6,793952 \cdot 10^{-2} T-9,095290 \cdot 10^{-3} T^{2} \\
& +1,001685 \cdot 10^{-4} T^{3}-1,120083 \cdot 10^{-6} T^{4}+6,536332 \cdot 10^{-9} T^{5},
\end{aligned}
$$
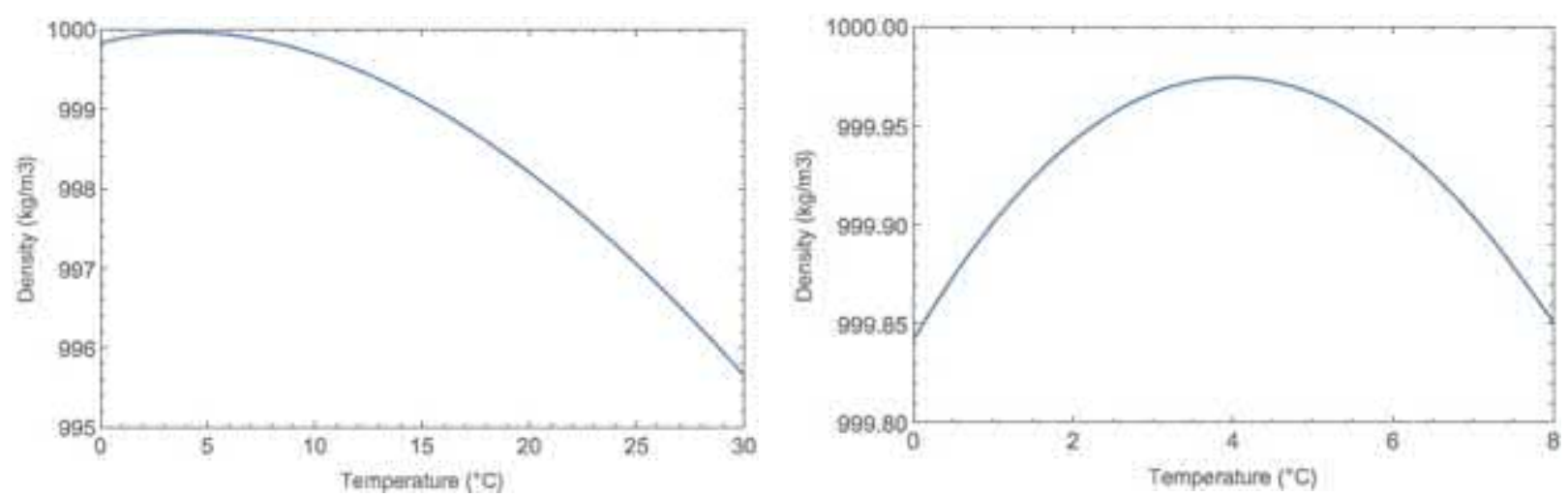

Kuva 3-8. Puhtaan veden tiheys ilmakehän normaalipaineessa lämpötilan funktiona välillä $0{ }^{\circ} \mathrm{C}-30$ ${ }^{\circ} \mathrm{C}$. Oikealla vielä tarkennettu käyrä $0{ }^{\circ} \mathrm{C}$ ja $8{ }^{\circ} \mathrm{C}$ välille.

Monissa sovelluksissa riittää tehdä yhtälöön (3.5a) yksinkertainen toisen asteen sovitus

$$
\rho\left(T, 0, p_{0}\right)=\rho_{m}-\alpha\left(T-T_{m}\right)^{2},
$$

missä $\rho_{m}=999,975 \mathrm{~kg} \mathrm{~m}^{-3}$ ja $T_{\mathrm{m}}=3,98^{\circ} \mathrm{C}$ ovat maksimitiheys sekä vastaava lämpötila, ja $\alpha$ on sovitusparametri, joka riippuu tarkasteltavasta lämpötila-alueesta. Makeisiin vesiin kuten 
Suomen pinta- ja pohjavesiin voidaan yleensä käyttää puhtaan veden tiheyden kaavaa. Sen tiheys on $997-1000 \mathrm{~kg} \mathrm{~m}^{-3}$, kun lämpötila on $0{ }^{\circ} \mathrm{C}$ ja $25^{\circ} \mathrm{C}$ välillä ja paine on 1 bar. Paineen SI-yksikkö on Pascal (Pa), mutta hydrologiassa käytetään paljon myös baaria (bar), 1 bar = $100 \mathrm{kPa} \approx 1$ ilmakehän paine.

Esimerkki 3-2. Jos tarkastellaan kylmiä vesiä $\left(T<10{ }^{\circ} \mathrm{C}\right)$, parametri $\alpha$ voidaan määrittää niin, että approksimaatio (3.5b) on tarkka lämpötilassa $0{ }^{\circ} \mathrm{C}$. Tällöin saadaan $\alpha=8,333 \cdot 10^{-3} \mathrm{~kg} \mathrm{~m}^{-3}{ }^{\circ} \mathrm{C}^{-2}$. Kun $T=10^{\circ} \mathrm{C}$, tiheydeksi saadaan $999,675 \mathrm{~kg} \mathrm{~m}^{-3}$, kun tarkka arvo (3.5a) on 999,702 $\mathrm{kg} \mathrm{m}^{-3}$.

Vesi on kokoonpuristuva aine, mutta paineen vaikutus veden tiheysrakenteeseen tulee merkittäväksi vasta satojen metrien syvyyksissä. Paine voidaan laskea hydrostatiikan perusyhtälöstä

$$
\frac{d p}{d z}=\rho g
$$

missä $z$ on syvyyskoordinaatti. Jos tiheys otetaan vakioksi, saadaan

$$
p=p_{0}+\rho g z
$$

missä $p_{0}$ on ilmanpaine pinnalla. Nähdään, että kymmenen metrin paksuinen vesikerros lisää painetta noin yhden baarin eli yhden ilmakehän verran. Paine kasvattaa tiheyttä 100 baaria (vastaa $1 \mathrm{~km}$ syvyyttä) kohti noin 0,5\%. Niinpä Baikal-järvessä $1 \mathrm{~km}$ syvyydessä veden tiheys on $1005 \mathrm{~kg} \mathrm{~m}^{-3}$. Tämä asettaa oikean mittasuhteen. Paineen kasvaessa jäätymispisteen $\left(T_{f}\right)$ ja maksimitiheyden $\left(T_{m}\right)$ lämpötilat laskevat hieman, $1 \mathrm{~km}$ syvyydessä $T_{m}=1,90{ }^{\circ} \mathrm{C}$ ja $T_{f}=$ $-0,75^{\circ} \mathrm{C}$. Syvistä vesistä tutkittaessa esimerkiksi niiden tiheyskerrostuneisuuden vakautta on käytettävä tarkkaa empiiristä tilayhtälöä, sillä syvällä hyvin pienet tiheyserot ovat merkitseviä (Myrberg ym. 2017). Tässä kirjassa ei kuitenkaan mennä tarkemmin näihin kysymyksiin.

Suolaisuus vaikuttaa tiheyteen samaan tapaan kuin paine: tiheys kasvaa ja jäätymispiste sekä tiheysmaksimin lämpötila alenevat suolaisuuden kasvaessa. Likimääräinen veden tiheyden kaava ilmakehän normaali-paineessa on

$$
\rho\left(T, S, p_{0}\right) \cong \rho\left(T, 0, p_{0}\right)+S \cdot 0,82 \mathrm{~kg} \mathrm{~m}^{-3},
$$

missä suolaisuus on promilleina. Kun $S=0,5 \%$, veden tiheys on $0,41 \mathrm{~kg} \mathrm{~m}^{-3}$ suurempi kuin puhtaan veden. Ison suolajärven (Utah, Yhdysvallat) veden suolaisuus vaihtelee paljon mutta on suuruusluokkaa $100 \%$, jota vastaava tiheys on noin $1100 \mathrm{~kg} \mathrm{~m}^{-3}$. Kun suolaisuus on suurempi kuin noin $1 \%$, yhtälö (3.8) ei riitä veden tiheyden kerrostuneisuuden tutkimiseen, ja on otettava mukaan korkeamman kertaluvun termejä. Tässä kirjassa ei mennä pidemmälle suolaisiin vesiin, niitä on käsitelty laajemmin meritieteen kirjallisuudessa (Myrberg \& Leppäranta 2014, Myrberg ym. 2017).

Meriveden tilayhtälö on määritetty hyvin tarkasti merentutkimuksen tarpeiden takia. Nykyisin käytetään TEOS-2010 standardia. Aiemmin oli käytössä UNESCOn (1981) tilayhtälö, johon TEOS-2010 toi hyvin pieniä suolaisuuden määrittämiseen liittyviä korjauksia ${ }^{8}$. Tilayhtälö on voimassa suolaisuuksille $0 \leq S \leq 40 \%$ ja sitä voidaan käyttää makean veden, murto-

\footnotetext{
${ }^{8}$ Merentutkimuksessa suolaisuus $S$ kirjoitetaan nykyisin ilman \%o merkkiä: $S=35$ luetaan $S=35 \%$. Tässä kirjassa \% merkkiä käytetään selvyyden vuoksi.
} 
veden ja suolaisen veden tarkasteluissa. Jos vesi poikkeaa kemialliselta koostumukseltaan paljon merivedestä, niin tarkkuus heikkenee. Tarkkaan ottaen oma tilayhtälö pitäisi konstruoida erilaisille luonnon vesiliuoksille, erityisesti hypersuolaisten vesien tapauksessa.

Makeiden luonnonvesien tiheyden suhteelliset vaihtelut lämpötilan suhteen ovat muutaman tuhannesosan sisällä, mutta nämä vaihtelut ovat vesien sekoittumisen kannalta merkittäviä. Periaatteessa on mahdollista asettaa raskasta vettä kevyemmän päälle, mutta tällainen rakenne on epästabiili ja särkyy luonnonoloissa nopeasti. Niinpä tiheyden kerrostuminen voidaan aina olettaa olevan neutraali - tiheys on syvyyden suhteen vakio - tai stabiili-tiheys kasvaa syvyyden suhteen. Makeavetiset järvet kerrostuvat lämpötilan mukaan, mutta virtaavissa jokivesissä turbulenttinen sekoittuminen on voimakasta ja vesimassa sen vuoksi homogeeninen.

Esimerkki 3-3. Lämpötilan ja paineen vaikutusta veden tiheysmaksimin ja jäätymispisteen lämpötiloihin voidaan arvioida seuraavien kaavojen avulla (ks. Leppäranta 2015):

$$
\begin{aligned}
& T_{m}\left[{ }^{\circ} \mathrm{C}\right]=3,982-0,2229 \cdot S-0,02004 \cdot p \cdot(1+0,00376 \cdot S) \cdot(1+0,000402 \cdot p) \\
& T_{f}\left[{ }^{\circ} \mathrm{C}\right]=-0.0575 \cdot S+1.710523 \cdot 10^{-3} S^{3 / 2}-2.154996 \cdot 10^{-4} S^{2}-7.53 \cdot 10^{-3} p
\end{aligned}
$$

missä paine on annettu baareina ja suolaisuus promilleina.

\subsection{2 Ä̈̈nen nopeus vedessä}

Ääni etenee vedessä hyvin. Sen nopeus on hydromekaniikan teorian mukaisesti $V=\sqrt{K / \rho}$, missä $K \sim 10^{9} \mathrm{~Pa}$ on veden kokoonpuristuvuus. Suureita $K$ ja $\rho$ varten on olemassa empiiriset moniparametriset yhtälöt, mutta äänen nopeus voidaan arvioida riittävän tarkasti yksinkertaisemmasta kaavasta.
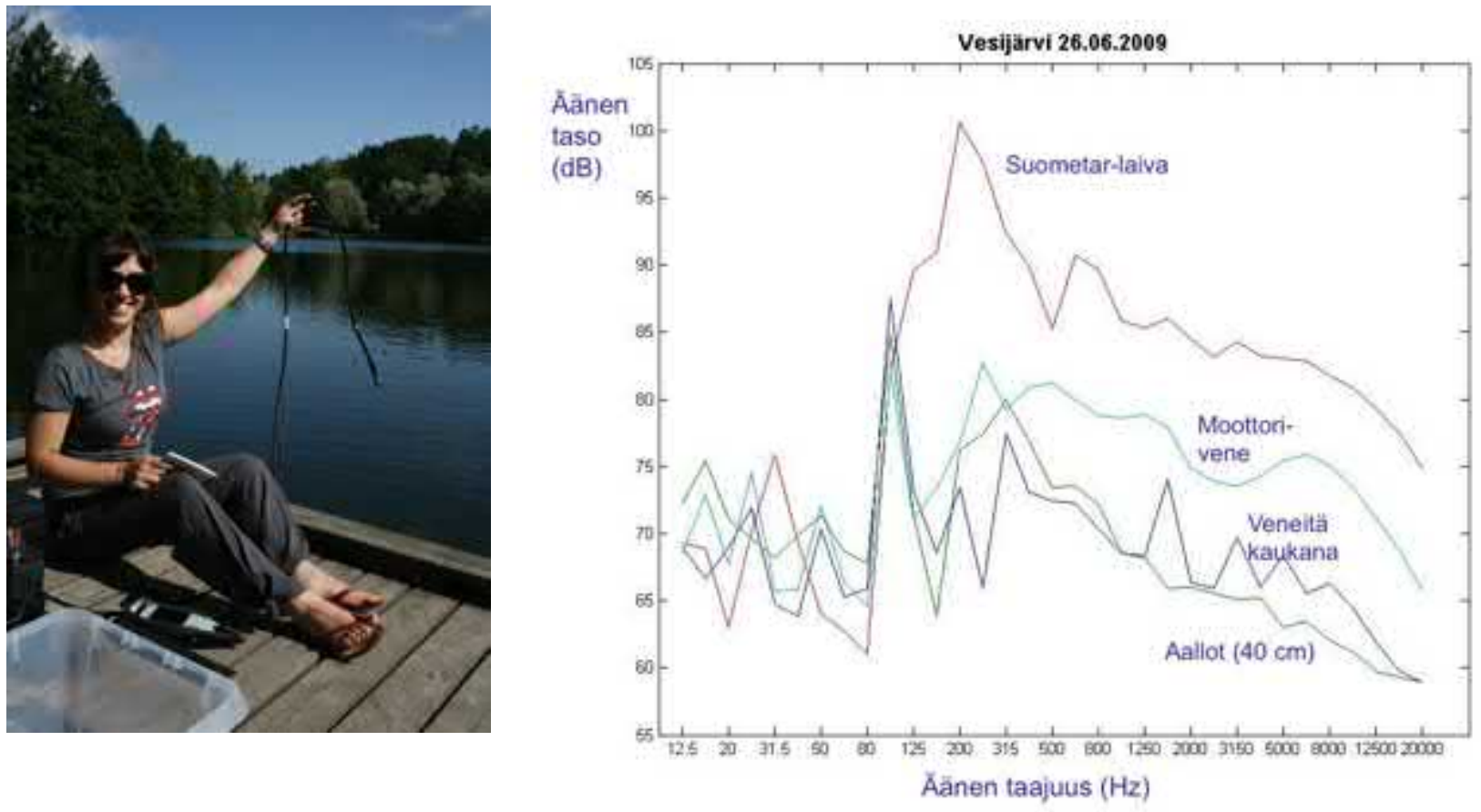

Kuva 3-9. Hydrofoniluotauksia Päijät-Hämeen Vesijärvellä. a) Maastotyössä ja b) Mitattu äänen taajuusspektri, josta voidaan erottaa ympäristön ja inmistoiminnan vaikutuksia. Kuvat: a) Matti Leppäranta, b) Leppäranta \& Merkouriadi (2017).

Yleinen makeisiin ja suolaisiin luonnonvesiin sopiva yhtälö on 


$$
V=V(T, S, z)=V_{0}+c_{S}(S-35)+c_{T} T+c_{T 2} T^{2}+c_{z} z
$$

missä äänen nopeus saadaan metreinä sekunnissa, suolaisuus on promilleina, lämpötila Celsius-asteina, ja painetta vastaava syvyys $z$ metreinä, Kaavan vakiot ovat

$$
V_{0}=1449 \frac{\mathrm{m}}{\mathrm{s}}, c_{S}=1,4 \frac{\mathrm{m}}{\mathrm{s}}, c_{T}=4,6 \frac{\mathrm{m}}{\mathrm{s}}{ }^{\circ} \mathrm{C}^{-1}, c_{T 2}=-0,55 \frac{\mathrm{m}}{\mathrm{s}}{ }^{\circ} \mathrm{C}^{-2}, c_{z}=0,017 \frac{1}{\mathrm{~s}} .
$$

Jos $S=0$ ja $z=0$, äänen nopeus on $1400 \mathrm{~m} \mathrm{~s}^{-1}$, kun $T=0{ }^{\circ} \mathrm{C}, 1391 \mathrm{~m} \mathrm{~s}^{-1}$, kun $T=10^{\circ} \mathrm{C}$ ja $1272 \mathrm{~m}$ $\mathrm{s}^{-1}$, kun $T=20^{\circ} \mathrm{C}$. Kaikuluotaus perustuu äänen heijastumiseen kohteesta, ja sitä käytetään syvyyden kartoituksessa, ja äänen taajuutta säätämällä voidaan myös tarkastella pohjan laatua. Keilaavalla kaikuluotauksella voidaan tuottaa kaksiulotteisia kuvia pohjan topografiasta. Kalastuksessa voidaan kaikuluotausta käyttää kalaparvien etsintään, ja pieniä taskumalleja on kalastusliikkeistä jo saatavissa harrastelijoille. Viime vuosina on tehty myös akustisia mittauksia järvien ääni-ilmastosta (kuva 3-9), jonka ympäristöllinen merkitys ei vielä ole kovin selvä.

\subsection{Veden kiertokulku ja vesitase}

Tässä kohdassa tarkastellaan aluksi virtausopin perusteita ja sääolojen vuotuista kulkua. Ne ovat tarpeellista veden kiertokulkuun kuuluvaa taustatietoa ja koskevat veden liikkumista sekä ilmakehän ja vesivarojen vuorovaikutusta. Sen jälkeen esitellään veden kiertokulku ja siihen liittyvät käsitteet. Kiertokulkuun kuuluvia varastoja sekä siirtoreittejä varas-tosta toiseen käsitellään yksityiskohtaisemmin seuraavissa luvuissa.

\subsubsection{Virtausopin perusteita}

Virtausoppi tarkastelee viskoosin nesteen virtauksen määrittämistä. Tehtävässä on neljä dynamiikan perusyhtälöä: liikeyhtälö, jatkuvuusyhtälö, tilayhtälö ja lämmön säilymislaki. Näiden avulla voidaan laskea veden virtausnopeus, paine, lämpötila ja tiheys. Analyyttisten menetelmien avulla saadaan mittasuhteita ja peukalosääntöjä, ja numeeristen mallien avulla voidaan tehtävä ratkaista valitussa hilassa. Jos suolaisuus on merkittävä tekijä, suolan säilymislaki on otettava mukaan.

Virtausopissa nestettä tarkastellaan jatkumona, jossa neste koostuu äärettömän pienistä hiukkasista. Tällöin tutkimuksessa voidaan hyödyntää differentiaali- ja integraalilaskennan menetelmiä. Newtonin mekaniikan II laki 'kappaleeseen vaikuttavien voimien summa antaa sille kiihtyvyyden' sovellettuna luonnonvesien dynamiikkaan kirjoitetaan

$$
\frac{d}{d t}(u, v, w)=-g-\frac{1}{\rho} \nabla p+\frac{1}{\rho} F
$$

missä $u, v$ ja $w$ ovat virtausnopeuden itä-, pohjois- ja pystykomponentit, $t$ on aika, $p$ on paine ja $F$ on nesteen sisäinen kitka. Paine vaikuttaa virtaukseen gradienttinsa ${ }^{9} \nabla p$ eli paine-erojen kautta. Niinpä jos veden pinta on kalteva, painegradientti ajaa virtausta korkeasta paineesta alempaan.

\footnotetext{
${ }^{9}$ Nabla-operaattorin $\nabla=\left(\frac{\partial}{\partial x}, \frac{\partial}{\partial y}, \frac{\partial}{\partial z}\right)$ avulla voidaan kompaktilla tavalla merkitä derivointeja.
} 
Luonnonvesien virtauksissa kitka on yleensä merkittävä tekijä. Vakaassa jokivirtauksessa painovoima ja kitka ovat tasapainossa. Tuulen ajamassa järvivirtauksessa aluksi tuulen voima ja pohjakitka ovat tasapainossa, ja vakaan tilan kehittyessä myös painegradientti tulee merkittäväksi, kun tuulen kuljettamat vesimassat muokkaavat painekenttää. Maaperän virtausten tarkasteluissa sovelletaan 'virtaus huokoisen materian läpi' teoriaa. Virtaukset ovat hitaita, paineen ajamia, ja painegradientti sekä kitka ovat niissä tasapainossa.

Virtausopin perusyhtälöt ovat liikeyhtälö ja jatkuvuusyhtälö eli massan säilymislaki. Luonnonvesien virtauksissa vettä pidetään kokoon puristumattomana jatkuvasti jakautuneena aineena eli kontinuumina. Nesteiden liikeyhtälö-Navier-Stokes-yhtälö-perustuu Newtonin II lakiin ja kirjoitetaan yleisesti

$$
\begin{aligned}
& \frac{\partial \boldsymbol{u}}{\partial t} \quad=-\boldsymbol{u} \cdot \nabla \boldsymbol{u}-\boldsymbol{g} \quad-\frac{1}{\rho} \nabla p+N \nabla^{2} \boldsymbol{u}, \\
& \text { nopeuden }=\text { kulkeu- }+ \text { paino- }+ \text { paine- sisäinen } \\
& \text { muutos tuminen voima voima kitka }
\end{aligned}
$$

missä $\boldsymbol{u}=(u, v, w)$ on virtausnopeus, $\boldsymbol{g}=(0,0, g)$ on painovoima ja $N$ on viskositeetti, joka on molekylaarinen laminaarisessa virtauksessa, $N=v$, ja turbulenttinen turbulenttisessa virtauksessa, $N=K$. Yhtälö kuvaa, miten virtausnopeus muuttuu kulkeutumisen eli advektion, paine-erojen ja sisäisen kitkan vaikutuksesta. Tuulen vaikutus tulee reunaehdon kautta pinnasta, josta viskositeetti vie sen syvemmälle.

Lepotilassa olevassa altaassa paine on horisontaalisuunnassa vakio, mutta jos paineessa on horisontaalisia eroja, näistä syntyvä painegradientti ajaa vettä liikkeeseen. Jos virtauskentän ominaisuudet eivät riipu ajasta, virtaus on stationäärinen eli pysyvä. Muussa tapauksessa virtaus on ei-stationäärinen eli muuttuva. Reunaehdot ovat keskeinen osa virtaustilanteen ratkaisua. Kitkattoman virtauksen teoriassa käytetään liukuehtoa, jossa virtaus on reunalla samansuuntainen reunan kanssa. Kitkalliseen virtaukseen käytetään jännityksen jatkuvuutta, jonka mukaan reunaan kohdistuva voima vastaa virtauskentän sisäistä kitkaa.

Hydrologian virtauskysymyksissä vettä voidaan pitää kokoonpuristumattomana, jolloin jatkuvuusyhtälön mukaan vesi säilyttää tilavuutensa Jatkuvuusyhtälö perustuu siihen, että vesi säilyttää tilavuutensa, jolloin se reagoi pinnankorkeudellaan veden paikalliseen kerääntymiseen tai vähenemiseen:

$$
\begin{gathered}
\frac{\partial u}{\partial x}+\frac{\partial v}{\partial y}+\frac{\partial w}{\partial z}=0 \\
\underset{\substack{\text { muutos } \\
\text { itään }}}{\text { pohjoiseen }}+\underset{\text { muutos }}{\text { ylöspäin }}=0
\end{gathered}
$$

Kun vesi virtaa vaakatasossa samaa paikkaa kohti, vedenpinta tällä paikalla vastaavasti kohoaa. Jos vesi on homogeenista, sen tiheys on vakio, ja silloin yhtälöt (3.11-3.12) riittävät virtaustehtävän ratkaisemiseksi. Yleisessä tapauksessa otetaan mukaan tilayhtälö (3.4) ja lämmön säilymislaki, jolloin tiheyserot tulevat mukaan virtauksia aiheuttavaksi tekijäksi.

Veden horisontaalinen virtausnopeus on suuruusluokaltaan $1 \mathrm{~m} \mathrm{~s}^{-1}$ jokivirroissa ja $10 \mathrm{~cm}$ $\mathrm{s}^{-1}$ tuulen ajamissa järvien virtauksissa. Pystysuora nopeuskomponentti on monta suuruusluokkaa pienempi kuin horisontaalinen virtaus. Yleensä liikeyhtälöstä lasketaan horisontaalinen virtaus, ja pystyvirtaus saadaan sen jälkeen jatkuvuusyhtälöstä. Paine voidaan hydro- 
logian tehtävissä ottaa hydrostaattisena (yhtälö 3.6). Pohjaveden virtaus vaihtelee suuresti maaperän mukaan, mutta se on hyvin pieni jokien ja järvien virtauksiin verrattuna.

Virtaus voi olla laminaarista tai turbulenttista. Laminaarinen virtaus on sileälinjaista hyvin käyttäytyvän monikaistaisen liikenteen tapaan. Virtaviivat kulkevat mutkissa ja esteiden ohitse säännöllisesti. Turbulenttinen virtaus on sen sijaan epäsäännöllistä, kaoottista ja erikokoiset voimakkaat pyörteet ovat sille tyypillistä. Hyvä esimerkki on tehtaan piipusta tupruava savu tai jokivirta. Virtauksen tyyppi riippuu Reynoldsin luvusta

$$
R e=\frac{U L}{v},
$$

missä $U$ on nopeuden mitta, $L$ on pituusmitta ja $v=\frac{\mu}{\rho} \approx 0,01 \mathrm{~cm}^{2} \mathrm{~s}^{-1}$ on veden kinemaattinen viskositeetti. Reynoldsin luku on yksi virtausopin fundamentaalisista dimensiottomista suureista. Se kuvaa viskositeetin merkitystä: mitä pienempi se on, sitä suurempi viskositeetin vaikutus on. Lisäksi se kuvaa virtauksen tyyppiä. Virtaus on yleensä laminaarinen, kun $R e<$ $10^{3}$, ja turbulenttinen, kun $R e>10^{4}$. Näiden välissä on siirtymäalue, jossa virtaus muuttuu laminaarisesta turbulenttiseksi. Esimerkiksi jos $U=1 \mathrm{~cm} \mathrm{~s}^{-1}$ ja $L=1 \mathrm{~m}$, on $R e \approx 10^{4}$.

Jokien ja järvien virtaukset ovat turbulenttisia, lukuun ottamatta jään kattamia pieniä järviä. Pienimittaisissa kohteissa kuten pohjan läheisyydessä tai kasvien ja eliöiden pinnalla virtaus on laminaarista, millä on suuri merkitys ekologiassa. Maaperän virtaukset ovat yleensä laminaarisia, sillä nopeudet ovat pieniä, kanavat kapeita ja Reynoldsin luku jää pieneksi.

Laminaarisessa virtauksessa veden sisäinen kitka on molekylaarista, joka siirtää liikemäärää heikosti. Siirtoaika etenee ajan mukana suhteessa $T \sim L^{2} v^{-1}$, esimerkiksi siirto $L=1 \mathrm{~m}$ matkan päähän kestää 10 päivää. Sen sijaan turbulenttisessa virtauksessa intensiiviset pyörteet toimivat tehokkaasti. Jos $\ell$ on pyörteiden koko ja $u_{*}$ karakteristinen turbulenttisten fluktuaatioiden nopeus, sekoittuminen tapahtuu pyörteiden mitassa ajassa $T \sim \ell u_{*}^{-1}$. Järvien ja jokien virtausten vertikaalisessa sekoittumisessa on $\ell \sim 1-10 \mathrm{~m}$ ja $u_{*} \sim 0,1-1 \mathrm{~cm} \mathrm{~s}^{-1}$, joten $T \sim$ $10^{2}-10^{4} \mathrm{~s}$. Tämä laminaarisen ja turbulenttisen siirron vertaus pätee yleensä veden ominaisuuksia kuten lämpömäärää ja ainespitoisuuksia tarkasteltaessa. Turbulenttinen sekoittuminen on huomattavan paljon molekylaarista tehokkaampaa. Kahvikin jäähtyy kupissa nopeammin kun sitä lusikalla sekoittaa.

Vertikaalisessa turbulenttisessa sekoittumisessa suureen $B$ siirto poikkipinta-alaa ja aikaa kohden on $Q=-B w$, missä $w$ on vertikaalivirtauksen nopeus. Suureet $B$ ja $w$ vaihtelevat nopeasti ja ne voidaan kirjoittaa $B=\langle B\rangle+B^{\prime}$ ja $w=\langle w\rangle+w^{\prime}$, missä $\langle\cdot\rangle$ tarkoittaa aikakeskiarvoa ja heittomerkit kuvaavat hetkellisiä fluktuaatioita. Aikakeskiarvot lasketaan yleensä noin 10 minuutin välein, ja fluktuaatiot, joiden aikakeskiarvo on nolla, mitataan useita kertoja sekunnissa. Suureen $B$ siirto vertikaaliliikkeen vaikutuksesta on

$$
\langle Q\rangle=-\langle B w\rangle=-\left\langle B^{\prime} w^{\prime}\right\rangle \approx K \frac{d B}{d z}
$$

missä $K$ on turbulenttinen diffuusiokerroin. Kun lasketaan siirron $B w$ keskiarvo, vain fluktuaatioiden kovarianssi $\left\langle B^{\prime} w^{\prime}\right\rangle$ jää jäljelle, sillä fluktuaatioiden keskiarvo on nolla ja myös vertikaalisen nopeuden keskiarvo on nolla (kun oletetaan että veden pinta pysyy paikallaan). Tämä kovarianssi voidaan ilmaista korrelaation $r_{B w}$ ja hajontojen $\sigma_{B}$ ja $\sigma_{w}$ avulla: $\left\langle B^{\prime} w^{\prime}\right\rangle=$ $r_{B w} \sigma_{B} \sigma_{w}$. Viimeinen yhtälöistä (3.14) perustuu Prandtl'n turbulenttisen siirron malliin, joka on analoginen molekylaarisen siirron $v \frac{d B}{d z}$ kanssa. Kokeellisten tutkimusten perusteella luon- 
nonvesissä on $K \sim 1-100 \mathrm{~cm}^{2} \mathrm{~s}^{-1}, K>>$. Kun tarkastellaan siirron aiheuttamaa nettovaikutusta, otetaan tulojen ja menojen erotus, jolloin päästään toiseen derivaattaan. Niinpä diffuusion nettovaikutus vertikaalisessa sekoittumisessa on molekylaarisessa tapauksessa $v \frac{d^{2} B}{d z^{2}}$ ja turbulenttisessa $K \frac{d^{2} B}{d z^{2}}$.

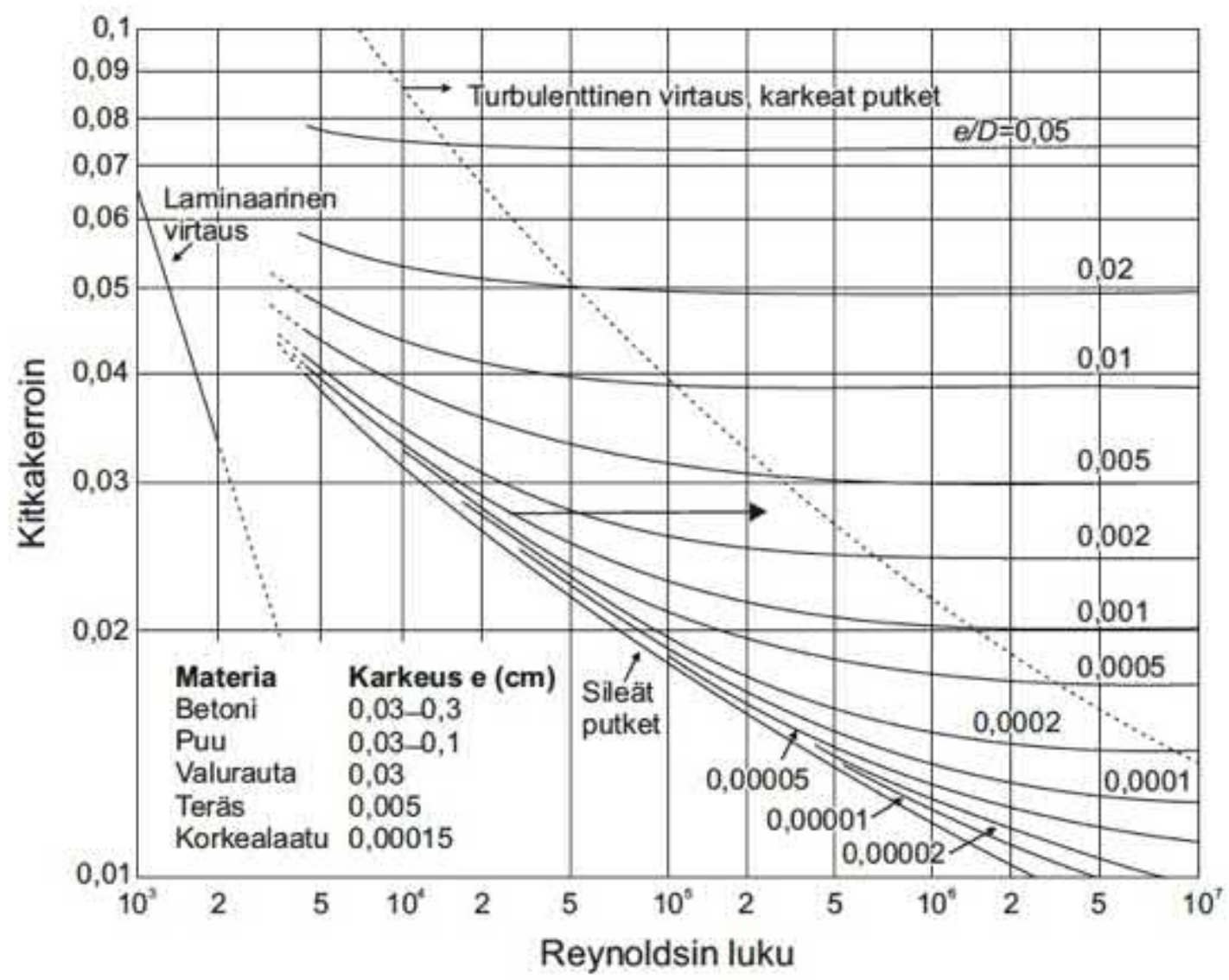

Kuva 3-10. Putkivirtauksen kitkakerroin $f$ Reynoldsin luvun sekä putken halkaisijan $D$ ja pinnankarkeuden e funktiona. Laminaarisessa virtauksessa $f \propto R e^{-1}$. Turbulenttisessa virtauksessa $f$ ei riipu Reynoldsin luvusta mutta kylläkin voimakkaasti pinnankarkeudesta ja putken halkaisijasta. Lähde: Moody (1944), muokattu.

Esimerkki 3-4.Tarkastellaan sylinteriin kohdistuvaa vastusvoima virtauksessa dimensioanalyysin avulla.

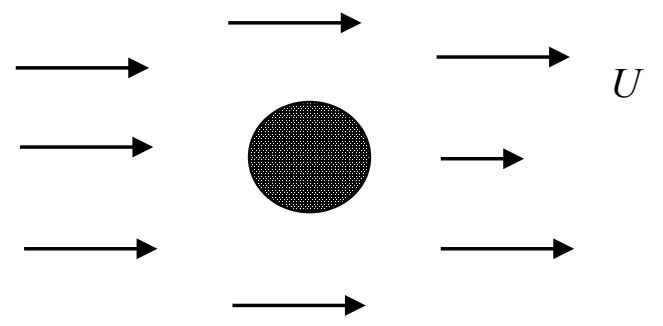

Neste virtaa $d$-halkaisijan omaavan sylinterin ohitse nopeudella $U$. Mikä on sylinterin aiheuttama vastusvoima $F$, kun nesteen tiheys on $\rho$ ja viskositeetti $\mu$ ?

Näistä suureista lähtien saadaan suhde

$$
F \propto d^{A} U^{B} \rho^{C} \mu^{D} .
$$

Dimensiot ovat $[F]=M L T^{-2},[d]=L,[U]=L T^{-1},[\rho]=M L^{-3}$ ja $[\mu]=M L^{-2} T^{-1}$. Eksponentit $A$, $B, C$ ja $D$ voidaan ratkaista yhtälöryhmästä 


$$
\begin{aligned}
M: & 1 & =C+D \\
L: & 1 & =A+B-3 C-D \\
T: & -2 & =-B-D
\end{aligned}
$$

Tässä on kolme yhtälöä ja neljä tuntematonta. Dimensiottomia suureita tulee kaksi. Ratkaisuun jää yksi vapaa muuttuja, joksi voidaan ottaa $A$. Sitten saadaan $B=A, C=A-1, D=2-A$. Suureella $\rho d^{2} U^{2}$ on voiman dimensio ja on kätevä ottaa $F$ :n skaalaksi yhdessä dimensiottomassa suureessa

$$
\frac{F}{\rho U^{2} d^{2}}=U^{A-2} d^{A-2} \rho^{A-2} \mu^{2-A}=\left(\frac{\rho U d}{\mu}\right)^{A-2} \text { eli } \frac{F}{\rho U^{2} d^{2}}=f\left(\frac{\rho U d}{\mu}\right)=f(R e) .
$$

Vasemman puolen dimensioton voima ja oikealla oleva Reynoldsin luku ovat tehtävän luonnolliset dimensiottomat suureet. Tekemällä mittauksia voidaan funktio $f$ konstruoida.

Tehtävää voidaan vielä laajentaa ottamalla mukaan levyn pinnankarkeus. Jos levyn karakteristinen rosoisuus on $e,[e]=L$, saadaan dimensioton karkeus $e / d$ ja edelleen

$$
\frac{F}{\rho d^{2} U^{2}}=f\left(R e, \frac{e}{d}\right) \text {. }
$$

Nyt tuntematon funktio riippuu kahdesta argumentista, mutta se on edelleen melko helposti konstruoitavissa mittausjärjestelyjen avulla (kuva 3-10).

Edellä oleva esimerkki kertoo laminaarisen ja turbulenttisen vastuksen kvalitatiivisesta erosta. Edellisessä kitka on nopeuden suhteen lineaarinen, jälkimmäisessä neliöllinen. Tämä on yleinen piirre ja koskee kaikenmuotoisia kappaleita sekä myös virtauksen pohjakitkaa.

Aaltoliike on ajan ja paikan suhteen muuttuva jaksollinen ilmiö. Se syntyy häiriöstä, jonka painovoima palauttaessaan 'ampuu yli' ja saa liikkeen jatkumaan ${ }^{10}$. Esimerkiksi heilurin liike voidaan käynnistää tällä tavalla. Aaltoliikkeen matemaattinen perusmalli on siniaalto. Tarkastellaan $x$-suuntaan ajassa $t$ etenevää aaltoa

$$
f(x, t)=A \sin (k x+\omega t+\phi),
$$

missä $A$ on aallon amplitudi, $k$ on aaltoluku, $\omega$ on taajuus, ja $\phi$ on vaihe. Aallon korkeus eli harjan ja laaksonpohjan välinen pystysuora etäisyys on $2 A, \lambda=2 \pi / k$ on aallonpituus, ja $T=$ $2 \pi / \omega$ on aallon periodi. Lineaarisessa teoriassa aaltoja voidaan laskea yhteen ja siten kuvata monijaksoisia ilmiöitä; kääntäen voidaan mikä tahansa jaksollinen ilmiö palauttaa harmonisen analyysin avulla sinimuotoisiin perusaaltoihin.

Joissakin tapauksissa virtaustehtäviin voidaan soveltaa kitkatonta mallia. Näillä voidaan hahmottaa geometrian määräämiä virtauskentän yleisiä piirteitä, mutta pohjakitkan ja tuulen mukaan ottamiseksi kitka tarvitaan mukaan. Kitkatonta mallia on järvi- ja jokivirtauksissa käytetty aaltoliikkeen tutkimuksissa. Vesi ei kulkeudu aaltoliikkeen mukana eteenpäin, vaan aallon edetessä vesihiukkaset liikkuvat edestakaisin ympyrän tai ellipsin muotoisilla radoilla.

Aallot jaetaan kolmeen perustyyppiin sen mukaan, mikä on aallonpituuden $\lambda$ suhde veden syvyyteen $H$ (kuva 3-11):

- Matalan veden aallot eli pitkät aallot $[\lambda>20 H]$ "tuntevat" pohjan. Vesipartikkelit tekevät aallon edetessä edestakaista ellipsirataista liikettä koko vesirungon osallistuessa liikkeeseen.

\footnotetext{
${ }^{10}$ Kapillaariaalloissa palauttavana voimana on pintajännitys. Aallonpituus on alle $2 \mathrm{~cm}$ ja periodi alle $0,1 \mathrm{~s}$.
} 
- Syvän veden aallot eli lyhyet aallot $[\lambda<2 H]$ eivät "tunne" veden pohjaa. Vesipartikkelit tekevät ympyräliikettä aallon etenemisen mukana ja tämä ympyräliike vaimenee nopeasti syvyyden mukana. Syvyydessä $1 / 2 \lambda$ ei aaltoja enää tunneta.

- Kahden edellisen välimuoto $[2 H<\lambda<20 H]$, jolloin esiintyy sekä matalan että syvän veden aaltojen piirteitä.

Aaltojen nopeudet ovat

$$
\begin{array}{ll}
\text { matalan veden aallot } & V_{1}=\sqrt{g H}, \text { ja } \\
\text { syvän veden aallot } & V_{2}=\sqrt{\frac{1}{2 \pi} g \lambda} .
\end{array}
$$

\section{aallon kulkusuunta}

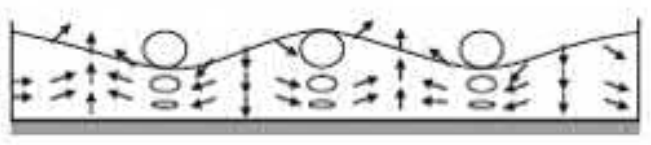

$\rightarrow$ aallon kulkusuunta

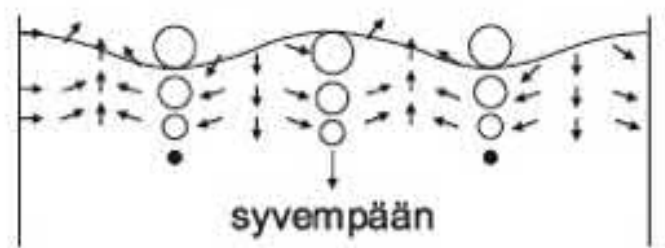

Kuva 3-11. Skemaattinen kuva matalan veden aalloista (vasen) ja syvän veden aalloista (oikea). Aallot kulkevat vasemmalta oikealle. Matalan veden aaltoliike litistyy pohjaa kohti mentäessä, ja syvän veden aallot vaimenevat pohjaa saavuttamatta.

Matalan veden aaltojen etenemisnopeus riippuu vain syvyydestä, ja siksi ne ovat ei-dispersiivisiä. Syvän veden aaltojen etenemisnopeus riippuu aallonpituudesta ja ovat puolestaan dispersiivisiä. Reynoldsin luvun ohella toinen hydrologian virtausopin fundamentaalisista dimensiottomista suureista on Frouden luku

$$
F r=\frac{U}{\sqrt{g H}} .
$$

Frouden luku kuvaa painovoiman merkitystä ja esittää virtausnopeuden suhdetta matalan veden aallon etenemisnopeuteen. Virtaus on alikriittinen (ylikriittinen), kun $F r<1(F r>1)$. Tällä on merkitystä esimerkiksi jokivirtausten tutkimuksissa. Kun virtaus on ylikriittinen, virtauksen häiriöt eivät etene ylävirtaan.

Geofysikaalisessa virtausopissa maapallon (tai planeetan) pyöriminen on merkittävä tekijä. Pyörimisen vaikutusta kuvataan Coriolis-parametrilla $f=2 \Omega \sin \phi$, missä $\Omega$ on maapallon pyörimisnopeus ja $\phi$ on leveysaste. Tästä saadaan Rossbyn luku $R o=\frac{U}{f L}$, joka on yhteydessä geofysikaalisten virtausten pituusmittoihin, kuten kerrosten paksuuksiin ja pyörteiden kokoon. Kun $R o \ll 1$, Coriolis-ilmiö on merkittävä. Näin on suurissa järvissä.

\subsubsection{Veden kiertokulku}

Vesi muodostaa varastoja: meri, ilmakehä, järvet, pohjavesi, maavesi, lumi ja jäätiköt. Varaston koko ilmoitetaan yleensä tilavuutena. Tässä yhteydessä veden tiheydeksi voidaan olettaa $1000 \mathrm{~kg} \mathrm{~m}^{-3}$, joten tilavuus voidaan helposti muuntaa massaksi. Veden kiertokulussa vesi kiertää varastosta toiseen sen kokonaismäärän pysyessä vakiona (kuva 3-12).

Mannerten vedet muodostavat valuma-alueita ja vesistöjä. Valuma-alue on vesistön perusyksikkö. Se on maa- ja vesialue, jolle satanut vesi poistuu alueelta samaa uomaa pitkin ulos- 
virtauksena. Valuma-alue rajoittuu vedenjakajaan ja voi sisältää pohjavesivarastoja, jokia ja järviä. Vesistö on laajempi kokonaisuus ja muodostuu yhdestä tai useammasta valuma-alueesta. Esimerkiksi Vanajaveden valuma-alue sisältää suuren osan Kanta-Hämeen vesistä ja on osa Kokemäenjoen vesistöä. Vedenjakajat määritetään suurimittakaavaisesta topografikartasta tarkastellen korkeita maastokohtia, lähteitä sekä purojen kulkusuuntia. Epäselvissä tapauksissa turvaudutaan maastossa suoritettuihin pinnan korkeuden määrityksiin. Tärkemmät veden kiertokulun vuosuureet eli veden siirtymien käsitteet ovat

\begin{tabular}{|c|c|}
\hline Sadanta & $\begin{array}{l}\text { Ilmakehässä tiivistyneen ja härmistyneen maapallon pinn } \\
\text { veden ja lumen määrä. }\end{array}$ \\
\hline Interseptio & Puiden lehvästöön jäävä osuus sadannasta. \\
\hline $\begin{array}{r}\text { Haihdunta eli } \\
\text { evaporaatio }\end{array}$ & $\begin{array}{l}\text { Veden höyrystyminen ja siirtyminen maan, veden tai ka } \\
\text { nalta ilmakehään. }\end{array}$ \\
\hline Transpiraatio & $\begin{array}{l}\text { Kasvien elintoimintaan liittyvä, juuri-varsi-lehti-systeemin } \\
\text { va veden siirtyminen ilmakehään. }\end{array}$ \\
\hline Evapotranspiraatio & Haihdunta + sublimaatio + transpiraatio. \\
\hline $\begin{array}{l}\text { Tiivistyminen eli } \\
\text { kondensaatio }\end{array}$ & $\begin{array}{l}\text { Haihtumiselle vastakkainen ilmiö, jossa ilmakehän vesih } \\
\text { deksi suoraan maanpintaan. Kun vesihöyry tiivistyy ja al } \\
\text { ilmassa ja pisarat jäätyvät maan pintaan ja rakenteisiin, } \\
\text { retta. }\end{array}$ \\
\hline Sublimaatio & Jään tai lumen höyrystyminen pinnalta. \\
\hline Härmistyminen & $\begin{array}{l}\text { Vesihöyryn kiteytyminen maan pintaan tai kasvillisuutee } \\
\text { kuuran muodostumiseksi. }\end{array}$ \\
\hline Valunta & $\begin{array}{l}\text { Maan pinnalla tai maassa tapahtuvien virtauksien kau } \\
\text { määrä alueen pinta-alaa ja aikaa kohden. Alueelta pois } \\
\text { pohjavesien kautta poistuvaa pohjavesivaluntaa tai puro } \\
\text { ta poistuvaa pintavaluntaa. }\end{array}$ \\
\hline Virtaama & Veden kuljetus uomissa (joet, purot ja kanavat). \\
\hline $\begin{array}{l}\text { Infiltraatio eli } \\
\text { imeytyminen }\end{array}$ & Sadeveden tunkeutuminen maan pinnan läpi maaperään. \\
\hline Suodanta & Imeytyneen veden tunkeutuminen alaspäin pohjavete \\
\hline
\end{tabular}

Vettä haihtuu maapallon pinnalta ja kulkeutuu ilmakehässä vesihöyrynä, joka tiivistyy vesipisaroiksi, ja sadantana palauttaa veden maanpintaan nestemäisessä tai kiinteässä olomuodossa. Vähäisessä määrin vesihöyry tiivistyy kasteeksi tai huurteeksi tai härmistyy kuuraksi maanpintaan. Osa sadannasta - interseptio - jää puiden ja kasvien lehvästöön ja haihtuu sieltä pois saavuttamatta koskaan maan pintaa.

Maahan tullut vesi haihtuu takaisin, imeytyy maaperään ja kulkeutuu pintavesiin. Maaperässä on ylimpänä maavesivyöhyke, jossa maahiukkasten väleissä on sekä vettä että ilmaa, ja sen alla on kokonaan veden kyllästämä pohjavesivyöhyke. Painovoiman ohjaamana maavesivyöhykkeessä vesi painuu suoraan alaspäin, ja pohjavesi virtaa kohti alempaa painetta. Pintavesistä ja maaperästä vesi vähitellen kulkeutuu meriin tai haihtuu ilmakehään. Lumipeite toimii veden talvikautisena varastona, josta kevätsulanta sen palauttaa kiertoon. Vuoristojäätiköihin vesi varastoituu sadoiksi, mannerjäätiköihin jopa sadoiksi tuhansiksi vuosiksi. Lumen ja jäätiköiden pinnalta tapahtuu jonkin verran sublimaatiota ilmakehään säätilasta riippuen.

Veden kiertokulku voi olla paikallinen eli lyhyt kierto, jolloin haihtuva vesi palaa sateena melko pian takaisin, tai pitkä kierto veden kulkiessa useiden varastojen lävitse. Pääosa (noin 80 \%) ilmakehään siirtyvästä vedestä on peräisin meristä. Usein on tarpeellista erottaa pintavesien ja pohjavesien vedenjakajat. Pintavesien vedenjakajat voidaan arvioida kartoista edellä esitetyn mukaan, kun taas pohjavesien vedenjakajien ei välttämättä tarvitse noudatella tar- 
kalleen maan pinnan muotoja. Jos pintavesien vedenjakaja sijaitsee hyvin vettä läpäisevällä, karkeammista maalajeista muodostuneella alueella, saattaa pohjavesien vedenjakajaa poiketa siitä huomattavasti.

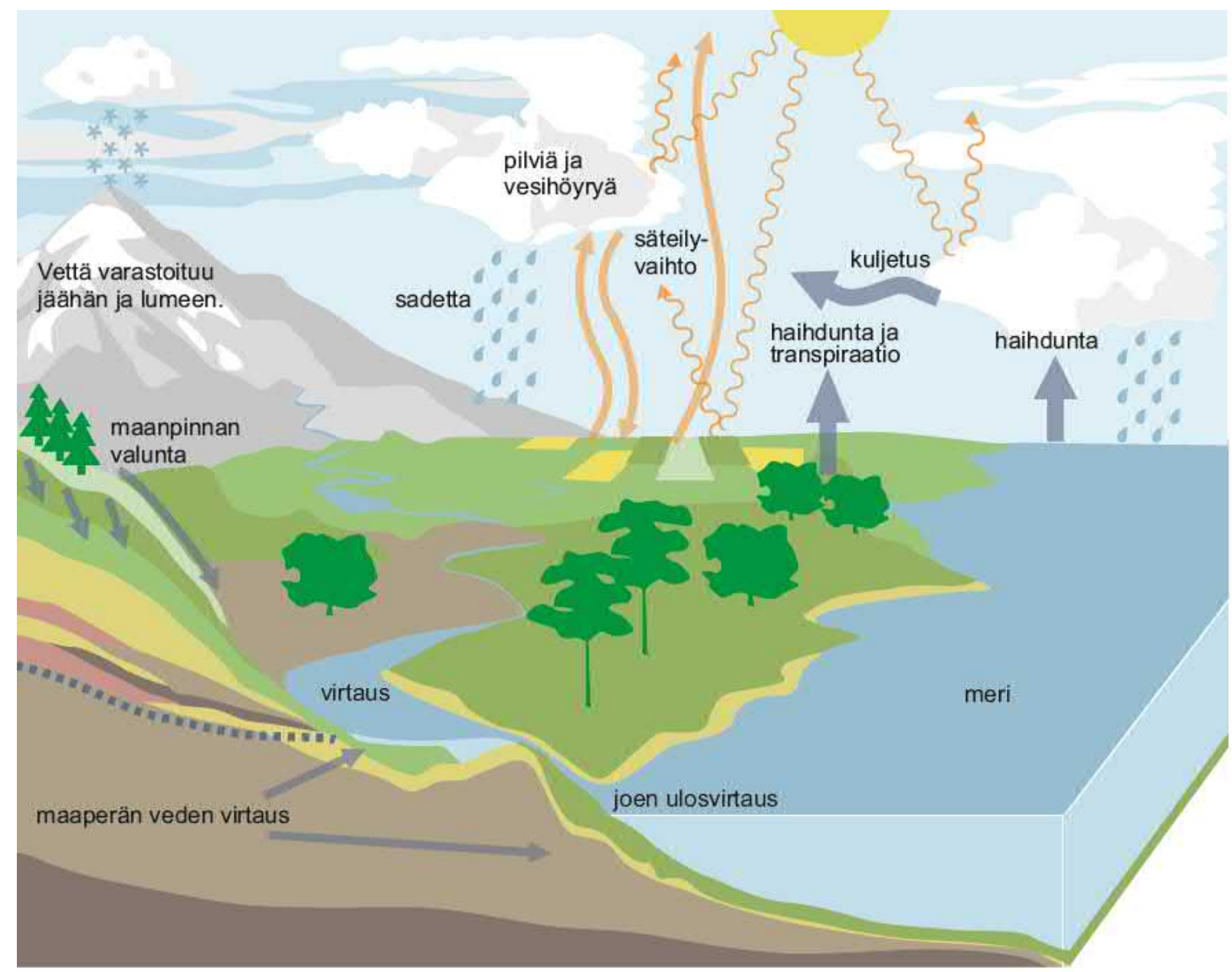

Kuva 3-12. Veden kiertokulku. Vesi haihtuu maapallon pinnalta ilmakehään, jossa se kulkeutuu tuulten mukana ja sataa lopulta maahan. Maasta vettä palautuu takaisin ilmakehään ja kulkeutuu eteenpäin pinta- ja pohjavesivaluntana pintavesiin ja valtameriin. Piirros: Salla Jokela.

Kiertokulussa vesi kulkee varastosta toiseen vuosuureina eli veden tilavuuden siirtymisinä aikayksikköä kohti tai aika- ja pinta-alayksikköä kohti (kuva 3-13). Vuosuureet kertovat tulevan tai lähtevän vesitilavuuden siirtymisestä varastosta toiseen. Virtaama ilmaistaan tilavuutena aikayksikköä kohti ja muut vuosuuret kertyvän vesimassan tilavuutena aika- ja pintaala yksikköä kohti. Virtaaman yksikkönä on yleensä kuutiometriä sekunnissa, muiden millimetrejä vuorokaudessa, kuukaudessa tai vuodessa.

Esimerkki 3-5. a) Jos vuorokauden aikana $100 \mathrm{~km}^{2}$ alueelle sataa $10 \mathrm{~mm}$, veden kokonaismäärä on $10^{6} \mathrm{~m}^{3}$. Siirtonopeus on tällöin $12,6 \mathrm{~m}^{3} \mathrm{~s}^{-1}$. Virtaama on uomassa kulkevan veden tilavuuden kuljetus aikayksikköä kohti. Amazon on $209000 \mathrm{~m}^{3} \mathrm{~s}^{-1}$ virtaamallaan paljon suurempi muita jokia. Suomen suurimpien jokien (Kemijoki, Vuoksi) virtaama on hieman yli $500 \mathrm{~m}^{3} \mathrm{~s}^{-1}$ ja Vantaan $15 \mathrm{~m}^{3} \mathrm{~s}^{-1}$.

b) Järven pinta-ala on $100 \mathrm{~km}^{2}$, ja siihen laskee joki, jonka virtaama on $50 \mathrm{~m}^{3} \mathrm{~s}^{-1}$. Vuorokauden aikana joki tuo järveen vettä $4,32 \mathrm{~km}^{3}$, joka levitettynä tasaisesti koko järven alueelle nostaisi veden pintaa $43,2 \mathrm{~mm}$. 


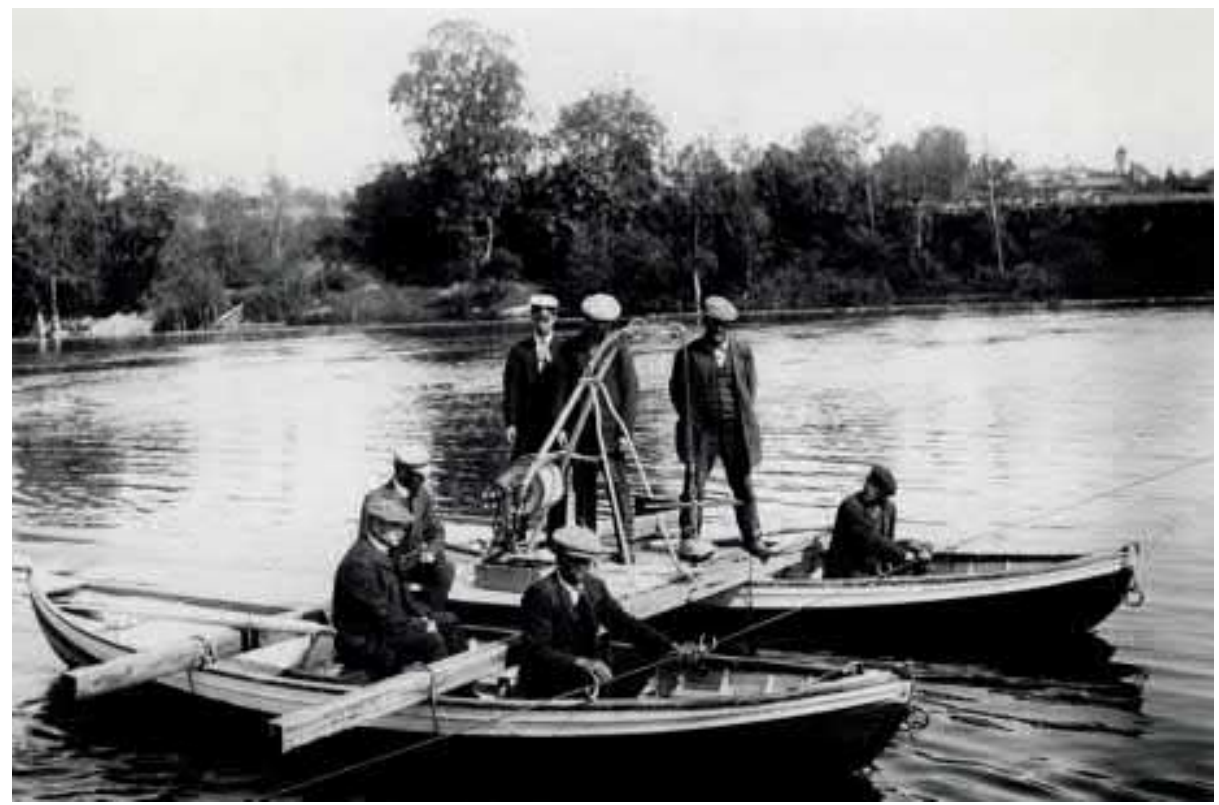

Kuva 3-13. Virtaamamittaus Valkeakoskella vuonna 1913. Mittalaitteena on riippasiivikko. Virtaus pyörittää siivikon lapoja, ja kierrosnopeus voidaan kalibrointikäyrän avulla muuttaa virtausnopeudeksi. Mittauksia tehdään useasta pisteestä, ja niiden perusteella arvioidaan virtaama eli veden tilavuuskuljetus joen poikkileikkauksen läpi. Lähde: Suomen ympäristökeskus (Kuusisto 2008).

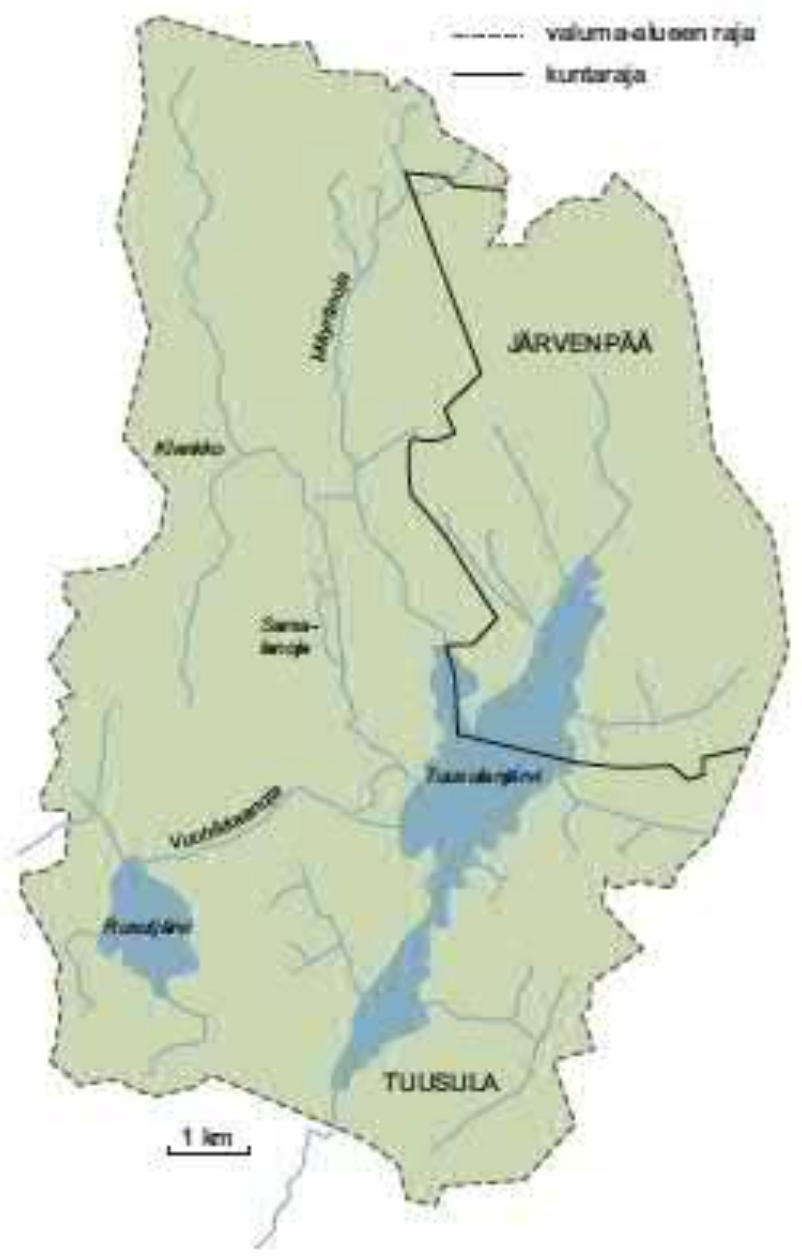

Kuva 3-14. Tuusulanjärven valuma-alue Keski-Uudellamaalla. Järven pinta-ala on $6 \mathrm{~km}^{2}$ ja keskisyvyys 3,2 m. Ulosvirtaus etelässä Tuusulanjokeen ja edelleen Vantaanjokeen. Piirros: Salla Jokela. 
Vesistön hydrologista luonnetta kuvaavat alueen pinta-ala, muoto ja kaltevuussuhteet, pintavesien pinta-ala (järvien osuus) ja sijainti, eri maastolajien (pelto, suo, metsä) pinta-alat ja sijainnit, maaperän laatu, ihmistoiminnan maankäyttö (maatalous, turveteollisuus, taajamien vedenkäyttö yms.) ja vesiväylien pituus (kuva 3-14). Vesistöjen rajat ovat suuresti vaikuttaneet ihmisasutuksen leviämiseen sekä heimojen ja kansojen maantieteelliseen vaellukseen ja sijoittumiseen.

Valunnan muodostumiseen vaikuttaa sadannan ajallinen ja alueellinen jakautuminen. Jos sadanta on keskittynyt tiettyyn aikaan, seuraa siitä suuri valunta. Tasaisesti jakaantuneen sadannan tapauksessa haihdunta voi poistaa alueelta suuren osan sataneesta vedestä. Osa valunnasta tapahtuu melko pian sateen jälkeen pintavaluntana (välitön valunta) ja osa suodattuu hitaasti pohjaveteen. Pintavalunnan osuus riippuu sateen voimakkuudesta, maan pintakerroksen vesipitoisuudesta, kasvipeitteestä ja maaperän laadusta. Pohjavesivalunta on tärkeä alueilla, joissa pintakerroksen maalaji on karkeaa (esimerkiksi soraharjut) ja vesi virtaa hyvin. Korkeilla leveysasteilla, kuten meillä Suomessa sadanta varastoituu tilapäisesti lumipeitteeseen, ja sitten lyhyenä sulamiskautena seuraa voimakas valuntahuippu.

Vuosisadanta on suurimmillaan kosteilla merellisillä vyöhykkeillä, $2000-3000 \mathrm{~mm}$. Metsävyöhykkeillä se on tyypillisesti $400-600 \mathrm{~mm}$ ja autiomailla sekä polaarialueilla alle 200 $\mathrm{mm}$. Haihdunnan määrä riippuu ilman kosteudesta ja lämpötilasta. Maa-alueilla se on sadantaa pienempi, metsävyöhykkeillä 20 - 70 \% sadannasta. Autiomailla haihdunta on miltei sadannan suuruinen. Sadannan ja haihdunnan erotus menee valuntaan, josta yleensä suurin osa on pintavaluntaa.

\subsubsection{Sä̈̈olot}

Ilmakehä on välittömässä kytköksessä pintakerroksen vesivarastoihin. Hydrologiset mallit tarvitsevat siksi yksityiskohtaisia tietoja säästä ja ilmastosta, erityisesti lämpötilasta ja kosteudesta, tuulesta ja säteilytaseesta. Taulukossa 3-5 on esimerkkinä Jokioisten sääaseman kuukausikeskiarvoja. Auringon säteily ja lämpötila seuraavat voimakkaasti vuodenaikoja. Suhteellinen kosteus ja pilvisyys ovat pienimmillään ja sadanta suurimmillaan kesällä.

Ilmakehän vesivarasto on osa hydrologista kiertoa. Ilmassa olevan vesihöyryn määrää absoluuttista kosteutta - kuvataan ominaiskosteudella $q$, joka tarkoittaa vesihöyrymassan suhteellista osuutta ilmassa. Suure $q$ on dimensioton eli $[q]=1$ ja sen suuruusluokka on $10^{-3}$ $10^{-2}$. Toisinaan $q: 1 \mathrm{le}$ annetaan 'yksiköksi' $\mathrm{g} \mathrm{kg}^{-1}=10^{-3}$, joka samalla kertoo, että kyse on massasuhteesta. Ilman kosteus ilmaistaan absoluuttisena tai suhteellisena. Ilman kosteus voidaan antaa myös vesihöyryn paineena $e$, joka kuvaa vesihöyryn aiheuttamaa osaa ilman kokonaispaineesta. Ominaiskosteuden ja vesihöyrynpaineen välillä on suhde

$$
q=0,622 \cdot \frac{e}{p}
$$

Vesihöyryn määrää rajoittaa lämpötilasta riippuva kyllästyskosteus (kuva 3-15). Suhteellinen kosteus määritellään suhteessa kyllästysarvoon eli kuinka monta prosenttia vallitseva kosteus on kyllästysarvosta. Kylmän ilman kyky sitoa kosteutta on huomattavasti alempi kuin lämpimän ilman. Kun vesihöyryä on vähemmän kuin kyllästystilan verran, ilmaan voi haihtua lisää kosteutta. Ylikyllästynyt vesihöyry voi puolestaan tiivistyä vesipi-saroiksi tai härmistyä jääkiteiksi ja muodostaa pilviä. Tiivistyminen ja härmistyminen voivat myös tapahtua maan pintaan kasteeksi, huurteeksi tai kuuraksi. Ilman kosteus ilmoitetaan säähavainnoissa yleensä suhteellisena. 
Taulukko 3-5. Keskimääräiset säämuuttujien kuukausiarvot Jokioisten havaintoasemalla $\left(60^{\circ} 48^{\prime} \mathrm{N}\right.$ $23^{\circ} 30^{\prime} E$ ) kaudella 1981-2010 (Pirinen ym. 2012). Pilvisyys Ilmatieteen laitoksen (1982) tilastosta vuosilta 1971-1980.

\begin{tabular}{|c|c|c|c|c|c|c|c|c|}
\hline & $\begin{array}{l}\text { Ilman- } \\
\text { paine }\end{array}$ & $\begin{array}{l}\text { Auringon- } \\
\text { säteily }\end{array}$ & \begin{tabular}{|l} 
Lämpö- \\
tila
\end{tabular} & Kosteus & $\begin{array}{l}\text { Tuulen- } \\
\text { nopeus }\end{array}$ & Pilvisyys & Sadanta & $\begin{array}{l}\text { Lumen } \\
\text { paksuus }\end{array}$ \\
\hline Kuukausi & mbar & $\mathbf{W} \mathbf{m}^{-2}$ & ${ }^{\circ} \mathrm{C}$ & $\%$ & $\mathrm{~m} \mathrm{~s}^{-1}$ & $1 / 8$ & $\mathrm{~mm} \mathrm{kk}^{-1}$ & $\mathrm{~cm}$ \\
\hline 1 & 1009 & 10,8 & $-5,6$ & 89 & 3,7 & 6,4 & 46 & 14 \\
\hline 2 & 1012 & 37,3 & $-6,3$ & 87 & 3,6 & 6 & 32 & 20 \\
\hline 3 & 1012 & 87,4 & $-2,4$ & 82 & 3,7 & 5,5 & 32 & 24 \\
\hline 4 & 1014 & 151,6 & 3,5 & 72 & 3,6 & 5,6 & 30 & 1 \\
\hline 5 & 1014 & 207,6 & 9,8 & 65 & 3,6 & 5,1 & 41 & - \\
\hline 6 & 1011 & 215,3 & 14 & 68 & 3,4 & 4,9 & 63 & - \\
\hline 7 & 1011 & 218 & 16,7 & 71 & 3,2 & 5,3 & 75 & - \\
\hline 8 & 1012 & 162,4 & 15 & 77 & 3,2 & 5,6 & 80 & - \\
\hline 9 & 1012 & 97,2 & 9,9 & 83 & 3,4 & 5,9 & 58 & - \\
\hline 10 & 1012 & 40,7 & 4,9 & 88 & 3,7 & 6,2 & 66 & 0 \\
\hline 11 & 1011 & 13,1 & $-0,2$ & 91 & 3,8 & 6,7 & 57 & 1 \\
\hline 12 & 1010 & 6 & $-3,9$ & 91 & 3,8 & 6,5 & 47 & 8 \\
\hline Vuosi & 1012 & 105 & 4,6 & 80 & 3,6 & 5,8 & 52 & - \\
\hline
\end{tabular}

Kun lämpötilan yksikkönä on Celsius-aste ja vesihöyrynpaineen millibaari, kyllästyskosteus $e_{s}$ vesipinnan yllä $\left(e_{s, \mathrm{w}}\right)$ ja jääpinnan yllä $\left(e_{s, i}\right)$ saadaan kaavoista

$$
\begin{aligned}
& \log _{10} e_{S, w}(T)=\frac{0,7859+0,03477 \cdot T}{1+0,00412 \cdot T} \text { ja } \\
& \log _{10} e_{S, i}(T)=\log _{10} e_{S, w}(T)+0,00422 \cdot T, T \leq 0{ }^{\circ} \mathrm{C} .
\end{aligned}
$$

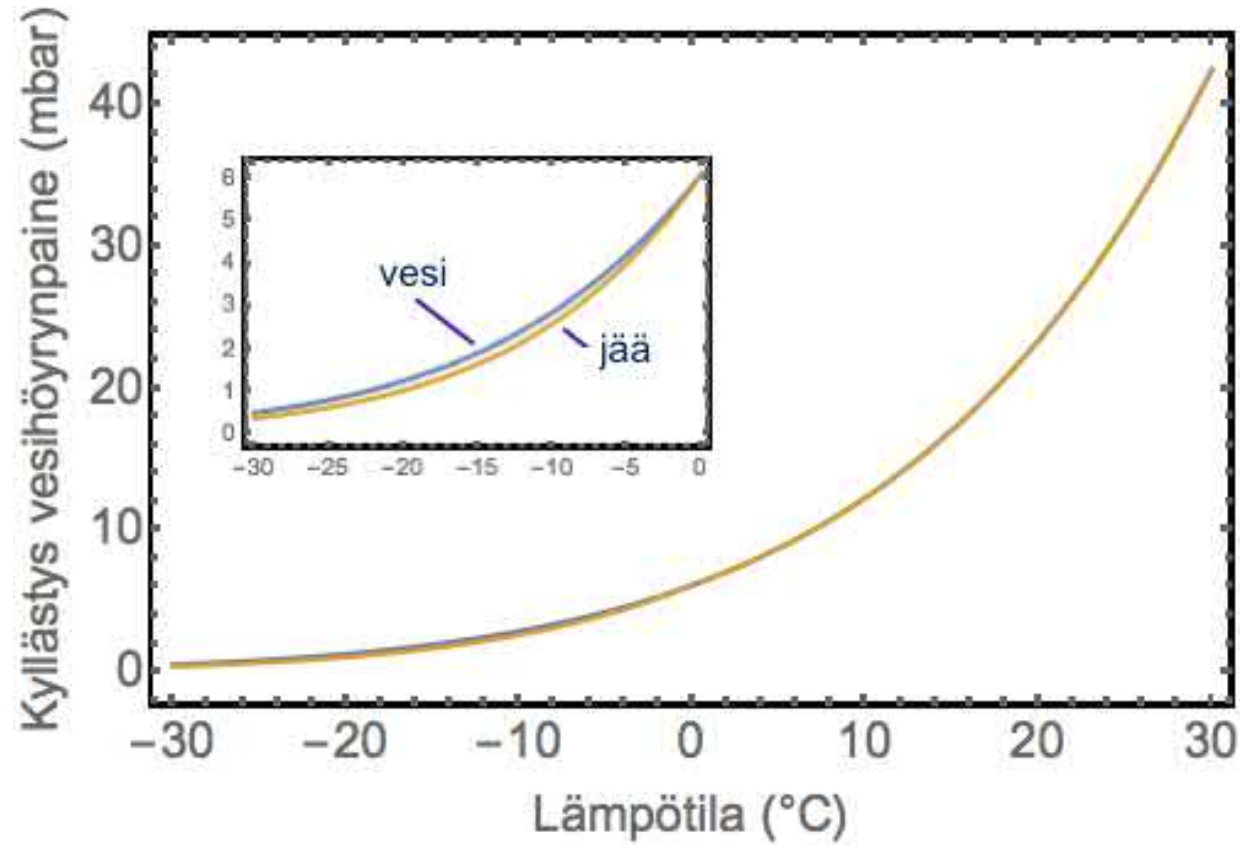

Kuva 3-15. Kyllästyskosteus lämpötilan funktiona. Ilma voi sisältää vesihöyryä korkeintaan kyllästystilan, joka riippuu voimakkaasti lämpötilasta. Jäätymispisteen alapuolella jääpinnan ja vesipinnan kyllästysarvot eroavat hieman. 
Esimerkki 3-5. Normaali ilmanpaineessa ja $10{ }^{\circ} \mathrm{C}$ lämpötilassa kyllästyskosteuden arvo on $q_{s}=$ $7,5 \cdot 10^{-3} \mathrm{ja}-10^{\circ} \mathrm{C}$ lämpötilassa se on $q_{s}=1,8 \mathrm{~g} \mathrm{~kg}^{-1}$ (vesipinta) tai $1,6 \mathrm{~g} \mathrm{~kg}^{-1}$ (jääpinta). Ilman tiheys voidaan laskea ideaalikaasun tilayhtälöstä $\rho_{a}=\frac{p}{R_{a} T}$, missä $R_{a}=287,04 \mathrm{~J} \mathrm{~kg}^{-1} \mathrm{~K}^{-1}$ on ilman kaasuvakio. Yksi kuutiometri ilmaa painaa siis $1,2-1,3 \mathrm{~kg}$ lämpötilasta riippuen, joten vesihöyryä siinä on kyllästystilassa kylmässä ilmassa $\left(T<-15^{\circ} \mathrm{C}\right)$ alle $1 \mathrm{~g}$ ja lämpimässä $\left(T>25^{\circ} \mathrm{C}\right)$ yli $20 \mathrm{~g}$. Jos vesihöyryä on $10{ }^{\circ} \mathrm{C}$ lämpötilassa $5,0 \mathrm{~g} \mathrm{~kg}^{-1}$, suhteellinen kosteus on $66,7 \%$. Tällöin vesihöyryn osapaine on 8,1 mbar.

\subsubsection{Vesitaseyhtälö}

Valuma-alueen tai vesistön vesitaseyhtälö kuvaa vesivaraston $V$ kehitystä. Se kirjoitetaan

$$
\frac{d V}{d t}=(P-E) A-R
$$

missä $P$ on sadanta, $E$ on haihdunta, $A$ on alueen pinta-ala ja $R$ on valunta. Kaikki vesi valuma-alueeseen ja vesistöön tulee sisään sateena ja poistuu valuntana ja haihduntana (kuva 316). Vesivaraston laatuna eli dimensiona on vesimäärän tilavuus, ja yhtälön (3.17) termit kuvaavat tämän tilavuuden muutosta aikayksikköä kohti. Vesitaseyhtälö voidaan yleistää mielivaltaiselle alueelle lisäämällä oikealle puolelle alueeseen tuleva sisäänvirtaus $I$.

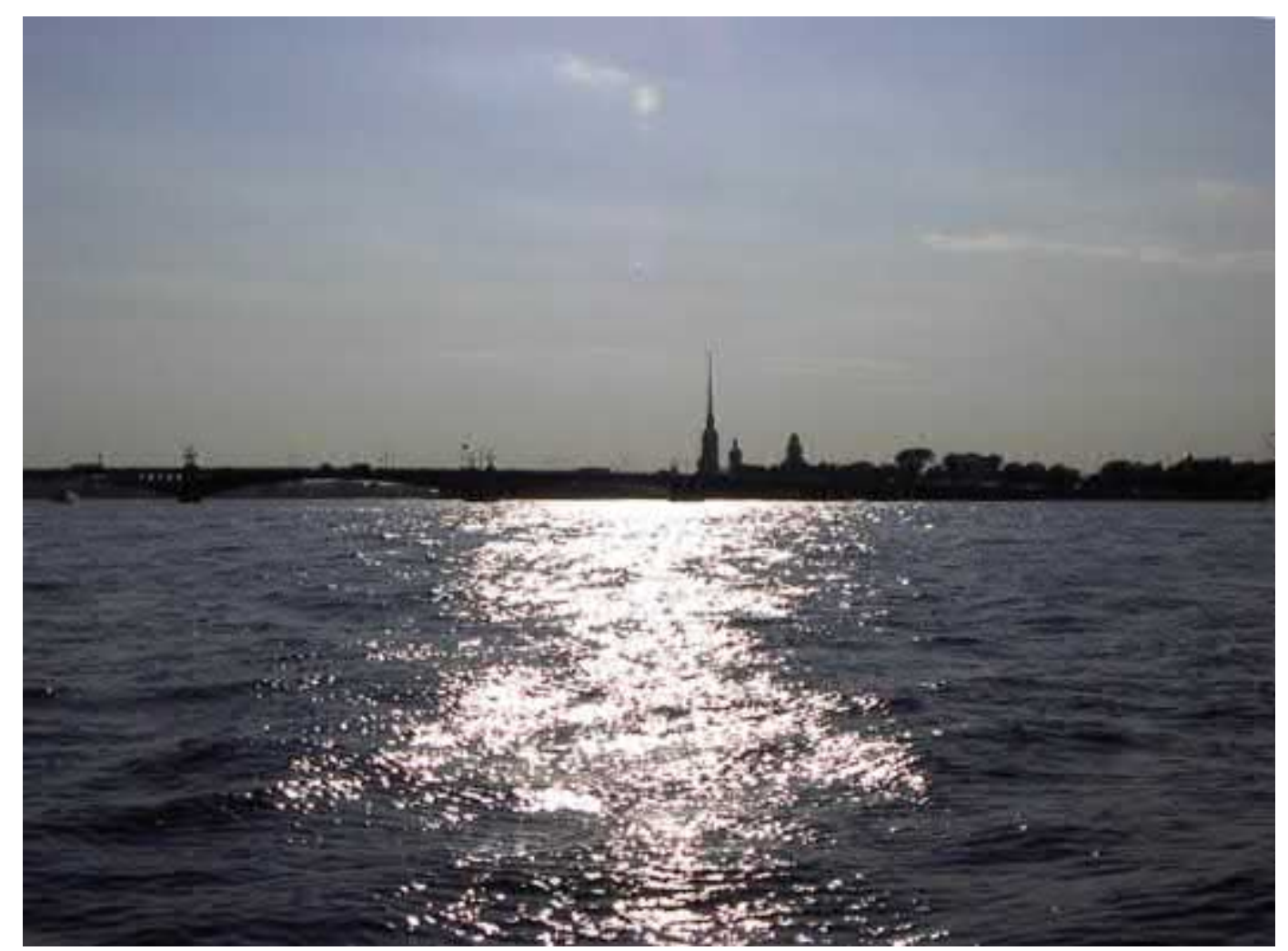

Kuva 3-16. Itäisen Suomen ja Venäjänkarjalan vedet kulkeutuvat Nevaa pitkin Suomenlahteen. Kuva: Matti Leppäranta.

Pitkällä aikavälillä vesivarastossa ei useinkaan tapahdu merkittäviä muutoksia ja voidaan asettaa $V=$ vakio. Esimerkiksi vuosittainen nettotase on usein suunnilleen nolla eli $(P-E) A \approx$ $R$. Laskujoettomassa vesistössä on $R=0$, ja vesivaraston säilymiseksi ennallaan on siis oltava $P=E$. Mantereiden vesitaseessa ulosvirtaus tapahtuu valuntana meriin (taulukko 3-6). Suo- 
men oloissa sadanta on 500 - $650 \mathrm{~mm}$ vuodessa, ja haihdunta noin $400 \mathrm{~mm}$ vuodessa, joten nettovaihto on ilmakehän kanssa 100 - 200 mm vuodessa.

Taulukko 3-6. Mantereiden ja koko maapallon vuotuinen vesitase.

\begin{tabular}{l|r|r|r|r} 
& Ala & Sadanta & Haihdunta & Valunta \\
\hline & $10^{6} \mathrm{~km}^{2}$ & $\mathrm{~mm}$ & $\mathrm{~mm}$ & $\mathrm{Mm}$ \\
\hline Eurooppa & 9,8 & 734 & -415 & -319 \\
Aasia & 45 & 726 & -433 & -293 \\
Afrikka & 30,3 & 686 & -547 & -139 \\
$\begin{array}{l}\text { Pohjois- } \\
\text { Amerikka }\end{array}$ & 20,7 & 670 & -383 & -287 \\
Etelä-Amerikka & 17,8 & 1684 & -1065 & -583 \\
Australia & 8,7 & 736 & -510 & -226 \\
Etelämanner & 14 & 150 & -50 & -100 \\
Mantereet & $\mathbf{1 5 8 , 1}$ & $\mathbf{8 3 4}$ & $\mathbf{- 5 4 0}$ & $\mathbf{- 2 9 4}$ \\
yhteensä & 351,9 & 1120 & -1250 & 130 \\
Meret & $\mathbf{5 1 0}$ & $\mathbf{1 0 2 0}$ & $\mathbf{- 1 0 2 0}$ & $\mathbf{0}$ \\
Koko & & & &
\end{tabular}

\#Arvot karkeita havaintojen vähyyden takia.

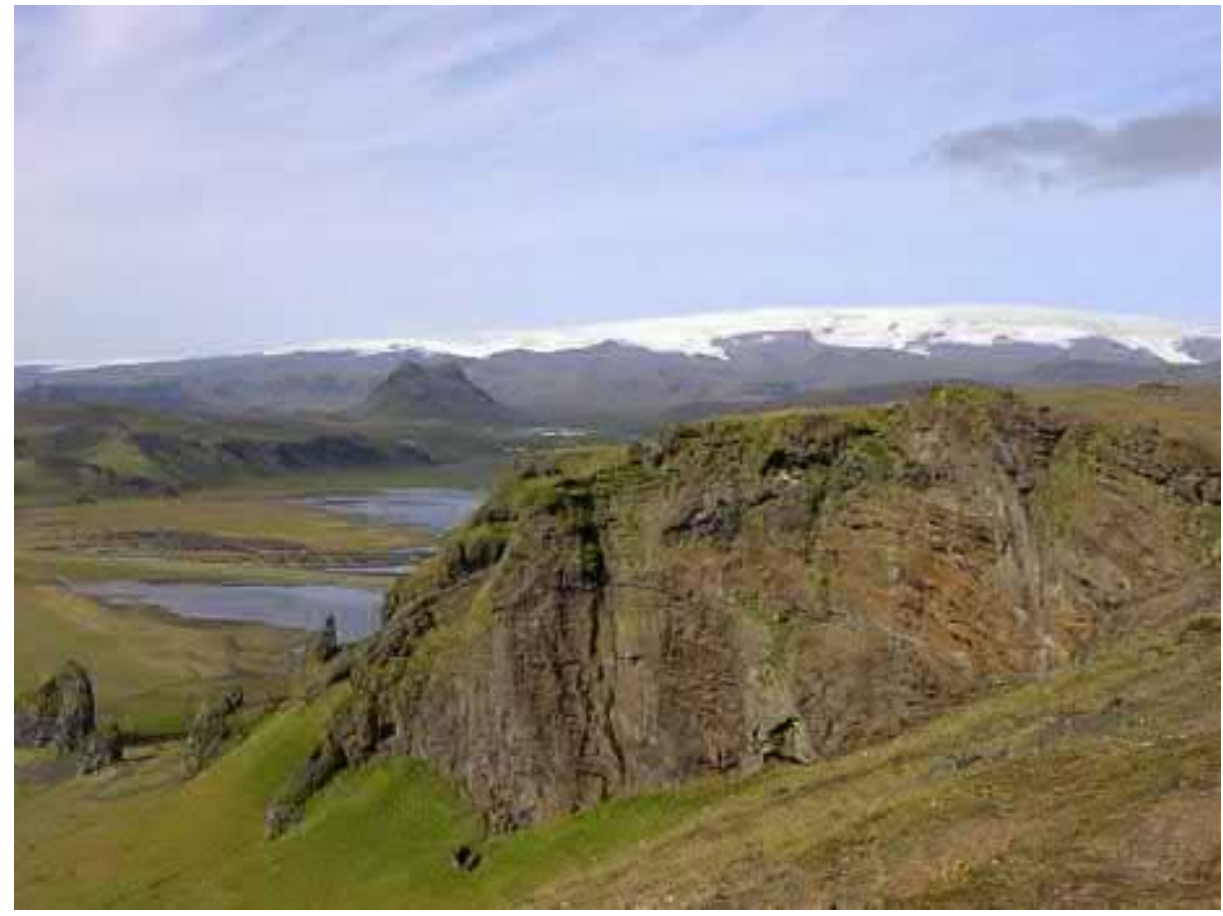

Kuva 3-17. Vatnajökull-jäätikön edustalle muodostunut järvi Islannissa. Kuva: Matti Leppäranta.

Edellä esitetty vesitaseyhtälö soveltuu myös jäätikkövesistöihin, joissa vesivarasto on pääosin kiinteässä olomuodossa (kuva 3-17). Jäätikköhydrologiassa puhutaan jäänjakajasta analogisesti vedenjakajan kanssa. Mereen ulottuvien jäätiköiden ulosvirtaukseen kuuluu lisäksi jäävuorien sekä pienempien jäätikön palojen lohkeaminen, mitä kutsutaan jäätikön poikimiseksi. Etelämantereen mannerjäätikön ulosvirtaus onkin miltei kokonaan jäävuorien poikimista. 
Vesitaseyhtälön avulla voidaan arvioida ihmisen vedenkäytön vaikutuksia vesistöihin. Vesien säännöstelyn avulla pintavesivarasto voidaan pitää tietyissä rajoissa. Pohjaveden käyttö vaikuttaa pohjavesivarastoihin, minkä vuoksi varaston suuruutta on seurattava. Liiallinen vedenkäyttö on johtanut suuriin ongelmiin. Esimerkiksi Araljärveen virtaavan veden käyttö puuvillapeltojen kasteluun 1960-luvulta lähtien on aiheuttanut järven pinta-alan ja tilavuuden pienenemisen, ja siitä seurannut järven suolaisuuden kasvu on aiheuttanut paikallisen ekokatastrofin. Araljärvi on myös suolainen, joten vesivaraston muutokset heijastuvat sen suolaisuudessa.

Viimeksi kuluneiden 100 vuoden aikana valtamerten pinta on noussut $1-2 \mathrm{~mm}$ vuodes$\mathrm{sa}^{11}$, kun samaan aikaan ilman lämpötila on kasvanut $0,3-0,6^{\circ} \mathrm{C}$. Jäätiköiden pienenemi-nen on lisännyt merten vesimäärää, ja lisäksi meriveden lämpölaajeneminen on nostanut merenpintaa. Kaikkien nykyisten jäätiköiden sulaminen nostaisi merenpintaa noin $70 \mathrm{~m}$.

Tässä luvussa on esitelty luonnonvesi ja sen fysikaaliset ominaisuudet, virtausopin perusteita sekä veden kiertokulku. Vesi kulkee kierrossaan varastosta seuraavaan. Sen kokonaismäärä maapallolla säilyy ja ilmakehässä käynnillään se puhdistuu vieraista aineista. Tulevissa luvuissa näitä tietoja luonnonvesien fysikaalisista ominaisuuksista ja virtausopista käytetään hyväksi ja veden kiertokulun varastoja ja väyliä käsitellään yksityiskohtaisemmin (kuva 3-18). Heti seuraavaksi tarkastellaan lähemmin ilmakehän vesivarastoa ja sen uusiutumista. Myös talvi-kautinen lumipeite, sateen väliaikainen varasto maan pinnalla, käsitellään tässä yhteydessä.

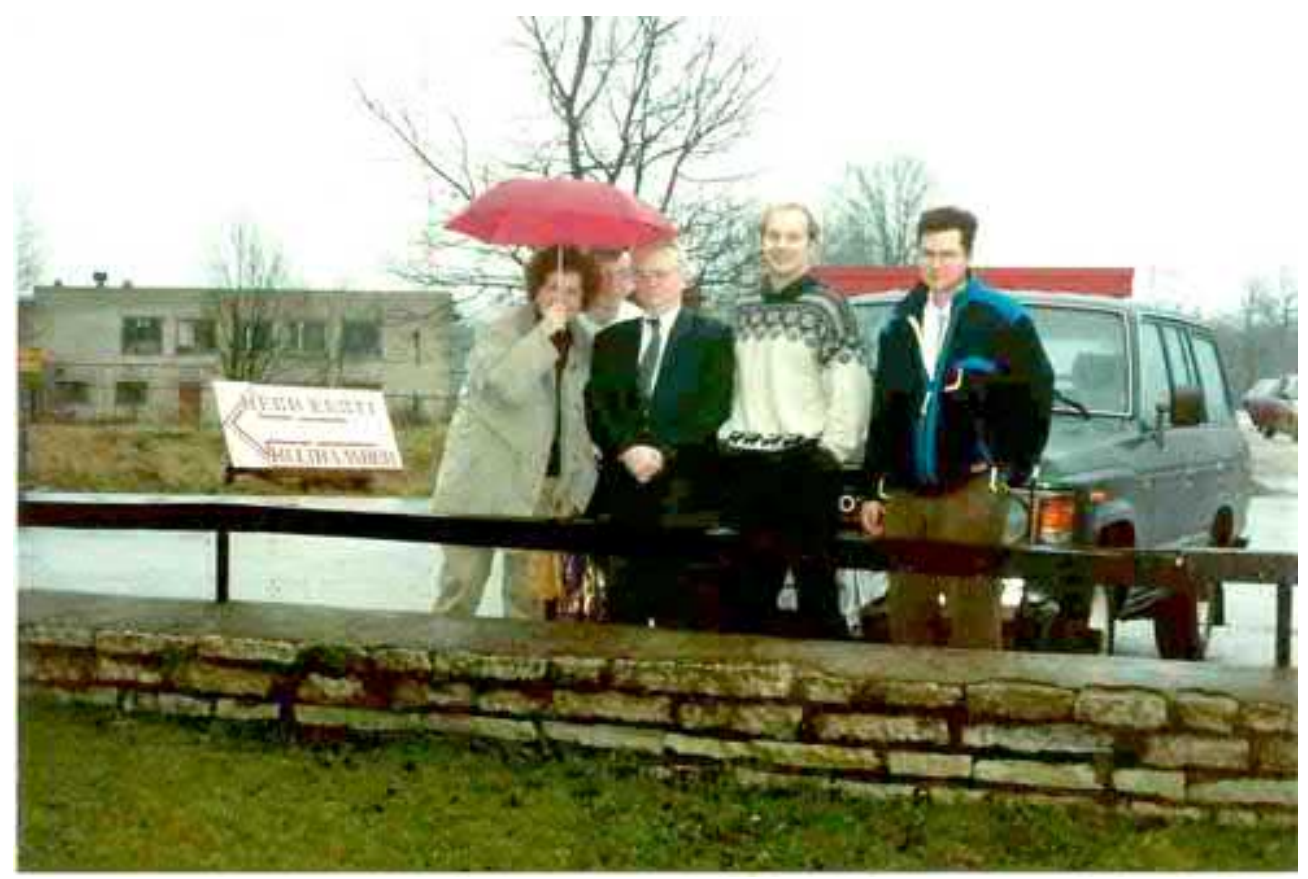

Kuva 3-18. Hydrologian ekskursio Viroon syksyllä 1997. Suomen ja Viron yhteistyöohjelma SUVI käsitteli pintavesien optiikkaa ja veden laatua. Vasemmalla ohjelman koordinaattorit tohtori Helgi Arst ja professori Juhani Virta, oikealla Antti Hellevi ja Alberto Blanco Sequeiros.

\footnotetext{
${ }^{11}$ Globaalia merenpinnan korkeuden muutosta jäätiköiden sulamisesta ja meriveden lämpölaajenemisesta johtuen sanotaan eustaattiseksi merenpinnan muutokseksi.
} 


\section{Hydrometeorologia}

\subsection{Maanpinnan lämpötase}

\subsubsection{Perusyhtälö}

Monissa hydrologian kysymyksissä on arvioitava lämpötasetta maan pinnalla. Esimerkiksi haihdunta ja routaantuminen ovat tällaisia kysymyksiä (kuva 4-1). Asetetaan nyt z-akseli korkeusakseliksi osoittamaan ylöspäin ja sen nollakohta maanpintaan, joka voi tässä olla maaperää, kasvillisuutta, vettä, lunta tai jäätä. Yleisesti maanpinnan energiatase kirjoitetaan

$$
\left.k \frac{\partial T}{\partial z}\right|_{z=0^{-}}=Q_{s}-Q_{r}+Q_{L a}-Q_{L 0}+Q_{c}+Q_{e}+Q_{P}
$$

missä $k$ on alustan lämmönjohtokerroin, $Q_{s}$ on pintaan tuleva auringonsäteily, $Q_{r}$ on pinnasta heijastuva ja siroava auringonsäteily, $Q_{L a}$ on ilmakehästä pintaan tuleva lämpösäteily, $Q_{L o}$ on pinnasta lähtevä lämpösäteily, $Q_{c}$ on aistittavan lämmön vuo ${ }^{1}, Q_{e}$ on haihtumislämpö ja $Q_{P}$ on sateen mukana tuleva lämpö. Yhtälön (4.1) vasemmalla puolella $\left.\right|_{z=0-}$ merkintä tarkoittaa sitä, että lämmönjohtokertoimen ja lämpötilan vertikaaliderivaatan tulo otetaan välittömästi pinnan alapuolella, jolloin saadaan pinnasta sisään johtuva lämpö. Oikealla puolella on auringosta sekä ilmakehästä pintaan tulevat lämpövuot. Lämmönsiirrot ovat positiivisia, kun lämpö siirtyy alaspäin.

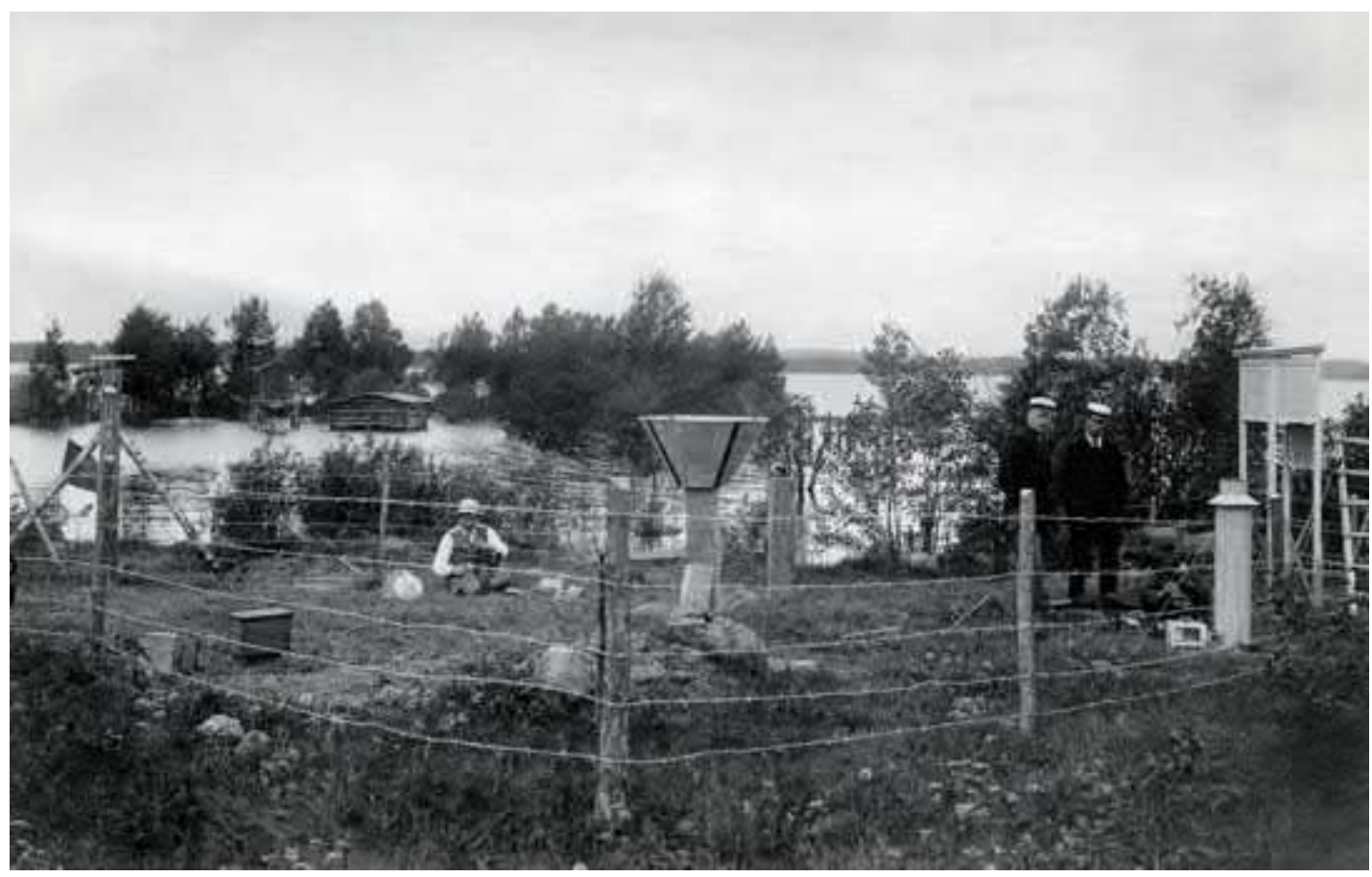

Kuva 4-1. Tampereen Pyhäjärven haihduntamittauksia varten rakennettiin Pirkkalan Toppariin ilmastoasema, kuvattuna vuonna 1912. Haihdunta-astiat kelluvat rantavedessä taustalla näkyvän niemen takana. Kuva: Suomen ympäristökeskuksen hydrologinen arkisto (Kuusisto 2008).

\footnotetext{
${ }^{1}$ Aistittavan lämmön vuo -termin 'aistittavuus' viittaa siihen, että lämmönsiirto perustuu lämpötilaeroon. Lämpö siirtyy lämpimästä kylmään. Termiä kutsutaan myös nimellä havaittavan lämmön vuo.
} 
Säteilytermien summa $Q_{R}=Q_{s}-Q_{r}+Q_{L a}-Q_{L 0}$ on säteilytase. Säteilyn määrittäminen perustuu Planckin mustan kappaleen säteilylakiin

$$
I(\lambda ; T)=\frac{2 h c_{0}^{2}}{\lambda^{5}} \frac{1}{\exp \left(\frac{h c_{0}}{\lambda k_{B} T}\right)-1},
$$

missä $\lambda$ on aallonpituus, $T$ on lämpötila Kelvin-asteina, $h=6,6261 \cdot 10^{-34} \mathrm{~J} \mathrm{~s}$ on Planckin vakio, $c_{0}=2,9979 \cdot 10^{8} \mathrm{~m} \mathrm{~s}^{-1}$ on valon nopeus tyhjiössä ja $k_{B}=1,3807 \cdot 10^{-23} \mathrm{~J} \mathrm{~K}^{-1}$ on Boltzman-nin vakio. Tämän lain mukaan säteilyn intensiteetti riippuu aallonpituudesta ja lämpötilasta niin, että mitä korkeampi lämpötila on, sitä lyhyempi on säteilymaksimin aallonpituus ja sitä korkeampi kokonaissäteily. Auringonsäteilyä sanotaan myös lyhytaaltoiseksi säteilyksi (se on pääosaltaan spektrikaistalla $0,3-3 \mu \mathrm{m}$ ), ja maapallon pinnan sekä ilmakehän säteilyä sano-taan myös pitkäaaltoiseksi säteilyksi (ne ovat pääosaltaan spektrikaistalla 5-15 $\mu \mathrm{m}$ ) tai ter-restriseksi säteilyksi.

Auringonsäteily voidaan arvioida laskennallisesti ajan, paikan ja ilmakehän aiheuttaman suodatuksen perusteella. Terrestristen säteilytermien laskemiseksi sovelletaan Planckin säteilylakia, joka integroidaan aallonpituuden suhteen kokonaistehon saamiseksi:

$$
Q_{L}(T)=\int_{0}^{\infty} I(\lambda ; T) d \lambda=\sigma T^{4},
$$

missä $\sigma=5,6704 \cdot 10^{-8} \mathrm{~W} \mathrm{~m}^{-2} \mathrm{~K}^{-4}$ on Stefan-Boltzmannin vakio. Integroitu muoto on nimeltään Stefan-Boltzmannin säteilylaki. Harmaa kappale säteilee kuten musta, mutta sen säteilyjakauman taso on alempi emissiokertoimen $\varepsilon(0<\varepsilon<1)$.

Aistittavan lämmön vuon ja haihtumislämmön summa $Q_{\mathrm{c}}+Q_{\mathrm{e}}$ on turbulenttinen lämmönvaihto maanpinnan ja ilman pintakerroksen välillä. Näitä termejä arvioidaan käyttäen turbulenttisen vuon $Q_{T}$ peruskaavaa

$$
Q_{T} \propto\left(B_{a}-B_{0}\right) U_{a}
$$

missä $B$ on tarkasteltava ominaisuus (tässä lämpötila tai kosteus), alaindeksi 0 viittaa pintaan ja $a$ ilmaan, ja $U_{a}$ on tuulen nopeus. Lämpövuon dimensio on $\left[Q_{T}\right]=M T^{-3}$, joten suhteen (4.4) verrannollisuuskertoimen dimension tulee olla $M L^{-1} T^{-2}[B]$. Sateen mukana tuleva lämpö voidaan kirjoittaa

$$
Q_{P}=\rho\left[c\left(T-T_{0}\right)+I_{f} L_{f}\right] .
$$

Tässä $c \approx 4,2 \mathrm{~kJ} \mathrm{~kg}^{-1}{ }^{\circ} \mathrm{C}^{-1}$ on veden ominaislämpökapasiteetti, $T$ on sateen lämpötila, $L_{f}=333,6$ $\mathrm{kJ} \mathrm{kg}^{-1}$ on jään sulamislämpö ja funktio $I_{f}$ on faasimuutosindikaattori. Jos sadevesi jäätyy lumeen tai jäähän, niin $I_{f}=1$, jos lumihiutaleet sulavat veden pinnalla, niin $I_{f}=-1$, tai jos faasimuutosta ei tapahdu, niin $I_{f}=0$. Tämä lämpövuo on merkittävä, kun $I_{f} \neq 0$.

Esimerkki 4-1. Vesisade lankeaa lumipeitteeseen. Sen lämpötila on $5{ }^{\circ} \mathrm{C}$, ja sademäärä on $20 \mathrm{~mm}$ vuorokaudessa. Jos sadevesi jäähtyy jäätymispisteeseen, lämpöä siirtyy lumipeitteeseen $4,9 \mathrm{~W} \mathrm{~m}^{-2}$ teholla. Jos $0{ }^{\circ} \mathrm{C}$ vesi edelleen jäätyy, tulee siitä lämmitystehoa lisää $77 \mathrm{~W} \mathrm{~m}^{-2}$, mikä on jo sangen suuri luku. 


\subsubsection{Adiabaattinen lämpötilan muutos}

Ilman lämpötilan vertikaalista profiilia voidaan tarkastella adiabaattisen mallin avulla. Lämpöopin 1. pääsäännön mukaan tilavuusalkion $d V$ sisäisen energian muutos $d U$ on siihen tehdyn ulkoisen työn $d W$ ja paineen tekemän työn summa

$$
d U=d W-p d V .
$$

Adiabaattisen muutoksen teoriassa ulkoinen pakote jätetään pois, $d W=0$. Sisäisen energian muutos on silloin paineen muutoksesta johtuvaa lämpenemistä tai jäähtymistä.

Ilmanpaine laskee maanpinnalta ylöspäin mentäessä, sillä yllä on ilmamassaa sitä vähemmän mitä korkeammalla ollaan ${ }^{2}$. Ilmahiukkasen lähtiessä adiabaattisesti kohoamaan sen tilavuus kasvaa paineen laskiessa. Ideaalikaasujen tilayhtälön mukaan

$$
\frac{p d V}{T}=\text { vakio }
$$

Adiabaattisen oletuksen pohjalta voidaan osoittaa, että ideaalikaasujen tapauksessa paineen ja tilavuuden muuttumista kuvaa yhtälö $p(d V)^{\kappa}=$ vakio, missä $\kappa$ on kullekin kaasulle ominainen vakio. Ilmalle $\kappa=1,4$. Sijoittamalla tämä tulos tilayhtälöön saadaan

$$
T=T_{0} \cdot\left(\frac{p}{p_{0}}\right)^{\frac{\kappa-1}{\kappa}}
$$

missä alaindeksi 0 viittaa maanpintaan. Voidaan osoittaa, että $\frac{\kappa-1}{\kappa}=\frac{R_{G}}{c_{p}}$, missä $R_{G}$ on kyseessä olevan kaasun kaasuvakio ja $c_{p}$ on ominaislämpökapasiteetti vakiopaineessa. Kaavan (4.8) mukainen ilman lämpötilaprofiili antaa potentiaalilämpötilan pinnan suhteen. Profiili kuvaa ilmakehän kerrostuneisuuden vakautta. Jos potentiaalilämpötila on korkeuden suhteen vakio, lämpötilan muutos vastaa adiabaattista muutosta ja kerrostuneisuus on neutraali; jos potentiaalilämpötila kasvaa (laskee) korkeuden mukana, kerrostuneisuus on vakaa (epävakaa). Kaavaa voidaan myös käyttää, kun lämpötilaa arvioidaan vuoristoalueilla.

Ilmanpaine saadaan korkeuden $z$ funktiona hydrostatiikan perusyhtälöstä

$$
\begin{aligned}
& \frac{d p}{d z}=-\rho_{a}(z) g, \\
& \rho_{a}=\frac{p}{R_{a} T},
\end{aligned}
$$

missä $\rho_{a}$ on ilman tiheys ja $R_{a}=287,04 \mathrm{~J} \mathrm{~kg}^{-1}{ }^{\circ} \mathrm{C}^{-1}$ on ilman kaasuvakio. Ilman tiheyden yhtälö (4.9b) on tilayhtälön (4.7) yksi muoto. Ilman tiheys on $1,2-1,3 \mathrm{~kg} \mathrm{~m}^{-3}$ alimmassa kilometrissä, ja ilmanpaine laskee siinä noin $10 \mathrm{~Pa} \mathrm{~m}^{-1}$. Kun paineen muutos muunnetaan korkeuden muutokseksi, alimmissa kilometreissä kuiva adiabaattinen jäähtyminen on $1,0{ }^{\circ} \mathrm{C}$ ja kostea $0,6{ }^{\circ} \mathrm{C}$ sadan metrin korkeuden muutosta kohti. Kuivassa jäähtymisessä on vain lämpötilan

\footnotetext{
${ }^{2}$ Havaintopisteen (esimerkiksi mäenhuipun tai lentokoneen) korkeutta voidaan mitata ilmanpaineen perusteella, jos vain referenssi-ilmanpaine tietyllä korkeustasolla tiedetään.
} 
muutosta, ja kostean ilman jäähtymisessä kosteuden tiivistyminen pienentää lämpötilan laskua. Normaali adiabaattinen jäähtyminen on $0,65{ }^{\circ} \mathrm{C}$ sataa metriä kohti.

Esimerkki 4-2. Kilpisjärven korkeus on $473 \mathrm{~m}$ ja viereisen Saanatunturin korkeus 1029 m merenpinnan yläpuolella. Normaalin adiabaattisen jäähtymisen mukaan Kilpisjärvellä ilman keskilämpötila on $3,1^{\circ} \mathrm{C}$ alempi kuin merenpinnan tasolla ja Saanan laella ilman lämpötila on $3,6^{\circ} \mathrm{C}$ alempi kuin Kilpisjärvellä.

\subsubsection{Auringonsäteily}

Auringon säteily noudattaa likimain Planckin säteilylakia. Auringon ulkokehän lämpötila on $5900 \mathrm{~K}$ ja sen säteilyn intensiteetin maksimi on noin $500 \mathrm{~nm}$ aallonpituuden kohdalla (kuva 4-2). Säteilytehoa kuvataan aurinkovakiolla $Q_{s c}=1,367 \mathrm{~kW} \mathrm{~m}^{-2}$, joka määritellään ilmakehän ulkopuolelle tulevaa säteilyä kohtisuoraan pintaan vasten kohdistuvan auringonsäteilyn vuosikeskiarvona. Maan pintaan tulee suoraa auringonsäteilyä, pilvistä heijastuvaa ja ilmakehästä siroavaa hajasäteilyä sekä puista ja rakenteista heijastuvaa säteilyä. Yhdessä nämä muodostavat globaalisäteilyn.

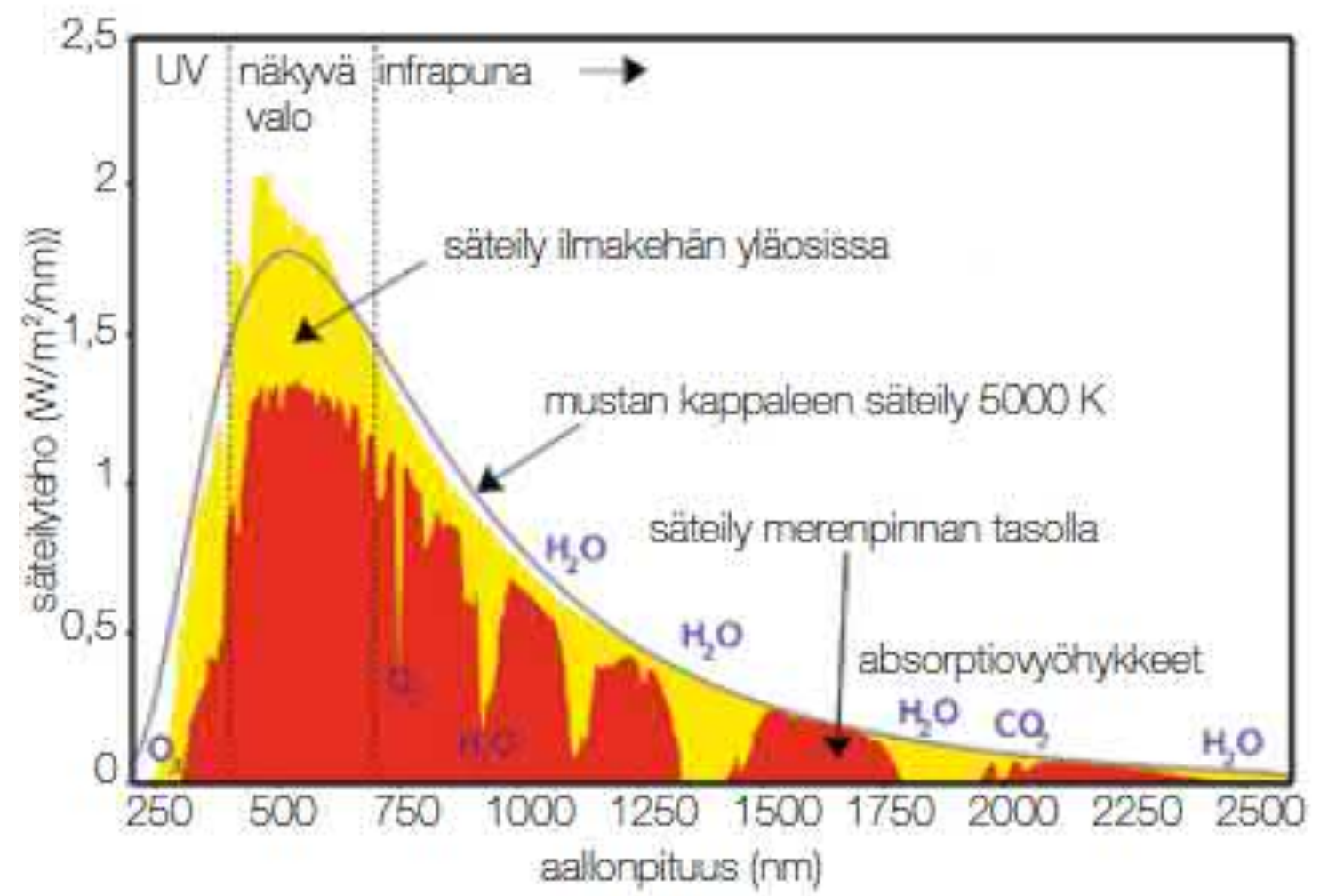

Kuva 4-2. Auringon säteilyjakauma aallonpituuden suhteen ilmakehän yläpuolella (keltainen) ja maapallon pinnalla (punainen). IImakehä leikkaa kokonaissäteilystä pois noin puolet. Erityisesti kasvihuonekaasut kuten vesihöyry ja hiilidioksidi absorboivat säteilyä absorptiokaistoillaan.

Tulevan auringonsäteilyn taso vaihtelee auringon korkeuskulman $(\theta)$, pilvisyyden $(N, 0 \leq N \leq$ 1) ja kasvihuonekaasujen pitoisuuden mukaan. Yleinen laskennallinen kaava horisontaaliselle pinnalle lankeavan säteilyn arvioimiseksi on

$$
Q_{s}=F(N, \theta) \cdot \mathcal{T}(e, \theta) \cdot \sin \theta \cdot\left(\frac{r_{0}}{r}\right)^{2} Q_{s c}
$$


missä $F(N, \theta)$ on pilvisyyskorjaus, $\mathcal{T}$ on kirkkaan ilmakehän läpäisykerroin sekä $r$ ja $r_{0}$ ovat hetkellinen ja keskimääräinen maa-aurinko etäisyys. Zillmanin (1972) läpäisykerroin (4.10b) ja Lumbin (1964) pilvisyyskorjaus (4.10c) ovat

$$
\begin{aligned}
\mathcal{T} & =\frac{\sin \theta}{1,085 \sin \theta+\frac{e}{\mathrm{mbar}}(2,7+\sin \theta) \cdot 10^{-3}+0,01}, \mathrm{ja} \\
F & \approx 1-(0,6-0,1 \cos \theta) \cdot N
\end{aligned}
$$

Näiden avulla voidaan myös konstruoida korjauskaavoja suorien mittauksien soveltamiseksi läheisiltä säteilyasemilta tavallisille sääasemille. Kirkkaan ilman säteily saadaan kertoimen (4.10b) avulla arvioitua melko tarkasti, mutta pilvisyyskorjaukseen liittyy paljon epävarmuutta pilviverhon paksuuden ja pilvien laadun takia. Auringon korkeuskulma voidaan arvioida pallotrigonometrian avulla:

$$
\begin{aligned}
& \sin \theta=\sin \phi \sin \delta+\cos \phi \cos \delta \cos \tau, \text { ja } \\
& \sin \delta=\sin \varepsilon_{c} \sin \left(2 \pi \cdot \frac{j-80}{365}\right),
\end{aligned}
$$

missä $\phi$ on leveysaste, $\delta$ on deklinaatio, $\tau$ on tuntikulma (aurinkoajan keskipäivällä $\tau=0$, aurinkoaikana klo 6 on $\tau=-90^{\circ}$, klo 18 se on $\tau=90^{\circ}$, jne.), $\varepsilon_{c}=23^{\circ} 27^{\prime}$ on ekliptikan kaltevuus, ja $j$ on päivän numero vuoden alusta laskien. Aurinkoajan keskipäivä on GMT-ajassa ${ }^{3}$

$$
t_{G M T}=-\frac{\Lambda}{15^{\circ}} \mathrm{h}+\Delta t
$$

missä $\Lambda$ on pituusaste (positiivinen itään päin), ja $\Delta t$ on aikakorjaus, joka johtuu siitä, että maapallon kiertorata auringon ympäri on ellipsin muotoinen. Tässä $h$ tarkoittaa tuntiyksikköä. Aikakorjaus on itseisarvoltaan pienempi kuin 0,25 h eikä sille ole yksinkertaista laskukaavaa. Se löytyy taulukoituna tai vaikkapa Yliopiston almanakasta.

Esimerkki 4-3. Kumpulan kampuksen koordinaatit ovat $60^{\circ} 12^{\prime} \mathrm{N} 24^{\circ} 58^{\prime} \mathrm{E}$. Juhannuksena auringon korkeus on $53^{\circ} 15^{\prime}$. Aurinkoajan keskipäivä on GMT ajassa $10.20+\Delta t$. Suomen kesäaika on GMT + 3 tuntia, joten Helsingin kesäajassa keskipäivän hetki on klo $13.20+\Delta t$. Almanakan mukaan juhannuksena $\Delta t=2 \mathrm{~min}$.

Tulevasta auringonsäteilystä $Q_{s}$ osa imeytyy pintaan ja osa palautuu takaisin heijastumalla ja siroamalla. Palautuva osa on $\alpha Q_{s}$, missä $\alpha(0 \leq \alpha \leq 1)$ on albedo ${ }^{4}$. Jos alusta on säteilyä läpäisevä, osa nettosäteilystä tunkeutuu pinnan alaiseen kerrokseen. Pintaan jäävä osa on $\gamma(1-$ a) $Q_{s}$, missä $\gamma(0 \leq \gamma \leq 1)$ on pinta-absorptiokerroin. Näin auringonsäteilyn absorptio jakaantuu pintaan jäävän (4.11a) ja sisään tunkeutuvaan säteilyyn (4.11b)

$$
\begin{aligned}
Q_{s 0} & =\gamma(1-\alpha) Q_{s} \mathrm{ja} \\
Q_{s 0} & =(1-\gamma)(1-\alpha) Q_{S} .
\end{aligned}
$$

\footnotetext{
${ }^{3}$ GMT (Greenwich Mean Time) aika on pituusasteen $0^{\circ}$ mukainen aurinkoaika. Siitä käytetään myös nimitystä UTC (Universal Time Code) aika.

${ }^{4}$ Albedo tulee latinasta ja tarkoittaa 'valkoisuutta', vrt. albiino.
} 
Maan pinnalla $\gamma \approx 1$ ja veden pinnalla $\gamma \approx \frac{1}{2}$ (näkyvä valo tunkeutuu veteen ja se käsittää noin puolet auringonsäteilyn energiasta). Lumen ja jään pinnat käyttäytyvät tässä suhteessa samalla tavalla kuin veden. Albedo vaihtelee laajasti (taulukko 4-1).

Taulukko 4-1. Erilaisten pintojen tyypillisiä albedon arvoja.

\begin{tabular}{l|r} 
Pinnan laatu & Albedo \\
\hline Veden pinta & $0,05-0,10$ \\
Tiheä metsä & $0,10-0,15$ \\
Viljakasvit & $0,10-0,20$ \\
Rehevä ruoho & 0,25 \\
Märkä jää & $0,20-0,30$ \\
Kuiva jää & 0,5 \\
Märkä lumi & $0,50-0,70$ \\
Kuiva lumi & $0,80-0,90$ \\
Maapallo & 0,34 \\
keskimäärin &
\end{tabular}

Pintaan tuleva auringonsäteily koostuu suorasta säteilystä ja eri suunnista siroavasta hajasäteilystä. Kirkkaana kesäpäivänä pääosa säteilystä on suoraa ja pilvisellä tulee pääosin hajasäteilyä. Pinnan heijastuskyky riippuu tulevan säteilyn tulokulmasta siten, että vinosti pintaan tulevasta säteilystä heijastuu suhteellisesti enemmän kuin kohtisuoraan pintaa vastaan tulevasta säteilystä. Tästä seuraa, että hajasäteilyn ja suoran säteilyn albedot ovat hieman erilaiset. Keskimääräisenä vedenpinnan albedona voidaan pitää $7 \%$. Lumi on erittäin voimakas sirottaja, ja sen albedo pienenee, kun pintakerroksen sisältämän nestemäisen veden määrä kasvaa. Erityisesti keväällä sulamisen edetessä lumi pystyy absorboimaan auringon säteilyä yhä tehokkaammin.

\subsubsection{Terrestrinen lämpösäteily}

Maapallon pinnan ja ilmakehän lämpösäteilyä arvioidaan käyttäen harmaan kappaleen mallia $Q_{L}=\varepsilon \sigma T^{4}$, joka perustuu Stefan-Boltzmannin mustan kappaleen säteilylakiin (4.3). Terrestrisen säteilyn aallonpituuksilla pinnan emissiokerroin $\left(\varepsilon_{0}\right)$ on hyvin lähellä yhtä $\left(\varepsilon_{0}=0,96\right.$ $-0,98)$ ja vaihtelee vain vähän.

Ilmakehän emittoima säteily on monimutkaisempi ilmiö. Sitä tulee eri ilmakerroksista, joissa on erilaiset lämpötilat ja joissa emissio vaihtelee paljon pilvisyyden ja kasvihuonekaasujen mukana. Harmaan kappaleen mallia ei heterogeenisten säteilylähteiden takia voida tarkkaan ottaen soveltaa, mutta usein tätä mallia käytetään analogiaperiaatteen pohjalta. Ilman lämpötilaa (2 m korkeudella) käytetään säteilylämpötilan referenssinä, ja emissiviteettiä edustaa referenssilämpötilaan liitetty tehoisa emissiokerroin $\varepsilon_{a}$. Laajalti käytetty muoto on

$$
\varepsilon_{a}=\varepsilon_{a}(N, e)=(a+b \sqrt{e}) \cdot\left(1+c N^{2}\right),
$$

missä sopivat empiiriset kertoimet ovat $a=0,68, b=0,036 \mathrm{mbar}^{-1 / 2}$ ja $c=0,18$. Kirchhoffin lain perusteella emissio ja absorptio ovat yhtä suuret. Lumi, jää ja vesi emittoivat hyvin lämpösäteilyä, mutta heijastavat valoa aivan eri voimakkuuksilla. 
Esimerkki 4-4. Olkoon maanpinnan ja ilman lämpötila $10^{\circ} \mathrm{C}$. Maanpinnan lähettämä lämpösäteily on silloin harmaan kappaleen $(\varepsilon=0,97)$ mallin mukaan $354 \mathrm{~W} \mathrm{~m}^{-2}$. Jos vesihöyryn osapaine on 10 mbar ja pilvisyys $50 \%$, ilmakehän emissiokerroin on 0,830 (kaava 4.12) ja säteily näin ollen $302 \mathrm{~W} \mathrm{~m}^{-2}$. Nettolämpösäteily on $-52 \mathrm{~W} \mathrm{~m}^{-2}$.

Yleensä pinnan ja ilmakehän lämpösäteilyn nettosumma on vahvasti negatiivinen, suuruusluokkaa $-50 \mathrm{~W} \mathrm{~m}^{-2}$, koska ilmakehä on huonompi säteilijä kuin maanpinta. Tämä nettosumma vaihtelee melko vähän. Nettoauringonsäteily on meillä kirkkaana kesäpäivänä parhaimmillaan keskipäivällä $700 \mathrm{~W} \mathrm{~m}^{-2}$ ja sydäntalvella lähellä nollaa. Säteilytase on positiivinen huhtikuusta syyskuuhun ja negatiivinen lokakuusta maaliskuuhun. Seuraavassa jaotelmassa esitetään eräitä keskimääräisiä säteilykomponentteja Suomessa (Laitinen 1970).

\begin{tabular}{l|r|r|r|r|}
\cline { 2 - 5 } & \multicolumn{2}{c|}{ Etelä-Suomi } & \multicolumn{2}{c|}{ Pohjois-Suomi } \\
\cline { 2 - 5 } & tammikuu & heinäkuu & tammikuu & heinäkuu \\
\hline Auringonsäteily & $8,7 \mathrm{~W} \mathrm{~m}^{-2}$ & $230 \mathrm{~W} \mathrm{~m}^{-2}$ & $3,4{\mathrm{~W} \mathrm{~m} \mathrm{~m}^{-2}}_{223 \mathrm{~W} \mathrm{~m}^{-2}}$ \\
Albedo & 0,44 & 0,14 & 0,45 & 0,13 \\
Säteilytase & $-27 \mathrm{~W} \mathrm{~m}^{-2}$ & $126 \mathrm{~W} \mathrm{~m}^{-2}$ & $-34 \mathrm{~W} \mathrm{~m}^{-2}$ & $124 \mathrm{~W} \mathrm{~m}^{-2}$
\end{tabular}

Esimerkki 4-5. Aurinkoa kiertävän planeetan säteilytase voidaan kirjoittaa

$$
\frac{1}{4}(1-\alpha)\left(\frac{a u}{R}\right)^{2} Q_{s c}=\varepsilon \sigma T^{4},
$$

missä $R$ on planeetan etäisyys auringosta ja $a u=149,6$ miljoonaa kilometriä, tähtitieteellinen yksikkö (astronomical unit), on maapallon ja auringon välinen keskietäisyys. Vasemmalla puolella on auringonsäteily ja oikealla planeetan lämpösäteily. Kerroin $1 / 4$ tulee planeetan pyörimisestä, kun vain osa planeetasta vastaanottaa auringonsäteilyä samanaikaisesti. Yhtälöstä saadaan planeetan pintalämpötila

$$
T=\sqrt[4]{\frac{(1-\alpha)}{4 \varepsilon \sigma}\left(\frac{a u}{R}\right)^{2} Q_{s c}} .
$$

Maapallon tapauksessa $T=254 \mathrm{~K}$, kun valitaan $\alpha=0,3$ ja $\varepsilon=1$. Marsin $(R=227,9$ milj. km $)$ pintalämpötilaksi tulee $217 \mathrm{~K}$, kun $\alpha=0,15$ ja $\varepsilon=1$ ja Venuksen $(R=108,2$ milj. km) $252 \mathrm{~K}$, kun $\alpha=$ 0,65 ja $\varepsilon=1$. Havaitut arvot ovat maapallolle $288 \mathrm{~K}$, Marsille $210 \mathrm{~K}$, ja Venukselle $736 \mathrm{~K}$. Ero lasketun ja havaitun välillä riippuu ilmakehän aiheuttamasta kasvihuoneilmiöstä, joka maapallolla on $34 \mathrm{~K}$, Marsilla suunnilleen nolla, ja Venuksella hyvin suuri.

\subsubsection{Turbulenttinen lämmönvaihto}

Maanpinnan lähellä olevassa ilmakerroksessa tuuli aiheuttaa turbulenttista sekoittumista, joka siirtää lämpöenergiaa, vesihöyryä, liike-energiaa sekä hiukkasia maanpinnan ja ilmakehän välillä. Turbulenttiset pyörteet tuovat pinnan tuntumaan aina uusia ilmahiukkasia, eikä pinnan läheinen ilma sen takia pääse eristymään (kuva 4-3). Laajahkon tasaisen aukean yläpuolella siirto tapahtuu lähinnä vertikaalisessa suunnassa. Jos pinnan ja ilman lämpötilat eivät ole samat, lämpöä siirtyy lämpimästä kylmään. Haihtumislämpöä siirtyy pinnalta pois veden haihtuessa ja lämpöä tulee pintaan vesihöyryn tiivistyessä. Vastaavasti lämpöä siirtyy jään sublimoituessa ja vesihöyryn härmistyessä. Nämä olomuodonmuutosprosessit liittyvät ilman kosteuteen, jota käsiteltiin kohdassa 3.3.3.

Aistittavan lämmön (4.14a) ja haihtumislämmön (4.14b) siirtoja voidaan arvioida bulkkikaavoilla

$$
Q_{c}=\rho_{a} c_{a} C_{H}\left(T_{a}-T_{0}\right) U_{a} \text { ja }
$$




$$
Q_{e}=\rho_{a} L_{E *} C_{E}\left(q_{a}-q_{0}\right) U_{a}
$$

missä $L_{E *}$ on haihtumis- tai sublimoitumislämpö, $C_{H} \approx C_{E} \sim 1,5 \cdot 10^{-3}$ ovat aistittavan lämmön ja haihtumislämmön vaihtokertoimet ja $U_{a}$ on tuulen nopeus ${ }^{5}$. Ilman tiheys riippuu lämpötilasta ja paineesta, ja lähellä maan pintaa se vaihtelee noin $10 \%$ arvon $1,23 \mathrm{~kg} \mathrm{~m}^{-3}(T=$ $15^{\circ} \mathrm{C}, p=1013,25$ mbar) ympärillä. Yleensä ilman suhteellinen kosteus $R_{h}$ ja lämpötila $T_{a}$ saadaan säähavainnoista, jolloin ilman ominaiskosteus $q_{a}$ voidaan laskea määritelmästä

$$
q_{a}=R_{h} q_{s}\left(T_{a}\right)
$$

Maanpinnan kosteutta ei saada rutiinihavainnoista. Jos pinta on märkä (esimerkiksi vesi-, lumi- ja jääpinta), voidaan olettaa, että kyllästysaste on $100 \%$ ja siis $q_{0}=q_{s}\left(T_{0}\right)$. Jos $q_{a}-q_{0}>0$, on $Q_{e}>0$ eli tapahtuu kosteuden tiivistymistä. Aistittavan lämmön ja haihtumislämmön suhdetta $B=\frac{Q_{c}}{Q_{e}}$ sanotaan Bowenin suhteeksi, jolla on stabiilisuutta eräissä olosuhteissa. Jos Bowenin suhde tunnetaan, voidaan koko turbulenttinen lämmönsiirto määrittää, kun toinen ter-meistä tunnetaan.

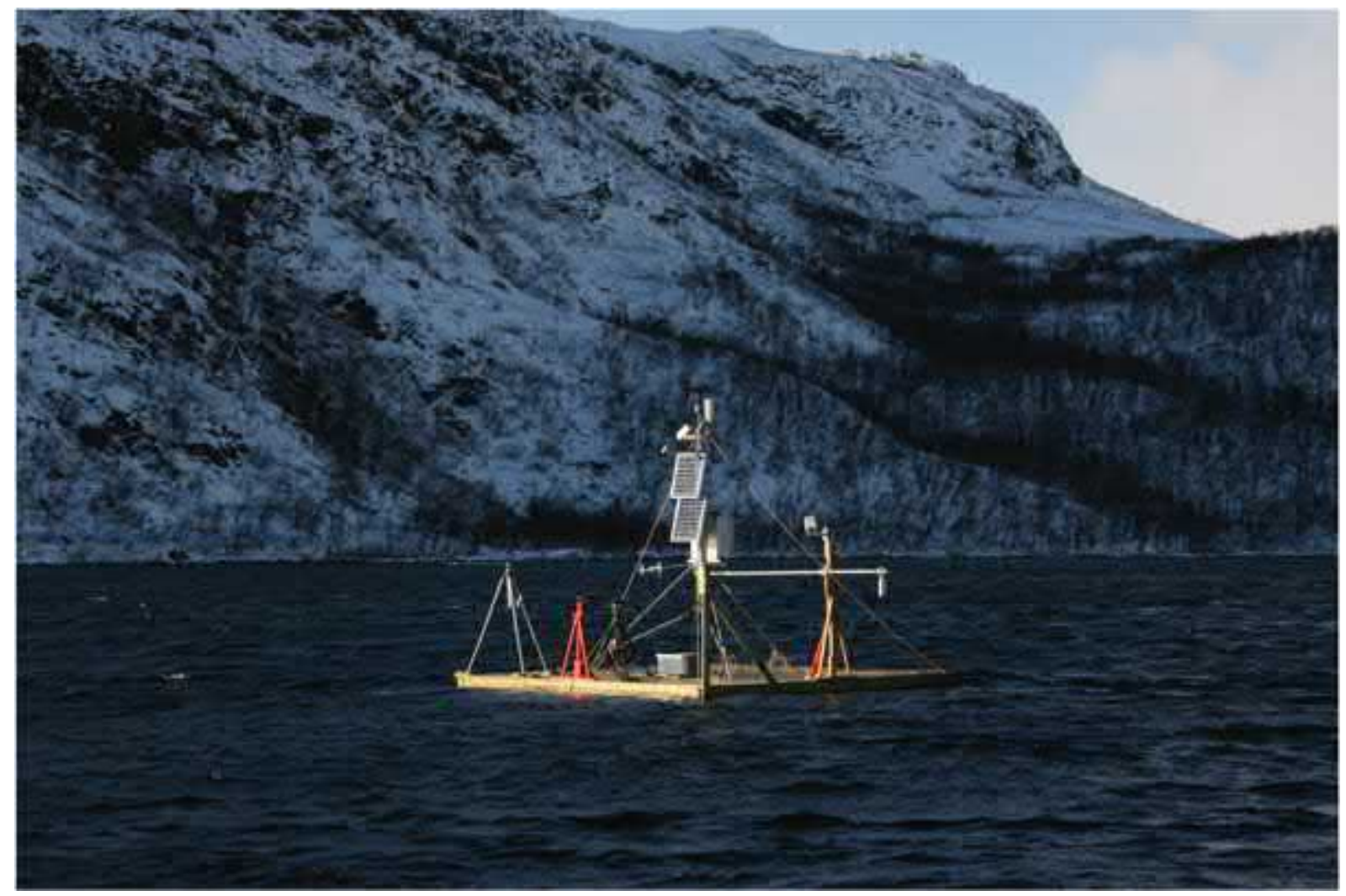

Kuva 4-3. Maanpinnan ja ilman välistä vaihtoa tutkitaan maastossa rajakerrosmittausten avulla. Kuvassa Lotus-asema Kilpisjärvellä. Kuva: Matti Leppäranta.

Esimerkki 4-6. Jos ilman ja veden välinen lämpötilaero on $2{ }^{\circ} \mathrm{C}$, ominaiskosteusero $3 \mathrm{~g} \mathrm{~kg}^{-1}$ ja tuulen nopeus $5 \mathrm{~m} \mathrm{~s}^{-1}$, kaavoilla (4.13) voidaan laskea, että aistittavan lämmön vuo on $18 \mathrm{~W} \mathrm{~m}^{-2}$ ja haihtumislämmön vuo $68 \mathrm{~W} \mathrm{~m}^{-2}$. Bowenin suhde on 0,26 .

\footnotetext{
${ }^{5}$ Ilman lämpötila- ja kosteushavaintojen standardikorkeus on $2 \mathrm{~m}$, tuulihavaintojen $10 \mathrm{~m}$.
} 
Turbulenttiset vaihtokertoimet riippuvat pinnan karkeudesta ja ilman lämpötilan vertikaalisesta kerrostuneisuudesta, joka voi olla stabiili, neutraali tai epästabiili. Neutraalin kerrostuneisuuden vallitessa ilman lämpötila laskee ylöspäin mentäessä adiabaattisen muutoksen verran. Stabiilissa tilanteessa lämpötila laskee hitaammin, ja turbulenttinen siirto on vaimeaa, ja epästabiilissa tilanteessa tilanne on päinvastainen. Tällöin vaihtokertoimet arvioidaan Richardsonin luvun Ri funktioina

$$
R i=\frac{g}{\bar{\theta}} \cdot z \frac{\theta_{a}-\theta_{0}}{U_{a}^{2}}
$$

missä $\theta_{a}$ ja $\theta_{0}$ ovat ilman ja pinnan potentiaalilämpötilat, $\bar{\theta}$ on pintakerroksen referenssilämpötila (Kelvin-asteissa) ja $z$ on havaintokorkeus. Richardsonin luku kuvaa nosteen ja virtauksen sekoitustehojen suhdetta. Kun $R i>0(R i<0)$, on kyseessä stabiili (epästabiili) kerrostuneisuus. Kuvassa 4-4 on esitetty vaihtokertoimien riippuvuus Richardsonin luvusta. Neutraalin tilanteen arvoon verrattuna vaihtokerroin voi olla puolet siitä stabiilissa tilanteessa ja kaksinkertainen epästabiilissa tilanteessa.

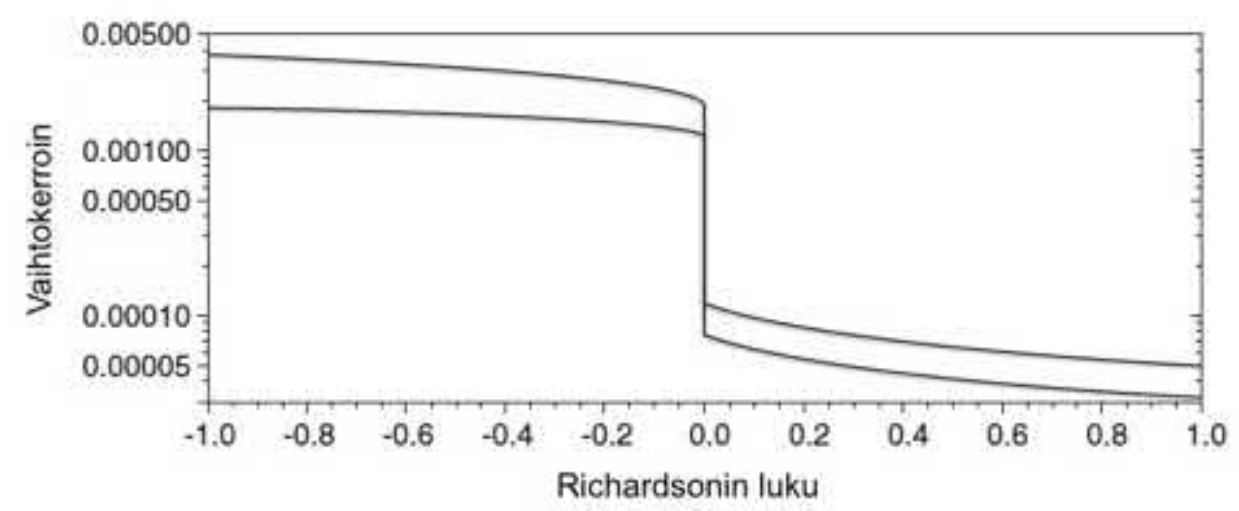

Kuva 4-4. Turbulenttisten vaihtokertoimien riippuvuus Richardsonin luvusta. Alempi käyrä edustaa sileämpää pintaa kuten lumi ja ylempi karkeata kuten nurmi.

\subsection{Sadanta}

\subsubsection{Sateen muodostuminen}

Sade alkaa valmistautua, kun ilmakehän vesihöyryä tiivistyy vesipisaroiksi tai härmistyy jäätai lumikiteiksi. Tämän jatkuessa pisarat ja kiteet kasvavat ja muodostuu pilviä, joista sade laskeutuu painovoiman vaikutuksesta maan pinnalle. Sateen määrä ilmaistaan sadantana eli sataneen vesipatsaan paksuutena pinta-alayksikköä ja aikayksikköä kohti. Sateiden maantieteellinen jakautuminen on seurausta ilmavirtauksista, maanpinnan topografiasta sekä maameri suhteista.

Sateen syntymisen edellytyksiä on kolme: ilman viileneminen, tiivistymis- tai kiteytymisytimien saatavuus ja pisaroiden tai lumi/jää kiteiden kasvu. Ilman viilentyessä suhteellinen kosteus kasvaa (kuva 3-14) ja voi saavuttaa kyllästysarvon. Tämä on alempi jääpinnalla kuin vesipinnalla, ja siksi lumi/jää kiteitä muodostuu paljon. Ilman epäpuhtaudet puolestaan toimivat tiivistymis- tai kiteytymisytiminä. Keskinäisten törmäysten seurauksena pisaroiden koko kasvaa ja kiteisiin liittyy lisää molekyylejä. Lopulta niiden koko tulee niin suureksi, että 
painovoima pystyy voittamaan vastakkaiseen suuntaan vaikuttavan ilman kohoamisen, ja sade alkaa.

Kohoava ilma jäähtyy adiabaattisesti. Tällöin suhteellinen kosteus nousee, mikä kosteuden tiivistymisen seurauksena voi johtaa sateen muodostumiseen. Kohoamisen voi aiheuttaa noste, mekaaninen pakote tai ilmamassojen kohtaaminen. Sateet jaetaan kolmeen ryhmään muodostumismekanismin perusteella.

1. Konvektiiviset sateet. Kun auringon säteily lämmittää jotakin maastokohtaa enemmän kuin sen ympäristöä, lämmenneen kohdan yläpuolella oleva ilma laajenee ja alkaa kohota ylöspäin. Kohoavan ilman paine alenee ja laajeneminen voimistuu, jolloin ilma jäähtyy, ja vesipisaroiden muodostuminen alkaa tietyllä korkeudella. Tällainen epästabiili tilanne on mahdollinen, jos ennen pinnan lämpenemistä ilman lämpötila laskee korkeuden mukana enemmän kuin $1^{\circ} \mathrm{C} / 100 \mathrm{~m}$. Konvektiiviset sateet ovat tyypillisiä trooppisilla alueilla. Lisäksi, kun kylmää ilmaa virtaa lämpimän meren ylle, alustan aiheuttaman lämmityksen takia syntyy konvektiota. Suomessa konvektiiviset sateet ovat luonteeltaan paikallisia ja liittyvät usein ukkosiin. Sademäärät saattavat olla suuria.

2. Orografiset sateet. Kun ilmavirtauksen tiellä on este, esimerkiksi korkea vuoristo, etenevä ilma joutuu kohoamaan ylöspäin. Kohoamiseen liittyy jälleen viileneminen, ja sateen edellytykset ovat voimassa. Tämän tyyppiset sateet keskittyvät esteen ilmavirtauksen puoleiselle sivulle. Esimerkiksi Norjan rannikon suuret sademäärät johtuvat Kölivuoriston vaikutuksesta. Suomessa ilmiö tuntuu siten, että osa länsivirtausten kosteudesta jää Norjan rannikolle. On todettu, että Suomen pienimuotoisetkin korkeusvaihtelut vaikuttavat sateen alueelliseen jakautumiseen.

3. Rintamasateet. Tärkeä sateen mekanismi liittyy matalapaineiden yhteydessä muodostuvaan rintamatoimintaan. Rintaman alueella kylmä, painavampi ilma tunkeutuu lämpimän, kevyemmän ilman alle ja pakottaa lämpimän ilman kohoamaan ylöspäin. Lämmin ja kostea ilmamassa voi myös liikkua ja kohota kohdatessaan viileän ilmamassan. Sade syntyy samasta syystä kuin edellä eli kohotessaan ilma jäähtyy ja kosteus tiivistyy. Rintamatoimintaan liittyvä sade on yleensä laaja-alaista ja sen kestoaika on suurempi kuin konvektiivisten sateiden kestoaika, usein 6-12 tuntia. Suomessa suurin osa sateista liittyy rintamatoimintaan.

Vuotuinen sademäärä vaihtelee maapallolla aavikoiden alle $100 \mathrm{~mm}$ tasosta aina $3000 \mathrm{~mm}$ : iin päiväntasaajavyöhykkeellä (kuva 4-5). Suomessa se on 500-650 mm. Suuri sadanta on myös monsuunituulten alueilla ja keskileveysasteiden mantereiden länsirannikoilla. Kuivia alueita löytyy subtrooppiselta vyöhykkeeltä, jossa sijaitsevat suurimmat aavikot kuten Sahara ja Kalahari. Myös korkeilla leveysasteilla on vähäinen sadanta johtuen siitä, että ilman absoluuttinen kosteus on kylmissä oloissa aina pieni. Niinpä Etelämantereen keskustasangolla sademäärä on alle $100 \mathrm{~mm}$ vuodessa, mikä on samaa luokkaa kuin Saharassa.

\subsubsection{Sadannan mittaaminen}

Sadanta mitataan suoraan eikä se juurikaan riipu olosuhteista maan pinnalla. Siksi pintavesien ja geohydrologian tutkimuksissa sadantaa pidetään puhtaasti ulkoisena tekijänä. Sadannan mittalaitteita on esitetty kuvassa 4-6. Tavallinen sademittari on tärkein väline. Sadevesi 
kertyy keräysastiaan, joka tyhjennetään päivittäin yleensä klo $6.00 \mathrm{GMT}^{6}$. Sadeastian suuaukon pinta-ala on $100 \mathrm{~cm}^{2}$. Sen ympärillä on suojus, jonka tehtävänä on vähentää tuulen aiheuttamien virheiden muodostumista. Satavan vesimäärän ohella on usein tarpeen tietää myös sateen olomuoto. Suomen sadehavaintoverkko uusittiin vuosina 1981-1982, jolloin Wildin suojus korvattiin tehokkaammalla Tretjakovin suojuksella. Rekisteröivän sademittarin avulla voidaan sateen kertymistä seurata jatkuvasti siinä olevan uimurin avulla. Uimurikammio tyhjennetään ajoittain lappoa käyttäen. Ilmatieteen laitos pitää yllä Suomen sadehavaintoverkkoa, joka käsittää noin 800 sadeasemaa.

Sadannan määrityksessä ei ole epäsuoriin mittauksiin liittyviä ongelmia. Perinteiseen mittausmenetelmään liittyy kuitenkin virhelähteitä: haihtumishäviö, kostumishäviö ja tuulivirhe. Koska sademittari tyhjennetään ainoastaan kerran tai kahdesti päivässä, siinä voi olla vettä useita tunteja. Haihtumissuojasta huolimatta sadevettä saattaa haihtua. On arvioitu, että haihtumisvirhe saattaa kesällä olla noin $1 \mathrm{~mm}$ kuukaudessa. Kostumishäviö tulee siitä, että sateesta jää jonkin verran vettä sademittarin kuivaan pintaan, minkä virheraja on Suomessa noin 0,2 mm jokaista sadevuorokautta kohden. Kovalla tuulella puolestaan vesipisarat saattavat leijua sademittarin ohitse. Virheen pienentämiseksi mittarit pyritään asettamaan tuulelta suojattuihin paikkoihin tai maan pinnan alapuolelle siten, että niiden suuaukko on maan pinnan tasalla. Tuulivirheen suuruudeksi on arvioitu noin $5 \%$, mutta lumisateiden tapauksessa virhe saattaa olla jopa 50-75\%. Kaikki edellä olevat systemaattiset virheet pienentävät mittaustulosta. Nykyisin käytetyn Tretjakovin sademittarin virheraja on Etelä-Suomessa kesällä keskimäärin noin $6 \%$ ja talvella 30-40\% (Mustonen 1986), ja vuosisadannan virheraja on noin $20 \%$.

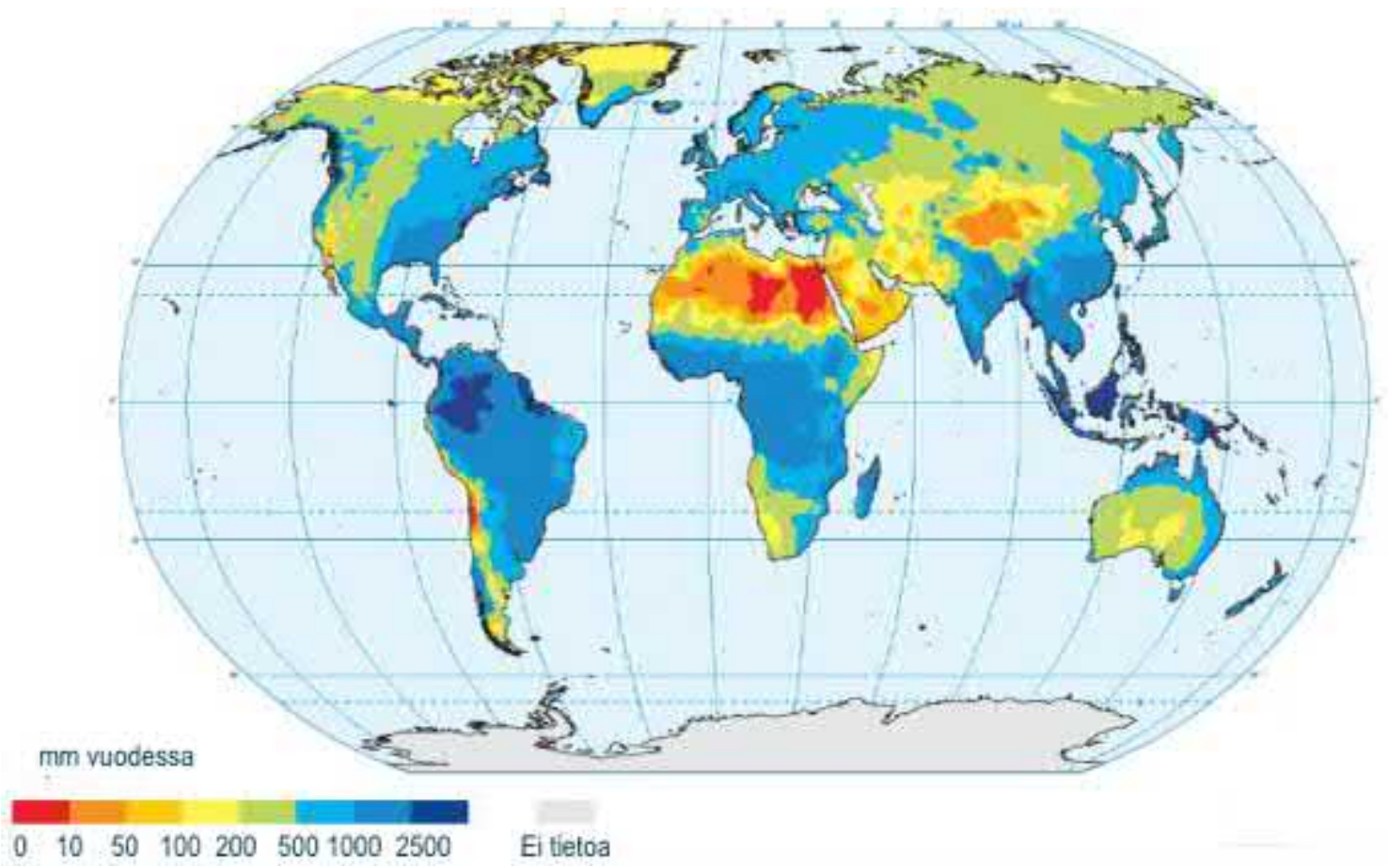

Kuva 4-5a. Keskimääräinen vuotuinen sademäärä $(\mathrm{mm})$ maapallolla (1961-1990). Lähde: Global Precipitation Climatology Centre / Deutscher Wetterdienst.

\footnotetext{
${ }^{6}$ Useimmat säähavainnot tehdään kansainvälisten sopimusten mukaan kiinteinä GMT-tasatunteina 3 tunnin välein 0 GMT, 3 GMT jne. Kertynyt sadanta kirjataan 1-2 kertaa vuorokaudessa.
} 


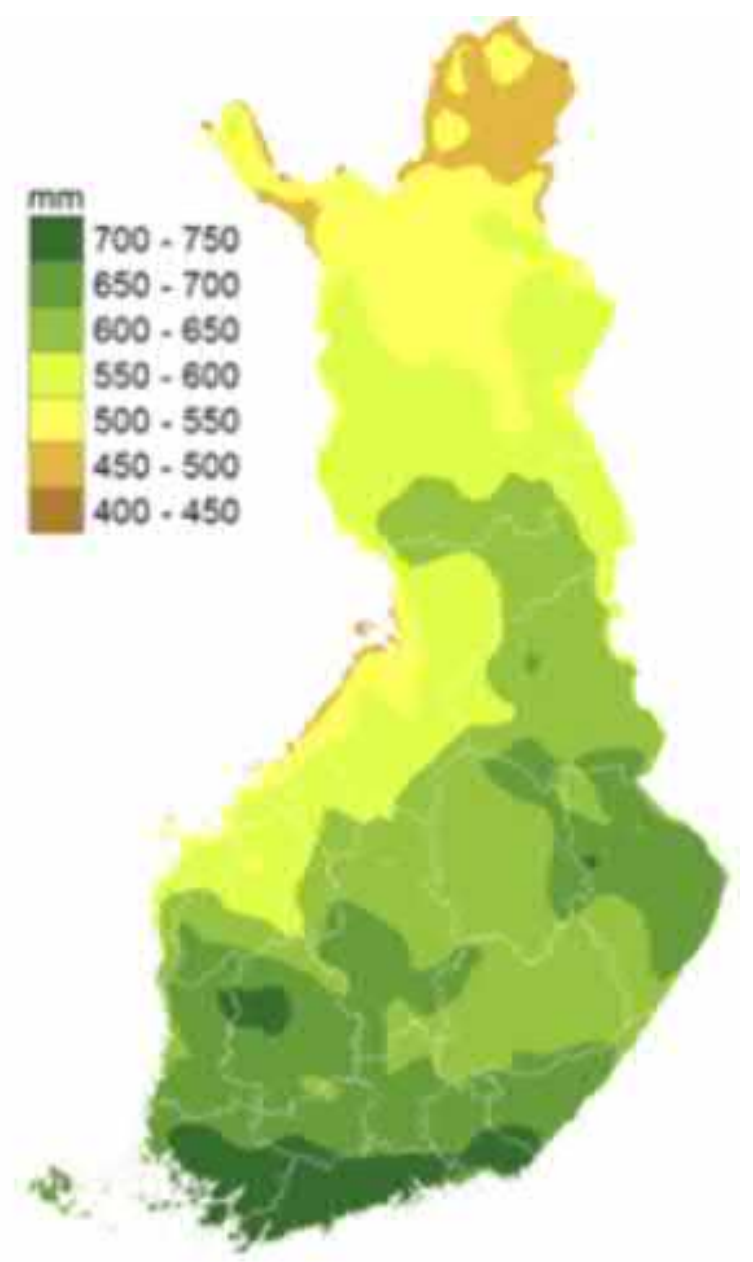

Kuva 4-5b. Keskimääräinen vuotuinen sademäärä $(\mathrm{mm})$ Suomessa (1981-2010). Lähde: Ilmatieteen laitos.
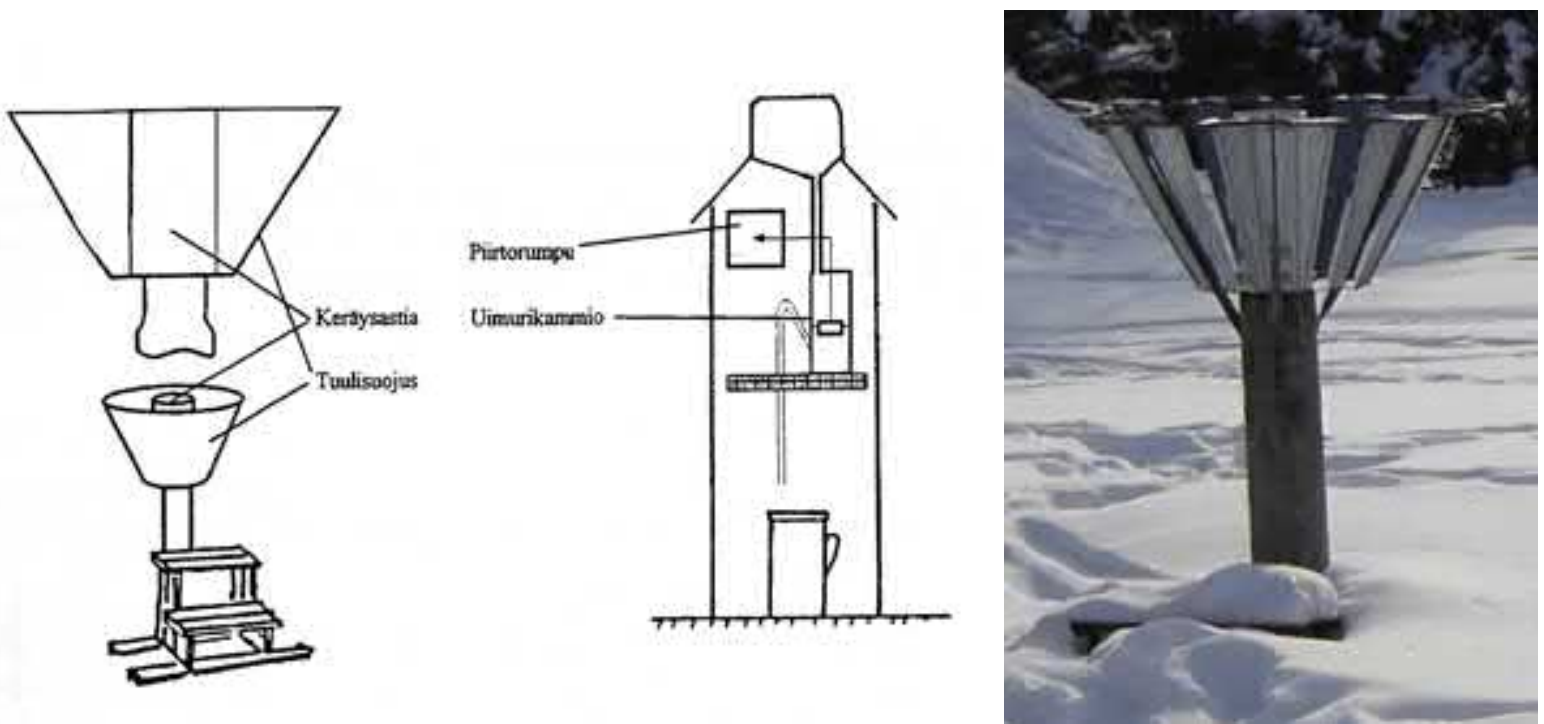

Kuva 4-6. Sateen mittaamiseen käytettyjä laitteita. Vasemmalla tavallinen sademittari, jossa on sadeastia ja Wildin suojus, keskellä rekisteröivä sademittari, josta sadevesi ohjataan uimurikammioon ja siellä uimuri rekisteröi sademäärän kertymistä, ja oikealla Tretjakovin suojukselle varustettu sademittari. 
Sadantaa voidaan havaita myös säätutkan avulla. Mittaus perustuu siihen, että tutkasignaalin takaisinsironta riippuu kohteen vesipisaroiden konsentraatiosta, joka taas indikoi sateen intensiteettiä. Menetelmän etuna on se, että yksi ainoa säätutka pystyy kartoittamaan sadannan jakautumisen sekä kulkeutumisen suurella alueella (75 km säteellä) ja että mittaustulos voidaan välittömästi arvioida esimerkiksi valunnan ennusteita varten. Tutka on erinomainen apuväline sääpalvelussa, mutta menetelmään liittyy epävarmuutta, minkä takia perinteisten sademittarien aineisto on yhä sadannan kvantitatiivisen kartoittamisen perusta.

Interseptio, puiden ja muun kasvipeitteen pintaan jäävä osa, haihtuu suoraan takaisin ilmakehään (kuva 4-7). Sen määrä riippuu kasvillisuuden laadusta. Latvustolla on tietty suurin sen kokonaispinta-alasta riippuva vedenpidätyskyky, mistä syystä interseption osuus pienenee sateen aikana. Koska latvuston kokonaispinta-alaa on vaikea mitata, interseptiota arvioidaan usein puulajin ja puuston tilavuuden mukaan. tutkimuksen mukaan interseption osuus vaihtelee välillä 0,1-0,5 sade- ja puustotyypistä riippuen (taulukko 4-2).

Taulukko 4-2. Interseption osuus sateesta eri puustotyypeillä (Päivänen 1966).

\begin{tabular}{l|r|r} 
& \multicolumn{2}{|c}{ Sadetyppi } \\
\hline Puustotyyppi & Pienet sateet & Suuret sateet \\
\hline Koivikko & 0,45 & 0,1 \\
Männikkö & 0,45 & 0,2 \\
Kuusikko & 0,5 & 0,3
\end{tabular}

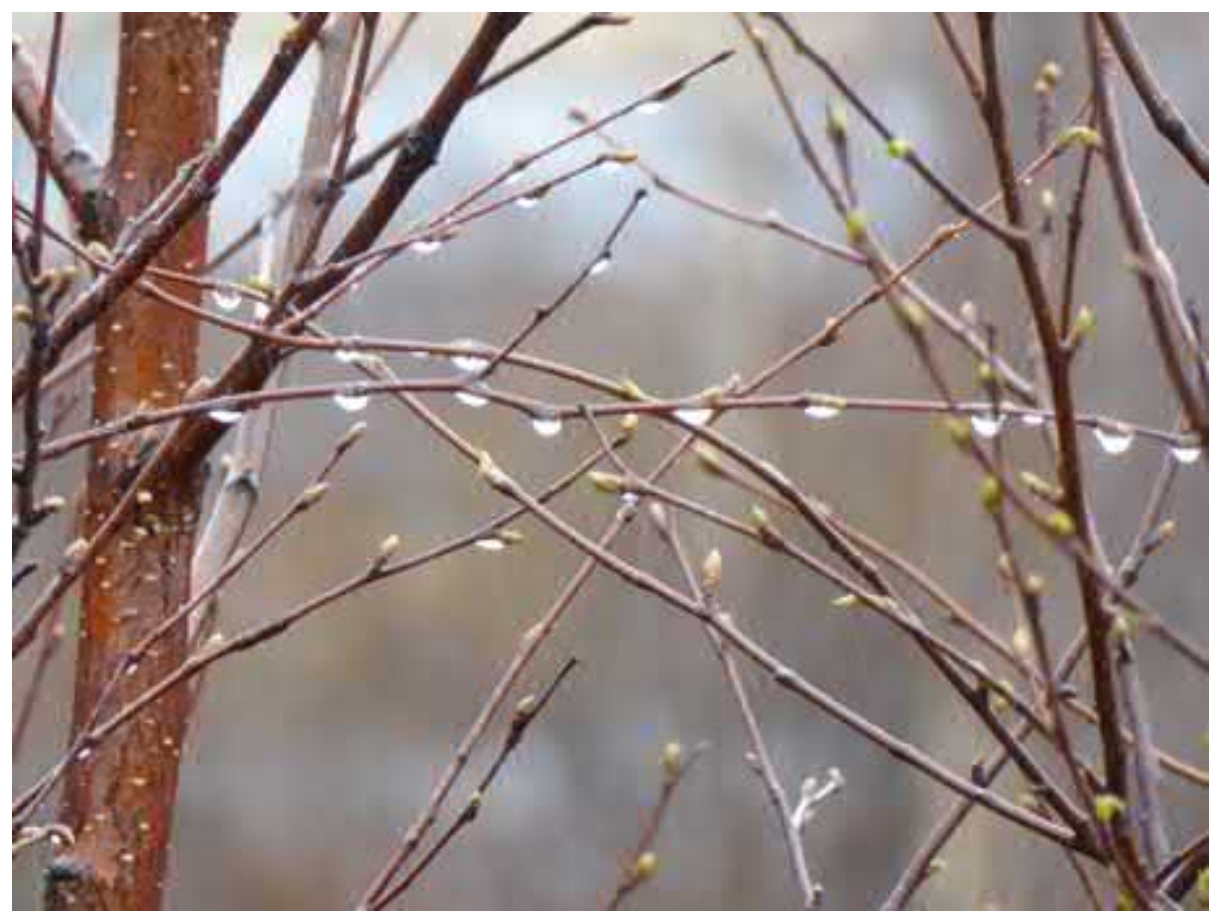

Kuva 4-7. Interseptiota oksistossa. Kuva: Matti Leppäranta.

Hydrologinen tutkimus tarvitsee yleensä alueellisia sadantatietoja. Siksi tärkeä toimenpide on arvioida sadannan alueellista jakautumista useissa pisteissä tehtyjen havaintojen avulla. Spatiaalistatistiikassa käytetään yleisesti kriging-interpolointia, jossa suureen spatiaalinen kenttä lasketaan havaintojen painotettuna keskiarvona. Painot määrätään suureen autokorrelaatiorakenteen perusteella ja näin ollen ne riippuvat etäisyyksistä havaintopisteisiin. 

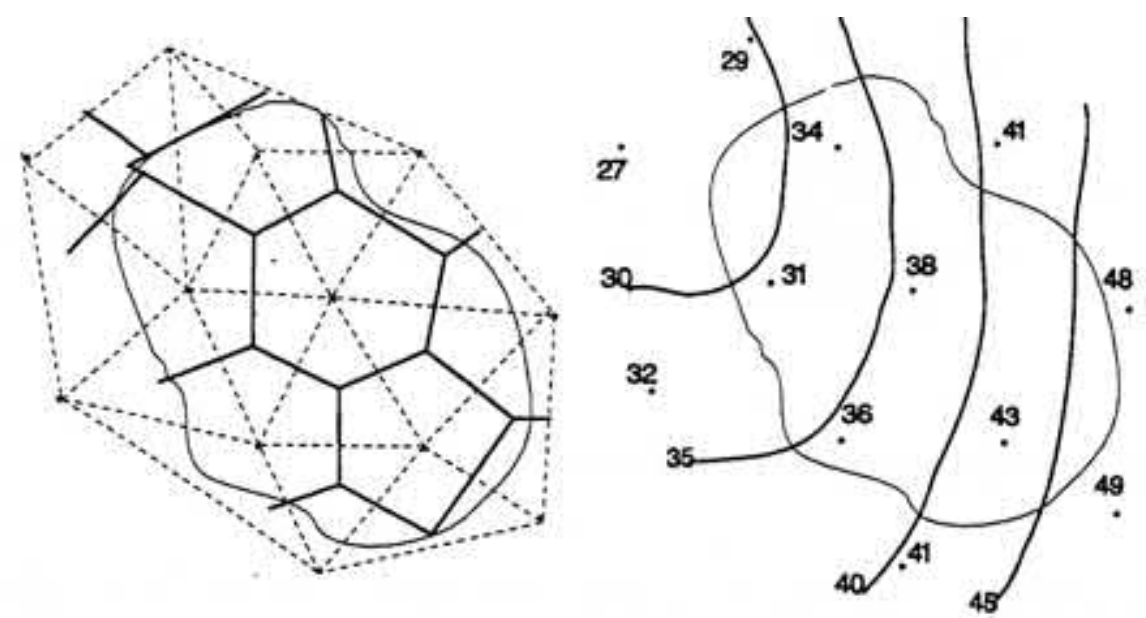

Kuva 4-8. Sadannan aluearvon laskeminen käyttäen Thiessenin menetelmää (vasen) ja isohyeettimenetelmää (oikea).

Kun haetaan vesistö- tai valuma-alueen sadannan aluearvoa, voidaan käyttää useita menetelmiä:

- Aritmeettinen keskiarvo. Aluearvo lasketaan suoraan pistehavaintojen keskiarvona.

- Thiessenin monikulmiomenetelmä. Sadeasemien ympärille laaditaan monikulmio, jonka sivut ovat kyseisen aseman ja viereisten asemien yhdysjanojen keskinormaaleja (kuva 4-8). Aluearvo saadaan laskemalla havaintojen painotettu keskiarvo, kun painot ovat monikulmioiden suhteellisia pinta-aloja.

- Isohyeettimenetelmä. Sadehavaintojen avulla piirretään aluksi isohyeetit eli sadannan tasa-arvo käyrät (kuva 4-8). Tämän jälkeen mitataan isohyeettien väliin jäävät pintaalat. Sadannan aluearvo saadaan painotettuna keskiarvona, kun painot ovat edellä mainittujen osa-alueiden suhteelliset pinta-alat, ja näiden osa-alueiden sadanta on niitä rajoittavien isohyeettien sadanta-arvojen keskiarvo.

Nämä menetelmät perustuvat kriging-interpolointi ajatteluun, mutta painot valitaan niissä suoraviivaisesti ilman tietoa autokorrelaatiorakenteesta. Aritmeettinen keskiarvo sopii, kun sadehavaintoverkko on riittävän tasainen ja tiheä. Usein sadannan aluearvo määritetään samalla kertaa vesistöalueelle ja sen osa-alueille. Tällöin voidaan pienten osa-alueiden sadannat arvioida suoraan isohyeettien perusteella niiden painopisteisiin ja suuremman alueen sadanta laskea osa-alueiden sadantojen painotettuna keskiarvona.

Ouryvaev \& Toebes (1970) määrittivät aluesadantaa alueellisen autokorrelaation avulla. Laskelman tarkkuus riippuu alueen koosta, sateen alueellisesta vaihtelevuudesta, asematiheydestä sekä jakson pituudesta. Alla olevat luvut kuvaavat rintamasateen aluearvon suhteellista virhettä $25 \%$ :n virhetasolla.

\begin{tabular}{r|r|r|r|r} 
& \multicolumn{3}{c}{ Virheraja (\%) } \\
\cline { 3 - 5 } Alueen koko & Asemien lukumäärä & \multicolumn{3}{c}{ Jakson pituus (vrk) } \\
\hline $\mathbf{k m}^{2}$ & & $\mathbf{1}$ & $\mathbf{1 0}$ & $\mathbf{3 0}$ \\
\hline 1000 & 10 & 22 & 9 & 5 \\
1000 & 100 & 4 & 2 & 1 \\
100 & 1 & 70 & 28 & 16 \\
100 & 10 & 14 & 6 & 3
\end{tabular}


Näissä virhearvioissa ei ole otettu huomioon mittaustekniikasta johtuvaa systemaattista virhettä. Konvektiivisen sateen tapauksessa virheet saattavat olla kaksin- tai kolminkertaisia. Sateen aluearvon laskeminen muuttuu vaikeammaksi vuoristoseuduilla, joissa sadannalla on voimakas alueellinen vaihtelevuus korkeuserosta johtuen. Tällöin sadannan aluearvon laskemisessa on tarkasteltava korkeussuhteiden lisäksi ilmavirtausten suuntia yksittäisissä sadetapauksissa. Vuosisadanta voidaan myös laskea epäsuorasti keskimääräisen vuosivalunnan ja keskimääräisen vuosihaihdunnan erotuksena.

\subsection{Haihdunta}

\subsubsection{Haihdunnan fysiikka}

Haihtumisessa nestemäinen vesi muuttuu vesihöyryksi. Sen dimensio on $L T^{-1} j a$ yksikkönä käytetään yleensä millimetrejä vuorokautta, kuukautta tai vuotta kohti samoin kuin sateen tapauksessa. Haihtumista voi tapahtua vapaan veden, maan ja kasvipeitteen pinnalta, mitä kutsutaan yleisesti evaporaatioksi. Kasvien elintoimintaan kuuluvaa haihtumista, missä vesi kulkeutuu kasvien juuri-varsi-lehti-systeemin lävitse, kutsutaan transpiraatioksi. Yhdessä transpiraatio ja evaporaatio muodostavat evapotranspiraation. Koska hydrologiassa ei yleensä voida erottaa näitä haihdunnan muotoja, käytetään evapotranspiraatio termiä puhuttaessa alueellisesta haihdunnasta. Jääpinnan höyrystyminen on sublimaatiota.

Haihtumiselle vastakkainen ilmiö on kosteuden tiivistyminen, joka havaitaan erityisesti loppukesän iltoina kasteen muodostumisena. Vesihöyryn kiteytyminen jääksi taas härmistymistä, jota näkyy kuurapintoina talvella. Alempana haihdunnasta puhuttaessa siihen otetaan sublimaatio mukaan yksinkertaisuuden vuoksi, ellei toisin mainita.

Haihduttavan pinnan läheisyydessä ilmassa on runsaasti liikkeessä olevia vesimolekyylejä. Osa näistä joutuu takaisin pintaan, ja toisaalta taas pinnasta vapautuu koko ajan vesimolekyylejä ilmaan. Mikäli tasapainotila vallitsee eli pintaan palaavien molekyylien lukumäärä on yhtä suuri kuin siitä lähtevien, ilma on haihduttavan pinnan läheisyydessä vesihöyryllä kyllästettyä. Tarkkaan ottaen kyllästetyn vesihöyryn osapaine riippuu lämpötilan lisäksi haihduttavan pinnan kaarevuudesta sekä veden epäpuhtauksista.

Jotta haihduntaa voisi tapahtua, täytyy vesihöyryn osapaineen olla haihduttavan pinnan tuntumassa suurempi kuin yläpuolisessa ilmassa. Vesihöyryn paineen kohottaminen edellyttää sitä, että vesimolekyylien nopeuksia suurennetaan eli haihduttavalle pinnalle tuodaan energiaa. On myös mahdollista, että haihtumiseen tarvittava lämpöenergia on peräisin itse haihduttavalta pinnalta, jolloin haihtuminen alentaa haihduttavan alustan lämpötilaa (kuva 4-9). Vesihöyryn paine-ero alustan ja ilman välillä ei riitä siihen, että haihduntaa voisi tapahtua jatkuvasti. Täytyy olla myös turbulenssia, joka kuljettaa vesihöyryn alustan läheltä ylempiin ilmakerroksiin. Haihdunta ja sublimaatio kuluttavat paljon energiaa, mikä merkittävästi rajoittaa niiden määrää. Energiankulutus on suoraan määritelmän mukaan

$$
Q_{e}=-\rho L_{E *} E,
$$

missä $E$ on haihdunta tai sublimaatio ja vastaavasti $L \mathrm{E}^{*}=L \mathrm{E}=$ höyrystymislämpö haihdunnan tapauksessa ja $L_{E^{*}}=L_{E}+L_{f}, L_{f}$ on jäätymislämpö, sublimaation tapauksessa. Yhtälön(4.17) avulla nähdään, että $5 \mathrm{~mm}$ haihdunta (sublimaatio) vuorokaudessa kuluttaa energiaa $145 \mathrm{~W}$ $\mathrm{m}^{-2}\left(150 \mathrm{~W} \mathrm{~m}^{-2}\right)$, mikä on sangen korkea arvo. 


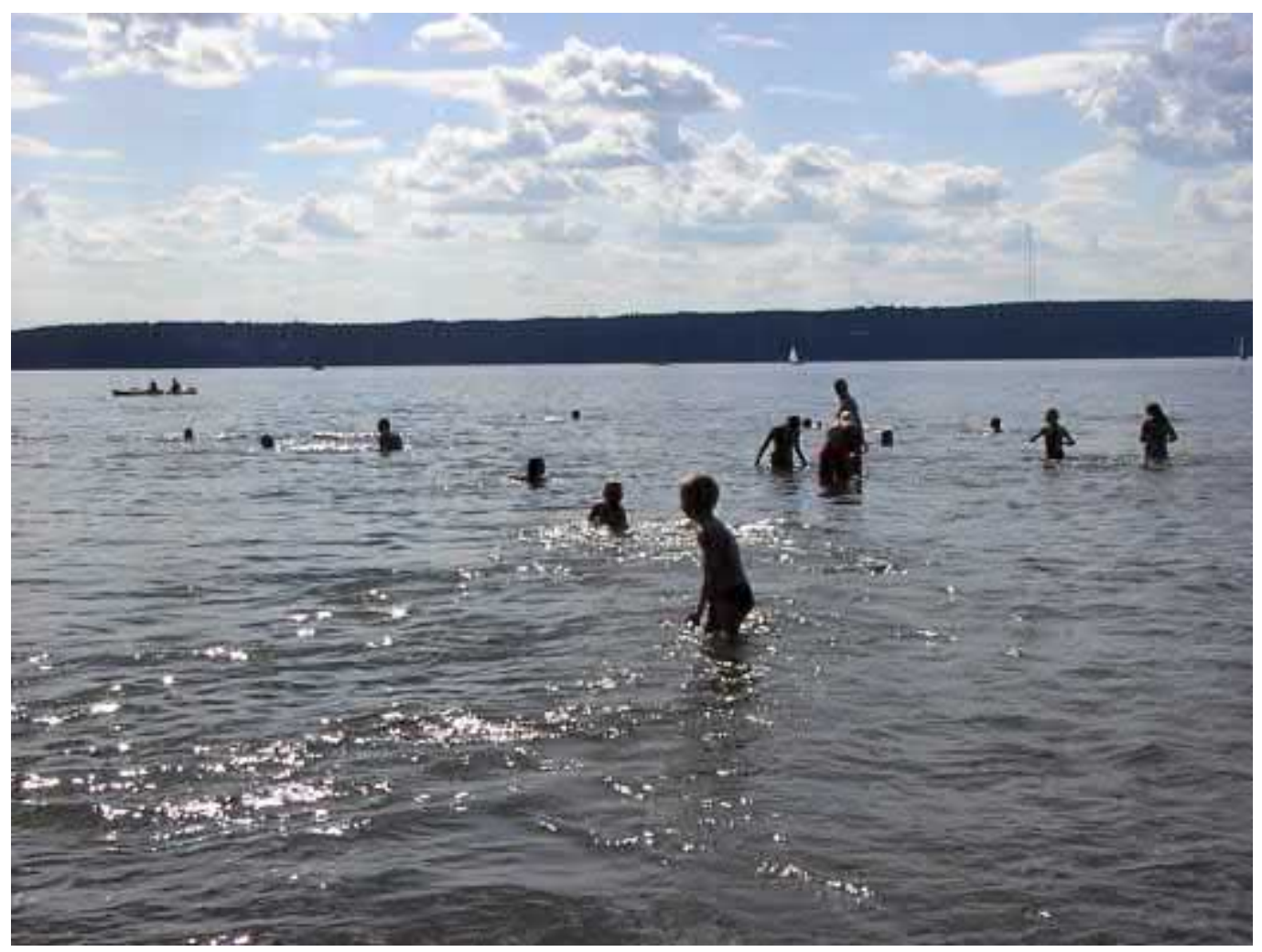

Kuva 4-9. Uimasta noustessa kylmä tunne aiheutuu veden haihtumisesta iholta, kun siihen siirtyy lämpöenergiaa. Kuva: Matti Leppäranta.

Haihdunnan jakautuminen maapallon pinnalla riippuu toisaalta käytettävissä olevasta energian määrästä ja toisaalta käytettävissä olevasta vedestä. Tämän vuoksi haihdunta on vähäistä aavikoilla ja voimakasta päiväntasaajan ympäristön runsassateisilla alueilla sekä merissä erikoisesti lämpimien merivirtojen alueilla (kuva 4-10). Napa-alueita lähestyttäessä haihdunta vähenee, sillä kylmän ilman absoluuttinen kosteus on aina alhainen. Haihdunnan arvioinnin tekee vaikeaksi se, ettei siitä ei saa visuaalista havaintoa toisin kuin sadannan tapauksessa.

Etelä-Suomen keskimääräiseksi aluehaihdunnaksi on arvioitu 400-500 mm vuodessa järvisyydestä riippuen. Järvialueilta arvioidaan haihtuvan vuodessa 500-600 mm, ja keskimääräinen vuorokausihaihdunta on kesällä $3 \mathrm{~mm}$. Pohjois-Suomessa haihdunta on vähäisempää, 150-250 mm vuodessa.

Fysikaalisesti evaporaatio ja transpiraatio eivät poikkea paljon toisistaan. Kumpikin vaatii suunnilleen saman energian, ja kuljetusmekanismi haihduttavan pinnan läheisyydessä on samankaltainen. Kasvit pystyvät kuitenkin muuttamaan tapahtumaa hieman. Niiden vedenkäyttö liittyy fotosynteesiin ja respiraatioon eli orgaanisen aineen muodostumiseen. Hiilidioksidin siirtyminen ilmakehästä kasviin tapahtuu lehtien ilmaraoissa eli stomatoissa olevien vesipisaroiden välityksellä. Koska haihtuminen kuivaa vesipisaroita, vettä tarvitaan koko ajan lisää. Tämä lisäys liittyy veden virtaukseen kasvin juuri-varsi-systeemin lävitse transpiraationa, joka muodostaa myös eräänlaisen jäähdytysjärjestelmän samalla tavalla kuin hikoilu ihmisellä ja eläimillä. Jotkut kasvit ja kasvin osat tarvitsevat vettä myös pysyäkseen koossa. Yöllä ja pilvisellä säällä orgaanista ainetta ei muodostu, ja useimpien kasvien veden tarve on vähäisempi. Useat kasvit voivat säännöstellä veden kulutusta lehtien alapinnalla olevien ilmarakojen avulla. Tällä on vaikutusta transpiraation vuorokautiseen kulkuun. Toinen tärkeä piirre transpiraatiossa on se, että kasvit ottavat tarvitsemansa veden juurivyö- 
hykkeestä maan pinnan alapuolelta laajalta alueelta. Maan pinnan kuivuminen ei siis estä transpiraatiota, sen sijaan evaporaatio estyy miltei kokonaan pinnan kuivuessa.

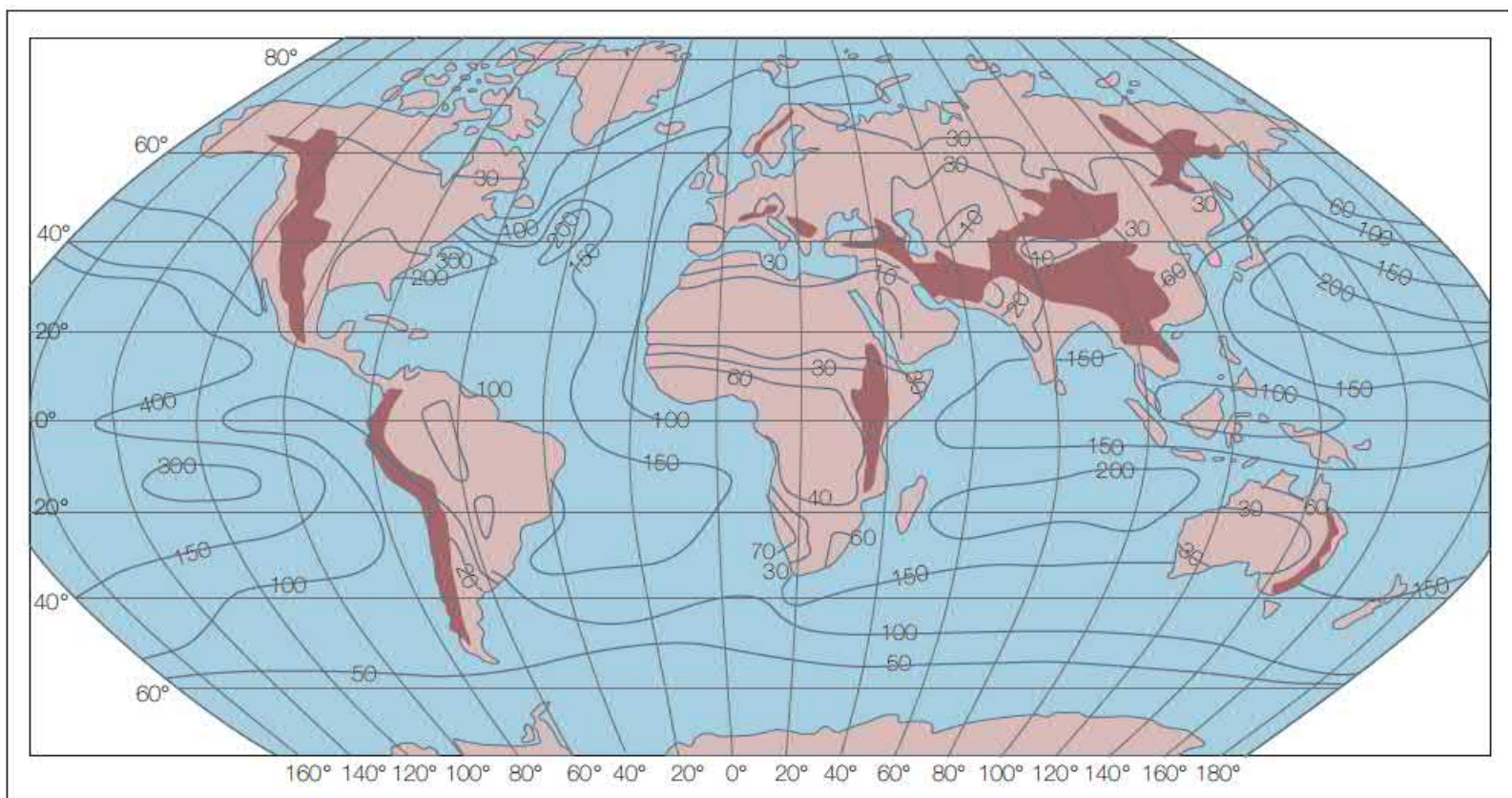

Kuva 4-10. Haihdunnan jakautuminen maapallolla (senttimetriä vuodessa). Suurimmillaan se on trooppisilla merillä, $300 \mathrm{~cm}$ eli $3000 \mathrm{~mm}$. Lähde: Budyko ym. (1962).

Kulkeutuessaan maaperästä kasvien lävitse ilmakehään vesiosasen energia muuttuu. Energian muutokset voidaan tulkita potentiaalienergian muutoksiksi $\delta E_{p}=\rho g \cdot \delta h$, missä $\delta h$ on potentiaalienergian muutosta vastaava vesipatsaan korkeuden muutos (taulukko 4-3). Juurien osmoosilla ja lehtien aukkojen kapillaarisella imulla on merkittävä vaikutus transpiraatioon. Taulukon arvoista huomataan, että höyrystymiseen kuluva energia on huomattavasti suurempi kuin muihin taulukossa esitettyihin tapahtumiin kuluva energia.

Taulukko 4-3. Potentiaalienergian muutos massayksikköä kohti $\delta E_{p} / \rho$ ja vastaava vesipatsaan korkeuden muutos $\delta h$ veden kulkiessa kasvin lävitse. Etumerkki kuvaa sitä kasvaako vai väheneekö energia. (Eagleson 1970).

\begin{tabular}{l|r|r|r} 
Tapahtuma & Etumerkki & $\frac{\boldsymbol{\delta} \boldsymbol{E}_{\boldsymbol{p}}}{\boldsymbol{\rho}} \mathbf{( \mathbf { k J ~ k g } ^ { - 1 } \mathbf { ) }}$ & $\boldsymbol{\delta} \boldsymbol{h}(\mathbf{m m})$ \\
\hline Irtoaminen maaperästä & - & $0-1,5$ & $0-150$ \\
Siirtyminen juuriin & + & $0-1,5$ & $0-150$ \\
Osmoosin vaikutuksesta & + & $0-0,15$ & $0-0,15$ \\
Siirtyminen lehtiin & - & $1-100$ & $100-10000$ \\
Siirtyminen lehtien & + & 2500 & - \\
aukkoihin & + &
\end{tabular}

\subsubsection{Potentiaalinen haihdunta ja todellinen haihdunta}

Potentiaalinen haihdunta tarkoittaa haihduntaa siinä tapauksessa, että haihduttava pinta ei kärsi veden puutetta. Sitä varten on kehitetty runsaasti empiirisiä kaavoja. Maan pintakerroksen ja juurivyöhykkeen vesipitoisuutta ei näissä kaavoissa oteta huomioon. Potentiaalisen haihdunnan määritelmään liittyy kuitenkin heikkouksia, sillä haihduntaan vaikuttavat myös 
pinnan laatu ja ympäristö sekä kasvipeitteen laatu, tiheys, korkeus ja kasvun vaihe. Toisen määritelmän mukaan potentiaalinen haihdunta tarkoittaa haihduntaa sellaiselta tiheältä, lyhyeksi leikatulta ruohokentältä, joka ei kärsi veden puutteesta. Tämä määritelmä on edellistä yksikäsitteisempi, koska pinnan ominaisuudet on täsmällisemmin määritelty. Järviltä ja muilta kosteilta pinnoilta todellinen haihdunta on aina sama kuin potentiaalinen haihdunta.

Maaperästä tapahtuvaan haihduntaan liittyvät seuraavat keskeiset käsitteet:
kenttäkapasiteetti
vesipitoisuuden tila, jossa suurin mahdollinen määrä on sitoutu- nut maaperään
lakastumisraja
hyötykapasiteetti
maan kosteus silloin, kun kasvit juuri ja juuri kykenevät irrotta- maan vettä maaperästä
kasvien kannalta käyttökelpoinen vesipitoisuus = kenttäkapasi- teetti - lakastumisraja

Kenttäkapasiteetti saavutetaan maalajista riippuen joidenkin tuntien tai vuorokausien kuluttua viimeisestä sateesta. Kun vesipitoisuus tulee alhaisemmaksi kuin lakastumisraja, veden ja maan hiukkasten väliset sidosvoimat ovat liian suuria, eivätkä kasvit enää kykene irrottamaan vettä.

Potentiaalisen haihdunnan $E_{P}$ ja todellisen haihdunnan $E$ yhteys riippuu maan vesipitoisuudesta $m$

$$
E=f\left(\frac{m}{m_{*}}\right) E_{P}
$$

missä $m_{*}$ on hyötykapasiteetti. Esimerkkejä funktiosta $f$ on kuvassa 4-11. Funktiolla on useita eri muotoja eri ilmastovyöhykkeitä ja erilaisia maaperätyyppejä varten, ja niiden kulku riippuu lähinnä sadeoloista. Kosteassa ilmastovyöhykkeessä $f>0,8$, kun $\frac{m}{m_{*}}>0,2$, ja kuivassa $f \sim \frac{m}{m_{*}}$. Raja-arvot ovat $f \rightarrow 0, \operatorname{kun} \frac{m}{m_{*}} \rightarrow 0$, ja $f \rightarrow 1, \operatorname{kun} \frac{m}{m_{*}} \rightarrow 1$. Kuvan 4-11 käyrä 5 edustaa kuivaa vyöhykettä, jossa sadetapausten pienestä lukumäärästä johtuen ei esiinny interseption haihduntaa eikä haihduntaa maan pinnalta.

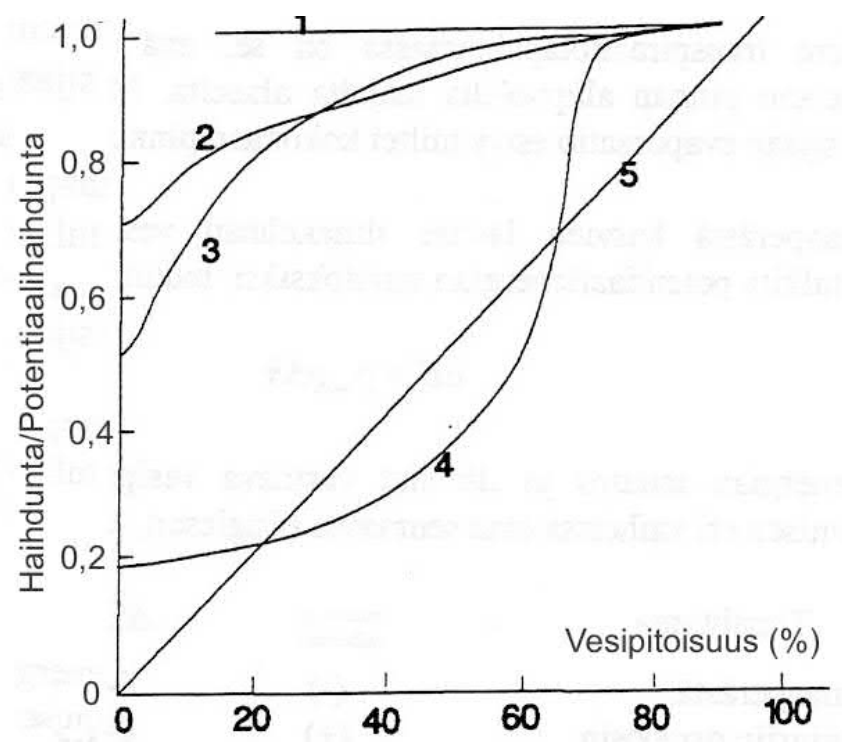

Kuva 4-11. Haihdunta suhteessa potentiaalihaihduntaan maaperän vesipitoisuuden (\% kenttäkapasiteetista) funktiona eri ilmastovyöhykkeillä. Käyrät 1-3 edustavat kosteampia ja 4-5 kuivempia alueita. Lähde: Mustonen (1973), muokattu. 


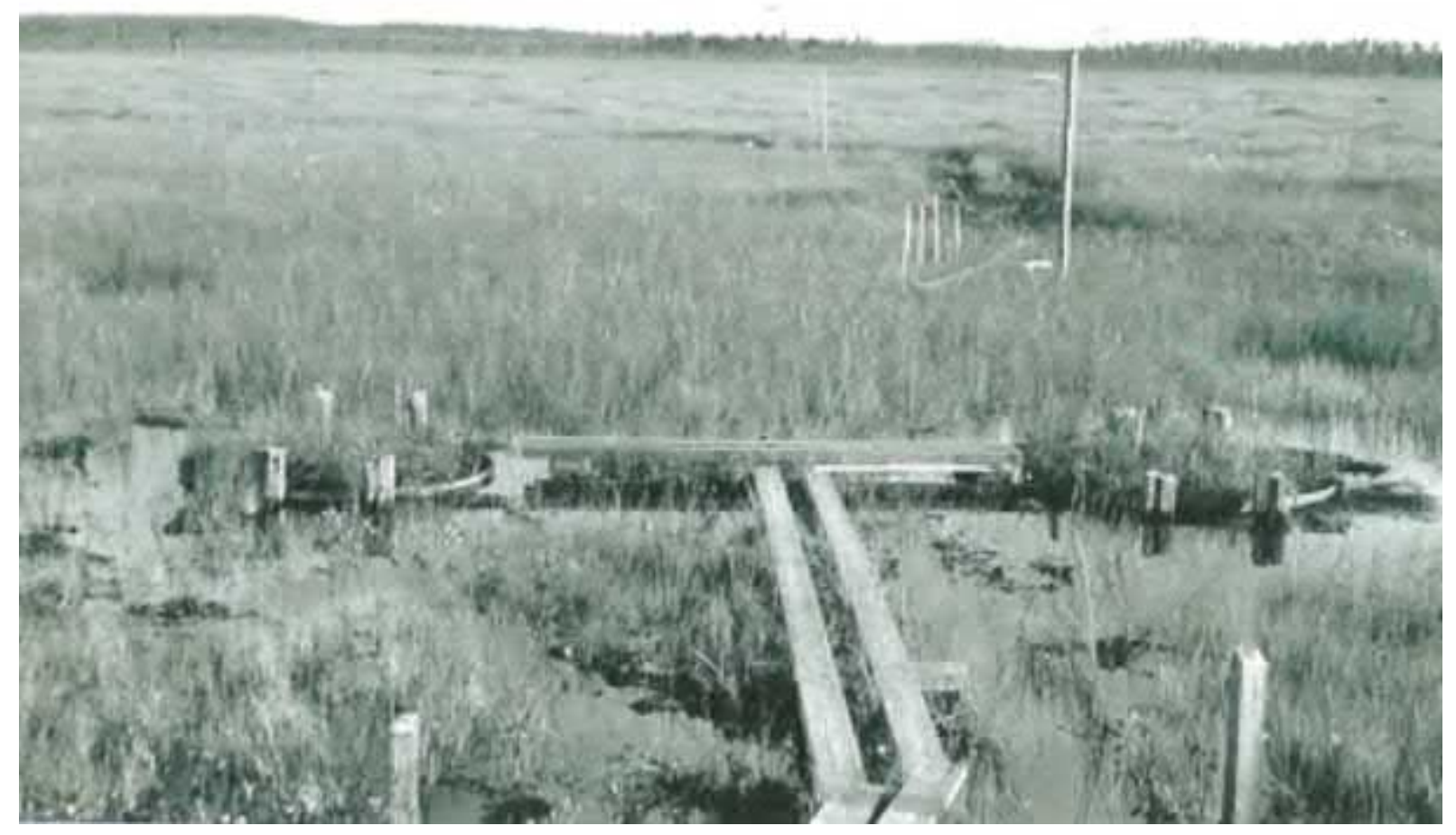

Kuva 4-12. Lysimetri Möksyn nevalla. Kuva: Juhani Virran arkisto.

Haihdunnan suora mittaaminen on erittäin vaikeaa. Haihdunta on kuitenkin niin monen meteorologisen ja hydrologisen tapahtuman osa, että usein voidaan käyttää monia riippumattomia menetelmiä samanaikaisesti ja tätä tietä päästä likimääräisilläkin menetelmillä luotettaviin tuloksiin. Lisäksi on osoittautunut, että vuorokautta pidemmille jaksoille voidaan usein käyttää yksinkertaisia laskentamenetelmiä.

Haihduntaa voidaan mitata haihtumisastioilla ja lysimetreillä (kuva 4-12). Haihtumisastia on vedellä täytetty astia. Se voi olla maan pinnalla tai asennettu kelluvalle lautalle. Lysimetri on astia, joka on täytetty mahdollisimman luonnonmukaisesti maalla ja jonka pintakerroksen muodostaa tutkittava kasvipeite. Haihdunta määrätään laitteen vesitaseen avulla. Lysimetrejä on erikokoisia, $500 \mathrm{~cm}^{2}$ kokoisesta kymmeniin neliömetreihin.

Pienempien lysimetrien vesipitoisuuden vaihtelu mitataan punnitsemalla, suurempien käyttämällä jotakin maan kosteuden mittausmenetelmää. Lahdessa on maaperäntutkimuskeskus Soilia, joka tarjoaa todellisia olosuhteita vastaavan ympäristön maaperän tutkimuksille. Keskuksen omistaa Lahden Seudun Kehitys LADEC Oy, joka ylläpitää sitä yhteistyössä Helsingin yliopiston Ympäristötieteiden laitoksen kanssa. Haihdunnan suora mittaaminen vaatii erittäin suurta huolellisuutta näyteastioiden käsittelyssä, sillä astian keinotekoinen täyttäminen muuttaa helposti veden vertikaalisia liikkeitä ja näytteen lämpötilarakennetta. Suuretkin systemaattiset virheet ovat mahdollisia, sillä maaperässä voi olla huomattavaa paikallista vaihtelua esimerkiksi keidasilmiön takia. 


\subsubsection{Haihdunnan määrittäminen laskennallisin menetelmin}

Vesitasemenetelmä antaa alueen haihdunnan vesitaseen (kohta 3.3.4) residuaalina

$$
E=P-R-\frac{d V}{d t}
$$

missä $R$ on valunta. Maa- ja pohjavesiin tapahtuva varastoituminen on merkittävää, mutta sitä on vaikea mitata koko vesistöalueelle. Tästä syystä vesitaseen käyttö on yleensä rajoittunut usean vuoden keskimääräisen haihdunnan laskemiseen, jolloin vesivaraston muutosta kuvaava termi jää pieneksi. Samankaltaista yhtälöä voidaan soveltaa myös suurehkon alueen yläpuolella olevaan ilmatilaan. Valunnan tilalla on silloin ilmavirtausten mukana tapahtuva vaakasuora vesihöyryn kuljetus, jolloin sadanta on ilmatilasta vettä pois kuljettava osa ja haihdunta on alueelle vettä tuova osa. Vesihöyryn varastoituminen ilmenee ilman kosteuden muutoksena ja pilviin tapahtuvana varastoitumisena. Menetelmää on sovellettu Suomessa Itämeren ja Etelä-Suomen alueisiin (Palmén \& Söderman 1966).
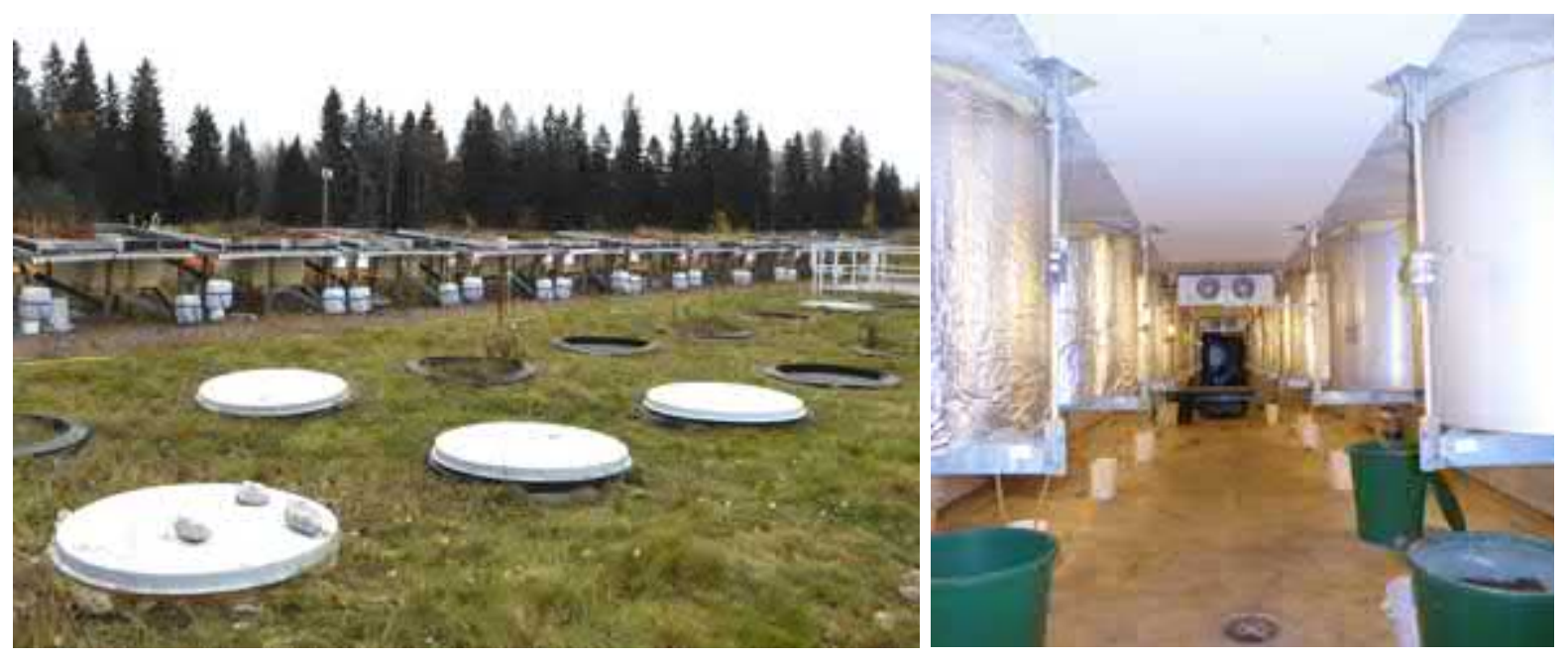

Kuva 4-13. Soilian lysimetrikenttä Lahdessa. Vasemmalla etualalla katettuja ja käytössä olevia lysimetrejä ja oikealla kuva lysimetrisäiliöistä maan alla. Kuvat: Leena Leppäranta.

Haihdunta tarvitsee paljon lämpöä (yhtälö 4.17), mikä tarjoaa mahdollisuuden sen arvioimiseksi. Lämpötasemenetelmässä haihdunta määritetään lämpötaseen (yhtälö 4.1) residuaalina. Sateen tuoma lämpö voidaan jättää pois, sillä sateen aikana ei haihduntaa tapahdu. Saadaan

$$
E=\frac{1}{\rho L_{E *}}\left(Q_{s}-Q_{r}+Q_{L a}-Q_{L 0}+Q_{c}-\left.k \frac{\partial T}{\partial z}\right|_{z=0^{-}}\right),
$$

Kaikista oikean puolen termeistä ei aina saada tarvittavaa tietoa. Suurin ongelma on tiedon puute pintalämpötilasta. Silloin terrestrinen nettolämpösäteily arvioidaan ilman lämpötilan perusteella ja turbulenttiseen lämmönvaihtoon käytetään Bowenin suhdetta. Saadaan

$$
E=\frac{1}{\rho L_{E *}(1+B)}\left[(1-\alpha) Q_{s}+\varepsilon_{0} \sigma\left(\varepsilon_{a}-1\right) T_{a}^{4}-\left.k \frac{\partial T}{\partial z}\right|_{z=0^{-}}\right] .
$$

Aerodynaaminen menetelmä soveltaa turbulenttisen rajakerroksen teoriaa. Vesihöyryä kulkeutuu turbulenttisissa pyörteissä ja nettosiirtymää tulee kosteasta kuivempaan suuntaan. Käyt- 
täen turbulenttisen vaihdon bulkkikaavaa $(4.14 \mathrm{~b})$ ja haihduntaenergian määritelmää (4.16) saadaan

$$
E=-\frac{\rho_{a}}{\rho} C_{E}\left(q_{a}-q_{0}\right) U_{a}
$$

Menetelmä antaa hyvän tuloksen, jos vain ilmakehän pintakerroksen tila tunnetaan. Kun haihduntaa tai sublimaatiota tapahtuu $(E>0)$, haihtumislämpö on negatiivinen $\left(Q_{e}<0\right)$. Jos $E$ $<0$, tapahtuu kosteuden tiivistymistä tai härmistymistä. Järvinen \& Huttula (1982) ovat käyttäneet aerodynaamista menetelmää järvihaihdunnan määrittämiseksi.

\subsubsection{Penmanin menetelmä}

Haihdunnan laskennallisessa arvioimisessa suurin ongelma on tiedon puute pinnan kosteudesta. Sääasemat mittaavat ilman kosteuden $2 \mathrm{~m}$ korkeudella, ja haihdunta määräytyy ilman ja pinnan välisestä kosteuserosta sekä tuulen nopeudesta. Potentiaalisen haihdunnan laskemiseksi riittää tietää pinnan lämpötila, sillä pinnan kosteuden oletetaan silloin olevan kyllästystilassa. Penmanin kaavan avulla voidaan määrittää potentiaalihaihdunta käyttäen sääasemahavaintoja. Menetelmän ideana on eliminoida pintalämpötila käyttäen kahta haihtumisyhtälöä lähtökohtana. Aerodynaamista yhtälöä (4.22) käytetään vesihöyryn siirron peruskaavana, ja energiataseen pohjalta tehdään korjaus pintalämpötilaan.

Aerodynaaminen yhtälö voidaan kirjoittaa muotoon $E=f\left(U_{a}\right)\left[e_{s}\left(T_{0}\right)-e_{a}\right]$, missä $e_{\mathrm{s}}$ on vesihöyryn kyllästyspaine (kuva 3-14). Energiataseesta (4.20) jätetään pois yleensä pienenä tekijänä esiintyvä lämmönjohtuminen sisään pinnasta. Kaksi tarvittavaa apusuuretta ovat psykrometrinen vakio $\gamma=0,66$ mbar ${ }^{\circ} \mathrm{C}^{-1}$ ja vesihöyryn kyllästyspaineen lämpötilaherkkyys $\Delta$, jotka saadaan Bowenin suhteesta ja vesihöyryn kyllästyspaineesta,

$$
\begin{aligned}
& B=\frac{Q_{c}}{Q_{e}}=\frac{\rho_{a} c_{a} C_{H}\left(T_{a}-T_{0}\right) U_{a}}{\rho_{a} L_{E *} C_{E}\left(q_{a}-q_{0}\right) U_{a}}=\frac{c_{a}}{L_{E *}} \frac{p}{0,622} \frac{\left(T_{a}-T_{0}\right)}{\left(e_{a}-e_{0}\right)}=\gamma \frac{T_{a}-T_{0}}{e_{a}-e_{0}}, \\
& \Delta=\frac{e_{S}\left(T_{0}\right)-e_{S}\left(T_{a}\right)}{T_{0}-T_{a}} .
\end{aligned}
$$

Lämpötaseesta (4.20) saadaan nyt lämpötilakorjaus, ja Penmanin menetelmän antama potentiaalinen haihdunta on (Mustonen 1986)

$$
\tilde{E}_{P}=\frac{1}{\rho L_{E *}} \cdot \frac{Q_{R 0}+\gamma \Delta^{-1} f\left(U_{a}\right)\left[e_{S}\left(T_{a}\right)-e_{a}\right]}{1+\gamma \Delta^{-1}}
$$

Penmanin kaavan on usein todettu antavan ylöspäin harhaisia arvioita, ja siksi siihen on kalibroitu korjauskerrointa: $E_{P}=r \cdot \widetilde{E}_{P}, r \approx 0,7-0,9$. Menetelmää on kehitetty myöhemmin koskemaan myös transpiraatiota.

Radiometriset lämpötilamittaukset ovat kehittyneet viime vuosina, ja satelliiteista voidaan mitata alustan lämpötilaa. Tämä saattaa jonkin verran vähentää tarvetta käyttää Penmanin menetelmää. Mutta sääasemahavaintoja käytettäessä se on edelleen soveltuva lähestymistapa. Transpiraatiotakin on lähestytty Penmanin menetelmään pohjatuvan muunnoksen avulla (Vakkilainen 1982). 


\subsection{Lumi}

\subsubsection{Lumiklimatologia}

Suomen ilmastossa osa sadannasta tulee lumena, joka muodostaa väliaikaisen vesivaraston. Talven aikana pintavesi-, maavesi- ja pohjavesivarastot vähenevät, ja keväällä lumen vesivarasto vapautuu ja muodostaa voimakkaan maksimin pinta- ja pohjavesivaluntaan. Tämä ilmenee esimerkiksi kaivojen ja vesistöjen vedenpinnan laskuna talvella ja nousuna keväällä.

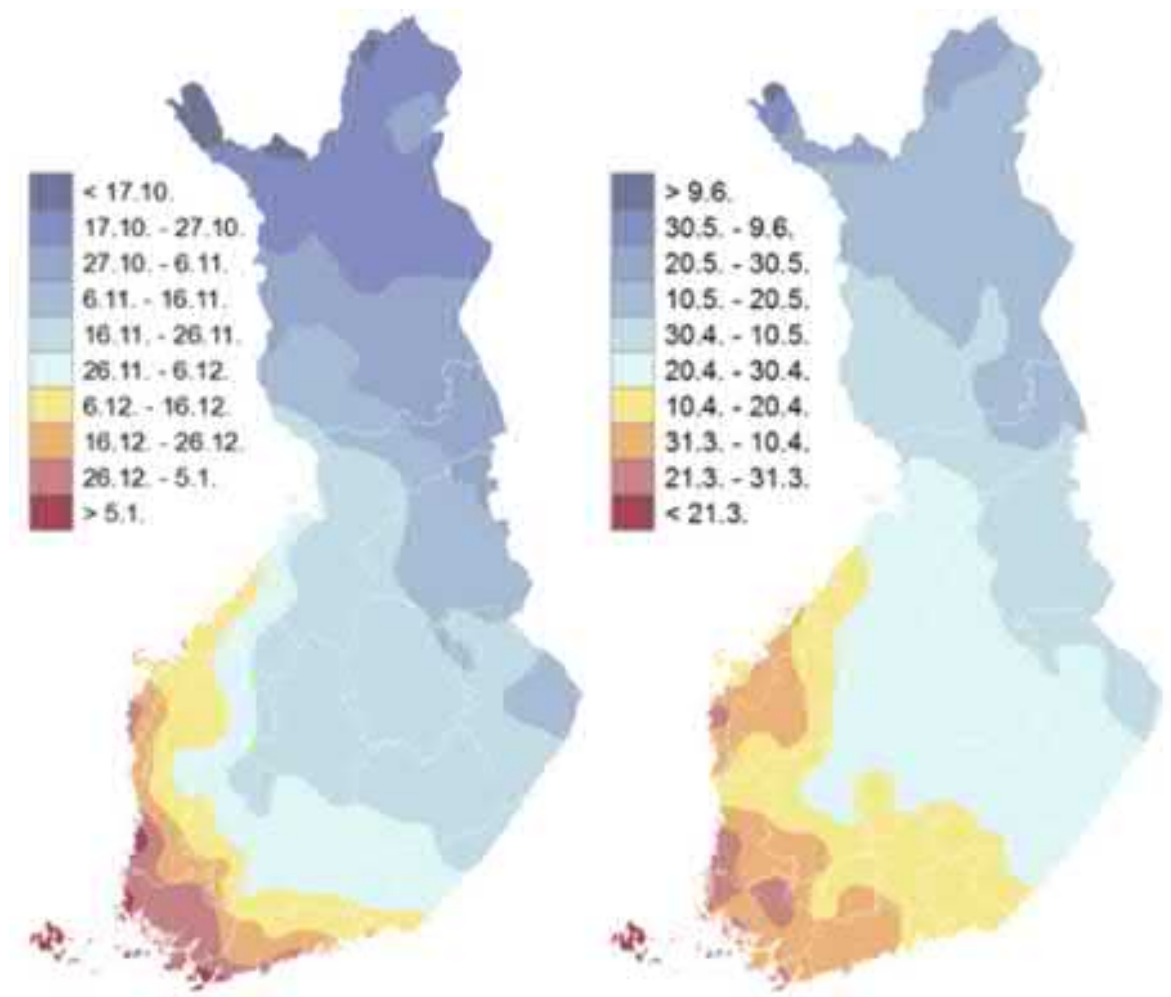

Kuva 4-14. Keskimääräiset lumipeitteen muodostumisen ja lumen sulamisen ajankohdat Suomessa 1981-2010. Lähde: Ilmatieteen laitos.

Lumipeite muodostuu Pohjois-Suomeen keskimäärin lokakuun lopussa (kuva 4-14). Marraskuun puolivälissä pysyvä lumipeite on yltänyt linjalle Tornio-Nurmes ja joulukuun alussa linjalle Kokkola-Haapamäki-Lappeenranta. Vuoden loppuun mennessä, aivan lounaisinta rannikkoa ja saaristoa lukuun ottamatta, pysyvä lumipeite on muodostunut koko maahan. Lumen lopullinen sulaminen alkaa Etelä-Suomessa maaliskuun lopussa ja tundralla toukokuussa. Ylivuotista, kesän ylitse säilyvää lunta on vain pieninä laikkuina Enontekiöllä. Jos ylivuotista lunta tulee säännöllisesti vanhan päälle, muodostuu ajan mittaan jäätiköitä lumen puristuessa jääksi oman painonsa alle.

Suomessa on kolme suurempaa lumialuetyyppiä: tundra, taiga ja reunavyöhyke. TunturiLapissa on arktinen tundralumivyöhyke, valtaosassa maata on talven ajan pysyvä taigalumivyöhyke, ja Lounais-Suomessa on reunavyöhyke, jossa lumi tulee ja sulaa useita kertoja talven aikana eikä pysyvää lumipeitettä muodostu. Lumen keskimääräinen paksuus maaliskuussa on suurimmillaan Tunturi-Lapissa, yli $80 \mathrm{~cm}$ (kuva 4-15). Lounaisrannikolla keskimääräinen paksuus on silloin alle $10 \mathrm{~cm}$. 


\subsubsection{Lumen ominaisuudet}

Lumi on sangen vaikeasti käsiteltävä ja mallitettava aines, joka koostuu jääkiteistä, nestemäisestä vedestä, kaasuonkaloista ja epäpuhtauksista, jotka ovat lumessa partikkeleina. Kreikkalaisen filosofin Herakleitoksen (535-475 eKr.) tunnettu ajatelma "kukaan ei voi astua kahdesti samaan virtaan" soveltuu muotoon "kukaan ei voi astua kahdesti samaan lumeen".
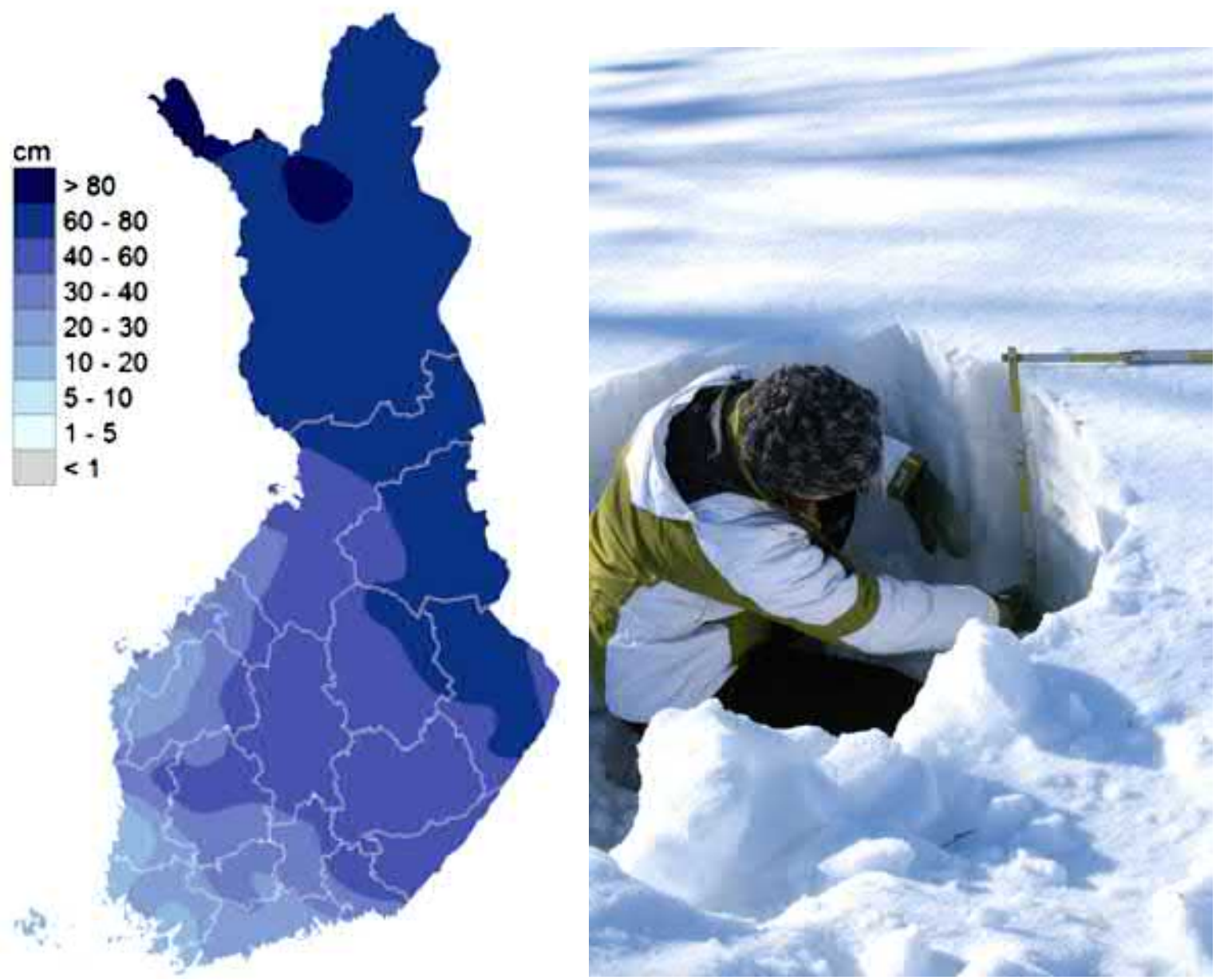

Kuva 4-15. Keskimääräinen lumipeitteen paksuus 15. maaliskuuta 1981-2010. Lumipeitteen rakennetta tutkitaan lumikuopan seinämästä. Kartta: IImatieteen laitos. Kuva: Matti Leppäranta.

Tärkeimmät lumen fysikaaliset perusominaisuudet ovat tiheys, kidekoko ja -muoto sekä nestemäisen veden määrä eli vetisyys. Kaasuonkaloita on paljon, ja niiden tilavuus määrää lumen tiheyden:

$$
\rho_{s}=\left(1-v_{a}\right) \rho_{i}
$$

missä $v_{a}$ on kaasujen suhteellinen tilavuus ja $\rho_{i}$ on jään tiheys. Kidekoko vaihtelee suuruusluokissa 0,1 - $10 \mathrm{~mm}$, ja yleensä luminäytteen suurinta kidettä käytetään karakterisoimaan kokoa. Pinnassa lumikiteiden muoto vaihtelee paljon, mutta syvemmällä ne ovat yleensä pyöristyneitä. Nestemäisen veden määrä määritellään sen suhteellisena tilavuutena. Suojasäällä lumen vetisyys kasvaa, ja kun tämä on noin $5 \%$, lumipallojen tekeminen käy helposti. Kun lämpötila on $0^{\circ} \mathrm{C}$ alapuolella, nestemäistä vettä ei juuri ole. 
Tiheys, kidekoko ja nestemäinen vesi määräävät paljolti lumen muita fysikaalisia ominaisuuksia, kuten kantokyky, lämmönjohtokyky, albedo ja valon vaimeneminen. Lumen lämmönjohtokyky riippuu ensi sijassa lumen tiheydestä: $k_{s}=\kappa \rho_{S}^{2}$, missä $\kappa$ on empiirinen kerroin. Kun lumen tiheys on $250 \mathrm{~kg} \mathrm{~m}^{-3}$, on lämmönjohtokyky noin $0,15 \mathrm{~W} \mathrm{~m}^{-2}{ }^{\circ} \mathrm{C}^{-1}$ eli kertaluokkaa pienempi kuin jään lämmönjohtokyky.

Lumipeitteen kemiaa tutkitaan analysoimalla sulatettuja luminäytteitä. Epäpuhtaudet voivat vaikuttaa merkittävästi lumen fysikaalisiin omaisuuksiin. Esimerkiksi likainen lumi imee auringonsäteilyä paljon tehokkaammin kuin puhdas lumi. Lumeen varastoituu myös ilmakehän laskeuma vapautuakseen myöhemmin lyhyen sulamiskauden aikana.

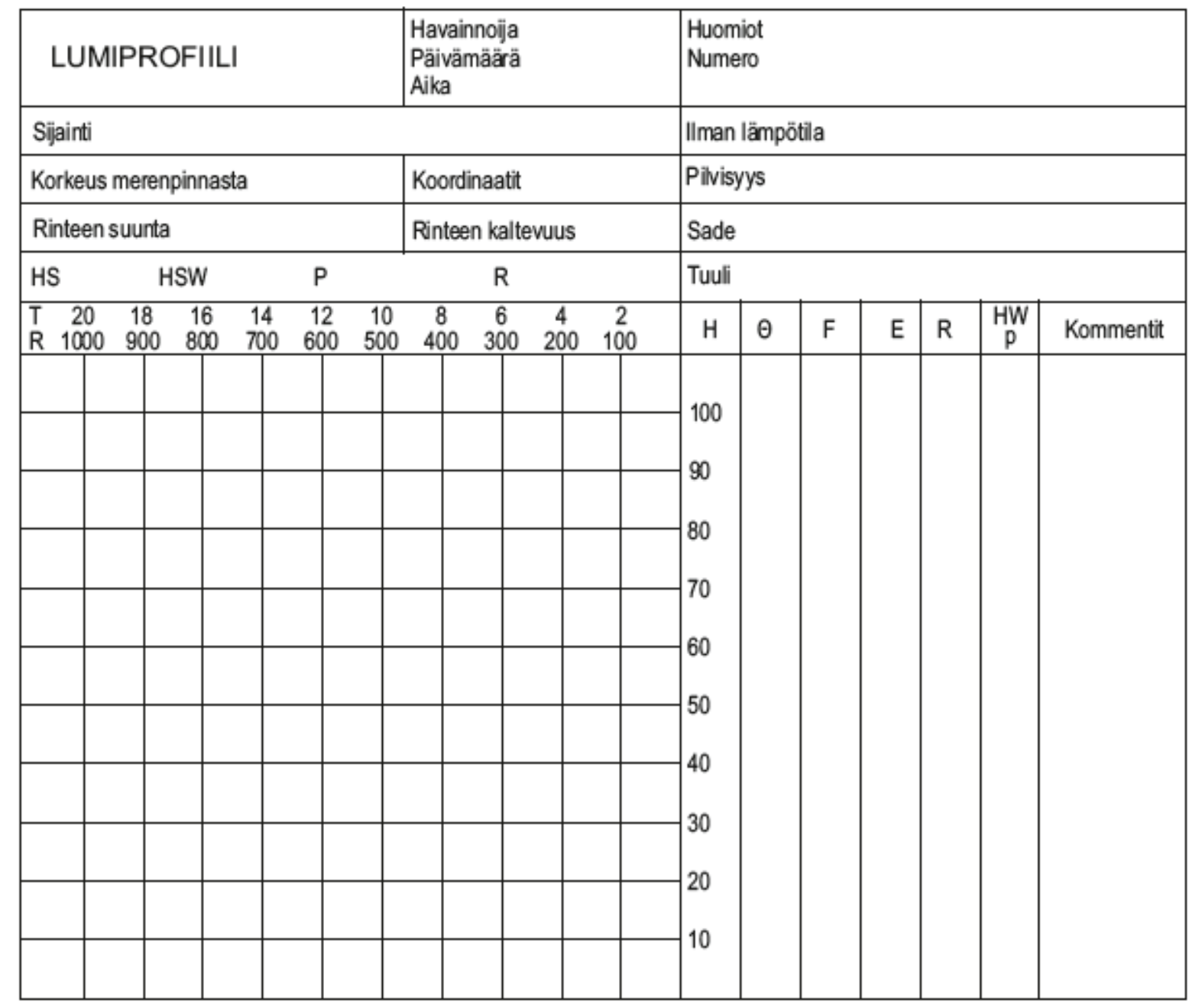

Kuva 4-16. Standardi lumikuopan havaintolomake. Kohtaan HS HSW P R tulevat lumen paksuus, vesiarvo, keskitiheys ja lujuus. Vasemmalla ruudukkoon piirretään lämpötilan ( $T$, ilman miinusmerkkiä) ja lujuuden tai tiheyden profilit sovelluksesta riippuen, oikealla sarakkeisiin tulevat syvyys $(\mathrm{H}, \mathrm{cm})$, nestemäisen veden määrä $(\theta)$, raemuoto $(F)$, raekoko $(E)$, lujuus $(R)$ ja vesiarvo/tiheys $(H W / P)$. Lähde; Fierz ym. (2009).

Lumipeite muuttuu ajan mukana sääoloista riippuen (kuva 4-16). Tätä kutsutaan lumipeitteen metamorfoosiksi. Mekaanisessa metamorfoosissa lumipeite painuu tiiviimmäksi oman painonsa alla ja tuulen vaikutuksesta. Lumen onkaloissa oleva vesihöyry on kyllästys-tilassa. Sen diffuusio ja massatalous muokkaavat merkittävästi lumipeitteen rakennetta. Vesihöyryä siirtyy kuperilta pinnoilta koveriin sublimaation-härmistymisen avulla, minkä ansiosta lu- 
mikiteet sidostuvat toisiinsa. Jos lumipeitteessä on pystysuuntainen lämpötilaero, vesihöyryä siirtyy lämpimistä kerroksista kylmempiin. Keväällä lumen rakenne muuttuu nopeasti sulamis-jäätymis-metamorfoosin avulla.

Lumen tiheys on Suomessa yleensä $200-300 \mathrm{~kg} \mathrm{~m}^{-3}$ (kuva 4-17). Silloin $100 \mathrm{~mm}$ lumikerros tuottaa sulaessaan $20-30 \mathrm{~mm}$ paksun vesipatjan. Tuore lumi voi olla tiheydeltään vain $100 \mathrm{~kg} \mathrm{~m}^{-3}$, ja laakealla tundralla tuuli pystyy pakkaamaan lunta noin $400 \mathrm{~kg} \mathrm{~m}^{-3}$ tiheyteen. Maaliskuussa lumipeite on paksuimmillaan ja vesiarvo on silloin keskimäärin 100-200 mm (kuva 4-17).

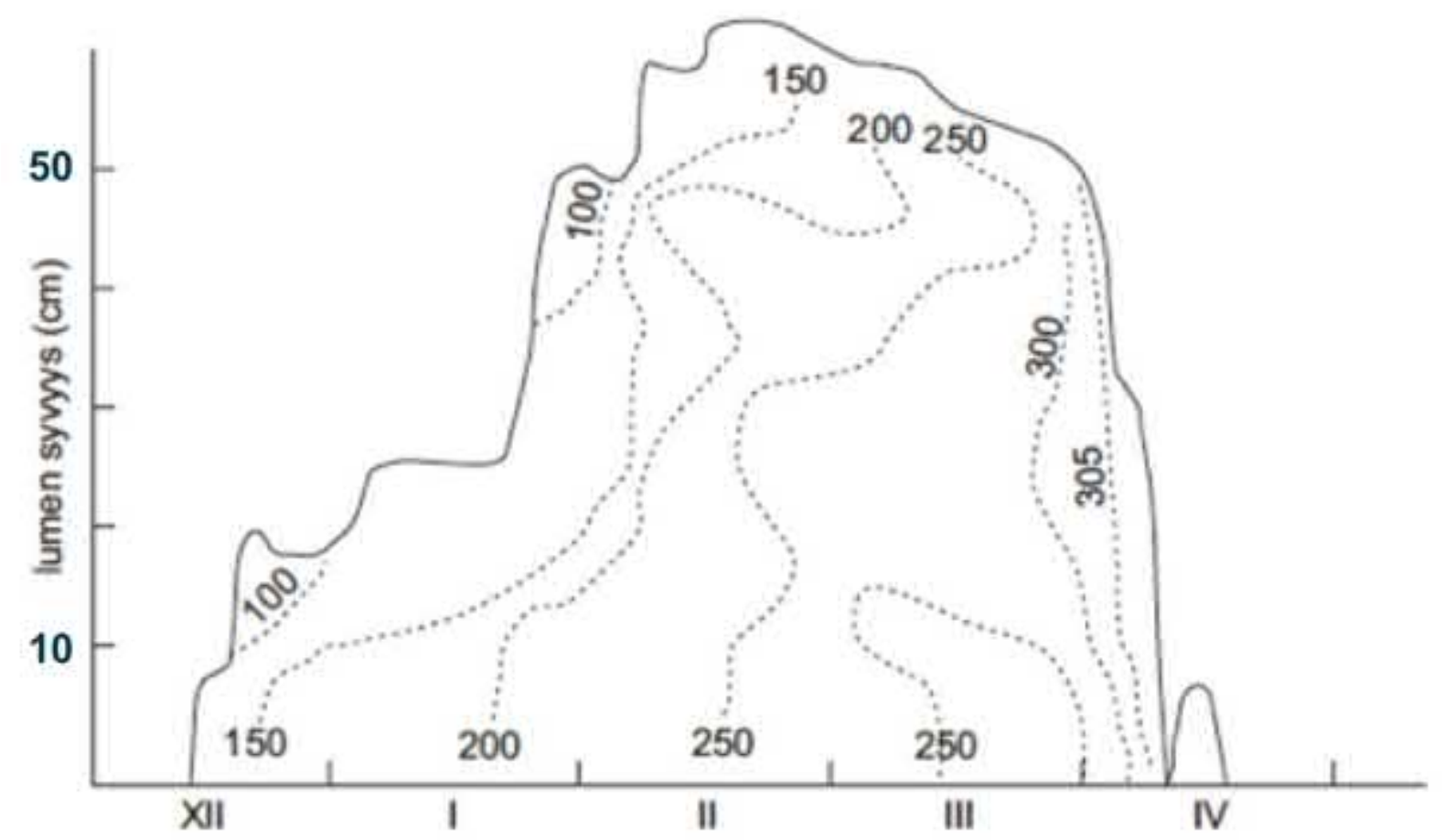

Kuva 4-17. Lumikerroksen paksuus $(\mathrm{cm})$ ja tiheys $\left(\mathrm{kg} \mathrm{m}^{-3}\right)$ joulukuusta 1968 huhtikuuhun 1969 EteläSuomessa. Lähde: Lemmelä (1970), muokattu.

\subsubsection{Lumen vesiarvo}

Lumipeitteen hydrologiassa tärkein elementti on lumen vesiarvo, joka kertoo. kuinka paljon vettä lumesta saataisiin sulattamalla ilman valunta- tai haihduntahäviöitä. Lumen vesiarvo ilmaistaan sitä vastaavan vesipatsaan korkeudella pinta-alayksikköä kohden

$$
h_{w}=\frac{\rho_{s}}{\rho} h_{s}
$$

missä $h_{s}$ on lumen paksuus. Vesiarvon yksikkönä käytetään yleensä millimetriä. Se kertoo, paljonko vesistöihin on odotettavissa vettä sulamiskauden aikana, ja sen kertymistä seurataankin valunnan ja tulvien ennusteita varten. Vesiarvon avulla voidaan myös arvioida rakenteiden lumikuormia. Vesiarvoa voidaan kartoittaa maastossa lumipuntarin avulla (kuva 4-18). Tämä koostuu lumeen painettavasta lieriöstä ja vaa'asta, jolta vesiarvo voidaan suoraan lukea.

Lumilinjat muodostavat lumen vesiarvon havaintoverkon rungon. Lumilinja käsittää 4 $\mathrm{km}$ pituisen lenkin, jossa tiheyden mittauksia tehdään 10 kappaletta ja lumen syvyyden mit- 
tauksia 80 kappaletta. Eri linjamittausten tulokset yhdistetään aluearvojen laskemista varten. Lumen vesiarvon mittaukset tehdään yleensä kaksi kertaa kuukaudessa.

Vesiarvo voidaan mitata lumiasemilla jatkuvasti lumityynyllä (Lemmelä 1970), jonka pääosan muodostaa suurehko (pinta-ala $10 \mathrm{~m}^{2}$ ), kumista valmistettu maan pinnalle ennen lumen karttumista asetettu litteä säiliö. Säiliö on täytetty jäätymättömällä nesteellä. Lumen vesiarvon muutoksista aiheutuva kuormituksen muutos voidaan rekisteröidä. Lumen vesiarvo voidaan kartoittaa kaukokartoitusmenetelmien avulla. Maaperästä tulevan gammasäteilyn absorptioon perustuvaa menetelmää on käytetty jo pitkän aikaa perustuen maaperän omaan luonnolliseen radioaktiivisuuteen. Gammasäteilyn absorptio riippuu lumipeitteen vesiarvosta, joka saadaan selville, jos tunnetaan säteilyn taso avomaan aikana. Suurenkin alueen lumen määrä voidaan näin inventoida lyhyessä ajassa. Menetelmää on käytetty Kemijoen vesistöalueessa lentokoneen avulla lumipeitteen ollessa paksuimmillaan (Kuittinen 1988).

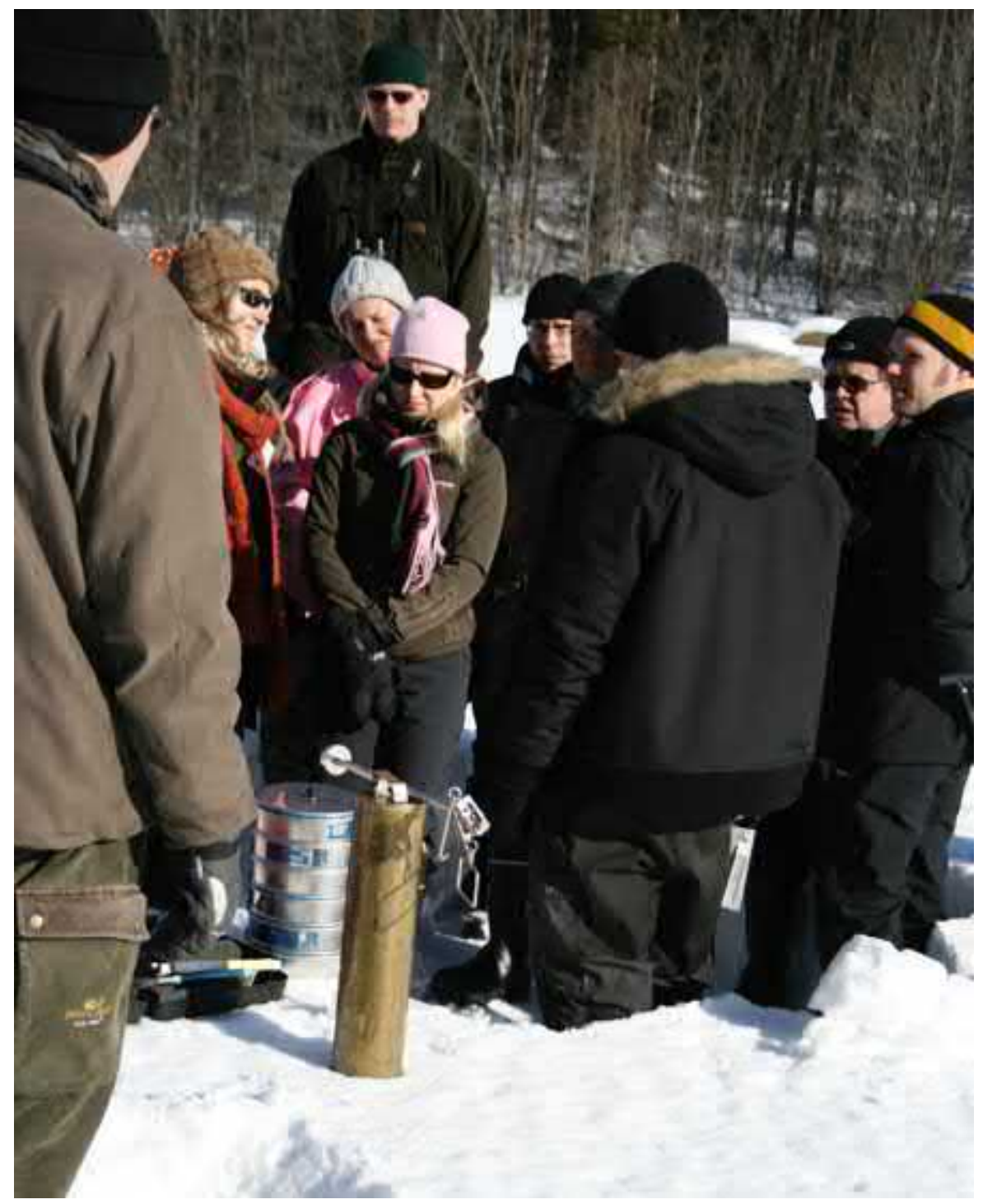

Kuva 4-18. Lumen vesiarvon mittaus lumipuntarin avulla. Jos mitataan myös lumen paksuus, saadaan lumipeitteen keskimääräinen tiheys. Kuvassa Lumen ja jään geofysiikan kurssin opiskelijoita Lammilla. Kuva: Matti Leppäranta

Esimerkki 4-5. Jos lunta sataa $50 \mathrm{~mm}$ ja lumen tiheys on $200 \mathrm{~kg} \mathrm{~m}^{-3}$, lumen vesiarvo on $10 \mathrm{~mm}$. Tällöin lumen massatiheys on $m=10 \mathrm{~kg} \mathrm{~m}^{-2}$, ja lumi kuormittaa alla olevaa pintaa $m g \approx 100$ Pa paineella. 
Satelliittikuvat ovat myös osoittautuneet soveltuviksi lumihavaintoiin (kuva 4-13). Ne kertovat ennen kaikkea lumipeitteen laajuuden, mutta vesiarvosta sen sijaan saadaan karkeampaa epäsuoraa tietoa, eikä satelliittikartoitus ole syrjäyttänyt maastossa tehtäviä perinteisiä lumimittauksia. Mikroaaltoinstrumentit ovat osoittautuneet soveltuvimmiksi lumipeitteen kartoitukseen. Ne kuvaavat maapallon pintaa säästä ja valaistuksesta riippumatta, ja niiden avulla on mahdollista saada havaintoja koko maapallosta päivittäin. Radiometrihavainnot yksinään ovat melko epätarkkoja, koska kaikkea havaintojen oikeaan tulkitsemiseen tarvittavaa tietoa on harvoin saatavilla. Kartoitusten tarkkuuden parantamiseksi satelliittihavaintoja voidaan yhdistää perinteisiin maastohavaintoihin.

Lumisateesta jää puuston ja muun kasvipeitteen pintaan interseptiota. Lumen määrä maan pinnalla riippuu tämän vuoksi myös puuston laadusta. Lumen karttumiseen vaikuttavat myös topografiset tekijät, tuuli ja lumisateen ominaisuudet (Kuusisto 1984). Lumen vesiarvon aluearvo lasketaan samalla tavalla kuin sateen aluearvo. Laskelmissa otetaan huomioon se, että lumen karttuminen erilaisiin metsiin ja aukeille paikoille on erilaista.

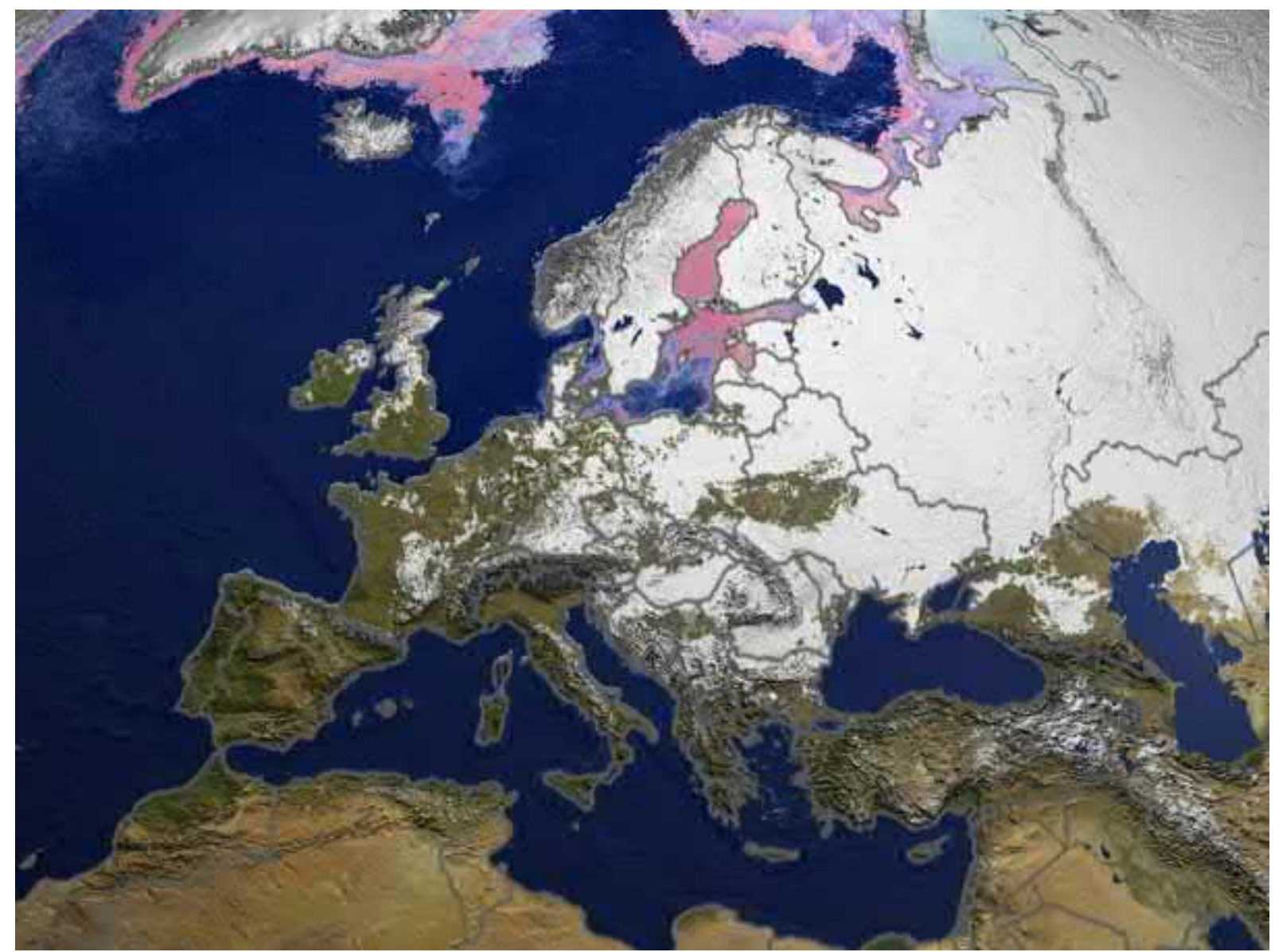

Kuva 4-19. Euroopan maa-alueiden lumitilanne tulkittuna satelliittihavainnoista 7.2.2003. Avomeri on tummansininen, jääpeitteisellä merellä värisävyt viittaavat jään pintalämpötilaan. @ NASA

Suurin lumen vesiarvo mitataan yleensä metsän aukoissa ja harvahkossa metsässä, missä tuulen vaikutus lumen kulkeutumiseen on vähäisempää. Lumipeitteen suurimman vesiarvon ajankohta keväällä merkitsee eräänlaista käännekohtaa talven kehittymisessä. Kuusiston (1984) mukaan kiinteillä mittausasemilla aukealla saatujen tulosten perusteella tämä ajankohta on Suomessa 20. maaliskuuta suunnilleen linjalla Pori-Kotka, 30. maaliskuuta linjalla 
Raahe-Pieksämäki-Kitee ja 10. huhtikuuta linjalla Kolari-Kuusamo. Viimeiseksi maksimi saavutetaan huhtikuun 20. päivänä Enontekiöllä.

Lumen häviäminen tapahtuu kahdella tavalla, sulamisen ja sublimaation kautta. Nämä riippuvat pinnan energiataseesta, ilman kosteudesta ja tuulesta. Sulaminen on meillä aina dominoiva, mutta joinakin keväinä merkittävä määrä lumesta on poistunut sublimaationa. Lumen ja ilman vuorovaikutus riippuu maastotyypistä, mistä alla muutama esimerkki.

\begin{tabular}{l|l} 
Maastotyyppi & Lumen ja ilmakehän vuorovaikutuksen piirteet \\
\hline Alue kokonaan metsää & $\begin{array}{l}\text { Lämpötilaerosta aiheutuva lämpösäteily puista ja } \\
\text { tiivistyminen. }\end{array}$ \\
Alueesta puolet metsää & Edellisen lisäksi vaikuttaa tuulen nopeus. \\
Aukea & Edellisten lisäksi ilmakehän lähettämä lämpösäteily.
\end{tabular}

Tärkeä tekijä on myös vesisade, joka tunkeutuessaan lumeen vie lämpöä sisään ja kostuttaa lumihangen, jolloin tulevan lyhytaaltoisen säteilyn heijastuskyky pienenee. Maaston laadusta on mainittava sen erityisesti sen kaltevuus. Etelärinteiltä lumi häviää nopeimmin.

Sulanut lumi on aluksi nestemäisenä vetenä sitoutunut pintavoimien vaikutuksesta lumivaipan jääkiteisiin. Vasta kun nestemäisen veden määrä ylittää 2-5 \% lumen tilavuudesta, veden pidäntäkapasiteetti lumessa ylittyy ja veden vapautuminen alkaa. Lumipeite katoaa keskimäärin siten, että huhtikuun lopussa Lounais-Suomi on lumeton, toukokuun puolessavälissä lumeton alue on linjan Oulu-Joensuu eteläpuolella ja toukokuun loppuun mennessä lumi on sulanut kaikkialta lukuun ottamatta tunturialueita.

Tässä luvussa on käsitelty hydrometeorologia ja lumihydrologia. Ilmakehä on nopeasti uudistuva vesivarasto, joka samalla toimii veden kiertokulussa veden kuljetus- ja puhdistusväylänä. Vesihöyryn tiheys on pienempi kuin ilman tiheys, ja siksi vesihöyry nousee ylöspäin maan pinnalta ja pääsee edelleen kulkeutumaan tuulten mukana. Kyllästystilan saavutettuaan vesihöyry alkaa tiivistyä nesteeksi tai härmistyä jääkiteiksi ja palaa takaisin sateena maan pintaan. Kylmänä vuodenaikana sadanta varastoituu lumipeitteeksi, mikä aiheuttaa valuntahuipun lumen sulamien aikana. Seuraavassa luvussa tarkastellaan järviä, jotka ovat merkittävä pintavesivarasto. Järvien diversiteetti on suuri ja ne muodostavat tärkeän habitaatin sekä virkistäytymiskohteen. 


\section{Järvet}

Tässä luvussa käsitellään järvien diversiteettiä, hydrologiaa ja veden laatua. Järvet toimivat vesistöjärjestelmien pintavesivarastoina, ja niiden tilan kehityksessä lämpötaloudella sekä kiertoliikkeellä on suuri merkitys. Sisältöön kuuluu myös limnologiaan liittyviä fysikaalisia kysymyksiä, erityisesti valaistus-olot viimeisessä kohdassa.

\subsection{Morfologia ja vesitase}

Järvi on maanpinnan painanne, jossa on vettä ja johon liittyy vesivarat uudistava valumaalue. Vesi tulee järveen sadantana ja valuntana ja poistuu haihduntana ja ulosvirtauksena. Eräät kuivien alueiden järvet ovat laskujoettomia. Alle $0,01 \mathrm{~km}^{2}: \mathrm{n}$ eli hehtaarin kokoisia altaita pidetään tavallisesti lampina (Järnefelt 1958) ja suurten järvien luokkaan otetaan pintaalaltaan vähintään $100 \mathrm{~km}^{2}$ :n kokoiset altaat. Nämä mitat vastaavat myös yleistä kielenkäyttöä. Suurimmat järvet ovat pinta-alaltaan $10^{4}-10^{5} \mathrm{~km}^{2}$.

Pienet lätäkötkin ovat hydrologisessa mielessä järviä. Pohjavesivalunnan ylläpitämät lammet ovat lähteitä. On sellaisiakin järviä, joiden valuntaa hallitsee pohjavesi, kuten Päijät-Hämeen Vesijärvi ja Hyvinkään Sääksjärvi. Suurin osa järvistä on makeavetisiä. Joitakin suolaisia järviä on kuitenkin olemassa, esimerkiksi murtovetinen Araljärvi ja hypersuolainen Kuollutmeri. Järvet jaotellaan syntyhistoriansa perusteella eri tyyppeihin (kuva 5-1):

- Tektonista alkuperää olevat järvet. Painanne on muodostunut peruskallioon siirrosten yhteydessä (Kaspianmeri, Tanganjikajärvi, Baikal).

- Jääkauden aiheuttamien muodostumien sulkemat järvet tai jääkauden kuluttamiin painanteisiin syntyneet järvet (useimmat Suomen järvet).

- Maankuoren tuliperäiseen toimintaan liittyviin painanteisiin syntyneet järvet (Shikotsujärvi, Hokkaido).

- Meteoriittikraattereihin muodostuneet järvet (Lappajärvi, Kaalin kraaterin järvi Saarenmaalla).

- Maanvyörymien padottamat järvet (Attabadjärvi Pakistanissa).

- Jäätiköiden reunalle sulamisvedestä muodostuvat epiglasiaaliset järvet (Mandronejärvi, Italia), jäätiköiden päällä olevat supraglasiaaliset järvet (Suvivesi, Kuningatar Maudin maa, Etelämanner) ja jäätiköiden alla olevat subglasiaaliset järvet (Vostokjärvi Etelämantereen keskustasanko).

- Tekojärvet (Lokan allas, Rybinskin allas Volgan vesistössä).

Järvien morfologiaa eli muotoa ja kokoa kuvataan useilla suureilla ja jakaumilla. Kokoa kuvataan pinta-alan $A$ ja tilavuuden $S$ avulla. Ne määrittävät myös keskisyvyyden $H$ siten, että $S=A H$. Järven horisontaalisiksi mitoiksi on kätevä ottaa karakteristinen halkaisija $L=\sqrt{A}$ sekä sen pienimmän suorakaidepeitteen sivut $L_{\max }$ ja $L_{\min }$. Järven muotoa voidaan kuvata sivujen pituussuhteella $\frac{L_{\max }}{L_{\min }}$ ja alasuhteella $\frac{A}{L_{\max } L_{\min }}$.
Horisontaalisia ominaisuuksia kuvataan rantojen muodolla ja saarisuudella. Järvialtaiden keskisyvyys on paljon pienempi kuin horisontaalinen pituusmitta: kun $L>$ $1 \mathrm{~km}$, on $H / L \sim 10^{-3}$.

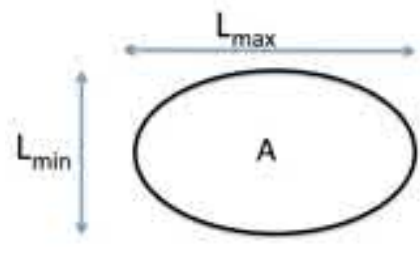



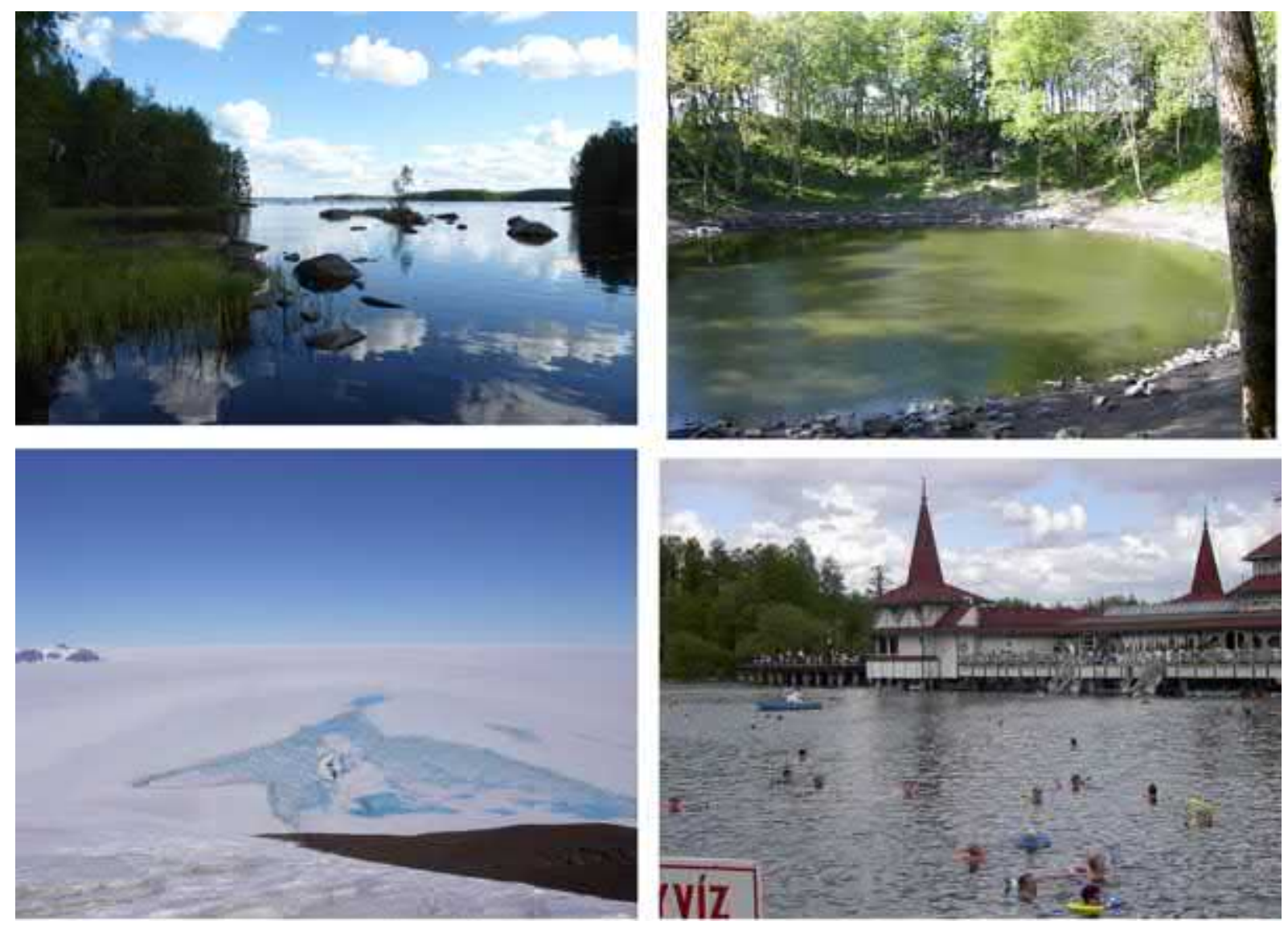

Kuva 5-1. Erilaisia järviä: Jääkauden painanteeseen muodostunut järvi (Puulavesi. Etelä-Savo), meteoriittikraatteriin muodostunut järvi (Kaalin kraatteri, Saarenmaa), supraglasiaalinen järvi (Suvivesi, Kuningatar Maudin maa, Etelämanner), ja geoterminen järvi (Hévizjärvi, Unkari). Kuvat: Matti Leppäranta.

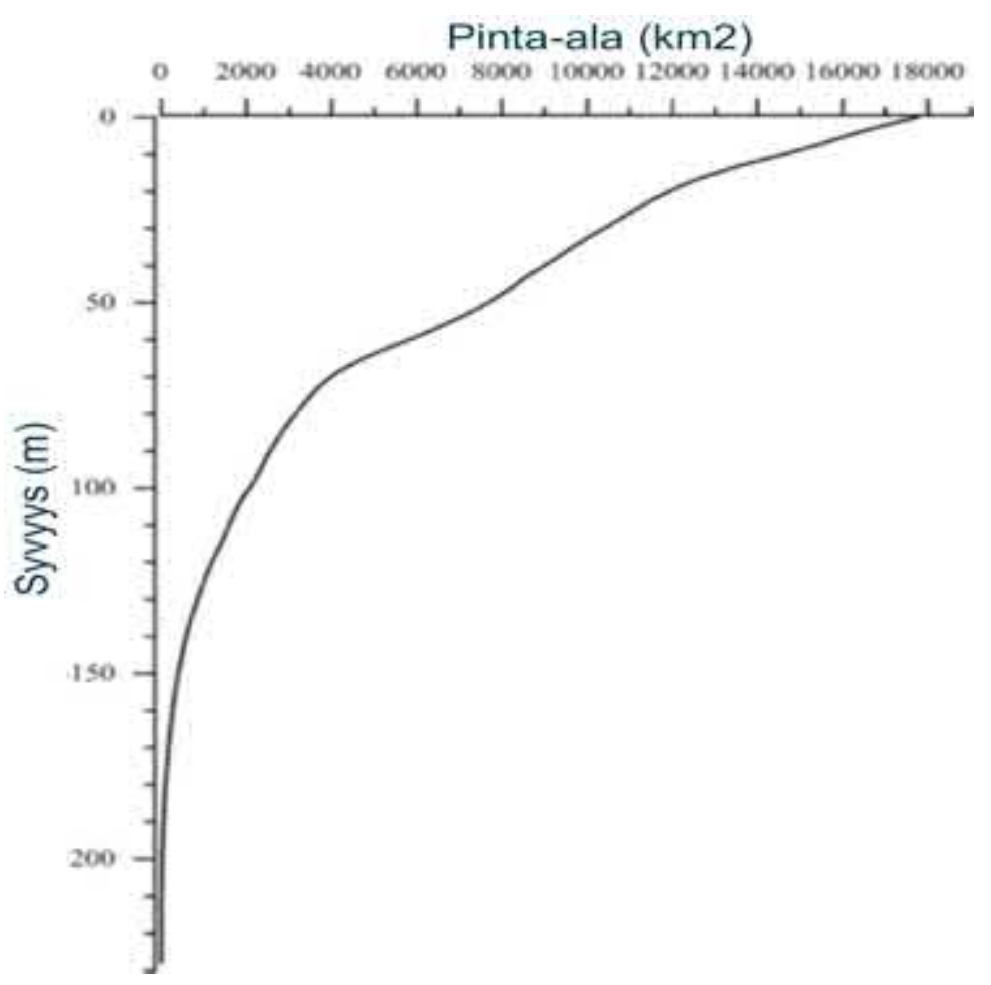

Kuva 5-2. Laatokan hypsografinen käyrä. Lähde: Naumenko (2013). 
Syvyysjakautumaa kuvaa hypsografinen käyrä (kuva 5-2)

$$
\Gamma(h)=\int_{A} I\left(h^{\prime}-h\right) d A,
$$

missä $h$ on syvyys, $h^{\prime}$ on syvyyttä kuvaava integrointimuuttuja, ja $I$ on Heaviside funktio, $I(z)=0(1)$, kun $z<0(z \geq 0)$. Hypsografinen käyrä pisteessä $h$ kuvaa siis kuinka suuri pinta-ala järvestä on syvempää kuin $h$. Siispä $\Gamma(0)=A, \Gamma\left(h_{\mathrm{md}}\right)=A / 2$, kun $h_{\mathrm{md}}$ on mediaanisyvyys, ja $\Gamma(h)=0$, kun $h>h_{\max }$.

Järvet ovat geometrisesti fraktaaleja. Nämä ovat tavanomaisia rakenteita maapallon morfologiassa. Fraktaalit ovat itsesimilaarisia eli niissä on mittaluokan muuttuessa toistuvia geometrisia ominaisuuksia, jolloin tietyt mittasuhteet säilyvät absoluuttisen mitan muuttuessa ${ }^{1}$. Fraktaalisuudesta seuraa, että järvien kaikki geometriset ominaisuudet eivät ole hyvin määriteltyjä, ja siksi sellaisiin suureisiin pitää suhtautua varauksella. Tällaisia suureita ovat rantaviivan pituus ja järvien lukumäärä. Näitä ilmaistessa pitää aina ilmoittaa mittauksessa käytetyn mittasauvan tai -ruudun koko.

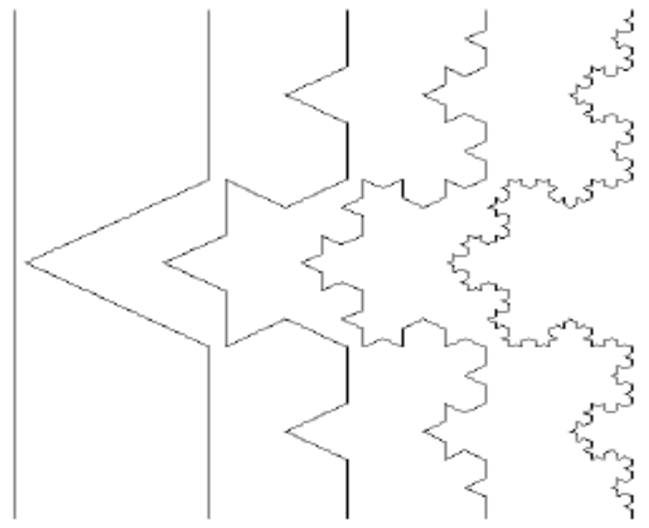

Rantaviiva on fraktaali, ja sen pituus $L$ voidaan mitata sopivan $\Delta$-pituisen mittasauvan avulla kartasta tai maastossa (maastossa vaikkapa askelmitalla). Tällöin $L=L(\Delta)$. Fraktaalin tapauksessa $L \rightarrow \infty$, kun $\Delta \rightarrow 0$. Tarkemmin

$$
L \propto \Delta^{D-1}, \text { kun } \Delta \rightarrow 0,
$$

missä parametri $D$ on rantaviivan fraktaalidimensio eli Hausdorffin dimensio, $1<D<2$. Se voidaan määrittää mittaamalla rantaviivan pituus eri mittasauvoilla ja sovittamalla tulokset yhtälöön (5.2). Vastaavasti alueen järvien määrä on fraktaalinen. Pinta-alaa $A$ suurempien järvien lukumäärä $n(A)$ noudattaa Korcak-Mandelbrotin yhtälöä

$$
n(A)=k\left(\frac{A}{A_{0}}\right)^{-D / 2}
$$

missä $k$ on jakauman parametri, $A_{0}=1 \mathrm{~km}^{2}$ ja $D \sim 1,5$. Järven pinta-ala on sen sijaan hyvin määritelty suure, sillä se on äärellinen ja sen arvo lähestyy äärellistä oikeata arvoa mittausruudukon.

\footnotetext{
${ }^{1}$ Itsesimilaarisuuden vuoksi fraktaaleja dokumentoitaessa kuvien avulla on mittakaava oltava aina kuvassa mukana.
} 
Esimerkki 5-1. Suomen järvien lukumäärä on useita kertoja yritetty arvioida. Mustonen (1986) esitti alla olevan jakauman.

\begin{tabular}{r|r} 
Järven ala $\left.\mathbf{( k m}^{\mathbf{2}}\right)$ & Lukumäärä \\
\hline$>100$ & 47 \\
$10-100$ & 279 \\
$1-10$ & 2263 \\
$0,1-1$ & 13114 \\
$0,01-0,1$ & 40309 \\
$0,0005-0,01$ & 131876 \\
Yhteensä (> 0,0005) & $\mathbf{1 8 7 8 8 8}$
\end{tabular}

Tämä noudattaa melko hyvin yhtälöä (5.3), kun $k=1535$, ja $D=1,32$. Näin ollen järvien lukumäärä riippuu voimakkaasti laskentakartan mittakaavasta. Järvien minimikoon puolittaminen kasvattaa järvien lukumäärää aina kertoimella 1,6. Zachris Topeliuksen termi tuhansien järvien maa on numeerisesti osuva, kun järven koon alarajaksi otetaan $0,5-1 \mathrm{~km}$.

Kaspianmeri on maailman suurin järvi, Itämereen verrattuna pinta-alaltaan suunnilleen yhtä suuri, mutta syvyydeltään kolminkertainen. Yli $10000 \mathrm{~km}^{2}$ :n laajuisia järviä on vähän. Suomen suurin järvi on Suur-Saimaa. Suurten järvien keskisyvyys on yleensä kymmenien metrien suuruusluokkaa. Hyvin syviä ovat Baikaljärvi ja Tanganjikajärvi. Kazakstanin Balkashjärvi on laaja mutta sangen matala.

\begin{tabular}{l|r|r|r} 
& Pinta-ala & Keskisyvyys & Suurin syvyys \\
\cline { 2 - 4 } & km $^{2}$ & $\mathbf{~ m}$ & $\mathbf{~ m}$ \\
\hline Kaspianmeri & 436000 & 182 & 946 \\
Yläjärvi & 83300 & 145 & 307 \\
Viktoriajärvi & 68800 & 40 & 79 \\
Huronjärvi & 59600 & 59 & 229 \\
Michiganjärvi & 58000 & 85 & 281 \\
Baikaljärvi & 31500 & 730 & 1741 \\
Tanganjikajärvi & 34000 & 572 & 1470 \\
Eriejärvi & 25700 & 19 & 64 \\
Ontariojärvi & 19000 & 86 & 244 \\
Laatokka & 18000 & 47 & 230 \\
Balkashjärvi & 17000 & 6 & 26 \\
Vostokjärvi & 14000 & 150 & 344 \\
Suur-Saimaa & 4400 & 17 & 82 \\
Päijänne & 1100 & 17 & 104 \\
Inarijärvi & 1100 & 14 & 100
\end{tabular}

Itämeren valuma-alueella on useita suuria järviä: Laatokka, Ääninen, Vänern, Saimaa ja Peipsijärvi (kuva 5-3). Itämeren allas muodosti 9000 vuotta sitten suuren, yli $400000 \mathrm{~km}^{2}$ laajuisen Ancylusjärven, ja maannousun seurauksena Perämeren odotetaan 500 - 1000 vuoden kuluttua erkanevan Itämerestä erilliseksi järveksi, jonka pinta-alaksi tulee noin 30000 km².

Hydrologiassa järvet toimivat puskurialtaina, veden väliaikaisina varastoina. Järven vesitaseyhtälö kirjoitetaan

$$
\frac{d V}{d t}=(P-E) A+R-O
$$


missä $R$ on järven valuma-alueelta tuleva valunta ja $O$ on ulosvirtaama, joka riippuu järven vedenkorkeudesta, ja siinä näkyy tulovirtaaman tasoittuminen ja viivästyminen (kuva 5-4). Vesitaseen muutokset heijastuvat vedenpinnan korkeuden vaihteluina (kuva 5-5). Koska $V=$ $A H$, voidaan järven tilavuuden muutos jakaa keskisyvyyden ja alan muutoksiin kaavalla

$$
\frac{d V}{d t}=H \frac{d A}{d t}+A \frac{d A}{d t}=\left(A+H \frac{d A}{d H}\right) \frac{d H}{d t} .
$$

Järven hypsografisesta käyrästä saadaan pinta-ala syvyyden funktiona. Jos $P A+R>E A+O$, niin $\frac{d H}{d t}>0$, ja vedenkorkeus kasvaa. Tällöin myös ulosvirtaus kasvaa, ja ennen pitkää päästään tasapainotilaan $\left(O^{\prime}, A\right)$, jossa $O^{\prime}=(P-E) A^{\prime}+R$ ja vesi on korkeimmillaan. Näin järvi kykenee varastoimaan vettä. Vastaavasti vedenkorkeuden alentuessa ulosvirtaus ja pinta-ala pienenevät.

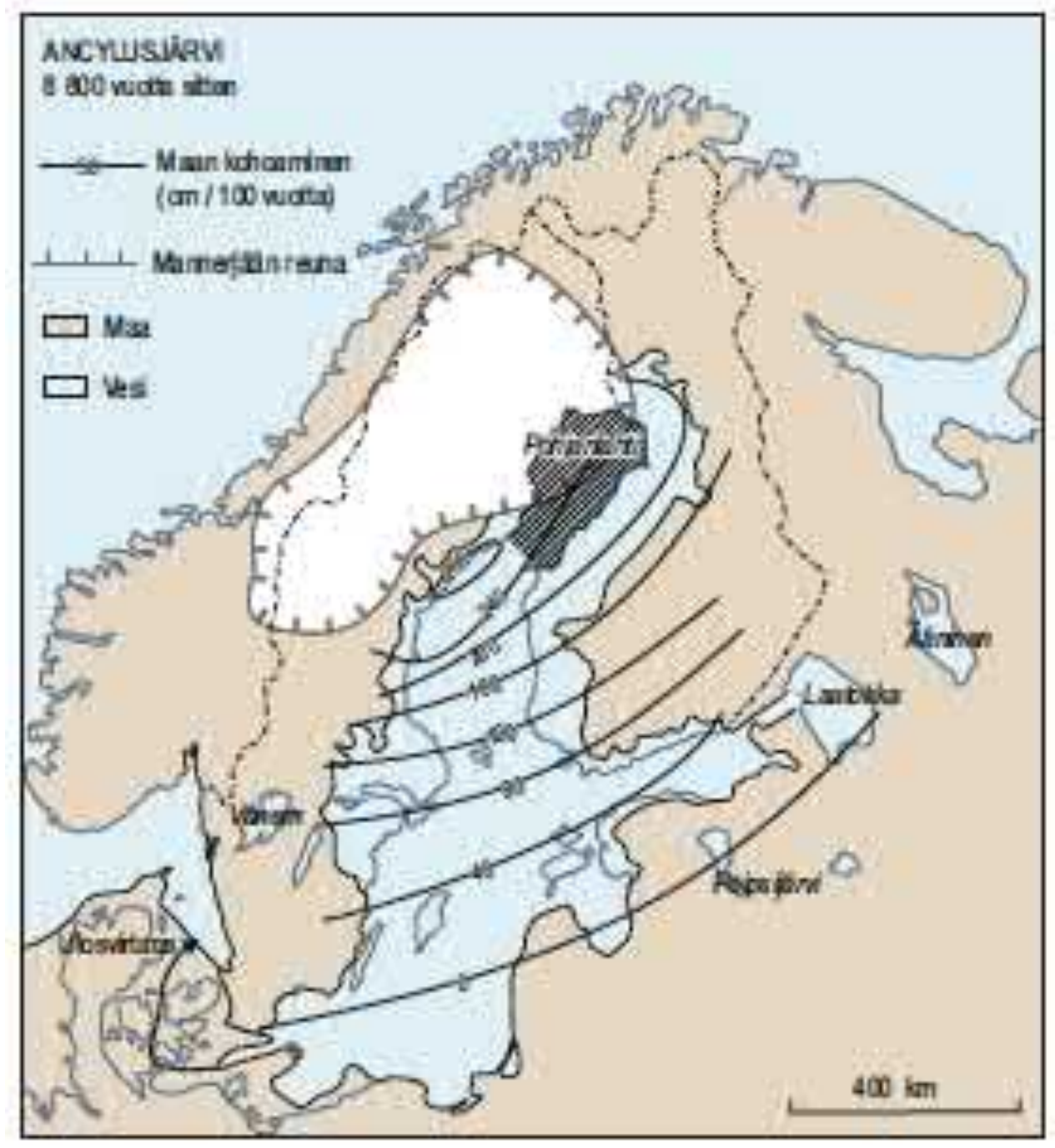

Kuva 5-3. Ancylusjärvi ja maannousu 8800 vuotta sitten sekä nykyiset Itämeren valuma-alueen suuret järvet. Perämerestä tulee 500 - 1000 vuoden kuluttua Euroopan suurin makeavetinen järvi.

Esimerkki 5-2. Araljärveen virtaavat joet Amu-Darja ja Syr-Darja, ja järvi on laskujoeton. Tasapaino vallitsee valunnan, sadannan ja haihdunnan välillä. Kun jokien vettä alettiin käyttää puuvillapeltojen kasteluun 1960-luvulla, Araljärven vesitase kääntyi negatiiviseksi ja vesivarasto alkoi vähentyä. Pinta- 
alan pienentyessä haihdunta pieneni, ja saavutettiin uusi tasapainotila $A=R /(E-P)$. Koska Araljärvellä oli laajat ja matalat ranta-alueet, järven pinta-ala supistui nopeasti. Nykyinen Araljärvi on jakaantunut kolmeen erilliseen osaan.
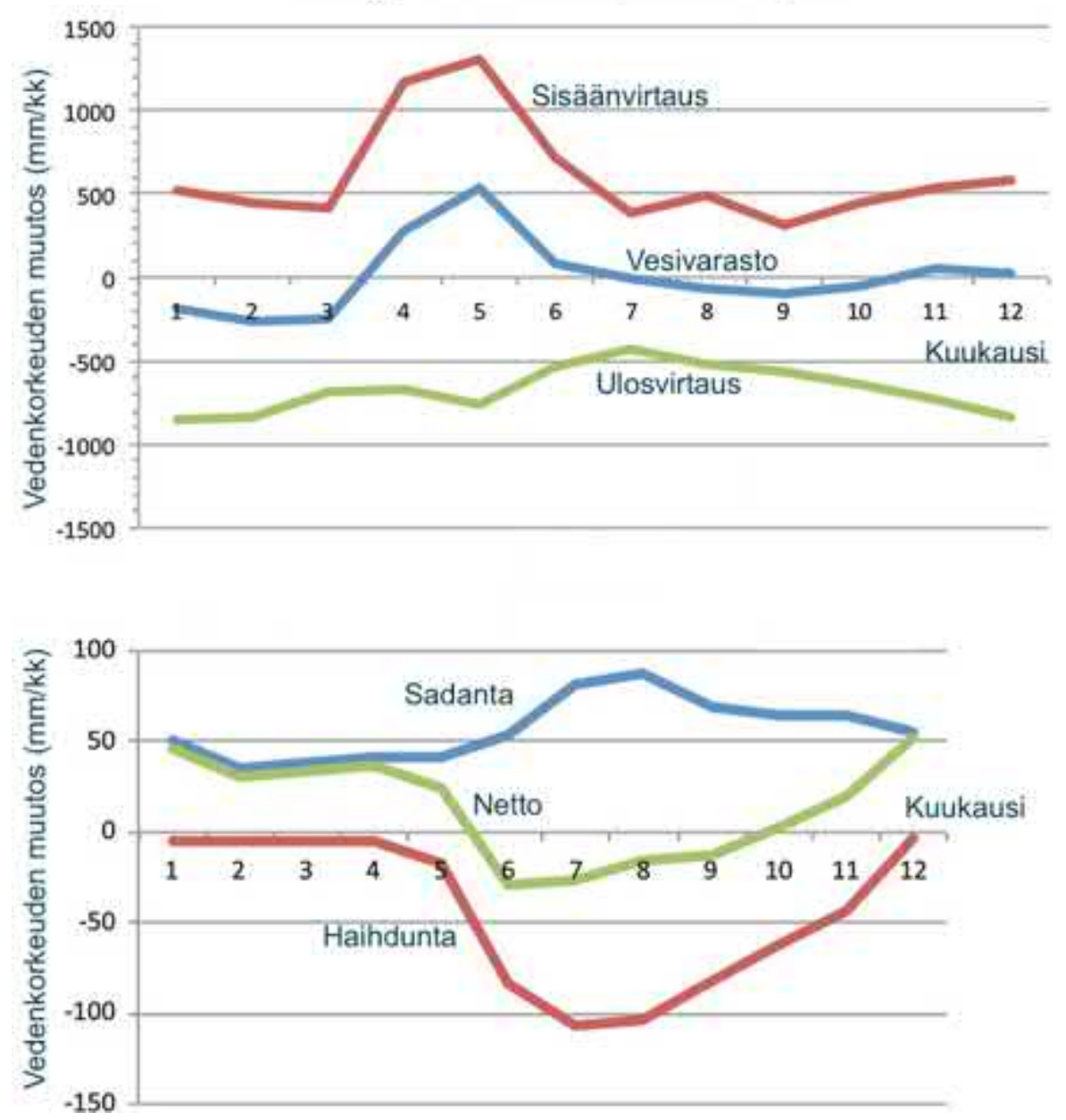

Kuva 5-4. Vanajaveden vesitalous. Ylemmässä kuvassa kuukausittainen vesitase, sisäänvirtaus (valunta) ja ulosvirtaus, alakuvassa sadanta, haihdunta ja niiden nettoarvo. Lähde: Jokiniemi (2011).

Esimerkki 5-3. a) Jos järvellä on pystysuorat rannat, pinta-ala pysyy vakiona, ja vesivaraston muutos heijastuu suoraan syvyyteen, $\frac{d V}{d t}=A \frac{d H}{d t}$.

b) Yleisemmin voidaan tarkastella kartion muotoista järveä, jonka syvyys on $H$, ja pinnan säde on $r$. Silloin on $A=\pi r^{2}, V=\frac{1}{3} \pi r^{2} H$ ja kartion reunan kaltevuus on $\beta=\frac{H}{r}$. Vesivaraston koon muuttuessa kaltevuus tässä säilyy, ja siis

$$
\frac{d r}{d t}=\frac{1}{\beta} \frac{d H}{d t}, \frac{d A}{d t}=\frac{2 \pi H}{\beta^{2}} \frac{d H}{d t}, \frac{d V}{d t}=\pi\left(\frac{H}{\beta}\right)^{2} \frac{d H}{d t}
$$

Jos $r=5 \mathrm{~km}$ ja $H=10 \mathrm{~m}$, rantaviivan pituus on $31,4 \mathrm{~km}, \beta=2 \cdot 10^{-3}, A=7,9 \cdot 10^{7} \mathrm{~m}^{2}$ ja $V=2,6 \cdot 10^{8} \mathrm{~m}^{3}$. Järven syvyyden kasvaessa yhden metrin sen säde kasvaa $500 \mathrm{~m}$. Pinta-ala kasvaa $1,6 \cdot 10^{7} \mathrm{~m}^{2}$ ja tilavuus kasvaa $0,79 \cdot 10^{8} \mathrm{~m}^{3}$. Rantaviiva pitenee $3,14 \mathrm{~km}$.

Järvien vaikutus vesistön hydrologiaan ilmenee ensisijaisesti niin, että järvet varastoaltaina tasoittavat virtaaman ja valunnan vaihteluita. Tämän seurauksena vesistön laskujokien alivirtaamat kasvavat ja ylivirtaamat vähenevät järvisyyden eli vesistön järvien suhteellisen alan 
myötä. Lisäksi haihdunta kasvaa järvisyyden mukana, ja siksi keskimääräinen ulosvirtaus vähenee järvisyyden kasvaessa. Tämä käy ilmi Hydrologian toimiston vuosikirjoista löytyvistä luvuista.

\begin{tabular}{l|r|r|r|r}
\cline { 2 - 5 } & \multicolumn{2}{|c|}{ Vesistön } & \multicolumn{1}{c}{} \\
\cline { 2 - 5 } & Ala & Järvisyys & MHQ/MNQ & Maksimi \\
\cline { 2 - 5 } & $\mathbf{k m}^{\mathbf{2}}$ & \% & & kuukausi \\
\hline Tainionkoski (Imatra) & 61300 & 20 & 1,49 & VII-VIII \\
Kemijärven luusua & 27300 & 2,4 & 18,6 & $\mathrm{~V}$
\end{tabular}

${ }^{\S} \mathrm{MHQ}$ on vuoden korkeimpien virtaamien keskiarvo ja MNQ matalimpien, näiden suhde kuvaa virtaamien vuotuista vaihtelua.

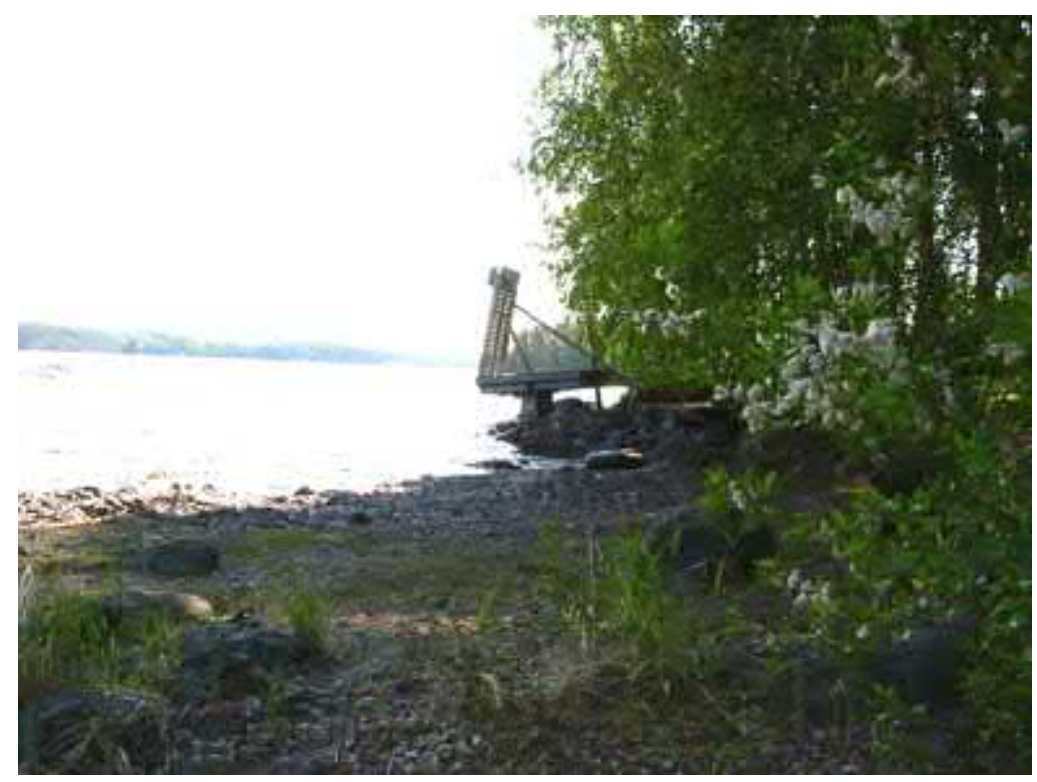

Kuva 5-5. Vesistöjen vedenkorkeusvaihtelut eivät Suomessa ole kovin suuria, mutta aiheuttavat kuitenkin ajoittain vilkastakin keskustelua. Kuvassa esimerkki Saimaalta Ruokolahden Salosaaresta aliveden aikaan. Esimerkiksi jaksolla 1984-2004 Saimaan vedenkorkeuden vaihteluväli oli 1,46 m. Kuva: Timo Huttula.

Järvien vesi on yleensä makeaa, suolaisuus on alle $0,5 \%$. Suomen järvissä suolaisuus on alle 0,1 \%o (eli liuenneitten aineiden pitoisuus alle $100 \mathrm{mg} \mathrm{L}^{-1}$ ). Näissä makeavetisissä järvissä suolaisuutta ei yleensä huomioida fysikaalisissa prosesseissa. Murtovesijärviä ovat esimerkiksi Balkashjärvi (suolaisuus 1-6 \%o) ja Kaspianmeri (suolaisuus 5-10 \%o), hypersuolaisia järviä Kuollutmeri (250 \%o) ja Don Juan-lampi Etelämantereella (440 \%o).

Viipymä on aika, jonka vesihiukkanen tai veden mukana liikkuva osanen viipyy järvessä. Vaihtumisaika tarkoittaa sitä aikaa, joka kuluu järven vesimassan täydelliseen vaihtumiseen. Näillä käsitteillä on merkitystä tarkasteltaessa päästöjen ja epäpuhtauksien etenemistä järvissä ja vesistöissä. Kun järven tilavuus $V$ säilyy samana, keskimääräinen viipymä voidaan arvioida sisään- tai ulosvirtaaman avulla käyttäen kaavaa

$$
T=\frac{V}{O+E}=\frac{V}{R+P} .
$$

Tämä ei ota huomioon järven kerrostuneisuutta. Veden vaihtuminen ei etene tasaisesti kaikkialla järvessä. Lahtiin ja syvänteisiin muodostuu kohtia, joissa veden vaihtuminen on heikompaa. Vaihtumisajan suuruusluokka on usein keskimääräisen viipymän suuruinen. 
Aineen vaihtumista tarkasteltaessa on tiedettävä sen konsentraatio järvessä sekä tulo- ja poistovirroissa. Haihdunnan mukana siirtyy vain vettä, mutta muutoin voidaan käyttää kaavojen (5.5 - 5.6) kanssa analogisia kaavoja. Niinpä puhtaasti valuman mukana tulevan aineksen viipymä on $T=\frac{C}{C_{R}} \cdot \frac{V}{R}=\frac{C}{C_{O}} \cdot \frac{V}{O}$, missä $c$ on konsentraatio, ja $C_{R}$ ja $c_{O}$ ovat valunnan ja ulosvirtaama konsentraatiot.

\subsection{Lämpötalous}

\subsubsection{Lämpötase}

Järviin siirtyy lämpöä pääasiassa pinnan kautta. Auringonsäteily lämmittää pintaa ja näkösyvyyden ${ }^{2}$ paksuista pintakerrosta, kun taas ilmakehän ja maanpinnan lämpösäteily sekä niiden välinen turbulenttinen lämmönvaihto ja sade kohdistuvat veden pintaan. Järvi vaihtaa lämpöä myös pohjansa kanssa. Lämpöä siirtyy pohjasedimenttiin kesällä ja vapautuu järviveteen talvella, millä on merkitystä erityisesti matalilla järvillä. Geotermisillä järvillä pohjasta tuleva lämmitys on merkittävä koko vuoden aikana. Lisäksi orgaanisen aineksen muodostuminen sitoo säteilyenergiaa, joka vapautuu aikanaan hapettumisen yhteydessä. Tämä energialähde on vähäinen muihin verrattuna, mutta talvella sillä voi olla merkitystä.

Maanpinnan energiatasetta käsiteltiin kohdassa 4.1 yleisesti. Järvien tapauksessa seuraavat tarkentavat seikat voidaan huomioida:

- Albedo on avovesikautena alhainen ja sangen stabiili, kun taas jääpeitteisenä kautena se vaihtelee paljon. Avovesikaudella käytetäänkin usein albedona 7 \%. Järveen tulevasta auringonsäteilystä noin puolet (infrapuna) jää pintaan alle $10 \mathrm{~cm}$ syvyyteen ja toinen puoli (valo) tunkeutuu veteen, jäähän tai lumeen näkösyvyyden paksuiseen kerrokseen (ks. kaava $4.12, \gamma \approx 1 / 2$ ). Näkösyvyys järvissämme on 0,5-10 m, jäässä se on 1-3 m ja lumessa $10-20 \mathrm{~cm}$.

- Lämpösäteilyn emissiokerroin on vesi-, jää- ja lumipinnalla $\varepsilon_{0} \approx 0,96-0,98$ (ks. kaava 4.12).

- Järven pinta on nestemäistä vettä tai jäätä, jolloin voidaan olettaa, että vesihöyryn paine on sen pinnalla kyllästyspisteessä (ks. kaavat 3.19 ja kuva 3-15). Turbulenttiset lämmön ja kosteuden vaihtokertoimet $C_{\mathrm{H}}$ ja $C_{\mathrm{E}}$ ovat tavallisesti $\approx 1,5 \cdot 10^{-3}$ (ks. kaavat 4.14).

- Sadevesi voi tunkeutua lumen ja hauraan jään sisään ja edesauttaa siellä lämpenemistä ja sulamista.

Säteilytase on järvien energiataseen päätekijä. Se on kesällä positiivinen ja talvella negatiivinen. Auringonsäteilyn vuorokautinen keskiarvo on Suomessa kesäpäivinä parhaimmillaan $300 \mathrm{~W} \mathrm{~m}^{-2}$ ja sydäntalvella lähellä nollaa. Koska ilmakehä emittoi heikommin lämpösäteilyä kuin järven pinta, ilmakehästä tulevan lämpösäteilyn ja järven pinnasta lähtevän lämpösäteilyn nettoarvo on vahvasti negatiivinen, suuruusluokaltaan $-50 \mathrm{~W} \mathrm{~m}^{-2}$. Tämä nettoarvo vaihtelee melko vähän vuodenaikojen mukana. Turbulenttinen lämmönvaihto tasoittaa ilman ja veden lämpötilaeroa niin, ettei tämä pääse kovin suureksi kasvamaan. Järven jäädyttyä lämpöä siirtyy ilmakehään, kun jää kasvaa ja jäätymisessä vapautuva lämpö johtuu jään

\footnotetext{
${ }^{2}$ Näkösyvyys tarkoittaa syvyyttä, johon asti valkoinen, $30 \mathrm{~cm}$ halkaisijaltaan oleva pyöreä levy, Secchi-levy, näkyy pinnalta.
} 
lävitse. Tämä johtuminen on sangen hidasta, minkä ansiosta jääkansi suojaa järven lämpövarastoa.

Järven lämpöenergia $\Theta$ riippuu lämpötilasta, jääpeitteestä ja tilavuudesta. Sen referenssinä $\Theta_{0}$ on kätevä käyttää nestemäisen veden energiaa lämpötilassa $0^{\circ} \mathrm{C}$. Tällöin

$$
\Theta=\Theta_{0}+\int_{V} \rho\left(c T-L_{f} J\right) d V
$$

missä $V$ on järven tilavuus, $L_{f}$ on jäätymislämpö, ja $J=0(1)$, jos vesihiukkasen $\mathrm{d} V$ olomuoto on nestemäinen (kiinteä). Energia koostuu siis aistittavasta lämmöstä ja jään tapauksessa lisäksi jäätymislämmöstä. Lämmönvaihto ilmakehän ja pohjasedimentin kanssa sekä auringonsäteily muuttavat lämpöenergiaa. Tämä muutos voidaan laskea kaavalla

$$
Q=\frac{d \Theta}{d t}=\int_{A_{0} \cup A_{b}}\left[Q_{0}+Q_{b}+(1-\alpha)\left(1-e^{-\kappa H}\right) \gamma Q_{s}\right] d A,
$$

missä $A_{0}$ ja $A_{b}$ ovat järven pinta ja pohja, $Q_{0}$ ja $Q_{b}$ ovat lämpövuot pintaan ja pohjaan, $H$ on syvyys, ja $\kappa$ on valon vaimenemiskerroin. Lämmönsiirto tapahtuu siis pinnoilta lukuun ottamatta auringonsäteilyä, joka lämmittää järveä myös sen sisältä. Kun $H>>\kappa^{-1}$, auringonsäteily jää järviveteen, muutoin osuus $(1-\alpha) \gamma e^{-\kappa H}$ läpäisee vesirungon ja imeytyy pohjasedimenttiin. Koska lämpö siirtyy järvissä pääasiassa vertikaalisuunnassa, tarkastellaan lämpötilan kehitystä usein vertikaaliprosessina (kuva 5-6).

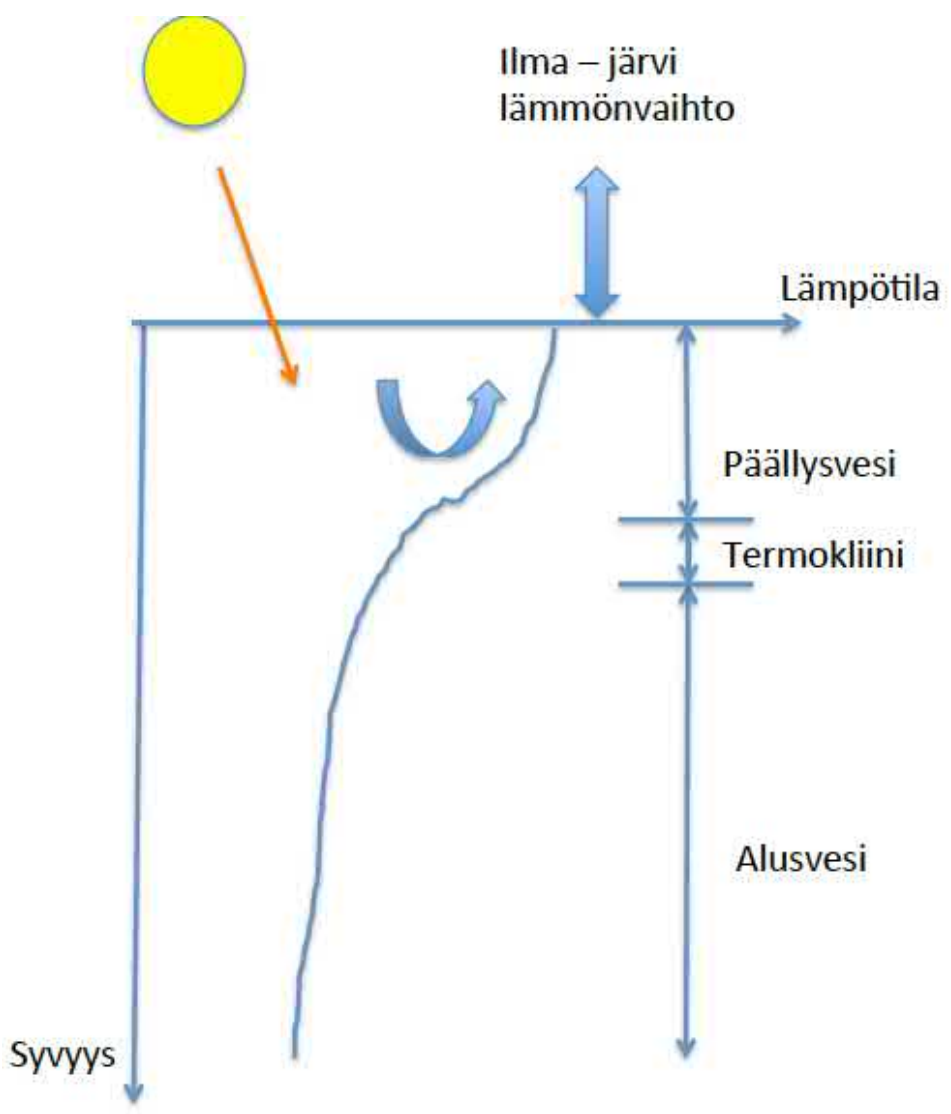

Esimerkki 5-4. Homogeenisen vesikerroksen lämpötila kasvaa nopeudella $\frac{Q}{\rho c H}$, missä $Q$ on lämmitysteho, ja $H$ on kerroksen paksuus. Jos $Q=100 \mathrm{~W} \mathrm{~m}^{-2}$, ja $H=10 \mathrm{~m}$, lämpötila kasvaa $0,21^{\circ} \mathrm{C}$ vuorokaudessa. 


\subsubsection{Kerrostuneisuus}

Vesirungon kerrostuneisuus viittaa sen pystysuoraan rakenteeseen. Kerrostuneisuuden laji tarkoittaa sitä, miten vesipartikkeli reagoi, jos sen asemaa hieman poikkeutetaan pystysuunnassa.

- jos partikkeli palaa takaisin alkuperäiseen asemaansa, kerrostuneisuus on tällä syvyydellä stabiili;

- jos partikkeli jää poikkeutettuun asemaansa, kerrostuneisuus on neutraali ja

- jos partikkeli jatkaa etääntymistään, kerrostuneisuus on epästabiili eli labiili.

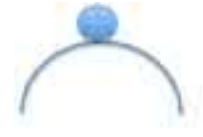

Labiili

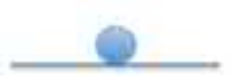

Neutraali

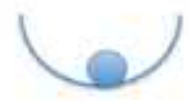

Stabiili

Analoginen tasapainotilanne on pallo (i) koveralla, (ii) tasaisella ja (iii) kuperalla alustalla. Periaatteessa kaikki tasapainotilat ovat järvien vesirungossa mahdollisia, mutta epästabiili tilanne on hyvin herkkä murtumaan. Lämpötilaluotaukset ovatkin osoittaneet, että kerrostuneisuus on käytännössä aina stabiili tai neutraali eli veden tiheys pysyy samana tai kasvaa syvemmälle mentäessä. Empiirisenä tuloksena voidaankin pitää seuraavaa: järvien vesirunko on neutraalisti tai stabiilisti kerrostunut. Tätä tietoa voidaan käyttää matemaattisessa mallintamisessa, mittausmenetelmien kontrollina ja havaintojen tarkastelussa.

Suolaisilla järvillä suolaisuuden vaikutus tiheyteen on myös huomioitava stabiliteettia tarkasteltaessa. Suolaisuuden kasvaessa tiheysmaksimin lämpötila vähenee. Jos suolaisuus on $0,1 \%$, niin $T_{\mathrm{m}} \approx 3,96{ }^{\circ} \mathrm{C}$. Jos se on $1 \%$, niin $T_{\mathrm{m}} \approx 3,72{ }^{\circ} \mathrm{C}$. Syvissä järvissä myös paineella on vesirungon stabiliteettiin vaikutusta.

Makeavetisen järven pintaveden jäähtyminen (kun $T>T_{\mathrm{m}}$ ) tai lämpeneminen ( $\mathrm{kun} T<T_{\mathrm{m}}$ ) kasvattaa pintaveden tiheyttä, ja silloin tapahtuu vertikaalista kiertoa eli konvektiota syvyyteen, jossa lämpötila vastaa jäähtyneen pintaveden lämpötilaa. Kun pintavesi saavuttaa tiheysmaksimin lämpötilan, koko vesirunko sekoittuu pinnasta pohjaan. Tätä sanotaan täyskierroksi, ja sen aikana vesi tulee homotermiseksi. Järvet jaetaan täyskiertojen perusteella.

\begin{tabular}{l|l|l} 
Tyyppi & Kierto & Alue \\
\hline Amiktinen & ei ole & $\begin{array}{l}\text { polaarialueilla, kun lämpötila aina alle } 4{ }^{\circ} \mathrm{C} \\
\text { tropiikki, kun lämpötila aina yli } 4{ }^{\circ} \mathrm{C}\end{array}$ \\
\hline Oligomiktinen & harvoin & polaarialueet, tropiikki \\
\hline $\begin{array}{l}\text { Kylmä } \\
\text { monomiktinen }\end{array}$ & yksi vuodessa & polaarialueilla, lämpötila käy yli $4{ }^{\circ} \mathrm{C}: s s a$ \\
\hline $\begin{array}{l}\text { Lämmin } \\
\text { monomiktinen }\end{array}$ & yksi vuodessa & subtropiikki, lämpötila käy alle $4{ }^{\circ} \mathrm{C}: \mathrm{n}$ \\
\hline Dimiktinen & $\begin{array}{l}\text { kaksi } \\
\text { vuodessa }\end{array}$ & lauhkea vyöhyke, kuten Suomi \\
\hline Polymiktinen & usea vuodessa & $\begin{array}{l}\text { heikko kerrostuneisuus, tuuli voi sekoittaa järven, } \\
\text { korkeat leveysasteet }\end{array}$ \\
\hline Meromiktinen & ei ole & $\begin{array}{l}\text { suolaisuus kerrostaa järven vahvasti eivätkä } \\
\text { lämpötilaerot murra rakennetta }\end{array}$
\end{tabular}

Suomen ilmastovyöhykkeen järvissä tapahtuu kaksi täyskiertoa, keväällä ja syksyllä, ja ne siis ovat dimiktisiä. Monomiktiset järvet sijaitsevat polaarisella tai subtrooppisella ilmastovyöhykkeellä. Ne sekoittuvat kerran vuodessa, kun vesi on tiheimmillään, eikä niiden läm-pötila välttämättä tavoita $4{ }^{\circ} \mathrm{C}$ lämpötilaa. Oligomiktisen järven kierto tapahtuu harvoin, esi- 
merkiksi erittäin kovan tuulen tai kylmän sadeveden vaikutuksesta. Meromiktisistä järvistä esimerkkeinä ovat merenlahdet, joissa jokien tuoma vähäsuolainen kevyt vesi sijaitsee pinnalla ja syvällä suolaisempi merivesi, ja suolajärvet. Jos suolaisuuden kerrostuneisuus on tarpeeksi voimakas, ei pintavesi jäähtyessäänkään muutu painavammaksi kuin pohjalla oleva vesi ja kerrostuneisuudesta tulee pysyvä. Suomessa on myös joitakin pieniä meromiktisiä järviä, kuten Lammin Lovojärvi ja Kolarin Pakasaivo, joihin on pitkän ajan kuluessa muodostunut pintavettä merkittävästi suolaisempi alusvesi.

Kerrostuneessa makeavetisessä järvessä on yleensä jossain määrin homoterminen yläkerros eli päällysvesi (epilimnium), alakerros eli alusvesi (hypolimnium) ja niiden välissä oleva termokliini (metalimnium), jossa lämpötila muuttuu jyrkästi lyhyen matkan aikana. Dimiktisellä vyöhykkeellä järvien vesirungon kerrostuneisuudessa voidaan erottaa kolme eri tyyppiä (kuva 5-7).

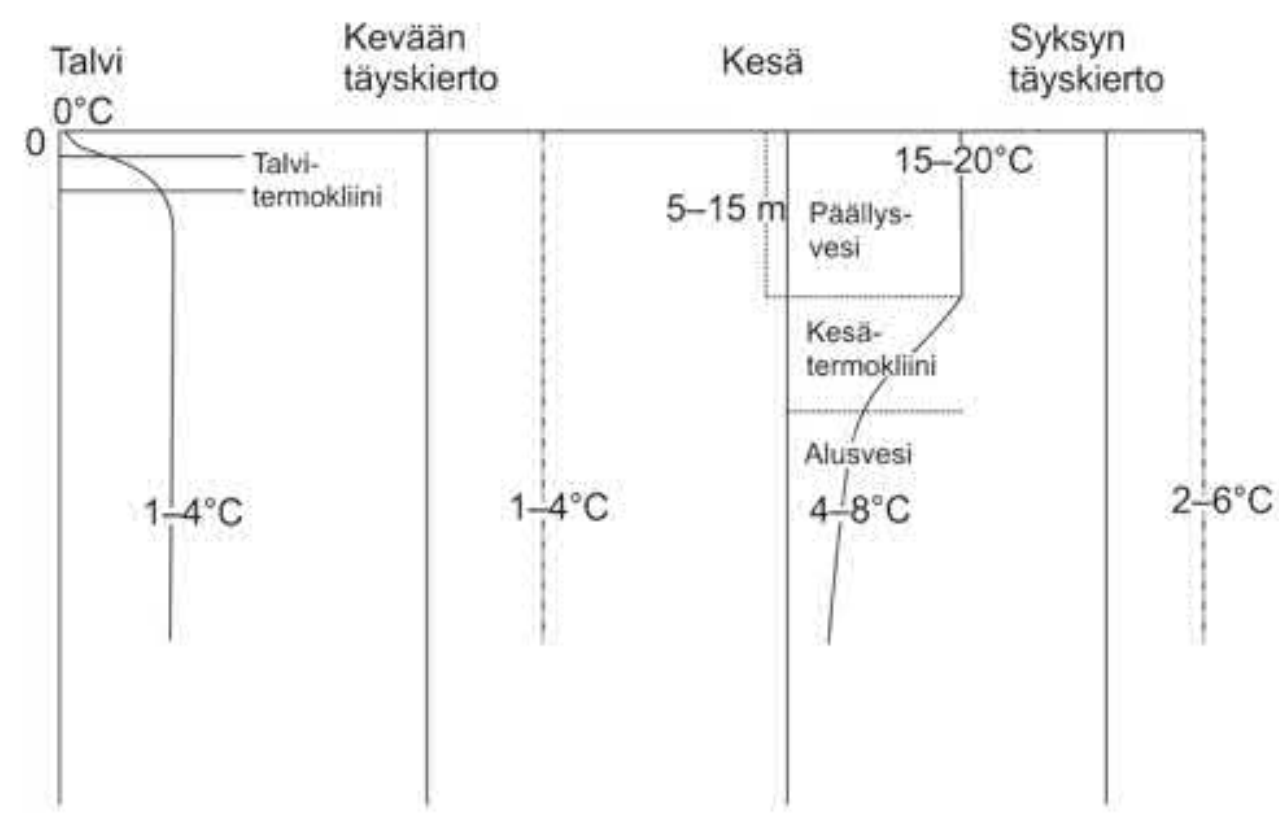

Kuva 5-7. Järven lämpötilakerrostuneisuus Suomen oloissa. Kuvassa esitetyt lämpötilat ovat suuntaa an-tavia, ne vaihtelevat riippuen järven syvyyssuhteista ja avoimuudesta.

Kesäkerrostuneisuuden aikana vesi sekoittuu tuulen vaikutuksesta 5-20 m syvyyteen järven morfologiasta ja sääoloista riippuen. Päällysvesi on alttiina tuulen sekoittavalle vaikutukselle ja lämpötila muuttuu vertikaalisuunnassa vain vähän. Termokliinin alapuolella sijaitsee verrattain tasalämpöinen ja viileä alusvesi, jossa sekoittuminen on vähäistä ja riippuu järven virtausoloista.

Talvikerrostuneisuuden aikana järvessä on jääpeite, joka eliminoi tuulen vaikutuksen pois ja pitää veden lämpötilan heti jään alla jäätymispisteessä. Matalissa järvissä pohjakerros lämpenee talvella pohjaan kesällä varastoituneen lämpöenergian vaikutuksesta, ja keväällä vesi lämpenee jään lävitse tunkeutuvan auringonsäteilyn avulla. Alusvesi on $0-4{ }^{\circ} \mathrm{C}$ :een lämpöistä järven syvyydestä ja syksyn täyskierron kulusta riippuen, ja termokliini on ylempänä kuin kesällä.

Syksyn ja kevään täyskierroissa vesimassa saavuttaa $4{ }^{\circ} \mathrm{C}$ lämpötilan. Tätä lähestyttäessä termokliini heikkenee ja lopulta murtuu, jolloin konvektio ulottuu pohjaan ja koko vesirunko sekoittuu. Lähellä $4{ }^{\circ} \mathrm{C}$ lämpötilaa tiheyserot ovat hyvin pieniä, ja mekaaninen tuulen ja aallokon aiheuttama sekoittuminen pääsee tunkeutumaan helposti syvälle. Tuulisina syksyinä 
voi sekoittuminen jatkua aina $1{ }^{\circ} \mathrm{C}$ :een lämpötilan alapuolelle, jolloin talveksi järveen varastoituu kylmää ja happirikasta vettä. Kevään täyskierto alkaa jään sulamisen aikana ja jopa ennen sulamista auringon lämmittäessä pintavettä paljaan jään läpi. Tämän lämmityksen takia pian jäänlähdön jälkeen veden lämpötila nousee $4{ }^{\circ} \mathrm{C}$ :een yläpuolella, ja kevätkierto voi jäädä lyhyeksi. Täyskierron ansiosta syvän veden happivarastot uusiutuvat. Ellei järveä voida "tuulettaa" riittävän usein, happi voi loppua syvänteistä. Suomessa erityisesti pitkä jäätalvi ja ravinteiset vedet ovat happitalouden kannalta ongelmallisia.

Pohjaveden virtaus järveen saattaa vielä nostaa alusveden lämpötilaa. Vuotuiseen vaihteluun liittyvän kerrostuneisuuden lisäksi järvissä esiintyy myös vuorokausivaihtelun aiheuttamaa kerrostuneisuutta sekä ajoittain sääolojen kehitykseen liittyviä 5-10 vuorokauden pituisia vaihteluita.

\subsubsection{Mekaaninen sekoittuminen}

Konvektion lisäksi neutraalisti tai stabiilisti kerrostuneessa vesirungossa voi tapahtua mekaanista sekoittumista, mikäli energiaa on saatavissa vesirungon potentiaalienergian kasvattamiseksi. Yleensä taustatekijänä on tuuli tai aallokko, mutta niiden lisäksi järven sisäiset aallot ${ }^{3}$ voivat murtuessaan sekoittaa syvempiä vesimassoja. Mekaanista sekoittumista kutsutaan myös pakotetuksi konvektioksi ja turbulenttiseksi sekoittumiseksi.

Mekaaninen sekoittuminen tarvitsee energiaa nostaakseen vesirungon painopisteen korkeammalle. Tarvittava energia kasvaa nopeasti sekoittuneen pintakerroksen syvyyden mukana. Siksi pintakerroksen alle muodostuu termokliini. Vesihiukkasen potentiaalienergia saadaan kertomalla sen massa painovoiman kiihtyvyydellä ja syvyydellä. Syvyyden referenssi on kätevä sijoittaa järven pintaan $(z=0)$, jolloin hiukkasen potentiaalienergia on $d E_{p}=$ $-\rho g z d V$ (miinusmerkki aiheutuu siitä, että syvyys kasvaa alaspäin). Jos järvi on ker-rostunut horisontaalisesti niin, että tiheys riippuu vain syvyydestä, potentiaalienergia pinta-alayksikköä kohden on

$$
E_{p}=-\frac{g}{A_{0}} \int_{0}^{h} \rho(z) A(z) z d z
$$

missä $A(z)$ on syvyyttä $z$ vastaava järven pinta-ala ja $A_{0}=A(0)$. Jos tiheyden muutokset ovat pieniä ja jos lämpötila on paljon korkeampi kuin $4{ }^{\circ} \mathrm{C}$, niin veden tiheyden voidaan olettaa riippuvan lineaarisesti lämpötilasta. Silloin järven pinnankorkeus ei muutu järven sisäisten lämpötilamuutosten yhteydessä.

Oletetaan järvi ensin sekoittuneeksi ja sen lämpötilaksi $T_{1}$ sekä tiheydeksi $\rho_{1}$. Järveen ilmakehästä ja auringosta tuotu lämpöenergia lämmittää aluksi ylimmän pintakerroksen. Tuulen vaikutuksesta lämpö sekoittuu syvemmälle, ja järveen muodostuu vertikaalinen lämpötilajakautuma $T=T(z)$ ja edelleen vertikaalinen tiheysjakautuma $\rho=\rho(z)$. Järven potentiaalienergia kasvaa määrällä

$$
\delta E_{p}=\frac{g}{A_{0}} \int_{0}^{h}\left(\rho-\rho_{1}\right) A z d z
$$

Tuuli aiheuttaa järven pintaan horisontaalisen leikkausvoiman $\tau_{a}$, joka siirtää tuulen liikeenergiaa veteen neliöllisen vastuslain mukaan:

\footnotetext{
${ }^{3}$ Sisäisiä aaltoja voi muodostua esimerkiksi termokliiniin, jossa ne rannan lähellä saattavat murtua ja sekoittaa vesikerroksia.
} 


$$
\tau_{a}=\rho_{a} C_{a} U_{a}^{2}
$$

missä $U_{\mathrm{a}}$ on tuulen nopeus, $\rho_{\mathrm{a}}$ on ilman tiheys, ja $C_{a} \approx 1,5 \cdot 10^{-3}$ on ilma-vesi-rajapinnan vastuskerroin. Tämän leikkausvoiman tekemä työ on $\tau_{a} U_{w / a}$, missä $U_{w / a}$ on pintavirtauksen projektio tuulen suuntaan, ja se syötetään virtauksiin, aaltoihin sekä potentiaalienergian kasvattamiseen. Kun pintavirtaus ja tuuli kulkevat samaan suuntaan, $\tau_{a} U_{w / a} \propto U_{a}^{3}$ eli leikkausvoiman tekemä työ on verrannollinen tuulen nopeuden kolmanteen potenssiin. Koska potentiaalienergian kasvu syventää termokliinia, tämänkin kasvunopeus on verrannollinen tuulen nopeuden kolmanteen potenssiin.

Esimerkki 5-5. Lähdetään tilanteesta, jossa $10 \mathrm{~m}$ syvä lieriön muotoinen järvi on $T_{0}=10{ }^{\circ} \mathrm{C}$ lämpötilassa. Ensin $h_{1}=1 \mathrm{~m}$ syvä pintakerros lämmitetään $T_{1}=15{ }^{\circ} \mathrm{C}$ lämpötilaan, ja sen jälkeen tuuli sekoittaa veden $h_{2}=2 \mathrm{~m}$ syvyyteen. Lopputilassa yläkerroksen lämpötila on $T_{2}=12,5{ }^{\circ} \mathrm{C}$. Veden tiheys on 999,702 $\mathrm{kg} \mathrm{m}^{-3}$ lämpötilassa $T_{0}, 999,102 \mathrm{~kg} \mathrm{~m}^{-3}$ lämpötilassa $T_{1}$, ja $999,441 \mathrm{~kg} \mathrm{~m}^{-3}$ lämpötilassa $T_{2}$.

Pintakerroksen lämmetessä sen lämpöenergia kasvaa määrän $\rho c\left(T_{1}-T_{0}\right) h_{1}=2,1 \cdot 10^{7} \mathrm{~J} \mathrm{~m}^{-2}$. Potentiaalienergiaa määrän

$$
\delta E_{p}=g \int_{0}^{2 \mathrm{~m}}\left(\rho_{2}-\rho\right) z d z=g\left[\frac{1}{2}\left(\rho_{2}-\rho_{0}\right)+\frac{3}{2}\left(\rho_{2}-\rho_{1}\right)\right] \mathrm{m}^{2}=3,71 \mathrm{~J} \mathrm{~m}^{-2} .
$$

Jos tuulen nopeus on $5 \mathrm{~m} \mathrm{~s}^{-1}$, ja pintavirtaus kulkee tuulen suuntaan nopeudella $10 \mathrm{~cm} \mathrm{~s}^{-1}(2 \%$ tuulen nopeudesta), niin tuulityö on $0,0045 \mathrm{~J} \mathrm{~m}^{-2} \mathrm{~s}^{-1}$. Jos kaikki tuulityö kuluisi termokliinin syventämiseen, sekoittuminen tapahtuisi 14 minuutissa, mutta tuulityötä kuluu myös aaltoihin ja virtauksiin.

Vesirungon stabiliteetti ilmoittaa järven pinnan pinta-alayksikköä kohden sen energian, joka tarvitaan veden täydelliseen sekoittamiseen. Sekoittuneen järven stabiliteetti on nolla. Mitä voimakkaammin järvi on kerrostunut, sitä suurempi on stabiliteetti ja sitä enemmän mekaanista energiaa tarvitaan sekoittamiseen.

\subsection{Järvien talvi}

\subsubsection{Jään esiintyminen ja rakenne}

Boreaalisella vyöhykkeellä, tundralla ja korkealla vuoristoissa järvet jäätyvät, kun talvella lämpötila on joitakin viikkoja tai kauemmin jäätymispisteen alapuolella. Poikkeuksina voivat olla geotermiset, suolaiset ja syvät järvet. Suomen järvet ovat vuosittain jäässä 4-7 kuukauden ajan. Jää muodostuu yleensä marras-joulukuussa ja sulaa huhti-toukokuussa.

Järvien jääpeite koostuu kolmesta kerroksesta: lumi, kohvajää ja teräsjää. Teräsjää kasvaa alapinnasta järviveteen, ja kohvajää kasvaa yläpinnasta vettyneeseen lumeen. Teräsjää on suurikiteistä ja kirkasta, kun taas kohvajää on hienokiteistä ja sisältämiensä ilmakuplien takia sameaa. Nämä kerrokset on helppo tunnistaa jäästä sahatusta näytteestä (kuva 5-8). Teräsjäätä on 10-100 \% jääkannesta riippuen lumikertymän määrästä ja ajoituksesta, keskimäärin sitä on ${ }^{2} / 3$. Jää kelluu Arkhimedeen lain mukaan eli paino = noste:

$$
\rho_{i} h_{i}+\rho_{s} h_{s}=\rho_{w} h_{w}
$$

missä $\rho_{i}$ on jään tiheys, $h_{i}$ on jään paksuus, $\rho_{s}$ on lumen tiheys, $h_{s}$ on lumen paksuus, $\rho_{w}$ on veden tiheys ja $h_{w}$ on jääkannesta veden alla oleva osa. Lumen tiheys vaihtelee pakkaustiheyden mukaan laajasti, yleensä se on välillä $150-300 \mathrm{~kg} \mathrm{~m}^{-3}$, ja jään tiheys on $910 \mathrm{~kg} \mathrm{~m}^{-3} \pm 1$ 
\%. Nähdään, että vesiraja on jää/lumi rajapinnassa $\left(h_{w}=h_{i}\right)$, kun $h_{s}=\frac{\rho_{w}-\rho_{i}}{\rho_{s}} h_{i} \approx \frac{1}{3} h_{i}$. Kun lunta tulee enemmän, jään pinta painuu vedenpinnan alapuolelle ja jäässä olevista halkeamista tulvii järvivettä lumikerrokseen muodostaen sohjoa.

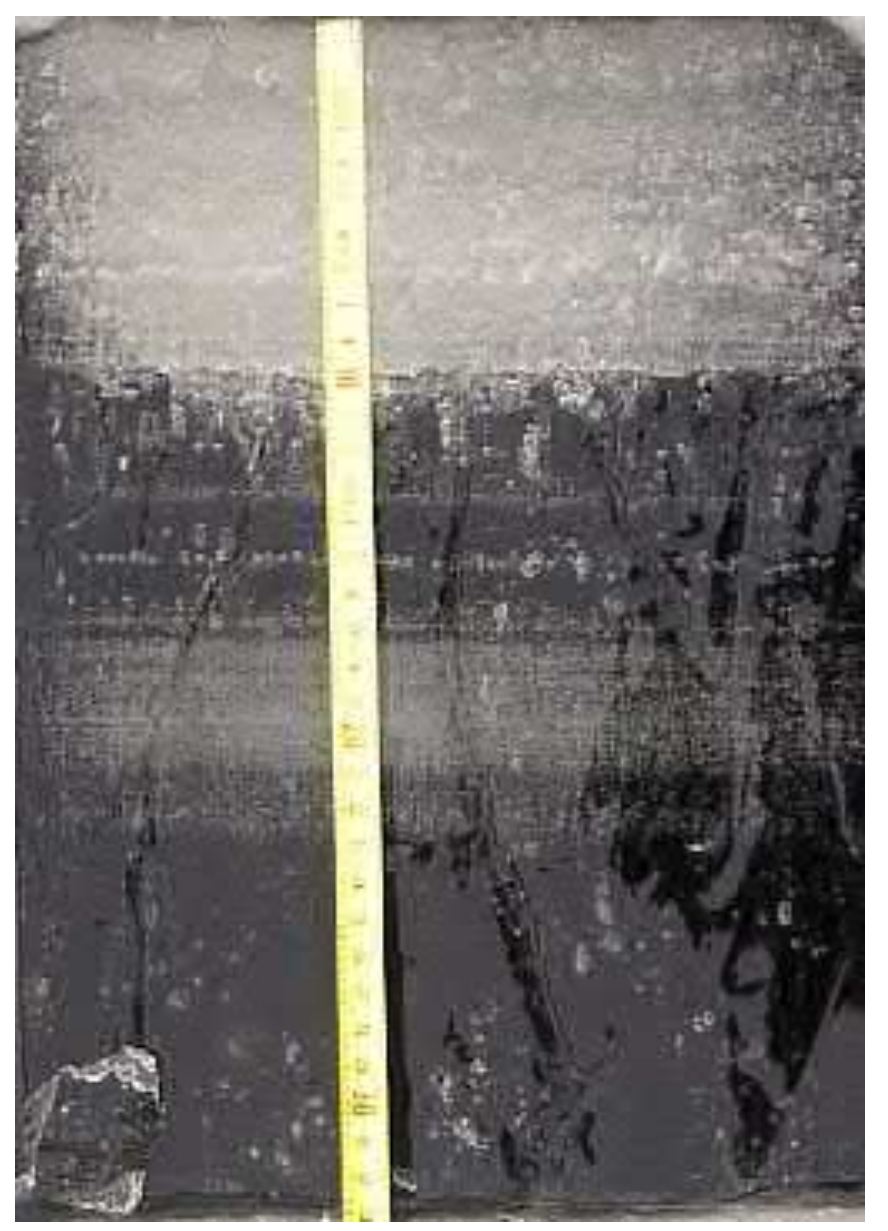

Kuva 5-8. Järvijään kerrosrakenne. Jään paksuus on $33 \mathrm{~cm}$, josta ylin $10 \mathrm{~cm}$ on sameaa kohvajäätä ja alempi $23 \mathrm{~cm}$ krkasta teräsjäätä. Teräsjäässä näkyy kaasukuplakerroksia. Kuva: Matti Leppäranta.

Aivan alku- ja lopputalvea lukuun ottamatta järviemme jääpeite on staattinen, ts. jääpeite on ehyt, yhtenäinen kansi. Joinain keväinä tuuli aiheuttaa pieniä siirtymiä suurten järvien jääkanteen (kuva 5-9). Hyvin suurilla järvillä kuten Laatokalla, Peipsijärvellä ja Vänern-järvellä esiintyy ajojäätä, joka voi liikkua voimakkaiden tuulten ja virtausten mukana.

\subsubsection{Jään paksuus}

Jään paksuuskasvua voidaan arvioida yksinkertaisen lämmönsiirtoyhtälön pohjalta. Jäätymisessä vapautuu lämpöä, joka johtuu jään ja lumen läpi ja siirtyy edelleen jään pinnalta ilmakehään. Asettamalla nämä lämmönsiirrot jatkuvuuden perusteella yhtä suuriksi, saadaan malli:

$$
\rho_{i} L_{f} \frac{d h_{i}}{d t}=k_{i} \frac{T_{f}-T_{i}}{h_{i}}=k_{s} \frac{T_{i}-T_{0}}{h_{s}}=Q_{0} \geq 0
$$

missä $L_{f}$ on jäätymislämpö, $k_{i}$ on jään ja $k_{s}$ lumen lämmönjohtokyky, $T_{f}$ on jäätymispisteen lämpötila, $T_{i}$ on jään pinnan lämpötila, $T_{0}$ on lumen pintalämpötila, $T_{a}$ on ilman lämpötila ja $Q_{0}=Q_{0}\left(T_{a}-T_{0}\right)$ on energiansiirto pinnasta ilmakehään. Yhtälöryhmä on voimassa jään kasvu- 
vaiheessa, jolloin $T_{f} \geq T_{i} \geq T_{0} \geq T_{a}$ ja lämpö siirtyy aina lämpimästä kylmään. Makeavetisillä järvillä on $T_{f}=0^{\circ} \mathrm{C}$.

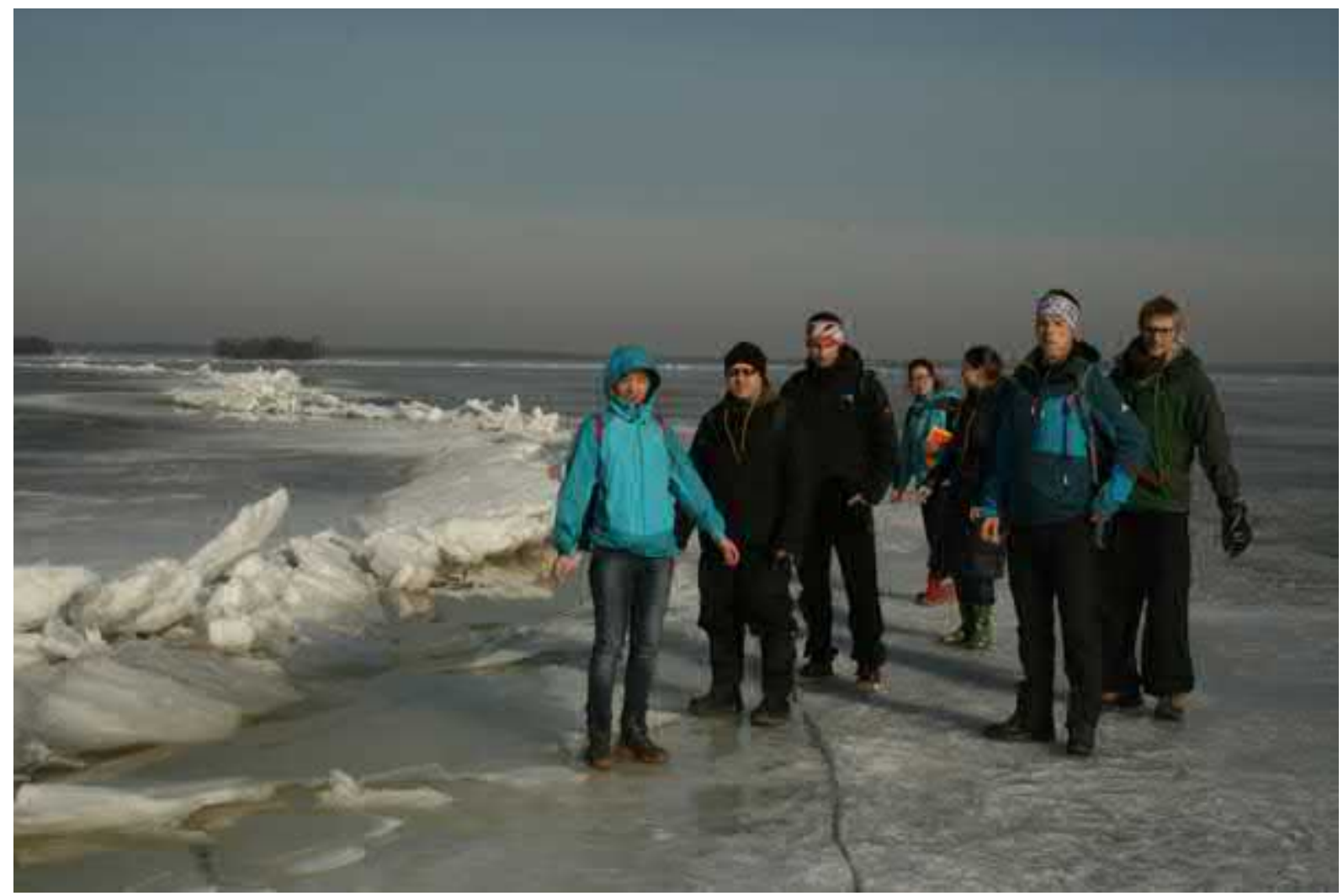

Kuva 5-9. Tuulen ajama ahtojääharjanne Vanajavedellä. Kuva: Matti Leppäranta.

Yhtälöistä (5.13) nähdään, että jään kasvua ohjaa ilman lämpötila ja lumen kertyminen. Niitä ei voi yleisessä tapauksessa analyyttisesti ratkaista, mutta niiden kanssa voi numeerisesti edetä esimerkiksi päivä kerrallaan. Yksinkertaisin tapaus on Stefan-Zubov malli, jossa lunta ei huomioida. Kun jään aloituspaksuudeksi otetaan nolla, saadaan

$$
\begin{aligned}
& h_{i}(t)=\sqrt{a^{2} S+b^{2}}-b, \\
& a=\sqrt{\frac{2 k_{i}}{\rho_{i} L_{f}}}, S=\int_{0}^{t}\left[T_{f}-T_{i}(\tau)\right] d \tau,
\end{aligned}
$$

missä $a \approx 3,3 \mathrm{~cm}^{\circ} \mathrm{C}^{-1 / 2} \operatorname{vrk}^{-1 / 2}$ ja $b \approx 10 \mathrm{~cm}$ ovat mallin parametrit ja $S$ on pakkassumma. Pakkassummassa lasketaan yhteen pakkaspäivien keskilämpötilat, yksikkönä ${ }^{\circ} \mathrm{C} \cdot v r k$. Parametri $a$ kuvaa lämmön johtumista jään läpi, ja parametri $b$ kuvaa ilman pintakerroksen tehoisaa eristävyyttä. Lumen kertyminen hidastuttaa jään kasvua, ja sen huomioimiseksi käytetään empiiristä kerrointa $a^{*}, \frac{1}{2}<\frac{a^{*}}{a}<1$, kertoimen $a$ asemasta (kuva 5-10).

Esimerkki 5-6. Jos on 100 pakkaspäivää ja niiden keskiarvo on $-10{ }^{\circ} \mathrm{C}$, saadaan $S=1000{ }^{\circ} \mathrm{C} \cdot \mathrm{vrk}$ ja edelleen $h_{\mathrm{i}}=95 \mathrm{~cm}$. Jos otetaan empiirinen kerroin $a^{*}=2,5 \mathrm{~cm} \cdot\left({ }^{\circ} \mathrm{C} \cdot \mathrm{vrk}\right)^{-1 / 2}$, saadaan $h_{i}=70 \mathrm{~cm}$. Lapissa pakkassumma voi kylminä talvina saavuttaa arvon $1500^{\circ} \mathrm{C} \cdot \mathrm{vrk}$ ja jää voi havaintojen mukaan saavuttaa $110-120 \mathrm{~cm}$ paksuuden. 


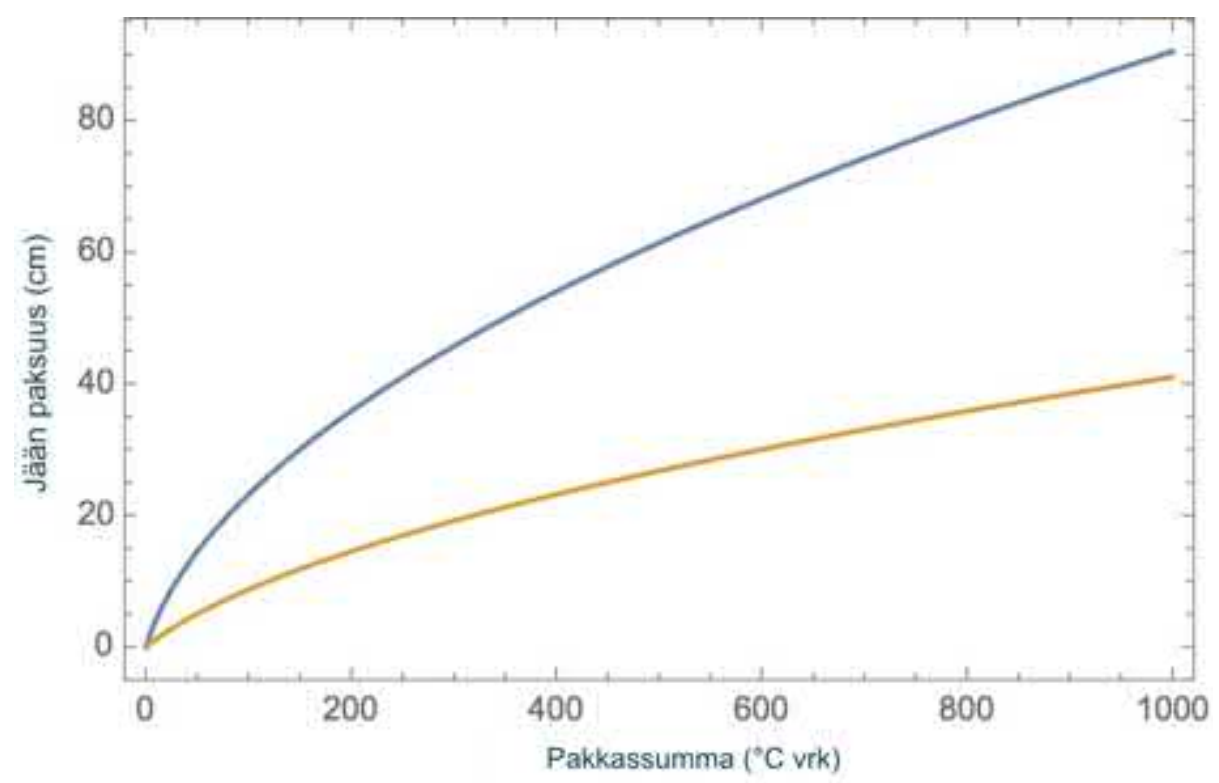

Kuva 5-10. Järvijään paksuuskasvu Stefan-Zubovin mallin mukaan. Ylempi käyrä kuvaa lumettoman jään kasvua $\left(a^{*}=a\right)$, alempi lumen aiheuttamaa suurinta kasvun hidastumista $\left(a^{*}=1 / 2 a\right)$.

Jään sulaminen alkaa keväällä, kun sen lämpötase $Q_{n}$ (jään ylä- alapinnan lämpötaseet + jäähän imeytyvä auringonsäteily) kääntyy positiiviseksi. Sulamisen etenemistä voidaan arvioida suoraan lämpötaseen avulla tai, jos lämpötaseesta ei ole riittävästi tietoa, ilman lämpötilaan perustuvan empiirisen kaavan avulla:

$$
\frac{d h_{i}}{d t}=-\frac{Q_{n}}{\rho_{i} L_{f}} \approx-A T_{a} ; Q_{n^{\prime}} A \geq 0
$$

missä kerroin $A \sim 0,5 \mathrm{~cm}^{\circ} \mathrm{C}^{-1} \operatorname{vrk}^{-1}$. Jos lämpötase on $100 \mathrm{~W} \mathrm{~m}^{-2}$, yhden päivän aikana sulaa jäätä 2,8 cm; empiirinen kaava antaa saman jos $T_{a}=5{ }^{\circ} \mathrm{C}$. Lämpötaseen arviointi on usein vaikeata ja siksi yksinkertaisempaa lähestymistapaa käytetään paljon. Se antaa lämpösummakaavan muotoisen ratkaisun:

$$
h_{i}(t)=h_{i}(0)-A \int_{0}^{t} \max \left(0, T_{a}\right) d \tau \approx h_{i}(0)-A \sum_{k=0}^{n} \max \left(0, T_{a}\right) \Delta t
$$

missä sulamiskauden pituus on $t=n \Delta t$, yleensä $\Delta t=1$ vrk. Jää sulaa positiivisten ilman lämpötilojen summaan suhteessa. Kerroin $A$ riippuu ajasta ja sitä voidaan säätää sulamiskauden aikana käytännön työssä.

\subsubsection{Jääpeitteen ympäristövaikutukset}

Jääpeite vaikuttaa olennaisesti olosuhteisiin järven vesirungossa. Suomen järvissä pohjasedimentistä tulee veteen hieman lämpöä, ja jään läpi ilmakehään vuotaa pieniä määriä lämpöä. Kaiken kaikkiaan lämpötilarakenne on sangen stabiili. Geotermisissä järvissä pinta voi pysyä avoimena. Keväällä aurinko lämmittää jäänalaista vettä ja käynnistää koko vesirunkoa lämmittävän konvektion.

Tuuli ei pääse ajamaan jääpeitteisten järvien kiertoliikettä, ja siksi talviajan virtaukset ovat heikkoja, suuruusluokaltaan $1 \mathrm{~mm} \mathrm{~s}^{-1}$. Kiertoliike on termohaliinista eli johtuu vesirungon tiheysrakenteen kehityksestä. Sydäntalvella pohjasta tuleva lämpö muokkaa tiheysrakennetta 
ja keväällä sen tekee veteen tunkeutuva auringonvalo. Kun jäällä on yli $10 \mathrm{~cm}$ lunta, valoa ei juuri pääse veteen asti.

Jääkansi on hyvä lämmöneriste eikä jää siksi pääse kasvamaan kovin paksuksi. Siperiassakin $2 \mathrm{~m}$ järvijään paksuus on jo äärirajoilla. Lumipeitteinen jää ei päästä valoa läpi, ja silloin perustuotanto seisahtuu. Itse jää läpäisee valoa suunnilleen yhtä hyvin kuin järven vesi. Kriittisimpiä talviajan kysymyksiä on happitalous, sillä happivarat uudistuvat ilmakehän ja avoveden rajapinnan kautta. Pitkinä talvina meillä esiintyykin kalakuolemia (kuva 5-11) ja useita järviä 'tekohengitetään' hapetuslauttojen avulla. Talviajan sade ja sateen mukana tuleva laskeuma varastoituvat jääpeitteeseen ja vapautuvat veteen sitten lyhyenä sulamiskautena.

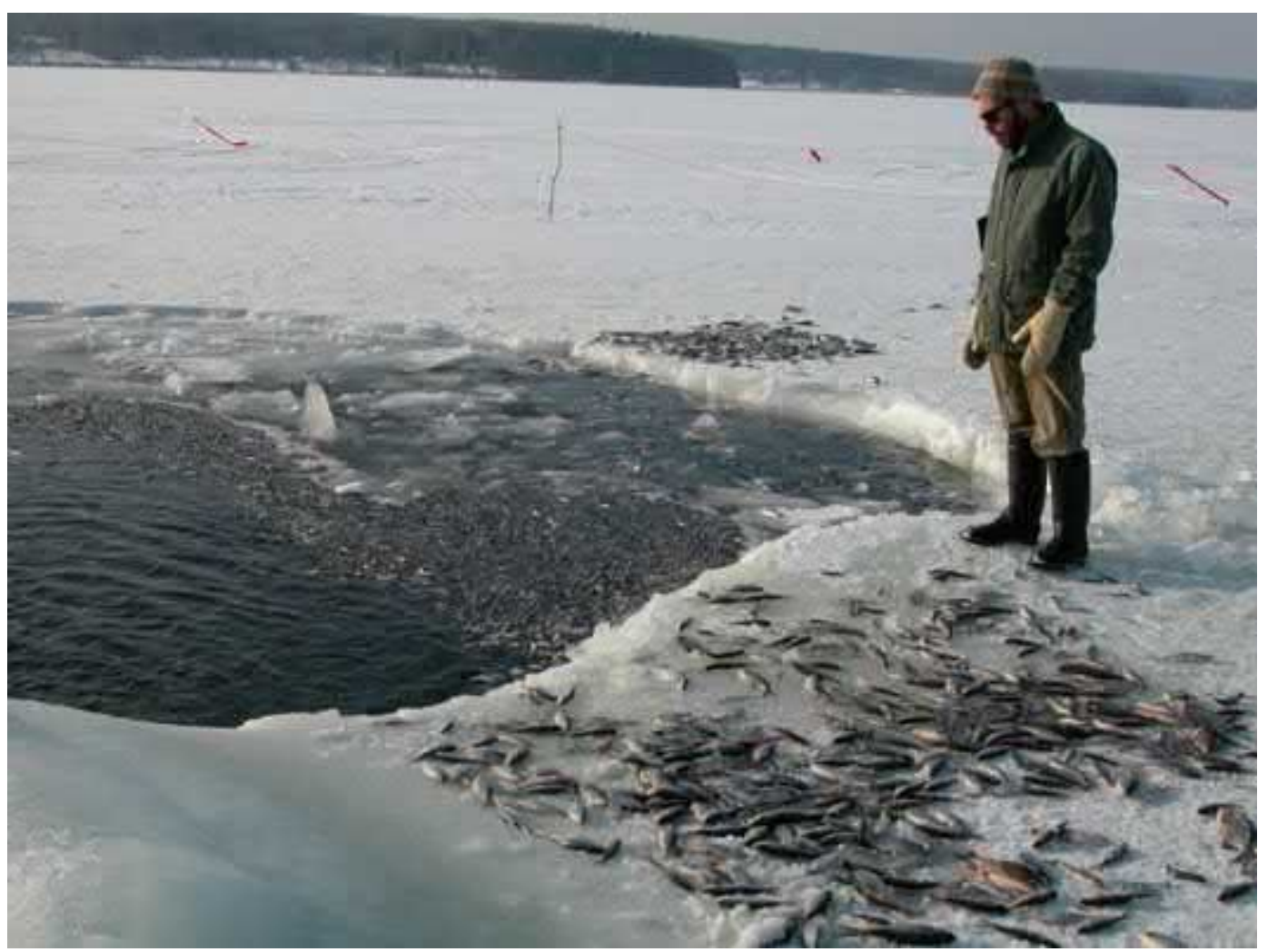

Kuva 5-11. Kalakuolema Äimäjärvellä Etelä-Suomessa maaliskuussa 2003. Syksyllä 2002 järvet jäätyivät varhain ja happi loppui talven aikana useista järvistä. Kuva: Jouni Tulonen.

Jäät aiheuttavat kuormituksia järvillä oleviin rakenteisiin kuten laitureihin ja vesiliikenteen ohjausmerkkeihin. Rantaan työntyvät jäät aiheuttavat myös pohjan ja ranta-alueen eroosiota. Tärkein käytännön kysymys on jään kantokyky. Jäällä kulkeva ihminen tai ajoneuvo aiheuttaa jäähän taipuman, jota veden paine vastustaa. Jos taipuma on tarpeeksi suuri, jää murtuu. Kantokyky $P$ on verrannollinen jään paksuuden neliöön, ja sitä voidaan arvioida semiempiirisellä kaavalla

$$
P=\beta h_{i}^{2}
$$

missä $\beta$ on jään laadusta riippuva kerroin, joka on likimain verrannollinen jään lujuuteen. Teräsjään tapauksessa $\beta \approx 5 \mathrm{~kg} \mathrm{~cm}^{-2}$, ja silloin $5 \mathrm{~cm}$ jää kantaa ihmisen $(125 \mathrm{~kg})$ ja $20 \mathrm{~cm}$ paksu jää auton (2000 kg). Kohvajää on merkittävästi heikompaa kuin teräsjää. Kun jääpeite koos- 
tuu teräsjäästä ja kohvajäästä, teräsjään paksuuteen lisätään puolet kohvajään paksuudesta ja käytetään sen jälkeen teräsjään kerrointa kaavassa (5.17).

\subsection{Järvien virtaukset ja aaltoliikkeet}

\subsubsection{Tuulen ajovirta ja painekentän aiheuttama virtaus}

Järvien dynamiikassa tutkitaan veden virtauksia ja aaltoliikkeitä, jotka käynnistävä ja joita ylläpitävä voima on yleensä tuuli. Veden kulkeutuminen muuttaa vedenpinnan korkeutta ja aiheuttaa horisontaalisia paine-eroja, jotka niin ikään ajavat virtauksia. Muita mahdollisia pakotetekijöitä ovat tulo- ja lähtövirtaaman aiheuttama läpivirtaus, ilmanpaineen vaihtelut sekä vesirungon tiheysrakenteen muutokset. Esimerkkinä viimeksi mainitusta on syksyinen vesirungon jäähtyminen: matalilla rannoilla vesi jäähtyy nopeammin, tulee raskaammaksi ja virtaa pohjan lähellä keskemmälle, kun taas keskiselältä virtaa pintavettä rannan suuntaan.

Tuulen aiheuttamaa virtausta sanotaan tuulen ajovirraksi, ja vesirungon tiheyden muutoksia seuraava painekenttä aiheuttaa termohaliinisen kiertoliikkeen. Koska tuuli vaihtelee merkittävästi vuorokausien aikamitoissa, tuulen ajovirrat ovat suurelta osin epäsäännöllisiä ja lyhytkestoisia. Termohaliinista kiertoliikettä syntyy veden pinnalla tai pohjalla tapahtuvan lämmityksen ja jäähdytyksen ansiosta. Suolaisilla järvillä myös sadanta ja haihdunta voivat toimia taustatekijöinä. Virtauksiin vaikuttavat myös vesirungon ja pohjan välinen kitka sekä suurissa järvissä Coriolis-kiihtyvyys, joka poikkeuttaa virtauksen suuntaa tuulen suunnasta oikealle pohjoisella ja vasemmalle eteläisellä pallonpuoliskolla. Suurtenkin järvien koko on vielä niin pieni, ettei vuorovesi-ilmiöllä ole merkitystä niissä.

Virtausopin perusyhtälöt ovat liikeyhtälö ja jatkuvuusyhtälö eli massan säilymislaki (kohta 3.3.1). Järvien virtauksista voidaan ratkaista liikeyhtälöstä horisontaalinen osa $(u, v)$, ja vertikaalinen osa saadaan sitten kokoon puristumattoman virtauksen jatkuvuusyhtälöstä. Järvien virtaukset ovat anisotrooppisia siten, että virtausnopeudet ovat horisontaalisuunnassa paljon suurempia kuin vertikaalisuunnassa. Edelliset ovat suuruusluokaltaan 1-100 $\mathrm{cm} \mathrm{s}^{-1}$ ja jälkimmäiset alle $1 \mathrm{~mm} \mathrm{~s}^{-1}$.

Tuulen ajamaan virtaukseen sovelletaan kitkallisen virtauksen teoriaa. Järven yllä puhaltava tuuli aiheuttaa järven pintaan leikkausjännityksen (yhtälö 5.11), joka siirtää tuulivoimaa veteen ja synnyttää tuulen ajovirran. Veden turbulenttinen kitka siirtää tuulivoimaa edelleen syvempään, ja järven pohjalla taas pohjakitka kuluttaa virtauksen kineettistä energiaa. Pohjakitka on samaa muotoa oleva turbulenttinen vastus kuin tuulen kitkavoima. Pohjakitkayhtälö kirjoitetaan

$$
\tau_{b}=\rho C_{\boldsymbol{b}} u^{2}
$$

missä $C_{b} \sim 10^{-3}-10^{-2}$ on pohjan vastuskerroin, ja $u$ on veden virtausnopeus. Matalilla järvillä tuuli synnyttää järveen ajovirran, joka kulkee tuulen suuntaan ja jonka pohjakitka tasapainottaa. Pintavirtauksen nopeus on

$$
u_{0}=\sqrt{\frac{\rho_{a} C_{a}}{\rho C_{b}}} U_{a}
$$

Pintavirtaus on 1-3 \% tuulen nopeudesta järven syvyydestä ja pohjan laadusta riippuen. Myös järven geometria ohjaa virtauksen suuntaa. Vakaassa tilassa virtauksen profiilia voi- 
daan pitää likimain lineaarisena. Syvillä järvillä tuulen ajama virtaus syntyy vahvimmillaan noin $30 \mathrm{~m}$ syvyiseen pintakerrokseen.

Järvien äärellisestä koosta johtuen tuulen vastaisella rannalla vedenkorkeus alkaa vähitellen nousta, mistä seuraa tuulen suuntainen pinnankaltevuus $\beta$ ja edelleen painegradientti $\nabla p=-\rho g \beta$. Vakaassa tilassa tämä tasapainottaa tuulivoiman eli

$$
\rho g H \beta=\tau_{a}
$$

missä $H$ on järven syvyys. Paineen vaikutus kerrotaan syvyydellä, sillä paine on runkovoima, joka vaikuttaa koko vesirunkoon. Tasapainotilassa veden kokonaiskuljetus tuulen suuntaan täytyy olla nolla. Pintavesi kulkee tuulen mukana, syvemmällä virtaa paineen ajama paluuvirtaus. Homogeenisen vesirungon pohjakerroksessa tapahtuu tasapainottava paluuvirtaus (kuva 5-12a).

Esimerkki 5-7. Jos tuulen nopeus on $10 \mathrm{~m} \mathrm{~s}^{-1}$, niin $\tau_{a} \approx 0,2 \mathrm{~N} \mathrm{~m}^{-2}$; tämä leikkausvoima kohdistuu järven pintaan. Jos $H \approx 10 \mathrm{~m}$, painevoima on $0,2 \mathrm{~N} \mathrm{~m}^{-2}$, kun vedenpinnan kaltevuus on $2 \cdot 10^{-6}$, mikä vastaa $2 \mathrm{~mm}$ vedenpinnan nousua kilometrin matkalla. Koska yleisesti $\tau_{a}<1 \mathrm{~Pa}$, vedenpinnan kaltevuus on $10 \mathrm{~m}$ syvyisellä järvellä alle $1 \mathrm{~cm}$ kilometriä kohden. Näin pieniä kaltevuuksia ei voi havaita silmällä.

Kerrostuneessa järvessä tuulen ajama pintavirtaus aiheuttaa kallistuman termokliiniin, mikä puolestaan muodostaa paluuvirtauksen pintakerroksen pohjalle. Painejakauma ajaa edelleen vastakkaissuuntaisen kierron alusveteen (kuva 5-12b). Tilanteen alkuvaiheessa tuulen vaikutus ulottuu pelkästään päällysveteen, johon muodostuu tuulen suuntainen virtaus. Vedenpinnan kallistumiseen liittyvä painegradientti synnyttää tuulelle vastakkaiseen suuntaan tapahtuvan paluuvirtauksen päällysveden alaosaan ja edelleen vastakkaisen kiertoliikkeen alusveteen. Painegradientin vaikutus alusvedessä on pieni, sillä termokliinin kallistuminen kumoaa suurelta osin pinnan kaltevuuden vaikutuksen.

Kuva 5-13 esittää tuulen suunnan kääntymiseen liittyvää virtauksen vertikaalisen jakautumisen vaihtelua Päijänteellä Hyrkön salmessa (Pulkkinen 1989). Tulokset vastaavat ajallisesti kuvan 5-12b kehitysvaihetta. Alusvedessä esiintyvät suurehkot nopeudet aiheutuvat vaakasuoraan lämpötilaeroon liittyvistä tiheyseroista.
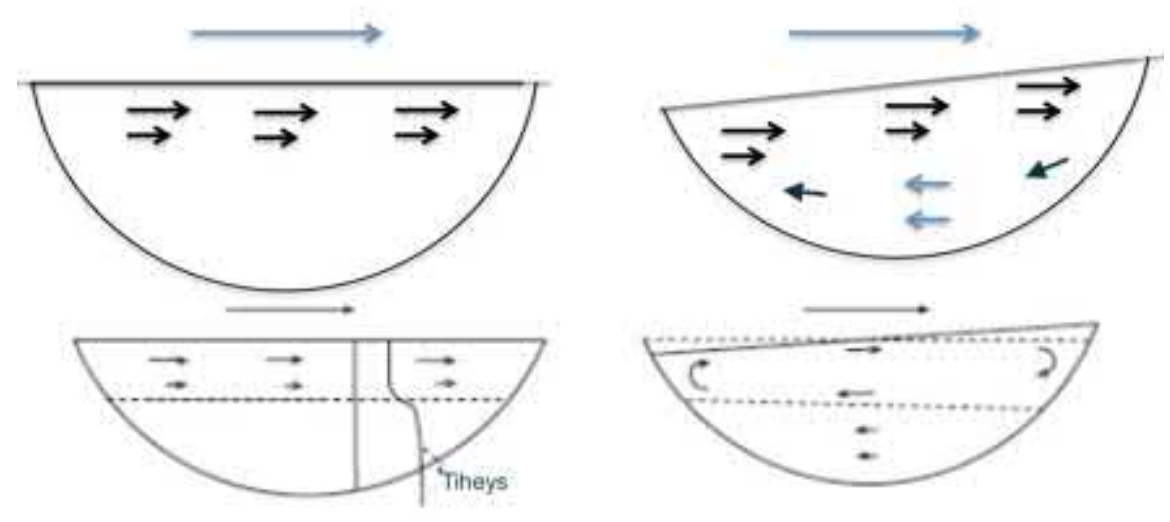

Kuva 5-12. Tuulen aiheuttaman virtauksen kehittyminen homogeenisessa järvessä (ylempi kuva) ja kerrostuneessa järvessä (alempi kuva). 

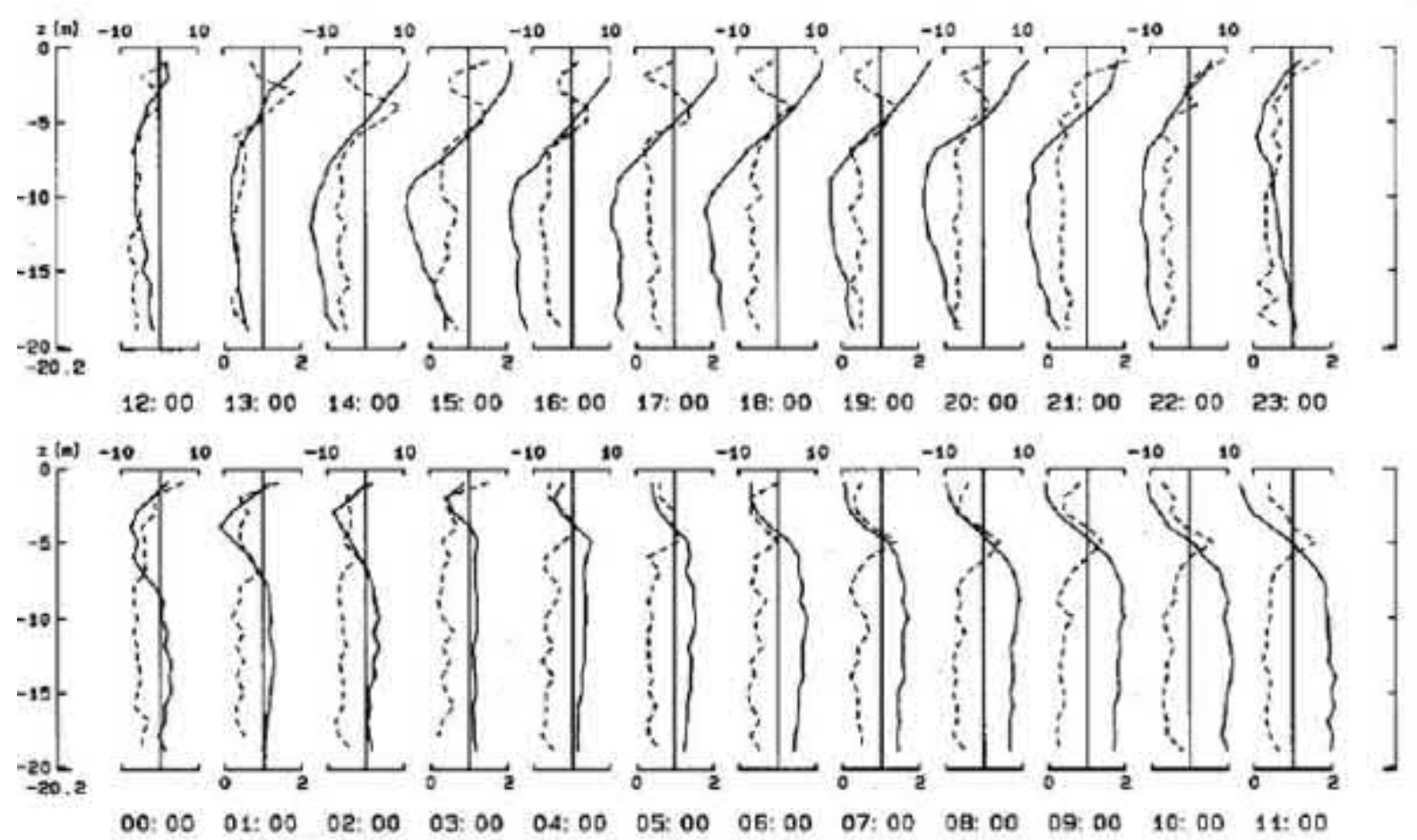

Kuva 5-13. Akustisella virtausmittarilla mitattu virtauksen tuntikeskiarvon profiili (yhtenäinen viiva, asteikko ylhäällä $-10-10 \mathrm{~cm} \mathrm{~s}^{-1}$ ) sekä nopeuden virhearvio (katkoviiva, asteikko alhaalla $0-2 \mathrm{~cm} \mathrm{~s}^{-1}$ ) Päijänteellä Hyrkönsalmessa 9.-10.7. Merkinnät 12:00 ja vastaavat profiilien alla viittaavat kellonaikaan. Lähde: Pulkkinen (1989).

\subsubsection{Aaltoliike}

Aaltoliikettä (katso kohta 3.3.1) esiintyy järvien pinnalla ja vesirungon sisällä veden tiheyden muutosvyöhykkeissä. Syvän veden aaltoja edustaa tuulen ajama aallokko, mutta järvien mataluuden takia tämä aaltoliike ulottuu usein pohjaan asti. Tällöin sovelletaan matalan ja syvän veden välimuodon teoriaa, joka on sangen vaikeaa. Matalan veden aaltoja ovat altaan ominaisheilahdukset eli seicheaallot.
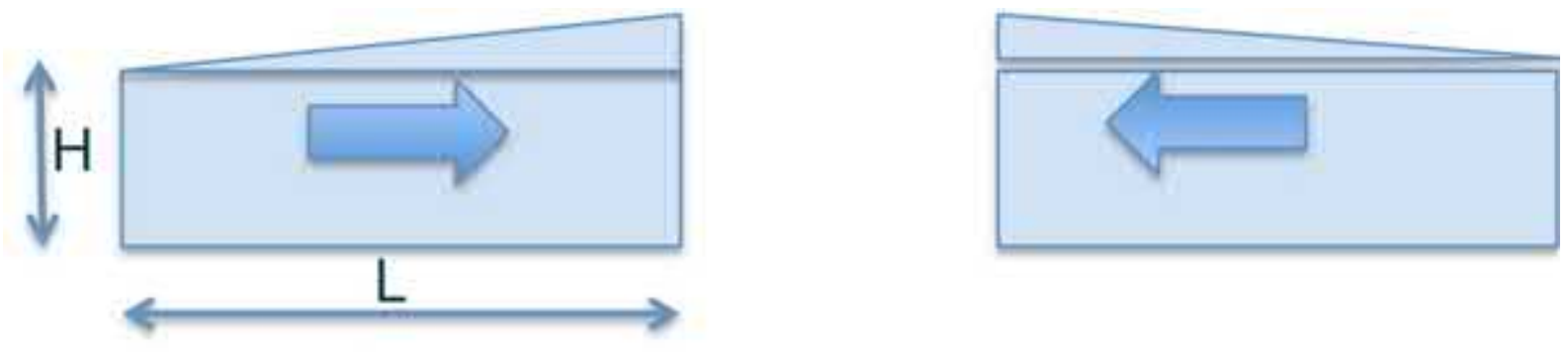

Seicheaallon alkuehtona on vesirungon kallistuminen, joka voi tapahtua tuulen vaikutuksesta tai ilmanpaine-erosta järven eri puolilla. Kun kallistavan voiman vaikutus lakkaa, vesirunko alkaa heilahdella tasapainoasemansa ympärillä heilahdusajan vastatessa ominaisheilahdusaikaa. Tämä aaltoliike on tullut tunnetuksi Geneve-järvellä 1700-luvulla, vaikkakin ilmeisesti atsteekit tunsivat ilmiön Texcoco-järvellä Meksikossa jo ennen vuotta 1519. Seiche ${ }^{4}$ on seisova aalto, jossa pinnankorkeus voidaan esittää kahden vastakkaisiin suuntiin etene-

\footnotetext{
${ }^{4}$ Sana 'seiche' on sveitsinranskaa ja tarkoittaa heilahdusta.
} 
vän siniaallon summana. Altaassa on solmupisteitä, joissa vedenkorkeus ei muutu lainkaan, ja anti-solmupisteitä, joissa vedenkorkeus muuttuu eniten eli amplitudi on $A$.

Seicheaallon heilahdusaika riippuu altaan koosta. Se voidaan käsittää ajaksi, joka aallolta kuluu matkaan altaan toisesta päästä toiseen ja takaisin. Suorakaiteen muotoisen altaan 1solmuisen seichen heilahdusaika on

$$
T=\frac{2 L}{\sqrt{g H}},
$$

missä $L$ on altaan pituus. Altaan keskellä on solmupiste ja reunoilla antisolmut. Tämä on $M e-$ rianin kaava, peräisin vuodelta 1828 . Sen on todettu antavan verrattain hyviä tuloksia myös todellisille järville. Jos solmujen lukumäärä on $n$, on heilahdusaika $\frac{1}{n} T$.

Esimerkki 5-8. Jos järvialtaan syvyys on $H=10 \mathrm{~m}$ ja pituus $L=10 \mathrm{~km}$, seicheaallon etenemisnopeus on $V=9,90 \mathrm{~m} \mathrm{~s}^{-1}$, ja yksisolmuisen seichen jakso $T=33,6 \mathrm{~min}$. Jos taas $H=4 \mathrm{~m}$ ja $L=1 \mathrm{~km}$, niin $V=$ $6,3 \mathrm{~m} \mathrm{~s}^{-1}$ ja $T=5,3 \mathrm{~min}$.

Kun vesirunko on kerrostunut, kerrosten välipintaan saattaa syntyä sisäisiä aaltoja. Palauttavana voimana toimii tehoisa painovoima eli painovoiman ja nosteen erotus, joka on verrannollinen kerrosten väliseen tiheyseroon. Sisäiset aallot eivät vaadi suurta ajavaa voimaa, koska tiheyserot vesirungon sisällä ovat pieniä, ja siksi niiden amplitudi voi olla kertaluokkaa suurempi kuin järven koko vesirungon aaltoilussa.

Kerrostuneen järven termokliiniin voi muodostua sisäinen seicheaalto. Mikäli tiheys muuttuu termokliinissa äkillisesti, siinä etenevän aallon nopeus $V_{i}$ voidaan esittää muodossa

$$
V_{i}=\sqrt{g \frac{\rho_{2}-\rho_{1}}{\rho_{2}}\left(\frac{1}{d_{1}}+\frac{1}{d_{2}}\right)^{-1}},
$$

missä $d_{1}$ ja $d_{2}$ ovat päällysveden ja alusveden kerrospaksuudet, ja $\rho_{1}$ ja $\rho_{2}$ niiden tiheydet. Termokliinin heilahdusaika saadaan samalla tavalla kuin pinnan heilahdusaika, $T_{i}=2 L V^{-1}$. Tämä heilahtelu ilmenee lämpötilan ja isotermien syvyyden vaihteluna. Koska sisäisen seicheaallon heilahdusaika on verrattain pitkä, useita tunteja tai vuorokausia, tuuli ennättää muuttua heilahduksen aikana. Tästä syystä puhtaita pysyvän tuulen ajamia sisäisiä heilahteluja havaitaan harvoin. Heilahteluun liittyviä lämpötilan vaihteluita havaitaan myös alusvedessä. Esimerkkinä kuvaan (5-14) on piirretty lämpötilan kulku usealla syvyydellä Lammin Pääjärvessä. Huomataan, että lämpötila vaihtelee eri syvyyksillä samanaikaisesti. Vertailemalla käyriä toisiinsa voidaan todeta, että lämpötilan vaihteluun liittyy jopa 6 metrin vertikaalisia liikkeitä.

Jos stabiilisti kerrostuneessa vedessä vesipartikkelia poikkeutetaan tasapainoasemastaan ja päästetään vapaaksi, syntyy värähtelyä, jonka taajuus on

$$
N=\sqrt{\frac{g}{\rho} \cdot \frac{\partial \rho}{\partial z}}
$$

missä $z$ on syvyys. Tätä taajuutta sanotaan löytäjänsä, suomalaisen meteorologin Vilho Väisälän (1889-1969) mukaan Väisälä-taajuudeksi. Vastaava periodi $T=2 \pi / N$ on lyhin periodi, jol- 
la kerrostunut vesirunko voi värähdellä. Kesäkerrostuneisuuden aikana se on suuruusluokaltaan 1-10 minuuttia. Esimerkiksi termokliinissä havaitaan usein tätä värähtelyä.

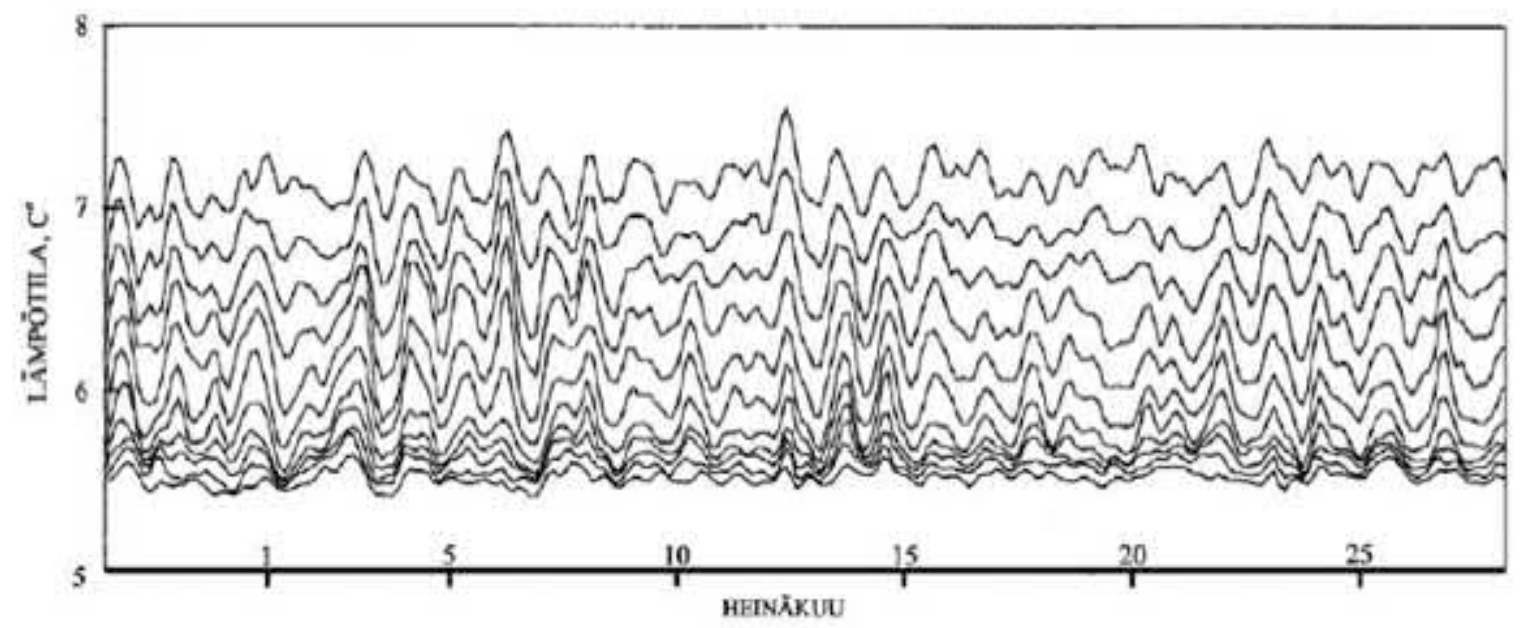

Kuva 5-14. Veden lämpötila syvyyksillä 22,9 m, 24,9 m, 26,9 m,... ja 42,9 m Lammin Pääjärvellä heinäkuussa vuonna 1986.

\subsection{Valaistusolot}

\subsubsection{Auringonsäteilyn pääsy järviveteen}

Auringonsäteily sisältää laajan osa sähkömagneettisen säteilyn spektristä, mutta vesi läpäisee käytännössä vain näkyvää valoa $(380-760 \mathrm{~nm})$. Yhteyttämiseen soveltuvana valona pidetään yleensä 400-700 nm:n kaistaa. Ultravioletti- ja infrapunasäteilyn tunkeutumissyvyys on yhden metrin suuruusluokkaa. Säteilyn vapaata etenemistä estävät absorptio eli säteilyn imeytyminen veteen ja muuttuminen lämmöksi sekä kemialliseksi energiaksi ja sironta eli säteilyn hajaantuminen eri suuntiin, mikä aiheutuu veden tiheyden fluktuaatioista sekä vedessä olevista partikkeleista. Luonnonvesien optisiin ominaisuuksiin vaikuttavat vesi itse sekä vedessä olevat optisesti aktiiviset aineet.

Saapuessaan vedenpintaan auringonsäteily osittain tunkeutuu veteen ja osittain heijastuu ja siroaa takaisin (kuva 5-15). Takaisinpalautuva osa on $\alpha Q_{s}$, missä $\alpha$ on albedo. Tyynestä pinnasta heijastuminen noudattaa Fresnelin peiliheijastuslakia, jonka mukaan säteilyn tulokulma ja lähtökulma ovat yhtä suuret. Peiliheijastuminen on riippumaton valon aallonpituudesta, mutta riippuu säteilyn tulokulmasta. Suoraan ylhäältä tulevasta säteilystä heijastuu $2 \%$. Kun auringon korkeuskulma on yli $20^{\circ}$, suoran säteilyn heijastuminen on alle $5 \%$; matalilla korkeuskulmilla suoran säteilyn heijastavuus kasvaa nopeasti, mutta toisaalta silloin hajasäteilyä on enemmän, ja sen kokonaisheijastuvuus on 6,6 \%. Rosoisesta vedenpinnasta tapahtuu eri suuntiin lähtevää diffuusia heijastumista.

Säteilyn tunkeutuessa veteen säde taittuu Snellin lain mukaisesti (kuva 5-15):

$$
\frac{\sin \theta_{i}}{\sin \theta_{j}}=n_{i j}
$$

missä $n_{i j}=1,33$ on ilma-vesi rajapinnan taitekerroin, $\theta_{i}$ on tulokulma ja $\theta_{j}$ on taittuneen säteen lähtökulma pinnan normaaliin nähden. Vedessä auringonsäteily absorboituu ja siroaa, ja ta- 
kaisinsironta kohtaa vesi/ilma rajapinnan, jossa tapahtuu taas heijastumista ja läpityöntymistä. Valon palautuessa veden sisältä vesi-ilma rajapinnan taitekerroin on $n_{j i}=1 / n_{i j}=0,752$, ja tällöin tulokulman on oltava pienempi kuin $48,5^{\circ}$, jotta valonsäde pääsisi pinnan läpi. Jos tulokulma on tätä suurempi, tapahtuu kokonaisheijastus, jonka takia vesi-ilma rajapinnan heijastavuus takaisinsironnalle on noin $50 \%$.

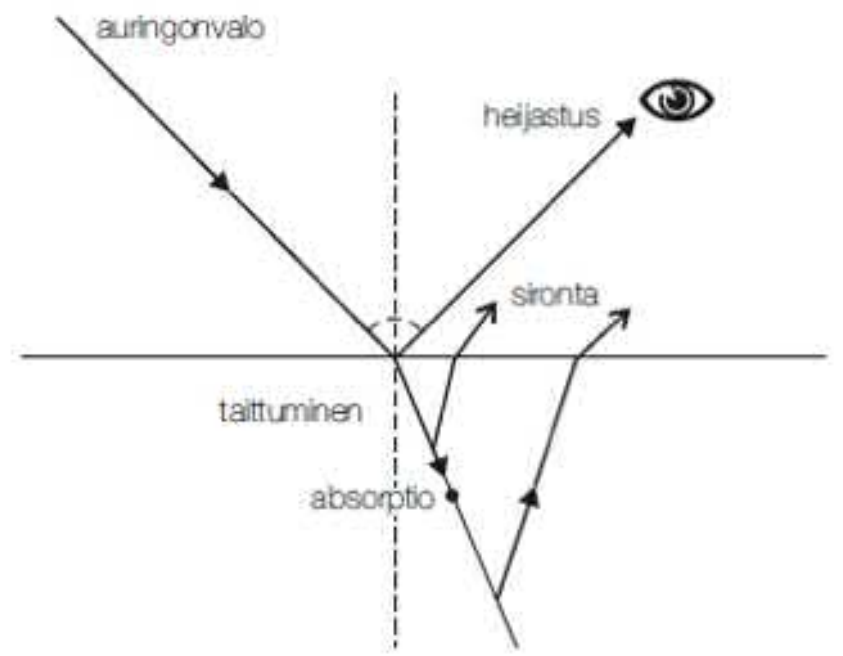

Kuva 5-15. Auringonsäteilyn heijastuminen, taittuminen ja sironta vedenpinnassa.

Vedestä ylös kumpuava takaisinsironta on suuruusluokaltaan $10 \%$ pinnan peiliheijastuksesta. Kerros, josta tämä takaisinsironta tulee, on paksuudeltaan noin puoli näkösyvyyttä. Takaisin siroavan säteilyn spektri riippuu veden ja siinä olevien optisesti aktiivisten aineiden ominaisuuksista, minkä takia ylhäältä päin tarkasteleva satelliitti (tai ihmissilmä) näkee erilaisia värisävyjä. Sininen valo siroaa parhaiten, ja siksi puhtaat luonnonvedet, kuten valtamerten keskusaltaat, näkyvät avaruuteen sinisinä.

\subsubsection{Optisesti aktiivit aineet luonnonvesissä}

Luonnonvesien tärkeimmät optisesti aktiiviset aineet ja absorption ja sironnan riippuvuus aal-lonpituudesta ovat alla olevassa jaotelmassa.

\begin{tabular}{l|l|l} 
& Absorptio & Sironta \\
\hline Puhdas vesi & voimakas $>650 \mathrm{~nm}$ & heikko taso \\
\hline Kelta-aines & voimakas $<550 \mathrm{~nm}$ & ei sirontaa \\
\hline Kiintoaines & heikko riippuvuus & $\begin{array}{l}\text { riippuu partikkelien } \\
\text { koosta }\end{array}$ \\
\hline a-klorofylli & absorptiokaistat & heikko taso
\end{tabular}

Puhdas vesi läpäisee valoa niin, että auringonsäteilystä parhaiten etenevää sinistä valoa voidaan havaita vielä 100 m syvyydessä. Kelta-ainesta kutsutaan myös värilliseksi liuenneeksi orgaaniseksi aineeksi (coloured dissolved organic matter, CDOM). Se absorboi erityisesti lyhyitä, alle $550 \mathrm{~nm}$ aallonpituuksia. Esimerkiksi humuspitoisissa järvissä lyhyet aallot absorboituvat nopeasti pois, ja valoilmastosta tulee ruskean sävyinen (kuva 5-16). Valon edetessä sen spektri muovautuu optisesti aktiivisten ainesten vaikutuksesta (kuva 5-17). Absorptiokerroin $a=a(\lambda)$ kuvaa, kuinka nopeasti valoa absorboituu veteen, ja sirontakerroin $b=b(\lambda)$ puolestaan kertoo, kuinka paljon säteilyn kulusta syvemmälle estyy sironnan takia. 


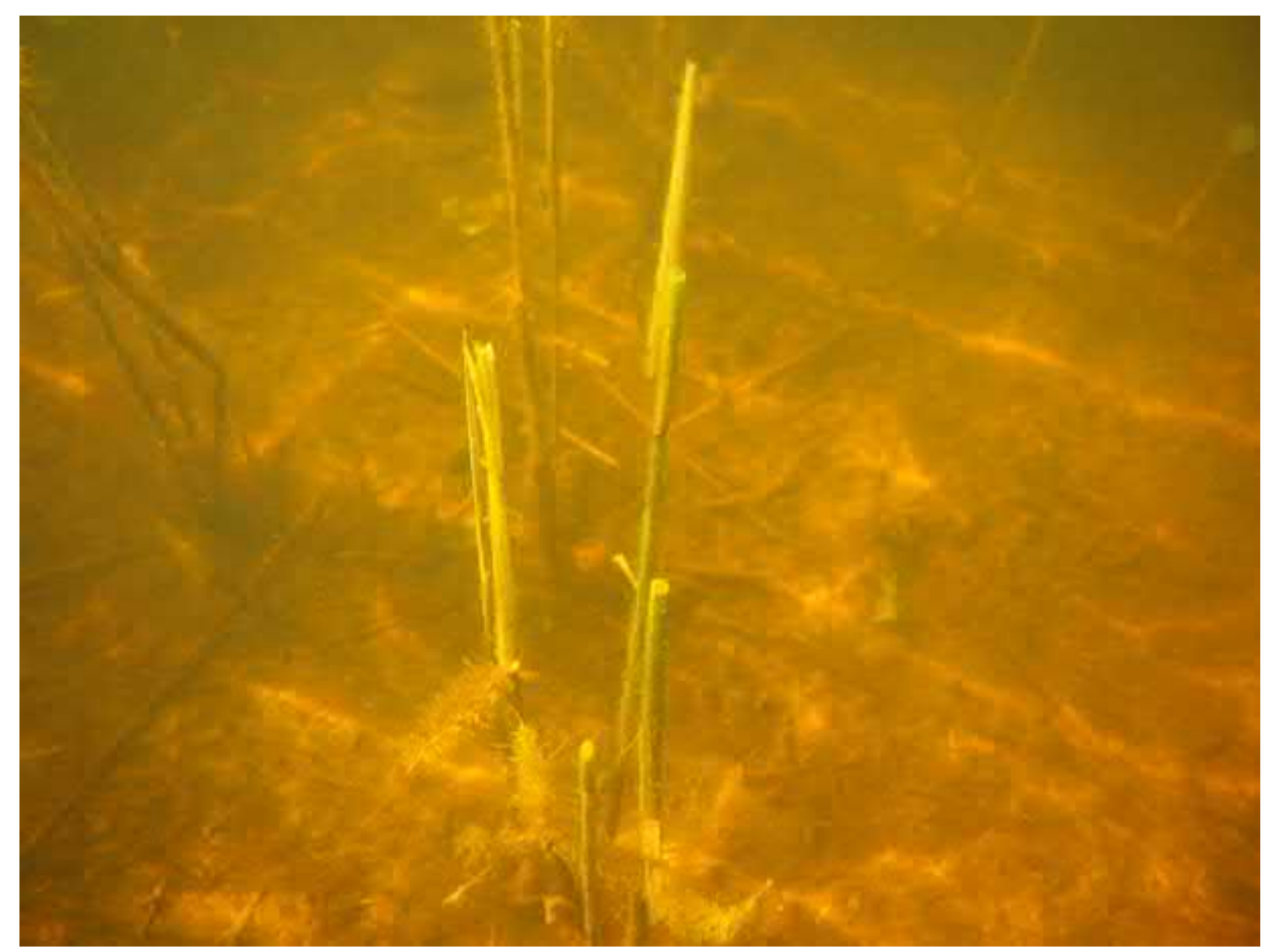

Kuva 5-16. Humuspitoisissa järvissä valoilmasto on ruskean sävyinen. Kuva: Matti Leppäranta.

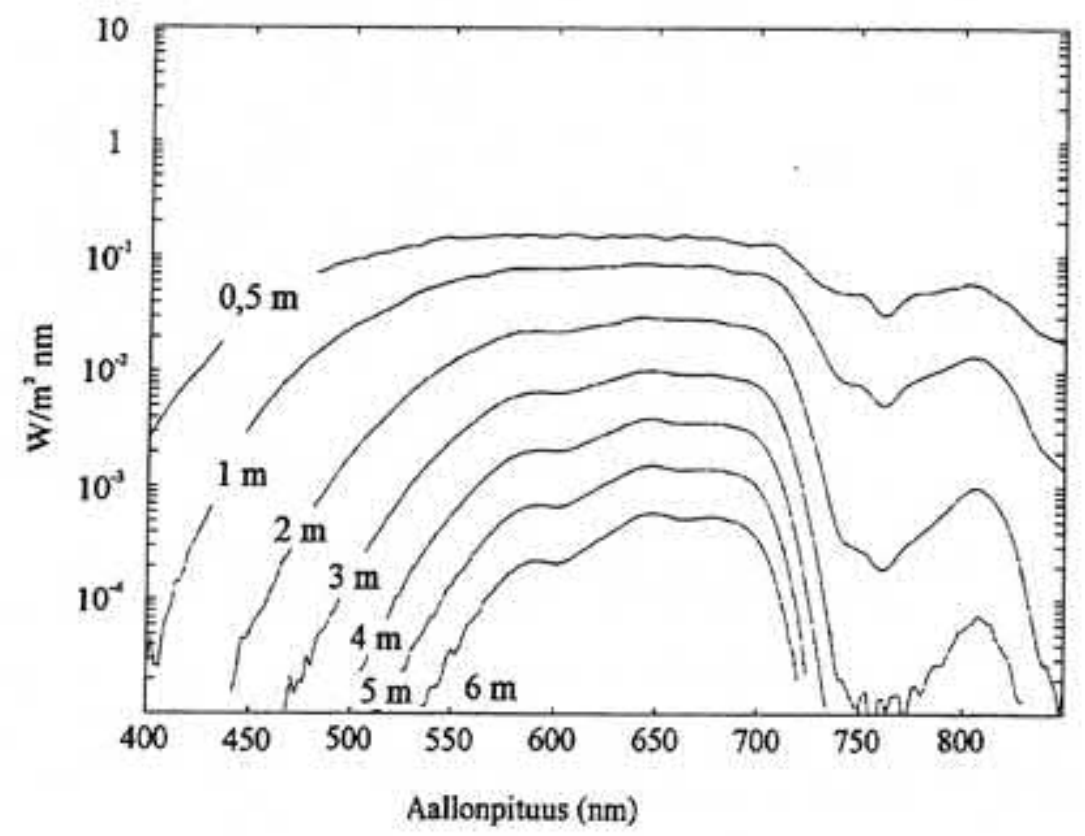

Kuva 5-17. Auringonsäteilyn spektri eri syvyyksillä Lammin Pääjärvellä. Lähde: Blanco (1994).

Kelta-aines eli liuennut orgaaninen väriaines (coloured dissolved organic matter, CDOM) sisältää erilaisia orgaanisia aineksia, jotka absorboivat erityisesti lyhyitä aaltoja. Tämän takia valon spektrin huippu siirtyy pidempiin aallonpituuksiin eli veden väri kellertyy, kun kelta- 
aineksen määrä kasvaa. Tästä kelta-aines onkin saanut nimensä. Sen absorptiota mallinnetaan eksponentiaalisen lain mukaan:

$$
a_{y}(\lambda)=a_{y}\left(\lambda_{0}\right) \mathrm{e}^{-S\left(\lambda-\lambda_{0}\right)}
$$

missä $a_{y}$ on kelta-aineksen absorptiokerroin, $S \approx 0,01 \mathrm{~nm}^{-1}$ on mallin parametri, $\lambda$ on aallonpituus ja $\lambda_{0} \approx 400 \mathrm{~nm}$ on referenssi-aallonpituus. Absorptio alenee tekijällä $e^{-1} \approx 0,37$ aina $S^{-1} \approx$ $100 \mathrm{~nm}$ aallonpituuden kasvua kohti. Humusaineet kuuluvat kelta-aineksiin ja ne antavat ruskean värin monille järvillemme. Kuvassa 5-18 on suodattamattomien ja suodatettujen vesinäytteiden absorptiospektrejä Vanajavedeltä ja Inarijärveltä. Suodattaminen poistaa kiintoaineksen vaikutuksen. Kuvasta nähdään, että kelta-aines absorboi lyhyitä aaltoja ja puhdas vesi pitkiä. Kiintoaineksen vaimentava vaikutus näkyisi voimakkaammin sironnan kautta.

Kiintoaines absorboi enemmän lyhytaaltoisella alueella, mutta riippuvuus aallonpituudesta on yleensä heikko. Sironnan määrä on merkittävä ja siihen vaikuttaa kiintoainespartikkelien koko. Alle mikrometrin kokoiset partikkelit sirottavat voimakkaimmin lyhyitä aaltoja, mutta suurempien partikkelien sironta riippuu aallonpituudesta vain heikosti. Kiintoaineksella voi olla myös yksilöllisiä ominaisuuksia, kuten saastelaikun väri, jolloin se eroaa selvästi ympäristöstään. $a$-klorofyllin absorptio on aallonpituuden suhteen hyvin selektiivistä, maksimit ovat 430-440 nm ja 660-690 nm kohdilla.

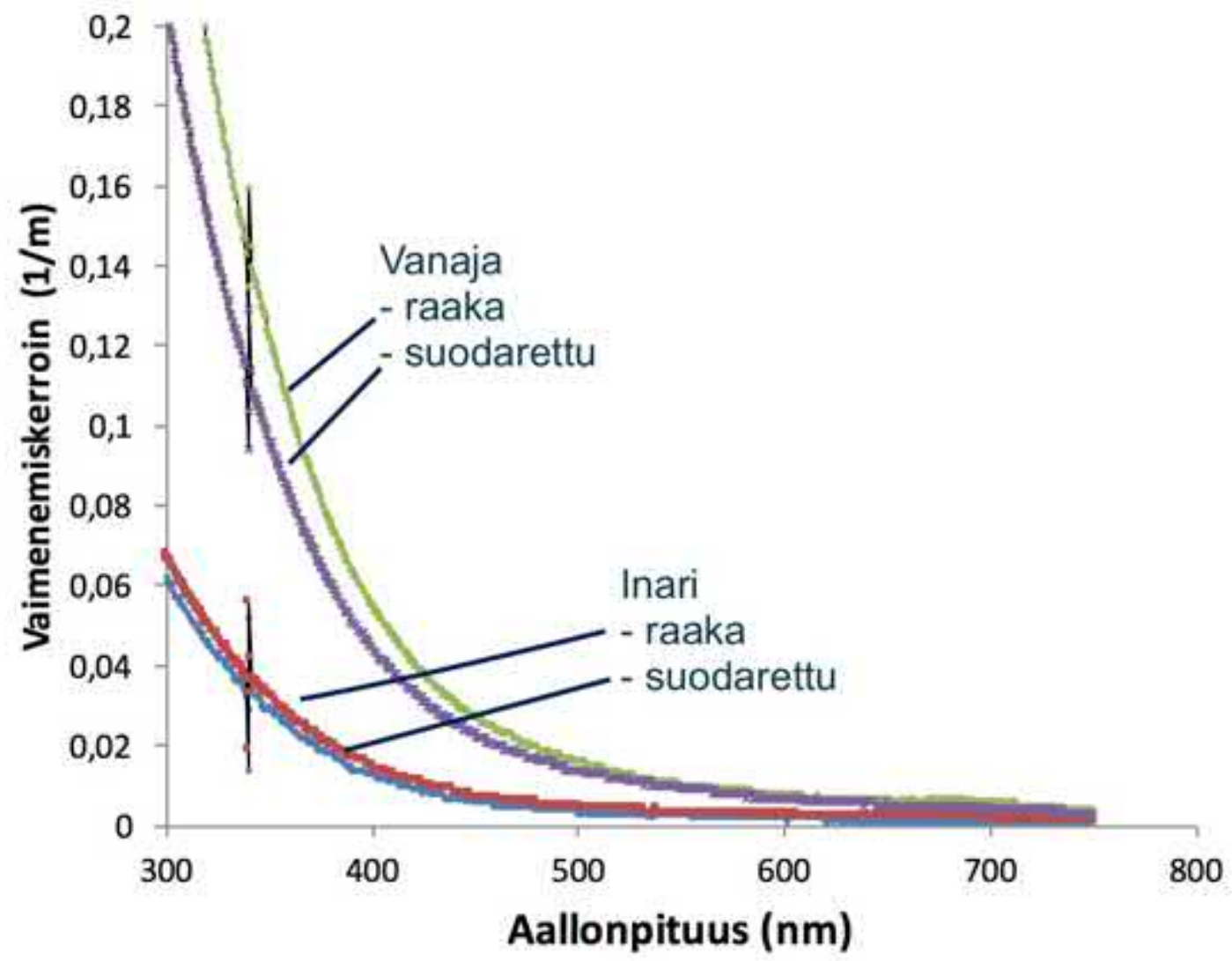

Kuva 5-18. Valon absorptiospektrit Inarijärveltä ja Vanajavedeltä kesältä 2014. Niistä on vähennetty puhtaan veden osuus pois. Suodatetussa näytteessä on värillinen orgaaninen liuennut aines (CDOM) ja raakanäytteessä sen lisäksi kiintoaines ja a-klorofylli. Lähde: Lammin biologinen asema,

Absorptio ja sironta aiheuttavat sen, että säteily vaimenee syvyyden mukana. Järvissämme valo tunkeutuu 0,5-10 metriin asti veden laadusta riippuen. Säteilyn vaimenemista järvessä 
kuvataan Beerin lailla

$$
\frac{d E}{d z}=-c(\lambda ; z) E
$$

Tässä $E=E(z, \lambda)$ on irradianssi eli pinta-alayksikölle lankeava säteily yläpuolisesta puoliavaruudesta, $z$ on syvyys, ja $c$ on vaimenemiskerroin, joka on absorptiokertoimen ja sirontakertoimen $b$ summa: $c=a+b$. Jos $c$ ei riipu syvyydestä, ratkaisuna on eksponentiaalinen vaimeneminen

$$
E(z, \lambda)=E(0, \lambda) \mathrm{e}^{-c(\lambda) \mathrm{z}}
$$

Säteilytaso siis vaimenee syvyyden suhteen siten, että syvyydellä $z=c^{-1}$ säteily on osa $e^{-1} \approx$ 0,37 pinta-arvosta.

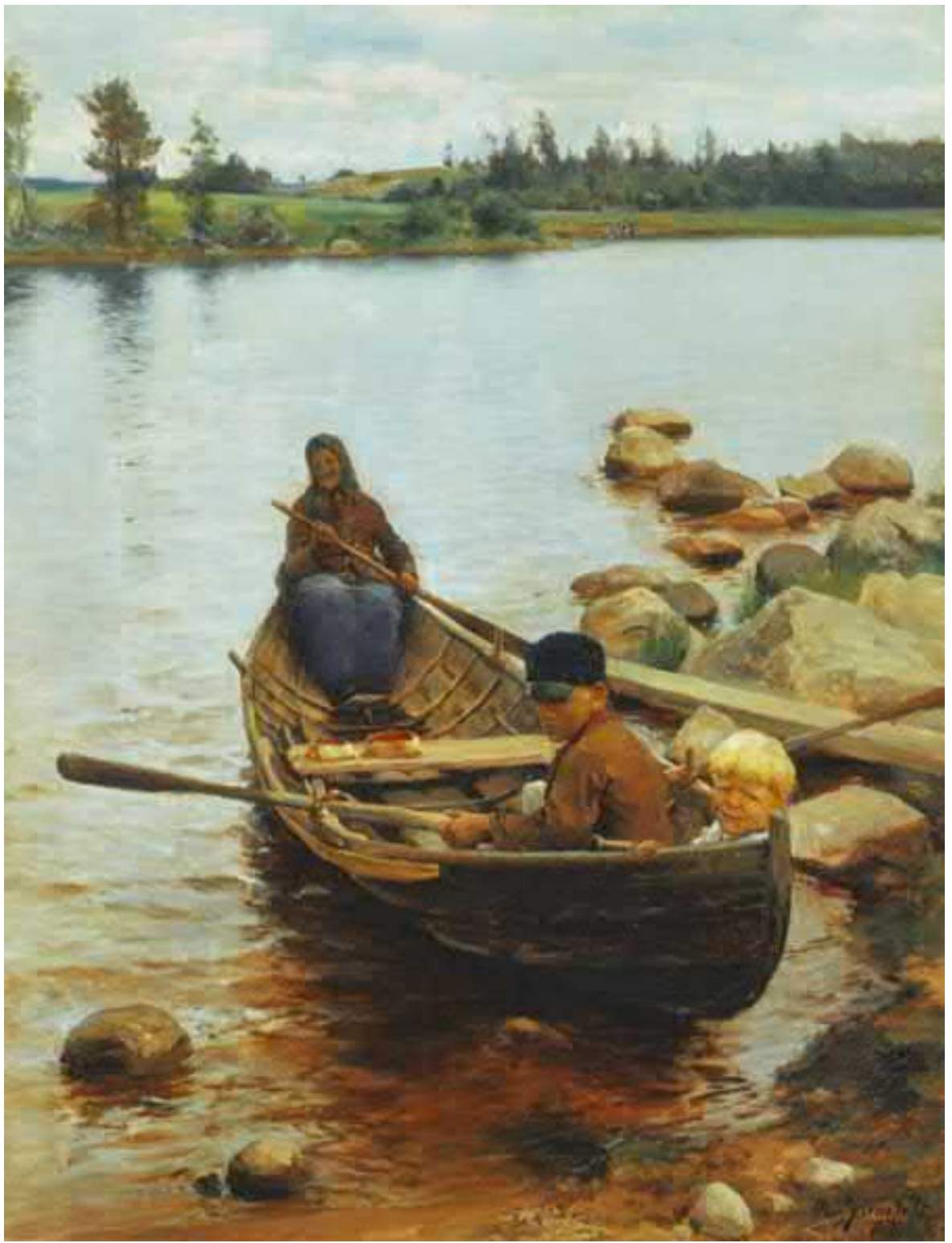

Kuva 5-19. Savolaisvene. Eero Järnefeltin maalaus vuodelta 1888. @ Hämeenlinnan taidemuseo. 
Säteilyspektri voidaan integroida kokonaissäteilyksi ja sen pohjalta tarkastella säteily-energian siirtymistä veteen. Kokonaissäteilylle $\bar{E}=\bar{E}(z)$ käytetään myös aallonpituudesta riippumatonta tehoisaa vaimenemiskerrointa $C$, jolloin

$$
\bar{E}(z)=\bar{E}(0) e^{-C z}
$$

Kaksi tärkeätä optiikkaan liittyvää empiiristä suuretta ovat näkösyvyys $z_{D}$ ja eufoottinen syvyys $z_{e}$. Edellinen määritellään syvyydeksi, johon asti Secchi-levy näkyy. Eufoottinen syvyys on syvyys, jossa yhteyttäminen on vielä mahdollista. Se määritellään syvyydeksi, jossa valaistuksen taso on $1 \%$ pintaan tulevasta nettosäteilystä. Eksponentiaalisen vaimenemislain mukaan $z_{e}=4,6 \cdot C^{-1}$. Empiiristen aineistojen perustella voidaan arvioida, että näkösyvyys ja eufoottinen syvyys ovat $z_{D} \approx 2 \cdot C^{-1}$ ja $z_{e} \approx 2,5 \cdot z_{D}$.

Vesiekologisissa tutkimuksissa vielä tärkeämpi on integroida valokvanttien määrä, josta yhteyttäminen riippuu. Tämä saadaan lausekkeesta

$$
\bar{E}_{q}(z)=\int_{\lambda_{1}}^{\lambda_{2}} \frac{h c_{0}}{\lambda} E(\lambda ; z) d \lambda,
$$

missä $\lambda_{1}=400 \mathrm{~nm}$ ja $\lambda_{2}=700 \mathrm{~nm}, h$ on Planckin vakio ja $c_{0}$ on valon nopeus tyhjiössä. Tässä lasketaan yhteyttämiseen soveltuvat kvantit eli integroidaan ne PAR ${ }^{5}$ kaistan ylitse. Auringosta tulevien valokvanttien määrä on maapallon pinnalla suuruusluokkaa $1000-5000 \mu \mathrm{mol}$ $\mathrm{m}^{-2} \mathrm{~s}^{-1}$ ja perustuotannon ylläpitämiseksi tarvittava taso on noin $25 \mu \mathrm{mol} \mathrm{m} \mathrm{m}^{-2} \mathrm{~s}^{-1}$.

Maan pinnalla säteily on PAR-kaistalla lähes tasaista ja silloin $\bar{E}_{q} \approx a \cdot \bar{E}$, missä $a \approx 4,6$ $\mu \mathrm{mol} \mathrm{J}{ }^{-1}$. Vedessä spektri muuttuu ja kertoimen 4,6 sijaan käytetään kertoimen $a$ numeerista arvoa 4,5-5,5 veden laadusta riippuen.

Tässä luvussa on tarkasteltu järvien fysiikkaa ja merkitystä hydrologisessa kierrossa. Järvillä on ollut suuri merkitys suomalaisessa elämänmuodossa ja kulttuurissa. Vesiliikenneolot suojaisilla Suomen järvillä ovat helpommat kuin merellä, ja siksi järviveneet ovat sulavalinjaisia ja keveitä käsitellä. Jo keskiajalla muotonsa saavuttanut savolaisvene on tästä oiva esimerkki (kuva 5-19). Seuraavassa luvussa paneudutaan uomien eli jokien ja kanavien maailmaan.

\footnotetext{
5 Photosynthetically Active Radiation
} 


\section{Uomien virtaus}

\subsection{Uomien karakterisointi}

Uomalla tarkoitetaan jokea, puroa tai rakennettua kanavaa, jossa vesi virtaa painovoiman ajamana (kuva 6-1). Tässä luvussa tarkastellaan niiden morfologiaa, virtausta sekä virtauksen aiheuttamaa eroosiota. Painovoima on pysyvä pakote, ja siksi virtauskin on säännöllistä. Järvissä sen sijaan tärkein virtauksia ajava voima on tuuli, ja painovoima toimii palauttavana ja tasapainottavana tekijänä. Joet siirtävät vettä järvestä toiseen ja edelleen mereen, ja niiden hydrologian pääkysymyksinä ovatkin veden sekä vedessä olevien ainesten kuljetus ja virtauksen aiheuttama eroosio.
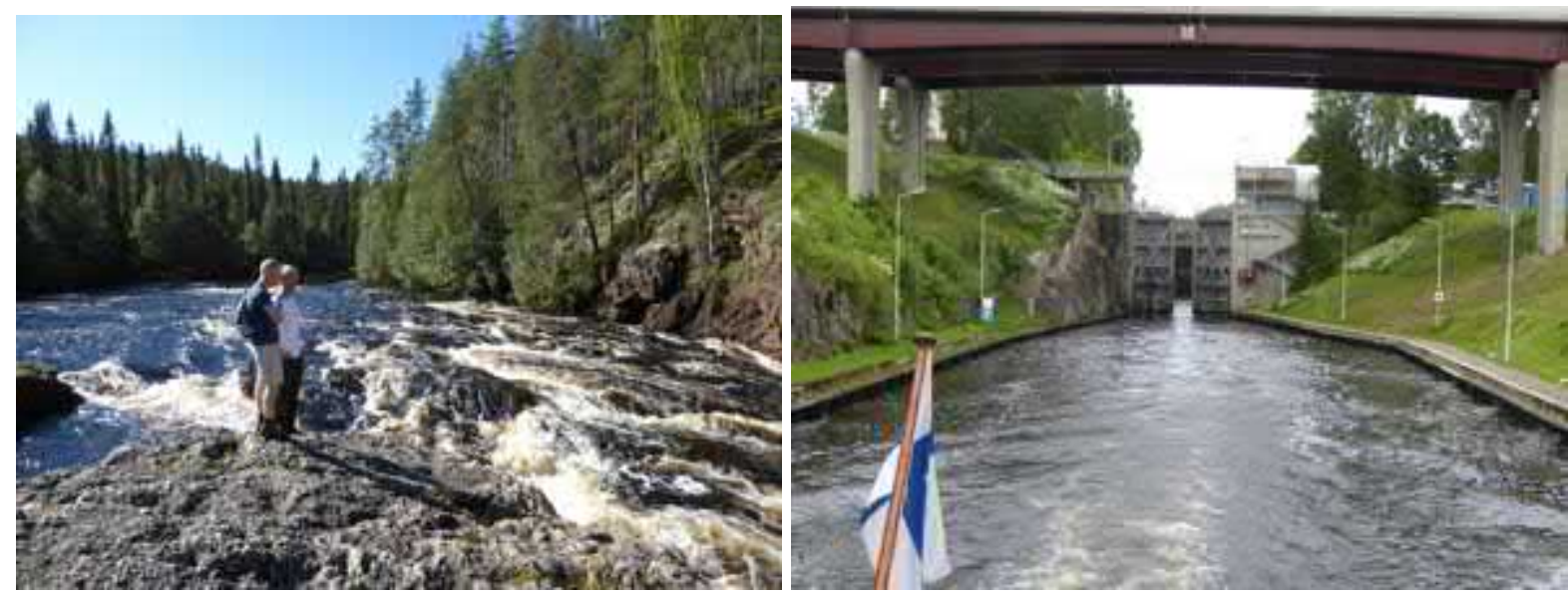

Kuva 6-1. Vienanmereen laskevan Oulankajoen Kiutaköngäs Kuusamossa (vasen kuva) ja Saimaan kanavan Mälkiän sulku (oikea kuva). Kuvat: Matti Leppäranta.

Jokien veden kuljetus kuvataan virtaamana eli vesitilavuuden kulkunopeutena, dimensiona $L^{3} T^{-1}$. Vesi tulee jokeen valuntana joen vesistöalueelta. Jos virtauksen nopeus on suuruusluokaltaan $1 \mathrm{~m} \mathrm{~s}^{-1}$, ja joen pituus on $500 \mathrm{~km}$, vesi kulkee sen lävitse kuudessa päivässä. Maailman suurimmassa joessa, Amazonissa veden kuljetus on $209000 \mathrm{~m}^{3} \mathrm{~s}^{-1}$, Suomen suurimmassa joessa, Kemijoessa, se on $560 \mathrm{~m}^{3} \mathrm{~s}^{-1}$ (Taulukko 6-1). Pienten jokiemme, kuten Vantaan ja Aurajoen keskivirtaamat ovat suuruusluokaltaan $10 \mathrm{~m}^{3} \mathrm{~s}^{-1}$. Veden kertymä valuma-alueelta pinta-alayksikköä kohti on Amazonilla 2,6 mm vrk-1, Kemijoella 0,9 mm vrk ${ }^{-1}$ ja Niilillä 0,1 mm vrk ${ }^{-1}$.

Uomaa karakterisoidaan sen poikkileikkauksen alan $A$ ja pituuden $L$ perusteella (kuva 62). Märkäpiiri $P$ on se matka, jossa poikkileikkauksen maaperä ja vesi ovat kontaktissa. Näistä kahdesta suureesta saadaan uoman hydraulinen säde

$$
R=\frac{A}{P}
$$

Yksikköpituutta $d x$ kohti painovoima vaikuttaa koko vesirunkoon $A d x$ ja kitka vain pintoihin $P d x$, ja näin ollen mitä suurempi hydraulinen säde on, sitä pienempi on kitkan suhteellinen vaikutus. Kitka vaikuttaa aina uomaa eteenpäin mentäessä, ja siksi kitkallisessa virtauksessa uoman pituus vaikuttaa virtausnopeuden määräytymiseen. Uoman korkeus $h$ kertoo vesi- 
massan potentiaalienergiasta. Veden virratessa potentiaalienergiaa kuluu kitkatyöhön ja muuntuu liike-energiaksi.
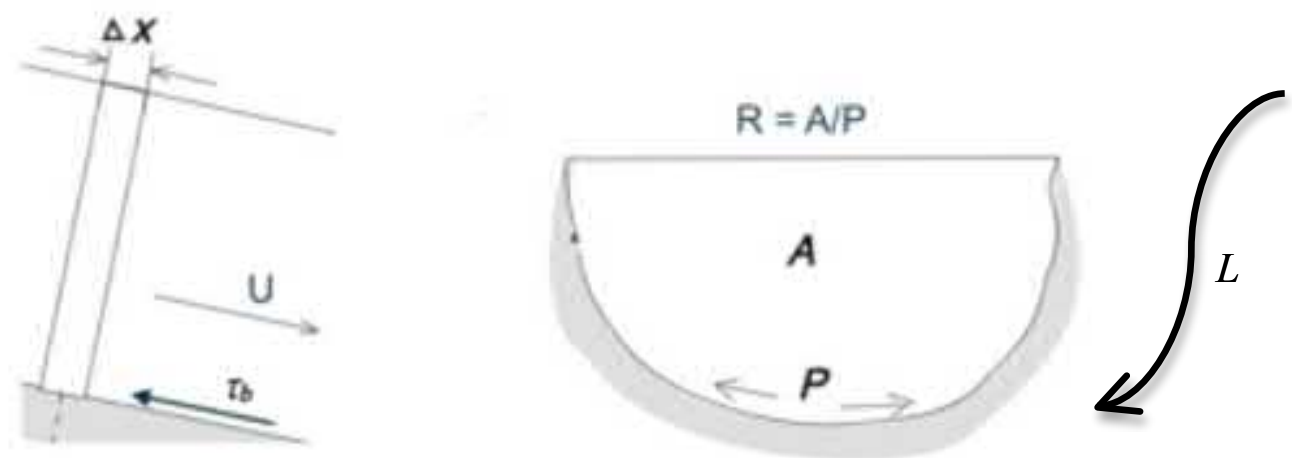

Kuva 6-2. Uoman pitkittäis- ja poikkileikkaus ja niihin liittyvät keskeiset suureet. $\Delta x$ on askel uoman pituussunnassa, $\tau_{b}$ on pohjaan kohdistuva kitkavoima pinta-ala yksikköä kohti, $U$ on virtausnopeus, $A$ on poikkileikkauksen ala, $P$ on märkäpiiri, ja $L$ on uoman pituus.

Taulukko 6-1. Esimerkkejä suurten jokien sekä suomalaisten jokien pituuksista, keskivirtaamista ja valuma-alueiden aloista.

\begin{tabular}{|c|c|c|c|}
\hline & Pituus & Virtaama & Valuma-alue \\
\hline Joki & km & $m^{3} s^{-1}$ & $10^{3} \mathrm{~km}^{2}$ \\
\hline Amazon & 7000 & 209000 & 7050 \\
\hline Niili & 6900 & 2800 & 3250 \\
\hline Jangtsekiang & 6300 & 31900 & 1800 \\
\hline $\begin{array}{l}\text { Mississippi- } \\
\text { Missouri }\end{array}$ & 6280 & 16200 & 2980 \\
\hline Jenisei & 5540 & 19600 & 2580 \\
\hline Keltainen joki & 5460 & 2100 & 745 \\
\hline Parana & 4880 & 18000 & 2580 \\
\hline Kongo & 4700 & 41800 & 3680 \\
\hline Lena & 4400 & 17100 & 2490 \\
\hline Niger & 4200 & 9570 & 2090 \\
\hline Volga & 3650 & 8080 & 1380 \\
\hline Eufrat & 3600 & 856 & 884 \\
\hline Rio Grande & 3060 & 82 & 570 \\
\hline Tonava & 2890 & 7130 & 817 \\
\hline Ganges & 2620 & 12000 & 907 \\
\hline Kemijoki & 550 & 560 & 51 \\
\hline Tornionjoki & 520 & 370 & 40 \\
\hline Kymijoki & 204 & 280 & 37 \\
\hline Vuoksi & 162 & 690 & 68 \\
\hline Kokemäenjoki & 121 & 240 & 27 \\
\hline Vantaa & 101 & 15 & 2 \\
\hline Aurajoki & 70 & 7 & 1 \\
\hline
\end{tabular}

Esimerkki 6-1. Jos joen poikkileikkaus on suorakaiteen muotoinen, leveys $50 \mathrm{~m}$ ja syvyys $5 \mathrm{~m}$, poikkileikkauksen ala on $250 \mathrm{~m}^{2}$ ja märkäpiiri $60 \mathrm{~m}$. Silloin hydraulinen säde on $250 \mathrm{~m}^{2} / 60 \mathrm{~m}=4,17 \mathrm{~m}$. 
Yleisesti suorakaiteen muotoisen $H$-syvyisen uoman hydraulinen säde on $R=\frac{H^{2}}{\delta} \frac{1}{2 H+H \delta^{-1}}=\frac{H}{1+2 \delta}$, missä $\delta$ on uoman syvyyden ja leveyden suhde. Jos poikkileikkaus on $H$-säteinen puoliympyrä, hydrauliseksi säteeksi tulee $R=\frac{1}{2} H$.

Uoman pituus on paljon suurempi kuin sen syvyys ja leveys eli se on viivamuotoinen. Vesi virtaa uomassa suunnilleen sen pituusakselin suunnassa alavirtaan. Tämän takia uoman virtausta voidaan usein tarkastella yksiulotteisena, jossa pituusakseli ( $x$-akseli) kulkee alavirtaan uoman keskilinjaa pitkin. Silloin virtausta hallitsee $x$-akselin suuntainen nopeus $u$ $=u(x, y, z ; t)>0$, ja $x$-akselia vastaan kohtisuorassa olevat nopeuskomponentit $v$ (virtaus joen poikkisuuntaan) ja $w$ (vertikaalinen nopeus) ovat hyvin pieniä, $u>>v, w$. Veden lämpötila ja samalla myös tiheys oletetaan vakioksi, sillä uomat ovat suhteellisen matalia, ja niiden virtaus on voimakasta, jolloin turbulenssi pystyy huolehtimaan hyvin sekoittumisesta.

Veden virtaama on poikkileikkauksen alan $A$ ja sen yli lasketun virtausnopeuden $u$ keskiarvon $U$ tulo

$$
Q=U A
$$

Virtaama ilmaisee veden kokonaiskuljetuksen. Tyypillisessä joessa Suomessa $U \sim 1 \mathrm{~m} \mathrm{~s}^{-1}, A \sim$ $250 \mathrm{~m}^{2}$, ja siis $Q \sim 250 \mathrm{~m}^{3} \mathrm{~s}^{-1}$, pienessä ojassa $U \sim 0,1 \mathrm{~m} \mathrm{~s}^{-1}, A \sim 10 \mathrm{~m}^{2}$, ja $Q \sim 1 \mathrm{~m}^{3} \mathrm{~s}^{-1}$. Uomien virtausoppiin sovelletaan virtausopin perusyhtälöitä, jotka ovat liikeyhtälö (3.11) ja jatkuvuusyhtälö (3.12). Uomien tutkimuksessa virtaaman määrittäminen on yksi perustehtävistä. Virtaus on säännöllistä, koska painovoima ajaa sitä. Tärkeitä uomiin liittyviä ongelmia ovat myös aineksen kulkeutuminen virtauksen mukana sekä valuma-alueen maaperän ja itse uoman eroosio.

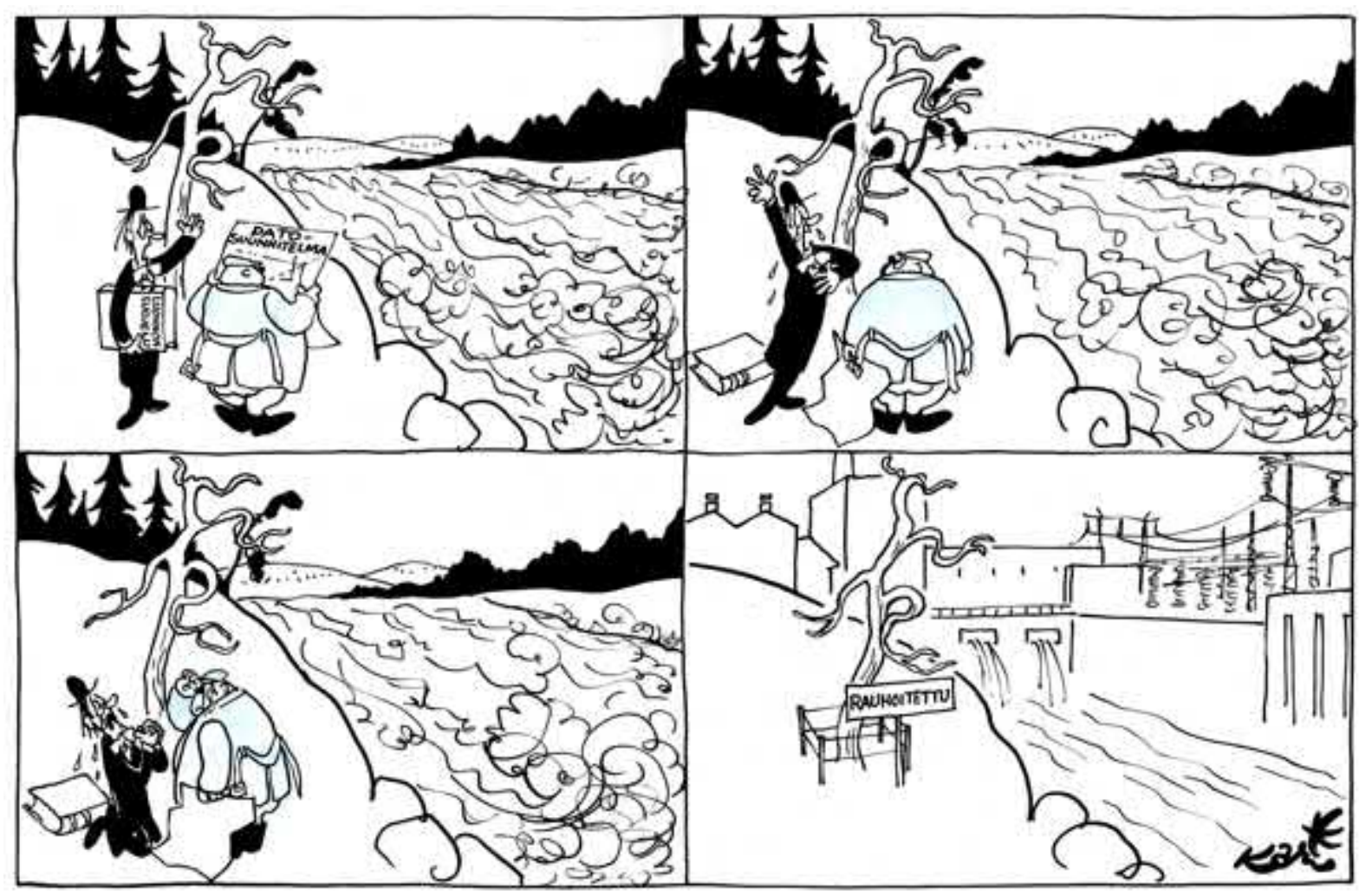

Kuva 6-3. Myönnytys, Kari Suomalaisen piirros 19.5.1961. @ Kari Suomalaisen perikunta. 
Jos uoman virtaus on vakaa eikä sivu-uomia ole, virtaaman täytyy olla sama kaikissa poikkileikkauksissa eli $U A=$ vakio. Tätä uomavirtausten keskeistä kaavaa voitaisiin kutsua keksijänsä mukaan Leonardo da Vincin kaavaksi. Epävakaassa tilanteessa voidaan käyttää jatkuvuusyhtälöä (5.18), jonka mukaan virtaaman muuttuessa uoman suunnassa virran poikkileikkaus muuttuu:

$$
\frac{\partial A}{\partial t}=\frac{\partial Q}{\partial x}
$$

missä $t$ on aika. Toisin sanoen uoman vedenpinta nousee tai laskee.

Turbulenttisessa virtauksessa vesirunko sekoittuu tehokkaasti. Jos $c$ on jokin ainespitoisuus (massa) nesteen tilavuusyksikköä kohden, aineskuljetus on

$$
M_{c}=\int_{A} c u d A \text {. }
$$

Sekoittuneessa vesirungossa olevat ainekset ovat jakautuneet tasaisesti koko poikkileikkauksen alalle, ja kuljetusta voidaan tarkastella virtaaman avulla. Silloin aineskuljetus on $M_{c}=c Q$.

Jokien merkitys ihmiselle on jo vahain liittynyt vesihuoltoon, kalastukseen, kuljetukseen, matkustamiseen ja virkistyskäyttöön. Teknologian kehittyessä voimatalous alkoi hyödyntää jokia, mistä seurasi ristiriitoja jokien muun käytön ja suojelun kanssa (kuva 6-3). Läntisessä Suomessa suuret joet hallitsevat maisemaa ja vesitaloutta, ja Pohjois-Pohjanmaahan viitataankin 'kymmenen virran maana' A. V. Koskimiehen sanoittamassa maakuntalaulussa

\author{
Kemi, Tornio, Ounas, Oulu ja Ii, \\ olen nähnyt uomanne aavat. \\ Ja mieleni laajeten lainehtii \\ ja suoneni tarmoa saavat. \\ Jokes uljahat syöntäni suurentaa, \\ oi Kymmenen virran maa.
}

\title{
6.2 Uomien virtausoppi
}

\subsubsection{Bernoullin yhtälö}

Virtausopin liikeyhtälö (3.11) yksinkertaistuu suuresti yksiulotteisessa tapauksessa, kun uoman suuntaisessa virtauksessa nopeuskomponenttien $v$ ja $w$ vaikutus voidaan jättää pois. Tämä yhtälö voidaan kirjoittaa

$$
\frac{\partial u}{\partial t}=-u \frac{\partial u}{\partial x}-g \frac{\partial h}{\partial x}-\frac{\mathbf{1}}{\boldsymbol{\rho}} \frac{\partial p}{\partial x}+N \nabla^{2} u
$$

Vasemmalla puolella on virtausnopeuden paikallinen muutos, ja oikealla puolella on kulkeutuminen, uoman kaltevuudesta seuraava painovoiman komponentti, painegradientti ja sisäinen kitka. Virtausta vastaan kohtisuoraan olevissa poikkileikkauksissa pätee hydrostaattinen tasapaino. Uomien virtaus on yleensä turbulenttinen eli Reynoldsin luku $R e=U L / v$ on suurempi kuin $10^{4}$. Tässä nopeusmitta on tyypillinen virtausnopeus ja pituusmitta on uoman syvyys. Jos esimerkiksi $U=1 \mathrm{~cm} \mathrm{~s}^{-1}$ ja $L=100 \mathrm{~cm}$, niin $R e=7700$ eli virta on jo lähes turbu- 
lenssialueelle. Luonnonuomat ovat suurempia ja virtaus on niissä voimakkaampaa kuin annetussa esimerkissä, joten turbulenssi on niissä vallitseva olotila.

Tarkastellaan aluksi vakaata ja kitkatonta virtausta, $\partial u / \partial t=0$ ja $N=0$. Kitkattomuus jokivirtauksia tarkasteltaessa huomattava rajoitus, mutta se edustaa kuitenkin hyödyllistä teoreettista referenssiä. Yhtälö (6.5) voidaan kirjoittaa

$$
0=\frac{\partial}{\partial x}\left(\frac{u}{2}+g h+\frac{p}{\rho}\right)
$$

Tästä saadaan uomavirtauksen Bernoullin yhtälö (Daniel Bernoulli, 1700-1782)

$$
\frac{u^{2}}{2 g}+h+\frac{p-p_{0}}{\rho g}=\text { vakio, }
$$

missä $p_{0}$ on ilmanpaine veden pinnalla. Bernoullin yhtälö voidaan ajatella mekaanisen energian taseena, joka yhtälössä (6.6b) on ilmaistu energiakorkeutena eli energiana massayksikköä kohti (kuva 6-4). Vasemman puolen termit kuvaavat kineettistä energiakorkeutta, potentiaalienergian korkeutta, joka on sama kuin geometrinen korkeus, ja painekorkeutta. Uoman pinnalla $p=p_{0}$, ja silloin yhtälö (6.6) kuvaa kineettisen energian ja potentiaalienergian tasapainoa

$$
\frac{u^{2}}{2 g}+h=\text { vakio }
$$

Jos $u=0$, yhtälöstä (6.6b) saadaan hydrostatiikan perusyhtälö $p=p_{0}-\rho g h$.

Yhtälön (6.6b) toinen tulkinta saadaan, kun se kerrotaan tekijällä $\rho g$. Tällöin dimensioksi tulee paine, ja termiä $\frac{1}{2} \rho u^{2}$ kutsutaan dynaamiseksi paineeksi. Jos $u=1 \mathrm{~m} \mathrm{~s}^{-1}$, dynaaminen paine on $0,5 \mathrm{kPa}$, mikä vastaa $5 \mathrm{~cm}$ paksun vesikerroksen tuottamaa hydrostaattista painetta. Kun virtausnopeus tulee tätä suuremmaksi, dynaamisella paineella alkaa olla merkitystä kokonaispaineen kannalta.

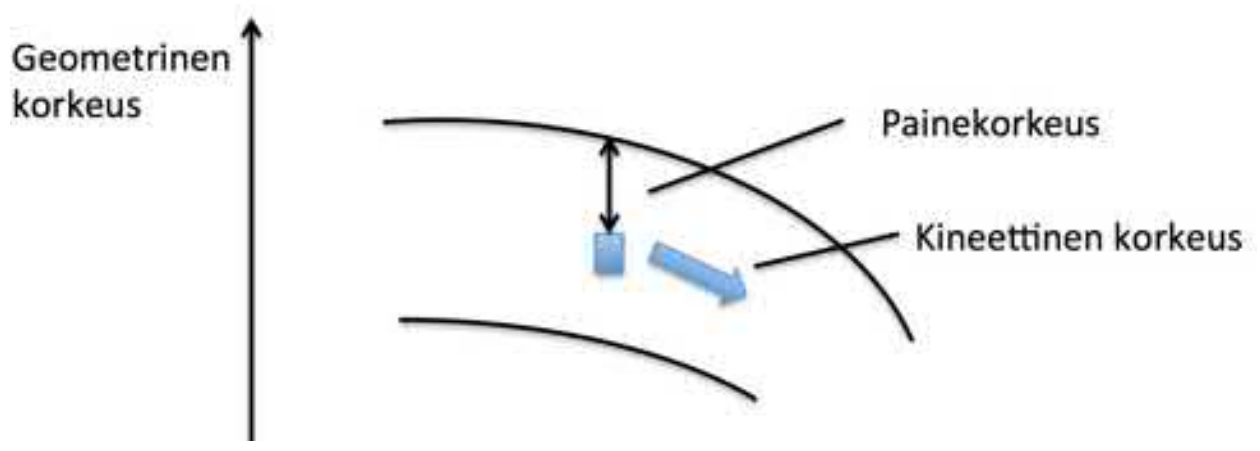

Kuva 6-4. Skemaattinen esitys Bernoullin yhtälöstä.

Esimerkki 6-2. Torricellin (1608-1647) kaava. Tarkastellaan laakeaa vesiastiaa, jossa on suljettu putkensuu pinnasta katsoen syvyyden $h$ kohdalla. Kun putki avataan, astia alkaa tyhjentyä. Pinnalla $u \approx 0$, joten reiästä ulos virtaavan veden nopeus on $u=\sqrt{2 g h}$ (yhtälö 6.7). Torricellin kaava on Bernoullin yhtälön erikoistapaus.

Vastaavaan tapaan voidaan osoittaa, että virtausta vasten kohtisuoraan uoman poikki (y-akseli) ja syvyyssuunnassa ( $z$-akseli) pätee 


$$
\begin{aligned}
& 0=\frac{\partial}{\partial y}\left(\frac{p}{\rho}\right) \text { ja } \\
& 0=\frac{\partial}{\partial z}\left(g h+\frac{p}{\rho}\right) .
\end{aligned}
$$

Uoman poikkisuuntaan kulkiessa syvyys = vakio ja siksi myös paine = vakio, ja syvyyssuunnassa on voimassa hydrostaattinen tasapaino.

Tarkastellaan vakaan tilan virtausta. Kerrotaan Bernoullin yhtälö (6.6b) puolittain $u d A$ :lla ja integroidaan poikkileikkauksen ylitse, jolloin saadaan

$$
\int_{A} \frac{u^{3}}{2 g} d A+\int_{A} u\left(h+\frac{p-p_{0}}{\rho g}\right) d A=\int_{A} u \cdot \text { vakio } \cdot d A,
$$

Uoman suuntainen nopeus $u$ ei reunojen takia ole aivan vakio, ja sen kuution integrointi tehdään teknisesti korjauskerrointa $\alpha$ käyttäen: $\int_{A} u^{3} d A \approx \alpha A U^{3}$, missä $\alpha \geq 1$ riippuu virtauksen poikkileikkauksesta. Mittausten perusteella luonnonuomissa on $\alpha \approx 1,3-1,4$. Jos virtausnopeus on poikkileikkauksessa vakio, $\alpha=1$, jota yleensä käytetään, kun muuta tietoa ei ole. Yhtälön toinen integraali voidaan kirjoittaa $\int_{A} u\left(h+\frac{p-p_{0}}{\rho g}\right) d A=\left(h+\frac{p-p_{0}}{\rho g}\right) \int_{A} u d A$, sillä suluissa oleva lauseke on kaikkialla poikkileikkauksessa vakio. Koska pinnalla $p=p_{0}$, tämä vakio on $h$. Jatkuvuusyhtälön mukaan vedenkuljetuksen $u d A$ integraali poikkileikkauksen yli eli virtaama on vakaassa tilassa vakio $U A$. Kun yhtälö (6.9) nyt jaetaan virtaamalla, saadaan uomavirtauksen Bernoullin yhtälö

$$
\alpha \frac{U^{2}}{2 g}+h=\text { vakio }
$$

Uomavirtauksissa pohjan aiheuttama kitka on merkittävä, ja siksi uomaa alaspäin mentäessä Bernoullin yhtälö 'jää vajaaksi'. Tämä vajaus on kitkaa vastaava energiahäviön korkeus.

Esimerkki 6-3. Tarkastellaan järvestä lähtevää jokea. Järven pinnan korkeus on $h_{0}$, ja virtausnopeus on pinnalla $U_{0} \approx 0$. Alempana joen juoksulla $h<h_{0}$ ja $U>0$, ja Bernoullin (tai Torricellin) yhtälön mukaan $U=\sqrt{2 g\left(h_{0}-h\right)}$. Virtaus siis nopeutuu alaspäin mentäessä. Koska kitkaa ei ole mukana, virtausnopeus riippuu vain korkeuden muutoksesta, ei kokonaismatkasta. Jos $h_{0}-h=5 \mathrm{~m}$, saadaan $U$ $=10 \mathrm{~m} \mathrm{~s}^{-1}$, mikä on aivan liian suuri jokivirtauksia ajatellen. Viiden metrin korkeuden laskuun liittyvä matka on tyypillisesti $\sim 5 \mathrm{~km}$ eli siihen liittyy paljon kitkaa vastaan tehtävää työtä.

\subsubsection{Kitka uomavirtauksessa}

Turbulenttisen virtauksen vastus $\tau$ eli kitka on verrannollinen nopeuden neliöön. Hydrodynaamista vastusta tarkasteltiin virtausopin perusteissa kohdassa 3.3.1 (kuva 3-10). Uoman pohjakitkaa merkitään tässä $\tau=\rho C_{b} U^{2}$, missä $C_{\mathrm{b}}$ on pinnan karkeudesta riippuva vastuskerroin. Kitkaa vasten tehtävä työ matkalla $\mathrm{d} x$ on

$$
d W=\rho C_{b} U^{2} P d x
$$

missä $P$ on märkäpiiri (kuva 6-2). Kitkahäviö saadaan jakamalla tämä työ pinta-alalla $A$, ja edelleen kitkahäviö muuntuu energiakorkeuden häviöksi $h_{f}$ jakamalla tekijällä $\rho g$ : 


$$
d h_{f}=\frac{C_{b} U^{2}}{R g} d x
$$

Kitkahäviöt huomioiden päästään uoman energiayhtälöön

$$
\frac{\alpha}{2 g} U^{2}+h-x \frac{C_{b}}{R g} U^{2}=\text { vakio, }
$$

missä $x$ on virtauksen kulkema matka. Jos olosuhteet ovat vakaat, alavirtaan mentäessä kitka kuluttaa energian, joka korkeuden laskusta tulee.

Tasapainotilanteessa $U=$ vakio, ja energiayhtälöstä (6.13) saadaan klassinen uoman virtausyhtälö, Chezyn kaava, vuodelta 1775:

$$
U=\sqrt{\frac{h R g}{x C_{b}}}=C \sqrt{R S}
$$

missä $S=\frac{h}{x}$ on uoman geometrinen kaltevuus, ja $C=\sqrt{\frac{g}{C_{b}}}$ on Chezyn kerroin. Antoine Chézy (1718-1798) tarkasteli kertoimen $C$ arvoa Seine-joelle kanavointisuunnitelmien yhteydessä ja päätteli, että se on vakio. Myöhemmin Chezyn kertoimen arvoa on tutkittu kokeellisesti eri puolilla maailmaa ja todettu sen riippuvan uomaparametreista. Näistä tutkimuksista on jäänyt jäljelle Manningin nimellä kulkeva vuodelta 1889 peräisin oleva muoto

$$
C=M R^{1 / 6}
$$

missä $M$ on Manningin kerroin. Taulukossa 6-2 on kertoimen arvoja erilaisille uomanpohjille.

Taulukko 6-2. Uomien Manningin kertoimia $(M)$.

\begin{tabular}{l|r} 
Uoman pohja & $\boldsymbol{M}\left(\mathbf{m}^{\mathbf{1 / 3}} \mathbf{s}^{-1}\right)$ \\
\hline Tasapintainen, kiinteä, puhdas uoma & 40 \\
Kivikkopohjainen uoma & $25-28$ \\
Sileä jää & $85-100$ \\
Hiottu betonipinta & 100
\end{tabular}

Esimerkki 6-4. Tarkastellaan kitkahäviön vaikutusta virtausnopeuteen. Olkoon hydraulinen säde $R=$ $5 \mathrm{~m}$, uoman kaltevuus $S=10^{-3}$ ja Manningin kerroin $M=30 \mathrm{~m}^{1 / 3} \mathrm{~s}^{-1}$. Tällöin on $U=2,8 \mathrm{~m} \mathrm{~s}^{-1}$ ja kineettinen energiakorkeus on $\frac{\alpha}{2 g} U^{2}=0,40 \mathrm{~m}$, kun otetaan $\alpha=1$, ja se pysyy vakiona vakaassa virtauksessa. Silloin geometrisen korkeuden pienentyessä kitkahäviö kasvaa vastaavan määrän. Jos joen pituus on $L=100 \mathrm{~km}$, alussa geometrinen korkeus on $S L=100 \mathrm{~m}$ ja kitkahäviö nolla. Matkalla jokisuulle kitkaa vasten tehdään työtä 99,6 energiakorkeushäviön verran ja luodaan 0,4 m:n kineettinen energiakorkeus. Ilman kitkaa tulisi nopeudeksi jokisuulla 44,3 $\mathrm{m} \mathrm{s}^{-1}$.

Kehittyneemmät menetelmät, Reynoldsin luvusta riippuva kitkakerroin sekä turbulenssiteoria eivät ole tuoneet selvää parannusta virtausnopeuden laskemiseen luonnonuomissa. Näitä luokittelemalla ja uomakuvastoja laatimalla on pyritty löytämään menetelmä, jolla Manningin kerrointa voitaisiin arvioida tarkemmin. On kuitenkin osoittautunut, että kerroin tulisi määrittää kullekin uomalle suoraan mittauksien perusteella. 


\subsubsection{Uoman vesirungon aaltoliike}

Matalan veden aallot (ks. kohta 5.4.4) etenevät uomien vesirungossa. Niiden etenemisnopeus on $v=\sqrt{g H}$. Jos $H=2,5 \mathrm{~m}$, niin $v=5 \mathrm{~m} \mathrm{~s}^{-1}$, joka on samaa suuruusluokkaa kuin virtauksen nopeus. Aaltoliike kuljettaa häiriöitä, joten sen nopeuden suhde virtauksen nopeuteen kertoo, etenevätkö häiriöt vastavirtaan. Siksi aaltoliikkeellä on suuri merkitys uomien hydrauliikassa.

Virtauksen ja matalan veden aallon nopeuksien suhdetta kuvataan Frouden luvulla $\mathrm{Fr}=$ $U / \sqrt{g H}$ (ks. kohta 2.3.1). Frouden luku kuvaa samalla myös inertian ja painovoiman suhdetta. Virtaukset jaotellaan seuraaviin luokkiin:
$F r>1$
$F r=1$
ylikriittinen eli kiitovirtaus
$F r<1$
kriittinen virtaus
alikriittinen eli verkasvirtaus

Ylikriittisessä virtauksessa matalan veden aallon muodostama häiriö ei kykene etenemään vastavirtaan, koska vesi virtaa sitä nopeammin. Alikriittisessä tapauksessa häiriöt voivat edetä ylävirtaan, ja virtausdynamiikan käsittely on vaikeampaa.

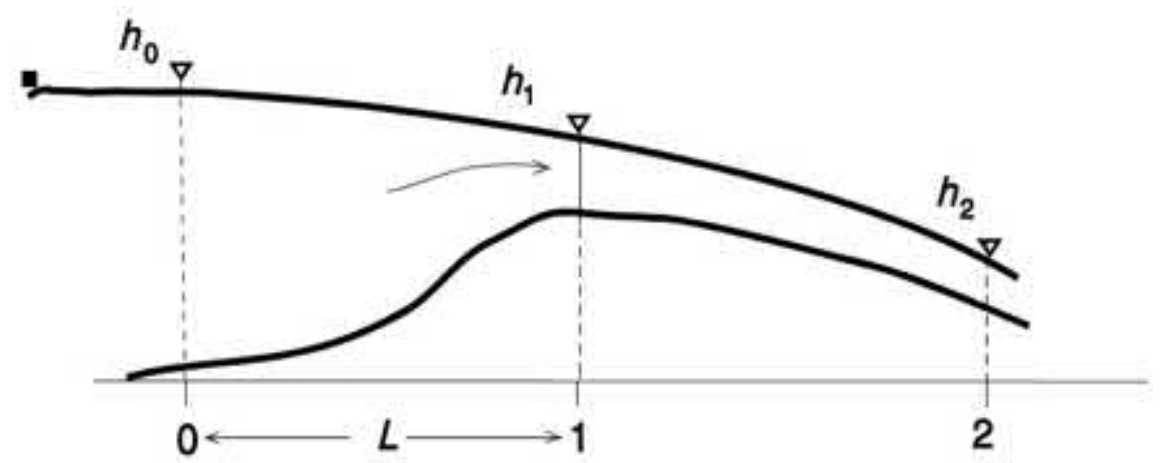

Kuva 6-5. Joen pitkittäisprofiili. Lähtöjärven vedenkorkeus on $h_{0}$.

Tarkastellaan järven laskujokea (kuva 6-5). Laskujoessa voidaan usein tunnistaa määräävä poikkileikkaus, josta joki varsinaisesti alkaa ja joka säätelee vedenkorkeuden ja virtaaman riippuvuuden. Joen pohjan korkein kohta on yleensä määräävän poikkileikkauksen kohdalla, ja sitä kutsutaan kynnykseksi. Järvessä, määräävässä poikkileikkauksessa ja alajuoksulla mitattuja suureita merkitään alaindeksein 0,1 ja 2 . Koska järvessä $U_{0}=0$, energiakorkeuden yhtälöstä (6.11) saadaan

$$
U_{1}=\sqrt{\left(h_{0}-h_{1}-h_{f}\right) \frac{2 g}{\alpha_{1}}} .
$$

Poikkileikkauksen korkeuden $h_{1}$ osalta erotetaan kaksi tapausta:

1. Korkeus $h_{1}$ riippuu ainoastaan korkeudesta $h_{0}$. Näin on silloin, kun kohdan 1 alapuolella vallitsee ylikriittinen virtaus eikä alajuoksulla muodostuva häiriö pysty etenemään vastavirtaan. Myös jos alajuoksulla virtaukseen vaikuttavat rakenteet ja altaat ovat kaukana, tämä riippuvuus on voimassa. Tällöin voidaan asettaa $h_{1}=f_{0}\left(h_{0}\right)$.

2. Kun $h_{1}$ riippuu myös alajuoksulla kohdassa 2 sijaitsevan paikan vedenkorkeudesta, $\operatorname{niin} h_{1}=f_{2}\left(h_{0}, h_{2}\right)$. 
Ylikriittinen virtauksen muodostuminen edellyttää uoman muutosta. Tällainen muutos voi olla kuvassa (6-5) näkyvä kynnys. Kriittisen virtauksen nopeus on $U_{c}=\sqrt{g H_{1}}$, missä $H_{1}$ on uoman syvyys kynnyksen kohdalla. Koska väli järvestä kynnykseen on lyhyt, voidaan kitkan vaikutus jättää usein huomioimatta. Kun vielä valitaan korkeuden nollatasoksi kynnys, saadaan yhtälöstä (6.15)

$$
U_{c}=f_{c} \sqrt{\frac{2}{3} g h_{0}}
$$

missä $f_{\mathrm{c}}$ on kitkasta ja poikkileikkauksen muodosta riippuva kerroin.

Vedenkorkeushavainnot pyritään järjestämään siten, että tapausta 1 vastaavat oletukset ovat voimassa. Funktio $f_{0}$ voidaan silloin muuntaa purkautumiskäyräksi, joka kuvaa järven vedenkorkeuden ja lähtövirtaaman välistä suhdetta (kuva 6-6). Se määritetään samanaikaisten virtaaman ja vedenkorkeuden havaintojen avulla. Yhden muuttujan purkautumiskäyrän konstruointi edellyttää, että uoma on muuttumaton eikä siinä saa olla muuttuvia esteitä kuten vaihteleva jää ja kasvillisuus. Jos vedenkorkeus muuttuu ajan suhteen niin nopeasti, ettei vakaan tilan Bernoullin yhtälö ole voimassa, purkautumiskäyrästä saattaa tulla kuvassa 6-6 esitetyn b-käyrän kaltainen.

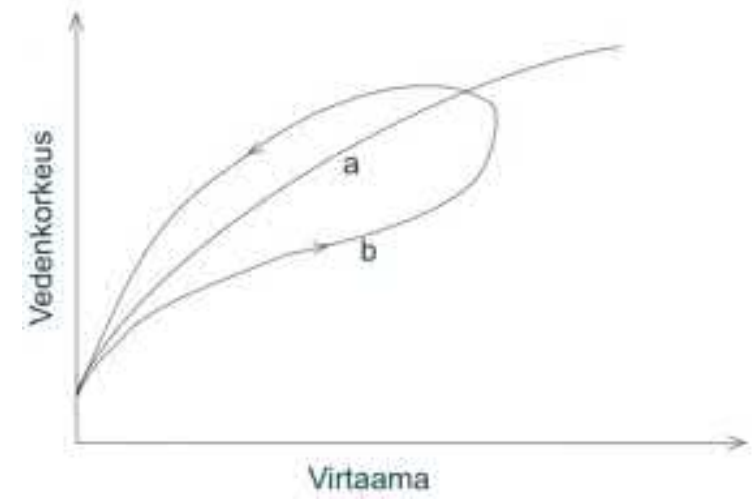

Kuva 6-6. Järven purkauskäyrä ylikriittisen lähtövirtauksen vakaassa tilanteessa (a) sekä muuttuvassa tilanteessa (b).

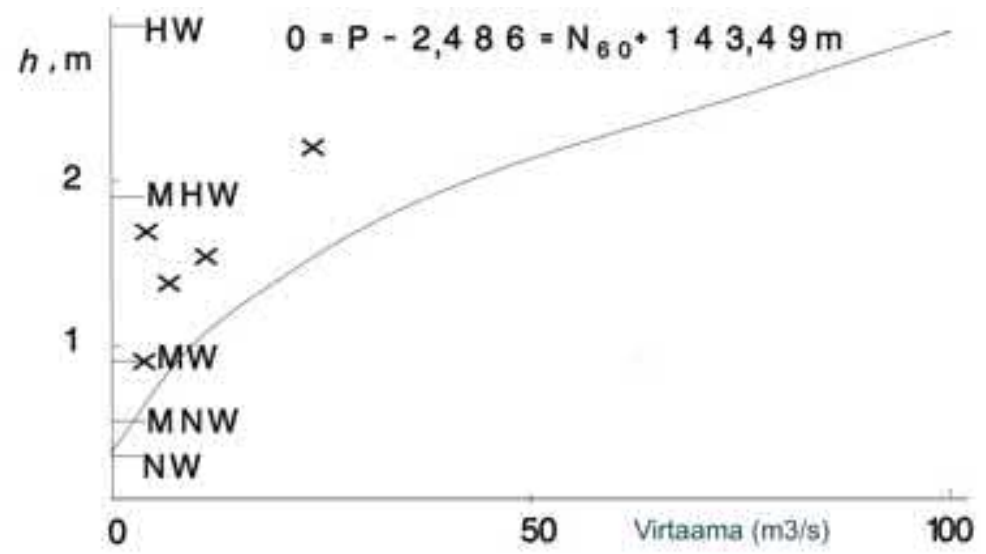

Kuva 6-7. Saarijärven reitissä sijaitsevan Pääjärven Kouheroisenkosken purkautumiskäyrä. Kuvan yläreunassa oleva teksti osoittaa vedenkorkeusasteikon nollakohdan korkeutta $(\mathrm{m})$ suhteessa asteikon kiintopisteeseen $(P)$ ja vuoden 1960 korkeusjärjestelmään N60 nähden. Talvimittaukset on merkitty symbolilla $\mathrm{x}$. HW = ylivesi, $\mathrm{MHW}=$ keskimääräinen ylivesi, $\mathrm{HW}=$ keskivesi, $\mathrm{MNW}=$ keskimääräinen alivesi, NW = alivesi. 


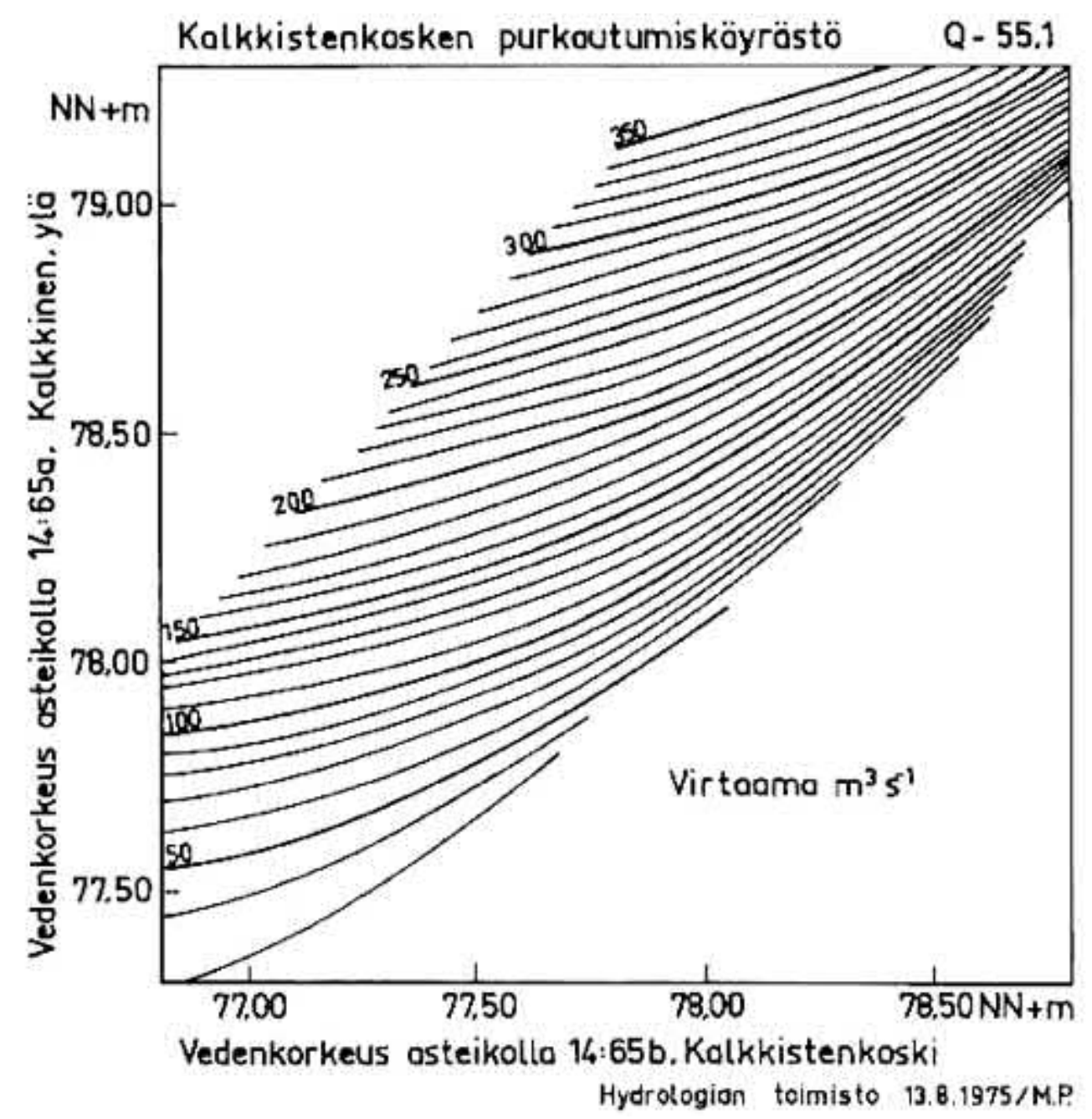

Kuva 6-8. Päijänteen Kalkkistenkosken purkautumiskäyrä, virtaama Q (Mustonen 1986). Pystyakselilla on Päijänteen vedenkorkeus ja vaaka-akselilla Kalkkistenkosken vedenkorkeus. Vedenkorkeudet on annettu korkeusjärjestelmään NN nähden.

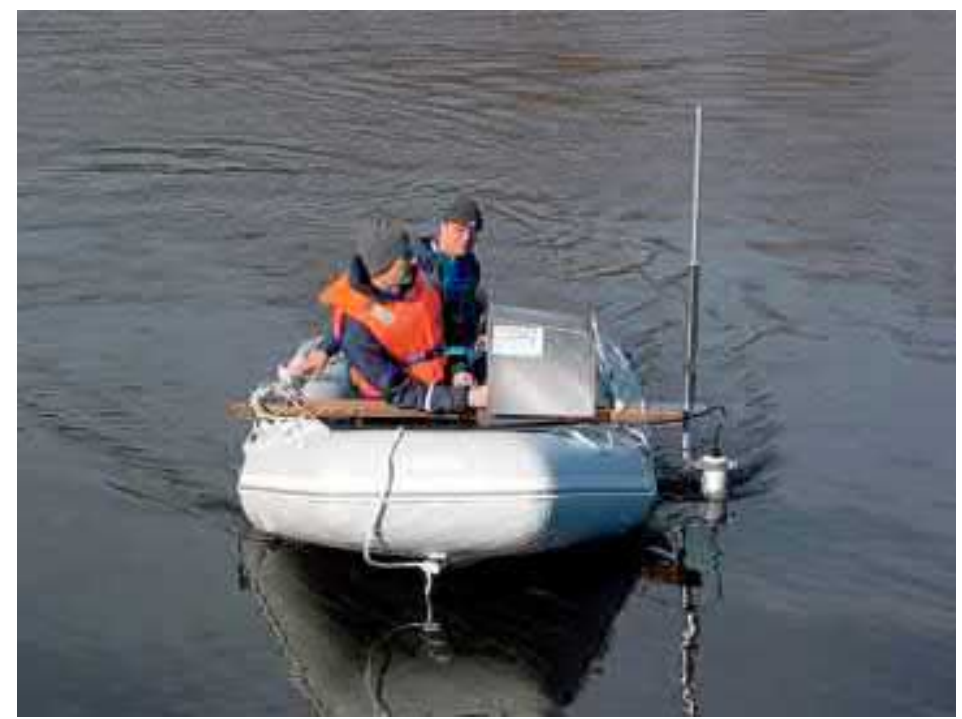

Kuva 6-9. Merkittävin siivikon jälkeinen mittaustekninen uudistus on ollut akustinen profilova virtausmittari (ADCP, Acoustic Doppler Current Profiler). Suomessa tämä menetelmä otettiin käyttöön vuonna 1994, ja se on helpottanut ratkaisevasti suurten virtaamien mittaamista. Kuva: Suomen ympäristökeskus (Kuusisto 2008). 
Suomessa virtaama lasketaan yleensä yhden muuttujan purkautumiskäyrän avulla. Ylä- ja alapuolisesta vedenkorkeudesta riippuvaa kahden muuttujan purkautumiskäyrää joudutaan käyttämään, jos peräkkäisten järvien vedenkorkeuden ero on pieni. Esimerkkinä on kuvassa (6-7) Hydrologian toimistossa laadittu purkautumiskäyrä. Toisena esimerkkinä (kuva 6-8) on tilanne, jossa virtaama riippuu sekä ylä- että alapuolisesta vedenkorkeudesta. Virtaamien aikasarjat lasketaankin yleensä vedenkorkeuden ja purkautumiskäyrän avulla.

\subsection{Virtaaman ja vedenkorkeuden mittaaminen}

Virtaamia on mitattu käyttäen hydrometristä siivikkoa. Se on potkurin muotoinen laite, jonka pyörimisnopeus riippuu virtauksen nopeudesta. Uomaan valitaan vertikaalisuunnassa 37 mittauskohtaa, ja kussakin mittauskohdassa nopeus mitataan 3-5 pisteessä. Virtaama saadaan integroimalla virtausnopeus uoman poikkileikkauksen ylitse suoraan määritelmän perusteella. Nykyisin on yhä enemmän käytetty akustista Doppler-siirtymään perustuvaa virtausmittaria, joka mittaa poikkileikkauksen virtausjakauman nopeasti (kuva 6-9). Näitä suoria mittauksia käytetään purkautumiskäyrien laatimiseen.

Pienissä uomissa voidaan käyttää erikokoisia mittapatoja (kuva 6-10), joissa virtaaman ja vedenkorkeuden välisen yhteyden perusmuoto voidaan määrittää teoreettisella laskelmalla. Kuvassa 6-11 on esimerkkejä teräväharjaisista mittapadoista. Kuva 6-11a esittää kolmioaukkoa, jonka kärjen kulma on $90^{\circ}$. Suomessa käytetyn padon (kuva 6-11b) muoto varmistaa sen, että sekä ylemmät että alemmat virtaamat voidaan määrittää vedenkorkeuden avulla ilman, että vedenkorkeuden vaihteluväli tulee liian suureksi (Mustonen 1965). Padon alaosa on helppo suojata talvella jäätymiseltä. Kuva 6-11c esittää suorakaideaukkoa, ja kuvasta 611d ilmenee, miten vesi kulkee padon terävän harjan ylitse.

Purkautumiskäyrä saadaan kuvan (6-11c) suorakaideaukolle, kun korkeus $h$ lasketaan padon alareunasta positiivisena ylöspäin. Padon leveys on $B$. Kuvaan on katkoviivoilla merkitty 'virtausputkia', joiden energiakorkeus yläaltaassa $(U=0)$ on $h=h_{0}$. Valitaan laskelman kohteeksi poikkileikkaus, jossa suihkun alareuna on korkeimmillaan, suihkun suunta on lähellä vaakasuoraa suuntaa ja vertikaalinen kiihtyvyys on nolla. Oletetaan lisäksi, että virtaus on kitkaton lyhyellä matkalla yläaltaasta patoaukkoon. Bernoullin yhtälön mukaan suihkun nopeudeksi saadaan $u=\sqrt{2 g\left(h_{0}-h\right)}$. Virtaama $Q$ saadaan nyt integroimalla

$$
Q=\int_{\Delta_{1}}^{h-\Delta_{2}} \sqrt{2 g y} B d y=\frac{2}{3} \sqrt{2 g} B h_{0}^{3 / 2}\left[\left(1-\frac{\Delta_{2}}{h_{0}}\right)^{3 / 2}-\left(\frac{\Delta_{1}}{h_{0}}\right)^{3 / 2}\right]
$$

missä on merkitty $y=h_{0}-h$ : Pituuksia $\Delta_{1}$ ja $\Delta_{2}$ on vaikea mitata suoraan, mutta joka tapauksessa ne ovat pieniä verrattuna korkeuteen $h_{0}$. Hakasuluissa oleva lauseke voidaankin yhdistää yhdeksi tekijäksi, purkautumiskertoimeksi $m$, jolloin saadaan patokaava

$$
Q=\frac{2}{3} m \sqrt{2 g} B h_{0}^{3 / 2}
$$

Purkautumiskerroin on määritettävä kalibroimalla, yleensä se vaihtelee välillä 0,6-0,7. Koska $\Delta_{1}$ ja $\Delta_{2}$ riippuvat korkeudesta $h_{0}$, myös $m$ riippuu siitä.

Esimerkki 6-5. Virtaamia voidaan arvioida myös voimalaitosten tehon, hyötysuhteen ja putouskorkeuden avulla. Tämä teho on $M=\gamma \rho g\left(h_{0}-h_{2}\right) Q$, missä $\gamma$ on hyötysuhde, ja $h_{0}$ ja $h_{2}$ ovat voimalai- 
toksen ylä- ja ala-altaan vedenpintojen korkeudet. Mahdollinen ohijuoksutus tapahtuu padossa olevien suorakulmaisten aukkojen kautta. Jos korkeusero on $10 \mathrm{~m}$ ja virtaama $100 \mathrm{~m}^{3} \mathrm{~s}^{-1}$, teho olisi teoreettisella $100 \%$ hyötysuhteella $10 \mathrm{MW}$.

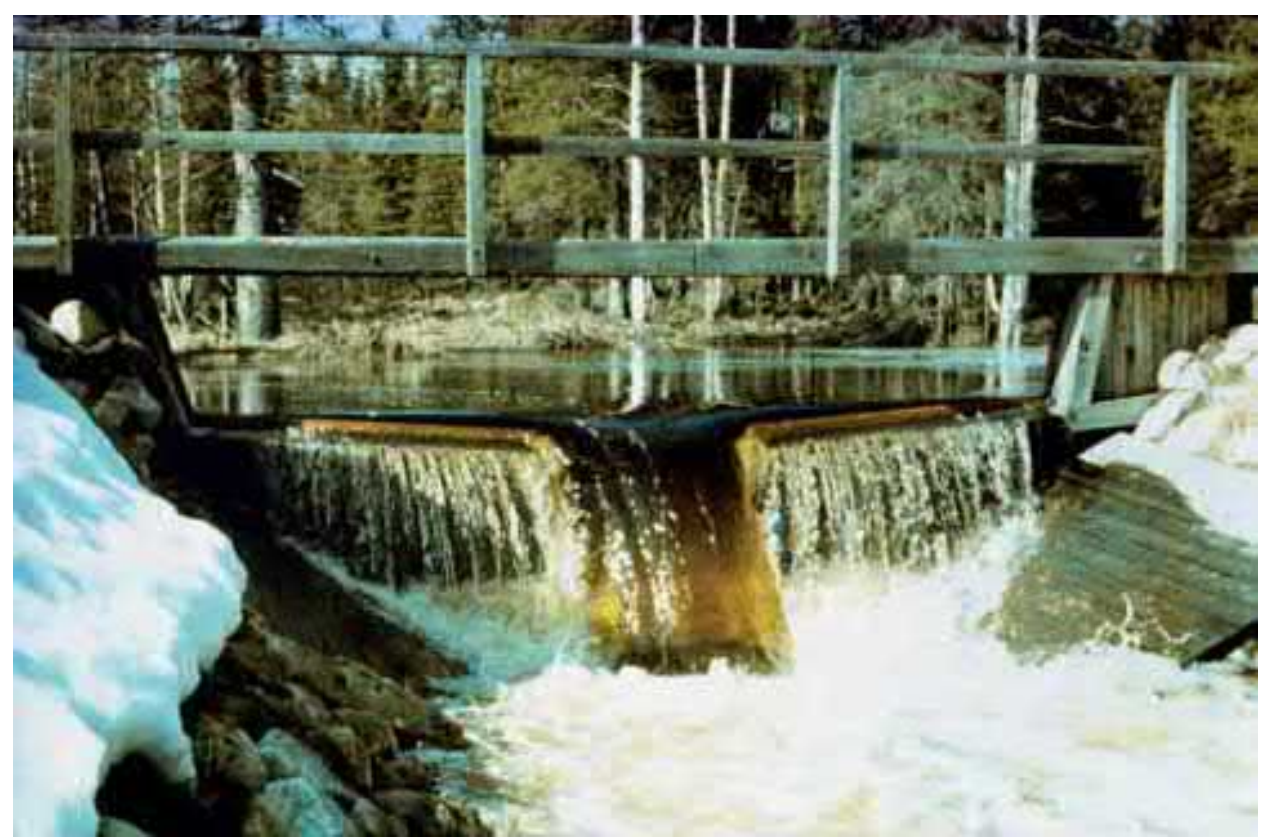

Kuva 6-10. Sulamisvedet virtaavat Ranuan Kotiojan mittapadolla. Alue perustettiin vuonna 1976 metsätalouden vaikutustutkimuksia varten. Kuva: Suomen ympäristökeskus (Kuusisto 2008).
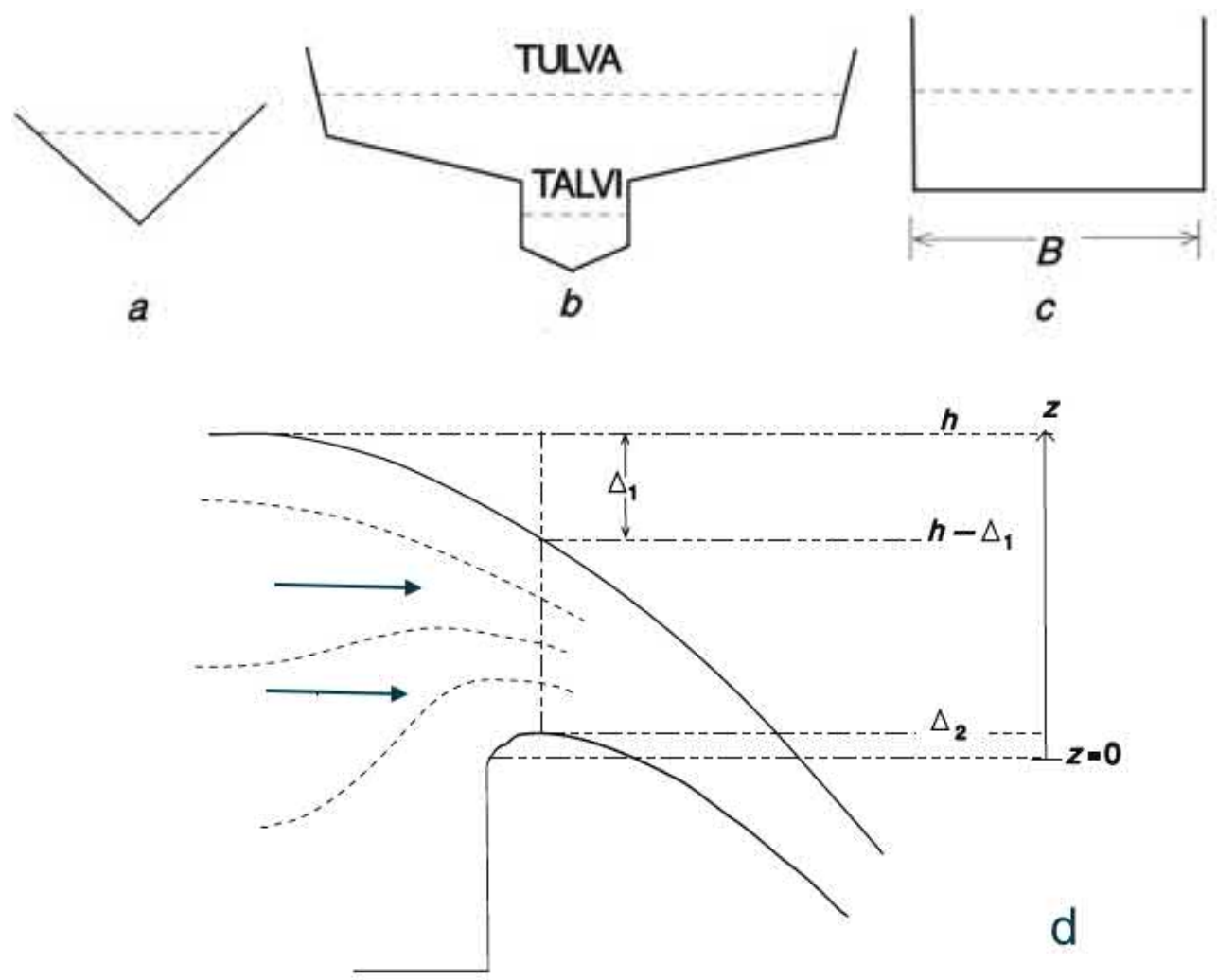

Kuva 6-11. Mittapatojen aukkoja: (a) kolmioaukko, kärjen kulma $90^{\circ}$, (b) Suomessa yleisesti käytetyn padon aukko, (c) suorakaideaukko ja (d) Veden kulkua aukon harjan ylitse. 


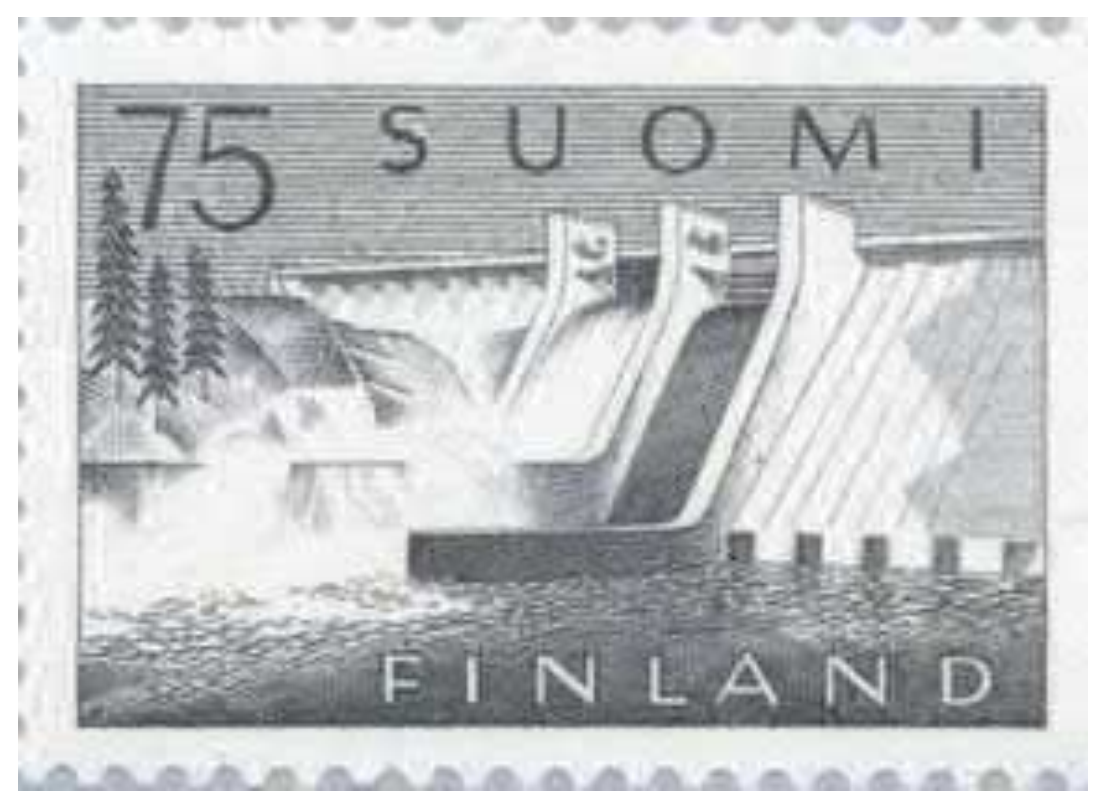

Kuva 6-12. Pyhäkosken voimalan postimerkki (1963). Voimala sijaitsee Oulujoessa Muhoksella ja on yksi Suomen suurimmista. Se avattiin vuonna 1951, Sen sähköteho on 122 MW ja putouskorkeus 32,4 m. Postimerkin on suunnitellut Olavi Vepsäläinen.

Virtaaman määrittäminen palautuu siis usein paljon yksinkertaisemmin mitattavissa olevaan vedenkorkeuteen. Tämä voidaan mitata kolmella tavalla (kuva 6-12):

- rannalla kiveen, kallioon tai siltapilariin kiinnitetyn kiinteän asteikon avulla

- pohjaan lyödyn kiinteän tapin ja irtonaisen mitan avulla tai

- rekisteröivän mittalaitteen eli limnigrafin avulla.

Yleisin limnigrafityyppi on mekaaninen laite, jossa vedenpinnan vaihtelut siirretään uimurin ja ohuen vaijerin avulla datamuistiin.

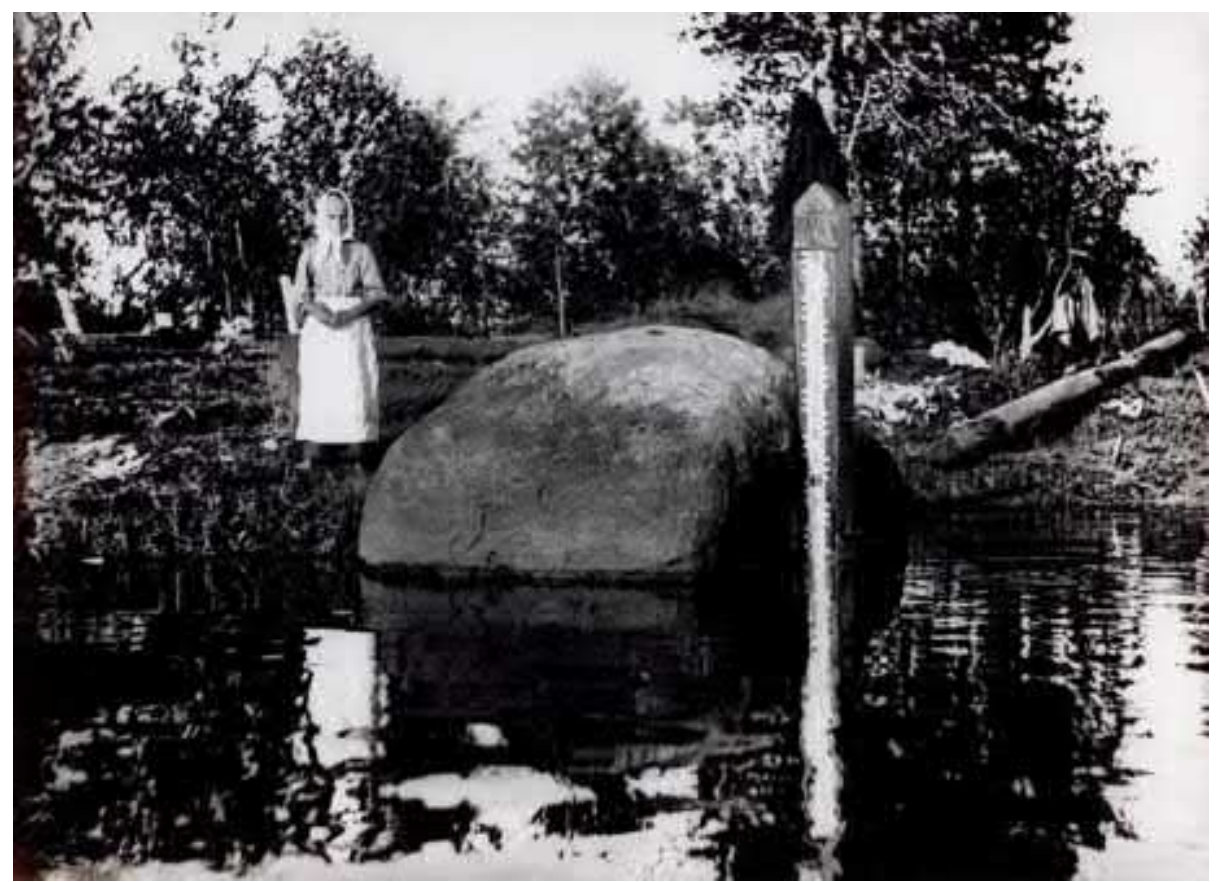

Kuva 6-13. Vedenkorkeusasteikko ja havaitsija 1920-luvulta. Kuva: Suomen ympäristökeskus (Kuusisto 2008). 
Virtaama voidaan myös määrittää käyttämällä jotakin merkkiainetta, jota ei ole ennestään luonnonvedessä. Merkkiaine kulkee virtauksen mukana, ja sen pitoisuus on helppo määrittää. Merkkiaineena on käytetty suoloja, radioaktiivisia aineita ja väriaineita. Ainetta voidaan lisätä jokeen liuoksena yhdellä kertaa tai pitämällä syöttövirtaamaa $q$ vakiona.

Kun syöttövirtaama on vakio, joen virtaama $Q$ voidaan laskea. Jonkin aikaa syötön aloittamisesta joessa alempana merkkiainepitoisuus on asettunut vakioarvoon $c_{2}$ ja merkkiainevirtaama on $c_{2} Q$. Jos syöttövirtaaman merkkiainepitoisuus $c_{1}$, aineen säilymisen lain perusteella on $c_{1} q=c_{2} Q$.

Kun koko merkkiainemäärä $C$ syötetään yhdellä kerralla jokeen, saadaan virtaama. Syöttökohdan alapuolella, jossa merkkiaine on täydellisesti sekoittunut veteen, merkkiainepitoisuus $c$ mitataan ajan funktiona (kuva 6-14). Koska merkkiaine on sekoittunut poikkileikkaukseen, hetkellinen ainevirtaama on $M=c Q$, ja poikkileikkauksen lävitse kulkenut merkkiaineen kokonaismäärä saadaan integroimalla syötön vaikutus:

$$
C=\int_{0}^{\infty} M d t=\int_{0}^{\infty} c Q d t=Q \int_{0}^{\infty} c d t
$$

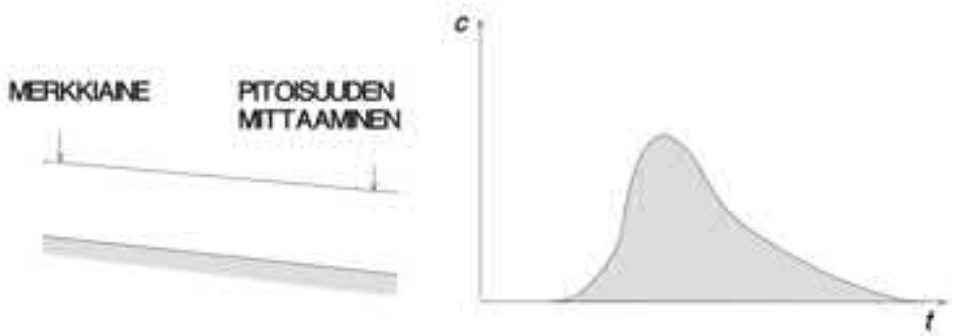

Kuva 6-14. Virtaaman mittaaminen merkkiaineella. Syöttö on hetkellinen.

\subsection{Talviolot}

\subsubsection{Uomien jäätyminen}

Suomen oloissa jokiin ja kanaviin muodostuu talvella jäätä (kuva 6-15). Jääolot ovat olennaisesti erilaiset kuin järvillä. Tärkeimmät ja näkyvimmät erot ovat jokien suppo ja jääpadot. Jääolojen kehitys on intensiivisessä vuorovaikutuksessa virtauksen kanssa, ja jokijäähän muodostuukin vaihtelevampi kerrosrakenne kuin mitä on järvijäässä.

Turbulenttisessa jokivirtauksessa vesi sekoittuu tehokkaasti erityisesti syksyllä, sillä viileässä vedessä lämpötilaerojen vaikutus tiheyteen on pieni. Siksi joen vesirunkoa voidaan pitää tasalämpöisenä. Virtaava ja jäähtyvä vesi alijäähtyy ${ }^{1}$ ennen pitkää, mutta vain muutamia asteen sadasosia. Jääkansi alkaa vahvistua rannoilta. Turbulenttisissa virtapaikoissa on hyvin saatavilla kiteytymisytimiä, joihin alijäähtyneessä vedessä jää kiteytyy. Ytiminä voivat toimia veteen satavat lumikiteet tai vedessä olevat kiintoainespartikkelit. Näin muodostuu suppoa eli jäähyhmää, pieniä, vapaita jääkiteitä, jotka kulkevat virtauspyörteiden mukana. Suppojääkiteet voivat myös tarttua uoman pohjaan tai jääkannen pohjaan, ja uoman pohjasta jäämuodostumat voivat nosteellaan nousta pintaan tai jääkannen alle.

Keväällä jää haurastuu auringon säteilyn ja jään lämpenemisen vaikutuksesta. Lopulta jääkansi murtuu ja rikkoutuu jäälautoiksi, jotka lähtevät ajautumaan alavirtaan veden mukana. Paikoin ne kasautuvat muodostaen jääpatoja.

\footnotetext{
${ }^{1}$ Nesteen alijäähtyminen tarkoittaa sen lämpötilan painumista jäätymispisteen alapuolelle.
} 


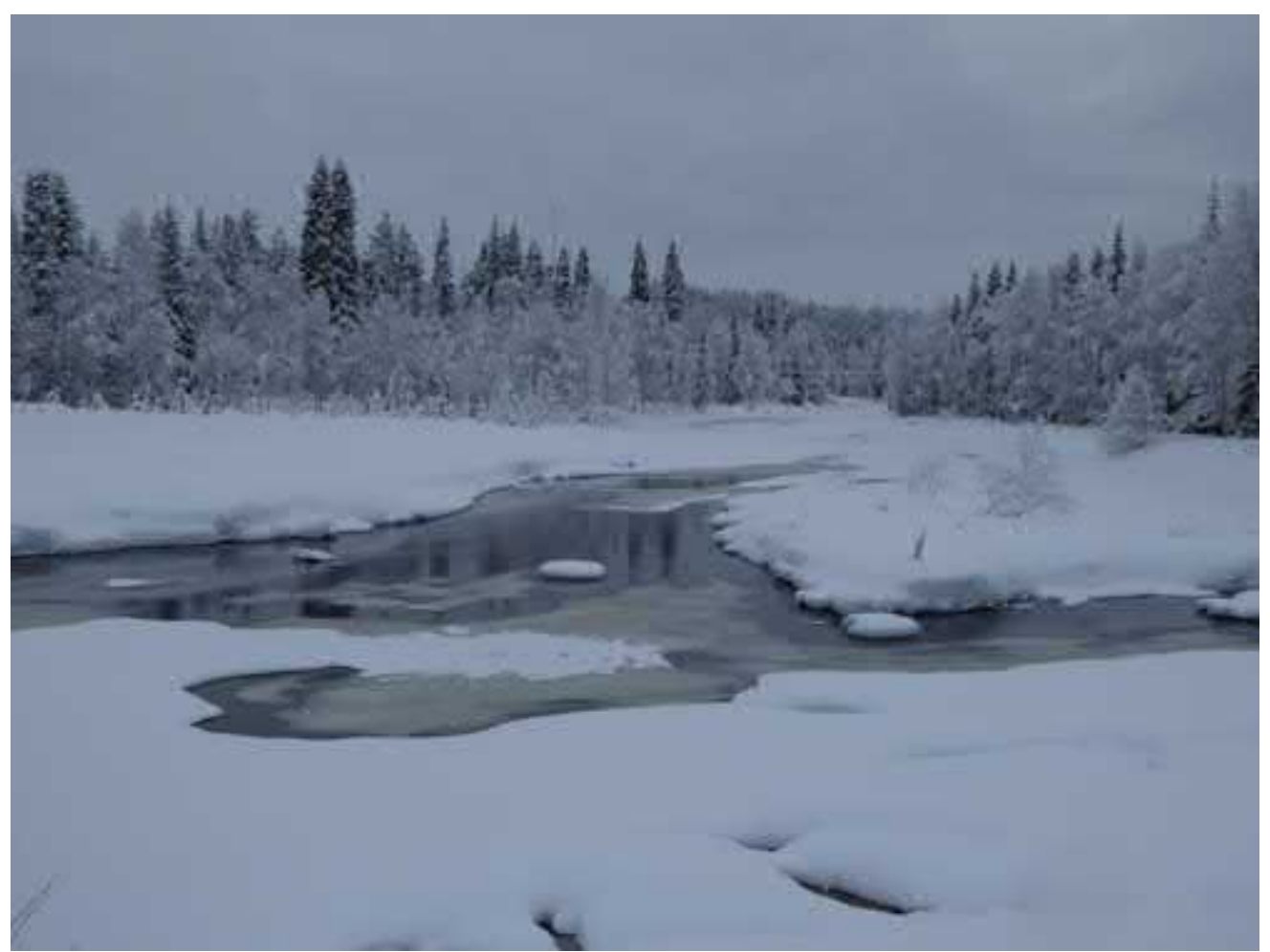

Kuva 6-15. Talvinen jokimaisema, pinta on osin jäätynyt ja osin avoin. Kuva: Matti Leppäranta.

Suponmuodostus kerää jokivedestä vieraita aineksia ja tuo niitä mukanaan jääkanteen. Tämän takia jokijää voi sisältää runsaasti epäpuhtauksia, toisin kuin järvien jää. Pohjajää saattaa vielä irtautua nosteellaan pohjasta ja tuoda pohjasedimenttiä jääpeitteeseen.

\subsubsection{Suppo ja jääkansi}

Lämmönvaihto virtaavan joen ja ilmakehän välillä tapahtuu kuten 4. luvussa esiteltiin. Niin kauan kuin suppoa tuottavan joen pinta on avoin, sen pintalämpötila on jäätymispisteessä. Jos ilma on kylmä, turbulenttinen lämmönvaihto voi silloin siirtää lämpöä tehokkaasti jokivedestä ilmakehään. Supon muodostuessa lämpötalousyhtälö on

$$
\rho_{i} L_{f} \eta=-Q_{n}
$$

missä $\rho_{\mathrm{i}}$ on jään tiheys, $L_{\mathrm{f}}$ on jäätymislämpö, $\eta$ on tuotetun jään tilavuus pinta-ala- ja aikayksikköä kohti ja $Q_{\mathrm{n}}$ on pinnan lämpötase. Suppojääkiteet ovat pieniä, kooltaan 0,1-1 mm.

Maanpinnan lämpötasetta käsiteltiin kohdassa 4.1. Supon muodostuksen aikana siitä voidaan huomioida seuraavaa. Hallitsevat tekijät ovat pinnan ja ilmakehän lämpösäteily sekä turbulenttinen lämmönvaihto, ja pintalämpötila on jäätymispisteessä. Lämpötaseesta voidaan käyttää lineaarista mallia:

$$
Q_{n} \approx K_{0}+K_{1}\left(T_{a}-T_{0}\right)
$$

missä $K_{0}$ ja $K_{1}$ ovat mallin parametrit, jotka riippuvat ajasta. Tietyissä rajoissa niitä voidaan pitää vakioina. $K_{0}$ määräytyy säteilytaseesta, ja $K_{1}$ tulee pääosin turbulenttisesta lämmönvaihdosta. Talvioloissa $K_{0} \approx-30 \mathrm{~W} \mathrm{~m}^{-2}$, ja $K_{1} \approx 10 \mathrm{~W} \mathrm{~m}^{-2}{ }^{\circ} \mathrm{C}^{-1}$. Supon muodostuessa $T_{0} \approx 0{ }^{\circ} \mathrm{C}$ ja $Q_{\mathrm{n}}<0$, jolloin yhtälöistä (6.18-6.19) saadaan kasvunopeudeksi $\eta=6,5 \mathrm{~cm} \mathrm{vrk}^{-1}{ }^{\circ} \mathrm{C}^{-1}$, jos 
ilman lämpötila on $-20^{\circ} \mathrm{C}$. Jään kasvunopeus on tällöin suurempi kuin jääkannen paksuuntuessa alapinnastaan, jolloin jääkansi eristää itseään paksuuntuessaan ja sen kasvu hidastuu.

Ehyt jääkansi alkaa kasvaa rannoilta samoin kuin järvien teräsjää (ks. kohta 5.3.2). Siihen voi kuitenkin liittyä myös suppokiteistä muodostuvia kerroksia. Sydäntalven aikana joet ovat laajalti yhtenäisen jään peitossa, mutta virtapaikoissa on pysyvästi avopaikkoja, joissa suppojääkiteitä muodostuu ja virtaa alas jokea. Suppojääkiteet voivat rauhallisemmin virtaavissa paikoissa kiinnittyä jään pohjaan ja kasvattaa jääkannen paksuutta tai jäätyä joen pohjaan muodostaen pohjajäätä. Suppo voi myös johtaa paksujen jäähyhmämassiivien muodostumiseen ja tulviin ja tuottaa ongelmia voimalaitoksille jäätyessään näiden rakenteisiin.

Kiinteä jääpeitteen muodostuttua jään paksuus $h$ kasvaa, kun lämpöä siirtyy joesta ilmakehään $\left(Q_{\mathrm{n}}<0\right)$. Turbulenttisesta virtauksesta tulee jään pohjaan lämpöä, joka hidastaa tai estää jään kasvua. Jään pohjan lämpötila on $T_{\mathrm{h}}=0{ }^{\circ} \mathrm{C}$ makeissa vesissä. Approksimoidaan lämmönsiirtoa lämmön johtumisella jään läpi, jolloin

$$
\begin{aligned}
& \rho_{i} L_{f} \frac{d h}{d t}+Q_{w}=k_{i} \frac{T_{h}-T_{a}}{h} \text { ja } \\
& Q_{w}=\rho c C_{H}\left(T_{w}-T_{h}\right) U,
\end{aligned}
$$

missä $Q_{\mathrm{w}}$ on vedestä jään pohjaan tuleva lämpö, $c$ on veden ominaislämpökapasiteetti, $C_{\mathrm{H}} \sim$ 10-3 on lämmönvaihtokerroin ja $T_{w}$ on veden lämpötila. Yhtälön (6.22a) vasemmalla puolella on jäätymisessä vapautuva lämpö ja lämmönsiirto vedestä jäähän, ja oikealla puolella on lämmön siirto jään läpi ilmakehään. Vedestä tuleva lämpö voidaan ilmaista $Q_{w}=K_{2} T_{w}$, missä $K_{2} \sim 500 \mathrm{~W} \mathrm{~m}^{-2}{ }^{\circ} \mathrm{C}^{-1}$.

Yhtälöä (6.22) ei voida ratkaista suoraan yleisessä muodossa, mutta kaksi erikoistapausta valaisee hyvin jään kasvua. Jos vedestä ei tule lämpöä (6.23a), tai jos jään paksuus on muuttumaton niin että vedestä siirtyvä lämpö ja jään läpi johtuva lämpö tasapainottavat toisensa (6.23b), saadaan

$$
\begin{aligned}
& h=a \sqrt{S}, a=\sqrt{\frac{2 k_{i}}{\rho_{i} L_{f}}}, S=-\int_{0}^{t} T_{0}\left(t^{\prime}\right) d t^{\prime} \text { ja } \\
& h=\frac{k_{i}\left(-T_{0}\right)}{K_{2} T}, T_{0}<0{ }^{\circ} \mathrm{C}, T>0{ }^{\circ} \mathrm{C},
\end{aligned}
$$

missä $S$ on pakkassumma ja $T_{0}$ on jään pintalämpötila. Usein asetetaan $T_{0} \approx T_{\mathrm{a}}$, mutta kun jää on ohutta, tämä approksimaatio ei ole kovin hyvä. Yhtälö (6.23b) antama tasapainopaksuus soveltuu, kun veden lämpötila on ainakin suuruusluokaltaan $0,1{ }^{\circ} \mathrm{C}$, muutoin tasapainotilan kehittymiseen menee niin kauan, ettei se ole luonnossa enää realistista.

Talvella virtaama on usein pieni, kun sadanta varastoituu lumipeitteeseen. Lämpiminä talven jaksoina tosin tulvia on esiintynyt. Jääkansi pienentää virtausnopeutta kitkan vaikutuksesta, sillä jään pohja kasvattaa jokiuoman märkää piiriä ja pienentää hydraulista sädettä, mistä seuraa suoraan virtausnopeuden lasku (ks. Chezy-Manningin kaava 6-12a-b). Jääpeitteen paksuus on samaa suuruusluokkaa kuin järvissä. Joen turbulenssi tuo vesirungosta enemmän lämpöä jään pohjaan hidastaen paksuuntumista, mutta toisaalta avopaikoissa ta- 
pahtuva supon muodostus voi aiheuttaa lisäkasvua jääpeitteeseen alavirrassa, jos suppoa kiinnittyy jään pohjaan.

Taulukko 6-3. Jäähän kerääntyneitä epäpuhtauksia Porvoonjoessa ja kahdessa järvessä 1997 1999 (Leppäranta ym. 2003). Luvut ovat keskiarvoja kolmelta talvelta. Jään paksuus oli $40-50 \mathrm{~cm}$.

\begin{tabular}{l|r|r|r|r}
\multirow{2}{*}{ Paikka } & \multicolumn{2}{|c|}{ Liuennut aines (mg/L) } & \multicolumn{2}{|c}{ Kiintoaines (mg/L) } \\
\cline { 2 - 5 } & \multicolumn{1}{|c|}{ Vesi } & \multicolumn{1}{|c}{ Jää } & Vesi & Jää \\
\hline Vesijärvi, Lahti & 52,3 & 12,7 & 1,1 & 2 \\
Päijänne, & 31,3 & 11,3 & 1,4 & 2,1 \\
Asikkala & 127,3 & 24 & 16 & 190 \\
Porvoonjoki, & 135 & 19 & 17 & 24,5 \\
Pukkila & & &
\end{tabular}

Kiteytyessään vedessä oleviin partikkeleihin suppojää kerää tehokkaasti vieraita aineksia uoman vedestä. Siksi suppojään muodostamat jääpeitteen kerrokset sisältävät runsaasti epäpuhtauksia (kuva 6-16). Pohjajään irtoaminen ottaa pohjasedimenttiä mukaansa ja kuljettaa sitä alavirtaan. Vertailua järvien ja jokien epäpuhtauksista on taulukossa 6-3. Jokijään runsas kiintoainespitoisuus näkyy luvuista selvästi. Luvuissa on mukana myös kohvajäähän jäänyt ilmakehän laskeuma.

\subsubsection{Jäänlähtö}

Jokien jäänlähtö on myös dynaaminen tapahtuma. Keväällä jääkansi alkaa haurastua lämpimän ilman ja auringonsäteilyn vaikutuksesta ja rikkoutuu jäälautoiksi, jotka liikkuvat virtauksen ajamina. Jäälauttojen liikkeeseen vaikuttaa niiden välinen kitka sekä jokiuoman kitka. Lauttajoukkojen tiivistyessä kitkavaikutus kasvaa, ja ne kasautuvat paikoin jääpadoiksi. Jään patoutumisen käynnistyminen riippuu uoman morfologiasta, jäälauttojen koosta ja rakenteesta sekä virtausnopeudesta. Rajatilan kriittinen nopeus on

$$
U_{c}=K \sqrt{2 g \frac{\rho-\rho_{i}}{\rho} h},
$$

missä $\rho$ on veden tiheys, $K \approx 1$ lauttojen muodosta riippuva kerroin ja $h$ on jäälauttojen paksuus. Jos $U>U_{\mathrm{c}}$, jäälautat ajautuvat päällekkäin ja pato alkaa muodostua (kuva 6-17).

Jääpadolla on sisäinen koheesio, ja se murtuu vain, kun patoon kohdistuva kuorma on riittävän suuri. Vedennousu padolla ja jään keräytyminen padon ylävirran puolelle lisäävät patoon kohdistuvaa painetta, kun taas jäälauttojen haurastuminen heikentää padon lujuutta. Ennen pitkää pato murtuu, ja jäälautat lähtevät liikkeelle patoutuen mahdollisesti uudestaan. Jokaisella liikahduksella jäät kuitenkin pääsevät lähemmäs suistoa. Joen jäänlähtöä voidaan näin karakterisoida sarjana kvasivakaita tiloja, joissa jääpatoja syntyy ja murtuu jäämassojen ajelehtiessa ja seisoessa patosysteemin dynamiikan askelten tahdissa.

Jääpadot voivat aiheuttaa tulvia, ja niiden ehkäisemiseksi patoja räjäytetään tai jokiin asennetaan liikettä ohjaavia puomeja. Useilla joilla Etelä-Lapissa heikennetään jääpeitettä sahausten avulla alajuoksulta lähtien, jolloin jäänlähtö voisi tapahtua hallitummin. Sahaukset tehdään traktoriin liitetyllä moottorikäyttöisellä sahalla. 


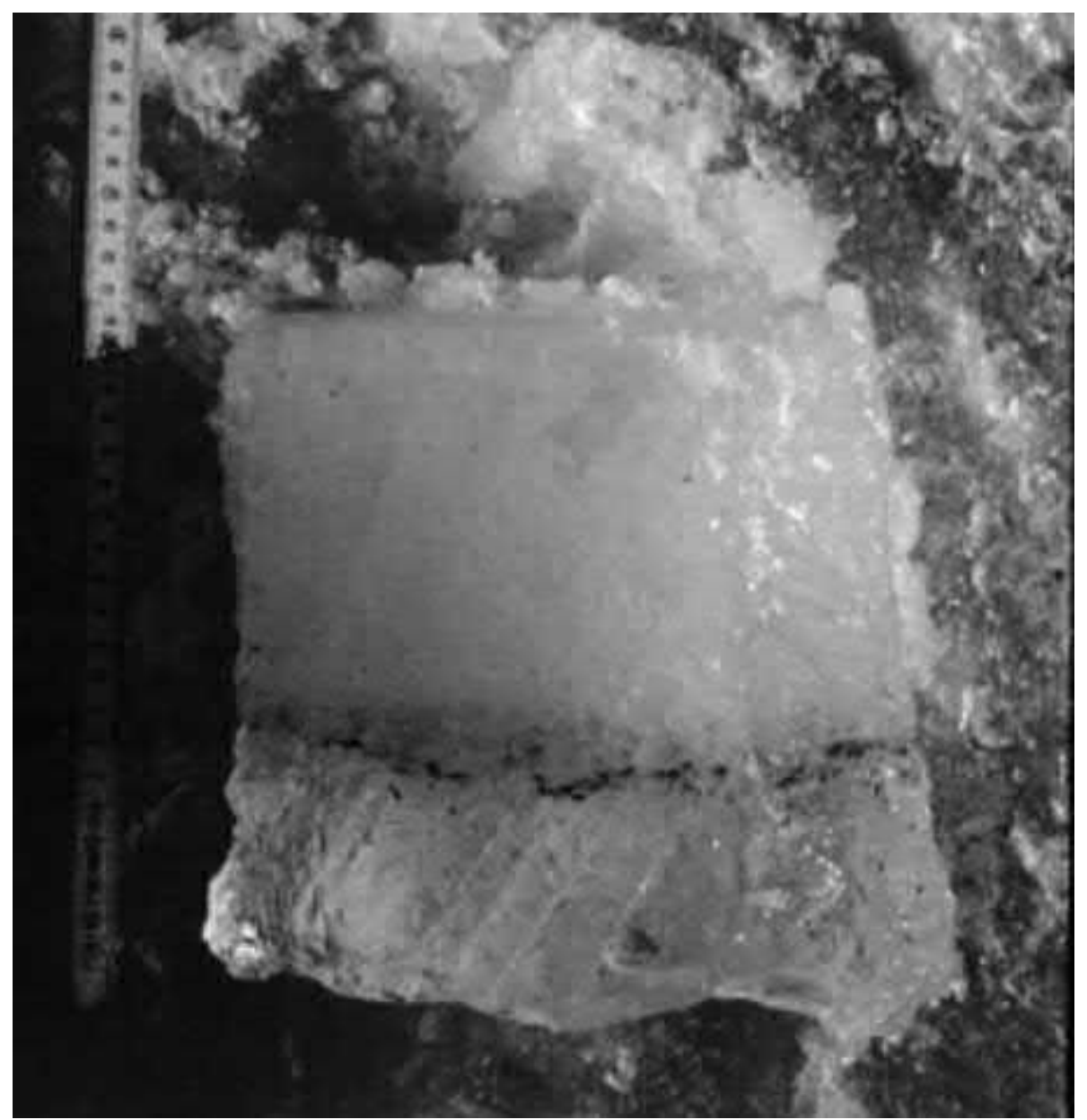

Kuva 6-16. Jään vertikaalirakenne Porvoonjoen Pukkilassa, maaliskuu 1997. Kuva: Matti Leppäranta.

\subsection{Vesi kuluttavana ja kuljettavana väliaineena}

\subsubsection{Kuljetuksen muodot}

Hydrologisen kierron mukana kulkeutuu veden lisäksi lämpöä sekä vedessä olevia vieraita aineita liuenneessa muodossa ja kiintoaineshiukkasina. Uomissa myös mekaanisen energian kuljetuksella on merkitystä. Seuraava tarkastelu kohdistuu kiintoaineksen kulkeutumiseen uomissa. Kiintoainesta voi tulla valunnan mukana tai tuulen kuljettamana.

Kiintoaines kulkeutuu uomissa veden virtauksen välityksellä. Se jaetaan kahteen ryhmään:

- Suspensioaines, joka pysyy virtaavassa nesteessä turbulenssiin liittyvän sekoittumisen välityksellä ja

- Pohjakuormitus muodostuu hiukkasista, jotka vierivät pitkin pohjaa tai suorittavat hyppäyksiä pohjasta virtaavaan veteen ja vajoavat takaisin pohjaan. Hiukkasten koko on niin suuri, että ne eivät pysy virtauksessa.

Suspensioaineksen ja pohjakuormituksen määrä riippuu virtaavan nesteen nopeudesta, tiheydestä ja viskositeetista sekä hiukkasten koosta ja tiheydestä. Stokesin lain (yhtälö 3.3) mukaan vajoamisnopeus on verrannollinen hiukkaskoon neliöön. Kiintoaineen kulkeutuminen tapahtuu ketjun irtoaminen eli eroosio - kulkeutuminen - asettuminen eli akkumulaatio mukaan. 


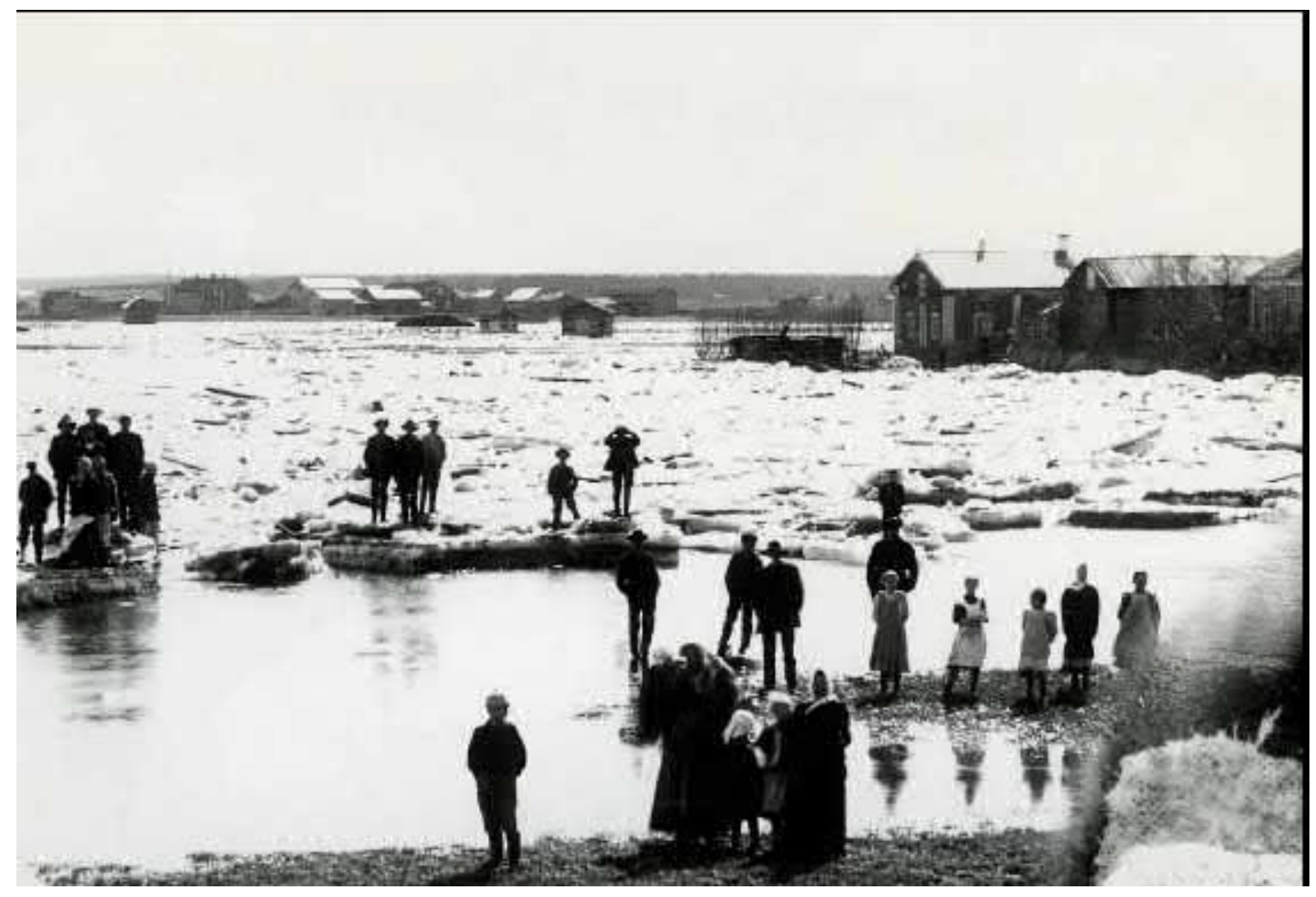

Kuva 6-17. Jääpato on nostanut vedenpintaa Olmanvirran niskalla Kalajoella 24.4.1912. Jokivarren asukkaat ovat aina seuranneet joen vapautumista jäistä. Kuva: Suomen ympäristökeskus (Kuusisto 2008).

Alkuperänsä perusteella kiintoaines jaetaan kolmeen ryhmään:

- Huuhteluainesta huuhtoutuu maan pinnalta uomaan pintakerrosvalunnan mukana.

- Pohjakuormituksesta muodostaa pääosan uoman pohjasta irtoava aines.

- Teollisuus- ja asumajätteet ovat usein orgaanisia, niiden tiheys on pienempi kuin kiviaineksen tiheys ja ovat muodoltaan usein kuitumaisia.

\subsubsection{Hiukkaskuljetuksen vaikutus maan pintaan}

Kiinteän aineksen kulkeutumisen näkyvimmät seuraukset ovat maan pinnalla korkeiden paikkojen, erityisesti vuoristojen hidas madaltuminen ja alavien paikkojen täyttyminen. Aineen siirtymistä mantereilta meriin tapahtuu jatkuvasti, ja samalla mantereiden keskikorkeus alenee. On arvioitu, että maapallon pinnan keskimääräinen kuluminen on $13,6 \mathrm{~km}^{3}$ vuodessa, mikä vastaa mantereiden pinnan keskimääräistä $3 \mathrm{~cm}$ alenemista tuhannen vuoden aikana. Lisäksi hiukkaskuljetuksen seurauksena jokiuomat muuttuvat joko jaksollisesti tai jatkuvasti samaan suuntaan (kuva 6-18).

Vesi, lämpötilan vaihtelut ja kemialliset prosessit aiheuttavat kiinteän kalliopeitteen rapautumista pienempiin osiin. Kun rapautumisen tuottamat partikkelit ovat tarpeeksi pieniä, ne lähtevät kulkeutumaan tuulen tai veden virtauksen mukana alaspäin. Kulumisen paikalliset erot ovat kuitenkin suuria. Siellä missä lämpötilan ja sademäärän vaihtelut ovat suuria, kuluminenkin on nopeaa. Suurinta kulutus on Kaakkois-Aasian monsuunisateiden alueella ja pienin Afrikan ja Aasian kuivilla aavikoilla. Taulukossa 6-4 on esitetty jokia, joiden kuljettamat kiintoainemäärät ovat suuria. 


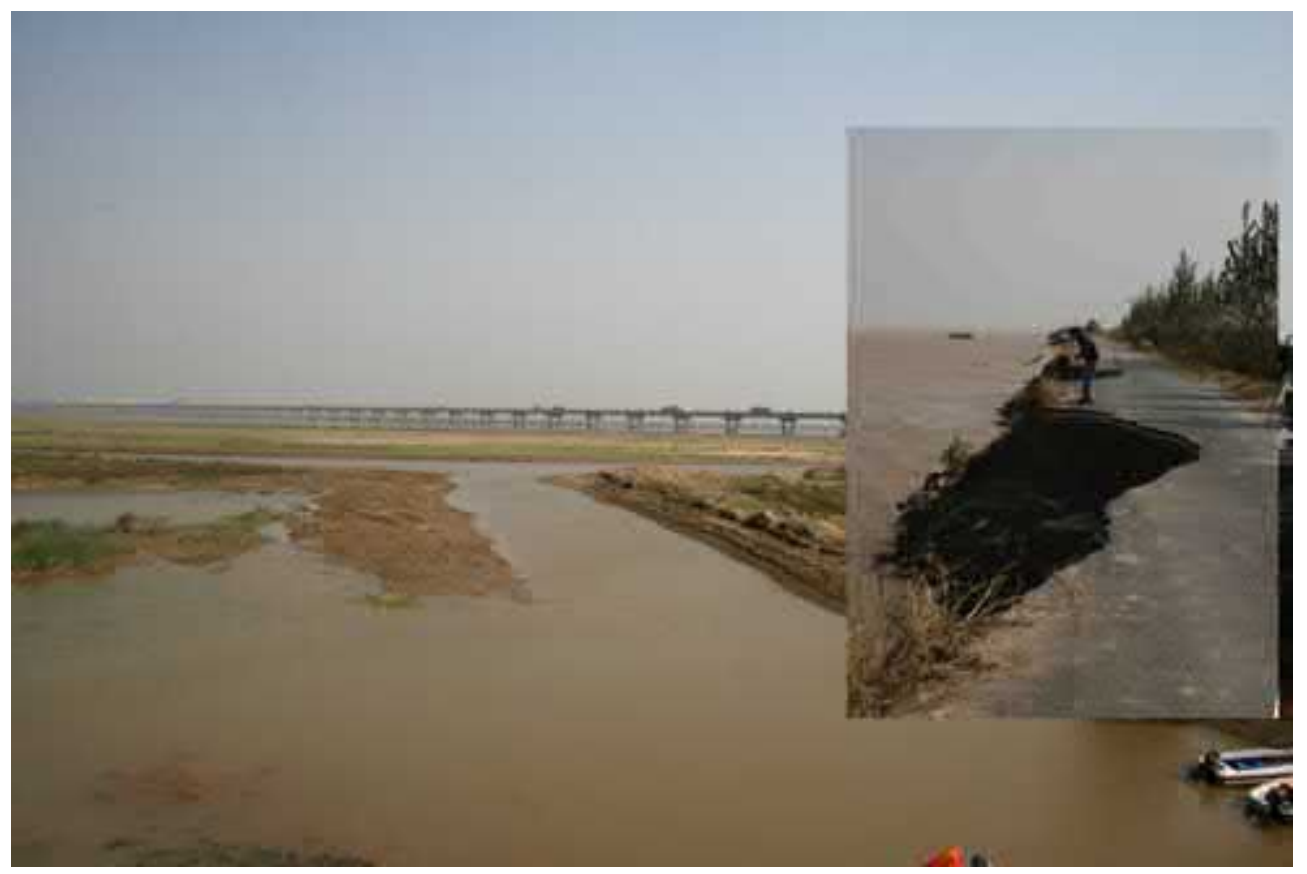

Kuva 6-18. Keltaisella joella Kiinassa eroosio on hyvin voimakasta ja uoman paikka siirtyy laajoilla tasangoilla. Iso kuva esittää uomatasanko, pieni kuva rannan eroosiota. Kuvat: Matti Leppäranta.

Taulukko 6-4. Eräiden jokien kiintoaineen kuljetus.

\begin{tabular}{l|r|r|r} 
& $\begin{array}{l}\text { Vesistöalueen } \\
\text { pinta-ala }\end{array}$ & Kiintoainevirtaama & $\begin{array}{l}\text { Kiintoainevirtaama/ } \\
\text { pinta-ala }\end{array}$ \\
\cline { 2 - 4 } Joki & $\mathbf{1 0}^{\mathbf{3}} \mathbf{~ m}^{\mathbf{2}}$ & $\mathbf{1 0}^{\mathbf{9}} \mathbf{~ \mathbf { g }} / \mathbf{v u o s i}$ & $\mathbf{1 0}^{\mathbf{3}} \mathbf{~ \mathbf { g }} / \mathbf{v u o s i} / \mathbf{k m}^{\mathbf{2}}$ \\
\hline Keltainen joki & 673 & 1900 & 2800 \\
Ganges & 956 & 1450 & 1500 \\
Brahmaputra & 670 & 730 & 1100 \\
Jangtse & 1900 & 500 & 260 \\
Indus & 970 & 440 & 450
\end{tabular}

Eräissä Indokiinan pienemmissä joissa on suurin kiintoainevirtaama alueen pinta-alaa kohden, yli 7000 tonnia neliökilometriä kohti vuodessa. Pohjoisilla alueilla kiintoainevirtaamat ovat pieniä. Pohjois-Euroopassa kasvipeite suojelee kulumiselta. Ruotsissa tehtyjen mittausten perusteella Tornionjoen kiintoainevirtaama pinta-alaa kohden on Pellossa 4 tonnia vuodessa ja Selkämereen laskevassa Ångermanjoessa 2 tonnia vuodessa.

Hiukkaskuljetus vaikuttaa myös jokiuomien muutoksiin maan pinnan kulumisen ja tasoittumisen lisäksi (kuva 6-19). Uomien geometria ja morfologia muovautuvat ajan kuluessa. Esimerkiksi Keltaisen joen uoman elää jatkuvasti laajoilla tasangoilla. Muutokset voidaan luokitella muutamaan tyyppiin alla olevan mukaan.

- Kaareilu eli meanderointi. Pitkin uomaa voi tapahtua vuorottaista eroosiota ja kasaantumista, mikä aiheuttaa uoman kaareutumista. Kun kaareilu on edennyt tarpeeksi pitkälle, tapahtuu uoman oikeneminen, ja kaareilu alkaa uudelleen.

- Virtaaman vaihteluihin liittyy uoman liettyminen ja avautuminen. Tulvan nousuvaiheessa ja sen aikana virtauksen nopeus on niin suuri, että vesi kykenee irrottamaan uoman pohjasta hiukkasia ja kuljettamaan ne pois, ja uoma syvenee. Kun tulva päättyy, ei hidastunut virtaus enää kykene kuljettamaan hiukkasia, vaan hiukkaset vajoavat takaisin pohjaan ja uoma liettyy uudelleen. 
- Tulvakerrostumien muodostuminen. Kun joki tulvii yli äyräittensä, vesi kuljettaa kiinteitä hiukkasia uoman ulkopuolella olevalle tulvatasangolle, jossa hiukkaset laskeutuvat pohjaan. Näin tulvatasanko saa uutta kiintoainesta ja siihen sitoutuneita ravinteita.

- Altaiden täyttyminen. Kun joki purkautuu altaaseen, virtauksen nopeus pienenee ja veden mukanaan kuljettama kiintoaine laskeutuu pohjaan. Tämä aiheuttaa suvantopaikkojen, järvien sekä keinotekoisten altaiden täyttymisen (Kuva 6-20). Samasta syystä muodostuvat jokien suistot.

\subsubsection{Hiukkaskuljetus uomassa}

Virtaus aiheuttaa uoman pohjaan leikkausvoiman, joka pyrkii irrottamaan hiukkasia kuljetettavaksi. Tämä voima on verrannollinen nopeuden neliöön turbulenttisen vastuslain mukaisesti. Painovoima sekä hiukkasten väliset sidosvoimat pyrkivät pitämään hiukkasta uoman pohjassa.

Kuvassa esitetään hiukkaskuljetuksen alueet $(u, d)$-koordinaatistossa, missä $u$ on virtauksen nopeus ja $d$ hiukkasen läpimitta. Esitystä kutsustaan Hjulströmin diagrammiksi (Graf 1971). Kun virtausnopeus on alhainen ja hiukkaskoko suhteellisen pieni (alue "kuljetus"), ei pohjalle asettumista eikä pohjasta irtoamista tapahdu. Riittävän voimakas virtausnopeus alkaa irrota hiukkasia pohjasta virtaukseen (alue "irtoaminen"). Kun taas hiukkaskoko ylittää tietyn arvon, hiukkasia alkaa laskeutua virtauksesta pohjaan (alue "asettuminen"). Hiukkaset, joiden läpimitta on $0,2-0,3 \mathrm{~mm}$, irtoavat alhaisimmalla nopeudella. Tämä johtuu siitä, että sidosvoimien osuus kasvaa, kun hiukkasen koko pienenee, ja painovoiman osuus kasvaa hiukkasen koon kasvaessa. Mainitulla hiukkaskokovälillä näiden yhteisvaikutus on pienin.

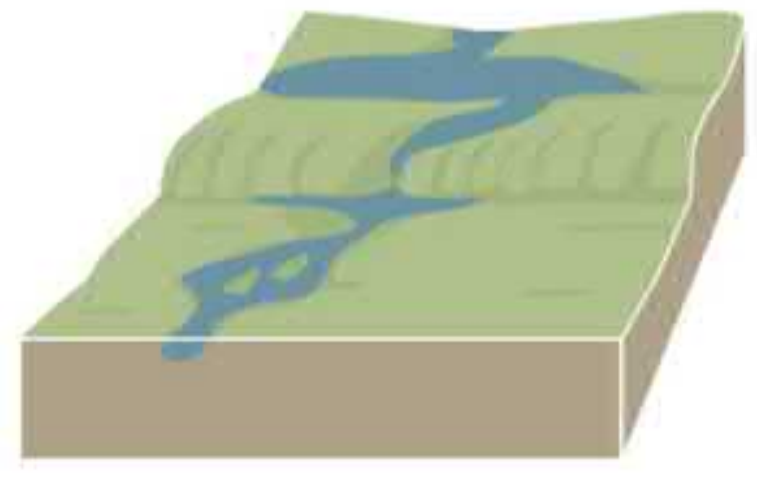

Uusi joki - koskia

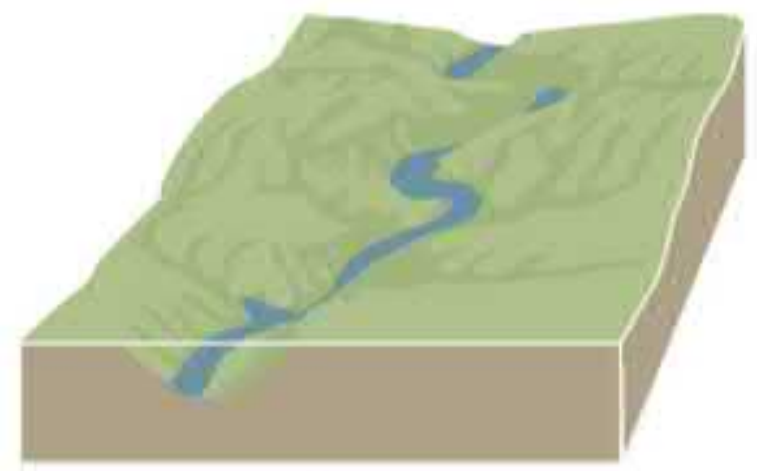

Reunaeroosio $\rightarrow$ laaksolevenee

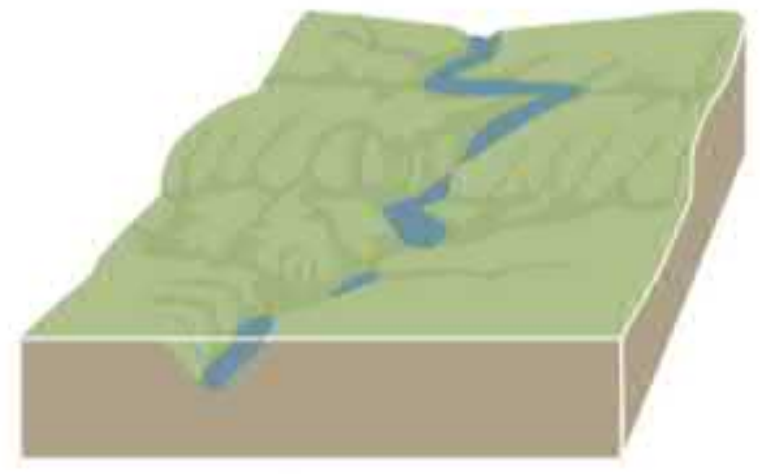

Pohjaeroosio $\rightarrow$ V-laakso

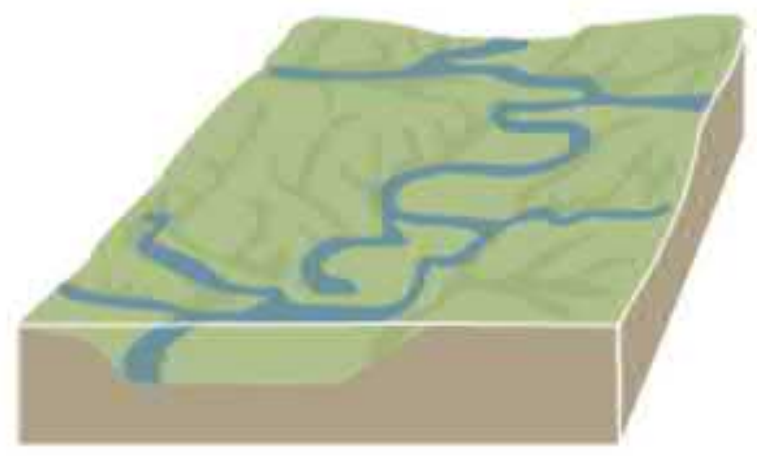

Vanha joki - mutkainen

Kuva 6-19. Jokiuoman geometrian ja morfologian kehittyminen ajan saatossa. 


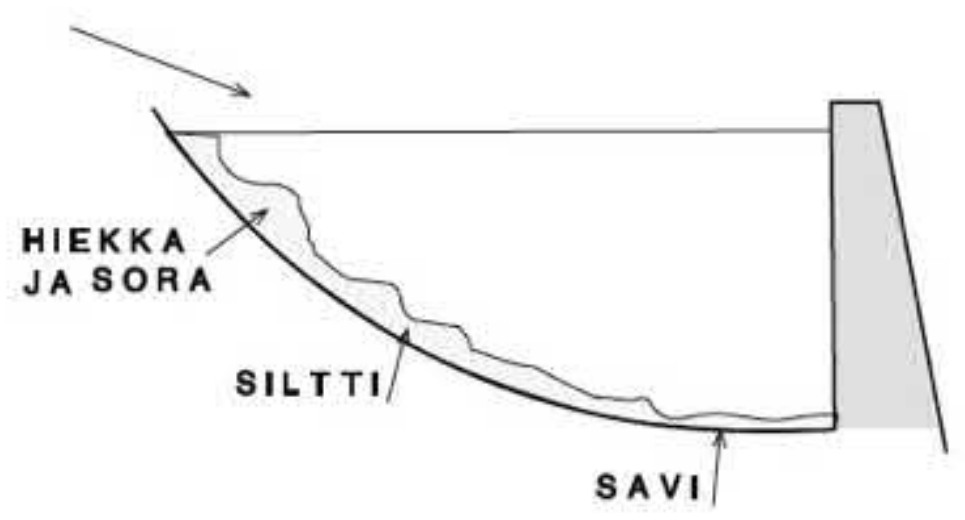

Kuva 6-20. Altaan täyttyminen kiintoaineella. Karkeammat hiukkaset asettuvat pohjaan altaan suulle ja hienommat etenevät altaaseen.

Koska hiukkasen irtoaminen uoman pohjasta riippuu lähinnä virtauksen nopeudesta, on pyritty selvittämään nopeuden tai virtaaman ja kiintoainevirtaaman välistä yhteyttä. Jos kiintoaine on peräisin pääasiassa uomasta, tämä riippuvuus voi olla verrattain voimakas. Jos taas huomattava osa kiintoaineesta on valuma-alueelta huuhtoutunutta, riippuvuus on heikompi. Tällöin virtaaman ja kiintoainekonsentraation maksimien ajankohdat saattavat poiketa toisistaan. Aikaero voi olla tunneista useisiin kuukausiin.

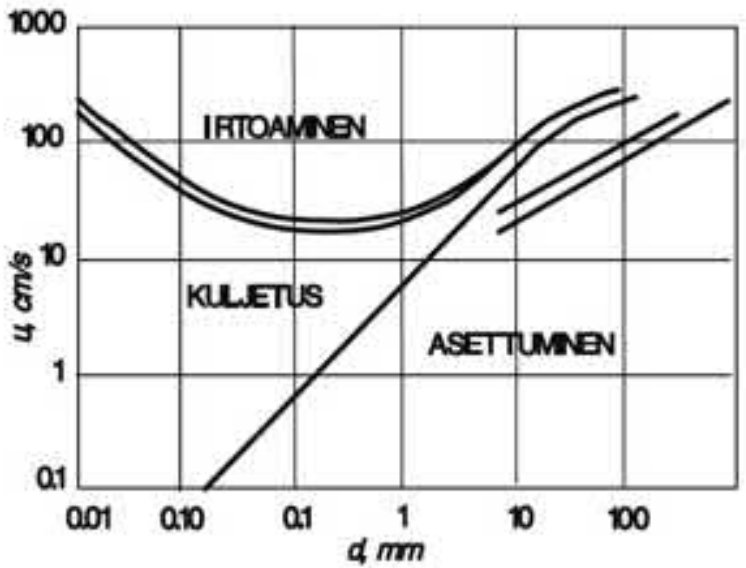

Kuva 6-21. Hiukkaskuljetuksen alueet Hjulströmin mukaan; $d$ on hiukkaskoko ja $u$ on virtausnopeus. Lähde: Graf \& Altinakar (1971), muokattu.

Tässä luvussa on käsitelty jokien ja kanavien morfologiaa ja virtauksia sekä virtausten aiheuttamaa eroosiota. Joet ovat tehokas siirtoväylä vesistöalueiden välillä. Talvioloissa näissä uomissa muodostuu jäätä, joka vaikuttaa virtauksiin ja aiheuttaa suponmuodostusta sekä jääpatoja. Seuraavassa luvussa tarkastellaan maaperässä olevia vesivaroja. 


\section{Geohydrologia}

Tässä luvussa tarkastellaan maaperää ja sen vesivaroja. Nämä jakautuvat kahteen pääkerrokseen: maaveteen ja pohjaveteen, joista pohjavesi muodostaa suurimman nestemäisen makean veden varaston maapallolla. Maavesi valuu maaperässä alaspäin, ja pohjavesi kulkeutuu paineen vaikutuksesta. Kylmässä ilmastossa maaperän vedet jäätyvät roudaksi, jota on kausittaista sekä pitkäaikaista ikiroutaa. Luvun lopussa käsitellään vielä kyhyesti jäätikköhydrologiaa.

\subsection{Maavesi}

\subsubsection{Maalajit ja vedenpidätyskyky}

Maaperä sisältää tärkeimmän osan maapallon makean veden resursseista ajatellen ihmiskunnan vesitaloutta (kuva 7-1). Veden fysikaalinen käyttäytyminen maaperässä riippuu maaperähiukkasten laadusta ja koosta. Suomen oloissa pintakerrokset jäätyvät talvella, mikä vaikuttaa hydrologiseen vuosikiertoon. Suomea kylmemmässä ilmastossa esiintyy ikiroutaa.
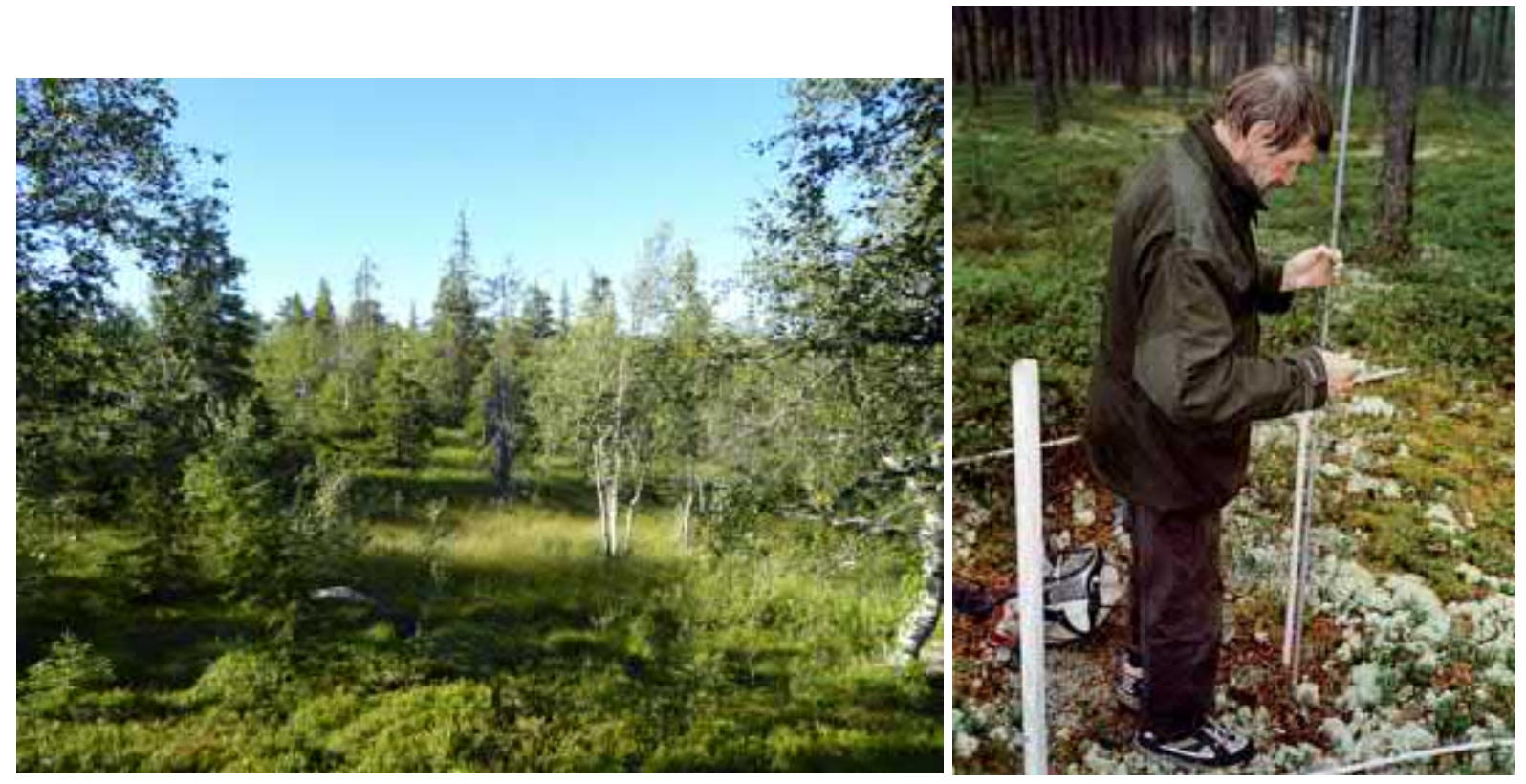

Kuva 7-1. a) Kosteaa suota Kainuussa, b) Arvo Koho routaputkea kunnostamassa Mietoisissa vuonna 2004. Kuvat: a) Matti Leppäranta, b) Suomen ympäristökeskus (Kuusisto 2008).

Maavesikerroksen vesimäärä vaihtelee vuodenaikojen mukaan. Yleensä loppusyksyllä syyssateiden ansiosta määrä on suurimmillaan. Talvella maavesivarasto ei juuri muutu, ja keväällä lumen sulaminen lisää lyhyeksi ajaksi liikkeessä olevan veden määrää. Runsas haihdunta kesällä puolestaan vähentää maavesivarastoa, joka on minimissään elo- syyskuus-sa.

Maanpinnan alaiset vedet jaetaan maaveteen ja pohjaveteen (kuva 7-2). Maavesi sijaitsee maaperän pintakerroksessa, jossa se maaperän rakeiden sitomana muodostaa vedellä kyllästymättömän vyöhykkeen. Kasvien vedenotto tapahtuu tästä kerroksesta, jossa on runsaasti happea, ja biologinen toiminta on aktiivista. Veden virtaus suuntautuu alaspäin. 
Maavedestä erotetaan juurivyöhyke, välivyöhyke ja kapillaarivyöhyke. Maan pinnalle satavasta vedestä osa valuu pintaa pitkin pois ja osa imeytyy maaperään eli infiltroituu. Imeytyneestä vedestä osa jää maan juurivyöhykkeeseen ja poistuu myöhemmin transpiraation kautta. Osa juurivyöhykkeen vedestä suotautuu painovoiman vaikutuksesta alaspäin ja saavuttaa vihdoin pohjaveden yläpuolella olevan kapillaarivesivyöhykkeen. Tätä hitaasti alaspäin liikkuvaa vettä kutsutaan vajovedeksi tai vapaaksi vedeksi.

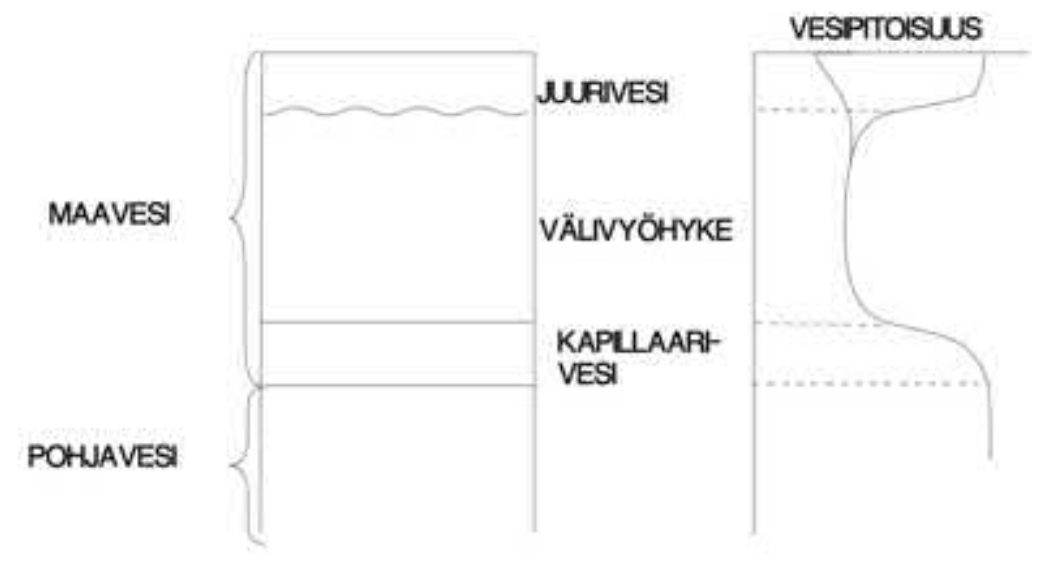

Kuva 7-2. Maaperän vesivyöhykkeet ja niiden vesipitoisuuden profiiili.

Maanalaisten vesien sitoutuminen ja liikkeet riippuvat oleellisesti maalajista, jotka luokitellaan kivennäismaalajeihin, eloperäisiin eli orgaanisiin maalajeihin ja kemiallisiin sedimantteihin. Maalajite on kivennäismaasta erotettavissa oleva tietynkokoisia maarakeita sisältävä osa. Maalajit luokitellaan raekoon perusteella. Tämä jaotus on karkea ja se vaihtelee hieman eri yhteyksissä (taulukko 7-1).

Maalaji saa nimensä (siltti, hiekka, sora) hiukkaskokojakauman mediaanin perusteella. Kuva (7-3) esittää esimerkkejä hiukkaskokojakaumista. Saveksi kutsutaan maalajia, jonka savilajitepitoisuus on yli 30 \% painosta. Moreeni on jäätikön toimintojen seurauksena syntynyt lajittumaton maalaji. Moreenimaalajit jaetaan siltti-, hiekka- ja soramoreeneihin. Turve ja lieju ovat eloperäisiä maalajeja. Liejun humuspitoisuus on yli $6 \%$ painosta. Kuivumisen aikana maaperässä tapahtuu kutistumista, joka riippuu maalajista sekä humus- ja savipitoisuudesta. Liejun tilavuuskutistuminen lisääntyy orgaanisen aineksen osuuden kasvaessa ja on 40-70 $\%$, kun orgaanisen aineksen osuus on 6-20\%.

Taulukko 7-1. Maalajitteet ja niiden raekoot (Vesihallitus 1976).

\begin{tabular}{l|r} 
Maalajite & $\begin{array}{r}\text { Raekoko } \\
(\mathbf{m m})\end{array}$ \\
\hline Savi & $<0,002$ \\
Siltti & $0,002-0,06$ \\
Hiekka & $0,06-2$ \\
Sora & $2-20$ \\
Kivet & $20-600$ \\
Lohkareet & $>600$
\end{tabular}

Esimerkki 7-1. Pieniä hiukkasia on yleensä lukumäärällisesti paljon enemmän kuin suuria. Jos maarakeiden lukumäärän todennäköisyystiheys on $f(R)$, missä $R$ on rakeiden säde, niin Kokoa $R$ pienempien rakeiden vaatima tilavuus on $V(R)=\frac{4}{3} \pi \int_{0}^{R} r^{3} f(r) d r$. Kaavan mukaan jos $f(R) \propto R^{-3}$, niin tilavuus on 
tasaisesti jakaantunut raekoon suhteen. Lukumääräjakauman eksponentti -3 kuvaa sitä, että raekoon pienentyessä kymmenenteen osaan niiden lukumäärä kasvaa tuhatkertaiseksi.

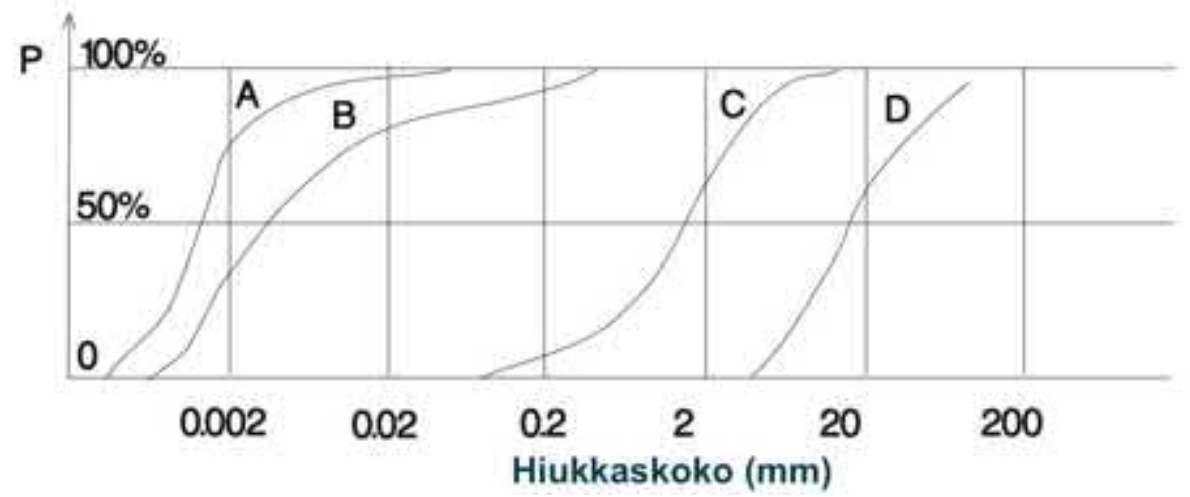

Kuva 7-3. Esimerkkejä maalajien hiukkaskokojakaumista: A ja B ovat savilajeja, $C$ on hiekka ja D sora. $P$ on läpimitaltaan pienempien hiukkasten yhteispainon osuus kokonaispainosta. $50 \%$ taso vastaa jakaumien mediaania.

Vesimolekyyli on dipoli, toisin sanoen sen sähkövaraukset ovat epäsymmetrisesti jakautuneet (kohta 3.1, kuva 3-1). Siksi se on vuorovaikutuksessa muiden molekyylien sähkövarausten kanssa. Maarakeiden pinta on usein varautunut negatiivisesti, jolloin dipolivoimien vaikutuksesta vesimolekyylit adsorboituvat ${ }^{1}$ rakeiden pinnalle. Dipolivoimat ovat dominoivia 0,5 $\mu \mathrm{m}$ etäisyydelle rakeen pinnasta. Sidostuneet kerrokset ovat ohuita, ja mitä pienempiä maarakeet ovat, sitä enemmän raepintoja on ja sitä enemmän maaperä pystyy sitomaan vettä. Rakeiden kokonaispinta-ala kasvaa hiukkaskoon pienentyessä empiiristen kokojakautumien mukaan, minkä takia pieneen hiukkaskokoon liittyy usein suuri vesipitoisuus. Hienojakoiset maalajit (savi ja siltti) voivat sitoa vettä paljon enemmän kuin karkeammat (hiekka).

Nesteen pintajännitys vaikuttaa maaperän ilma-vesi-rajapinnoilla maarakeiden pintavoimien lisäksi. Pintajännitys pyrkii pienentämään nestetilan pinta-alaa. Kapillaarinen nousukorkeus $h^{\prime}$ riippuu huokosputken säteestä $r$, ja likimain $h^{\prime}=150 \mathrm{~mm}^{2} r^{-1}$. Kapillaarivyöhyke on pintajännityksen aiheuttama. Erilaisten voimien vaikutuksesta muodostuu maaperään eri tavoin sitoutunutta vettä (kuva 7-4).

Tarkastellaan maaveden sitoutumista energian avulla lähtien Bernoullin yhtälöstä (6.6). Koska maavesien virtausnopeudet ovat pieniä (alle $1 \mathrm{~mm} \mathrm{~s}^{-1}$ ), liike-energiatermi voidaan jättää pois, ja niinpä maaveden energiakorkeus on

$$
H=h+\frac{p-p_{0}}{\rho g} .
$$

Korkeudet $H$ ja $h$ luetaan kiinteästä perustasosta positiivisena ylöspäin. Viimeistä termiä $h_{c}=\frac{p-p_{0}}{\rho g}$ kutsutaan kyllästymättömässä tilassa kapillaaripotentiaaliksi, joka kertoo vesiosasen maarakeesta irrottamiseen tarvittavan energian painoyksikköä kohden. Energiakorkeus $H$ ilmaisee energian painoa kohden ja $h$ on pisteen geometrinen korkeus. Energiakorkeutta kutsutaan potentiaaliksi, ja sovelluksissa sitä kutsutaan usein nousukorkeudeksi tai pietsometriseksi korkeudeksi, koska se ilmoittaa, mille korkeudelle nestepinta nousisi mittauskohtaan asetetussa pystysuorassa putkessa. Maaperän sidosvoimat sisältyvät painetermiin. Kuva 7-5

\footnotetext{
1 Adsorptio on fysikaalinen prosessi, jossa kaasu tai neste muodostaa ohuen kalvon kiinteän aineen pintaan. Huokoiset kiinteät pinnat adsorboivat hyvin suuren pinta-alan ansiosta.
} 
esittää säiliötä ja siihen liitettyä havaintoputkea paineen ja energiakorkeuden määrittämiseksi.

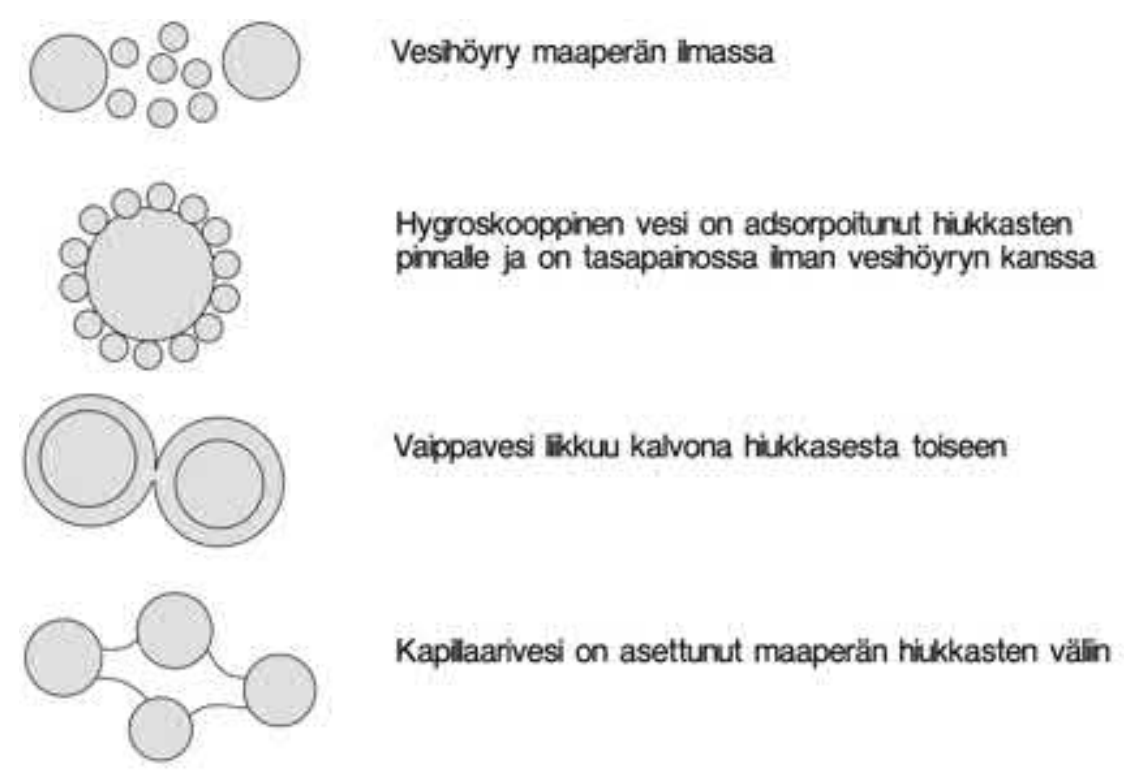

Kuva 7-4. Veden sitoutuminen maaperään.

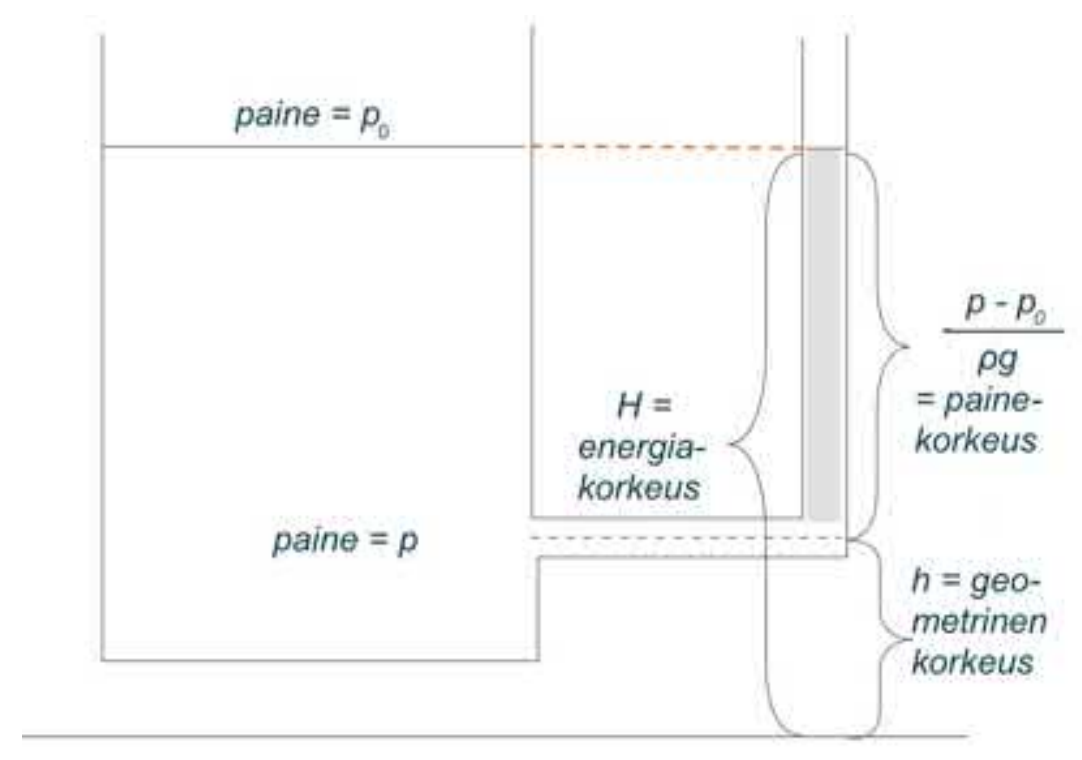

Kuva 7-5. Energiakorkeus vesiastiassa.

Maaperässä veden painetta voidaan mitata kyseiseen kohtaan asennetun putken avulla. Koska kyllästymättömässä tilassa vesi on imun alaisena eli painekorkeus on negatiivinen, mittausputki on asetettava alaspäin (kuva 7-6). Paine on alhaisempi kuin ulkoinen paine. Kuvan 7-6 laitetta kutsutaan tensiometriksi, ja sitä voidaan käyttää imun mittaamiseen silloin, kun imu on pienempi kuin yhden ilmakehän paine.

Kapillaaripotentiaali sisältää kapillaarivoimien ohella kaikki maaveden imuun vaikuttavat tekijät. Näitä tekijöitä ovat maaperän pintakerroksen lämpötilaerot, jotka vaikuttavat lähinnä vesihöyryn liikkeisiin, sekä osmoosi, jonka vaikutuksesta virtaus pyrkii suuntautumaan kohden korkeampaa liuenneiden aineiden konsentraatiota. Osmoosilla on merkitystä 
silloin, kun vesi tunkeutuu kasvin juureen. Kapillaaripotentiaali on painoyksikköä kohden se energia, joka tarvitaan vesiosasen irrottamiseen maaperän sidosvoimista. Vanhemmassa kirjallisuudessa kapillaaripotentiaalia ilmaisemaan on käytetty $p F-l u k u a$, joka on kapillaaripotentiaalin (cm yksikössä) vastaluvun kymmenkantainen logaritmi, $p F=\log _{10}\left(-h_{c}[\mathrm{~cm}]\right)$. Kapillaaripotentiaalin vastalukua kutsutaan vedenpidätyskyvyksi, jonka vuorovaikutussuhdetta maan kos-teuden kanssa kutsutaan vedenpidätyskäyräksi tai -käyräksi (kuva 7-7).

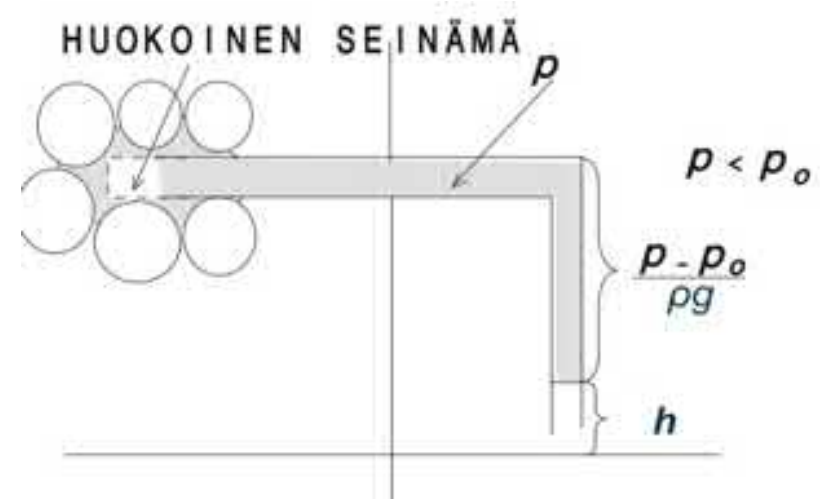

Kuva 7-6. Maaperän imun mittaus tensiometrillä.

Tarkastellaan maakerroksen pystysuoraa leikkausta. Tasapainotilassa, jossa virtausta ei esiinny, voidaan erottaa maanpinnan alaisten vesien vyöhykkeet (kuva 7-2). Veden virtaus juurivyöhykkeessä ja välivyöhykkeessä on hidasta. Se tapahtuu lähinnä vesihöyrynä tai vaippavetenä. Mikäli vyöhykkeen vesipitoisuus kasvaa sateen vaikutuksesta, tasapaino häiriintyy ja kapillaarisesti sitoutuneen veden osuus kasvaa. Tämä vesi liikkuu painovoiman vaikutuksesta alaspäin. Kapillaarivyöhykkeessä pienemmät huokoset ovat yhteydessä pohjaveteen, ja suurempiin huokosiin voi jäädä erillisiä, veden ympäröimiä ilmataskuja.

Juuri- ja välivyöhykkeessä kapillaaripotentiaali riippuu vesipitoisuudesta, kuten edellä on esitetty. Kapillaari- ja pohjavesivyöhykkeissä on, tässä järjestyksessä

$$
\begin{aligned}
& p-p_{0}=-\gamma\left(z-z_{0}\right)<0 \text { ja } \\
& p-p_{0}=-\gamma\left(z-z_{0}\right)>0,
\end{aligned}
$$

missä $z$ on syvyys, $z_{0}$ on pohjaveden pinnan syvyys, ja tiheyden ja painovoiman kiihtyvyyden tuloa $\rho g$ on merkitty symbolilla $\gamma$.

Kenttäkapasiteetti on vesipitoisuus, joka jää maalajiin, kun vesi poistuu vedellä kyllästyneestä maasta painovoiman vaikutuksesta. Taulukossa 7-2 on veden liikkeitä ja irtoamismahdolli-suuksia kuvaavia kapillaaripotentiaalin arvoja. Näiden rajojen avulla määritellään hyötykapasiteetti, joka on kenttäkapasiteettia ja lakastumisrajaa vastaavien vesipitoisuuksien erotus suhteessa tilavuuteen. Hyötykapasiteetin tyypillisiä arvoja on myös esitetty taulukossa 7-2.

\subsubsection{Maan vesipitoisuuden mittaaminen}

Maaperän vesipitoisuutta kuvaavat huokoisuus $n$ ja vesipitoisuus $m$. Samankokoisista palloista koostuvan materian harvin ja tihein pakkaustiheys ovat $\frac{\pi}{6} \approx 0,52$ ja $\frac{\pi}{3 \sqrt{2}} \approx 0,74$, joita voidaan käyttää hyvinä viitearvoina. Raekokojakauma vaikuttaa merkittävästi todellisen maalajiaineksen huokoisuuteen. Leveä jakauma pienentää huokoisuutta, sillä pienet rakeet voivat 
täyttää koloja suurten rakeiden välissä. Siksi esimerkiksi moreenin huokoisuus voi olla varsin pieni. Usein puhutaan efektiivisestä huokoisuudesta, joka saadaan liittämällä rakeisiin tiukemmin sitoutunut vesi rakeiden osuuteen.

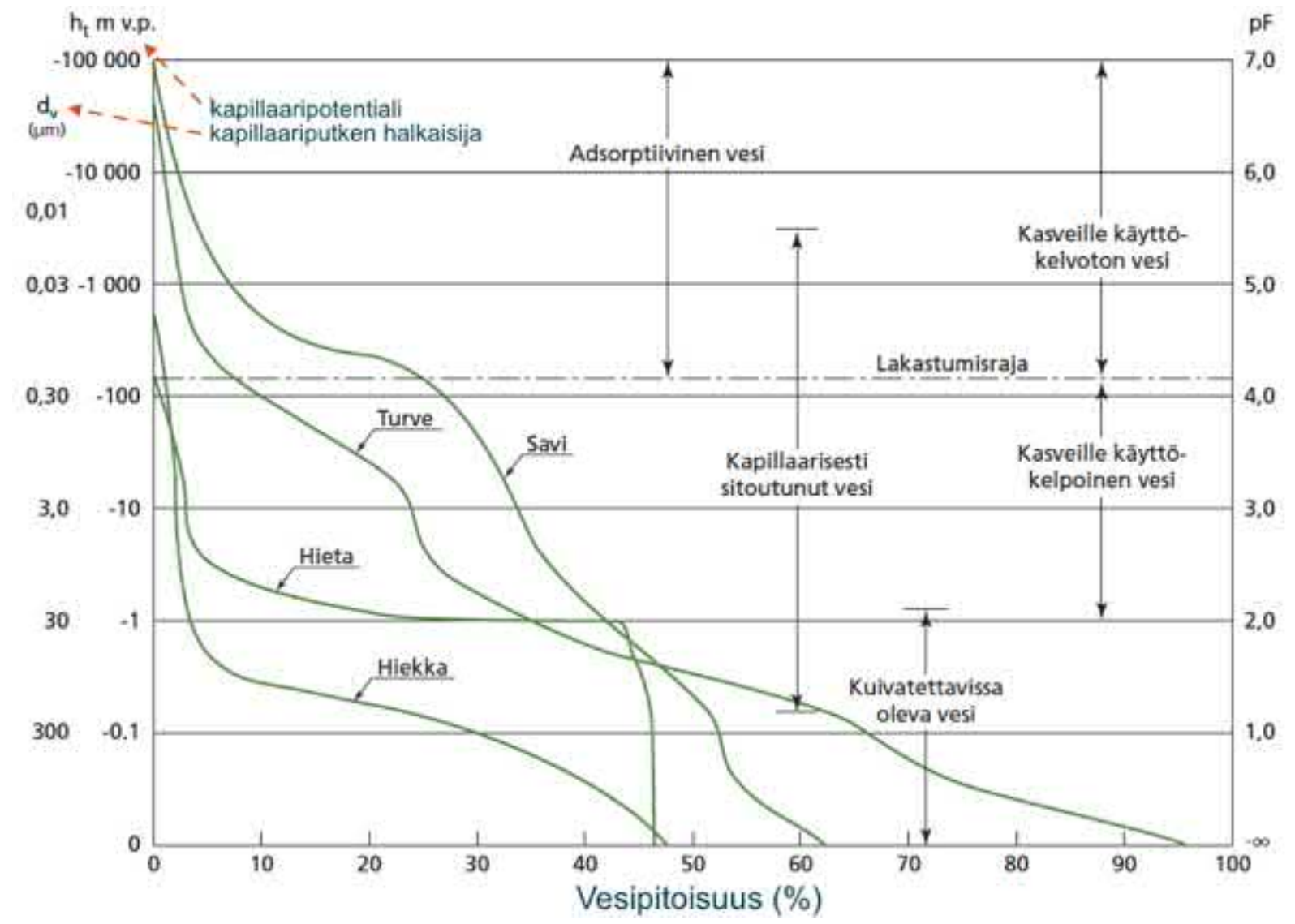

Kuva 7-7. Eräiden maalajien vedenpidätyskäyriä. Vaaka-akselilla on vesipitoisuus ja pystyakselilla vedenpidätyskyky ilmaistuna kapillaariputken halkaisijan $d_{v}$, kapillaaripotentiaalin $h_{t}$ ja $p F$-luvun $p F=$ $\log _{10}\left(-h_{t}[\mathrm{~cm}]\right)$ avulla.

Tilavuuden $V$, vesitilavuuden $V_{W}$ ja ilmatilavuuden $V_{A}$ välille saadaan yhtälöt

$$
\begin{aligned}
& V_{w}=m V, \text { ja } \\
& V_{A}=(n-m) V .
\end{aligned}
$$

Vesipitoisuuden tietäminen on tärkeää muun muassa maataloudessa ja hydrologiassa valuntaan vaikuttavana tekijänä. Hydrologiassa maan vesipitoisuus ilmoitetaan yleensä suhteessa tilavuuteen, mutta se voidaan ilmoittaa myös suhteessa kiinteän aineen massaan tai kokonaismassaan $M$. Vesipitoisuus on suhteessa

- $\quad$ tilavuuteen:

- $\quad$ kiinteän aineen massaan:

- $\quad$ kokonaismassaan:

$$
\begin{aligned}
& m_{w}=\frac{V_{W}}{V}, 0 \leq m_{V} \leq 1 \\
& m_{s}=\frac{M_{W}}{M_{S}}, 0 \leq m_{S} \leq \infty \\
& m_{s w}=\frac{M_{W}}{M_{S W}}, 0 \leq m_{\mathrm{sw}} \leq 1 .
\end{aligned}
$$

Tässä alaindeksi W viittaa veteen, $S$ kiinteään aineeseen ja $S W$ veden ja kiinteän aineen kokonaisuuteen. Maaperän ja veden tiheydet ovat 


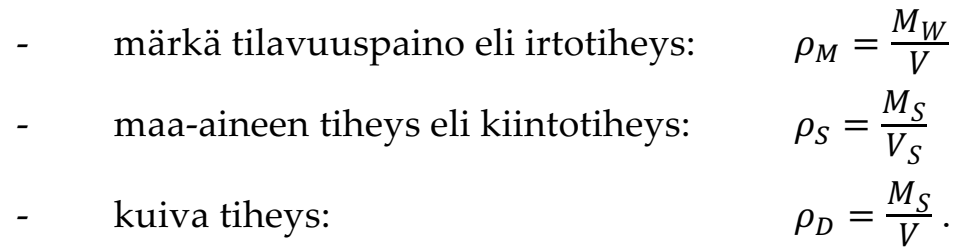

Esimerkki 7-2. Tarkastellaan maanäytettä, jonka tilavuus on $V=1 \mathrm{~m}^{3}$, kiinteän aineksen massa $M_{\mathrm{S}}=$ $4000 \mathrm{~kg}$ ja veden massa $M_{\mathrm{W}}=200 \mathrm{~kg}$. Tällöin määritelmän mukaan vesipitoisuus suhteessa tilavuuteen on $m_{W}=\frac{V_{W}}{V}=\frac{0,200 \mathrm{~m}^{3}}{1 \mathrm{~m}^{3}}=20 \%, 5 \%$ suhteessa kiinteän aineen massaan ja $4,8 \%$ suhteessa kokonaismassaan. Märkä tilavuuspaino on $200 \mathrm{~kg} \mathrm{~m}^{-3}$, kiintotiheys on $5000 \mathrm{~kg} \mathrm{~m}^{-3}$, ja kuiva tiheys on $4000 \mathrm{~kg} \mathrm{~m}^{-3}$.

Taulukko 7-2a. Veden sidostuminen ja kapillaaripotentiaali.

\begin{tabular}{|c|c|c|c|c|}
\hline \multirow[b]{2}{*}{ Veden sidostuneisuus } & Paine & $\begin{array}{l}\text { Kapillaari- } \\
\text { potentiaali }\end{array}$ & $p F$ & Paine \\
\hline & ilmakehiä & cm & & $\mathrm{kPa}$ \\
\hline $\begin{array}{l}\text { Hygroskooppisuusraja, tämän } \\
\text { alapuolella vesi liikkuu } \\
\text { vesihöyrynä }\end{array}$ & -30 & -30000 & 4,5 & -3000 \\
\hline $\begin{array}{l}\text { Lakastumisraja, tämän alapuo- } \\
\text { lella kasvien vedenotto tyrehtyy }\end{array}$ & -15 & -15000 & 4,2 & -1500 \\
\hline $\begin{array}{l}\text { Kenttäkapasiteetti, tämän ylä- } \\
\text { puolella vapaasti liikkuva vesi } \\
\text { valuu pois }\end{array}$ & $-0,3$ & -300 & 2,5 & -30 \\
\hline
\end{tabular}

Taulukko 7-2b. Eri maalajien hyötykapasiteetteja. Hyötykapasiteetti on kenttäkapasiteettia ja lakastumisrajaa vastaavien vesipitoisuuksien ero.

\begin{tabular}{l|r|r|r|r} 
Maalaji & Savi & $\begin{array}{r}\text { Hieno siltti - } \\
\text { keskisiltti }\end{array}$ & $\begin{array}{r}\text { Karkea siltti } \\
\text { hieno hiekka }\end{array}$ & Hiekka \\
\hline Raekoko $(\mathbf{m m})$ & $<0,002$ & $0,002-0,02$ & $0,02-0,2$ & $0,2-2$ \\
Hyötykapasiteetti & $14 \%$ & $16 \%$ & $10 \%$ & $7 \%$
\end{tabular}

Maan vesipitoisuuden mittaaminen hydrologisia tarkoituksia varten on vaikeaa. Vesipitoisuutta tulisi voida seurata samalla alueella vuodesta toiseen säännöllisin väliajoin siten, että mittaustulokset kuvastaisivat samalla kyseisen alueen keskimääräisiä arvoja. Tämä asettaa vaatimuksia laitteiston kenttäkelpoisuudelle ja sille, että mittaukset tulee voida toistaa samassa paikassa.

Vanhin ja kenties käytetyin menetelmä on ottaa maanäyte, jonka tilavuus tunnetaan, punnita se, ja kuivata se tämän jälkeen $105^{\circ} \mathrm{C}: n$ lämpötilassa. Kuivaamisen jälkeen näyte punnitaan uudelleen: painon keveneminen on sama kuin näytteessä alun perin ollut vesimäärä. Menetelmän puutteina ovat ennen kaikkea sen vaatima suuri työmäärä ja tutkimusalueen vähittäinen häiriintyminen.

Aikaisemmin käytettiin varsin paljon nopeiden neutronien hidastumiseen perustuvaa laitetta. Hidastuminen riippuu ympäröivän maan vesipitoisuudesta. Tämä sovellus on kehittynyt 1960-luvulla öljynetsijöiden kehittämistä menetelmistä hydrologisia tarkoituksia varten. Laitteen pääosat ovat nopeita neutroneja lähettävä radioaktiivinen aine (Am-Be tai Ra-Be) ja 
ilmaisija, joka on verrannollisuuslaskija tai kide. Ilmaisija kykenee tunnistamaan ainoastaan hidastuneet neutronit.

Sähkövastusmittaukset taas perustuvat siihen, että maaperän vastus on kääntäen verrannollinen vesipitoisuuteen. Vesipitoisuutta voidaan mitata myös dielektrisyyden perusteella, sillä suhteellinen permittiivisyys (dielektrisyysvakio) riippuu vesipitoisuudesta. Uudempi mittalaite perustuu maaperän dielektrisyyden mittaamiseen maatutkalla ja reflektometrillä (Time Domain Reflectometer, TDR).

\subsection{Pohjavedet}

\subsubsection{Pohjavesivarastot}

Pohjavedet sisältävät noin 30 \% maapallon makean veden varastosta, ja nestemäisen makean veden varastosta pohjaveden osuus on $99 \%$. Puolet pohjavedestä muodostaa matalan pohjaveden, jonka syvyys alle $800 \mathrm{~m}$, ja puolet tätä syvemmän pohjaveden. Suomessa 1970-luvun puolessa välissä pohjaveden osuus oli noin $30 \%$ kunnallisessa vesihuollossa käytetystä vedestä. Nykyään tämä osuus kokonaiskulutuksesta on yli $60 \%$, noin $35 \mathrm{~m}^{3} \mathrm{~s}^{-1}$. On arvioitu, että maamme suurimmat pohjavesivarat riittävät kulutustasolle $45 \mathrm{~m}^{3} \mathrm{~s}^{-1}$ asti. Tämän perusteella näyttäisi siltä, että Suomessa on riittävästi pohjavettä. Hyödyntämistä rajoittaa kuitenkin se, että yksittäiset esiintymät ovat pieniä, ja suurin osa niistä sijaitsee kaukana käyttöpisteistä. Pohjavesistä on olemassa myös suomenkielistä oheislukemistoa (Mälkki 1999).

Pohjaveden keskiviipymä² ${ }^{2}$ on noin 240 vuotta, mutta viipymä vaihtelee suuresti esiintymän mukaan. Syvimmällä maaperässä oleva pohjavesi on vain vähäisessä vuorovaikutuksessa ilmakehän ja matalammalla sijaitsevan pohjaveden kanssa. Eräät pohjavesiesiintymät ovat täyttyneet vuosituhansia sitten. Esimerkiksi Pohjois-Euroopassa on viime jääkauden ajalta periytyviä pohjavesivarastoja, ja $\mathrm{mm}$. Saharasta on löydetty vanhoja esiintymiä, jotka ovat säilyneet jääkaudesta toiseen.

Vapaapintainen pohjavesi muodostaa vedellä kyllästetyn kerroksen, jossa hydrostaattinen paine on ilmanpainetta suurempi. Kerroksen yläpinnalla $p=p_{0}$ ja pinnan korkeus vaihtelee sen mukaan, kuinka paljon vettä siihen suotautuu maavesivyöhykkeestä ja ympäristöstä tai ympäristöön tapahtuvasta suotautumisesta.

Vedenpidätyskäyrän (kuva 7-7) perusteella voidaan todeta, että kenttäkapasiteettia vastaavalla $p F$-luvun arvolla saven vesipitoisuus on $40 \%$ ja hiekan $10 \%$ tilavuudesta. Kummankin maalajin kyllästettyä tilaa vastaava vesipitoisuus on noin $50 \%$. Kenttäkapasiteettia ja kyllästettyä tilaa vastaavien vesipitoisuuksien eroa, savella 10 ja hiekalla 40 prosenttiyksikköä, kutsutaan vapaasti liikkuvaksi vedeksi. Vapaasti liikkuva vesi virtaa painovoiman vaikuksesta eikä sähköiset voimat sitä pidätä.

Ihmisen kannalta runsaasti vapaasti liikkuvaa vettä sisältävät pohjavesivarastot ovat tärkeitä. Tällaisia varastoja on löydettävissä hiekka- ja soramuodostumista, mutta muissa hienorakeisimmissa maalajeissa sidosvoimat ovat niin suuria, että veden irrottaminen on vaikeaa. Muodostumaa, jossa on runsaasti vapaata pohjavettä, kutsutaan akviferiksi. Suomen tärkeimmät akviferit ovat Fennoskandian mannerjäätikön vetäytymisvaiheessa muodostuneissa harjuissa. Käyttökelpoista pohjavettä löydetään myös peruskallion halkeamista. Arkikielessä pohjavedellä tarkoitetaankin juuri tätä käyttökelpoista pohjavettä.

\footnotetext{
${ }^{2}$ Keskiviipymä on varaston tilavuus jaettuna uudistusnopeudella.
} 
Pohjaveden tekee merkitykselliseksi sen puhtaus. Sitä voidaankin käyttää lähes sellaisenaan. Suotautuessaan maakerrosten läpi vesi menettää ihmisille haitalliset bakteerit ja muut epäpuhtaudet. Sen sijaan pohjaveteen kulkeutuu usein sopivassa määrin hyödyllisiä liuenneita suoloja. Pohjavesi on osittain suojassa ilmakehästä laskeutuvilta saasteilta, koska suurin osa epäpuhtauksista suodattuu maavesivyöhykkeeseen. Pohjavesiä uhkaa kuitenkin vähitellen etenevä happamoituminen ja maantiesuolan aiheuttama suolaisuuden kasvu. Pohjavesi on vaarassa myös silloin, kun soramonttu on kaivettu pohjaveden pintaan asti.

Akviferit muodostuvat huonosti vettä läpäisevän kerroksen päälle karkeampien maalajien muodostamaan kerrokseen. Niitä on kolmea eri perustyyppiä (kuva 7-8):

1) Rajoittamaton eli vapaapintainen akviferi,

2) Rajoitettu eli arteesinen pohjavesi, jonka yläreunan muodostaa vettä läpäisemätön kerros,

3) Orsivesi, joka on erillinen kyllästetty vyöhyke varsinaisen pohjaveden yläpuolella.

Vapaapintaisen akviferin yläpinnan muodostaa vapaa pohjaveden pinta, jolla paine on sama kuin ulkoinen paine eli ilmanpaine vastaavalla syvyydellä. Arteesisen pohjaveden eli salpaveden varaston yläpinnan muodostaa huonosti vettä läpäisevä kerros, ja paine on kaikkialla suurempi kuin ulkoinen paine. Jos rajoitettuun pohjavesivarastoon asetetaan havaintoputki, vedenpinta nousee siinä korkeammalle kuin varaston yläpinta, jopa korkeammalle kuin maan pinta. Tällaisten kuviteltujen havaintoputkien vedenpintojen muodostamaa pintaa kutsutaan pietsometriseksi pinnaksi, painepinnaksi tai potentiaalipinnaksi (pietsometrinen korkeus $=$ nousukorkeus). Rajoitetun varaston vesi saattaa olla peräisin kauempaa, kilometrien tai satojenkin kilometrien päässä sijaitsevilta korkeammilta, usein runsassateisimmilta alueilta. Huonosti vettä läpäisevän kerroksen yläpuolelle saattaa muodostua erillinen pohjavesivarasto, jota kutsutaan orsivedeksi.
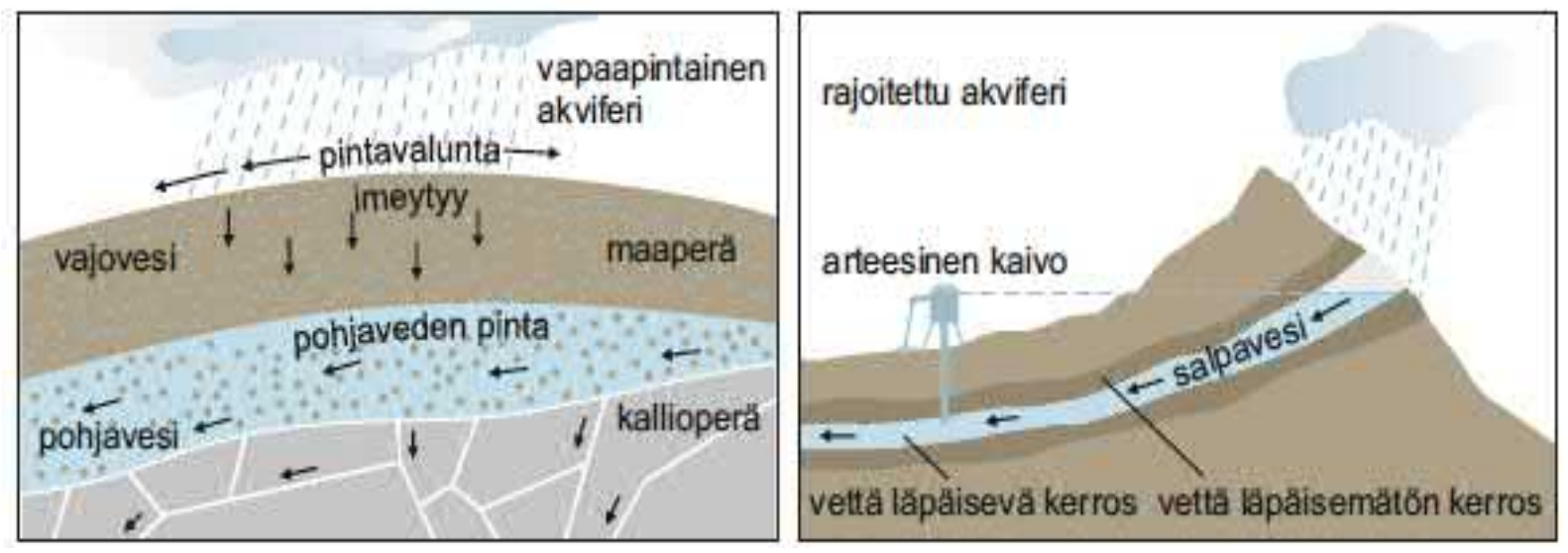

Kuva 7-8. Rajoittamattomassa pohjavesivarastossa (vasen) sadevesi imeytyy maaperään ja vajoaa pohjaveden pintaan asti, sen jälkeen virtaa pinnan kaltevuuden mukaan. Rajoitetussa pohjavesivarastossa (oikea) yläpuolella on eristävä kerros, ja pohjaveden paine määräytyy vapaan pinnan korkeuden perusteella.

Pohjavesivarasto saa täydennystä sadevedestä, ympäristön joista ja järvistä sekä muista pohjavesivarastoista. Täydennystä se voi saada myös keinotekoisen lisäyksen avulla. Tähän joudutaan turvautumaan, jos varasto lisääntyneen käytön johdosta muuten tyhjenisi. Tällaisten 
tekopohjaveteen perustuvien vesilaitosten varassa toimii useiden kaupunkien vesihuolto Suomessa (esim. Turku, Jyväskylä, Kuopio, Lappeenranta). Pohjavesivarasto purkautuu mereen, vesistöihin ja muihin pohjavesivarastoihin, tai se voi tyhjentyä lisääntyneen käytön kautta.

\subsubsection{Darcyn kaava ja pohjaveden virtaus}

Pohjaveden liike on virtausta huokoisen väliaineen läpi. Sen ulkoinen pakote on painovoima, joka pyrkii saattamaan pohjaveden pinnan horisontaaliseen tasoon. Veden liikettä vastustaa kitka $F$ väliaineen kanssa. Paine, geometrinen korkeus $h$ ja kitka muodostavat tasapainotilan, josta pohjaveden virtaus voidaan laskea. Kaavan yleinen muoto on

$$
-\frac{1}{\rho g} \nabla p+\nabla h+\frac{1}{\rho g} F=0 .
$$

Painekorkeuden ja geometrisen korkeuden summa on potentiaalikorkeus $H$, jonka gradientti $\nabla H$ ajaa virtausta. Kitka otetaan verrannollisena ${ }^{3}$ nopeuteen

$$
F=-\rho C U
$$

missä $C$ on kitkakerroin.

Tästä voidaan edetä Darcyn kaavaan (Henry Philibert Gaspard Darcy, 1803-1858), joka antaa virtaaman $Q=U A$ maatäytteisessä putkessa (kuva 7-9) poikkileikkauksen alaa $A$ kohden eli keskimääräisen virtausnopeuden:

$$
U=\frac{Q}{A}=K \frac{H_{1}-H_{2}}{L}
$$

missä $K=C^{-1}$ on hydraulinen johtavuus, $H_{1}$ ja $H_{2}$ ovat potentiaalit kohdissa 1 ja 2 (kuva 7-9), ja $L$ on näyteputken pituus. Suure $\frac{H_{1}-H_{2}}{L}$ on hydraulinen gradientti, ja hydraulinen johtavuus eli permeabiliteetti kuvaa maaperän vedenläpäisykykyä. Hydraulisella johtavuudella on nopeuden dimensio, ja esimerkiksi $K=1 \mathrm{~cm} \mathrm{~s}^{-1}$ antaa virtauksen laskennalliseksi keskinopeudeksi $U=10^{-4} \mathrm{~m} \mathrm{~s}^{-1} \approx 10 \mathrm{~m} \mathrm{vrk}^{-1}$, kun hydraulinen gradientti on $1 \%$.

Huomaa, että kaavassa (7.6a) potentiaaliero $H_{1}-H_{2}$ jaetaan putken pituudella $L$ eikä horisontaalisella etäisyydellä $x$, ja siksi

$$
\frac{H_{1}-H_{2}}{L} \rightarrow \frac{\partial H}{\partial s}, \text { kun } L \rightarrow 0
$$

missä $s$ on putken suuntainen etäisyys. Approksimaatio $\frac{\partial H}{\partial s} \approx \frac{\partial H}{\partial x}$ voidaan tehdä, jos putken kaltevuus on pieni.

Hydraulisen johtokyvyn vaihteluväli on suuri. Huokoisuuden lisäksi siihen vaikuttavat myös maalaji, erityisesti huokosten muoto ja raekokojakauma. Taulukko 7-3 kuvaa hydraulisen johtavuuden riippuvuutta maalajeista. Taulukosta ilmenevät myös johtavuusluokat sekä pohjavesivaraston luokittelu (Bear ym. 1968). Virtauksen todellinen keskinopeus huokosten välissä on

\footnotetext{
${ }^{3}$ Laminaarisen virtauksen kitka on suoraan verrannollinen nopeuteen.
} 


$$
\widetilde{U}=\frac{1}{n_{e}} U, n_{e}=\frac{V_{w e}}{V}
$$

missä $n_{\mathrm{e}} \sim 10-30 \%$ on tehoisa huokoisuus, ja $V_{\text {we }}$ on virtaukseen osallistuvan veden tilavuus. Adsorptiovesi ei osallistu virtaukseen. Pohjavesivirtaus on yleensä laminaarista, ja siihen vaikuttavat lämpötilasta riippuva viskositeetti, liuenneet kaasut ja veden kiintoainepitoisuus. Viskositeetti ja sen myötä virtaus riippuvat lämpötilasta. Monimutkaisten maahiukkasia kiertelevien reittien takia pohjavesivirtaus etenee satunnaiskulkuna ja siksi se hajaantuu nopeasti.

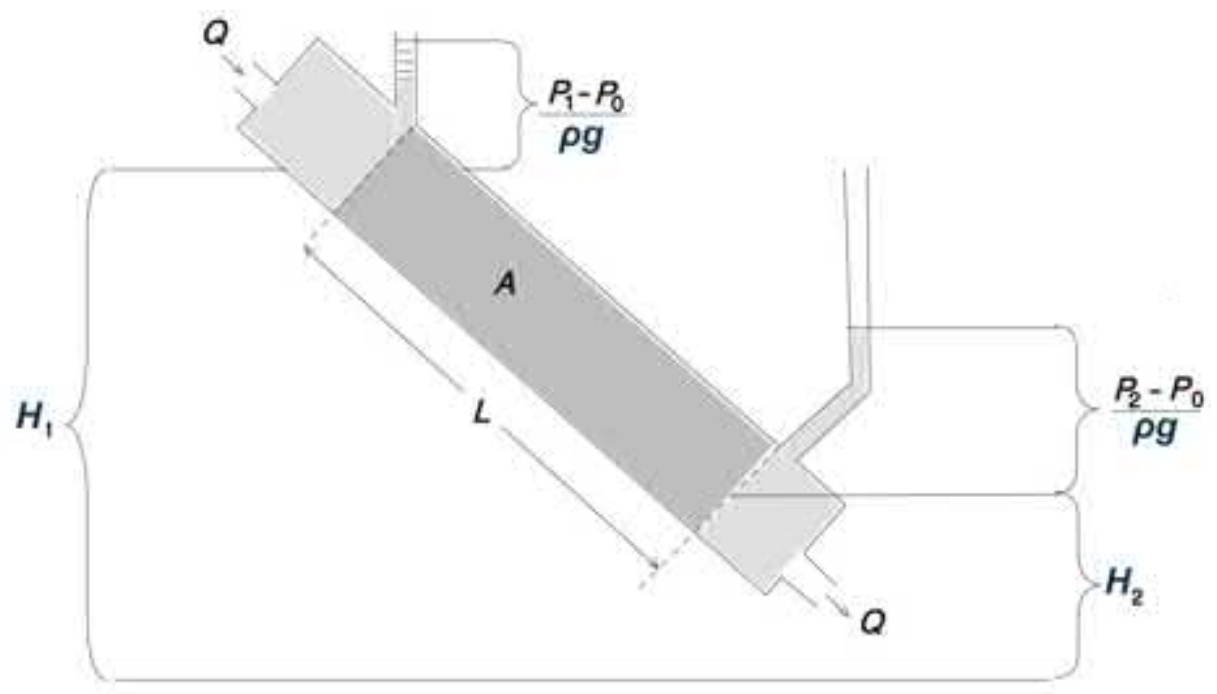

Kuva 7-9. Darcyn koe hydraulisen johtavuuden $K$ määrittämiseksi. Putken kaltevuus kerrottuna $K$ :lla antaa veden virtaaman putken poikkileikkauksen alaa kohden.

Taulukko 7-3. Hydraulinen johtavuus ja siihen perustuva pohjavesivaraston laatu.

\begin{tabular}{|c|c|c|c|}
\hline Maalaji & $\begin{array}{r}\text { Hydraulinen } \\
\text { johtavuus } \\
\left(\mathrm{cm} \mathrm{s}^{-1}\right)\end{array}$ & $\begin{array}{l}\text { Pohjavesi- } \\
\text { varasto }\end{array}$ & Johtavuusluokka \\
\hline Puhdas sora & $10^{2}-1$ & hyvä & läpäisevä \\
\hline Hiekka & $1-10^{-3}$ & hyvä & $\begin{array}{l}\text { läpäisevä }\left(1-10^{-2}\right) \\
\text { puoliläpäisevä }\left(10^{-2}-10^{-3}\right)\end{array}$ \\
\hline $\begin{array}{l}\text { Silttikerrostunut } \\
\text { savi }\end{array}$ & $10^{-3}-10^{-7}$ & huono & $\begin{array}{l}\text { puoliläpäisevä }\left(10^{-3}-10^{-6}\right) \\
\text { eriste }\left(10^{-6}-10^{-7}\right)\end{array}$ \\
\hline Savi & $<10^{-7}$ & olematon & eriste \\
\hline
\end{tabular}

Esimerkki 7-3. Tarkastellaan vapaan pohjavesivaraston pintavirtausta. Pinnassa potentiaalikorkeus on geometrista eli $H=h$. Hydraulinen gradientti on $5 \%$. Jos maaperän hydraulinen johtavuus on $K=1$ $\mathrm{cm} \mathrm{s}^{-1}$, niin veden virtausnopeus on $U=K \frac{H_{1}-H_{2}}{L}=0,05 \mathrm{~cm} \mathrm{~s}^{-1} \approx 50 \mathrm{~m} \mathrm{vrk}^{-1}$. Tämä johtavuuden $K$ arvo vastaa hyvälaatuista akviferia. Jos valitaan $K=10^{-7} \mathrm{~cm} \mathrm{~s}^{-1}$ edustamaan savimaata ja kaltevuutena pidetään edelleen $5 \%$, niin vuotuinen kulkeutuma on $2 \mathrm{~mm}$.

Edellä on tarkasteltu Darcyn kaavan soveltumista maanäytteelle. Kaava voidaan sellaisenaan yleistää virtauskenttään. Virtaus kulkee aina siihen suuntaan, jossa potentiaali muuttuu 
kaikkein nopeimmin eli potentiaalin gradientin suuntaan. Tuloksesta seuraa, että virtauksen suunta on kohtisuorassa potentiaalin tasa-arvokäyriä $H=$ vakio vastaan.

Darcyn kaavalla on rajoituksensa. Ensinnäkin se edellyttää riittävän pientä Reynoldsin lukua eli virtauksen laminaarisuutta. Mikäli virtaus on turbulenttinen (karkeat maalajit, suuri potentiaalin gradientti), kaava ei ole voimassa. Tällöin kitkaan pitäisi lisätä myös neliöllinen termi, siispä $F=-\left(\rho C U+\rho C_{2} U^{2}\right)$. Toiseksi, savessa ja maatuneessa turpeessa, jossa vettä pidättävät voimat ovat suuria, esiintyy eräänlainen kynnysgradientti. Jotta virtaus pääsisi käyntiin, tulee potentiaalin gradientin olla suurempi kuin tämä kynnys.

Kolmas rajoitus on Darcyn oletus maaperän homogeenisuudesta. Yleensä maaperä on muodostunut jaksottaisen sedimentaation seurauksena ja siksi maaperä ei ole isotrooppinen. Esimerkiksi järven tai meren pohjaan on vajonnut kiintoainesta eri vuodenaikoina erilaisia määriä. Vähitellen maan kohoamisen tai veden laskun yhteydessä pohjaa on paljastunut nykyiseen maaperään, joka on näin jäänyt kerrostuneeksi. Veden virtaus tapahtuu siinä helpommin kerrosten suuntaisena kuin niitä vastaan kohtisuoraan eikä siis välttämättä kohtisuoraan potentiaalipintoja vastaan. Koska kerrokset ovat yleensä lähes vaakasuoria, hydraulisella johtokyvyllä on vaakasuorassa suunnassa suurempi arvo kuin pystysuorassa suunnassa.

Darcyn kaavasta muodostettu pohjaveden virtausmalli yhdessä reunaehtojen kanssa määrittelee yksikäsitteisesti pohjavesivirtauksen. Maaperän laatu on tunnettava tai oletettava mallin jokaisessa hilapisteessä. Tärkeimmät reunaehdot kaavan soveltamiselle ovat seuraavat:

1) Vettä läpäisemätön kerros: lähellä olevan virtauksen tulee tapahtua tämän kerroksen suuntaisena eli potentiaalipinnat ovat kohtisuorassa tätä kerrosta vastaan.

2) Vesistön ja akviferin välisellä reunalla virtaus tapahtuu kohtisuoraan reunaa vastaan. Reuna on samalla potentiaalipinta, jossa potentiaalin arvo on sama kuin vesistön vapaan pinnan korkeus.

3) Pohjaveden vapaalla pinnalla paineen tulee olla vakio ja sama kuin ulkoinen paine. Potentiaalin arvo on sama kuin pohjaveden pinnan korkeus samalla kohdalla.

Yleensä pohjavesivirtauksen malleissa virtauskenttä ratkaistaan numeerisesti lähtemällä virtauksen differentiaaliyhtälöistä (7.4) ja jatkuvuusyhtälöstä. Joillekin yksinkertaisille virtauksille analyyttisiä ratkaisuja on olemassa. Esimerkki tällaisesta ratkaisusta esitetään seuraavassa kappaleessa.

\subsubsection{Dupuit'n kaivoyhtälö}

Rajoittamattoman virtauksen käsittely johtaa usein differentiaaliyhtälöihin, joita ei voida ratkaista analyyttisesti. Joissakin erikoistapauksissa voidaan kylläkin päästä analyyttisiin ratkaisuihin. Nämä ovat pohjavesivirtauksen ymmärtämiseksi sangen valaisevia.

Jules Dupuit (1804-1866) johti kaivoyhtälön, joka perustui seuraavaan kahteen olettamukseen:

1) Virtauksen kaltevuus on pieni. Tällöin korkeuspotentiaalin $H$ derivaattaa virtauksen suuntaan $s$ voidaan approksimoida vaakasuoran etäisyyden $x$ avulla: $\frac{\partial H}{\partial s} \approx \frac{\partial H}{\partial x}$.

2) Virtauksen nopeus $U$ on riippumaton pystykoordinaatista $z$. Tällöin nopeus on sama kuin vapaalla pinnalla, missä se on $U=K \frac{\partial H}{\partial x}$. 
Tarkastellaan rajoittamatonta akviferia, jonka pohja on vaakasuora ja jossa ei aluksi esiinny virtausta. Asetetaan akviferiin putki pumppausta varten. Kun pumppaus on kestänyt niin kauan, että pysyvä virtaus on saavutettu, tilanne on kuvan (7-10) mukainen. Ratkaisua kutsutaan Dupuit'n kaivoyhtälöksi, ja se kertoo kaivon antoisuuden.

Ratkaisu konstruoidaan seuraavasti. Vapaan pinnan korkeus ennen pumppauksen aloittamista on $H_{0}$, pumppausputken säde on $r_{0}$, ja $r$ on etäisyys putkesta. Pumppauksen stabiloiduttua pinnan korkeus pumppauskohdassa on $H_{1}$, ja etäisyydestä $r$ riippuva säteittäinen virtausnopeus on $u$, joka määritellään positiiviseksi putkea kohti. Vakaassa tilanteeessa täytyy jokaisen $r>r_{0}$ säteisen ylinteripinnan lävitse kulkea vakio virtaama $Q$. Dupuit'n olettamuksen mukaan virtausnopeus on riippumaton pystykoordinaatista.

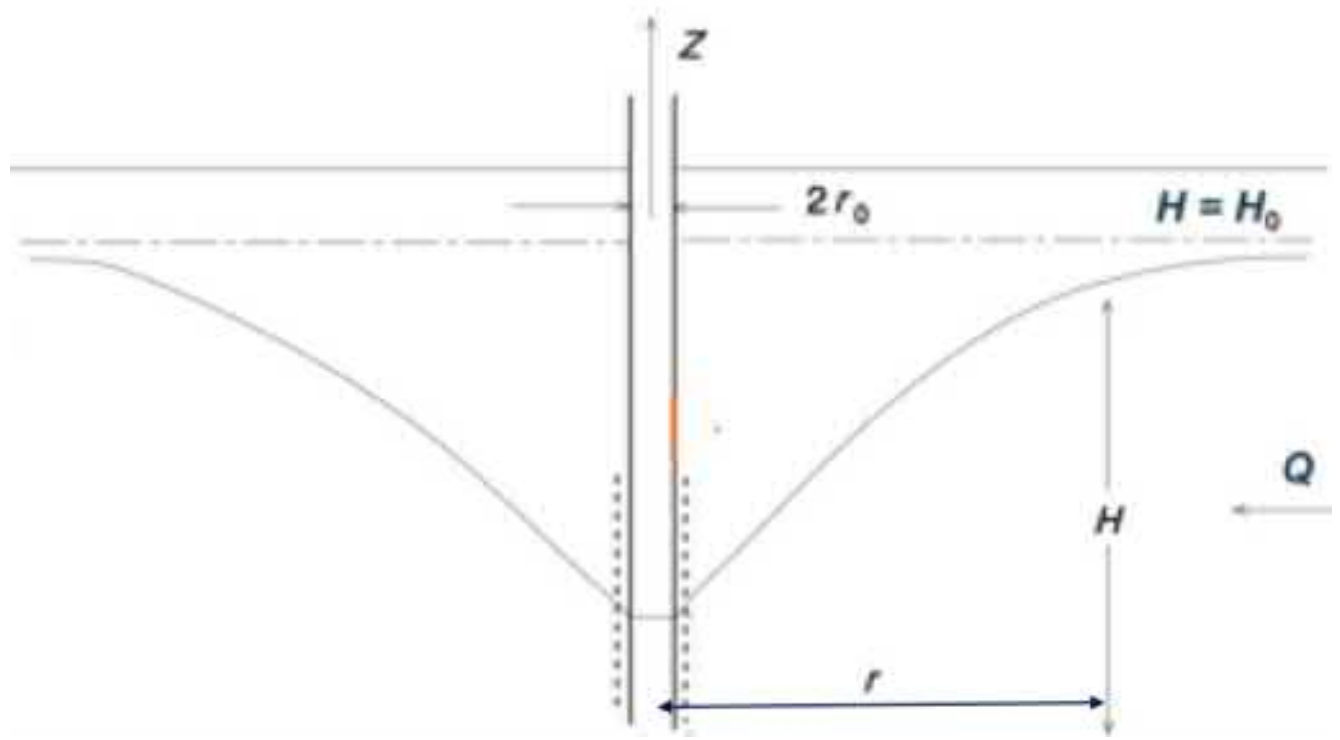

Kuva 7-10. Pumppaus rajoittamattomasta akviferista. Analyyttinen ratkaisu vakaasta tilasta, kun reunaehtona on $H=H_{0}$, kun $r=R$. $r_{0}$ on pumppauskaivon säde.

Virtauksen vaakasuora nopeus akselia kohti on $u(r)$. Tämän sylinteripinnan lävitse kulkee keskustaa kohden virtaama

$$
Q=2 \pi r H u,
$$

missä $H$ on etäisyydestä $r$ riippuva vapaan pinnan korkeus pumppauksen aikana. Pysyvässä tilanteessa $Q$ ei riipu etäisyydestä $r$. Koska $H$ on samalla potentiaalikorkeus, Darcyn kaavan mukaan säteittäinen virtausnopeus kohti putkea on

$$
u=K \frac{d H}{d r}
$$

Sijoittamalla nopeuden lauseke (7.9) yhtälöön (7.8) saadaan potentiaalikorkeuden differentiaaliyhtälö. Tämä separoituva differentiaaliyhtälö voidaan suoraan integroida:

$$
H^{2}=\frac{Q}{\pi K} \ln r+B
$$

\footnotetext{
${ }^{4}$ Merkintä ln viittaa aina luonnolliseen logaritmiin $\log _{e}$, jossa kantaluku on Neperin luku $e$. Muissa logaritmeissa kantaluku kirjoitetaan näkyviin, esim. $\log _{10}$.
} 
missä $B$ on integroimisvakio. Kaavan muodosta huomataan välittömästi tiettyjä rajoituksia. Kun $r$ kasvaa, potentiaalin raja-arvo on $H \rightarrow \infty$, mutta korkeuden täytyy olla aina lähtötasoa pienempi eli $H \leq H_{0}$. Tämä ongelma aiheutuu siitä, että oletettu virtaus on pysyvää. Mutta pumppauksen vaikutus etenee yhä kauemmaksi pumppauskohdasta, eikä pysyvää tilannetta saavuteta ennen kuin akviferi on pumpattu tyhjäksi tai ympäristöstä tulee pumpattavaa määrää vastaava vesimäärä tilalle. Yleensä käytännön tarpeita varten yhtälö (7.10) toimii jonkin ajan (viikkoja, kuukausia) pumppauksen aloittamisesta, koska muutokset akviferin tilassa ovat hitaita.

Voidaan määritellä pumppauksen "vaikutusalueen" säde $R$ ja asettaa integroimisvakion $B$ määrittämistä varten ehto $H=H_{0}$, kun $r=R$. Tällöin vapaan pinnan korkeuden laskemiseksi saadaan yhtälö

$$
H_{0}^{2}-H^{2}=\frac{Q}{\pi K} \ln \frac{R}{r}, \text { missä } H_{0}=H\left(r_{0}\right) \text { ja } r_{0} \leq r \leq R .
$$

Kuvassa 7-11 on esitetty kaivoyhtälön ratkaisuja erilaisilla hydraulisen johtavuuden arvoilla. Hydraulisen johtavuuden heikentyessä tasapainotilan kaivon profiili syvenee ja silloin reunoja pitäisi levittää realistisemman ratkaisun saavuttamiseksi. Yhtälö (7.11a) voidaan tehdä dimensiottomaksi merkitsemällä

$$
\begin{aligned}
& 1-\eta^{2}=\Omega \ln \frac{1}{\xi}, \xi_{0} \leq \xi \leq 1, \\
& \xi_{0}=\frac{r_{0}}{R}, \Omega=\frac{Q}{\pi K H_{0}^{2}}, \eta=\frac{H}{H_{0}}
\end{aligned}
$$

missä $\Omega$ on dimensioton virtaama, $\eta=\eta(\xi)$ on dimensioton vapaan pinnan korkeus ja $\xi$ on dimensioton etäisyys. Nähdään, että pumppaustehon ja hydraulisen johtavuuden suhteen samana pitäminen tuottaa saman vapaan pinnan ratkaisun. Lisäksi tilannetta voidaan tasapainottaa reunaehdon avulla. Tehtävän aikamitta saadaan hydraulisen johtavuuden avulla, $T \sim L K^{-1}$. Valitsemalla pituusmitaksi $L \sim R$, aikamitta on 1 tunti $-1 \mathrm{vrk}$, kun $K=0,1-1 \mathrm{~cm} \mathrm{~s}^{-1}$.

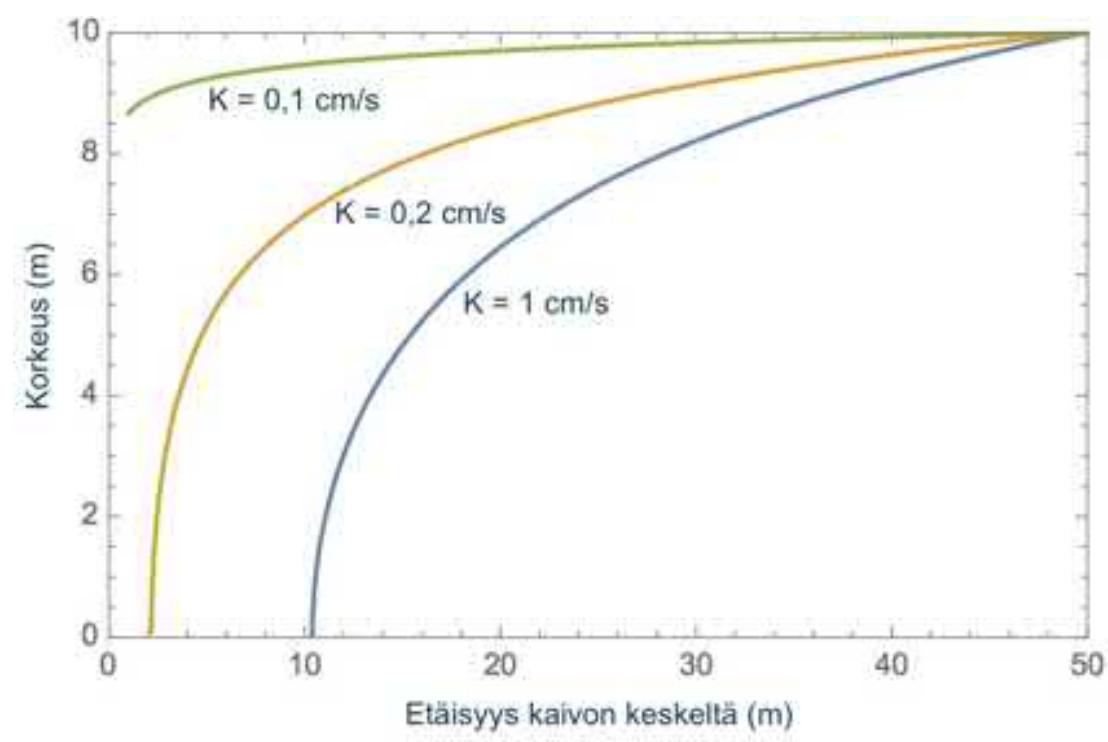

Kuva 7-11. Kaivon ympäristön vapaa veden pinta. Tässä pumppausteho on $0,2 \mathrm{~m}^{3} \mathrm{~s}^{-1}$ ja reunaehtona $10 \mathrm{~m}$ vapaan pinnan korkeus 50 metrin etäisyydellä kaivosta. Hydraulinen johtavuus on $0,1 \mathrm{~cm} \mathrm{~s}^{-1}, 0,2$ $\mathrm{cm} \mathrm{s}^{-1}$ ja $1 \mathrm{~cm} \mathrm{~s}^{-1}$. Korkeuden nollataso on yli $10 \mathrm{~m}$ maanpinnan alla. 
Pumppaus voidaan suorittaa joko hydraulisen johtavuuden $K$ määrittämiseksi tai veden hankintaa varten. Edellisessä tapauksessa mitataan virtaama $Q$ sekä vedenpinnan korkeus $H$ useilla etäisyyden $r$ arvoilla. Näistä havainnoista voidaan laskea $K$. Veden hankinnassa pumppaukselle on voitu asettaa ehto, että erotus $H_{0}-H$ ei saa sovitussa kohdassa nousta suuremmaksi kuin tietty arvo. Tätä ehtoa vastaava pumppausvirtaama voidaan laskea kaavasta (7.11).

\subsubsection{Mittaukset ja koepumppaukset}

Pohjavesitutkimuksia tehdään kentällä pohjavesiputkien avulla. Niitä kairataan akviferia edustaviin kohtiin tarpeeksi syvälle. Vedenkorkeus mitataan putkesta manuaalisesti sähkönjohtavuusanturilla tai paineanturilla. Tiedot voidaan tallentaa datamuistiin automaattisesti. Pohjavesiputkesta voidaan tehdä muitakin luotauksia ja ottaa vesinäytteitä. Lähteen virtaamaa voidaan mitata mittapadon avulla.

Seismisilllä luotauksilla seurataan täryaallon etenemistä, joka kertoo irtomaakerrosten paksuudesta ja peruskallion rakenteista. Matalataajuisia (VLF) radioaaltoja hyödynnetään mittaamalla kallioperän johteiden (esimerkiksi vesi kallioruhjeessa) ympärille indusoitunutta sähkömagneettista kenttää paikallistamalla johteita. Painovoimamittauksilla voidaan kartoittaa maaperän tiheysjakaumaa ja pohjavesitutkan avulla kerrostuneisuutta.

Pitkäaikaisella, useita vuorokausia tai jopa viikkoja kestävällä pumppauksella pyritään selvittämään tutkittavan akviferin luonnollinen täydentyminen sekä pumppauksen vaikutus ympäristöön. Pumppauskokeeseen kuuluu pohjavedenpinnan korkeuden mittauksia tutkittavalla alueella.

Lyhytaikaisen pumppauksen vaikutukselle akviferin pohjaveden pinnan korkeuteen on olemassa useita matemaattisia malleja. Näissä malleissa on parametreja, jotka riippuvat akviferin hydraulisesta johtavuudesta, paksuudesta, varastoimiskyvystä, reunojen laadusta ja ympäristöstä tapahtuvasta vuodosta. Pumppaukseen liittyy aina pohjavedenpinnan korkeuden seuraaminen useissa mittauspisteissä. Sovittamalla pohjavedenpinnan mittaukset mallin avulla laskettuihin tuloksiin, parametrien edustavat arvot voidaan määrittää.

Pohjaveden määrän ja pinnan korkeuden vaihtelu riippuu myös paikallisista tekijöistä. Pohjavesivarastot purkautuvat joko lähteen välityksellä tai suoraan vesistön pohjan lävitse. Pohjaveden ja uoman väliset vedenvaihtosuhteet voivat olla neljää perustyyppiä: (i) uoma saa vettä paikallisesta, intermediaarisesta tai alueellisesta pohjavesivirtauksesta, (ii) uoma on pohjaveden yläpuolella ja luovuttaa vettä pohjavesivirtaukseen, (iii) uoma on pohjaveden tasolla ja luovuttaa ajoittain vettä pohjavesivirtaukseen tai saa sitä ja (iv) läpivirtaussysteemi. Tilanne voi muuttua uoman vedenkorkeuden muuttuessa.

Meren rannikolla pohjavesivyöhykkeeseen muodostuu suolattoman ja suolaisen veden rajapinta (kuva 7-12). Tämän syvyydelle $z$ on johdettu hydrostaattiseen tasapainoon perustuva Ghyben-Herzbergin yhtälö

$$
z=\frac{\rho}{\rho_{s}-\rho} h
$$

missä $\rho_{\mathrm{s}} \approx 1025 \mathrm{~kg} \mathrm{~m}^{-3}$ on meriveden ( $S=35 \%$ ) tiheys, ja $h$ on pohjavedenpinnan korkeus merenpinnan tasoon nähden. Yhtälö ei ota huomioon suolattoman pohjaveden virtausta mereen. Niinpä pohjavesivyöhykkeen yläosassa todellinen suolaisen ja suolattoman pohjaveden rajapinta tunkeutuu kauemmas merelle päin. 
Suomen pohjavesien laatu on hyvä ja vettä on yleensä riittävästi. Paikallista kulutusta varten on myös valmistettu niin sanottua tekopohjavettä. Tärkeimpiä tutkimuskohteita ovat pohjavesivarojen epätasainen jakaantuminen ja raudan, mangaanin ja fluoridin pitoisuudet, maantiesuolan vaikutukset ja nitraattipitoisuuden kasvu. Paikallisten päästövahinkojen takia on syntynyt saastuneita maa-alueita. Myrkyllisiä raskasmetalleja on löytynyt harvoin ja ylitykset ovat olleet vähäisiä. Esimerkkinä kuvassa 7-13 on pohjavesiasema Puolangalta.

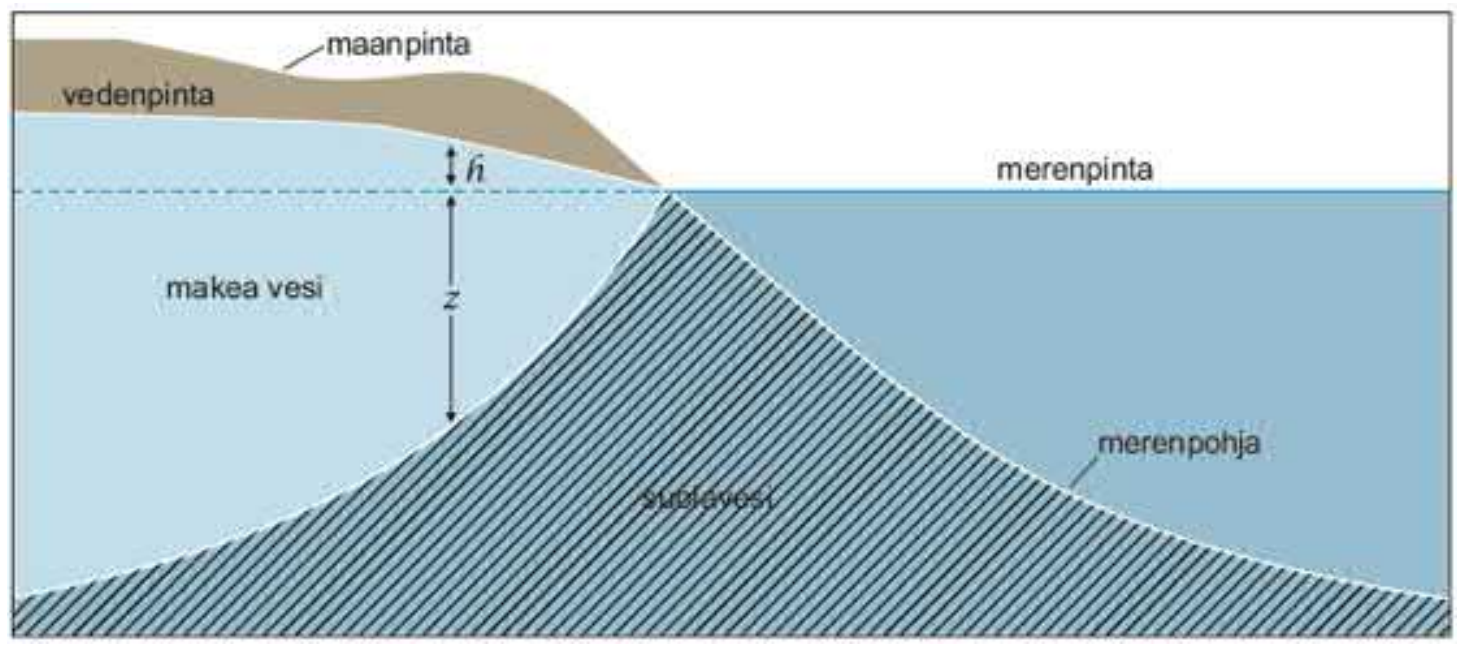

Kuva 7-12. Suolaisen ja makean veden rajapinta pohjavesivyöhykkeellä meren rannikon tuntumassa perustuen Ghyben-Herzbergin yhtälöön. Lähde: Barlow (2003) Ground water in freshwater-saltwater environments of the Atlantic coast, Fig. B-1. http://pubs.usgs.gov/circ/2003/circ1262/pdf/circ1262.pdf

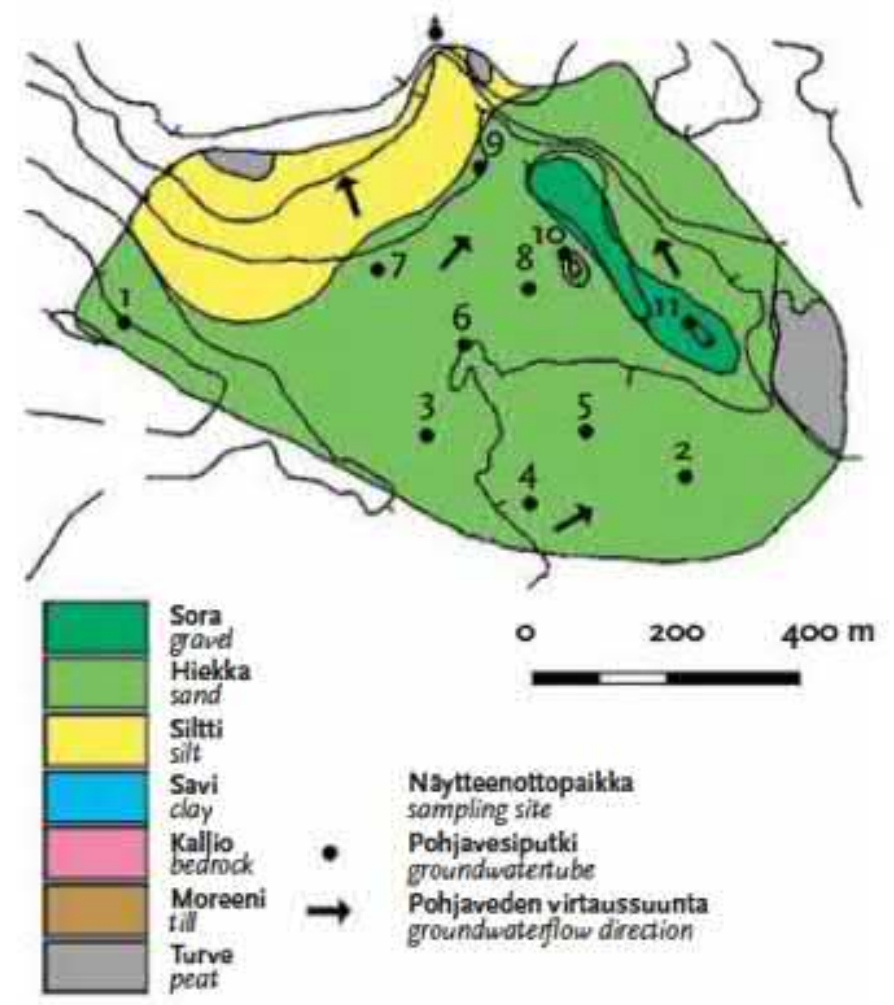

Kuva 7-13. Alakankaan pohjavesiasema Puolangalla. Aseman alue on osa Kuhmon-Paltamon-Haukiputaan harjujaksoa. Pintamaalaji on suurimmaksi osaksi hiekkaa, pohjaveden päävirtaussuunta on lounaasta koilliseen. Lähde: Suomen ympäristökeskus (Kuusisto 2008). 


\subsection{Maaperän lämpötila}

\subsubsection{Lämmönjohtumisyhtälö}

Maaperän lämpötila vaikuttaa hydrologiseen kiertoon usean tapahtuman välityksellä. Haihdunta on riippuvainen maan pinnalla olevan veden lämpötilasta, maaperän lämpötilagradientti vaikuttaa vesihöyryn liikkeisiin, ja kasvien juurien lämpötilalla on vaikutusta transpiraatioon. Lämpöenergian vuo maaperään on yksi maanpinnan lämpötaseen termeistä, ja se riippuu maanpinnan lämpötilasta. Routaantuminen on seurausta lämpötilan painumisesta jäätymispisteen alle. Maan pintakerroksen vesipitoisuuseroihin liittyvät lämmönjohtoerot ja tästä seuraavat pintakerroksen lämpötilaerot vaikuttavat maan ja ilmakehän lämmönvaihtoon.

Kuva 7-14 esittää lämpötilan vaihtelua Tuusulan Hyrylässä eräällä hyvin vettä johtavalla hiekkaisella alueella (Lemmelä ym. 1981). Lämpötilan vuotuinen vaihtelu eri syvyyksillä riippuu kohdan maalajeista sekä vesipitoisuudesta, joten kuvassa esitettyjä tuloksia ei voida pitää yleispätevinä. Tässä tapauksessa lämpötilan vuotuinen vaihtelu ulottuu 6-7 metrin syvyydelle ja on pintakerroksessa noin $20^{\circ} \mathrm{C}$. Kuivaan maaperään liittyvät suuremmat lämpötilan vaihtelut kuin kosteaan maaperään. Esimerkiksi kuivan suoturpeen pintalämpötila voi nousta yli $50{ }^{\circ} \mathrm{C}$ :seen. Kun vesipitoisuus on suuri, haihtuminen ja lämmön johtuminen syvempiin kerroksiin alentavat maksimilämpötilaa, ja minimilämpötila kohoaa johtuen maaperän suuremmasta lämmönjohtokyvystä ja lämpökapasiteetista.

Huokoisessa väliaineessa lämpöenergia voi siirtyä useiden mekanismien välityksellä (kuva 7-15). Näitä mekanismeja ovat

- lämmön johtuminen maaperän vedessä sekä kiinteissä hiukkasissa

- veden olomuodon muutokset

- vesihöyryn diffuusio

- vedessä tapahtuva konvektio

- ilmassa tapahtuva konvektio

- lämpösäteily

Konvektio tarkoittaa tässä vapaata konvektiota, missä veden ja ilman liikkuminen aiheutuu tiheyseroista. Näiden mekanismien lisäksi lämpöä siirtyy maaveden virtauksen mukana $a d-$ vektiona. Karkeammissa maalajeissa tällä tekijällä on merkitystä silloin, kun vertikaalinen suodanta on voimakasta. Kuvassa 7-15 esitetään eri lämmönsiirtomekanismien merkitys eri maalajeissa ja eri vesipitoisuuksilla. Huomataan, että yleensä johtumalla tapahtuva siirtyminen on voimakasta. Tästä syystä seuraavaksi tarkastellaan johtumista lähemmin.

Yksidimensionaalinen (vertikaali $-z$ ) lämmönjohtumisyhtälö kirjoitetaan

$$
\rho c \frac{\partial T}{\partial t}=\frac{\partial}{\partial z}\left(k \frac{\partial T}{\partial z}\right)
$$

missä $T$ on lämpötila, $\rho$ on tiheys, $c$ on ominaislämpö ja $k$ on lämmönjohtokyky. Yhtälön vasen puoli kuvaa lämpöenergian muutosta aikaa kohden ja oikea puoli lämmön diffuusiota. Lämpökapasiteetti $\rho c$ voidaan laskea maaperän osien (ilma, vesi ja orgaaninen sekä epäorgaaninen maa-aines) lämpökapasiteettien painotettuna keskiarvona.

Lämmönjohtokyky sen sijaan riippuu siitä, miten maaperän hiukkaset ovat asettuneet toisiinsa nähden ja miten vesi täyttää niiden väliset huokoset. Kostea maaperä johtaa lämpöä alempiin kerroksiin paremmin kuin kuiva maaperä, ja kosteassa maaperässä haihtuminen 
vie energiaa, mikä laskee lämpötilaa. Minimilämpötila kosteassa maaperässä on suurempi kuin kuivassa, koska veden lämpökapasiteetti on suuri.

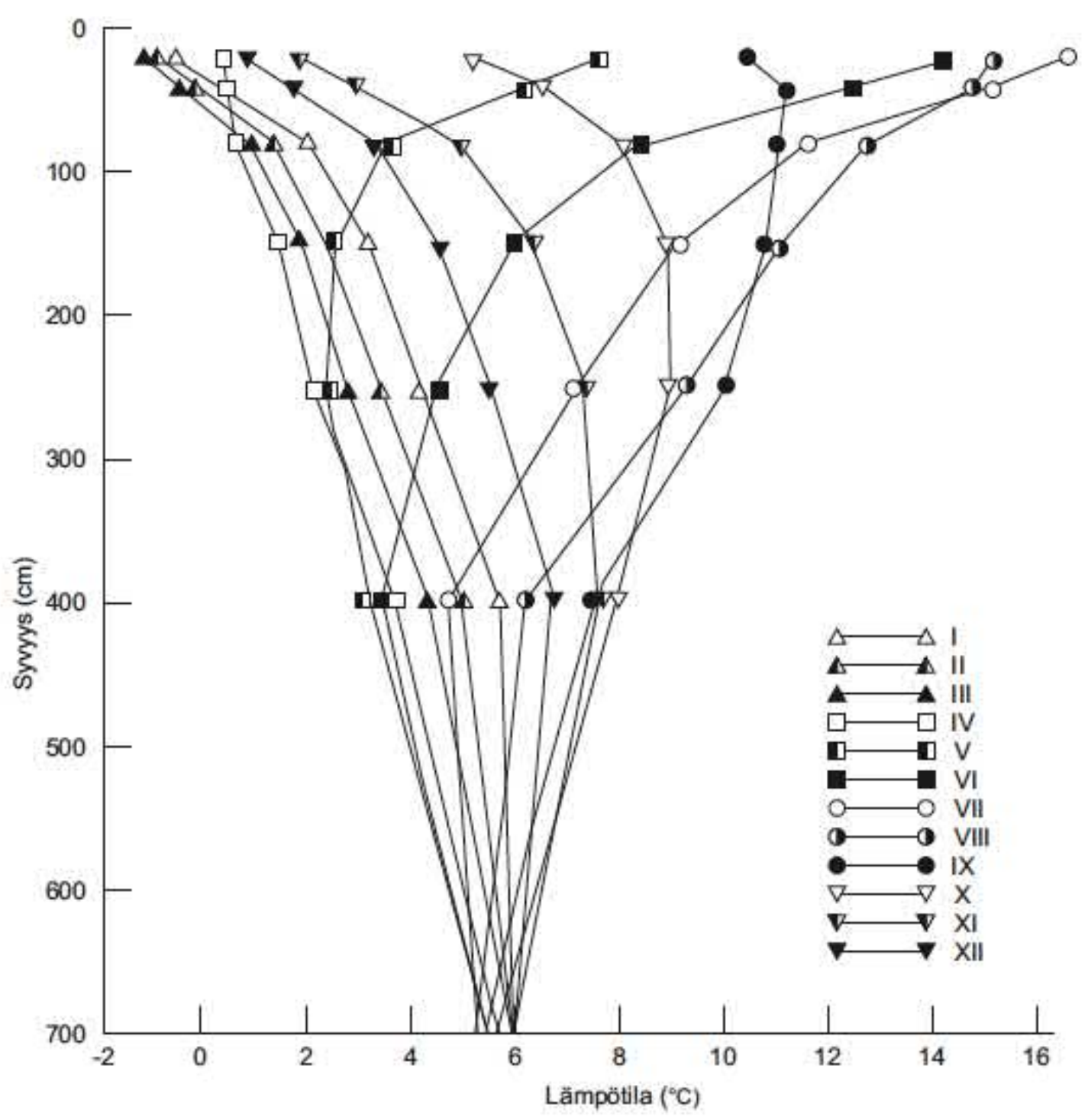

Kuva 7-14. Maaperän läm-pötilan kuukausikeskiarvot kaudella 1969-1973 Etelä-Suomessa Hyrylässä sijait-sevalla hiekkaisella alueella. Lähde: Lemmelä ym. (1981).

Oletetaan nyt lämpökapasiteetti ja lämmönjohtavuus vakioiksi. Kun yhtälö (7.13) jaetaan puolittain lämpökapasiteetilla, saadaan yhtälön oikealle puolelle lämmön diffuusiokerroin $D=\frac{k}{\rho c}$, jonka dimensio on $L^{2} T^{-1}$. Diffuusiokerroin voidaan määrittää lämpötilahavainnoista tutkimalla lämpötila-aallon kulkua. Taulukko 7-4 esittää maaperän osien termisiä ominaisuuksia kuvaavia lukuja, ja kuva 7-16 esittää esimerkin saven ja hiekan lämmönjohtokyvyn riippuvuutta vesipitoisuudesta ja lämpötilasta. Diffuusiokerroin kuvaa lämpötilasignaalin kulkua, $L^{2} \sim D T$. Jos $D=10^{-7} \mathrm{~m}^{2} \mathrm{~s}^{-1}$, yhden kuukauden aikana signaali etenee 0,5 metriä. Tämä viive näkyykin hyvin kuvassa 7-14.

Yhtälö (7.13) voidaan analyyttisesti ratkaista, kun reunaehtoina ovat sinimuotoinen lämpötilan vaihtelu pinnalla ja vakio lämpötila $\bar{T}$ syvällä: 


$$
\begin{aligned}
& T(z, t)=\bar{T}+\Delta T \mathrm{e}^{-\lambda z} \sin (2 \pi \omega t-\lambda \mathrm{z}+\varphi), \lambda=\sqrt{\frac{\pi \omega}{D}} \\
& z=0: T(0, t)=\bar{T}+\Delta T \sin (2 \pi \omega t+\varphi), \\
& z \rightarrow \infty: T \rightarrow \bar{T}
\end{aligned}
$$

missä $\bar{T}$ on lämpötila syvällä, $\Delta T$ on lämpötilan amplitudi pinnassa, $\omega$ on lämpötila-aallon kulmataajuus (vastaava periodi on $2 \pi \omega^{-}$), ja $\varphi$ on vaihe. Parametri $\lambda$ kuvaa yksinään lämpötila-aallon eksponentiaalista vaimenemista ja vaihesiirtoa syvyyden mukana. Jos diffuusiokerroin on $10^{-7} \mathrm{~m}^{2} \mathrm{~s}^{-1}$, vuosiaallon tapauksessa $\lambda^{-1}=1,0 \mathrm{~m}$. Lämpötilasignaalin tunkeutumissyvyys $Z$ voidaan määritellä $3 \cdot \lambda^{-1}$ suuruuiseksi, silloin $\frac{T(Z)}{T(0)}=e^{-\lambda Z} \approx 0,050$. Näin ollen vuoden pintalämpötilan vuotuinen vaihtelu tuntuu noin $4 \mathrm{~m}$ syvyydessä.

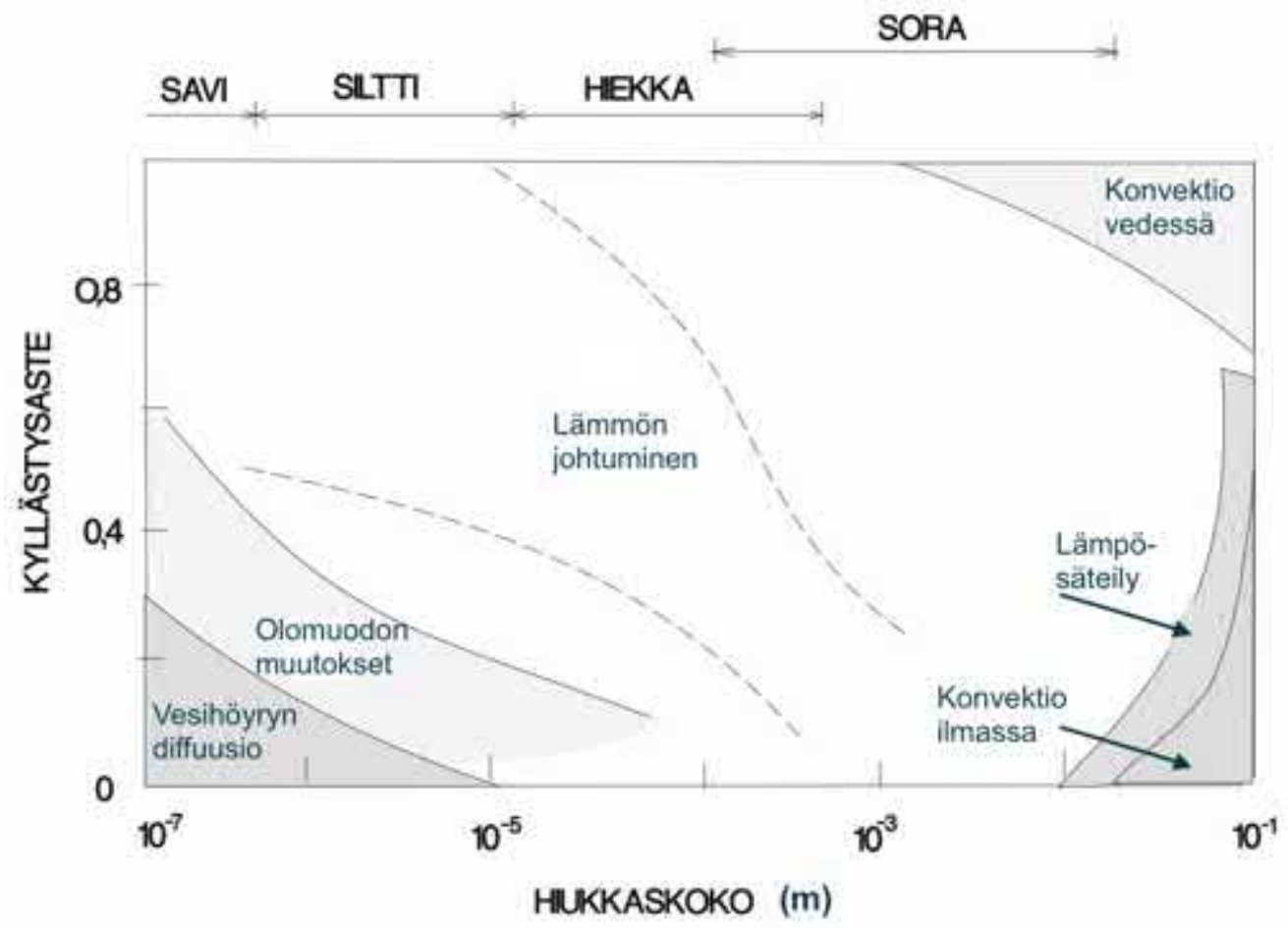

Kuva 7-15. Lämmönsiirtomekanismien merkitys eri maalajeille eri vesipitoisuuksilla. Vesipitoisuus on ilmoitettu suhteessa kyllästetyn tilan vesipitoisuuteen. Lähde: Farouki (1981), muokattu.

\begin{tabular}{|c|c|c|c|c|}
\hline & Tiheys & Ominaislämpö & Lämmönjohtavuus & Diffuusiokerroin \\
\hline Aines & $\mathrm{kg} \mathrm{m}^{-3}$ & $\mathrm{~J} \mathrm{~kg}^{-1}{ }^{\circ} \mathrm{C}^{-1}$ & 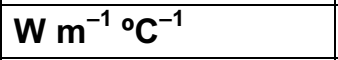 & $m^{2} s^{-1}$ \\
\hline Kivennäismaa (x) & 2650 & 730 & 2,9 & $15 \cdot 10^{-7}$ \\
\hline $\begin{array}{l}\text { Orgaaninen maa } \\
\text { (x) }\end{array}$ & 1300 & 1900 & 0,25 & $1,5 \cdot 10^{-7}$ \\
\hline Vesi & 1000 & 4200 & 0,6 & $1,4 \cdot 10^{-7}$ \\
\hline IIma & 1000 & 1004 & 0,026 & $0,21 \cdot 10^{-7}$ \\
\hline
\end{tabular}

Taulukko 7-4. Maaperän osien termiset ominaisuudet $20^{\circ} \mathrm{C}$ :een lämpötilassa. Merkintä (x) tarkoittaa, että luku kuvaa kyseisen osan keskiarvoa. Lähde: Farouki (1981). 

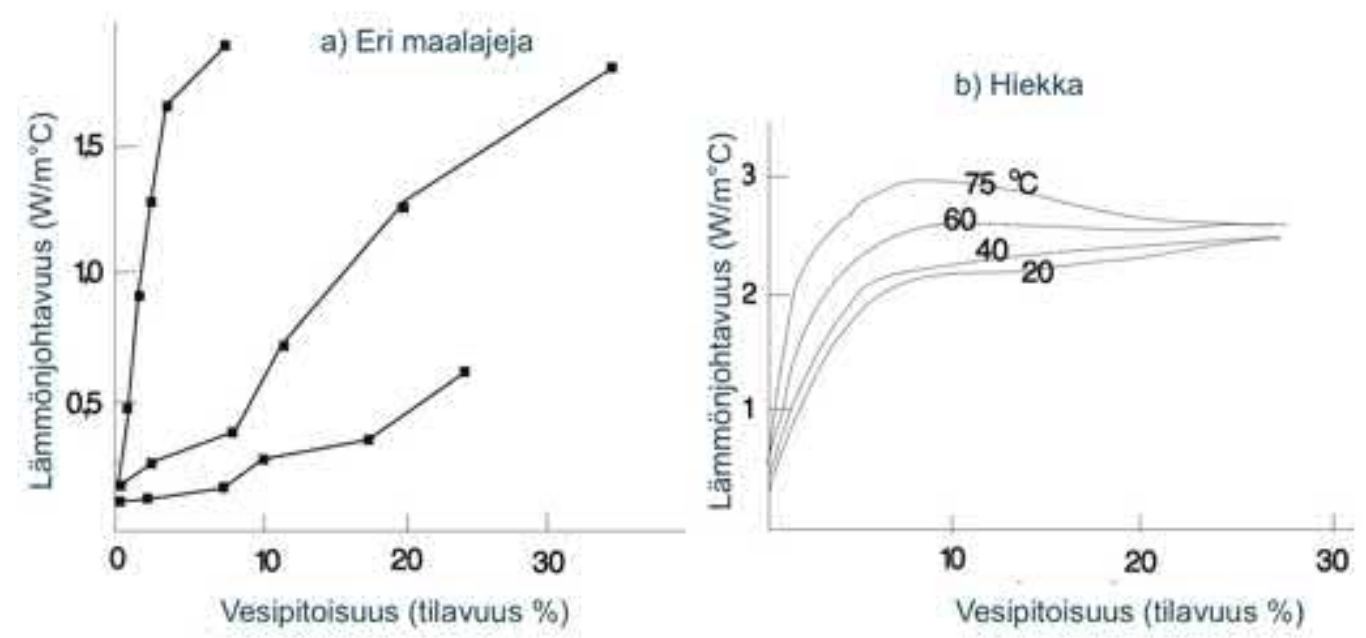

Kuva 7-16. Lämmönjohtokyvyn riippuvuus vesipitoisuudesta a) eri maalajeille sekä b) hiekalle eri lämpötiloissa. Lähde: Farouki (1981), muokattu.

\subsubsection{Routa}

Maaperän pintakerrosten vesi jäätyy eli routaantuu sen lämpötilan laskettua jäätymispisteeseen. Jäätynyttä kerrosta kutsutaan roudaksi. Ikirouta tarkoittaa routakerrosta, joka on säilynyt ainakin yhden kesän ylitse. Talvella muodostunut ja keväällä sulanut routa on kausittaista routaa. Roudan muodostuminen vaikuttaa hydrologiseen kiertoon sitomalla maaperän vettä kiinteään olomuotoon ja estämällä nestemäistä vettä suotautumasta pinnalta syvempään. Routa aiheuttaa ihmistoiminnalle ongelmia. Sen sulamisen aikana maaperä pehmenee, ja liikkuminen teillä ja maastossa vaikeutuu, jolloin puhutaan kelirikosta tai rospuutosta (kuva 7-17). Roudan muodostuminen ja sulaminen muokkaavat maaperää veden tilavuuden muutosten vuoksi jäätymisen ja sulamisen aikana, jolloin puhutaan routimisesta.

Ikiroutaa esiintyy laajoilla alueilla Pohjois-Venäjällä, Siperiassa, Pohjois-Amerikassa sekä vuoristoissa. Siperiassa ikiroudan syvyys voi olla satoja metrejä. Suomessa on ikiroutaa vain laikuittain Tunturi-Lapissa. Kausittaisen roudan syvyys eri talvina vaihtelee Suomessa yleensä 0-100 cm:n välillä (kuva 7-18). Yli metrin syvyistä routaa on lähinnä vain TunturiLapissa. Syvyys riippuu ilman lämpötilasta ja suojaavan lumikerroksen paksuudesta. Routatyyppejä ovat onkalorouta, massiivinen routa ja kerrosrouta. Onkalorouta muodostuu mururakenteiseen maaperään, kuten peltoon. Vesi jäätyy onkaloiden seinämiin neulasrakenteiksi, joka muistuttaa ruostetta. Massiivista routaa muodostuu hiekka- ja soramaissa, joissa on vähäinen vesipitoisuus. Se on yhtenäistä ja lähes näkymätöntä ja esiintyy harvoin paksuina kerroksina. Kerrosroutaan tulee maanpinnan suuntainen kerrosrakenne. Kerrokset voivat olla kiinni toisissaan tai erillään, ja niiden välimatka riippuu maan kosteudesta.

Yksi tunnetuista ja näkyvistä ikiroudan esiintymismuodoista on palsa, suoalueilla kehittyvä jäätä sisältävä kumpare. Palsa syntyy, kun kausiroudan kerros ei sulakaan kokonaan kesällä, jolloin se pääse jatkamaan kasvua seuraavan talven aikana. Paksumpana se selviää uusista kesistä aina paremmin. Palsa kuitenkin omalla dynamiikallaan hiipuu lopulta pois, sen elinkaaren mitta on joitain kymmeniä vuosia. 


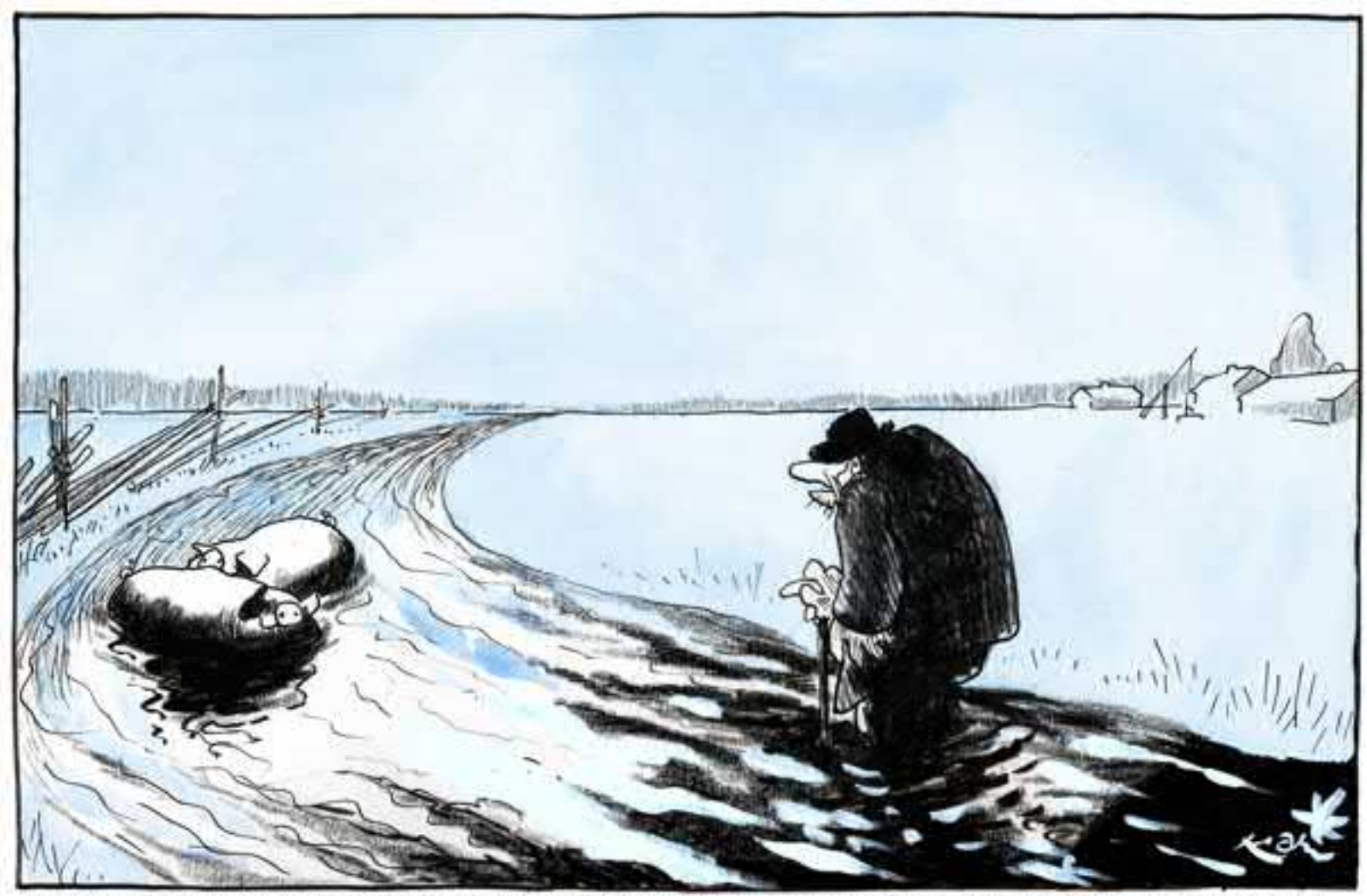

"KOKO IKÄNI OON MEITIN KYLÄSSÄ ELANY, ENKÄ TIAMMMÄ OO MUUALLA KAYYNY. VAAN JOKA KERTA KELIRIKOLLA TUUMAAN, MITENSE MAHTAA MUU MAAILMA SEN AIKAA ELAÄ̈ .... MEINAAN ..... KUN TIE MEITILLE ON POIKKI ....."

Kuva 7-17. Nurkkapatriootti, Kari Suomalaisen piirros 28.5.1957. @ Kari Suomalaisen perikunta.

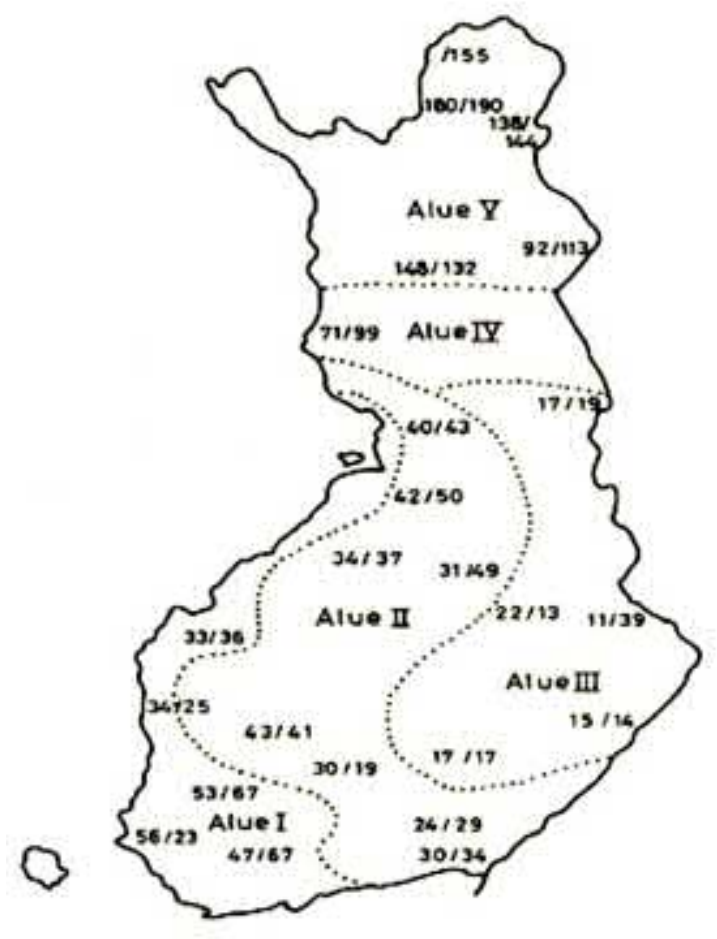

Kuva 7-18. Roudan aluejako ja roudan keskimääräinen maksimisyvyys (cm) 1968-1985 aukealla/ metsässä. Lähde: Mustonen (1986). 
Roudan kasvun ja sulamisen fysiikkaa voidaan tarkastella samaan tapaan kuin järvien jäätymistä. Roudan kasvun perusyhtälö saadaan lämmönsiirron jatkuvuudesta maaperästä lumen lävitse ilmakehään:

$$
\rho m L_{f} \frac{d h}{d t}=k_{r} \frac{T_{f}-T_{0}}{h}=k_{s} \frac{T_{o}-T_{s}}{h_{s}}=Q_{n}
$$

missä $m$ on maaperän vesipitoisuus, $h$ on roudan paksuus, $k_{\mathrm{r}}$ on roudan ja $k_{\mathrm{s}}$ lumen lämmönjohtokyky, $T_{\mathrm{f}}, T_{0}$ ja $T_{\mathrm{s}}$ ovat jäätymispisteen, maanpinnan ja lumenpinnan lämpötilat, $h_{\mathrm{s}}$ on lumen paksuus, ja $Q_{\mathrm{n}}$ on lämmönsiirto ilmakehästä. Jos $T_{0}=T_{0}(t)$ tunnetaan, saadaan ensimmäisestä yhtälöstä suoraan

$$
h=a_{m} \sqrt{S}, a_{m}=\sqrt{\frac{2 k_{r}}{\rho m L_{f}}},
$$

missä $S$ on pakkassumma. Verrattuna järvijäähän roudan paksuus on suurempi, $m^{-1 / 2}-$ kertainen. Tämä tulos edellyttää, että jää ja maa ovat paljaita.

Lumi on hyvä eriste ja hidastaa roudan kasvua. Järvien tapauksessa runsas lumentulo johtaa kohvajään muodostumiseen, mutta roudan kasvussa lumi ainoastaan eristää. Jos lumen pintalämpötila tunnetaan, saadaan yhtälöstä (7.15a)

$$
\rho m L_{f} \frac{d h}{d t}=k_{r} \frac{T_{f}-T_{s}}{h+\gamma h_{s}}, \gamma=\frac{k_{r}}{k_{s}} .
$$

Lumen lämmönjohtavuuden referenssiksi voidaan valita $0,15 \mathrm{~W} \mathrm{~m}^{-1}{ }^{\circ} \mathrm{C}^{-1}$, joka vastaa lumen tiheyden arvoa $250 \mathrm{~kg} \mathrm{~m}^{-3}$ (kohta 4.4.2). Roudan lämmönjohtavuus on kertaluokkaa suurempi maalajista ja vesipitoisuudesta riippuen, joten $\gamma \sim 10$ ja yhtälön (7.16) mukaan lumi eristää kymmenen kertaa niin hyvin kuin routamaa.

Esimerkki 7-4. Tarkastellaan idealisoitua tilannetta, missä roudan paksuus ja lumen paksuus korreloivat talven edetessä, $h_{\mathrm{s}}=\beta h$. Yhtälö (7.16) voidaan silloin ratkaista analyyttisesti

$$
h=\frac{a_{m}}{\sqrt{1+\gamma \beta}} \sqrt{S} \text {. }
$$

Paljaan maan tilanteeseen verrattuna roudan kasvu on hitaampaa: jos $\gamma \sim 10$ ja $\beta \sim 1$, saadaan kasvun reduktiokertoimeksi 0,3 . Jos taas lumen paksuus on vakio, roudan paksuudeksi saadaan

$$
h=\sqrt{a_{m} S+\left(\gamma h_{s}\right)^{2}}-\gamma h_{s} .
$$

Paljaan maan roudan paksuuden suhde kumipeitteisen maan roudan paksuus on silloin $\sqrt{1+\eta^{2}}-\eta$, missä $\eta=\frac{\gamma h_{s}}{\sqrt{a_{m} S}}$. Jos siis paljaan maan roudan paksuus on $100 \mathrm{~cm}$, niin roudan paksuus $20 \mathrm{~cm}$ paksun lumipeitteen alla on $24 \mathrm{~cm}$.

Esimerkki 7-5. Hydrologian toimistossa on ollut käytössä empiirinen roudan kasvukaava (Soveri \& Varjo 1977)

$$
h=\frac{42 \mathrm{~cm}}{h_{s}} \cdot \mu b \sqrt{S-15 \frac{h_{s}}{\mathrm{~cm}}{ }^{\circ} \mathrm{C} \cdot \mathrm{vrk}},
$$


missä $\mu$ on maalajikerroin, ja $b$ on maastokerroin. Aukeilla $b=1$ ja metsässä $b=0,9$, ja $\mu$ vaihtelee välillä $0,9-1,2$ niin, että pienemmät arvot vastaavat suurempaa vesipitoisuutta. Jos siis lumen paksuus on $20 \mathrm{~cm}$, ja pakkassumma $S=1000^{\circ} \mathrm{C} \cdot \mathrm{vrk}$, saadaan roudan paksuudeksi $45-67 \mathrm{~cm}$.

Edellä olevat esimerkit valaisevat roudan syvyyden herkkyyttä lumen kertymiselle. Sen takia Suomessa sekä lämpötila että lumen paksuus heijastuvat roudan paksuudessa voimakkaasti. Itä-Suomessa lunta on enemmän kuin Länsi-Suomessa, ja siksi routa on idässä ohuempaa.

Roudan sulaminen alkaa yläpinnalta, kun lumi on sulanut ja ilmasta sekä auringosta siirtyy sen jälkeen lämpöä maaperään. Sulamisen edetessä roudan pinta alenee, ja lämmön täytyy siirtyä sinne maanpinnalta johtumalla. Roudan yläpinta saadaan lämmönsiirron jatkuvuudesta

$$
\rho m L_{f} \frac{d h_{b}}{d t}=-k_{b} \frac{T_{f}-T_{0}}{h_{b}}=-Q_{n}
$$

Jos pintalämpötila tunnetaan, yhtälö voidaan integroida suoraan. Saadaan $h_{b}=a_{b} \sqrt{P}$, missä $a_{b}=\sqrt{\frac{2 k_{b}}{\rho m L_{f}}}$ sulamisen astepäiväkerroin, ja $P=\int_{0}^{t} \min \left(0, T_{f}-T_{0}\right) d t^{\prime}$ on positiivisten lämpötilojen summa. Routa siis sulaa samaan tapaan kuin kasvaakin suhteessa lämpötilaan, ja kasvu- ja sulamiskertoimet ovat lähellä toisiaan, $a_{r} \approx a_{b}$.

Lämpöä voi myös tulla maaperästä roudan alapuolelta routakerroksen pohjaan. Tämä hidastuttaa roudan kasvua ja nopeuttaa sulamista. Jos lunta sataa nopeasti heti talven alettua, maaperästä tuleva lämpö voi estää roudan muodostumisen.

Yhtälöiden (7.16 - 7.17) avulla voidaan tarkastella myös ikiroudan syntymistä. Ikiroudan muodostuminen edellyttää, että roudan paksuus on talvella suurempi kuin kesällä sulavan kerroksen paksuus. Kun lunta on vähän, ikirouta muodostuu, jos $h>h_{\mathrm{b}}$. Näin on, jos $S>P$ eli pakkassumma on suurempi kuin positiivisten lämpötilojen summa. Lumen kertymä ja sulaminen eivät kuitenkaan vaikuta routaan symmetrisesti. Mitä enemmän lunta tulee, sitä paremmin se eristää, mutta toisaalta sitä paremmin se myös suojaa routaa. Käsivarren Lapissa ehto $S>P$ täyttyy useampina vuosina, ja siellä ikiroutaa onkin havaittavissa laikuittain.

Hydrologiassa roudan syvyyden lisäksi sen sisältämällä vesimäärällä on merkitystä. Roudan vesipitoisuus riippuu edeltäneen syksyn sademäärästä sekä maaperän kapillaariominaisuuksista. Viimeksi mainittu tekijä aiheuttaa veden imeytymisen routakerrokseen syvemmältä. Paksu routakerros, jonka vesipitoisuus on suuri, nopeuttaa sulamisvesien poistumista alueelta keväällä. Etelään viettävillä aurinkoisilla alueilla roudan syvyys on pienempi kuin varjoisilla alueilla.

Routa muodostuu kerrokseen, jossa maankosteuden muutokset ovat suurimmat. Sen alapuolella maankosteus vähenee talven aikana, koska kosteutta valuu pohjaveteen ja koska routa imee kosteutta. Roudan kosteus on suurimmillaan heti sulamisen alkaessa. Pohjaveden lämpötila on aina hieman suurempi kuin ympäröivän maan ja siksi se luovuttaa lämpöä. Lämpötilan vaihtelut ovat pohjavedessä pienempiä kuin ympäröivässä maassa. Kun pohjaveden pinta on lähellä maan pintaa, routa jää matalaksi.

Roudan kehittyminen on riippuvainen myös paikallisesta kasvillisuudesta, joka toimii lämpöeristeenä. Aukeilla mailla on ruohovartisia kasveja ja metsässä puustoa. Eristyksen takia roudan syvyys on metsissä noin 11 \% pienempi kuin aukeilla. Toisaalta tiheä kuusimet- 
sän puusto pidättää lunta, mikä syventää routakerrosta. Lehti- ja mäntymetsässä sen sijaan lumen pidätys on heikompaa ja routa siksi matalaa.

Routa sulaa sekä ylhäältä että alhaalta, ja maan lämpötila seuraa viiveellä ilman lämpötilan kehitystä. Keväällä sulamisvedet poistuvat nopeasti alueelta, jolla on paksu vesipitoinen ja tiivis routakerros. Karkearakeisessa maaperässä routa läpäisee vettä, ja pohjavettä pääsee kertymään.

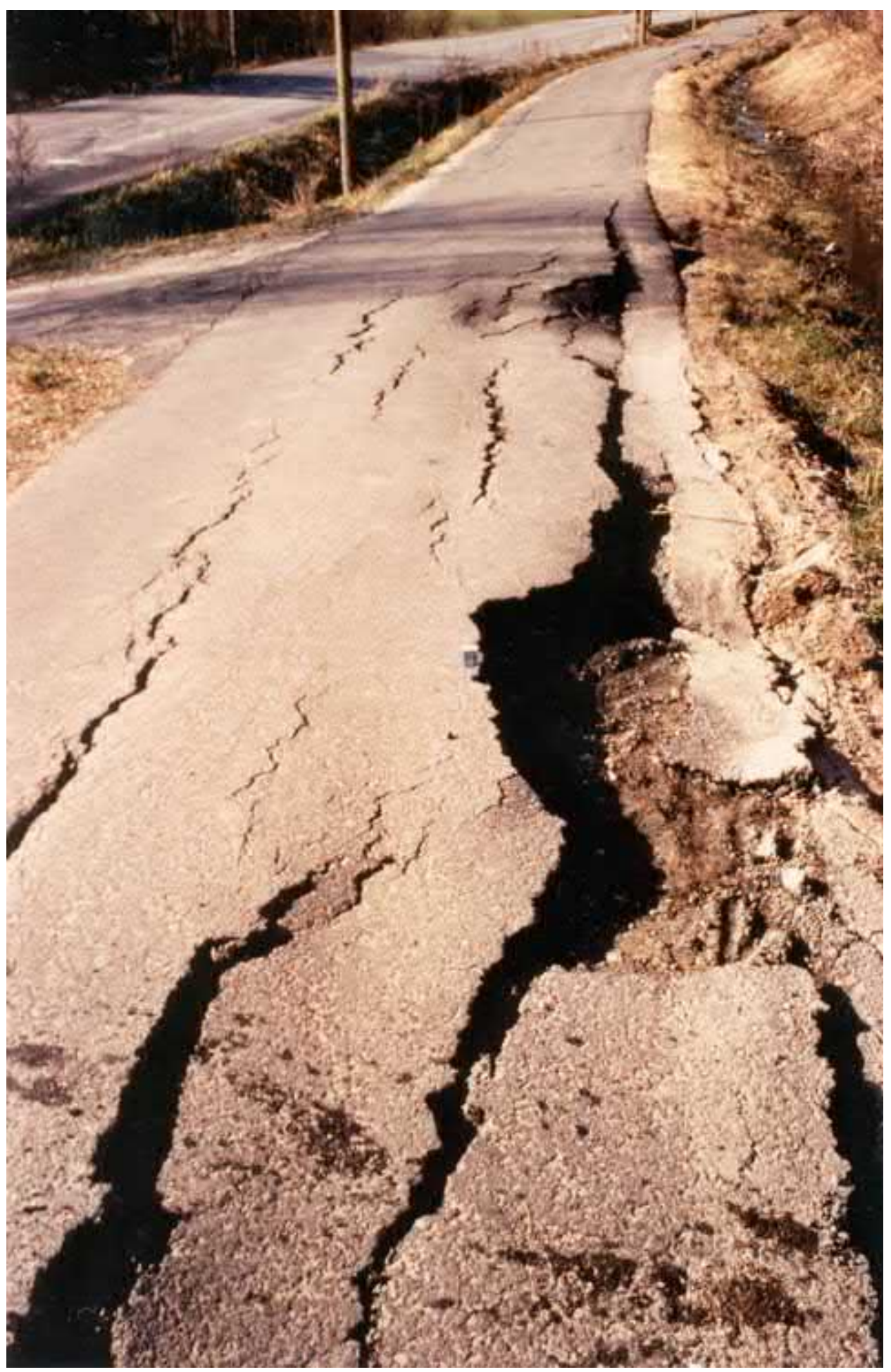

Kuva 7-19. Routavaurio. Haapaniemen paikallistie, kevyen liikenteen väylä, Jyväskylän mlk vuonna 1981. Kuva: Rismo Virpimaa. Liikenneviraston kuvakokoelma/Mobilia museo, Kangasala. 
Roudan syvyyden kehittymistä voidaan seurata routaputkien avulla. Ne sisältävät metyleenisiniä, joka on sulana sinistä ja jäätyneenä läpinäkyvä. Maan lämpötilamittaukset voidaan tehdä upottamalla lämpötila-anturiketjuja putkessa maaperään. Myös maatutkaa käyttämällä voidaan luodata routakerroksen paksuutta. Roudan pohja antaa tutkaan yleensä selkeän heijastuksen.

Routimisessa roudan kosteuden kasvu aiheuttaa maaperän tilavuuden muutoksia. Tämä ilmenee maanpinnan kohoamisena, pintavaurioina sekä rakenteiden siirtymisinä (kuva 719). Rakenteiden siirtymistä tehostaa se, että pilarin tai kiven alareunaan kehittyy jäälinssejä, jotka kasvaessaan nostavat rakennetta. Roudan kosteuden kasvu aiheutuu kapillaarisesta imusta, joka on yleensä merkittävin silttimaalajille. Saven kapillaarinen nousu on suuri, mutta veden virtausnopeus on niin pieni, että roudan kosteus ei savessa sanottavasti ehdi kasvaa talven kuluessa. Hiekan kapillaarinen nousu taas on niin pieni, ettei routakerros kykene imemään vettä syvemmistä kerroksista. Suomessa kaikki maalajit routaantuvat, mutta kaikki eivät roudi.

Roudalle herkät rakenteet perustetaan roudan arvioitua maksimisyvyyttä syvemmälle. Tämä johtuu siitä, että rakenteiden lämmönjohtavuus on suurempi kuin maaperän ja lumipeitteen yhdessä. Jäätyminen etenee syvemmälle rakenteiden ympärillä. Kapillaariominaisuudet vaikuttavat siihen, miten vesi imeytyy syvemmältä routakerrokseen. Maan kohoaminen jäätyneenä johtuu alhaalta tulevasta kapillaarisesta noususta jäätyneeseen kerrokseen.

\subsection{Jäätiköt}

Jäätiköiä muodostuu alueilla, joilla kaikki talven aikana satanut lumi ei sula seuraavana kesänä. Kesän yli säilynyttä lunta kutsutaan ylivuotiseksi lumeksi. Uusi lumipeite kasvaa aina vanhan päälle, ja kertymä voi saavuttaa huomattavan paksuuden vuosien kuluessa. Ylivuotinen lumi muuttuu vähitellen jääksi sulamis-jäätymis metamorfoosin avulla tai puhtaasti kokoonpuristumalla. Jälkimmäiseen tarvitaan 50-100 m paksun lumikerroksen aiheuttama paine. Lumi-jää muuntumisvaiheessa lumen ilmakanavat ovat sulkeutuneet ilmakupliksi, valon läpäisevyys on vahvistunut niin, että visuaalisesti materia muistuttaa jäätä sen arkikielisessä merkityksessä. Tiheys on tällöin $830 \mathrm{~kg} \mathrm{~m}^{-3}$ ja ilmakuplia on 9,5\% tilavuudesta. Syvemmälle mentäessä ilmakuplat puristuvat tiiviimmiksi ja vastaavasti jään tiheys kasvaa.

Jäätiköt jaetaan laajuuden suhteen kahteen kategoriaan: mannerjäätiköt ja vuoristojäätiköt. Edellisiä maapallon nykyisessä ilmastotilassa on kaksi: Etelämantereen ja Grönlannin mannerjäätiköt. Nämä ovat paksuimmillaan noin $4 \mathrm{~km}$ vahvuisia ja sisältävät $2 / 3$ maapallon makean veden resursseista. Niiden vesi on kuitenkin kiinteässä olomuodossa ja kaukana suurista asutuskeskuksista. Vuoristojäätiköitä löytyy kaikilta leveysasteilta aina päiväntasaajalle Andien vuoristossa. Suurimpia ovat Islannin Vatnajökull, Koillismaan jäätikkö Huippuvuorilla ja Patagonian jäätikkö Etelä-Amerikassa. Vatnajökullin on suurin pohjoisen pallonpuoliskon vuoristojäätiköistä. Sen paksuus on $400-700 \mathrm{~m}$ ja pinta-ala $8200 \mathrm{~km}^{2}$. Useilla vuoristojäätiköillä on merkitystä paikallisessa vesihuollossa.

Suomessa ei ole jäätiköitä. Viime jääkauden aikana maatamme peitti Fennoskandian mannerjäätikkö, joka oli vetäytynyt pois noin 5000 vuotta sitten. Lähellä olevia jäätiköitä ovat Storglaciären Ruotsin Kebnekaisella ja Steindalsbreen Norjan Skibotnissa (kuva 7-20). Enontekiön tuntureilla on monivuotisia lumen viipymiä, mutta niin vähän ja vuosittain vaihtelevasti, että nykyisessä ilmastossa jäätiköitä ei ala kasvaa. Ilmaston viileneminen tai lumen kertymän kasvu voisi käynnistää jäätiköitymisen Enontekiöllä. Suomalaiset tutkijat ovat tehneet 
jäätikkötutkimusta lähinnä Etelämantereella ja Huippuvuorilla. Toisallta viime jääkauden aiheuttamia jälkiä Suomen maisemassa ja maaperässä on jo pitkään tutkittu geologan ja maantieteen aloilla.

Veden varastointiaika jäätiköissä on pitkä, sadoista vuosista aina miljoonaan vuoteen asti. Nämä varastot ovat usein suuria, ja hydrologian kannalta on tärkeää, kuinka paljon sulamisvettä niistä saadaan kesällä.

Jäätiköt voidaan ennsi vaiheessa jakaa akkumulaatio- ja ablaatioalueisiin (kuva 7-21), joita rajaa tasauslinja. Akkumulaatioalueella lumen nettokertymä on positiivinen ja ablaatioalueella negatiivinen. Jäätikkö säilyy tasapainotilassa, kun jäätä virtaa akkumulaatioalueelta ablaatioalueelle. Akkumulatioalueen pinnalla on lunta lähes tasauslinjalle asti, sillä vuosikertymän täytyy olla positiivinen. Lähellä tasauslinjaa pinnalla on kuitenkin sulavan lumen sohjosta muodostunutta jäätä. Akkumulaatioalueilla esiintyy muuallakin jäätä jäätikön liikkeen tai lumen ajautumisen takia. Näitä sanotaan sinisen jään alueiksi. Ablaatioalueen pinta on jäätä. Mannerjäätiköiden keskusalue on akkumulaatioaluetta ja sulamista tapahtuu reunavyöhykkeillä. Vuoristojäätiköillä on ylinnä kuivan lumen vyöhyke ja alimpana paljaan, sulavan jään vyöhyke.

Jäätiköiden massataseyhtälö kirjoitetaan

$$
\frac{1}{\rho_{i}} \frac{d M}{d t}=P-E-R+Y
$$

missä $M$ on jään massa pinta-alayksikköä kohti, $P$ on sadanta, $E$ on haihdunta, $R$ on valunta ja $Y$ on ajolumen nettokertymä. Oikean puolen termit kuvaat muutosta veden nestemäisen olomuodon ekvivalenttina.

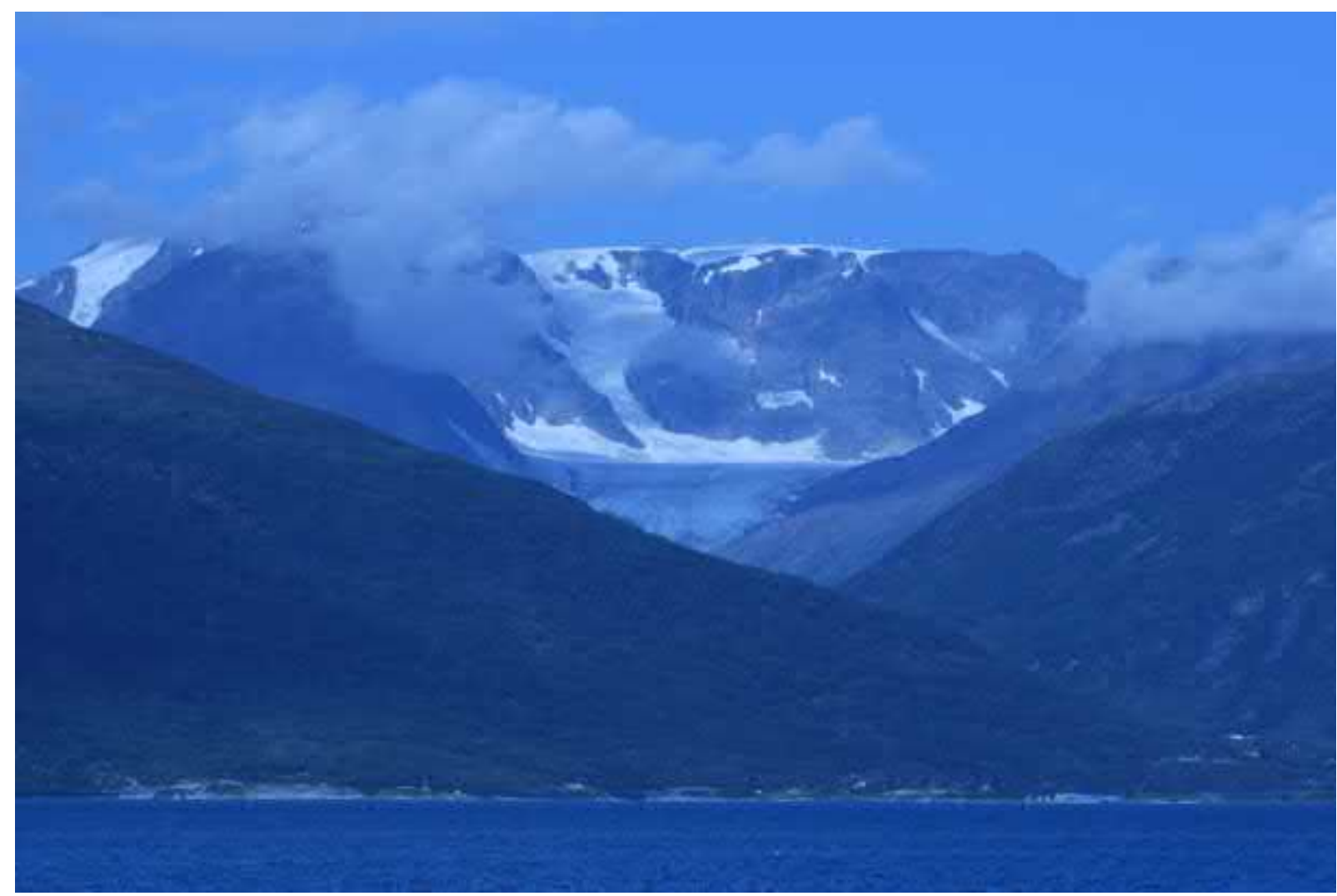

Kuva 7-20. Steindalsbreen jäätikkö, Skibotn, Norja. Jäätikkövirta lähtee ylhäältä ja tulee ensin kapeana alaspäin jatkaa leveämpänä muodostumana alhaalla. Kuva: Matti Leppäranta. 
Tasapainotilassa jäätikkö luovuttaa sadannan verran massastaan haihdunnan ja valunnan kautta, ja ajolumi aiheuttaa pintaan vuosikasvun paikallisia vaihteluita. Valuntaa tapahtuu myös kiinteässä olomuodossa, kun mereen ulottuva jäätikkö poikii jäävuoria. Vuotuinen massan kertymä on $P-E$, ja kun oletetaan ajolumen kokonaisvaikutus vähäiseksi, $R \sim P-E$. Sulamiskautena saatava vesimäärä on silloin $(P-E) A$, missä $A$ on jäätikön pinta-ala. Hydrologista menetelmää on käytetty suorien mittausten tekemiseksi massataseesta. Etelämantereen mannerjäätikän massatasetta dominoivat sadanta sekä suunnilleen sitä vastaava jäävuorien poikiminen. Sulaminen kuten haihtuminenkin ja nestemäinen valunta ovat pieniä.

Esimerkki 7-6. Vatnajökull-jäätikön pinta-ala on $A=8200 \mathrm{~km}^{2}$, ja vuosisadannaksi voidaan arvioida $1000 \mathrm{~mm}$. Jos haihdunta ja ajolumen kertymä oletetaan pieniksi, nettokertymän suuruusluokaksi tulee $P_{n}=500 \mathrm{~mm}$. Kun nettokertymä poistuu yhtä jokea pitkin mereen, tulee keskivirtaamaksi $P_{n} A /$ vuosi $=$ $130 \mathrm{~m}^{3} \mathrm{~s}^{-1}$. Tätä voidaan verrata vaikkapa Kymijoen virtaamaan, joka on $240 \mathrm{~m}^{3} \mathrm{~s}^{-1}$ (taulukko 6-1). Jäätikön sulamisjakso on lyhyt. Jos se kestäisi $4 \mathrm{kk}$, olisi keskivirtaama silloin $390 \mathrm{~m}^{3} \mathrm{~s}^{-1}$.

Jäätiköiden lämpötase on vastaavanlainen kuin maa-alueiden lämpötase yleensä. Albedo määräytyy sen mukaan, onko jäätikön pinta lunta vai jäätä. Lämpöä siirtyy pinnalta johtumalla syvemmälle. Vuoristojäätiköillä voi sulaminen olla yhden metrin suuruusluokkaa kesän aikana. Etelämantereella sulamista ei juurikaan tapahdu, vaan valunta tapahtuu jäävuorien poikimisena (kuva 7-22).

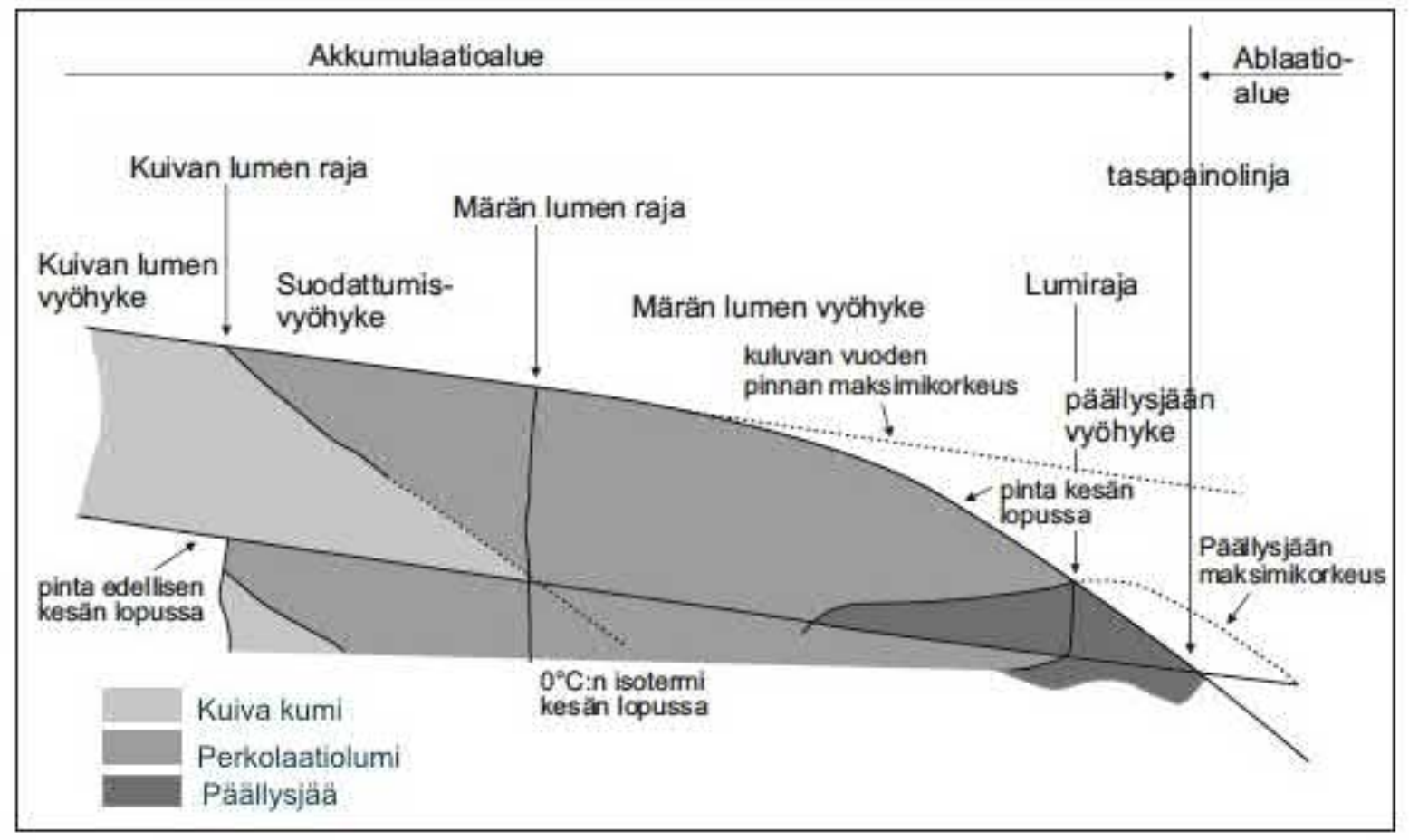

Kuva 7-21. Jäätiköiden vyöhykkeet. Lähde: Cuffey \& Paterson (2010), muokattu).

Jäätiköt virtaavat mutta sangen hitaasti. Jäätiköt ovat viskoosia ainetta ja virtaavat painovoiman vaikutuksesta. Vuoristoissa virtaus kulkee kaltevilla rinteillä, mutta mannerjäätiköt viruvat eli muovautuvat tahmean nesteen tavoin oman painonsa alla. Liikettä ajaa painovoima, ja virtausnopeudet ovat 10-1000 m vuodessa eli suuruusluokaltaan yksi metri vuorokaudessa. Jäätiköiden viskositeetti on hyvin korkea $\left(10^{15} \mathrm{~kg} \mathrm{~m}^{-1} \mathrm{~s}^{-1}\right)$. Vuoristojäätiköt ovat kaltevilla rinteillä ja valuvat alaspäin niin, että ne samalla sulavat alhaalla ja kasvavat ylhäällä. 
Vuoristojäätiköiden liikkeestä voidaaan erottaa pohjaliu'un ja sisäisen deformaation vyöhykkeet. Pohjaliuku voi periaatteessa olla mitä vain välillä $(0,100 \%)$ suhteessa kokonaisliikkeestä. Sisäinen deformaatio on viskoosia virumista. Jäätikkö ei siis valu alaspäin kiinteän kappaleen tavoin vaan muovautuu liukuessaan. Mannerjäätiköt leviävät oman painonsa alla tasaisella alustallaan. Etelämantereen jäätikön maksimipaksuus on lähes $5 \mathrm{~km}$, joka siellä vastaa jään lujuuden määräämää maksimia.

Jäätiköillä esiintyy nestemäistä vettä kerääntyneenä eri tyyppisiin proglasiaalisiin ${ }^{5}$ järviin. Sulamiskautena nestemäinen valunta kulkee ulosvirtausjokiin ja voi muodostaa epiglasiaalisia järviä jäätiköiden reunoille. Esimerkiksi 10000 vuotta sitten Itämeren kohdalla oli pääosin Fennoskandian mannerjäätikön valumasta kasvanut Baltian jääjärvi. Sinisen jään alueilla auringon säteily sulattaa pinnalle supraglasiaalisia järviä. Ne voivat olla avopintaisia tai ohuen jään peittämiä. Kausittaiset supraglasiaaliset järvet muodostuvat kesäisin ja jäätyvät talvisin umpeen, ja niiden syvyys on yhden metrin suuruusluokkaa. Ylivuotiset supraglasiaaliset järvet kasvavat vuosien saatossa ja lopulta purkautuvat oman paineensa ajamana. Nämä purkaukset voivat olla voimakkatakin ja aiheuttaa tulvia.

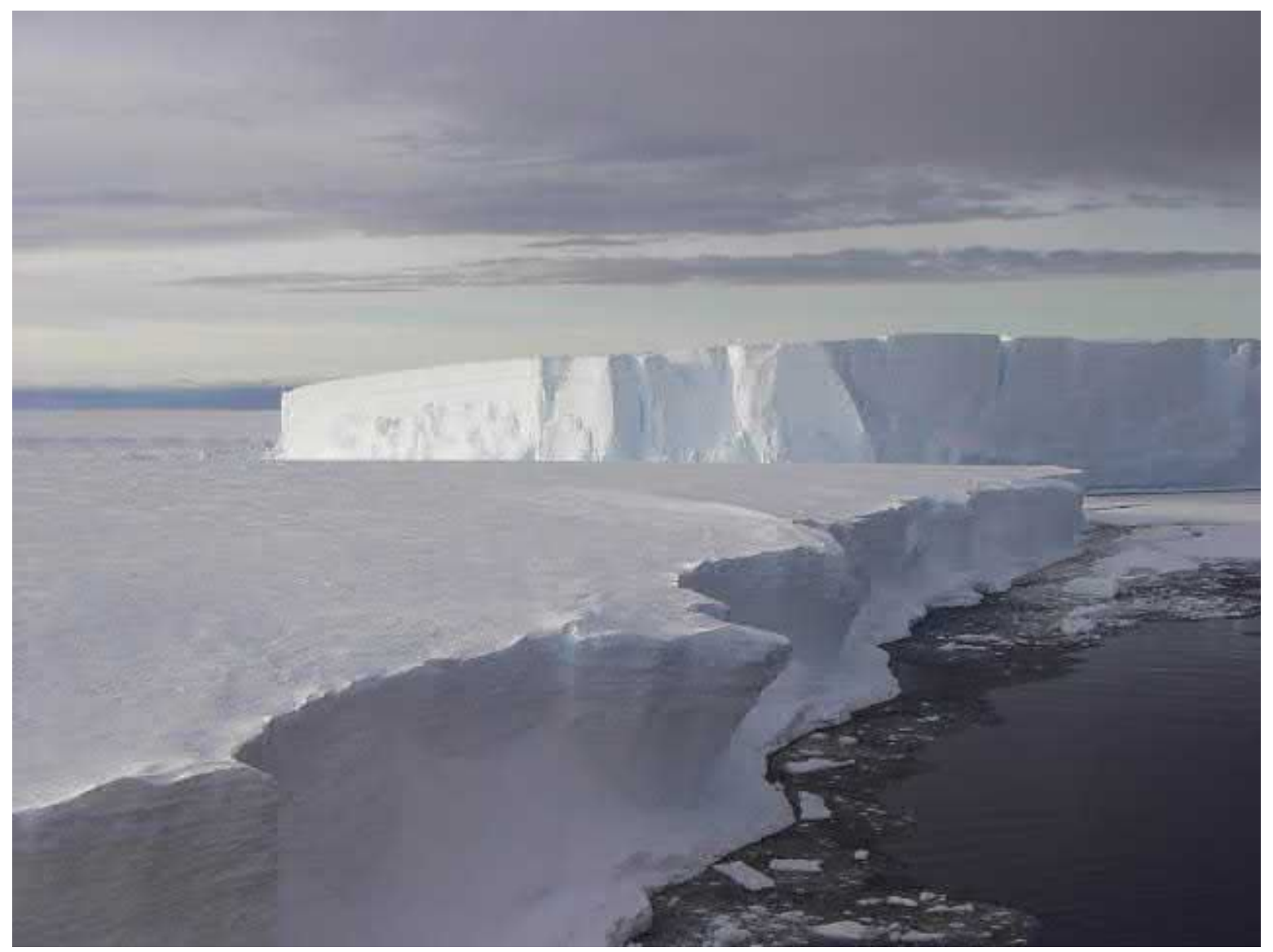

Kuva 7-22. Etelämantereen mannerjäätikön kelluvasta reunasta on juuri lohjennut jäävuori. Kuva: Matti Leppäranta.

Eksoottisin järvimaailma löytyy maapallolta Etelämantereen mannerjäätikön pohjalta. Geotermisen lämmön ja jäätikön läpi kulkevan lämpövuon tasapainon vallitessa jäätikön pohjal-

\footnotetext{
${ }^{5}$ Termi 'glasiaalijärvi' viittaa järvialtaan muodostumisen historiaan eli glasiaalijärvien altaat ovat muodostuneet jääkauden ajan morfologisissa prosesseissa. Suurin osa Suomen järvistä on glasiaalijärviä. Proglasiaalijärvi on olemassa olevan jäätikön tuntumassa.
} 
le on muodostunut sulavesistä koostuvia subglasiaalisia järviä. Näista suurin on Vostokjärvi, jonka ala on noin $15000 \mathrm{~km}^{2}$ ja syvyys $150 \mathrm{~m}$. Jäätikön pohjalla on korkea paine ja sen takia veden jäätymispiste on noin $3{ }^{\circ} \mathrm{C}$.

Esimerkki 7-7. Islannissa jäätikkövesien aiheuttamaa tulvavirtausta kutsutaan nimellä jökulhlaup. Yksi kuuluisista tapauksista on ollut Grimsvötnin jökulhlaup vuonna 1934. Huippuvirtaama oli silloin $5 \cdot 10^{4} \mathrm{~m}^{3} \mathrm{~s}^{-1}\left(1 / 4\right.$ Amazonin keskivirtaamasta) ja tulvan laajuus $100 \mathrm{~km}^{2}$.

Jäätiköt ovat maan päällä olevia vesivarastoja, joiden uusiutumisaika on sangen pitkä. Jäätiköiden sulamisvedet ovat merkittäviä paikallisessa vesihuollossa. Niitä on hyödyn-netty Norjassa vesivoimaloissa ja kuivilla maatalousalueilla kasteluvetenä. Esimerkiksi Poh-joisItalian maatalous käyttää Alppien jäätiköiden sulamisvesiä.

Tässä luvussa on käsitelty maaperän vesivaroja sekä jäätiköitä. Maavesi on heti maanpinnan alla oleva kyllästymätön kerros, jossa vesi kulkee pääosin vertikaalisuunnassa. Pohjavesi on vedellä kyllästetty kerros maaveden alapuolella, jossa vesi virtaa lähes horisontaalisuunnassa paineen ohjaamna. Maaperän vesitalouteen vaikuttaa myös lämpötila vesihöyryn taseen takia sekä kylmällä ilmasovyöhykkeellä maan routaantumisen takia. Eino Leinon säkein

Suot on suuret Suomenmaassa, rimmet sekä nevat,

Suomen soilla hallan immet öisin laulelevat.

Tämän luvun jälkeen on käsitelty vesivarastot eli ilmakehän vesi, järvet ja maaperän vesi. Näiden varastojen väliset siirtoväylinä toimivat ilmavirtaukset, joet sekä maanpinnalla ja maaperässä tapahtuva valunta, johon paneudutaan seuraavassa luvussa, ja joka päättää vedenkiertolun tarkasstelumme. 


\section{Valunta}

\subsection{Valunnan perusteet}

Valunta on hydrologian keskeisimpiä tapahtumia (kuva 8-1). Määritelmän mukaan "valunta on se osa sadannasta, joka virtaa vesistöä kohti maan pinnalla, maaperässä tai kallioperässä" (WMO 1974). Se kuljettaa maan pinnalle tullutta sadevettä takaisin meriin ja tarjoaa matkallaan vettä luonnon ja ihmisen käyttöön. Valuma tarkoittaa valuma-alueelta tulevaa valuntaa. Valuntatermillä tarkoitetaan sekä itse valuntailmiötä että aikayksikössä virtavaa veden määrää valuma-alueen koko pinta-alaa kohti. Valuntatermin käyttö on yleisintä valumisprosessin nimenä ja vesitaseen osatekijänä, ja valumakäsitettä käytetään yksinomaan veden siirtymisen merkityksessä.
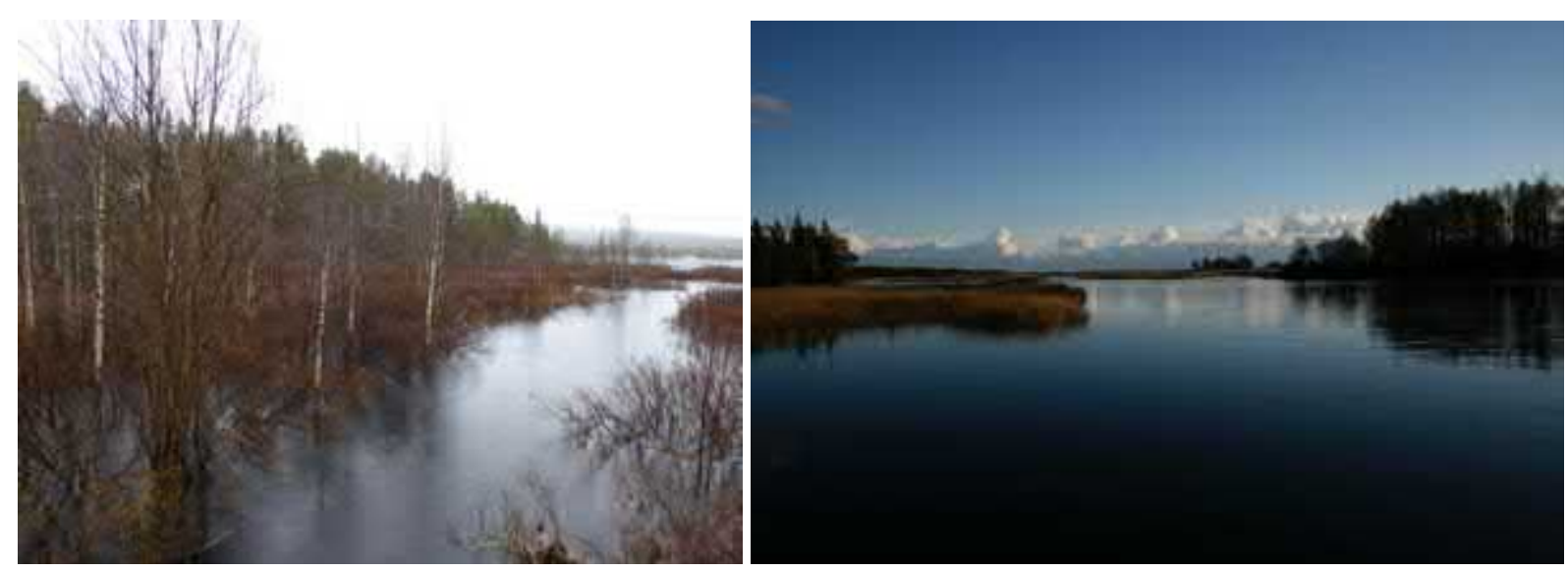

Kuva 8-1. a) Kevättulva Äkäslompolossa ja b) Kymijoen Ahvenkoskenhaaran suistossa Päijänteen vesistön valuma-alueen vesiä kulkeutuu Suomenlahteen. Kuvat: Matti Leppäranta.

Valuma-alue muodostaa kokonaisuuden, johon vesi tulee sateena ja josta vesi poistuu valuntana ja haihduntana. Näiden aiheuttama nettomuutos näkyy vesivaraston tilavuuden muutoksena. Vesitaseyhtälöstä (3.20) saadaan valunnaksi

$$
R=P-E-\frac{1}{A} \frac{d V}{d t}
$$

missä $A$ on alueen pinta-ala. Tämä varasto voi olla maaperässä, vesistöissä tai kasvipeitteessä. Valunta, kuten virtaamakin, kuvaa veden kuljetusta. Sen dimensio on pituus jaettuna ajalla. Yksikkönä käytetään millimetriä vuorokaudessa tai vuodessa kuten sadannan ja haihdunnan tapauksessa. Vastaavasti valunta saadaan veden tilavuutena aikayksikköä kohti kertomalla se valuma-alueen pinta-alalla. Virtaaman dimensio on puolestaan tilavuus jaettuna ajalla, ja se tarkoittaa uoman tai yleensä vesirungon poikkileikkausalan läpi kulkevaa vesimäärää.

Esim. 8-1. Itämereen tuleva valunta tuo vuosittain noin metrin paksuisen kerroksen vettä sen alalle. Valuma-alueen pinta-ala on 1,65 miljoonaa neliökilometriä ja Itämeren ala 0,393 miljoonaa neliökilometriä. Keskimääräinen sadanta on valuma-alueella noin $500 \mathrm{~mm}$ vuodessa. Valuma-alueen ala on 4,2 kertaa Itämeren ala, joten sen sademäärä vastaa $2,1 \mathrm{~m}$ paksua vesikerrosta Itämeren päälle levitettynä. Sadannasta siis noin puolet päätyy Itämereen ja toinen puoli haihtuu takaisin ilmakehään. 
Valunnan aiheuttaa painovoima. Sitä vastustavat kitka- ja koheesiovoimat veden liikkuessa maaperässä ja vesiuomissa. Kasvipeite vaikuttaa myös oleellisesti valuntaan. Kaiken kaikkiaan valunnan muodostuminen ja sen ajallinen ja paikallinen kehitys ovat monimutkaisia prosesseja. Näitä voidaan pelkistää eri tavoin, mitä käsitellään seuraavassa tarkemmin. Valunnan voidaan ajatella muodostuvan kolmesta osasta: maanpäällisestä valunnasta eli pintavalunnasta, maavesikerroksessa tapahtuvasta valunnasta ja pohjavesivalunnasta.

Kuvassa 8-2 on kuvattu, miten rankkuudeltaan tasainen sade vaikuttaa valuntaan ja muihin hydrologisen kierron komponentteihin ajan funktiona. Valunnan osuus ja erityisesti pintavalunnan osuus kasvaa sateen jatkuessa, koska muiden komponenttien osuus vakiintuu niihin liittyvien vesivarastojen täyttyessä. Maanpinnalla virtaava vesi joutuu pieniin painanteisiin ja uomiin jo minuuttien kuluessa sateen alkamisesta pintakerrosvalunnan kehittyessä muutamien tuntien kuluessa (kuva 8-3). Pohjavesivalunta riippuu voimakkaasti maaperän vesivaraston muutoksista ja se saavuttaakin vesiuomat vasta mahdollisesti viikkojen, kuukausien tai jopa vuosien päästä sadetapahtuman jälkeen. Sateen vaikutus pohjavesivirtaamaan voidaan havaita jo melko pian, mutta itse veden valuminen on hitaampaa. Pohjaveteen tulevan lisäyksen ja vanhan veden suhteesta yleinen käsitys on, että uusi vesi työntää vanhan veden pois vesistöön (Sklash \& Farwolden 1979, Rodhe 1981, Laudon et al. 2007). Tosin viime aikoina tätä käsitystä on kritisoitu. Prosessilla on merkitystä myös veden mukana kulkevan liuenneen aineen etenemisessä.

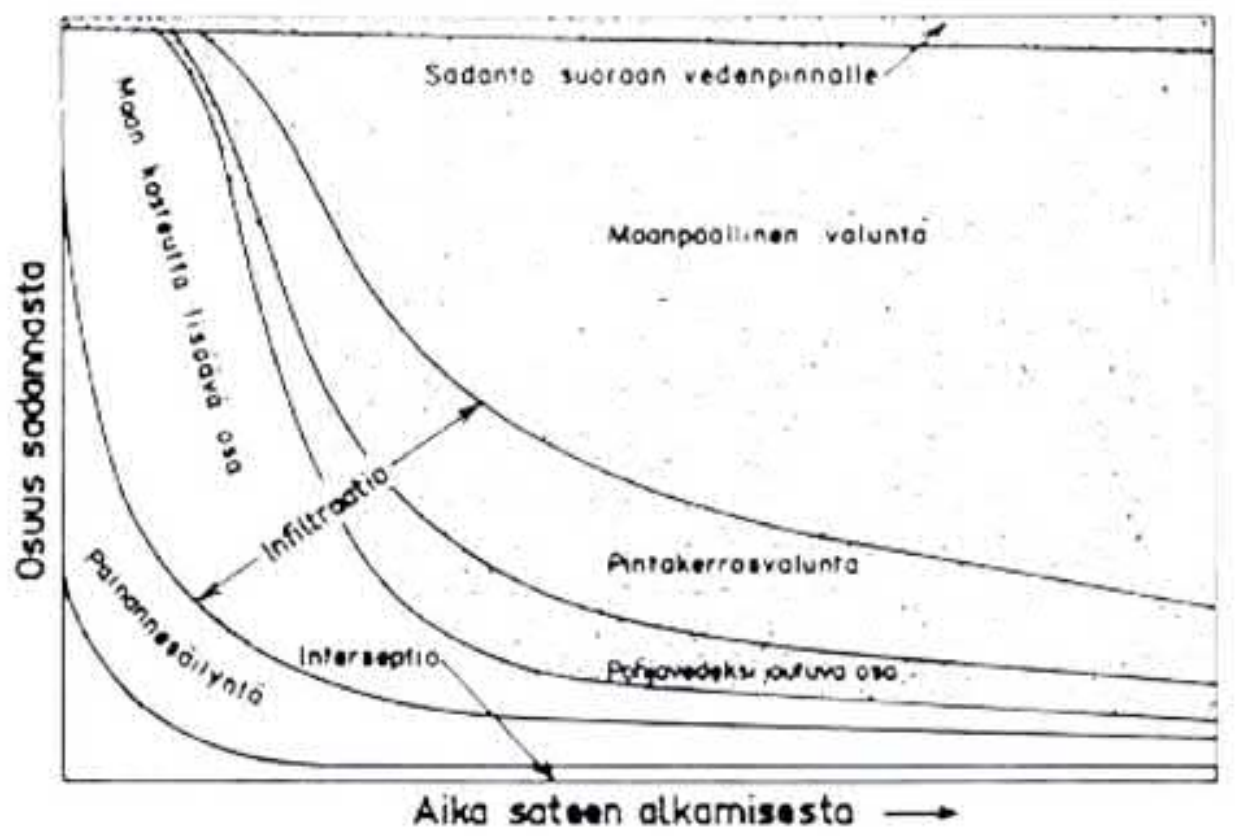

Kuva 8-2. Valunnan osien ajallinen kehitys sadantatapahtuman jälkeen. Lähde: Mustonen (1986).

Valunnan eri osien keskinäiset osuudet riippuvat sadannan tai lumen sulamisen ajallisesta kehityksestä sekä alueen pinnanmuodoista ja maaperästä. Maanpäällisen valunnan osuus muodostuu suureksi, jos maanpinta läpäisee huonosti vettä. Tällainen huono imeyntäkyky ${ }^{1}$ voi johtua maalajin hienorakeisuudesta, roudasta tai luonnollisesta tai ihmisen aiheuttamasta maan tiivistymisestä. Maaperän huokoset voivat myös olla edellisten sateiden jäljiltä kyllästyneet vedellä eikä maaperä voi ottaa silloin uutta vettä vastaan.

\footnotetext{
${ }^{1}$ Imeyntä tarkoittaa veden imeytymistä maanpinnan läpi.
} 
Maaperän pintakerrosvalunta on suuri, jos maanpinta läpäisee hyvin vettä, mutta kerroksen alapuolella on vettä läpäisemätön kerros, joka estää suotautumisen syvemmälle. Tällainen tilanne voi syntyä esimerkiksi peltomailla, jos ruokamullan alla on tiivis jankko². Pohjavesivalunnan osuus on suuri karkearakeisilla mailla, joissa pinnan imeyntäkyky on hyvä ja joissa myös alla olevat kerrokset johtavat hyvin vettä.

Valunnan jakaminen kolmeen edellä mainittuun osaan on kuitenkin melko teoreettista. Usein maanpäällinen valunta muuttuu pintakerrosvalunnaksi ja taas uudelleen maanpäälliseksi valunnaksi ennen vesiuomaan päätymistä. Runsaan veden aikana pohjavesivalunnan erottaminen pintakerrosvalunnasta on vaikeaa ja epätarkkaa. Sen sijaan pitkän kuivankauden jälkeen sekä pakkastalvina voidaan järvettömän vesistön valunnan katsoa olevan lähes yksinomaan pohjavesivaluntaa. Pelkistetyimmillään pohjavesivaluntaa esiintyy lähteissä, pintavaluntaa puolestaan päällystetyillä pinnoilla. Nurmijärven Sääksjärvi ja Päijät-Hämeen Vesijärvi saavat vetensä miltei kokonaan pohjavesivalunnasta ja ovat siis "suuria lähteitä".

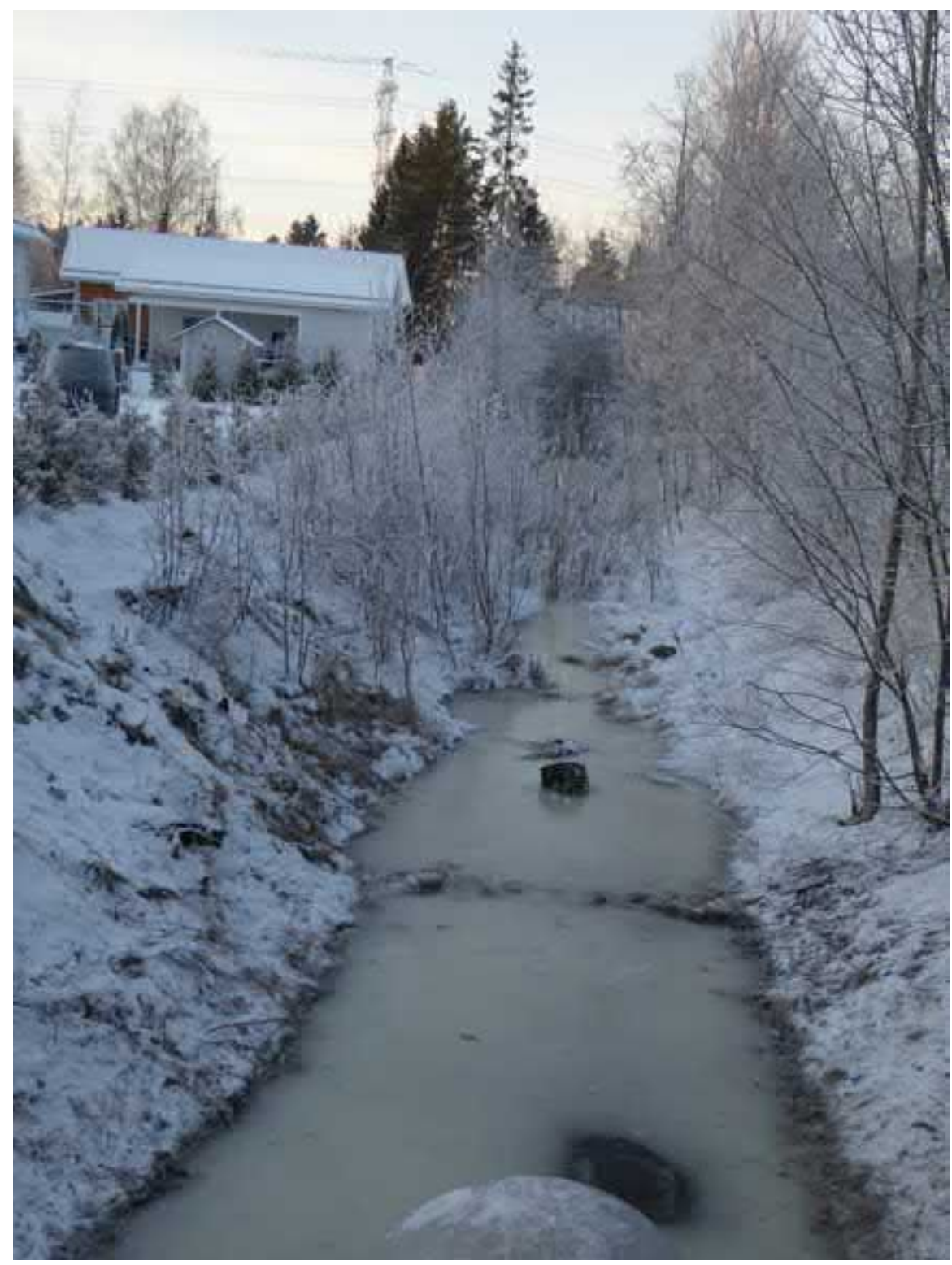

Kuva 8-3. Sade- ja sulamisvettä keräytyy ojiin. Kuva: Matti Leppäranta.

\footnotetext{
${ }^{2}$ Jankko on viljelysmailla esiintyvä ruokamullan ja pohjamaan välissä oleva tiivis maakerros.
} 
Eri valuntamuotojen suhteet vaihtelevat vuodenaikojen mukaan. Lumen sulamiskautena maanpäällisen valunnan ja pintakerrosvalunnan osuus on suuri. Normaalina kesänä melko suuri osa valunnasta on pohjavesivaluntaa. Syyssateet kasvattavat pintakerrosvalunnan osuutta ja saattavat aiheuttaa maanpäällistä valuntaa maan huokostilan täytyttyä. Talviajan valunta on satunnaisia suojasäitä lukuun ottamatta lähes kokonaan pohjavesivaluntaa.

Valuntakäyrä eli valunnan aikakäyrä tai hydrografi on keskeisimpiä kuvaajia hydrologian alalla. Kuvassa 8-4 on esitetty tyypillisen lyhytaikaisen virtaama- tai valuntakäyrän muoto ja osat. Valunta oletetaan siinä voitavan jakaa kahteen osaan: pohjavaluntaan ja välittömään valuntaan. Pohjavalunta muodostuu pohjavesivalunnasta ja hitaasta pintakerrosvalunnasta. Välitön valunta muodostuu sadannan tai lumen sulamisen aiheuttamasta nopeasti uomiin tulevasta valunnasta, joka on maanpäällistä valuntaa ja pintakerrosvaluntaa. Se sisältää sen sadannan osan, joka ei pidäty interseption, painannesäilynnän eikä imeynnän muodossa. Välitöntä valuntaa kuvataan myös termeillä tehoisa sadanta tai tehoisa sulanta ja se voidaan erottaa pidättymiskäyrän avulla.

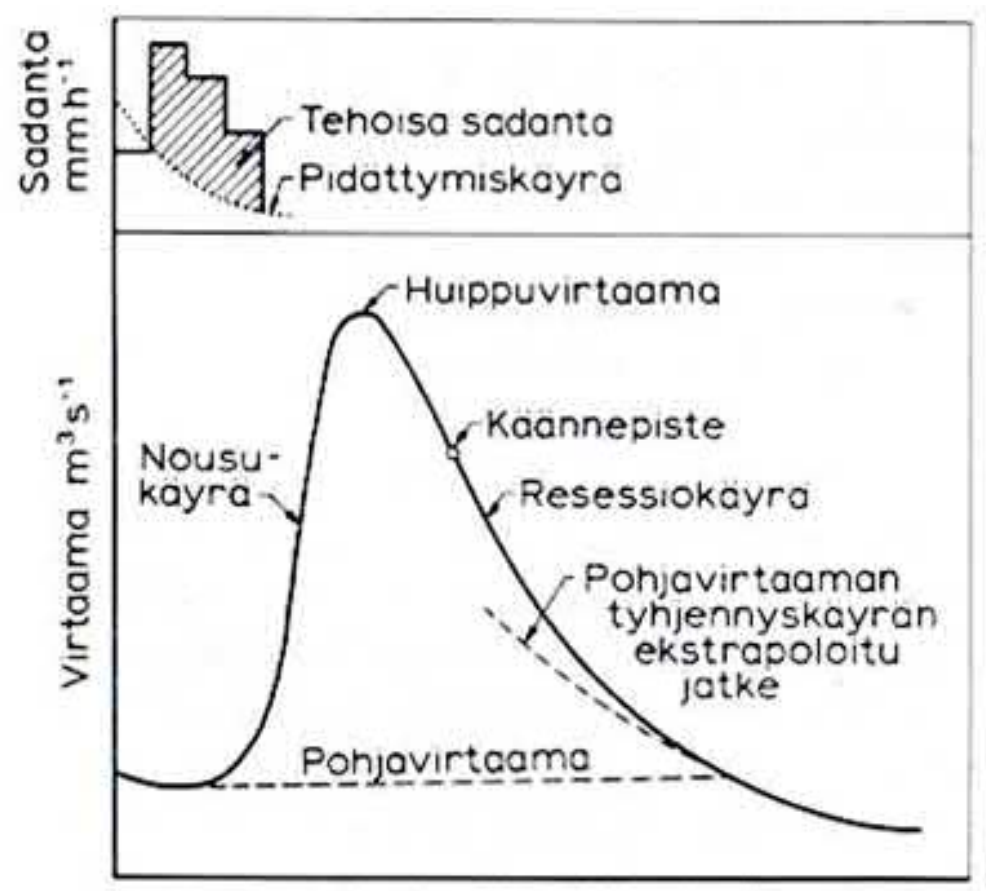

Aika tunteina toı paivina

Kuva 8-4. Virtaaman aikakäyrän osat. Lähde: Mustonen (1986).

Valuntakäyrästä voidaan erottaa kolme osaa: nousukäyrä, huippu ja tyhjentymisosa eli resessiokäyrä. Nousukäyrän muoto riippuu pääasiassa kustakin valuntatapahtumasta. Jos tehoisa sadanta tai sulanta kestää niin kauan, että valunta ehtii havaintopaikalle valuma-alueen etäisimmistä osista, niin valuntakäyrän nousuaika $t_{\mathrm{p}}$ kuvaa valuma-alueelle tyypillistä valunnan kertymisaikaa. Valuntakäyrän laskevalla osalla olevan käännepisteen katsotaan yleensä merkitsevän pintavalunnan päättymistä. Tämän jälkeen käyrä kuvaa syntyneen vesivaraston tyhjenemistä.

Mikäli valuntaa synnyttävä ilmiö on ulottunut koko valuma-alueelle, voidaan käännepisteen jälkeistä resessiokäyrää pitää alueelle tyypillisenä pysyvänä ominaisuutena. Valunnan pieneneminen oletetaan lineaariseksi, ja perusyhtälö sekä sen ratkaisu ovat 


$$
\begin{aligned}
& \frac{d R}{d t}=k_{r} R \text { jа } \\
& R\left(t+t_{0}\right)=R\left(t_{0}\right) e^{k_{r} t}
\end{aligned}
$$

missä $t \geq 0$ on käännepisteen ajankohdasta $t_{0}$ käynnistyvä aika ja $k_{\mathrm{r}}<0$ on resessiovakio. Prosessin aikaskaalaa kuvaa resessiovakion käänteisarvo, ja ajan $3 k_{r}^{-1}$ kuluttua valunta on lähes päättynyt, $R\left(t+t_{0}\right)=e^{-3} R\left(t_{0}\right)$, kun $t=3 k_{r}^{-1}$.

Pohjavalunnan erottamiseen valuntakäyrästä ei ole yksikäsitteistä menettelyä. Erottamisen alkukohta on se kohta, jossa valunta alkaa kasvaa. Loppupisteen määrittäminen vaatii kokemusta ja eri sadantatapahtumien tuottamien hydrografien tarkastelua. Apuna voidaan käyttää empiiristä kaavaa

$$
\frac{t}{\mathrm{vrk}}=0,87\left(\frac{A}{\mathrm{~km}^{2}}\right)^{0,2}
$$

Helpoimmin valuntakäyrän osien erottaminen onnistuu pienillä, järvettömillä valuma-alueilla silloin, kun pitkähköä kuivaa kautta seuraa rankka sade. Suuremmilla valuma-alueilla järvet sekä sateen epätasainen jakaantuminen tekevät valuntakäyrien osien erottelun vaikeaksi.

Suomen oloissa sadanta on paljon haihduntaa suurempi, joten valunta on aina merkittävä osa vedensiirtoa. Tämä on luonut vaihtelevan vesimaiseman suomalaiseen kulttuuriin (kuva 8-5).

\subsection{Valuntamallit}

\subsubsection{Yleistä}

Veden kiertokulkumallien avulla tarkastellaan koko kiertokulkua tai jotakin sen osaa. Malleissa on yleensä jokin keskeinen muuttuja, esimerkiksi valunta, maaperän vesipitoisuus, pohjavesivalunta tai haihdunta, jonka suhteen malli kalibroidaan. Mallintaminen on vaikeaa erityisesti maan pinnalla ja maaperässä tapahtuvan valunnan takia. Valuntamallien veden syöttö tulee sadannasta. Sääoloista ja maaperästä riippuu, kuinka paljon valuntaa muodostuu.

Vesistösysteemeissä käytetään englanninkieleen perustuvia lyhenteitä kuvaamaan virtaaman, vedenkorkeuden ja valunnan vaihteluita seuraavasti:

$\begin{array}{llll}\text { yli- } & \mathrm{H} & & \\ \text { keskiyli- } & \mathrm{MH} & \mathrm{Q} & \text { virtaama } \\ \text { keski. } & \mathrm{M} & \mathrm{W} & \text { vedenkorkeus } \\ \text { keskiali- } & \mathrm{MN} & \mathrm{q} & \text { valuta } \\ \text { ali- } & \mathrm{N} & & \end{array}$

Näitä yhdistämällä saadaan suureita kuten $\mathrm{MW}=$ keskivedenkorkeus, $\mathrm{HQ}=$ ylivirtaama ja $\mathrm{MNq}=$ keskialivalunta. Suureet viittaavat myös havaintojaksoon. Esimerkiksi 20 vuoden aikasarjassa $\mathrm{HQ}_{20}$ on maksimivirtaama, $\mathrm{MHQ}_{20}$ on vuosimaksimien keskiarvo ja $\mathrm{MQ}_{20}$ on koko jakson keskiarvo. 


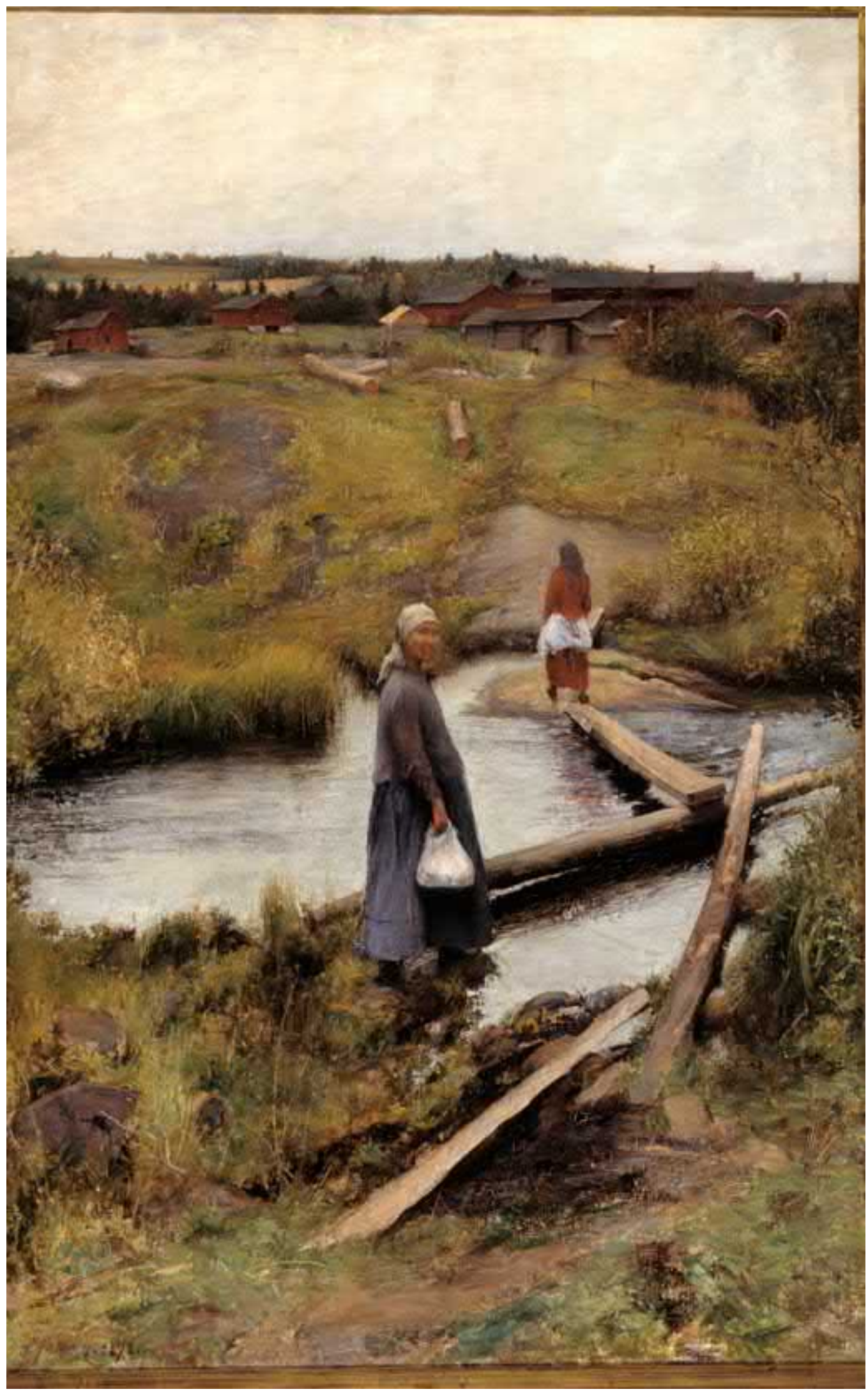

Kuva 8-5. Pekka Halosen maalaus Oijustie (1892). Kuva: Kansallisgalleria/Matti Janas, @ Kansallisgalleria/Ateneumin taidemuseo.

Useissa hydrologian sovellutuksissa on laskettava alueen sadantatietojen avulla alueelta virtaamana tai valuntana poistuva vesimäärä. Tämä tehtävä tulee vastaan esimerkiksi laaditta- 
essa hydrologisia ennusteita tai arvioitaessa virtaaman aikakäyrän tilastollisia parametreja vähäisen havaintoaineiston avulla. Kehittynyttä hydrologista valuntamallia tarvitaan myös selvitettäessä ympäristön muutosten vaikutusta hydrologiseen kiertokulkuun sekä arvioitaessa liuenneiden epäpuhtauksien etenemistä valuma-alueella.

Valuntamalleihin käytettiin varhain tilastollisia menetelmiä. Vanhemmat mallit perustuivat sadannan ja valunnan tai vedenkorkeuden väliseen kokeelliseen riippuvuuteen. 1930-luvulla kehitettiin yksikkövaluntakäyrämenetelmä lähinnä suurien sateiden aiheuttaman valunnan muodostumisen arvioimiseen. Matemaattisten, numeeristen mallien käyttö alkoi 1960-luvulla kasvaa voimakkaasti. Niistä ensimmäisiä oli Yhdysvalloissa kehitetty Stanfordin valuntamalli vuodelta 1961.

Seuraavana mallityyppinä oli niin sanottu konseptuaalinen malli, joka muodostetaan veden kiertokulkua jäljittelevien yksinkertaistettujen osien avulla. Laskentamenetelmien kehittyessä on tullut mahdolliseksi laskea valunnan muodostuminen suoraan ratkaisemalla virtauksen differentiaaliyhtälöt. Sovellettaessa laskelmaa todellisille vesistöalueille joudutaan tekemään aluetta koskevia yksinkertaistavia olettamuksia, koska laskelma vaatisi erittäin yksityiskohtaiset aluetta koskevat tiedot. Fysikaalisena perustana ovat virtausoppi vesialtaissa, uomissa ja huokoisen materian lävitse sekä lämpöoppi mukaan lukien faasimuunnokset. Suurin vaikeus on maan pinnalle lankeavan sateen kulun käsittelyssä, koska se riippuu hyvin voimakkaasti maanpinnan laadusta. Valuntamallien tuloksena saadaan vedenpinnan korkeus maaperässä ja järvissä, uomien virtaama, haihdunta sekä veden poistuminen valuma-alueelta. Tietoja tarvitaan tulvaennusteiden laatimiseksi ja vesivoimaloiden tuoton hallitsemiseksi sekä luonnon ja ympäristön suojelemiseksi.

Eräs laajimmin käytetyistä konseptuaalisista malleista on Sten Bergströmin kehittämä HBV-malli (Hydrologiska Byråns Vattenbalansavdelning, Sveriges Meteorologiska och Hydrologiska Institut SMHI, Bergström \& Forsman 1973). Siinä valuma-alue jaetaan osavaluma-alueisiin, joille kullekin lasketaan oma vesitaseensa. Valunta muodostuu eri varastojen täyttymisen myötä syntyvistä ylivuodoista. Suomen ympäristökeskuksen käytössä on koko maan kattava operatiivinen vesistömallijärjestelmä WSFS (Watershed Simulation and Forecasting System). Se pohjautuu Vehviläisen (1982, 1992, 1994) HBV-valuntamallista edelleen kehittämään malliin.

\subsubsection{Tehoisa sadanta ja yksikkövaluntakäyrä}

Maahan lankeava sade jakaantuu kolmeen osaan: välitön valunta, maa- ja pohjavesivarastoihin sateesta imeytyvä ja suotautuva vesi ja välitön haihdunta. Pohjavesiin joutunutta ja maan pinnalta haihtunutta osaa sateesta kutsutaan häviöksi. Sadannan ja häviöiden hetkellistä erotusta kutsutaan tehoisaksi sadannaksi, ja sitä merkitään symbolilla $P_{e}$.

L. K. Sherman loi 1930-luvulla tehoisan sadannan ja yksikkövaluntakäyrän käsitteet. Tehokkaammat mallit ovat jo osittain syrjäyttäneet yksikkövaluntakäyrään perustuvan menetelmän, mutta yksikkövaluntakäyrässä on piirteitä, jotka opettavat ymmärtämään valuntaprosessin yleistä kulkua. Tehoisan sadannan aiheuttamaa valuntaa kutsutaan välittömäksi valunnaksi $R_{d}$. Kuva 8-6 esittää sateen jakamista tehoisaan sadantaan ja häviöihin sekä valunnan jakamista välittömään valuntaan ja pohjavesivaluntaan.

Tehoisan sadannan ja välittömän valunnan kokonaismäärien tulee olla yhtä suuria. Nämä kokonaismäärät saadaan lausekkeista

$$
\wp_{e}=\int_{0}^{T} P_{e} d t \text { ja }
$$




$$
\Re_{d}=\int_{0}^{\infty} R_{d} d t
$$

missä $T$ on sateen kestoaika. Säilymislain perusteella $\wp_{e}=\Re_{d}$. Tehoisan sadannan kokonaismäärään vaikuttavat eniten sateen määrä, sateen kestoaika, vuodenaika sekä maan pinnan varastoimiskykyä kuvaava suure, jota kutsutaan esisadantaindeksiksi. Tämä kuvaa aikaisempien sateiden vaikutusta maan pintakerroksen vesipitoisuuteen ja pintakerroksen kykyä vastaanottaa uutta sadetta. Esisadantaindeksi saadaan palautuskaavasta

$$
\Gamma_{i}=r \Gamma_{i-1}+P_{i-1}
$$

missä $\Gamma_{i}$ on vuorokauden $i$ esisadantaindeksi, $P_{i}$ on vuorokauden $i$ sadanta ja $r$ on vakio tai vuodenajasta riippuva parametri. Kokeellisen aineiston avulla on mahdollista laatia tehoisan sadannan ja mainittujen tekijöiden välinen riippuvuus. Esisadantaindeksi riippuu siitä, kuinka paljon maaperässä on vettä ja kuinka paljon maaperä pystyy vielä ottamaan vettä lisää.

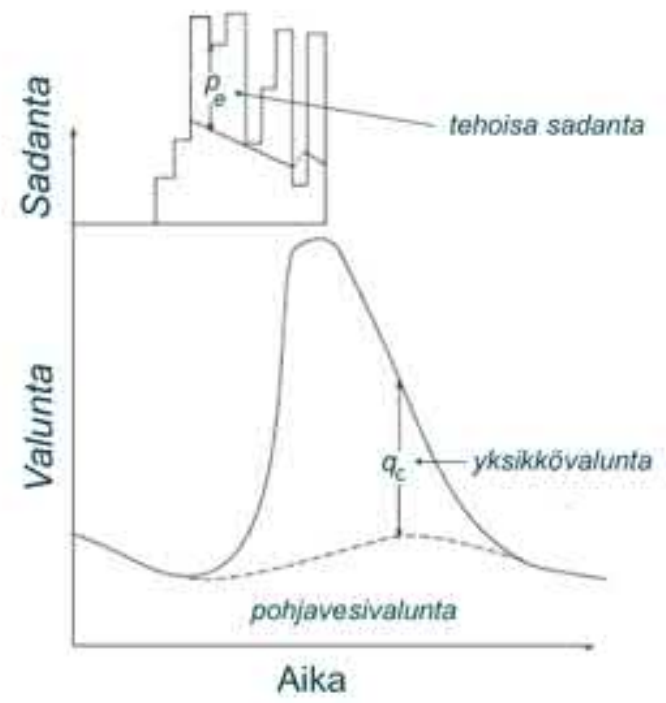

Kuva 8-6. Valunnan muodostuminen sateen aikana ja sen jälkeen. Tehoisan sadannan ja välittömän valunnan erottaminen.

Esimerkki 8-1. Esisadantaindeksi tulkitsemiseksi voidaan tarkastella kahta ääritapausta.

a) $P_{i}=10 \mathrm{~mm} \mathrm{vrk}^{-1}(i=0)$ tai $0(i>0)$ ja $r=0,2$. Tällöin $\Gamma_{1}=10 \mathrm{~mm} \mathrm{vrk}^{-1}, \Gamma_{2}=2 \mathrm{~mm} \mathrm{vrk}^{-1}, \Gamma_{3}=0,4$ $\mathrm{mm} \mathrm{vrk}^{-1}$, jne. Esisadantaindeksi vähenee, kun sadetapahtuma jää kauemmas historiaan.

b) $P_{i}=5 \mathrm{~mm} \mathrm{vrk}^{-1}=$ vakio ja $r=0,2$. Tällöin $\Gamma_{1}=5 \mathrm{~mm} \mathrm{vrk}^{-1}, \Gamma_{2}=6 \mathrm{~mm} \mathrm{vrk}^{-1}, \Gamma_{3}=6,2 \mathrm{~mm} \mathrm{vrk}^{-1}$, jne. Esisadantaindeksi kasvaa maan täyttyessä vedellä.

c) Raja-arvoina ovat $\Gamma_{i}=P_{i-1}$, kun $r=0$, ja $\Gamma_{i}=\sum_{k=0}^{i-1} P_{k}$, kun $r=1$. Edellisessä tapauksessa maaperä imee aina sadeveden syvemmälle, jälkimmäisessä tapauksessa sadevesi jää pintakerrokseen.

Edellä selitettiin, miten sateeseen liittyvän tehoisan sadannan kokonaismäärä voidaan määrittää. Seuraavaksi tarkastellaan, miten välitön valunta jakautuu ajallisesti. Oletetaan, että systeemi "tehoisa sadanta - välitön valunta" on lineaarinen, mikä tarkoittaa, että eri ajanhetkinä sattuneiden sateiden vaikutukset voidaan laskea yhteen. Todellisuudessa valuntaprosessissa lineaarisuus ei kuitenkaan ole täysin voimassa, sillä sateen vaikutuksen eteneminen vesistössä riippuu valunnasta.

Lineaarisuudesta seuraa, että hetkellä $s$ tulleen tehoisan sadannan määrän $P_{\mathrm{e}}(s) d s$ aiheuttama välitön valunta hetkellä $t$ on verrannollinen tähän tehoisaan sadantaan (kuva 8-7) eli 


$$
d R_{d}(t)=u(t-s) P_{e}(s) d s
$$

missä $u$ on hetkellisen sadannan aiheuttama yksikkövalunta (instantaneous unit hydrograph, IUH). Lineaarisuusperiaatteen mukaan IUH on tietylle vesistöalueelle ominainen funktio. Se ei riipu esimerkiksi tehoisasta sadannasta eikä valunnasta.

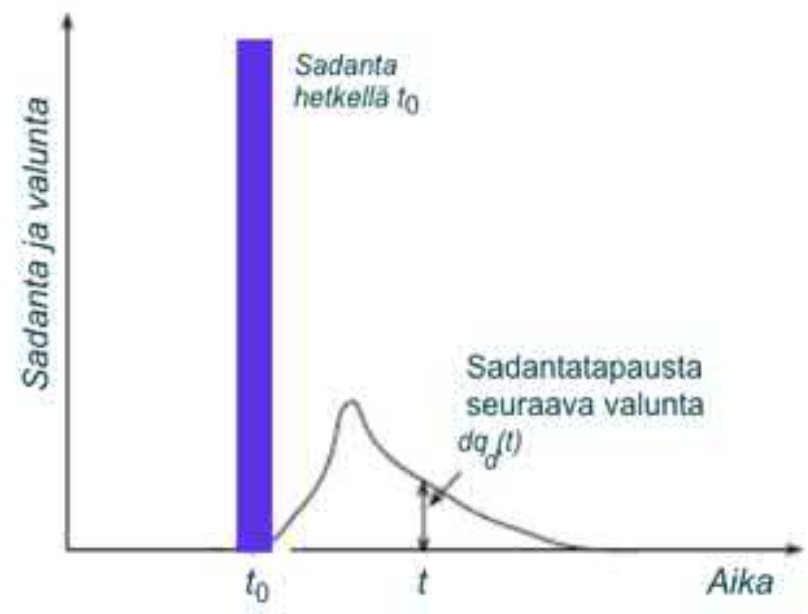

Kuva 8-7. Hetkellä $t_{0}$ sattuneen tehoisan sadannan aiheuttama välitön valunta $q(t)$.

Lineaarisuusperiaatteen mukaan edellisten sateiden aiheuttama valunta $R_{d}$ hetkellä $t$ saadaan integroimalla yhtälö ajan suhteen eli

$$
R_{d}(t)=\int_{0}^{t} u(t-s) P_{e}(s) d s
$$

Ajan nollahetki on asetettu samaksi kuin sateen alkuhetki.

Käytännössä valuntaa ei määritetä jatkuvana ajan funktiona, vaan se lasketaan lyhyille aikaväleille. Jaetaan aika sateen alusta lähtien $\Delta t$-pituisiin aikaväleihin. Merkitään aikavälien $[0, \Delta t],[\Delta t, 2 \Delta t], \ldots$ keskimääräisiä valunnan $R_{d}$ ja tehoisan sadannan $P_{e}$ arvoja alaindeksein 1 , $2, \ldots$ Nyt yhtälö (8.7) voidaan kirjoittaa

$$
\begin{aligned}
& R_{d 1}=P_{e 1} U_{1}, \\
& R_{d 2}=P_{e 2} U_{1}+P_{e 1} U_{2},
\end{aligned}
$$

Kerroin $U_{1}$ ilmoittaa, kuinka paljon tehoisasta sadannasta poistuu välittömänä valuntana saman aikavälin aikana, kerroin $U_{2}$ ilmoittaa, mikä osa tehoisasta sadannasta poistuu seuraavan aikavälin aikana, jne. Kerroin $U_{\mathrm{i}}$ on dimensioton suure, sen sijaan funktion $u(s)$ :n dimensiona on 1/aika. Koska tehoisan sadannan ja välittömän valunnan kokonaismäärä on sama, täytyy olla

$$
\sum_{i} U_{i}=1, \int_{0}^{\infty} u(s) d s=1
$$


Esimerkki 8-2. Tarkastellaan tapausta, kun $u=\lambda e^{-\lambda t}$.

a) Jos $P_{e}=$ vakio, niin $R_{d}=P_{e}\left(1-e^{-\lambda t}\right)$.

b) Jos saadaan äkillinen saderyöppy $P_{e}=\delta(s)$, niin $R_{d}=P_{e} e^{-\lambda t}$. Tässä $\delta$ on Kroneckerin deltafunktio, joka määritellään

$$
\delta(s)=0, s \neq 0 \text { ja } \int_{-\infty}^{\infty} \delta(s) f(s) d s=f(0) .
$$

c) Jos $P_{\mathrm{e}}=$ vakio, kaavan (8.8) painokertoimiksi saadaan $U_{1}=1-e^{-\Delta t}, U_{2}=e^{-\Delta t}-e^{-2 \Delta t}=$ $e^{-\Delta t}\left(1-e^{-\Delta t}\right)$, jne.

Yksikkövaluntakäyrä määritetään havaintoaineistosta tutkimalla mahdollisimman monen lyhytaikaisen sateen vaikutusta valuntaan. Yksikkövaluntakäyrän käyttöä rasittavat monet puutteet:

1. Olettamus, että vesistöalue toimii lineaarisen systeemin tavoin, aiheuttaa virheitä.

2. Todellisuudessa funktion $u(s)$ muoto riippuu tehoisan sadannan määrästä. Sen "pituus" kasvaa, kun $P_{e}$ kasvaa.

3. Menetelmän avulla ei voida laskea kokonaisvaluntaa, se soveltuu ainoastaan välittömään valuntaan.

4. Käsitteet välitön valunta ja pohjavalunta ovat epäselviä ja niiden erottaminen on vaikeaa.

5. Suomen olosuhteissa valunnan aiheuttavat yleensä lukuisat pienet sateet, erillisiä sadetilanteita ei usein ole tarpeeksi menetelmän kalibroimista varten.

\subsubsection{WSFS vesistöjärjestelmä}

Suomen ympäristökeskuksen (SYKE) WSFS (Watershed Simulation and Forecasting System) järjestelmän valuntamallin lähtötietoina ovat sadanta, keskilämpötila ja potentiaalinen haihdunta. Viimeksi mainittu suure voidaan myös laskea säähavaintojen avulla. Valuntamallin prosessimallit ovat sadantamalli, lumimalli, painannevarastomalli, maavesimalli sekä pintakerros- ja pohjavesivaluntaa kuvaavat mallit (kuva 8-8). Maanpinnan korkeuden vaikutus on myös mukana valuntamallissa.

Varastojen täyttöastetta kuvataan muuttujilla, joiden dimensio on pituus ja yksikkönä yleensä millimetri. Kullakin varastolla on oma raja-arvonsa. Varastojen täyttymistä ja tyhjentymistä ohjataan erilaisten säätelyparametrien avulla. Varastojen maksimiarvot ja eri parametrien arvot saadaan kokemuksen pohjalta ja kalibroimalla malli vesistöjen vedenkorkeusja virtaamahavaintojen avulla.

Sadantamallin avulla lasketaan valuma-alueelle kohdistuva sadanta, jonka olomuoto arvioidaan samalla. Sen jälkeen korjataan sademittarien mittausvirhe ja otetaan huomioon maanpinnan korkeuden vaikutus sadannan määrään. Lopuksi lasketaan aluesadanta. Säätutkan sadetietoja käytetään viiden viimeisen päivän ajan aluesadannan laskentaan. Sitä aiemmat aluesadannat lasketaan sadeasemien havaintojen avulla.

Lumimallin avulla lasketaan lumen kertyminen, sublimaatio, sulaminen ja lumen alueellinen peittävyys. Sulanta lasketaan vuorokauden keskilämpötilan perusteella aukealle ja metsälle erikseen. Sulanut vesi varastoituu aluksi lumeen, maaston painanteisiin ja soille (mallissa painannevarasto), joista se sulannan edistyessä purkautuu nopeutuvasti vesistön uomiin pinta- ja pintakerrosvaluntana. Osa vedestä pidättyy maavesivarastoon ja suotautuu pohja-veteen, josta purkautuminen tapahtuu hitaasti. 
Avoimilta pelto-, suo- ja hakkuualueilta lumi sulaa auringonsäteilyn ja tuulen ajaman turbulenttisen lämmönvaihdon vaikutuksesta aikaisemmin kuin metsistä. Metsän varjostus ja suoja pienentävät auringon säteilyn ja tuulen vaikutusta. Sulamisen aikaero on tyypillisesti pari viikkoa aukean ja metsän välillä. Sulannan keskeytyessä voi käydä niin, että metsässä säilynyt lumi yllättää loppukeväästä tulvalla, kun peltojen, tienvarsien ja taajamien lumet ovat jo ajat sitten sulaneet näkyvistä. Osa sulaneesta vedestä jäätyy ojiin ja painanteisiin, ja alueen korkeus ja viettosuunta vaikuttavat myös sulamiseen.

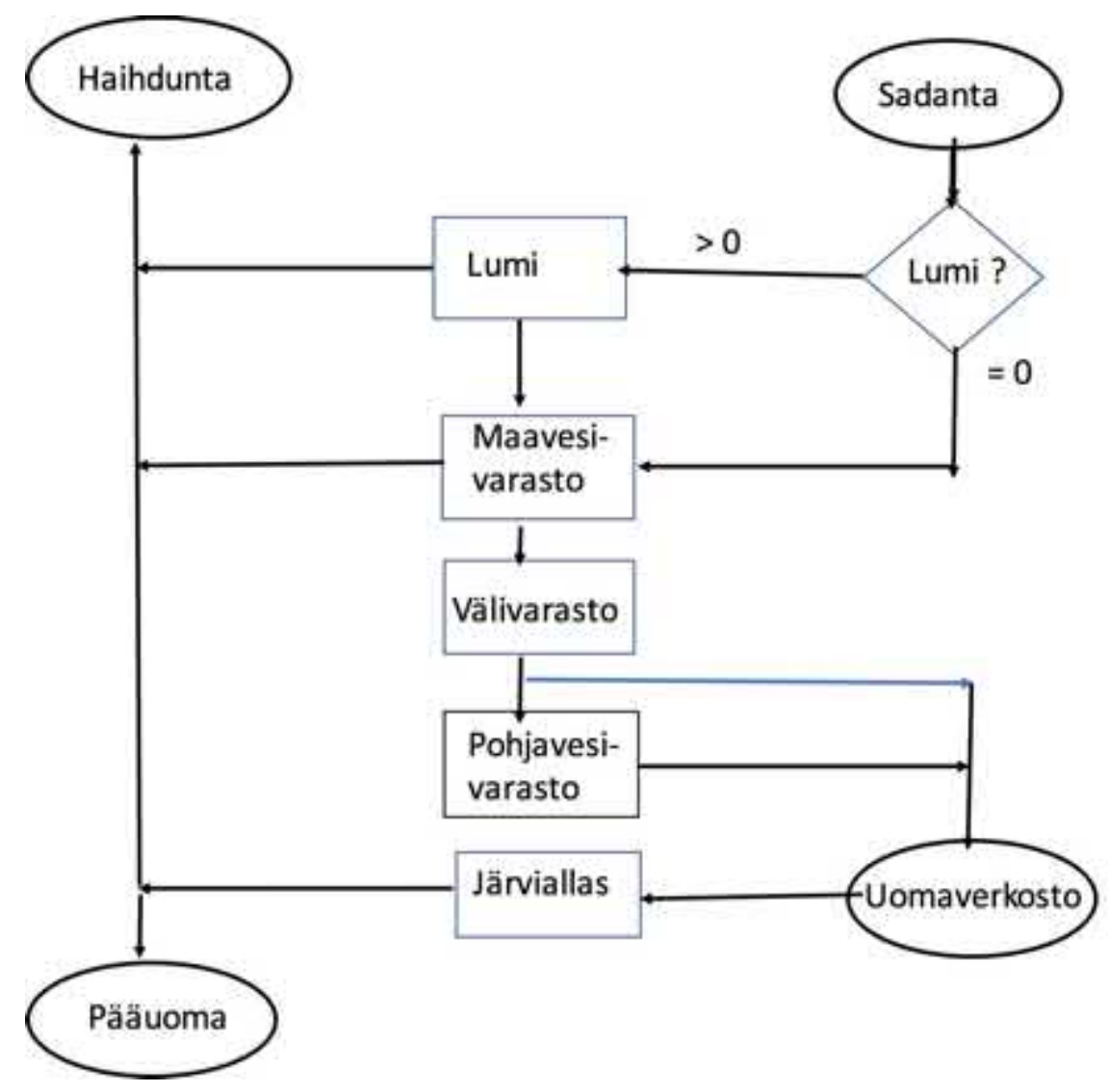

Kuva 8-8. WSFS vesistömallin perusosan rakenne. Suureet käsitellään vuorokausiarvoina. Vuomuuttujien yksikkö on mm vrk ${ }^{-1}$, lumi-, maavesi-, väli- (eli pintakerros-) ja pohjavesivaraston yksikkö on $\mathrm{mm}$, järvien vesivaraston yksikkö on $\mathrm{m}^{3}$ ja uomaverkoston sekä pääuoman virtaamien yksikkö on $\mathrm{m}^{3}$ $\mathrm{s}^{-1}$.

Maavesimalli laskee maaperän 0,5-1,5 metrin pintakerrokseen sitoutuneen vesivaraston, jota sade- ja sulamisvedet täyttävät ja haihdunta ja pohjaveteen suotautuminen tyhjentävät. Osa maavesivarastoon tulevasta sade- ja sulamisvedestä varastoituu siihen, osa haihtuu ja osa muodostaa valuntaa pintakerrosvaraston ja pohjavesivaraston kautta. Kesällä maavesivaraston vesimäärä vaihtelee $50-100 \mathrm{~mm}$ välillä, ja varaston täyttöaste ratkaisee sadannan lisäksi valunnan määrän ja tulvan kehityksen. Keväällä ja myöhään syksyllä maavesivarasto on yleensä täynnä, jolloin tulvaennusteen onnistuminen riippuu lähinnä alueellisen lumen vesiarvon ja/tai lämpötila- ja sadantaennusteen tarkkuudesta. Maahaihdunta lasketaan potentiaalisen haihdunnan ja maavesivaraston vajauksen perusteella. Maavesivarastosta vesi kulkeutuu pintakerrosvarastoon (välivarastoon), josta nopeasti purkautuva valunta muodostaa tulvahuipun, ja edelleen pohjavesivarastoon, josta vesi purkautuu pidemmän ajan kuluessa. Näiden eri varastomallien avulla saadaan laskettua sadannan häviöt, valunnan viiveet ja veden varastoituminen. 
Muita WSFS:n osamalleja ovat jokimalli, tulva-aluemalli ja järvimalli. Jokijaksojen mallintamiseen voidaan käyttää useita eri mallityyppejä: yksinkertaisia tulva-aallon viiveen ja vaimenemisen laskevia malleja tai dynaamisia fysiikan liike- ja varastoitumisyhtälöihin perustuvia malleja. Käytössä oleva jokimalli kuvaa joen peräkkäisinä altaina joen pituus-, kaltevuus- ja leveystietoa käyttäen. Joen vedenpinnankorkeus saadaan tällä mallityypillä myös laskettua koko joen pituudelta. Tärkeissä paikoissa laskentaa voidaan vielä tarkentaa havaintojen avulla.

Järvimalli laskee tulovirtaaman, lähtövirtaaman, lähivaluman, järvihaihdunnan ja järveen tulevan sadannan avulla järven tilavuuden ja vedenkorkeuden. Järvihaihdunta lasketaan potentiaalisen haihdunnan ja järven pintalämpötilan avulla. Järvi lämpenee keväällä ja jäähtyy syksyllä hitaasti, mikä pienentää järvihaihduntaa keväällä ja kasvattaa sitä syksyllä potentiaalisen haihduntaan verrattuna. Ihmisen vaikutus järvien vesitalouteen on merkittävä, sillä useita järviä säännöstellään juoksutusten ja patoamisten avulla. Tällaisia järviä varten on kullekin olemassa oma säännöstelyohje, jota laskentamalli käyttää ennusteajossa.

Esimerkkinä kuvassa 8-9 on WSFS mallin tuottama Pielisen vedenkorkeuden ennuste kahdeksi kuukaudeksi. Ennusteessa on otettu huomioon ennustettavan suureen, Pielisen vedenkorkeuden, tilastollinen vaihtelu. Tämän lisäksi ennusteen jakaumassa otetaan huomioon sääennusteiden vaihtelu. Tämä saadaan aikaan ajamalla mallia yli viidenkymmenen eri sääennusteen avulla. Ne saadaan pääosin Euroopan sääkeskuksesta.

Järvet, samoin kuin suoalueet toimivat luonnossa ja mallissa valunnan välivarastoina viivyttäen valuntahuipun kehittymistä ja tasoittaen sitä. Alivirtaamat ovat järvisellä tai soisella valuma-alueella suurempia kuin alueella, jossa järvien ja soiden määrä on vähäinen.

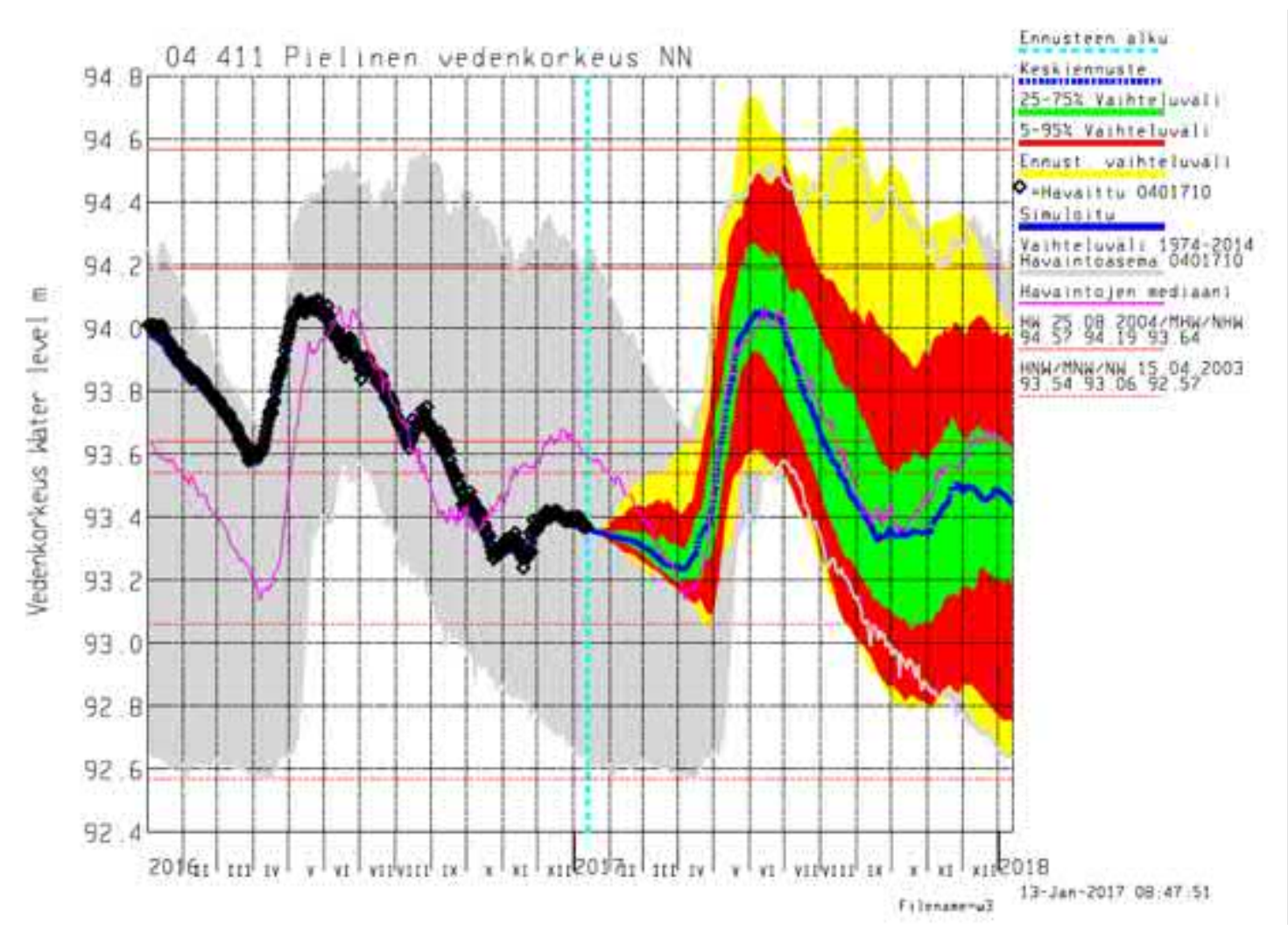

Kuva 8-9. WSFS-mallin laskentatulos Pielisen vedenkorkeudelle 13.1.2017.

Vesistömalli kootaan valunta-, joki-, tulva-alue- ja järvimalleista kutakin vesistöä kuvaavaksi malliksi. Vesistömalli kalibroidaan eli sovitetaan vesistöön hakemalla optimointimallilla sen 
yhtälöiden parametreille sopivat arvot. Kalibrointia tehdään jatkuvasti sekä ajantasaisten automaattisten mittaustulosten (tärkeimpänä vedenkorkeus) että muiden havaintojen avulla. Kalibroinnissa käytetään automaattisia algoritmeja ja myös asiantuntijoiden kokemusta.

\subsection{Vedenlaatua kuvaavat mallit}

\subsubsection{Valumavesien vedenlaatua kuvaavat mallit}

Valuma-alueelta vesistöön huuhtoutuvien kiintoaine- ja ravinnekuormien arviointia varten on kehitetty erilaisia malleja. Niiden keskeisenä osana on valunnan laskenta (kuva 8-10). Vedenlaatulaskennassa on sitten sovellettu erilaisia lähestymistapoja. Suomessa on käytetty sekä INCA (Integrated Nitrogen in CAtchments)-malliperheen malleja että SWAT (Soil and Water Assesment Tool)-mallia, jotka soveltuvat yksittäisen tutkijan käytettäviksi hänen omalla työasemallaan. Laajaan WSFS-järjestelmään on tehty oma VEMALA-vedenlaatuosansa (Huttunen ym. 2008), jota SYKE kehittää aktiivisesti. Sen avulla lasketaan mm. Suomen alueelta Itämereen tulevaa ravinnekuormitusta nykytilassa ja odotetun ilmastonmuutoksen aikana.

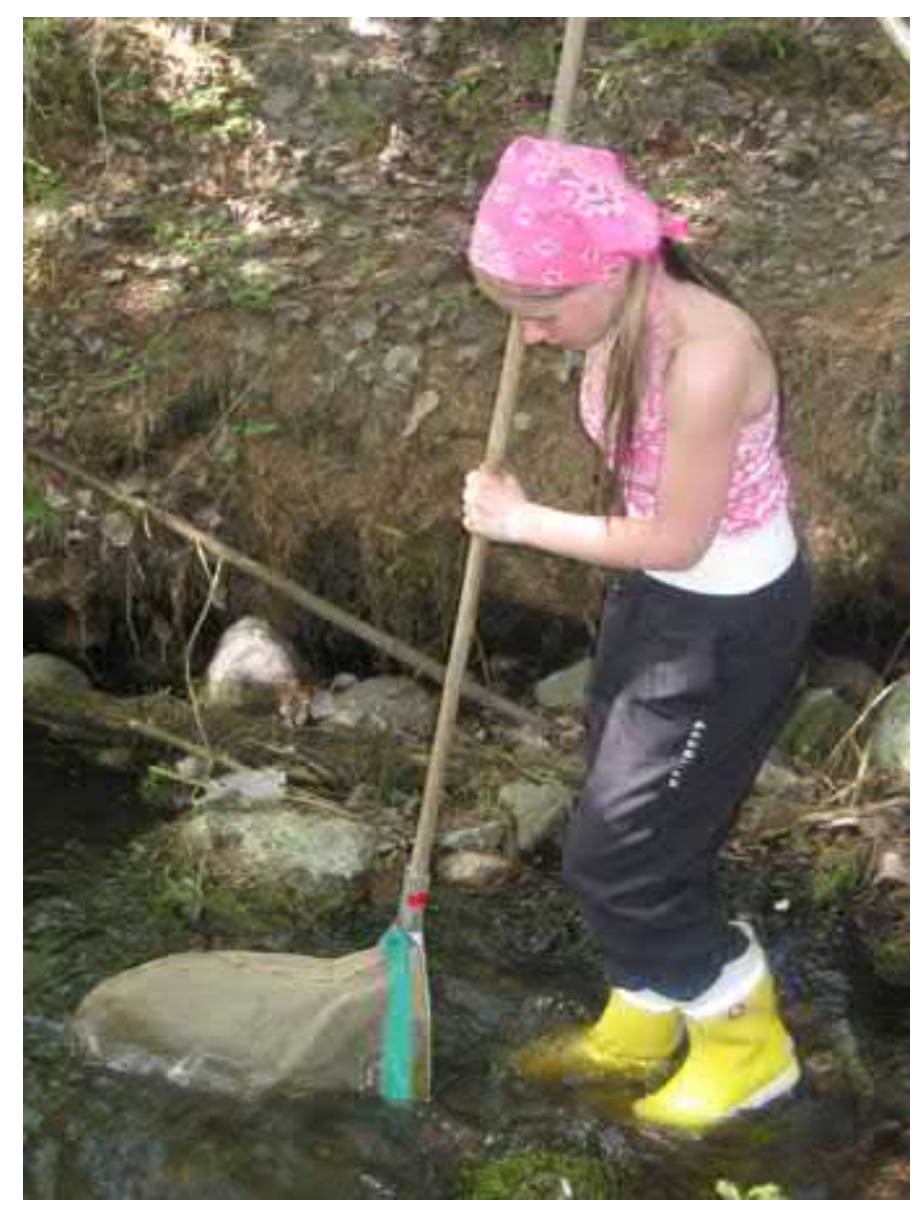

Kuva 8-10. Valunnan mukana kulkeutuvaa eliöstöä kerätään haaviin Pääjärven valuma-alueella kenttäkurssilla Lammin biologisellla asemalla. Kuva: Anna-Riikka Leppäranta.

INCA-N on matemaattinen, prosessipohjainen typpimalli, joka on alun perin kehitetty Englannissa (Wade ym. 2002). Mallilla simuloidaan ympäristömuutosten - ilmastonmuutos, 
maankäytön muutos, laskeuman muutos - vaikutusta typpikuormitukseen. Sitä on testattu laajalti sekä pienillä valuma-alueilla että isoilla jokivesistöalueilla. INCA-mallissa huomioidaan kaikki tärkeimmät typen lähteet ja simuloidaan eri kuormituslähteistä peräisin olevaa typpeä ja muutuntaprosesseja alueen maaperässä sekä vesiuomissa. Mallissa on käyttöliittymä sekä viisi osaa: maankäyttö, laskeuma, hydrologia, maaperäosa sekä jokiosa.

SYKE:ssä on kehitetty INCA-N mallin soveltuvuutta pohjoisiin oloihin lisäämällä malliin lumiosio ja parantamalla maaperän lämpötilan laskentaa (kuva 8-11). Mallin sovelluksessa Yläneenjoen alueelle voitiin hyödyntää uusia reaaliaikaisia nitraattimittausten tuloksia. Viime vuosina on kehitetty vastaavantyyppiset mallit kiintoaineen (INCA-Sed) ja hiilen (INCAC) mallinnukseen sekä erityinen patogeenien laskentamoduuli (Rankinen ym. 2016). Toinen työasemakäyttöön sopiva malli on SWAT, joka on Yhdysvalloissa kehitetty dynaaminen valuma-aluepohjainen malli (Arnold ym. 1998).

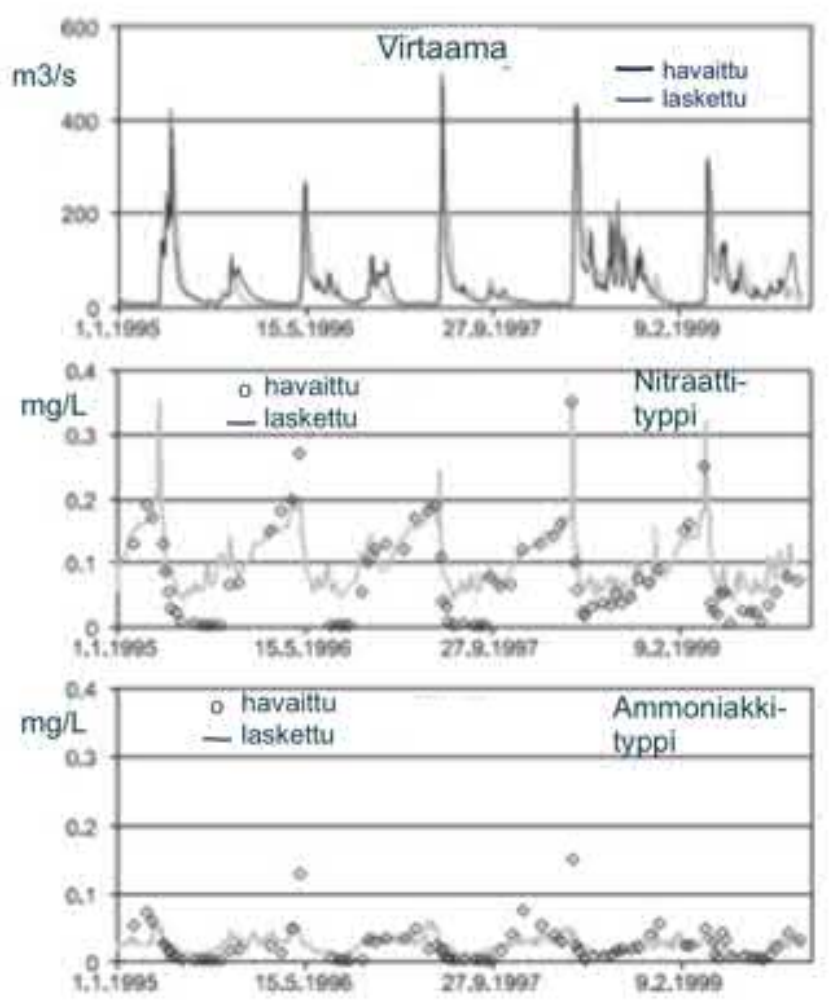

Kuva 8-11. INCA-N-mallin tulos Simojoen suulta kuvaten virtaamaa, nitraatityppeä $\left(\mathrm{NO}_{3}-\mathrm{N}\right)$ sekä ammoniakkityppeä $\left(\mathrm{NH}_{4}-\mathrm{N}\right)$. Lähde: Rankinen ym. (2004).

\subsubsection{Järvien vedenlaatua kuvaavat mallit}

Järvien vedenlaadun kehitystä voidaan kuvata useilla eri lähestymistavoilla. Yksinkertaisimmillaan jonkin aineen, esimerkiksi fosforin, pitoisuus $\left(c_{P}\right)$ järven luusuassa voidaan laskea järveen tulevan fosforikuorman (MP) avulla muokatulla sekoitetun tankin (continuously stirred tank, CSTR) -menetelmällä (Frisk 1989). Menetelmä perustuu seuraaviin oletuksiin. Järviallasta käsitellään täysin sekoittuneena, ja tuleva kuormitus sekoittuu koko vesimassaan viiveettä. Poistuvassa vedessä aineiden pitoisuuden oletetaan olevan saman kuin koko järven vesimassassa, mikä itse asiassa seuraa edellisestä oletuksesta. Vallitsee hydraulinen eli tulo- ja lähtövirtaamat ovat tasapainossa eikä systeemin tilavuus siis muutu.

Näiden oletusten perusteella voidaan kirjoittaa altaan yleinen aineen massataseyhtälö 


$$
V \frac{d c}{d t}=I_{c}-c Q+S_{c} V
$$

missä $V$ on altaan tilavuus, $c$ on aineen pitoisuus, $I_{c}$ on altaaseen tulevan aineen kokonaiskuormitus, $Q$ on veden ulosvirtaama, ja $S_{c}$ on lähde/nielu-termi, joka kuvaa altaan sisäisten reaktioiden aiheuttamaa aineen pitoisuuden muutosnopeutta $(\mathrm{mm}$. sedimentaatio, hajoaminen ja vapautuminen pohjasta). Yhtälö voidaan ratkaista käyttäen tasapainotilanteen oletusta $\frac{d c}{d t}=0$, jolloin altaan fosforin kokonaispitoisuudeksi $\left(c_{P}\right)$ saadaan

$$
c_{P}=\frac{I_{P}-S_{P}}{Q},
$$

missä $S_{P}$ on fosforin pidättyminen altaaseen (kg/vuosi), ja $I_{P}$ on altaaseen kohdistuva fosforin kokonaiskuormitus, joka on yleensä suoraan verrannollinen fosforin kuormitukseen, $I_{\mathrm{P}}=R^{*}$. $c_{0} T$. Verrannollisuuskerroin tai paremminkin pidättymiskerroin $R^{*}$ saa kullekin altaalle ominaisen arvon. Pidättymiskertoimelle on useita erilaisia kaavoja. Seuraavassa käytetään Friskin (1978) muotoa

$$
R^{*}=0,9 \frac{c_{0} T}{B+c_{0} T}
$$

missä $B=280 \mathrm{mg} \mathrm{m}^{-3} \mathrm{kk}$ on kaavan parametri, $c_{0}$ on kuormitus/tilavuus $\left(\mathrm{mg} \mathrm{m}^{-3}\right)$ ja $T$ on viipymä (kk). Pidättymiskerroin on dimensioton ja riippuu siis alkupitoisuudesta ja viipymästä. Viipymän laskemisessa käytetään yleisesti teoreettista arvoa $T=V / Q$. Sen laskemisessa oletetaan, että tuleva aine sekoittuu täydellisesti koko altaan vesimassaan. Fosforin pitoisuus altaan luusuassa voidaan nyt laskea kaavasta

$$
c_{P}=\left(1-R_{P}^{*}\right) \frac{I_{P}}{Q}=1-0,9 \cdot\left(1+B \frac{Q}{I_{P} T}\right)^{-1} .
$$

Meriläinen \& Veijola (1985) sovelsivat tätä menetelmää maaveteen tasapainotilanteessa. Heillä oli käytettävissään purohavaintopaikkojen virtaama- ja pitoisuushavaintoja. Pitoi-

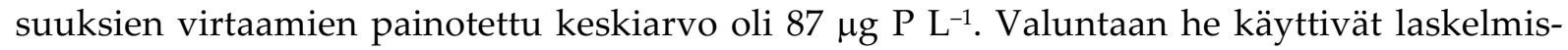
saan arvoa $0,45 \mathrm{~m}^{3} \mathrm{~s}^{-1}$, jolloin he saivat maaveteen kohdistuvaksi fosforikuormaksi $1200 \mathrm{~kg}$ vuodessa. He laskivat pidätyskertoimen maaveden kahdella eri keskisyvyydellä (1,5 m ja 2,0 $\mathrm{m})$ ja niitä vastavilla viipymillä (20 kk ja $26 \mathrm{kk})$ ja saivat pidätyskertoimiksi $R_{P}^{*}=0,80$ ja $R_{P}^{*}=$ 0,78. Maaveden luusuan fosforin keskipitoisuuksiksi saatiin näin $17 \mu \mathrm{g} \mathrm{P} \mathrm{L}^{-1}$ ja $20 \mu \mathrm{g} \mathrm{P} \mathrm{L}^{-1}$.

Pitoisuusyhtälön (8.4) ratkaisu voidaan esittää myös ajan mukaan kehittyvänä eli dynaamisena. Tällöin saadaan

$$
c(t)=c_{P}-\left(c_{P}-c_{0}\right) \exp \left[-\left(\frac{Q}{V}+K\right) t\right]
$$

missä $c_{0}$ on altaan ainepitoisuus alkutilanteessa, $c_{P}$ on vakaan tilan arvo, kun $t \rightarrow \infty$, ja $K$ on sedimentaatiokerroin. Muut altaan sisäiset prosessit on jätetty huomiotta. Kokonaisfosforin tilavuuden sedimentaatiokertoimen arvona on käytetty suomalaisissa järvissä $K=1 \cdot 10^{-6} \mathrm{mg}$ $\mathrm{P} \mathrm{m}^{-3} \mathrm{~s}^{-1}$. Malve (2007) on kehittänyt CSTR-malliin pohjautuvan tilastomatemaattisen LLR/ Lakestate-mallin, jossa ennustetulos voidaan esittää todennäköisyysjakaumana. Mallia voidaan käyttää esimerkiksi järvien kuormitusvähennystavoitteiden kustannustehokkaaseen ar- 
viointiin sekä ekologisen luokittelun todennäköisyyksien laskemiseen (kuva 8-12). CSTRhydrauliikka soveltuu mataliin järviin, jotka eivät kerrostu, sekä pitkän aikavälin keskiarvotarkastelujen kyseessä ollessa järviin, joissa esiintyy säännöllisesti täyskiertoja.

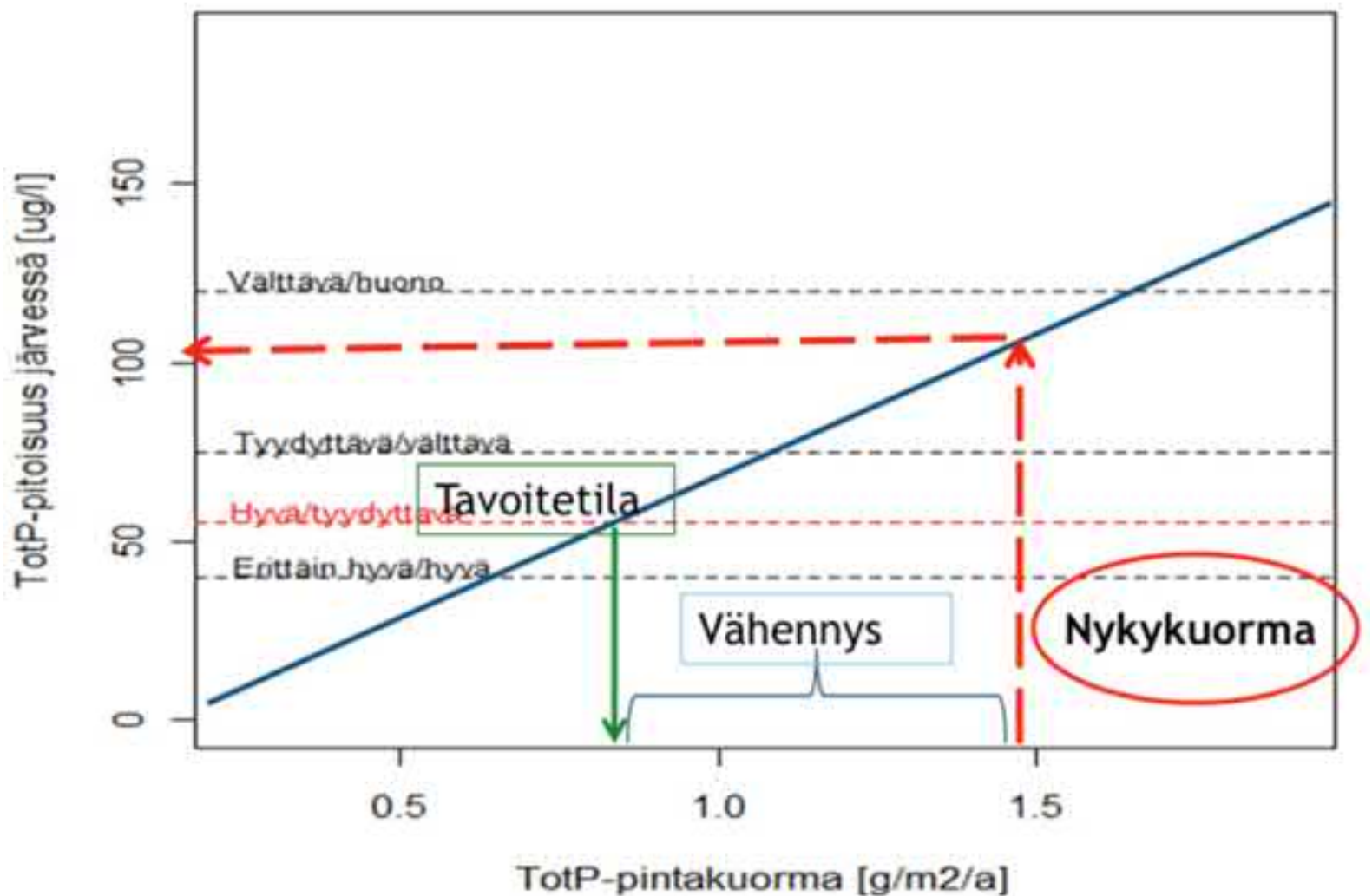

Kuva 8-12. LLR-kuormitusvaikutusmallin esimerkkitulos kokonaisfosforikuormituksen (TotP) keskimääräiselle vähennystavoitteelle. Tavoitetila määräytyy järvityyppikohtaisesti ekologisten luokkarajojen perusteella (hyvä/tyydyttävä raja).

Tulppavirtaus (Plug Flow Reactor, PFR) on täysin päinvastainen CSTR-kuvaukseen verrattuna. Tulppavirtaushydrauliikassa ei sekoittumista oleteta tapahtuvan ollenkaan, vaan aine kulkee virtauksen mukana. Siinä pitoisuusyhtälö ratkaistaan matkan $(x)$ suhteen ja ratkaisuksi saadaan

$$
c(x)=c_{0} \exp \left(-\frac{k x}{\langle u\rangle}\right),
$$

missä $k$ on aineen vähenemisvakio systeemistä (esimerkiksi hajoaminen) ja $<u>$ on keskimääräinen virtausnopeus uomassa. Ratkaisussa on sovellettu aineen häviämiseen ensimmäisen kertaluokan kinetiikkaa, jossa aineen väheneminen on suoraan verrannollinen sen pitoisuuteen. Kertoimelle $k$ on olemassa eri aineiden laboratorio- ja kenttäkokeisiin perustuvia arvoja. Tulppavirtaushydrauliikka soveltuu pääasiassa jokiin, mutta sitä on käytetty myös pitkänomaisissa järvissä esimerkiksi virtaavan päällysveden kuvaamiseen talvioloissa.

CSTR- tai tulppavirtauslaskenta ei riitä, kun halutaan tarkastella aineiden pitoisuuksien vaihtelua moniosaisessa järvi- tai jokisysteemissä tai kun halutaan tuloksia aineiden lyhytaikaisista vaihteluista. Jokisysteemiä tarkastellaan yleensä yksiulotteisena, kun taas järveä ja merialuetta tarkastellaan kaksi- tai kolmiulotteisena. Tällöin useimmiten sovelletaan advektio-dispersio-malleja, joissa tarkastellaan kuljetuksen eli advektion ja sekoittumisen eli dispersion aiheuttamaa siirtymistä. Advektio on aineen kulkeutumista virtauksen mukana, ja 
dispersio on molekyylisestä ja turbulenttisesta diffuusiota, joka pyrkii tasoittamaan pitoisuuseroja.

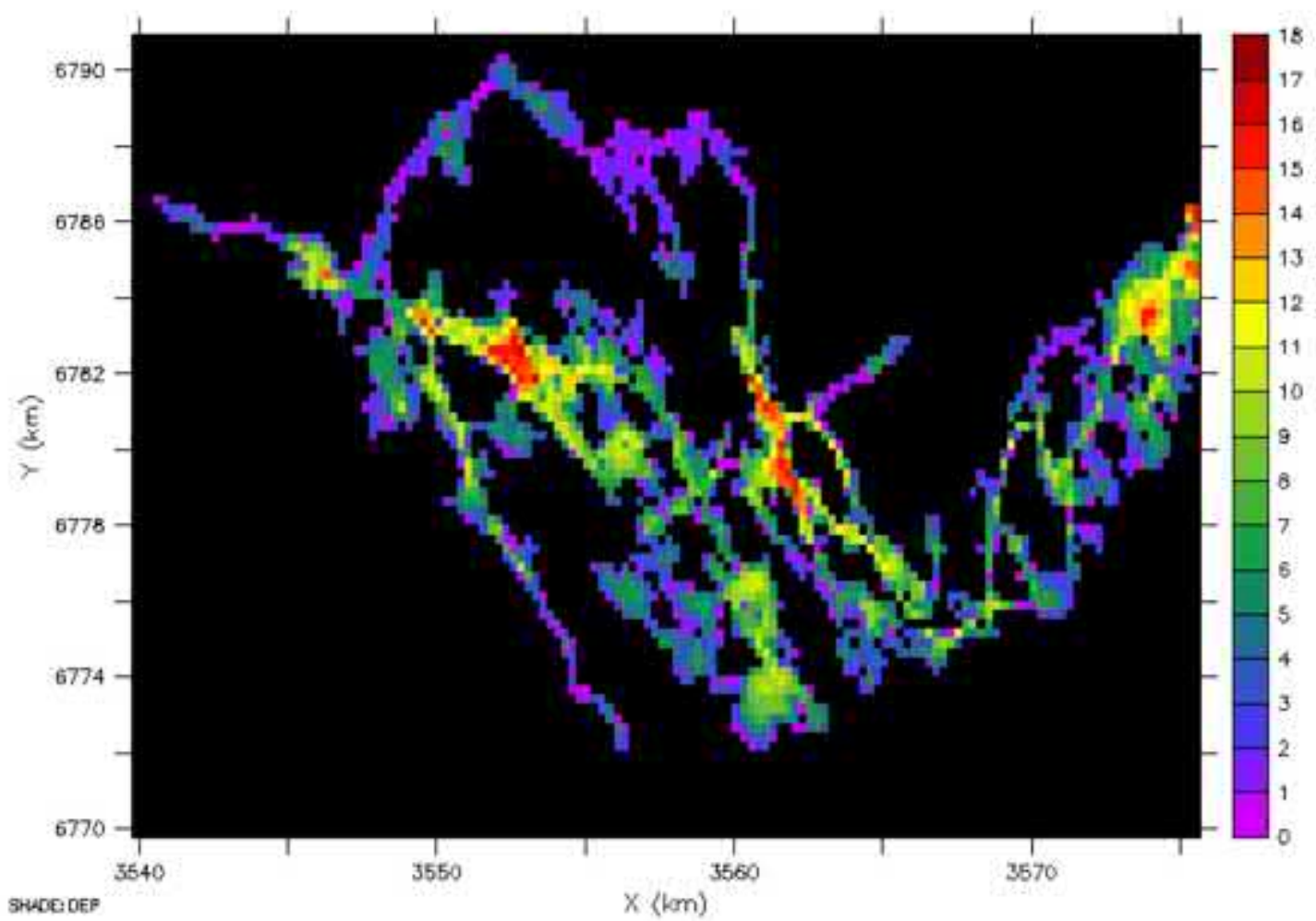

Maavesi

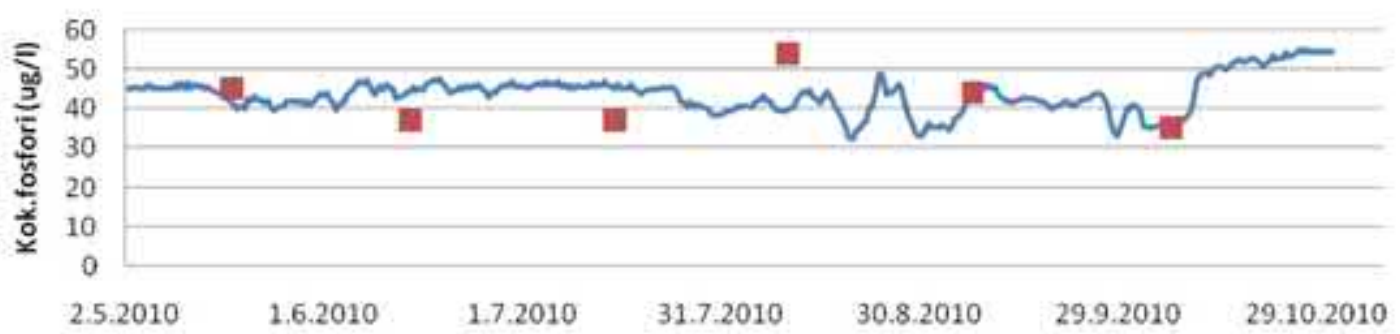

Kuva 8-13. Esimerkki 3-ulotteisen Coherens-mallin sovelluksesta. YIhääll̈ mallin sovellusalueen hilakartta, jossa värit kuvaavat veden syvyyttä $(\mathrm{m})$. Alhaalla laskentatulos (sininen viiva) ja havaintoja alueen pohjoisosasta Maavedeltä. Lähde: Liukko \& Huttula (2013).

Virtausmalleihin voidaan liittää jonkin aineen pitoisuutta $c=c(\boldsymbol{x}, t), \boldsymbol{x}=(x, y, z)$, alueella $\Gamma$ kuvaava advektio-diffuusio yhtälö

$$
\frac{\partial c}{\partial t}+\boldsymbol{u} \cdot \nabla c=\nabla \cdot(D \nabla c)+\psi(c, T, \cdots)
$$

missä $\boldsymbol{u}=(u, v, w)$ on virtausnopeus, $D$ on diffuusiokerroin, ja $\psi$ sisältää pitoisuuden biogeokemialliset muutokset, jotka riippuvat myös lämpötilasta $T$ ja muista veden ominaisuuksista. Yhtälön (8.10a) vasemmalla puolella on pitoisuuden paikallinen muutos sekä advektio ja oikealla puolella on diffuusio sekä biokemiallisten prosessien aiheuttama pitoisuuden muuttuminen. Vertikaalisen virtauksen seurauksena voi seurata laskeutuminen altaan pohjalle. Biogeokemiallisiin prosesseihin sisällytetään yleensä aineen hajoaminen, biologinen hengi- 
tys, vuorovaikutus pohjan kanssa, ilmastuminen yläpinnalla ja hapettomuuden aiheuttamat prosessit (esimerkiksi fosforin vapautuminen pohjalla). Avoimilla reunoilla yhtälön reunaehto kuvaa aineen pitoisuuden muuttumista sisään- tai ulosvirtauksen mukana:

$$
\boldsymbol{x} \in \partial \Gamma: \frac{\partial c}{\partial t}=c \frac{\partial u}{\partial \boldsymbol{n}}
$$

missä $\partial \Gamma$ on alueen reuna ja $\boldsymbol{n}$ sen normaali.

Yleisimmin käytettyjä vedenlaatua kuvaavia muuttujia näissä malleissa ovat happipitoisuus, ravinnepitoisuudet (fosfori ja typpi) sekä $a$-klorofylli (kuva 8-13). Biogeokemiallisissa reaktioissa sovelletaan lämpötilakorjausta ja Michaelis-Menten reaktiokinetiikkaa $a$-klorofyllin kasvun ja hajoamisen kuvauksessa. Siinä esimerkiksi $a$-klorofyllin kasvunopeus on lineaarisesti riippuvainen ravinnepitoisuuksista suurilla pitoisuuksilla tiettyyn rajoittavaan ylärajaan saakka. Valon vaikutusta kuvataan samalla lailla rajoitusfunktion avulla. Lämpötilan, valon ja ravinteiden yhteisvaikutus saadaan kertomalla kunkin osan rajoitustermit. Sama käsittely tehdään respiraatiolle ja muille laskennassa mukana oleville oleellisille prosesseille. Mallin kalibroimiseen ja validoimiseen eli toimivuuden vahvistamiseen tarvitaan ajan suhteen edustava joukko pitoisuusnäytteitä järven eri osista, jotta laskettujen tulosten ajallinen ja paikallinen vaihtelu voidaan todeta oikeiksi. 


\section{Hydrologia ja tulevaisuus}

Tässä kirjassa on esitetty hydrologian perusteet painottaen Suomen olojen keskeisiä kysymyksiä. Kirjan sisältöön kuuluu luonnonvesien fysikaalisten ja laadullisten ominaisuuksien esittely, hydrometeorologia, järvien ja jokien hydrologia ja geohydrologia. Veden kiertokulku peruskäsitteineen esitettiin ensin yleisesti, yksityiskohtia lisättiin vähitellen, ja kokonaiskuva seurasi valuntaa ja valuntamalleja käsittelevässä luvussa. Tavoitteena on ollut tarjota tieto- ja oppikirja hydrologian parissa aloittelevalle.

Vesi käy maapallolla ikuista kiertokulkua. Sitä haihtuu maapallon pinnalta ilmakehään, kulkeutuu vesihöyrynä ilmakehän kiertoliikkeen mukana ja palautuu takaisin sateena (kuva 9-1). Vesi puhdistuu kiertäessään ilmakehän kautta, sillä haihdunta siirtää ilmakehään vain vesimolekyylejä. Maahan langettuaan sadevesi kulkeutuu valuntana pinta- ja pohjavesiin ja lopulta meriin haihtuen matkalla tai merestä taas ilmakehään. Veden kiertokulussa maapallon vesien kokonaismäärä säilyy. Vähäistä vuotoa tapahtuu maapallolta lähiavaruuteen, mutta toisaalta komeetat tuovat tilalle uutta vettä.

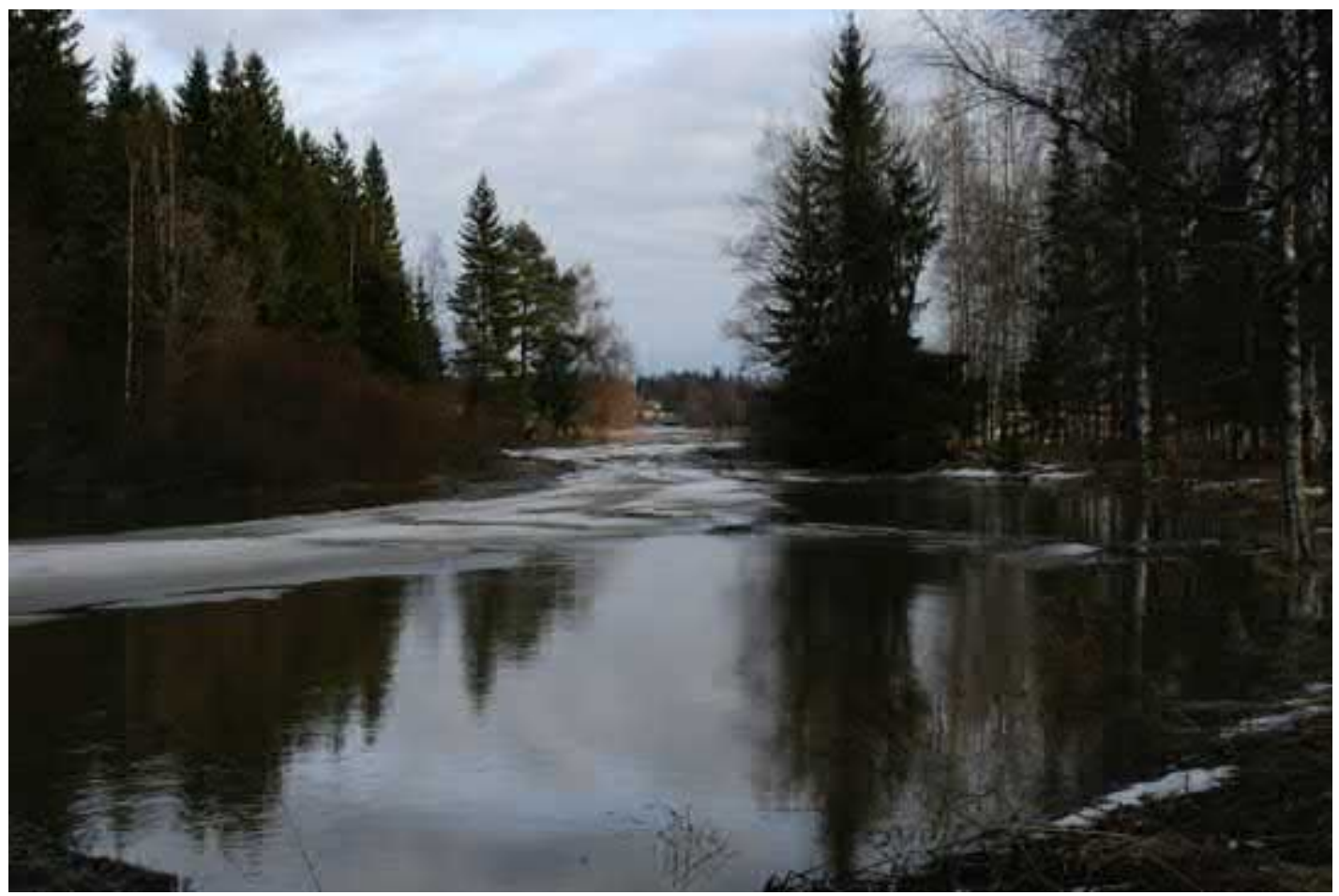

Kuva 9-1. Joet ovat veden kierron tärkeitä kuljettajia. Niiden jäänlähtö on aina vaikuttava tapahtuma. Vanhin hydrologinen aikasarjamme on Tornionjoen jäänlähdöstä, alkaen vuodesta 1696. Kuvassa Kaanaanjoki, Mäntsälä. Kuva: Matti Leppäranta.

Vettä kulkee biosfäärin ja ihmiskäsien lävitse. Maanpinnalla, pintavesissä ja maaperässä veteen liukenee vieraita aineita ja sekoittuu partikkeleita, jotka kulkevat eteenpäin veden mukana. Veden laatu ja sen käyttökelpoisuus muuttuvat. Ympäristökuormitus tuo vesiin haitallisia aineita, ja ilmaston muuttuminen vaikuttaa vesivarojen määrään ja lämpötilaan.

Makean, haitallisista aineista puhtaan veden saatavuus on elämän välttämätön edellytys. Puhtaan veden jakautuminen maapallolla ei ole tasaista, mikä on aiheuttanut ja tulee aiheuttamaan suuria taloudellisia ja poliittisia ongelmia. Suomessa vesivarat ovat riittävät, mutta 
meilläkin vesivarat ovat epätasaisesti jakautuneet, ja niinpä esimerkiksi pääkaupunkiseudun talousvesi on tuotava yli $100 \mathrm{~km}$ pitkää Päijänne-tunnelia pitkin. Vesien laatu on tullut alati tärkeämmäksi ja sen ylläpito tarvitsee nykyistä voimakkaampia toimenpiteitä.

Ihmistoiminnan suurimmat vedenkäyttäjät ovat maatalous ja teollisuus. Maatalouden tehostaminen on lisännyt kastelujärjestelmien rakentamista ja se on paikoin johtanut veden ylikäyttöön niin, että muualla on kärsitty veden puutteesta. Teollisuus tarvitsee vettä ennen kaikkea energiantuotantoon ja jäähdytykseen. Vesiteitä on myös käytetty kuljetukseen vuosituhansien ajan ja sen takia on rakennettu vesistöjen välisiä kanavajärjestelmiä. Kalastus on hyödyntänyt järvien ja jokien resursseja, vaikka nämä ovatkin paljon vähäisemmät kuin merissä. Viime vuosikymmeninä myös matkailuelinkeino ja virkistystoiminta ovat tulleet kasvavasti mukaan vesivarojen hyötykäyttäjiksi, mikä on asettanut vaatimuksia vesivarojen hyvän laadun ylläpitämiselle (kuva 9-2).

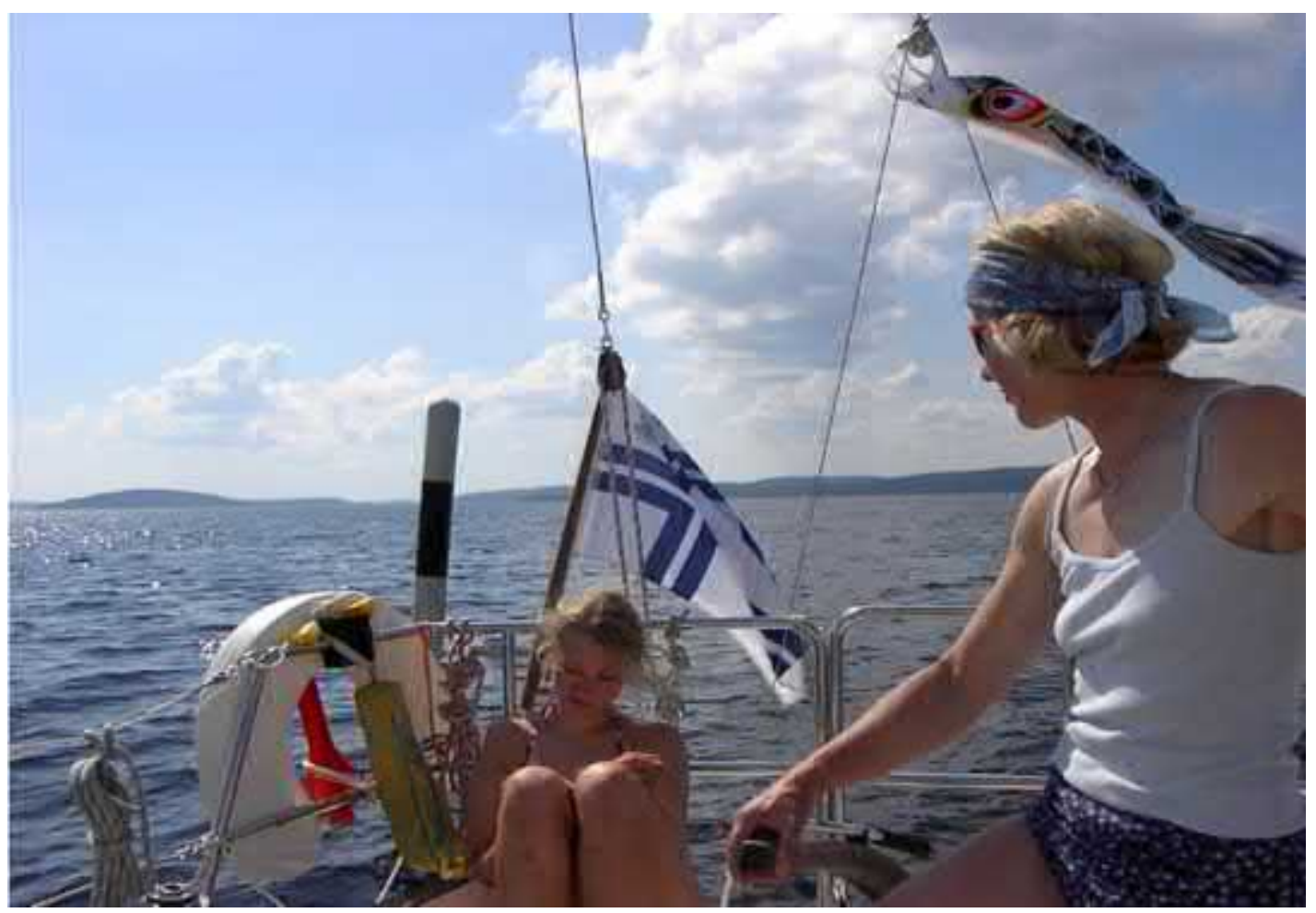

Kuva 9-2. Vesien virkistyskäyttö on voimakkaasti lisääntymässä. Kesäpäivä purjeveneessä Päijänteellä. Kuva: Matti Leppäranta.

Veden kierrossa esiintyy puutteen lisäksi myös runsauteen liittyviä ongelmia. Rankkasateiden ja suurten jokivirtaamien aiheuttamat tulvat ovat näistä merkittävimmät inhimillisissä ja taloudellisissa mitoissa tarkasteltuina. Runsaat sateet aiheuttavat esimerkiksi maanvyöryjä muuttaessaan maaperän fysikaalisia ominaisuuksia. Myös lumi ja jää voivat aiheuttaa vakavia ongelmia. Jokien jääpadot aiheuttavat vuosittain tulvia eri puolella Suomea, muun muassa Pohjanmaalla. Ilmaston muuttuessa ja talvien lauhentuessa supon aiheuttamien tulvien määrä lisääntynee eteläisessä Suomessa, kun joet eivät enää saa pysyvää jääpeitettä. PohjoisAmerikassa ajoittain esiintyvät 'jäämyrskyt' [ice storms] vahingoittava metsiä ja rakenteita ja haittaavat liikennettä. Näissä myrskyissä pohjoisesta kulkeutuu kylmää ilmaa ja sen mukana alijäähtyneitä vesipisaroita, jotka jäätyvät herkästi erilaisiin pintoihin. Ääritilanteessa vuonna 1998 Montrealin kaupunki oli viisi päivää ilman sähköä. 
Haitalliset aineet aiheuttavat ongelmia sekä pinta- että pohjavesissä. Ne voidaan jakaa ensi kädessä myrkkyihin ja ravinteisiin. Edelliset vahingoittavat vesien ekosysteemejä ja ovat uhkatekijä paikalliselle talousveden käytölle. Ravinteiden päästöistä on seurannut laaja-alaisia ongelmia niiden tapahtuessa sekä taajamien pistekuormituksina että maatalouden hajakuormituksena. Rehevöityminen on muodostunut erityisesti järvien suureksi ympäristökysymykseksi. Mikrobien huuhtoutuminen on myös ongelma. Suomessa on varsinkin kevättalvella erilaisia ripuliepidemioita, joiden syy on osittain epäselvä.

Vesirakentamisesta ja säännöstelystä sekä vesien muusta hyötykäytöstä ja suojelusta on noussut monenlaisia kiistakysymyksiä. Jokivarsien vesivoimalat rajoittavat lohikalojen nousua, mistä on seurannut pitkäaikaisia oikeudellisia prosesseja kuten Kemijoella 1950-luvulta lähtien. Viime aikoina erilaisia kalateitä onkin rakennettu $\mathrm{mm}$. Oulujoelle ja lisää hankkeita on tulossa kalojen nousun mahdollistamiseksi. Pienimpien voimaloiden kohdalla on jopa puhuttu niiden purkamisesta kalojen nousun edistämiseksi (esimerkiksi Vantaanjoki ja Hiittolanjoki). Vesiliikenteeseen on asetettu rajoituksia esimerkiksi kieltämällä moottoriveneily ja -kelkkailu. Järvien vesimassojen uusiutumisaika on Suomessa yleensä kuukausista useisiin vuosiin, mutta pelkästään vedenvaihto ei riitä tilan korjaamiseksi, sillä pohjasedimenttiin on kerrostunut haitallisia aineita, jotka voivat vielä vapautua vesirunkoon. Tunnetuimpia tällaisia kohteita ovat puunjalostusteollisuuden alapuoliset vedet, joissa on paljon ns. nollakuitua, jota ei ole saatu puhdistettua pois jätevesistä.

Pohjavesien tila on sangen tärkeä niiden hyvän talousvesikelpoisuuden takia. Teollisuusmyrkkyjen lisäksi suuri uhkatekijä on teiden suolaus, jota onkin rajoitettu useilla alueilla. Kaivostoiminta on yksi merkittävä pohjavesien uhkatekijä. Suurimpia viime vuosien vesivaroihin kohdistuneita onnettomuuksia on ollut Talvivaaran kaivos. Kotitalouksien vesien puhdistuksella ja esimerkiksi lääkejätteillä on myös suuri merkitys.

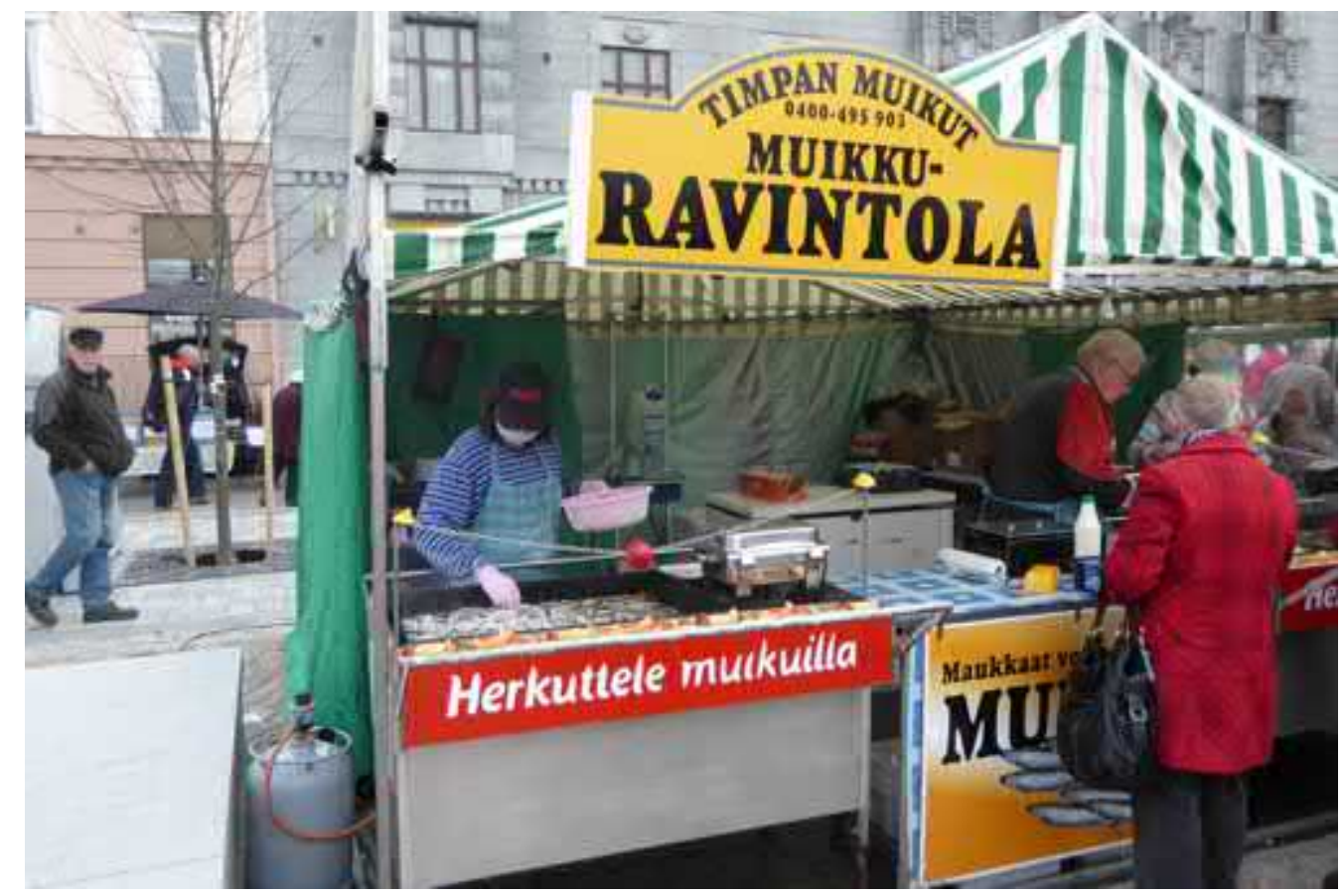

Kuva 9-3. Järviemme kalakannan hyödyntäminen on jäänyt valitettavan alhaiseksi. Muikku tokin pitää hyvin pintansa. Kuva: Matti Leppäranta.

Monien keskeisten järvien jokien suojelemiseksi on syntynyt säätiöitä ja yhdistyksiä kansalaistoiminnan tuloksena. Vanhin näistä on vuonna 1989 perustettu Pyhäjärvi-instituuttisäätiö 
(Eura), muita ovat esimerkiksi Vesijärvisäätiö (Lahti) ja Vanajavesisäätiö (Hämeenlinna). Jokien parissa tällaista toimintaa on ollut vähemmän, mutta ainakin Kymijoen vesi ja ympäristö yhdistys harjoittaa vastaavaa toimintaa. Järvien hyvän tilan ylläpitäminen edistää paikallisen väestön hyvinvointia, kalastusta, matkailuelinkeinoja ja luonnon ekologista tasapainoa (kuva 9-3).

Ilmaston luonnollinen vaihtelu on suurta ja kaoottista. Siitä löytyy säännöllisiä, kymmeniä tuhansia vuosia pitkiä Milankovićin jaksoja ${ }^{1}$ sekä epäsäännöllisiä vaihteluita kuten Pohjois-Atlantin värähtely (North Atlantic Oscillation, NAO) ja Tyynellä valtamerellä eteläinen värähtely (El Niño - Southern Oscillation, ENSO). NAO kuvaa Atlantilta tulevien länsituulten voimakkuutta ja tuntuu Euroopan alueella voimakkaasti. Sen vuoksi erityisesti talvien keskilämpötiloissa on suuri luonnollinen vaihtelu: meillä talvi voi olla lauha ja länsituulinen tai toisaalta kylmää mantereista ilmaa voi puhaltaa idästä pitkin talvea. Kuvaavana esimerkkinä on Helsingin keskilämpötila 1900-luvulla: kylmimmän tammikuun keskilämpötila oli $-17{ }^{\circ} \mathrm{C}$ ja lämpimimmän $+1{ }^{\circ} \mathrm{C}$.

Ihmisen mahdollista vaikutusta ei ole helppo erottaa ilmaston luonnollisesta vaihtelusta. Kansainvälisen ilmastonmuutoksen paneelin (IPCC) konsensus pohjautuu alan tutkijoiden valtaosan näkemyksiin ja sitä pidetään yleisesti parhaana saatavilla olevana ennusteena. On kuitenkin syytä tähdentää, että on tutkijoita, jotka eivät yhdy tähän ja pitävät ihmisen vaikutusta vähäisenä.

Maapallolle tulevan auringonsäteilyn ja siitä lähtevän lämpösäteilyn välillä on merkittävä ero. Auringonsäteily on lyhytaaltoista $(0,3-3 \mu \mathrm{m})$, ja maapallon avaruuteen lähettämä lämpösäteily on pitkäaaltoista $(5-50 \mu \mathrm{m})$. Ilmakehän kasvihuonekaasut toimivat samaan tapaan kuin kasvihuoneen lasikatto: ne päästävät auringonsäteilyn maan pinnalle mutta estävät osaa maapallon lämpösäteilystä karkaamasta pois. Näiden kaasujen aiheuttama kasvihuoneilmiö pitää planeettamme keskilämpötilan suotuisana elämälle. Merkittävimmät kasvihuonekaasut ovat vesihöyry, joka aiheuttaa noin 36-70 \% kasvihuoneilmiöstä, hiilidioksidi (9$26 \%$ ), metaani (4-9 \%) sekä otsoni (3-7\%). Hiilidioksidipitoisuudet ilmakehässä ovat lisääntyneet $31 \%$ ja metaanipitoisuudet $149 \%$ esiteollisiin tasoihin nähden vuoden 1750 jälkeen. Nykykäsityksen mukaan hiilidioksidin kaksinkertaistamisen vaikutus maapallon keskilämpötilaan on $2,0-4,5^{\circ} \mathrm{C}$ (IPCC, 2007).

Vuosina 1906-2005 maapallon lämpötilan keskimääräinen nousu oli $0,74{ }^{\circ} \mathrm{C}$ sadassa vuodessa. Viimeksi kuluneiden 50 vuoden aikana lämpötilan nousunopeus on ollut satavuotiseen trendiin verrattuna lähes kaksinkertainen, $0,13^{\circ} \mathrm{C}$ vuosikymmenessä. Arviot lämpötilan tulevasta noususta tällä vuosisadalla vaihtelevat laajasti: $1,1-6,4{ }^{\circ} \mathrm{C}$ vuosien $1980-1999$ keskiarvoon verrattuna. Vaihtelu johtuu useista seikoista. Ilmastojärjestelmän toimintaa ei vielä tunneta kaikin osin kovinkaan tarkasti, ja arviointia hankaloittaa myös ihmisen toiminnan heikko ennustettavuus. Päästöjen kehitysarviot vaihtelevat suuresti johtuen muun muassa erilaisista näkymistä koskien väestönkasvua ja energiantuotannon kehitystä. Pienempiin päästöihin perustuva skenaario antaa lämpenemisarvioksi vuoteen 2100 mennessä $1,8{ }^{\circ} \mathrm{C}$. Suurimman päästöskenaarion toteutuessa lämpenemisen todennäköisin arvio on $4,0^{\circ} \mathrm{C}$ ja maksimiarvio $6,4{ }^{\circ} \mathrm{C}$.

IPCC on raportoinut myös sademäärien ja tuulten pitkän aikavälin muutoksista. PohjoisEuroopassa sademäärät kasvoivat merkittävästi vuosina 1900-2005. Nykyisen todennäköisen ilmastoskenaarion mukaan sademäärän odotetaan Suomessa pysyvän vuositasolla ennal-

\footnotetext{
${ }^{1}$ Milankovićhin jaksot seuraavat Maan akselin kaltevuuden ja Maan kiertoradan jaksollisista vaihteluista.
} 
laan, mutta sen jakautuma vuodenaikojen mukana muuttuisi niin, että talvet muuttuisivat sateisimmiksi ja kesät kuivemmiksi.

Mikäli ennustettu (IPCC) ilmastonmuutos toteutuu, sillä on merkittäviä vaikutuksia veden kiertokulkuun. Välitön seuraus on pintavesien lämpötilan kasvu, kuten maanpinnan lämpötaseesta on helposti todettavissa. Tämä vaikuttaa järvien vesirungon kesäajan kerrostuneisuuteen ja alusveden happivaroihin sekä korkeilla leveysasteilla kuten Suomessa jäätalven pituuteen, erityisesti jäiden lähtöä aikaistaen. Lämpötilan kasvu lisää myös leväkukintoja ja edesauttaa pintavesien rehevöitymistä (kuva 9-4). Pohjavesissä lämpenemisen vaikutus näkyy hitaasti, mutta lopulta tuloksena voi olla virtauskentän muutoksia alentuvan viskositeetin takia.

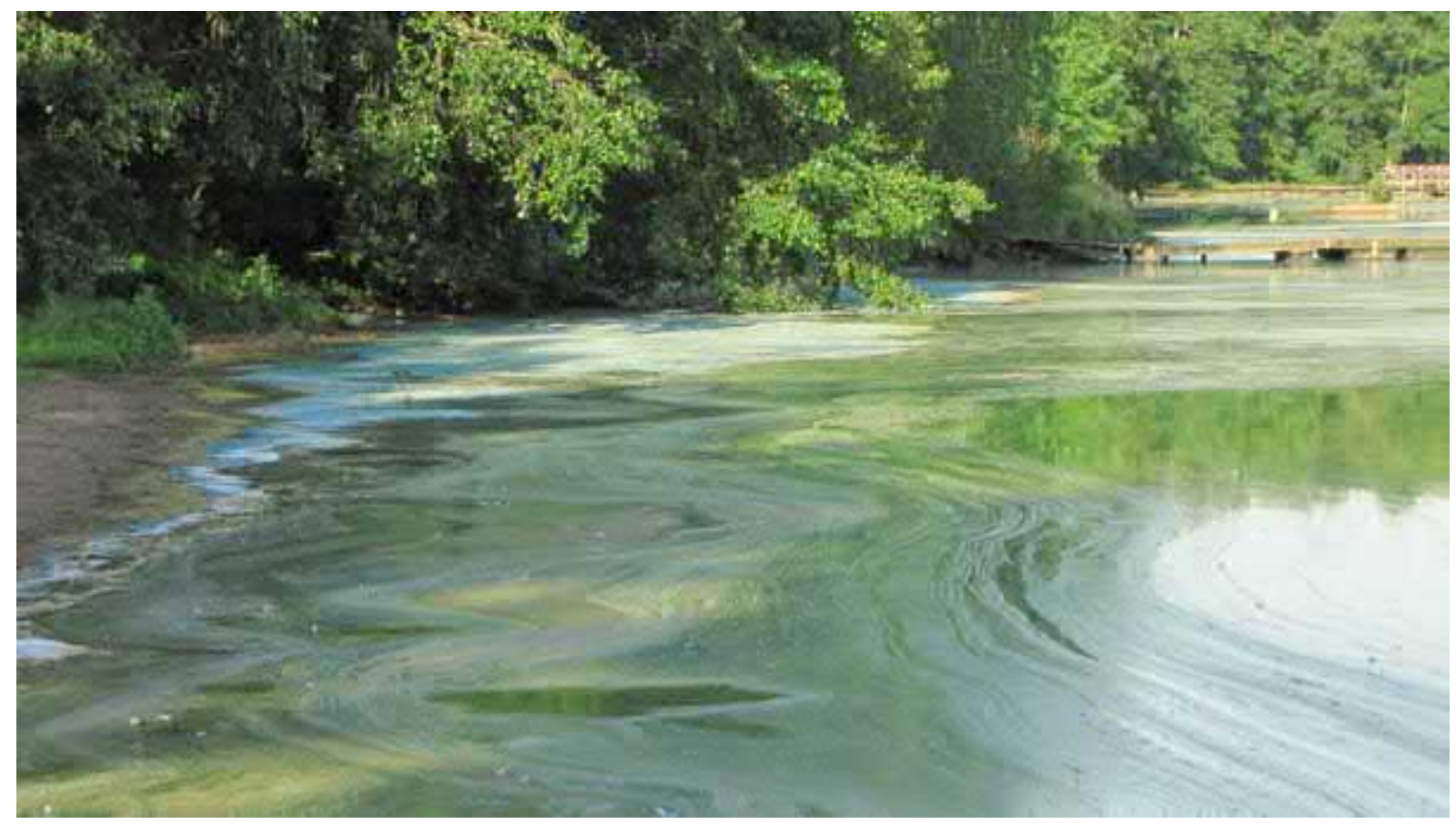

Kuva 9-4. Järvien rehevöityminen on johtanut usein esiintyviin runsaisiin leväkukintoihin. Kuva: Jouko Sarvala.

Talven lyhentyessä toisaalta kevättulvat pienenevät, jos lunta kertyy vähemmän, mutta toisaalta tulvia voi esiintyä keskellä talveakin leutoina jaksoina. Lumen kertyminen ja lumipeitteen ominaisuudet vaikuttavat voimakkaasti niin pintavesien kuin roudan kehitykseen. Kasvit ja eläimet voivat kohdata sopeutumisvaikeuksia lumiolosuhteiden muuttuessa, mutta lumiolosuhteiden muutoksia on vaikea ennustaa. Esimerkiksi porojen mahdollisuudet kaivaa jäkälää lumen alta voivat heikentyä.

Toinen ilmaston lämpenemisen välitön vaikutus ilmenee haihdunnan kasvuna, sillä ilman kyllästyskosteus kasvaa lämpötilan kasvaessa. Jos valuma-alueella on runsaasti pintavesiä, haihdunnan lisääntyminen pienentää vesivarastoa. Pohjavesivaroissa haihdunnan vaikutus voi ilmetä viivästyneenä. Haihdunnan muutos on sitä voimakkaampaa, mitä korkeampi lämpötila alunperin on. Koko vesistöalueella haihdunnan vesivarastoa vähentävä vaikutus voi kompensoitua vain sateiden lisääntymisenä. Sademäärän muutosten hydrologiset seuraukset ovat periaatteessa suoraviivaisia: mitä enemmän vettä, sitä suuremmat vesivarastot. Haihdunta kompensoi varaston kasvua, kun sateet ovat ensin kasvattaneet maaperän kosteutta. 
Onnistuuko ihmiskunta vähentämään päästöjä, on joka tapauksessa tulevaisuuden avainkysymys. Periaatteessa ilmaston mahdollisen lämpenemisen haitallisuus tai hyödyllisyys on aluekohtaista, mutta nopean lämpenemisen aiheuttama katastrofi tulisi tuntumaan globaalisesti. Ilmastonmuutoksesta riippumatta luonnonvesien laadun ja ekologisen tilan ylläpitäminen ja parantaminen ovat tärkeitä tulevaisuuden kysymyksiä. Hyvin hoidettujen vesistöjen laatu ja virkistyskäyttö tuovat positiivista takaisinkytkentää niiden hoidolle (kuva 9-5).

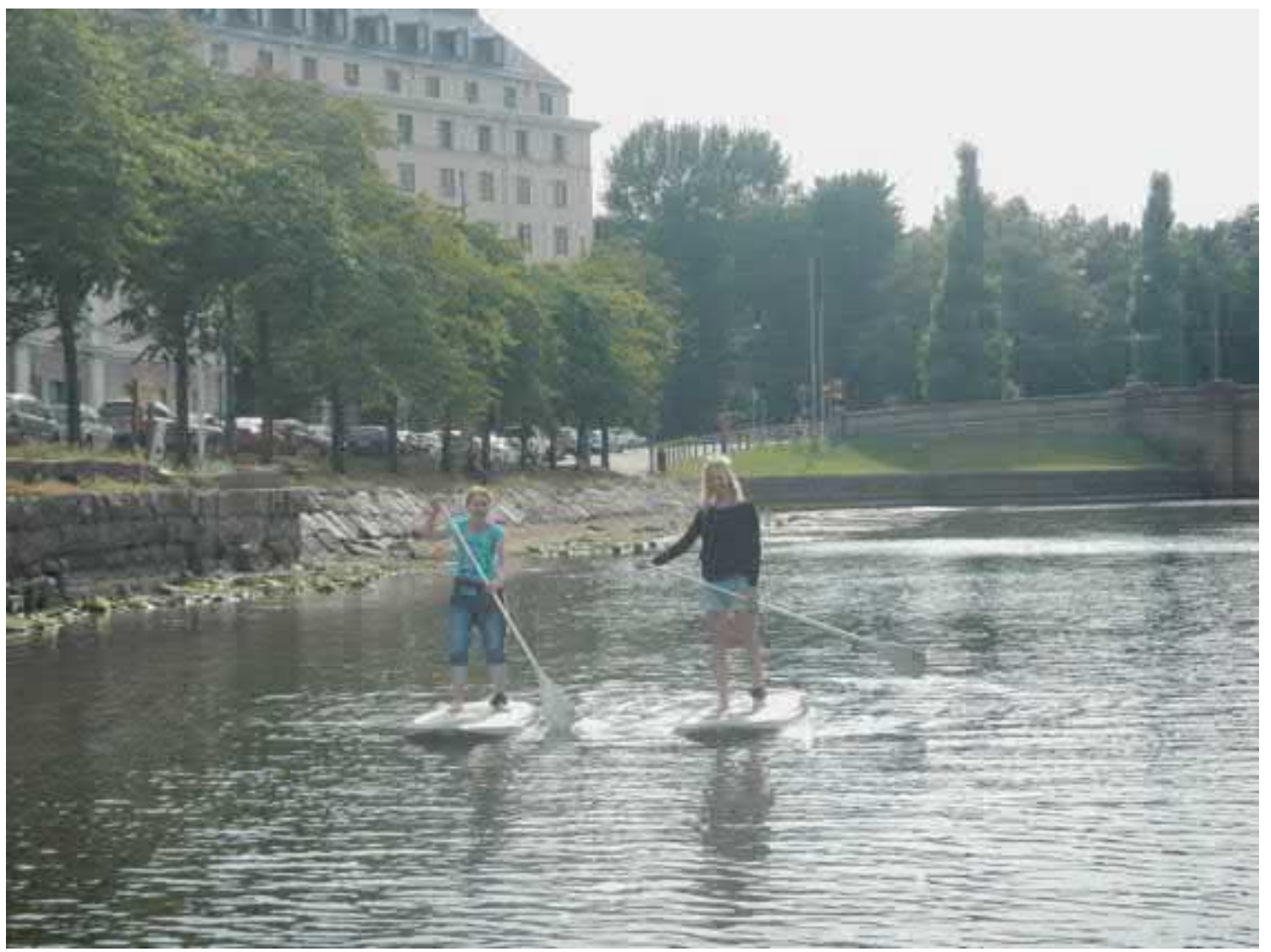

Kuva 9-5. Vesien virkistyskäyttö on laajentunut ja sillä on suuri merkitys pakallisen väestön ja matkailuelinkeinon kannalta. Tuoreimpia harrastuksia on suppaamien, jossa laudan päällä melotaan seisten ('suppaaminen tulee englanninkielisestä termistä 'stan-up paddle boarding'). Kuva: Petriina Köngäs.

Hydrologian voidaan odottaa pysyvän keskeisenä geofysiikan alana, sillä vesi hallitsee elämäämme hyvin voimakkaasti. Havainto- ja laskentateknologian kehittyminen jatkaa kulkuaan ja tuottaa yhä parempia tutkimus- ja seurantamenetelmiä sekä matemaattisia malleja. Veden kiertokulun fysiikka tunnetaan hyvin, mutta kiertokulun ympäristölliset tekijät ja pakotteet sen sijaan vaativat vielä paljon tarkentamista. Mallintamisessa erityisesti suuremmalla laskentateholla voidaan huomioida maaperän koostumus ja ominaisuudet entistä tarkemmin. Vielä haasteellisempaa on mallintaa liuenneiden ainesten ja kiintoaineen kulkeutumista veden kiertokulun mukana.

Hydrologiassa tieteidenvälinen tutkimus lähialojen kanssa on lisääntymässä. Erityisesti ekologiassa vesi on kriittinen resurssi, ja ekologia ja vesivarat ovat myös keskinäisessä vuorovaikutuksessa. Hydrologialla on lisäksi kytkentöjä ihmiskunnan historiaan, sillä asutuskeskuksissa on aina tarvittu vettä. Hydrologista tietoa on jo käytetty arkeologisissa tutkimuksissa muinaisia vesihuoltojärjestelmiä tarkasteltaessa. Planetaarisen geofysiikan alalla vesivarojen saatavuus maapallon ulkopuolella on myös yksi suurista tulevaisuuden kysymyksistä. 
Toistaiseksi hyödyntämättömiä vesivaroja on mannerjäätiköissä, mutta niiden etäisyys asutuskeskuksista on suuri käytännöllinen ongelma. Jäävuorien hinaamista veden puutteesta kärsiville alueille tutkittiin 1980-luvulla, jolloin se todettiin taloudellisesti kannattamattomaksi. Jäävuoret haurastuvat ja murenevat tullessaan lämpimiin vesiin. Niin ikään meriveden kemiallinen makeuttaminen ei vielä ole laajassa mitassa kannattavaa, vaikka sitä tehdäänkin paikallisesti useilla alueilla.

Vesivarat ja niiden hallittu käyttö sekä laadun ylläpitäminen ovat ihmiskunnan suurimpia haasteita tällä vuosisadalla. Veden kokonaismäärä säilyy, mutta sen laatu voi ympäristönmuutosten takia heikentyä ja vesivarojen jakautuminen voi muuttua ilmastollisten olojen kehityksen mukana. Suurimmat välittömät uhkatekijät aiheutuvat ympäristöongelmista. Vesi on ihmiselle biologinen välttämättömyys, mutta se on merkinnyt myös kaipuuta, harmoniaa ja kauneutta. Veden äärellä oleminen on tuonut mielenrauhaa (kuva 9-6).

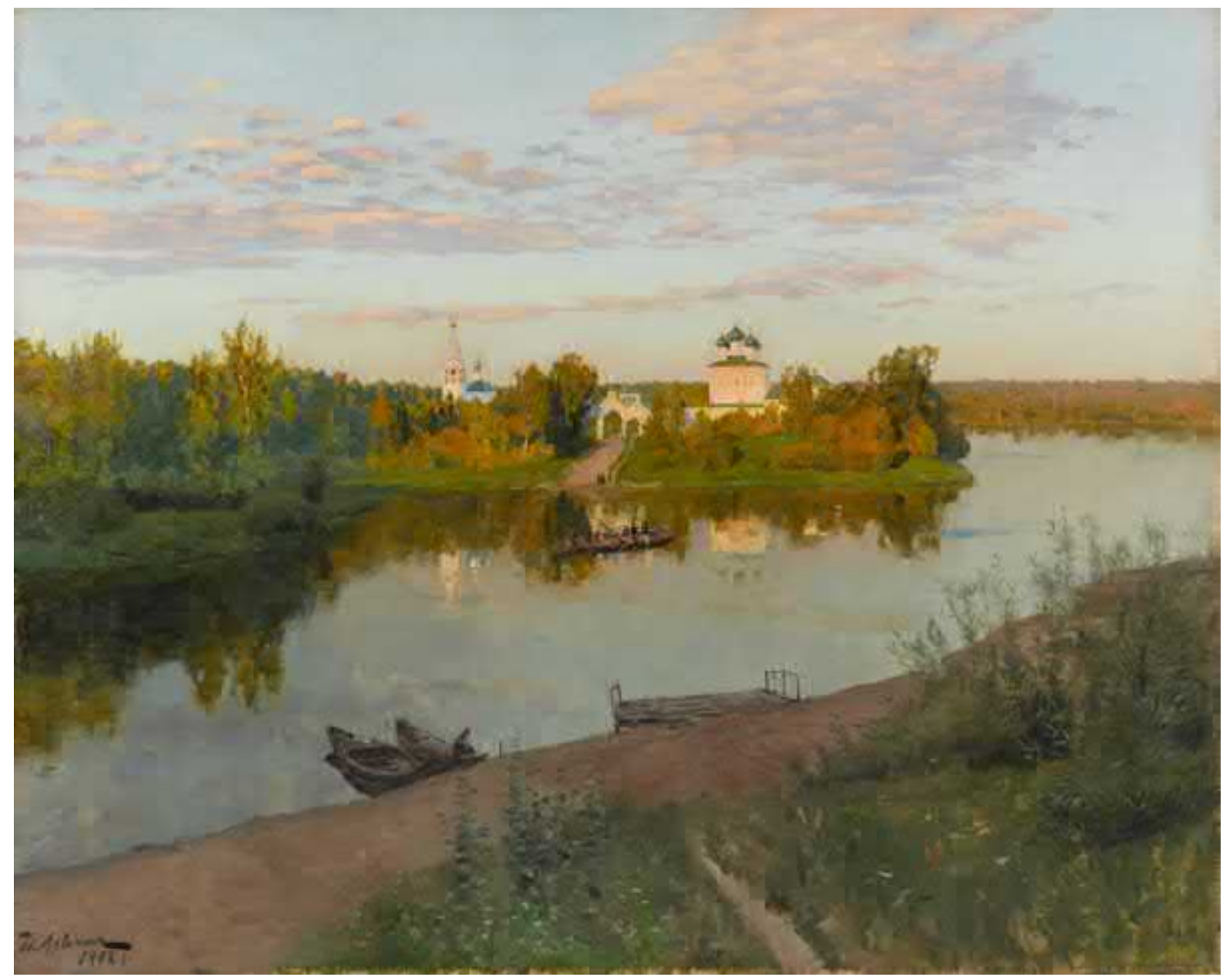

Kuva 9-6. Iltakellot, Isaak Levitan (1860-1900). Levitan oli liettualais-juutalainen kuuluisa taidemaalari, joka tunnettiin erityisesti naturalistisista maalauksistaan. (c) Tretjakovin taidegalleria, Moskova. 


\title{
MATEMATIIKKALIITE
}

\author{
ANNA-RIIKKA LEPPÄRANTA
}

\section{SISÄLTÖ}

1. Johdanto 1

2. Potenssit ja polynomit 1

2.1. Potenssien laskusääntöjä 1

2.2. Kymmenpotenssimuoto 3

2.3. Polynomifunktiot 3

3. Trigonometriset funktiot 5

3.1. Yksikköympyrä $\quad 7$

4. Eksponentti- ja logaritmifunktiot 9

4.1. Eksponenttifunktio 9

4.2. Logaritmit 10

5. Derivointi 12

5.1. Derivaatta 12

5.2. Osittaisderivaatta 15

6. Integrointi 16

6.1. Integraalifunktio 16

6.2. Määrätty integraali 17

6.3. Integrointimenetelmiä 20

7. Differentiaaliyhtälöt 22

7.1. Separoituvat differentiaaliyhtälöt 23

7.2. Ensimmäisen kertaluvun lineaariset differentiaaliyhtälöt 25 


\section{JohDANTO}

Tässä matematiikkaliitteessä esitellään tiiviisti hydrologiassa tarvittavia matemaattisia perustyökaluja. Liite on tarkoitettu avuksi lukion lyhyen matematiikan suorittaneille tai muuten matematiikan perusasioiden kertausta tarvitseville. Kaavojen johtamiset ja väitteiden todistukset sekä matemaattinen täsmällisyys on ainakin osittain sivuutettu. Lisätietoa ja matemaattista materiaalia löytyy runsaasti myös netistä. Näppäriä, helposti lähestyttäviä ja (tällä hetkellä 2017) ilmaiseksi netissä käytettäviä apuohjelmia matemaattiseen pohdiskeluun ovat esimerkiksi GeoGebra kuvaajien piirtämiseen ja Wolframalpha yhtälöiden ratkaisemiseen. Lisäksi Matlab on opiskelijoiden vapaasti käytettävissä Helsingin yliopiston tietokoneilla.

\section{Potenssit Ja POLYNomit}

\subsection{Potenssien laskusääntöjä.}

Potenssien laskusääntöjä tarvitaan muun muassa yksiköillä ja kymmenpotensseilla laskettaessa. Ne perustuvat potenssin määritelmään

$$
a^{n}=\underbrace{a \cdot a \cdot \ldots \cdot a}_{n \mathrm{kpl}} .
$$

Jos säännöt unohtuvat eikä niitä ole jostain syystä saatavilla, potenssit voidaan aina purkaa määritelmän mukaan kertolaskuiksi, jolloin sieventäminen on helpompaa. Seuraavat säännöt on hyvä osata esimerkiksi yksiköillä laskettaessa. Niitä voidaan käyttää molempiin suuntiin.

(1) $a^{m} \cdot a^{n}=a^{m+n}$

(2) $\frac{a^{m}}{a^{n}}=a^{m-n}$

(3) $(a b)^{n}=a^{n} b^{n}$

(4) $\left(\frac{a}{b}\right)^{n}=\frac{a^{n}}{b^{n}}$

(5) $\left(a^{m}\right)^{n}=a^{m n}$

(6) $a^{1}=a$

(7) $a^{0}=1, \quad$ kun $a \neq 0 . \quad 0^{0}$ ei ole määritelty.

(8) $a^{\frac{1}{n}}=\sqrt[n]{a}, \quad$ erityisesti $a^{\frac{1}{2}}=\sqrt{a}$.

(9) $(a+b)^{2}=a^{2}+2 a b+b^{2}$

(10) $(a-b)^{2}=a^{2}-2 a b+b^{2}$

(11) $(a+b)(a-b)=a^{2}-b^{2}$ 
Tekstissä käytetään usein negatiivisia eksponentteja jakoviivan sijasta, esimerkiksi $\mathrm{m} / \mathrm{s}=\mathrm{m} \mathrm{s}^{-1}$. Fysiikan suureilla laskettaessa vastauksen täytyy olla oikeassa yksikössä, mikä auttaa laskun tarkistamisessa.

Esimerkki 2.1.1. Yksiköillä laskeminen.

Paine lasketaan kaavalla $p=\rho g h$, missä $\rho$ on tiheys, $g$ on putoamiskiihtyvyys ja $h$ on syvyys. Jos kaavan avulla halutaan ratkaista syvyys, jaetaan yhtälö puolittain tekijällä $\rho g$ ja saadaan $h=\frac{p}{\rho g}$. Syvyyden yksiköksi pitäisi tulla metrejä. Lasketaan korkeus pelkillä yksiköillä, lisäselitykset alla. Hakasulkeet suureen tunnuksen ympärillä tarkoittavat kyseisten suureiden yksiköiden tarkastelua.

$$
\begin{aligned}
{[h]=\frac{[p]}{[\rho g]} } & =\frac{\mathrm{Pa}}{\mathrm{kg} / \mathrm{m}^{3} \cdot \mathrm{m} / \mathrm{s}^{2}} \stackrel{(1)}{=} \frac{\frac{\mathrm{kg} \cdot \mathrm{m} / \mathrm{s}^{2}}{\mathrm{~m}^{2}}}{\mathrm{~kg} / \mathrm{m}^{3} \cdot \mathrm{m} / \mathrm{s}^{2}} \\
& \stackrel{(2)}{=} \frac{\mathrm{kg} \cdot \mathrm{m} / \mathrm{s}^{2}}{\mathrm{~m}^{2}} \cdot \frac{1}{\mathrm{~kg} g / \mathrm{m}^{3} \cdot \mathrm{m} / \mathrm{s}^{2}}=\frac{1}{\mathrm{~m}^{2}} \cdot \frac{1}{1 / \mathrm{m}^{3}} \stackrel{(3)}{=} \frac{1}{\mathrm{~m}^{2}} \cdot \mathrm{m}^{3}=\mathrm{m}
\end{aligned}
$$

(1) Paineen yksikkö on Pa, joka täytyy saada perussuureiden yksiköistä koostuvaan muotoon eli samoihin yksiköihin, joita esiintyy tiheyden ja kiihtyvyyden yksiköissä. Paine lasketaan jakamalla voima pinta-alalla, ja voima kertomalla massa ja kiihtyvyys keskenään. Pyöritellään oikeat yksiköt esiin paineen laskukaavasta:

$$
[p]=\frac{[F]}{[A]}=\frac{[m][a]}{[A]}=\frac{\mathrm{kg} \cdot \mathrm{m} / \mathrm{s}^{2}}{\mathrm{~m}^{2}}
$$

(2) Jakolaskusta voi supistaa, jos osoittajassa ja nimittäjässä esiintyy vain kertolaskuja.

(3) Murtolukujen jakolasku = kerrotaan jakajan käänteisluvulla, $1: \frac{1}{\mathrm{~m}^{3}}=1 \cdot \frac{\mathrm{m}^{3}}{1}=\mathrm{m}^{3}$.

Einstein, Newton and Pascal are playing hide-and-seek on the beach. Einstein closed his eyes and started counting. Pascal ran away to hide, but Newton just took a stick and draw a square on a sand around himself and stayed at his place. Einstein opened his eyes and saw Newton.

Einstein: "You really suck at this game, Newton, I found you already!"

Newton: "No you didn't, you found Pascal. See - one Newton over one square meter!" 


\subsection{Kymmenpotenssimuoto.}

Kymmenpotensseja käytetään ilmaisemaan hyvin pieniä ja hyvin suuria lukuja. Laskin antaa pienet ja suuret vastaukset kymmenpotenssimuodossa.

Esimerkki 2.2.1. Pikakertaus.

(1) $10^{3}=10 \cdot 10 \cdot 10=1000$

(2) $10^{-2}=\frac{1}{10^{2}}=\frac{1}{100}=0,01$

(3) $2,5 \cdot 10^{5}=25000$

(4) $3,45 \cdot 10^{-4}=0,000345$

(5) Laskuissa voi olla helpompaa sieventää kymmenpotenssit potenssien laskusäännöillä ennen laskimeen näppäilemistä:

$$
\frac{10^{-3} \cdot 10^{5}}{10^{-7} \cdot 10^{22}}=\frac{10^{-3+5}}{10^{-7+22}}=\frac{10^{2}}{10^{15}}=10^{2-15}=10^{-13}
$$

Huomautus 2.2.2. Yksiköiden etuliitteet voidaan ilmaista kymmenpotensseina, esimerkiksi

(1) kilo $=\mathrm{k}=$ tuhat $=1000=10^{3}$

(2) milli $=\mathrm{m}=$ tuhannesosa $=0,001=10^{-3}$

(3) mikro $=\mu=10^{-6}$

(4) nano $=\mathrm{n}=10^{-9}$.

\subsection{Polynomifunktiot.}

Polynomifunktiot ovat funktioita, joissa esiintyy muuttuja, yleensä $x$, sen positiivisia kokonaislukupotensseja ja kertoimia ja mahdollisesti vakiotermejä. Esimerkiksi $y=x^{2}, y=3 x^{6}-7$ ja $f(x)=\frac{1}{3} x$ ovat polynomifunktioita, $y=\sqrt{x}$ ja $f(x)=\frac{1}{x}$ eivät ole. Polynomifunktiot jaotellaan niiden asteluvun eli muuttujan korkeimman potenssin mukaan.

(1) Vakiofunktiot $f(x)=a$, esimerkiksi $f(x)=5$ ja $y=0$ (kuva 1 ).

(2) Ensimmäisen asteen polynomifunktiot $f(x)=a x+b$, esimerkiksi $f(x)=3 x-1$ ja $f(t)=2 t$ (kuva 1$)$.

Jos vakiotermi puuttuu eli funktio on muotoa $f(x)=a x$, niin funktio kuvaa suoraan verrannollisuutta. Yleisesti ensimmäisen asteen funktio kuvaa lineaarista riippuvuutta.

(3) Toisen asteen polynomifunktiot $f(x)=a x^{2}+b x+c$, esimerkiksi $f(x)=x^{2}-2 x+10$ ja $y=x^{2}$ (kuva 2$)$. 
Toisen asteen polynomifunktion nollakohdat eli yhtälön $a x^{2}+b x+c=0$ ratkaisut saadaan ratkaisukaavalla

$$
x=\frac{-b \pm \sqrt{b^{2}-4 a c}}{2 a} .
$$

(4) Korkeamman asteen polynomifunktiot, esimerkiksi $f(x)=x^{3}$ (pariton, kuva 2) ja $f(x)=x^{4}$ (parillinen).

Huomautus 2.3.1. Toisen asteen ratkaisukaavaa voidaan käyttää myös kulman ratkaisemiseksi, ks. esimerkki 3.0.2.
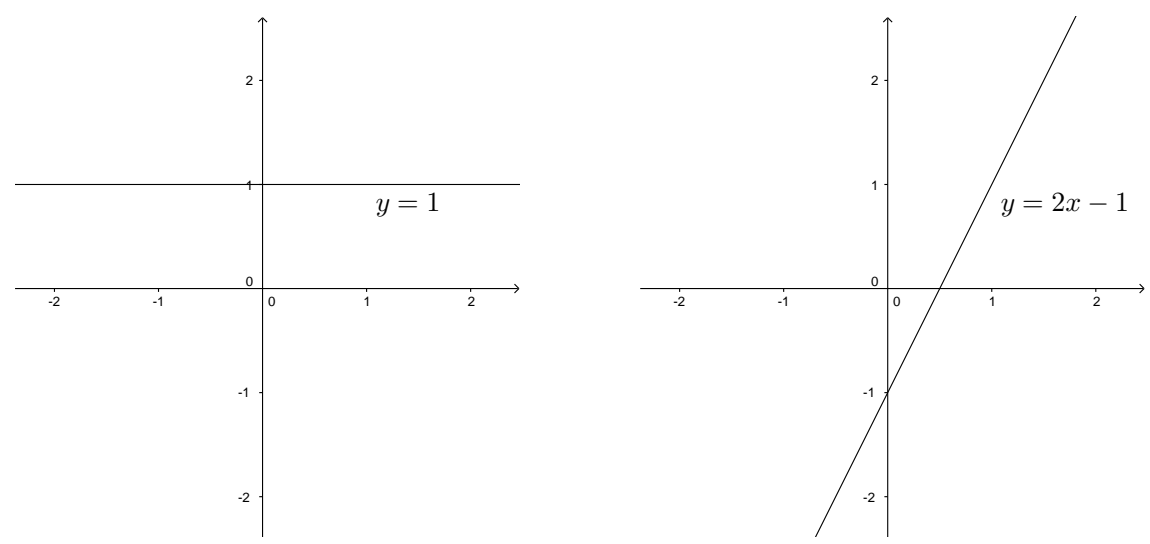

KUVA 1. Vakiofunktion ja ensimmäisen asteen funktion kuvaajat.
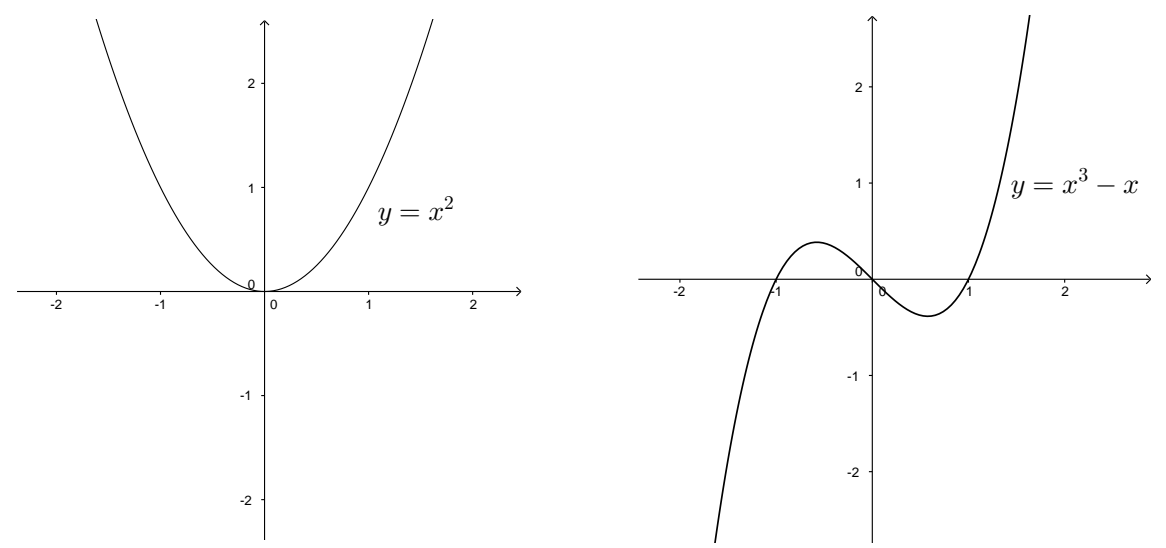

KUvA 2. Toisen ja kolmannen asteen funktioiden kuvaajat. 


\section{TRIGONOMETRISET FUNKTIOT}

Trigonometriset funktiot liittyvät kulmiin ja jaksollisiin ilmiöihin, ja niitä käytetään paljon fysiikassa. Trigonometriset funktiot voidaan määritellä suorakulmaisen kolmion (kuva 3) sivujen suhteiden avulla $($ tri $=$ kolme, gono $=$ kulma, metria $=$ mittaus $)$. Suhteita on yhteensä kuusi erilaista, mutta yleensä näistä tarvitaan vain kolmea tutuinta,

$$
\sin \alpha=\frac{a}{c}, \quad \cos \alpha=\frac{b}{c} \quad \text { ja } \quad \tan \alpha=\frac{a}{b} .
$$

Lisäksi voidaan tarvita Pythagoraan lausetta $a^{2}+b^{2}=c^{2}$.

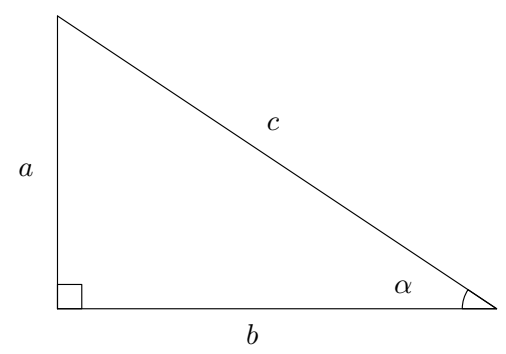

KUVA 3. Suorakulmainen kolmio.

Trigonometristen funktioiden ja Pythagoraan lauseen avulla voidaan ratkaista mikä tahansa suorakulmaisen kolmion sivuista tai kulmista, kunhan kolmiosta tiedetään kaksi muuta näistä mitoista. Kulmat voidaan ilmoittaa tehtävästä riippuen asteina tai radiaaneina, $360^{\circ}=2 \pi(\mathrm{rad})$.

Esimerkki 3.0.1. Vektorin jakaminen komponentteihin.

Usein vektori kannattaa jakaa $x$ - ja $y$-akseleiden suuntaisiin komponentteihin, mikä onnistuu kätevästi sinin ja kosinin avulla (kuva 4):

$$
\begin{array}{ll}
\cos \alpha=\frac{v_{x}}{v} & \Leftrightarrow v_{x}=v \cos \alpha \quad \text { ja } \\
\sin \alpha=\frac{v_{y}}{v} & \Leftrightarrow v_{y}=v \sin \alpha .
\end{array}
$$




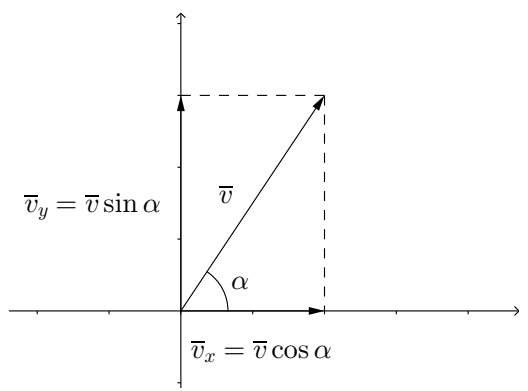

KUVA 4. Vektorin jakaminen komponentteihin.

Kulman ratkaisemisessa tarvitaan trigonometristen funktioiden käänteisfunktioita eli arkusfunktioita, jotka merkitään $\arcsin x, \arccos x$ ja $\arctan x$ tai vastaavasti esimerkiksi laskimissa $\sin ^{-1}, \cos ^{-1}$ ja $\tan ^{-1}$.

Esimerkki 3.0.2. Yhtälö $2 \sin ^{2} x+3 \sin x-2=0$ voidaan ratkaista toisen asteen ratkaisukaavalla (ks. 2.3):

$$
\sin x=\frac{-3 \pm \sqrt{3^{2}-4 \cdot 2 \cdot(-2)}}{2 \cdot 2}=\frac{-3 \pm 5}{4}
$$

josta saadaan $\sin x=\frac{1}{2}$ tai $\sin x=-2$. Näistä jälkimmäinen ei kelpaa, koska $\sin x \leq 1$ kaikilla $x$ (ks. 3.1.1), joten ratkaistaan kulma $x$ ensimmäisestä ratkaisusta: $\sin ^{-1} \frac{1}{2}=30^{\circ}$. (Tässä ratkaistiin vain yksi terävä kulma.)

Huomautus 3.0.3. Monissa laskimissa sekä taulukkolaskentaohjelmissa käytetään oletusasetuksena radiaaneja. Oman laskimen asetuksen voi tarkistaa esimerkin 3.0.2 avulla: jos laskin antaa tulokseksi $\sin ^{-1} \frac{1}{2}=$ $0,52 \ldots$, niin laskin antaa vastauksen radiaaneina. Taulukkolaskentaohjelmissa radiaanit voi muuttaa asteiksi funktiotoiminnolla.

Huomautus 3.0.4. Trigonometrisille funktioille on olemassa paljon muuntokaavoja, esimerkiksi kaksinkertaisten kulmien laskukaavat, jotka löytyvät taulukkokirjoista. Kompleksiluvut osaava voi johtaa kaikki nämä kaavat yhtälöstä $e^{\phi i}=\cos \phi+i \sin \phi$. 


\subsection{Yksikköympyrä.}

Yksikköympyrä on ympyrä, jonka säteen pituus on 1 (kuva 5). Ympyrän sisään muodostuu suorakulmainen kolmio, jolloin säteen ja $x$-akselin välisen kulman $\alpha$ sini ja kosini voidaan lukea suoraan koordinaattiakseleilta (tämä on yksikköympyrän idea). Yksikköympyrän avulla määritellään myös kulman matemaattinen suunta $x$-akselista vastapäivään ja maantieteellinen suunta pohjoisesta myötäpäivään.

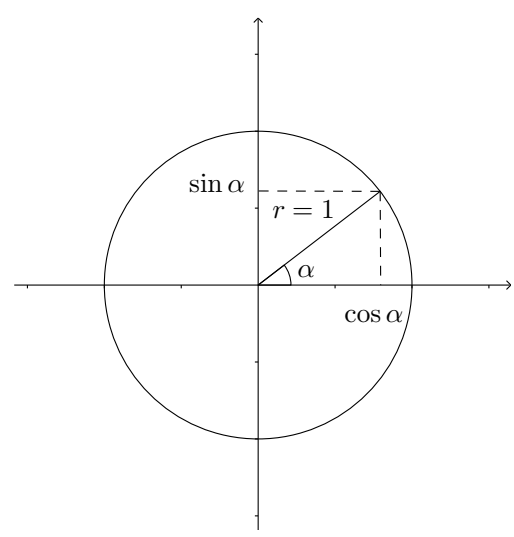

KuvA 5. Yksikköympyrä.

Lisäksi Pythagoraan lauseen mukaan $\sin ^{2} x+\cos ^{2} x=1$, missä merkinnät tarkoittavat $\sin ^{2} x=(\sin x)^{2}$ ja $\cos ^{2} x=(\cos x)^{2}$.

\subsubsection{Funktioiden kuvaajat.}

Sinin ja kosinin kuvaaajat ovat aaltoilevia (kuva 6), koska funktiot ovat jaksollisia eli samat arvot toistuvat aina muuttujan $x$ arvon $2 \pi$ välein, kulmat ilmoitetaan tässä radiaaneina. Monet luonnonilmiöt, esimerkiksi järven aallot ja maaperän lämpötilan vaihtelut, toistuvat jaksollisina, ja niiden kuvauksissa tarvitaan sini- tai kosiniaaltoja. Tässä käytetään tavan vuoksi muuttujaa $x$ kirjaimen $\alpha$ sijasta. Kuvaajista voi lukea 
sinin ja kosinin ominaispiirteitä:

$$
\begin{array}{lll}
\sin 0=0, & \sin \frac{\pi}{2}=1, & |\sin x| \leq 1 \quad \text { ja } \\
\cos 0=1, & \cos \frac{\pi}{2}=0, & |\cos x| \leq 1 .
\end{array}
$$

Lisäksi $\sin x=\cos \left(\frac{\pi}{2}-x\right)$.
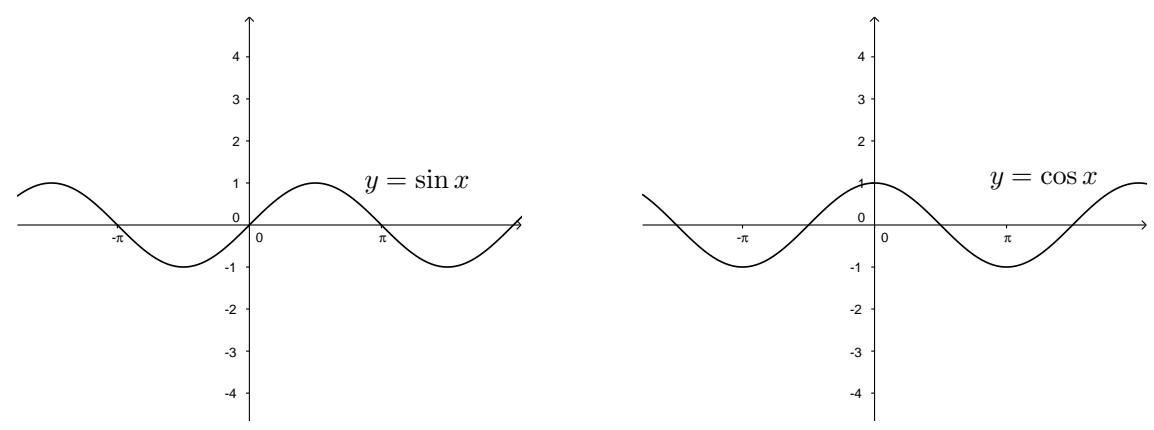

KuvA 6. Sini- ja kosinifunktioiden kuvaajat.

Tangenttifunktion kuvaaja on olennaisesti erilainen (kuva 7). Tangentti ei ole määritelty, kun $x=\frac{\pi}{2} n$, missä $n$ on kokonaisluku, koska näissä pisteissä $\cos x=0$. Tangentti ei ole rajoitettu sinin ja kosinin tapaan, vaan se voi saada mitä tahansa arvoja.

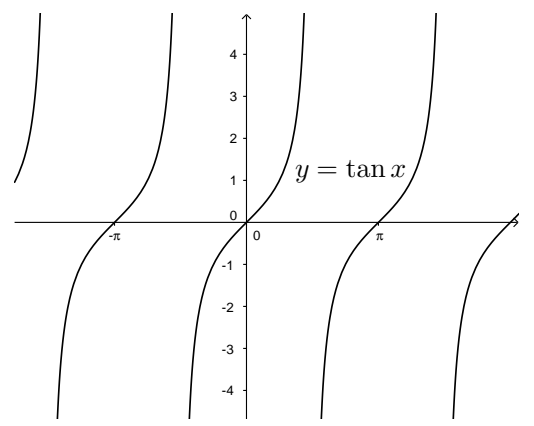

KuvA 7. Tangenttifunktion kuvaaja. 


\section{EKSPONENTTI- JA LOGARITMIFUNKTIOT}

\subsection{Eksponenttifunktio.}

Eksponenttifunktio on funktio, jossa muuttuja esiintyy eksponentissa, esimerkiksi $y=2^{x}$ tai $f(t)=3 t e^{t}-1$. Usein eksponenttifunktiossa esiintyy kantaluku $e=2,71828 \ldots$, Neperin luku. Tässä kappaleessa keskitytään $e$-kantaisiin eksponenttifunktioihin.

Eksponenttifunktio $e^{x}$ kasvaa nopeasti muuttujan arvojen kasvaessa, vastaavasti funktio $e^{-x}$ vähenee nopeasti (kuva 8). Usein puhutaankin eksponentiaalisesta kasvusta tai vaimenemisesta. Funktiot ovat määriteltyjä kaikilla muuttujan $x$ arvoilla ja saavat aina vain positiivisia arvoja. Jos eksponenttina on pitkä tai monimutkainen lauseke, voidaan käyttää merkintää $e^{x}=\exp (x)$. Eksponenttifunktioita käsiteltäessä on hyvä muistaa potenssien laskusäännöt (ks. 2.1), esimerkiksi

$$
e^{x} e^{y}=e^{x+y}, \quad e^{-x}=\frac{1}{e^{x}} \quad \text { ja } \quad e^{0}=1
$$
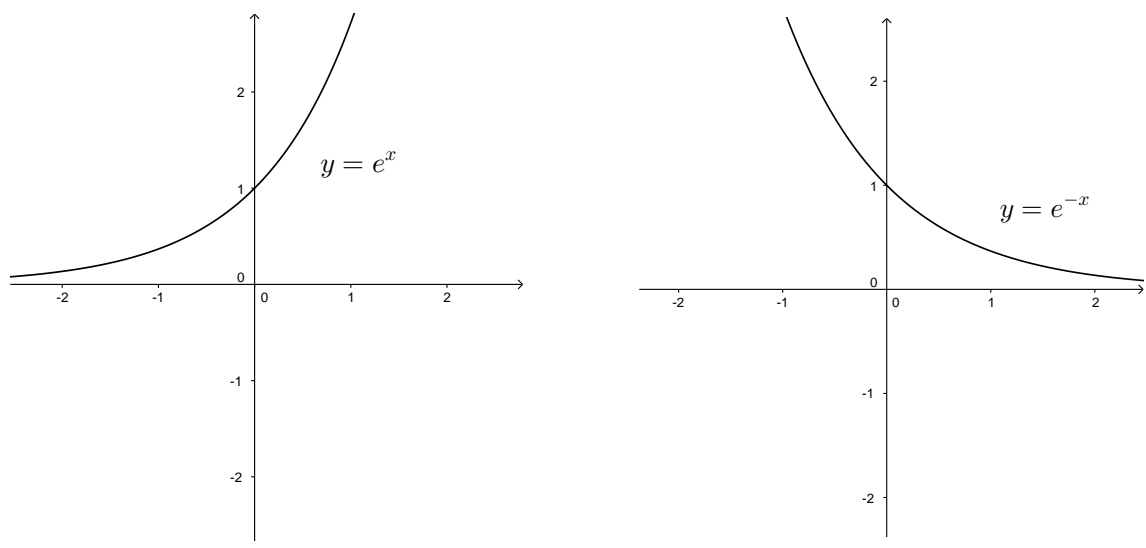

KUvA 8. Eksponenttifunktioiden kuvaajat.

Esimerkki 4.1.1. Eksponentiaalinen kasvu.

Bakteeripopulaation kasvu on eksponentiaalista tiettyyn rajaan asti. Bakteerit lisääntyvät jakaantumalla: yksi bakteeri jakaantuu kahdeksi 
bakteeriksi, jotka jakaantuvat yhteensä neljäksi bakteeriksi ja niin edelleen. Jokaisen jakaantumiskerran jälkeen bakteerien määrä on kaksinkertaistunut edelliseen verrattuna, ja määrää voidaan kuvata funktiolla $f(x)=2^{x}$, missä $x$ on jakaantumiskertojen määrä.

Esimerkki 4.1.2. Eksponentiaalinen väheneminen.

Jos säästeliäs piirakansyöjä jakaa piirakkansa ensin puoliksi, sitten jäljelle jääneen palasen puoliksi ja niin edelleen, piirakan määrä vähenee eksponentiaalisesti. Jäljelle jäänyttä piirakkaosuutta kuvaa funktio $f(x)=\frac{1}{2^{x}}=2^{-x}$, missä $x$ on puolituskertojen määrä.

\subsection{Logaritmit.}

Logaritmi ilmaisee eksponentin. Kun $x>0$, niin

$$
\log _{k} x=y, \quad \text { jos } \quad k^{y}=x .
$$

Tämä luetaan "luvun $x k$-kantainen logaritmi on $y$ ". Yleisimmin käytetyille logaritmeille on omat merkintänsä

$$
\begin{aligned}
\log _{e} x & =\ln x \quad \text { ja } \\
\log _{10} x & =\lg x .
\end{aligned}
$$

Joissakin laskimissa kymmenkantaista logaritmia merkitään lyhenteellä log. Tässä kappaleessa käsitellään seuraavan esimerkin jälkeen vain $e$ kantaisia logaritmeja. Kantaluku on aina myös mahdollista muuttaa.

Esimerkki 4.2.1. Logaritmien laskeminen.

(1) $\log _{2} 8=3$, koska $2^{3}=8$.

(2) $\lg 10000=5$, koska $10^{5}=10000$

(3) $\lg \frac{1}{100}=-2$, koska $10^{-2}=\frac{1}{100}$

Logaritmien laskusäännöt voidaan johtaa suoraan logaritmin määritelmästä.

$$
\begin{aligned}
\ln x y & =\ln x+\ln y, \\
\ln \frac{x}{y} & =\ln x-\ln y \quad \text { ja } \\
\ln x^{a} & =a \ln x .
\end{aligned}
$$


Määritelmästä seuraa myös

$$
\ln e^{x}=x, \quad e^{\ln x}=x \quad \text { ja } \quad \ln 1=0 .
$$

Logaritmifunktio on eksponenttifunktion käänteisfunktio. Se on määritelty vain positiivisilla muuttujan arvoilla, ja sen kasvunopeus pienenee kohti nollaa, kun $x$ kasvaa (kuva 9).

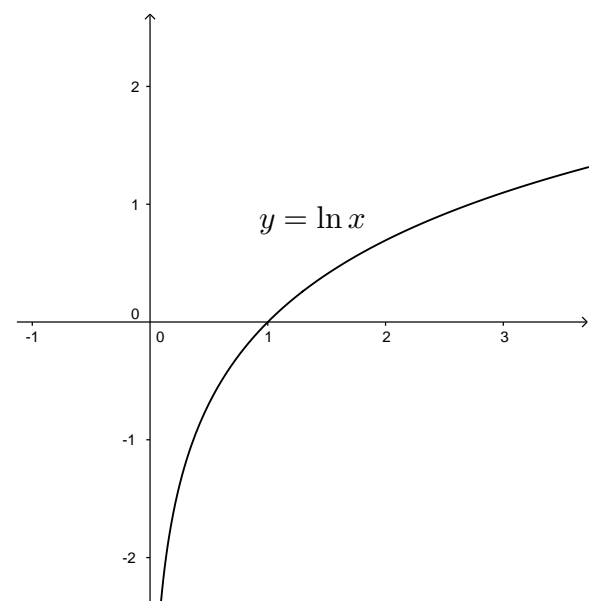

KuvA 9. Logaritmifunktion kuvaaja.

\subsubsection{Eksponenttiyhtälön ratkaiseminen.}

Esimerkki 4.2.2. Eksponenttiyhtälö ratkaistaan ottamalla puolittain (minkä tahansa kantaluvun) logaritmit ja käyttämällä eksponentin siirtosääntöä:

$$
\begin{aligned}
2^{t} & =20 \\
\ln 2^{t} & =\ln 20 \\
t \ln 2 & =\ln 20 \\
t & =\frac{\ln 20}{\ln 2} \approx 4,3 .
\end{aligned}
$$

\subsubsection{Kuvaajan piirtäminen.}

Kun tutkitaan kahden suureen välistä riippuvuutta, voidaan piirtää kuvaaja. Riippuvuuden havaitsemiseksi kannattaa muokata koordinaatisto niin, että kuvaajaksi saadaan suora. Jos riippuvuus on 
(1) lineaarista eli $y=a x+b$, niin kuvaaja on suora tavallisessa $(x, y)$-koordinaatistossa.

(2) eksponentiaalista eli $y=a e^{b x}$, niin kuvaaja on suora $(x, \ln y)$ koordinaatistossa

(3) verrannollinen johonkin muuttujan $x$ potenssiin eli $y=a x^{b}$, niin kuvaaja on suora $(\ln x, \ln y)$-koordinaatistossa.

Luonnollisen logaritmin ln sijaan voi käyttää minkä tahansa kantaluvun logaritmia.

\section{Derivointi}

\subsection{Derivaatta.}

Derivaatta kuvaa funktion muutosnopeutta. Derivaatta jossakin pisteessä $x$ on funktion kuvaajalle tähän pisteeseen piirretyn tangentin kulmakerroin (kuva 10).

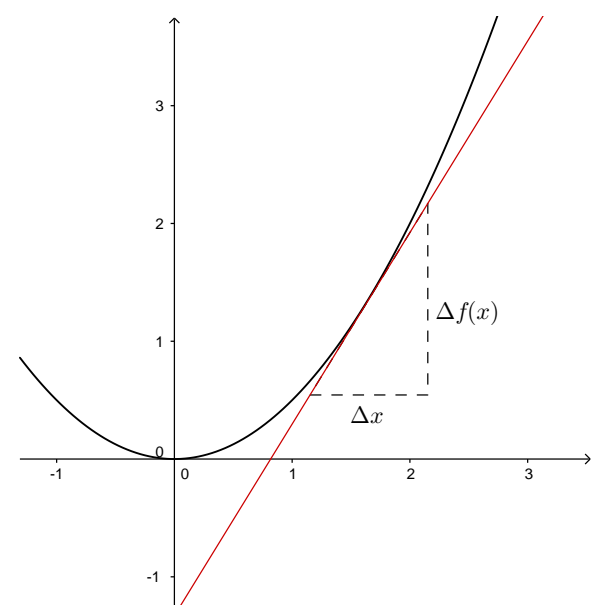

Kuva 10. Derivaatta on tangentin kulmakerroin.

Matemaattisesti määriteltynä kyse on erotusosamäärän raja-arvosta, jota merkitään $f^{\prime}(x)$,

$$
f^{\prime}(x)=\lim _{h \rightarrow 0} \frac{f(x+h)-f(x)}{h}=\lim _{\Delta x \rightarrow 0} \frac{\Delta f(x)}{\Delta x} .
$$

Jälkimmäinen merkintä on suosittu fysiikassa, siinä $\Delta$ ("delta") tarkoittaa (pientä) muutosta. "lim" tarkoittaa limestä eli raja-arvoa, kun $h$ tai 
$\Delta x$ lähestyy nollaa. Funktion $f(x)$ derivaattaa voidaan merkitä

$$
f^{\prime}(x), \quad D f(x), \quad \frac{d f(x)}{d x} \quad \text { tai } \quad \frac{d}{d x} f(x) .
$$

Funktiota voidaan myös derivoida useita kertoja. Esimerkiksi funktion $f(t)$ toista aikaderivaattaa merkitään $f^{\prime \prime}(t)$ tai $\frac{d^{2} f(t)}{d t^{2}}$.

Huomautus 5.1.1. Kaikki jatkuvatkaan funktiot eivät ole derivoituvia: esimerkiksi funktion $f(x)=|x|$ kuvaajassa on terävä kärki kohdassa $x=0$, joten tangenttia ei voida määrittää.

\subsubsection{Muutosnopeus.}

Muutosnopeutta eli derivaattaa voidaan tutkia funktion kuvaajan tai lausekkeen avulla. Tarkastellaan kuvan 11 funktiolle piirrettyjä tangentteja.

(1) Kuvaajalle kohtaan (1) piirretty tangentti osoittaa jyrkästi ylöspäin, joten sen derivaatta on positiivinen ja funktio tässä kohdassa kasvava.

(2) Kohdassa (2) tangetti on vaakasuora ja sen kulmakerroin on nolla, joten muutosnopeuskin on hetkellisesti nolla. Funktio itse on paikallisesti suurimmillaan juuri tässä pisteessä. Funktion ääriarvot eli (paikalliset) maksimit ja minimit löytyvät (tietyin oletuksin) derivaatan nollakohdista.

(3) Kohdassa (3) funktio vähenee hitaasti.

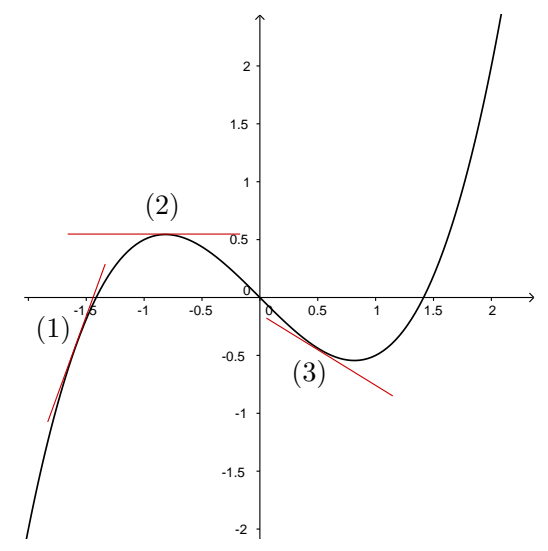

KUVA 11. Funktiolle piirretyt tangentit. 


\subsubsection{Derivaatta fysiikassa.}

Derivaatta on olennainen työkalu, kun tutkitaan muuttuvia suureita. Derivaattojen tunnistaminen auttaa fysiikan kaavojen lukemista: esimerkiksi $\frac{d T}{d t}$ tarkoittaa lämpötilan $T$ muutosta ajan $t$ muutosta kohti. Suureita derivoimalla voidaan saada suoraan uusia suureita. Esimerkiksi derivoimalla matka ajan suhteen saadaan nopeus, ja derivoimalla taas nopeutta ajan suhteen saadaan kiihtyvyys,

$$
\frac{d s}{d t}=v, \quad \frac{d^{2} s}{d t^{2}}=\frac{d v}{d t}=a .
$$

Derivoinnilla saatavan suureen voi päätellä esimerkiksi kuvaajasta: derivaatta on tangentin kulmakerroin, joka on $\frac{\Delta y}{\Delta x}$. Matkan kulmakertoimen yksiköksi tulisi siis $\frac{\Delta \mathrm{m}}{\Delta \mathrm{s}}$ eli nopeuden yksikkö.

\subsubsection{Derivointisääntöjä.}

Derivointi erotusosamäärän raja-arvona on työlästä, ja käytännössä derivointi suoritetaan derivointisääntöjen avulla. Tässä esitetään niistä yleisimpiä. Derivointi on lineaarinen operaatio eli derivointi voidaan suorittaa termeittäin ja vakiolla kertominen voidaan siirtää,

$$
\begin{aligned}
D(f(x)+g(x)) & =D f(x)+D g(x) \quad \text { ja } \\
D a f(x) & =a D f(x) .
\end{aligned}
$$

Lisäksi

(1) $D a=0$ (vakion derivaatta $=0)$

(2) $D x=1$

(3) $D x^{n}=n x^{n-1}$

(4) $D \sin x=\cos x$

(5) $D \cos x=-\sin x$

(6) $D \tan x=\frac{1}{\cos ^{2} x}$

(7) $D e^{x}=e^{x}$

(8) $D \ln x=\frac{1}{x}$

Esimerkki 5.1.2. Derivoidaan sääntöjen avulla.

(1) $D\left(x^{3}+5 x-1\right)=3 x^{2}+5$

(2) $D 2 \sin x=2 \cos x$ 
Funktioiden tulon ja osamäärän sekä yhdistetyn funktion derivoimiseen tarvitaan omat sääntönsä.

(1) Tulon derivaatta:

$$
D(f(x) g(x))=f^{\prime}(x) g(x)+f(x) g^{\prime}(x)
$$

(2) Osamäärän derivaatta:

$$
D \frac{f(x)}{g(x)}=\frac{f^{\prime}(x) g(x)-f(x) g^{\prime}(x)}{(g(x))^{2}}
$$

(3) Yhdistetyn funktion derivaatta:

$$
D(f(g(x)))=f^{\prime}(g(x)) g^{\prime}(x)
$$

Esimerkki 5.1.3. Yhdistetyn funktion derivointi.

Funktio $y=\sin x^{2}$ on yhdistetty kahdesta funktiosta, sisäfunktiona $g(x)=x^{2}$ ja ulkofunktiona $f(x)=\sin x$ (sisäfunktio on sijoitettu ulkofunktion muuttujan paikalle). Siis $f(g(x))=\sin x^{2}$, jolloin $f^{\prime}(g(x))=\cos x^{2}$ (derivoidaan vain ulkofunktiota) ja $g^{\prime}(x)=2 x$. Nyt voidaan derivoida kaavalla (3)

$$
D \sin x^{2}=\cos x^{2} \cdot 2 x=2 x \cos x^{2} .
$$

\subsection{Osittaisderivaatta.}

Osittaisderivaattoja käytetään, kun derivoidaan monen muuttujan funktiota yhden muuttujan suhteen. Esimerkiksi kahden muuttujan funktion $f(x, y)$ ensimmäisen kertaluvun osittaisderivaatat ovat

$$
\frac{\partial f(x, y)}{\partial x} \text { ja } \frac{\partial f(x, y)}{\partial y} .
$$

Osittaisderivointi suoritetaan samalla tavalla kuin derivointi. Jos funktiota derivoidaan muuttujan $x$ suhteen, niin muut muuttujat pidetään vakioina eli kohdellaan niitä samoin kuin lukuja tavallisessa derivoinnissa.

Esimerkki 5.2.1. Lasketaan funktion $f(x, y)=x^{2}-2 x y$ molemmat osittaisderivaatat.

$$
\frac{\partial\left(x^{2}-2 x y\right)}{\partial x}=2 x-2 y, \quad \frac{\partial\left(x^{2}-2 x y\right)}{\partial y}=-2 x .
$$


Esimerkki 5.2.2. Monissa käytännön laskuissa osittaisderivaattojen paikoille voidaan sijoittaa annettuja arvoja. Esimerkiksi, jos veden pinta on kallistunut tuulen vaikutuksesta pitkulaisessa järvessä, jonka pituus on $L$, niin hydrostaattisen paineen ero vastakkaisilla rannoilla on

$$
\frac{\partial p}{\partial x} \stackrel{(1)}{=} \frac{\partial \rho g h}{\partial x} \stackrel{(2)}{=} \frac{\rho g \partial h}{\partial x} \stackrel{(3)}{=} \frac{\rho g \Delta h}{L} .
$$

Tässä käytettiin paineen laskukaavaa (1), tiheys ja putoamiskiihtyvyys ovat vakioita (2). Veden pinnan korkeuden muutos eli korkeusero on $\Delta h$ ja $x$-suunnan muutos on järven pituus eli $L$.

\section{INTEGRointi}

\subsection{Integraalifunktio.}

Integrointi on derivoinnin käänteisoperaatio. Kun etsitään jonkin funktion intergaalifunktiota, voidaan miettiä, mitä funktiota on derivoitu. Siis

$$
\int f(x) d x=F(x), \quad \text { jos } \quad F^{\prime}(x)=f(x) .
$$

Tässä $d x$ on integroimistekijä, jota havainnollistetaan kappaleessa 6.2.1.

Esimerkki 6.1.1. Integroidaan funktio $2 x$. Tämä funktio on funktion $x^{2}$ derivaatta, joten

$$
\int 2 x d x=x^{2}
$$

Tarkistetaan: $D x^{2}=2 x$ eli oikea integraalifunktio löytyi. Toisaalta myös $D\left(x^{2}+5\right)=2 x$ ja $D\left(x^{2}-100\right)=2 x$, koska vakiotermin derivaatta on nolla. Integraalifunktion perässä voi siis olla mikä tahansa vakiotermi. Jotta integroidessa voidaan ilmoittaa kaikki mahdolliset ratkaisut, lisätään vastauksen perään termi $C$, joka on vakio:

$$
\int 2 x d x=x^{2}+C
$$




\subsubsection{Integrointikaavoja.}

Integrointikaavat ovat suoraan seurausta derivointisäännöistä. Tässä esitetään niistä yleisimpiä. Integrointi on lineaarinen operaatio eli integrointi voidaan suorittaa termeittäin ja vakiolla kertominen voidaan siirtää,

$$
\begin{aligned}
\int f(x)+g(x) d x & =\int f(x) d x+\int g(x) d x \quad \text { ja } \\
\int a f(x) d x & =a \int f(x) d x .
\end{aligned}
$$

Lisäksi

(1) $\int a d x=a x+C$

(2) $\int x^{n} d x=\frac{1}{n+1} x^{n+1}+C$

(3) $\int \sin x d x=-\cos x+C$

(4) $\int \cos x d x=\sin x+C$

(5) $\int e^{x} d x=e^{x}+C$

(6) $\int \frac{1}{x} d x=\ln |x|+C$.

Esimerkki 6.1.2.

$$
\int x^{3}-\frac{5}{x} d x=\int x^{3}-5 \cdot \frac{1}{x} d x=\frac{1}{4} x^{4}-5 \ln |x|+C .
$$

Lisää integroinnin apukeinoja esitellään kappaleessa 6.3.

\subsection{Määrätty integraali.}

Määrätty integraali ilmaisee funktion kuvaajan ja $x$-akselin väliin rajatun alueen pinta-alan. Integrointi suoritetaan tietyn välin $[a, b]$ yli, ja määrättyä integraalia merkitään

$$
\int_{a}^{b} f(x) d x=\int_{a}^{b} F(x)=F(b)-F(a) .
$$

Integrointi voidaan suorittaa myös esimerkiksi jonkin alueen pinta-alan yli, ja tätä voidaan merkitä $\int_{A} f d A$. 


\subsubsection{Pinta-ala.}

Funktion kuvaajan ja $x$-akselin väliin jäävän pinta-alan välillä $[a, b]$ laskeminen on helppoa, jos funktio on vakio tai ensimmäistä astetta (kuva 12). Esimerkiksi funktiolle $f(x)=x^{2}$ pinta-alan laskeminen ei enää onnistu geometrian peruskaavoilla.
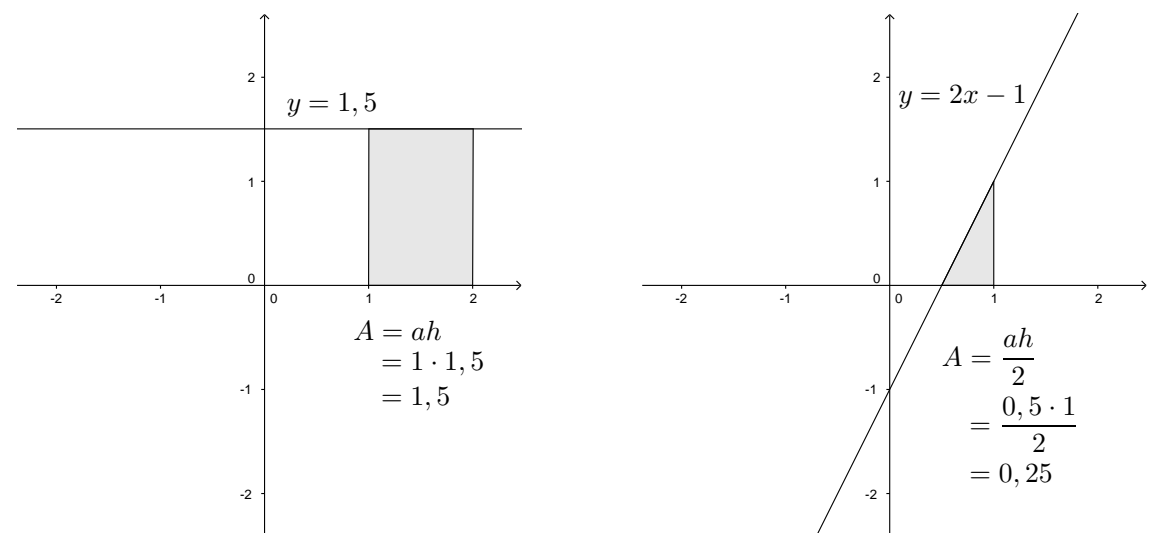

KuvA 12. Pinta-alojen laskeminen.

Kaikkien pinta-alojen laskeminen perustuu suorakulmion pinta-alan laskemiseen, joten yritetään viipaloida kiinnostava alue mahdollisimman tarkasti suorakulmioiksi (kuva 13). Mitä kapeampia suorakulmiot ovat, sitä tarkemmin niiden avulla saadaan kysytty pinta-ala selville. Suorakulmion korkeus on suurin piirtein funktion $f$ arvo kyseisessä kohdassa, ja kannan pituus on pieni muuttujan $x$ muutos, $d x$, joten yhden suorakulmion pinta-ala on $A=f(x) \cdot d x$. Numeerisella integroinnilla tarkoitetaan tällaisten suorakulmioiden pinta-alojen yhteenlaskua, ja sen avulla määrätylle integraalille saadaan aina likiarvo.

Koko alueen pinta-ala saadaan nyt summaamalla suorakulmioiden alat yhteen. Integraalimerkki onkin venytetty $S$, joka tarkoittaa summaa. Siis $A=\int_{a}^{b} f(x) d x$. 


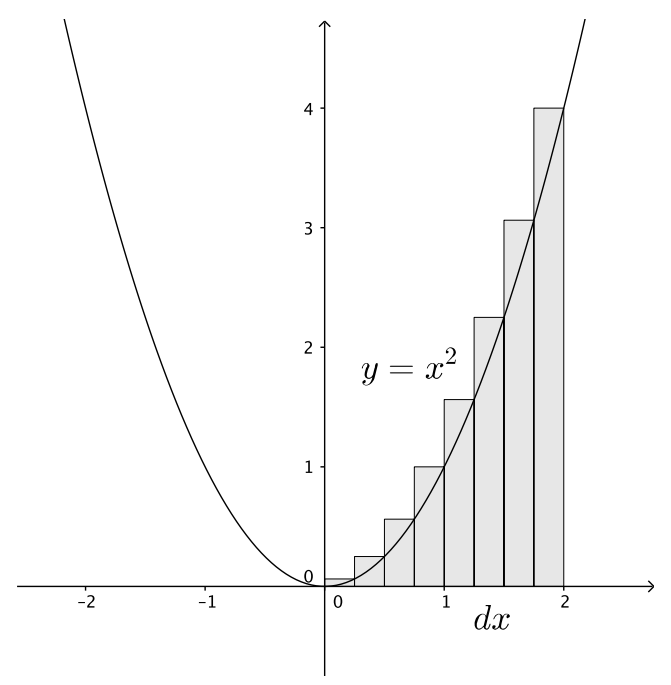

KuvA 13. Pinta-ala suorakulmioiden avulla.

Esimerkki 6.2.1. Lasketaan määrätyt integraalit.

(1) Toisen asteen funktio:

$$
\int_{0}^{1} x^{2} d x=\int_{0}^{1} \frac{1}{3} x^{3}=\frac{1}{3} \cdot 1^{3}-\frac{1}{3} \cdot 0^{3}=\frac{1}{3}
$$

(2) Eksponenttifunktio:

$$
\int_{0}^{2} e^{x} d x=\int_{0}^{2} e^{x}=e^{2}-e^{0}=e^{2}-1 \quad(\approx 6,4)
$$

\subsubsection{Integrointi fysiikassa.}

Määrätty integraali ilmaisee pinta-alan eli kertymän. Suureita integroimalla voidaan saada suoraan uusia suureita. Esimerkiksi integroimalla nopeus ajan suhteen saadaan matka (vertaa Derivointi fysiikassa, 5.1.2). Integroinnilla saatavan suure voidaan päätellä esimerkiksi kuvaajasta: integraali on pinta-ala, joka saadaan suorakulmioiden summana. Suorakulmion pinta-ala on kanta korkeus eli $x \cdot y$. Nopeuskäyrän rajaaman pinta-alan yksiköksi tulisi siis $\mathrm{s} \cdot \mathrm{m} / \mathrm{s}=\mathrm{m}$ eli matkan yksikkö. 


\subsection{Integrointimenetelmiä.}

Matemaattisesti integrointi on "helpompaa" kuin derivointi, sillä melkein kaikki funktiot voidaan integroida. Käytännössä integrointi voi olla haastavaa, jopa mahdotonta. Esimerkiksi yksinkertaisen näköisen funktion $f(x)=e^{x^{2}}$ integraalille ei ole olemassa analyyttistä lauseketta. Määrättyä integraalia $\int_{a}^{b} e^{x^{2}} d x$ voidaan tosin arvioida numeerisesti.

Tässä esitellään joitakin menetelmiä integraalien laskemiseksi. Jos integrointikaavoja ei jostain syystä ole saatavilla, mutta derivointisäännöt (ks. 5.1.3) ovat muistissa, niin kaavat voidaan johtaa integroimalla. Lisäksi täytyy huomioida, etsitäänkö tehtävässä integraalifunktiota vai lasketaanko määrättyä integraalia. Usein hankalan integraalin voi laskea monella eri tavalla. Aluksi kannattaa kokeilla omaa suosikkimenetelmäänsä, ja jos se ei toimi, vaihtaa seuraavaan menetelmään.

\subsubsection{Ketjusääntö.}

Ketjusääntö saadaan integroimalla yhdistetyn funktion derivointisääntöä:

$$
\int f^{\prime}(g(x)) g^{\prime}(x) d x=f(g(x)) .
$$

Tätä kaavaa voidaan käyttää, jos integraalista tunnistetaan yhdistetty funktio ja sisäfunktion derivaatta.

Esimerkki 6.3.1. Tarkastellaan integraalia $\int 2 x\left(x^{2}+1\right)^{3} d x$. Tässä voidaan valita sisäfunktioksi $g(x)=x^{2}+1$ (joka näyttääkin olevan ikään kuin sisällä), jolloin $g^{\prime}(x)=2 x$. Nyt ketjusäännöllä saadaan

$$
\int 2 x\left(x^{2}+1\right)^{3} d x=\frac{1}{4}\left(x^{2}+1\right)^{4}+C,
$$

minkä voi tarkistaa derivoimalla.

\subsubsection{Sijoitusmenetelmä.}

Sijoitusmenetelmä perustuu ketjusääntöön, ja sen avulla voi olla helpompaa laskea integraaleja. Sijoitusmenetelmällä laskettaessa korvataan jokin integroitavan funktion osa yksinkertaisemmalla osalla. Kun tällainen muuttujanvaihto tehdään, myös $d x$ ja määrätyssä integraalissa integrointirajat on muutettava. 
Esimerkki 6.3.2. Lasketaan uudestaan edellisen esimerkin integraali $\int 2 x\left(x^{2}+1\right)^{3} d x$. Kokeillaan tehdä sijoitus $t=x^{2}+1$. Kun tätä sijoitusyhtälöä derivoidaan puolittain, saadaan $d t=2 x d x$. Järjestellään tehtävän integroitava funktio uudelleen ja sijoitetaan sitten termit $t$ ja $d t$ paikoilleen:

$$
\begin{aligned}
\int 2 x\left(x^{2}+1\right)^{3} d x & =\int\left(x^{2}+1\right)^{3} \cdot 2 x d x \\
& =\int t^{3} d t=\frac{1}{4} t^{4}+C \stackrel{(1)}{=} \frac{1}{4}\left(x^{2}+1\right)^{4}+C,
\end{aligned}
$$

missä lopuksi sijoitettiin $t=x^{2}+1$ takaisin (1).

Esimerkki 6.3.3. Määrätty integraali.

Lasketaan määrätty integraali $\int_{0}^{1} e^{3 x} d x$ sijoitusmenetelmällä. Kokeillaan sijoitusta $t=3 x$, jolloin $d t=3 d x$, ja tästä voidaan ratkaista $d x=\frac{1}{3} d t$. Myös integrointirajat on vaihdettava. Lasketaan ne sijoittamalla: integraalin alarajalla $x=0$, joten $t=3 \cdot 0=0$. Ylärajalla $x=1$, joten $t=3 \cdot 1=3$. Sijoitetaan nämä integraaliin ja lasketaan

$$
\begin{aligned}
\int_{0}^{1} e^{3 x} d x & =\int_{0}^{3} e^{t} \cdot \frac{1}{3} d t=\frac{1}{3} \int_{0}^{3} e^{t} d t \\
& =\frac{1}{3} \int_{1}^{3} e^{t}=\frac{1}{3}\left(e^{3}-e^{0}\right)=\frac{1}{3}\left(e^{3}-1\right) \quad(\approx 6,4) .
\end{aligned}
$$

\subsubsection{Osittaisintegrointi.}

Osittaisintegroinnin kaava saadaan integroimalla tulon derivointisääntöä ja järjestämällä termit uudelleen. Tässä on jätetty muuttujat $x$ kirjoittamatta, jotta kaava olisi helppolukuisempi.

$$
\begin{aligned}
\int_{a}^{b} D(f g) d x & =\int_{a}^{b} f^{\prime} g+f g^{\prime} d x \\
\int_{a}^{b} f^{\prime} g d x & =\int_{a}^{b} f g-\int_{a}^{b} f g^{\prime} d x
\end{aligned}
$$

Osittaisintegroinnin ideana on tunnistaa integroitava funktio tulona, jonka tekijöistä ainakin toinen on helposti integroitava ja toinen helposti derivoitava. Kun funktiot sijoitetaan kaavaan, joudutaan edelleen integroimaan, mutta helpompaa funktiota. 
Esimerkki 6.3.4. Lasketaan integraali $\int_{0}^{1} x \sin x d x$. Tässä kannattaa valita $g(x)=x$, jolloin $g^{\prime}(x)=1$, ja $f^{\prime}(x)=\sin x$, jolloin $f(x)=$ $-\cos x$. (Jos valittaisiin $f^{\prime}(x)=x$, päädyttäisiin hankalampaan integraaliin.) Sijoitetaan valinnat osittaisintegroinnin kaavaan ja lasketaan

$$
\begin{aligned}
\int_{0}^{1} x \sin x d x & =\int_{0}^{1}-\cos x \cdot x-\int_{0}^{1}-\cos x \cdot 1 d x \\
& =-\int_{0}^{1} x \cos x+\int_{0}^{1} \sin x \\
& =-(1 \cdot \cos 1-0 \cdot \cos 0)+(\sin 1-\sin 0) \\
& =\sin 1 \quad(\approx 0,84) .
\end{aligned}
$$

\section{DifferentiaAliYhtäLÖT}

\subsubsection{Esimerkkejä differentiaaliyhtälöistä.}

Differentiaaliyhtälöt ovat yhtälöitä, joissa esiintyy sekä funktio (funktioita) että sen derivaatta (derivaattoja). Differentiaaliyhtälön ratkaiseminen voi olla monimutkaista, ja tässä esitelläänkin vain muutama erityyppinen yhtälö.

Esimerkki 7.0.1. Esimerkkejä differentiaaliyhtälöistä.

(1) Ensimmäisen kertaluvun yksinkertainen differentiaaliyhtälö:

$$
\frac{d y}{d x}=2 x
$$

(2) Ensimmäisen kertaluvun differentiaaliyhtälö, jossa esiintyy funktio $E$ ja sen ensimmäinen syvyysderivaatta:

$$
\frac{d E}{d z}=-\lambda E
$$

(3) Toisen kertaluvun differentiaaliyhtälö, jossa esiintyy funktio $h$ ja sen toinen aikaderivaatta:

$$
\frac{m d^{2} h(t)}{d t^{2}}=-m g
$$


Yhtälö (1) voidaan ratkaista suoraan integroimalla, jolloin saadaan $y=x^{2}+C$. Myös yhtälö (3) ratkeaa suoralla integroinnilla integroimalla kahdesti, sillä yhtälössä esiintyy vain funktion $h$ toinen derivaatta, ei funktiota $h$ eikä sen muita derivaattoja. Usein suora integrointi ei onnistu. Tässä kappaleessa käsitellään lyhyesti separoituvia ja ensimmäisen kertaluvun lineaarisia differentiaaliyhtälöitä.

\subsection{Separoituvat differentiaaliyhtälöt.}

Separoituvat differentiaaliyhtälöt ovat muotoa

$$
\frac{d y}{d x}=p(x) q(y)
$$

missä $y$ on muuttujan $x$ funktio eli $y=y(x)$. Separoituvan differentiaaliyhtälön toisella puolella on siis funktion $y$ derivaatta. Toinen puoli voidaan kirjoittaa tulona, jonka tekijöistä toinen on muuttujan $x$ funktio ja toinen funktion $y$ funktio.

Esimerkki 7.1.1. Esimerkkejä separoituvista differentiaaliyhtälöistä ja niiden separoinneista.

(1) Vain tekijästä y riippuva yhtälö:

$$
\frac{d y}{d x}=k y, \quad \text { missä } \quad p(x)=k, q(y)=y .
$$

(2) Tekijöistä $x$ ja $y$ riippuva yhtälö:

$$
\frac{d y}{d x}=\frac{y^{2}}{x}, \quad \text { missä } \quad p(x)=\frac{1}{x}, q(y)=y^{2} .
$$

Esimerkiksi yhtälö $\frac{d y}{d x}=x y-1$ ei ole separoituva.

Separoituvan differentiaaliyhtälön ratkaisemiseksi tehdään järkevä oletus $q(y) \neq 0$. Ratkaisemisen ideana on muokata yhtälöä niin, että vasemmalla puolella esiintyy vain funktio $q$ ja oikealla puolella funktio $p$, 
minkä jälkeen yhtälö voidaan ratkaista integroimalla puolittain.

$$
\begin{gathered}
\frac{d y}{d x}=p(x) q(y) \\
\frac{d y}{d x} \cdot \frac{1}{q(y)} \stackrel{(1)}{=} p(x) \\
\int \frac{d y}{d x} \cdot \frac{1}{q(y)} \not d x \stackrel{(2)}{=} \int p(x) d x \\
\int \frac{1}{q(y)} d y=\int p(x) d x .
\end{gathered}
$$

Tässä jaettiin ensin puolittain funkiolla $q(y)(1)$ ja integroitiin sitten molemmat puolet muuttujan $x$ suhteen (2). Alimman rivin kaavaa voidaan käyttää separoituvien differentiaaliyhtälöiden ratkaisemiseen.

Esimerkki 7.1.2. Ratkaistaan yhtälö $y \frac{d y}{d x}-2 x=0$.

Tutkitaan ensin, onko yhtälö separoituva. Siirretään termi $-2 x$ yhtälön oikealle puolelle ja jaetaan sitten puolittain funktiolla $y$ ja saadaan $\frac{d y}{d x}=\frac{2 x}{y}$. Nyt voidaan valita $p(x)=2 x$ ja $q(y)=\frac{1}{y}$, joten yhtälö on separoituva. Ratkaistaan vielä kaavaan sijoitusta varten $\frac{1}{q(y)}=y$. Nyt saadaan

$$
\begin{gathered}
\int \frac{1}{q(y)} d y=\int p(x) d x \\
\int y d y=\int 2 x d x \\
\frac{1}{2} y^{2}+C_{1}=x^{2}+C_{2} \\
\frac{1}{2} y^{2}-x^{2} \stackrel{(1)}{=} C_{2}-C_{1} \\
\frac{1}{2} y^{2}-x^{2} \stackrel{(2)}{=} C .
\end{gathered}
$$

Tässä integroitiin molemmat puolet, siirrettiin termit (1) ja merkittiin vakiota yhdellä kirjaimella $C=C_{2}-C_{1}(2)$.

Esimerkki 7.1.3. Ratkaistaan valon vaimenemista kuvaava differentiaaliyhtälö $\frac{d E}{d z}=-\lambda E$. Tässä voidaan ajatella $E=y$ ja $z=x$.

Yhtälö on separoituva, koska voidaan valita $p(z)=-\lambda$ ja $q(E)=E$, 
ja tällöin $\frac{1}{q(E)}=\frac{1}{E}$. Nyt saadaan

$$
\begin{aligned}
& \int \frac{1}{q(E)} d E=\int p(z) d z \\
& \int \frac{1}{E} d E=-\lambda d z \\
& \ln |E|+C_{1}=-\lambda z+C_{2} \\
& \ln |E|=-\lambda z+C \\
& e^{\ln |E|} \stackrel{(1)}{=} e^{-\lambda z+C} \\
&|E| \stackrel{(2)}{=} e^{-\lambda z} e^{C} \\
& E \stackrel{(3)}{=} A e^{-\lambda z} .
\end{aligned}
$$

Tässä jälleen integroitiin ja yhdistettiin sitten vakiot kirjaimeksi $C$. Asetetaan molemmat puolet luvun e eksponenteiksi (1), mikä kumoaa logaritmin, ja hajotetaan sitten oikea puoli potenssisäännön avulla (2). Oikea puoli on aina positiivinen, joten itseisarvot voidaan jättää pois, ja vakiota $e^{C}$ merkitään kirjaimella $A$. Ratkaisun mukaan valo vaimenee eksponentiaalisesti syvyyden kasvaessa.

\subsection{Ensimmäisen kertaluvun lineaariset differentiaaliyhtälöt.}

Ensimmäisen kertaluvun lineaariset differentiaaliyhtälöt ovat standardimuotoa

$$
\frac{d y}{d x}+P(x) y=Q(x)
$$

Ne riippuvat lineaarisesti funktiosta $y$. Esimerkiksi $\frac{d y}{d x}+x y^{2}+1$ eli ole lineaarinen yhtälö, koska siinä esiintyy funktion $y$ toinen potenssi.

Standardimuotoisen yhtälön yleinen ratkaisu on

$$
y=e^{-\int P(x) d x} \int e^{\int P(x) d x} Q(x) d x .
$$

Esimerkki 7.2.1. Ratkaistaan yhtälö $\frac{d y}{d x}-\frac{y}{x}=2 x$. Tässä $P(x)=-\frac{1}{x}$, $Q(x)=2 x$ ja $\int P(x) d x=-\int \frac{1}{x} d x=-\ln x$. Sijoitetaan nämä yleisen 
ratkaisun kaavaan ja saadaan

$$
\begin{aligned}
y & =e^{\ln x} \int e^{-\ln x} \cdot 2 x d x \\
& =x \cdot \int e^{\ln x^{-1}} \cdot 2 x d x \\
& =x \cdot \int x^{-1} \cdot 2 x d x \\
& =x \cdot \int 2 d x \\
& =x(2 x+C) .
\end{aligned}
$$

Niin kutsutuissa alkuarvo-ongelmissa vakio $C$ määrätään jonkin tehtävän alkuarvon avulla.

\subsubsection{Kiitokset.}

Kiitän lämpimästi FT Laura Härköstä tämän liitteen kommentoinnista akvaattisten tieteiden näkökulmasta sekä faijaa matemaattisluonnontieteellisestä yhteistyöstä. 